A F R I C A N M L I T A R Y S T U I E S • Volume 2

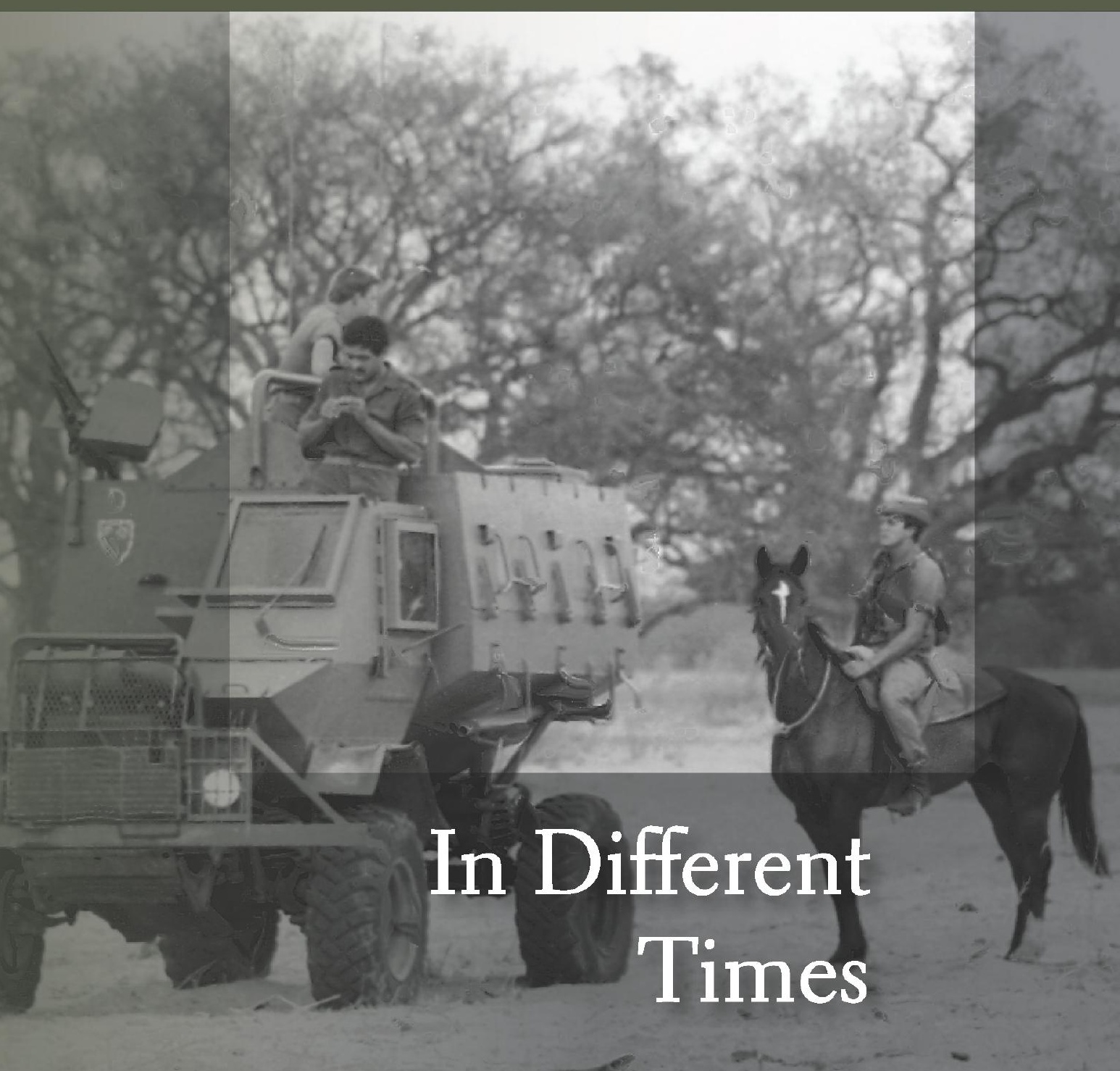

The War for Southern Africa

1966-1989 
A F R I C A N M I L I T A R Y S T U DIE S

Volume 2

\title{
In Different Times
}

\author{
The War for Southern Africa \\ 1966-1989
}

Ian van der Waag \& Albert Grundlingh

Editors

\section{${ }_{\text {? }}^{2} \mathrm{PROSS}$}


In Different Times: The War for Southern Africa, 1966-1989

Published by AFRICAN SUN MeDIA under the SUN PReSS imprint

All rights reserved

Copyright (c) 2019 AFRICAN SUN MeDIA and the authors

This publication was subjected to an independent double-blind peer evaluation by the publisher.

The authors and the publisher have made every effort to obtain permission for and acknowledge the use of copyrighted material. Refer all enquiries to the publisher.

No part of this book may be reproduced or transmitted in any form or by any electronic, photographic or mechanical means, including photocopying and recording on record, tape or laser disk, on microfilm, via the Internet, by e-mail, or by any other information storage and retrieval system, without prior written permission by the publisher.

Views reflected in this publication are not necessarily those of the publisher or Stellenbosch University.

First edition 2019

ISBN 978-1-928480-34-1

ISBN 978-1-928480-35-8 (e-book)

https://doi.org/10.18820/9781928480358

Set in Bembo Std 11/14

Cover design, typesetting and production by AFRICAN SUN MeDIA

Photographs appearing in this publication were obtained from the Department of Defence Archives

(South Africa), except where stated otherwise.

SUN PReSS is an imprint of AFRICAN SUN MeDIA. Scholarly, professional and reference works are published under this imprint in print and electronic formats.

This publication can be ordered from:

orders@africansunmedia.co.za

Takealot: bit.ly/2monsfl

Google Books: bit.ly/2k1Uilm

africansunmedia.store.it.si (e-books)

Amazon Kindle: amzn.to/2ktL.pkL

Visit africansunmedia.co.za for more information. 


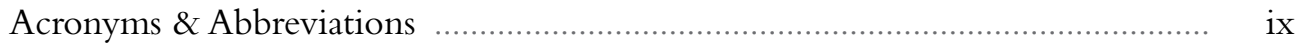

Introduction: South Africa's Border War in retrospect ................................ 2 Ian van der Waag \& Albert Grundlingh

\section{PLACES AND EVENTS}

1 The Namibian/Angolan border in the Namibian War for Independence

Chris Saunders

2 Operation Blouwildebees, 1966: The helicopter assault on Ongulumbashe

McGill Alexander

3 Operation Savannah, 1975-76: The initial South African Armour deployments into Anglo

Jean-Pierre Scherman

4 Namibia: Effective strategic buffer zone or draining foreign military adventure?

James Jacobs

\section{WAR AND SOCIETY}

5 The SADF and the militarisation of white South African Society

Rodney Warwick

6 The Kavango Jeugbeweging and the South African counterinsurgency campaign in Namibia

Evert Kleynhans

7 Caught in the crossfire: The Progressive Federal Party and defence politics during the 1980s in South Africa

Albert Grundlingh

8 "Ek het iemand op die grens": The Southern Cross Fund and mobilisation of white South African society 


\section{THE SOLDIERS' EXPERIENCE}

9 Confessions of a conscript, disclosures of a historian:

An autobiographical essay about the Border War

Gary Baines

10 Socialised to serve: An auto-ethnographical exploration

of the making of the (citizen) conscript in South Africa

Ian Liebenberg

11 The evolution of 32 Battalion: From renegade guerillas to township troopers

Will Gordon

12 SAWI! Leisure, comforts and military canteens in the SADF

Ian van der Waag

Contributors 


\section{Foreword}

\section{African Military Studies}

\section{Series Editor}

lan van der Waag, Stellenbosch University

African Military Studies is an exciting, new series of books on war, conflict and armed forces in Africa. Covering the whole span of African history, and the full conflict continuum, the series seeks to encourage works on the drivers of armed conflict, the ways in which societies and armed forces prepare for and conduct war, the development of technology, strategy, tactics, and logistics in the African battlespace, and the impact of warfare on African societies. African Military Studies presents the latest research and accepts high-quality monographs, collections of essays, conference proceedings, and annotated military and historical texts. It is a library for the academic specialist, for the policymaker, and for the practitioner with "boots on the ground".

\section{Acknowledgements}

A book of this nature incurs many debts. In the first instance, the contributors are thanked for their individual chapters as well as the contributions they made to the discussions during the symposium, The South African "Border War", 1966-2016; a quinquagenarial reflection, which led to this book. The Department of History at Stellenbosch hosted the symposium. Dr Anton Ehlers, the head of the department, is thanked for the support lent and the personal contribution he made to the success of the day, which went well beyond the call of duty. The same must be said for Dr Evert Kleynhans who drew all the maps for this volume. The five-person panel that peer reviewed all the papers submitted for this publication are equally thanked for their critical comments and insightful suggestions. And, finally, the team at African SunMedia have been fantastic. Special thanks must go to Emily Vosloo and Wikus van Zyl for their patience and understanding, and to Davida van Zyl for her careful eye and creativity. 


\section{Acronyms \& Abbreviations}

AFG Air Force Gymnasium

ANC African National Congress

Apla Azanian People's Liberation Army (formerly known as Poqo), military wing of the PAC

Armscor Armaments Corporation of South Africa

BAA Brigade Administrative Area

BOSS Bureau of State Security

C Army Chief of the Army

CDFA [HWA] Chief of Defence Force Administration [Hoof van Weermagsadministrasie]

CDS [HVS] Chief of Defence Staff [Hoof van Verdedigingstaf]

CF Citizen Force

CG [KG] Commandant General [Kommandant Generaal]

CGS Chief of the General Staff (predecessor of Commandant General, SADF)

CIR Centro de Instrução Revolucionária - Centre for Revolutionary Instruction

CLS Chief of Logistics Services

COIN Counterinsurgency

CSI Chief of Staff Intelligence

DC Secretary for Defence

DGGA $[D G A A]$ Director General of General Administration [Direkteur-Generaal van Algemene Administrasie]

DMZ Demilitarised Zone

DSADFI [DSAWI] Director SADFI [Direkteur SAWI]

DTA Democratic Turnhalle Alliance 
ECC End Conscription Campaign

Fapla Forças Armadas Populares de Libertação de Angola - People’s Armed Forces for the Liberation of Angola (armed wing of MPLA)

FAR Fuerzas Armadas Revolucionarias - Cuban Revolutionary Armed Forces

FME Focus of Main Effort

FNLA Frente Nacional de Libertação de Angola - National Front for the Liberation of Angola

Frelimo Frente para Liberação de Moçambique - Mozambique Liberation Front

HIO high-intensity operations

HMO high-mobility operations

HSRC Human Sciences Research Council

Idasa Institute for Democracy in South Africa

LMG light machinegun

MA Military Area

MK Umkhonto we Sizwe (military wing of the African National Congress $[\mathrm{ANC}])$

MMCA Misión Militar Cubana en Angola - Cuban Military Mission in Angola

MPLA Movimento Popular para a Libertação de Angola - Popular Movement for the Liberation of Angola

NAAFI Navy Army Air Force Institute (not to be confused with the term 'naafi')

NAM Non-Aligned Movement

NP National Party

NSM National Servicemen

OAU Organisation of African Unity

OCs Officers Commanding

PAC Pan Africanist Congress

PAIGC Partido Africano para a Independência da Guiné e Cabo Verde - African Party for the Independence of Guiné and Cape Verde 
PFP Progressive Federal Party

PLAN People's Liberation Army of Namibia

POW prisoner of war

PTSD post-traumatic stress disorder

PU for CHE Potchefstroom University for Christian Higher Education

QMG [KMG] Quartermaster General [Kwartiermeestergeneraal]

RAU Randse Afrikaanse Universiteit

(today University of Johannesburg)

RDL Revolta do Leste - The Eastern Revolt

Recce/s Reconnaissance Commando/s

SAAC South African Armoured Corps

SAAF South African Air Force

SABC [SAUK] South African Broadcasting Corporation

[Suid-Afrikaanse Uitsaaikorporasie]

SADF South African Defence Force

SADFI [SAWI] South African Defence Force Institute

[Suid-Afrikaanse Weermaginstituut]

SAGI South African Garrison Institute

SAI South African Infantry Battalion Group

SANDF South African National Defence Force

SAP South African Police

SCF Southern Cross Fund [Suiderkruisfonds]

SG [GG] Surgeon General [Geneesheer Generaal]

SMG submachinegun

SSB Special Service Battalion

SSC State Security Council

SWA South West Africa

SWA Command Command General Commanding South West Africa Command

Swapo South West Africa People's Organisation 
SWATF South West African Territorial Force

TRC Truth and Reconciliation Commission

UDF Union Defence Force

UDFI Union Defence Force Institute

UMU University Military Unit

UNGA United Nations General Assembly

Unisa University of South Africa [Universiteit van Suid-Afrika]

Unita União Nacional para Independência Total de AngolaNational Union for the Total Independence of Angola

USMU [USME] University Stellenbosch Military Unit

[Universiteit Stellenbosch Militêre Eenheid]

Wham winning the hearts and minds

ZDF Zairian Defence Force 



\section{Introduction}

\section{SOUTH AFRICA'S BORDER WAR IN RETROSPECT}

Ian van der Waag

$\&$

Albert Grundlingh 
"It's a nice story - what a shame nobody has written about it fully," Cuban dictator Fidel Castro wrote near the twentieth anniversary of the battles near Cuito Cuanavale. ${ }^{1}$ Despite the passage of another decade, a 'full history' of the Angolan conflict has yet to appear. Before the end of this century, it might. But today, although almost thirty years have elapsed since the war ostensibly ended, the emotion stirred, the wounds caused, and the problems left unresolved are too heated, too deep, and too complex, for any historian to produce one objective narrative that might find general acceptance. But that should come as no surprise. After all, we had to wait almost eight decades for the first single-volume history of the Anglo-Boer War to generally satisfy all shades of historical opinion over its origins, nature, and consequences. ${ }^{2}$

The 'Border War' - the nomenclature remains problematic - involved every state in Southern Africa and the nationals of several more. In several instances, most notably in Angola, Mozambique, and Rhodesia, insurgent movements fought guerrilla campaigns. The wars fought may have had their characteristics. Through common purpose, however, regional cooperation and the sharing of resources, they were also in many respects inseparably connected. The liberation wars in Angola and Mozambique (1961-1975) and the post-independence wars that followed 1975, the Rhodesian 'Bush War' (1964-1980), South Africa's Border War (1966-1989), and the 'armed struggle' for South Africa, are all perhaps campaigns of a larger, thirty-year Southern African War. Some states were directly involved in hot proxy wars of the Cold War. Host countries, providing succour and materiel to one or more insurgent movements, became at times targets of cross-border raids, as in the case of Swaziland, Lesotho, and Botswana, or targets for economic and political destabilisation by Rhodesia and then South Africa. Some Southern African states maintained strong links with former colonial masters, while Cuba, China, the USSR, and the USA courted others. While the 'War' escapes neat or easy positioning in both space and time, it is also true that there were no true neutrals in the region. ${ }^{3}$

Over the past fifty years, dozens of books, several special issues of journals, and more than 118 academic journal articles were written, and, more recently, tens of thousands of pages of documents declassified. ${ }^{4}$ Scholarly military histories of the Angolan conflict have taken a long time to emerge. Writing the first rough drafts of history, ${ }^{5}$ war correspondents and journalists produced the first accounts in South Africa ${ }^{6}$ and abroad. ${ }^{7}$ Feeding the demand for popular, 'instant' history, these appeared from 1976 and culminated more recently with The SADF in the Border War (2013) by Leopold Scholtz ${ }^{8}$ and the reprint of Willem Steenkamp's South Africa's Border War (2016). ${ }^{9}$ Many publications by official historians appeared as the Border War ended, but this official response, like the work of the journalists, satisfied neither the veteran participants nor an academic community seeking deeper reflection. ${ }^{10}$ An academic phase began with the presentation of theses and dissertations at several universities in South Africa ${ }^{11}$ and abroad, but much of this writing remained political and diplomatic. ${ }^{12}$ Unsurprisingly, 
a flood of personal accounts ensued, starting with Jacqui Thompson's An Unpopular War. ${ }^{13}$ The personal narratives and memoirs reached a high point in 2009, which seems to have been something of a 'golden year', although from an early stage this genre included unit, regimental and formation history. ${ }^{14}$ The Border War has therefore gone through the familiar cycle of military historiography: journalism and war reportage, followed by official history, then the personal and regimental accounts, all leading to studies that are academic and more critical in approach. ${ }^{15}$

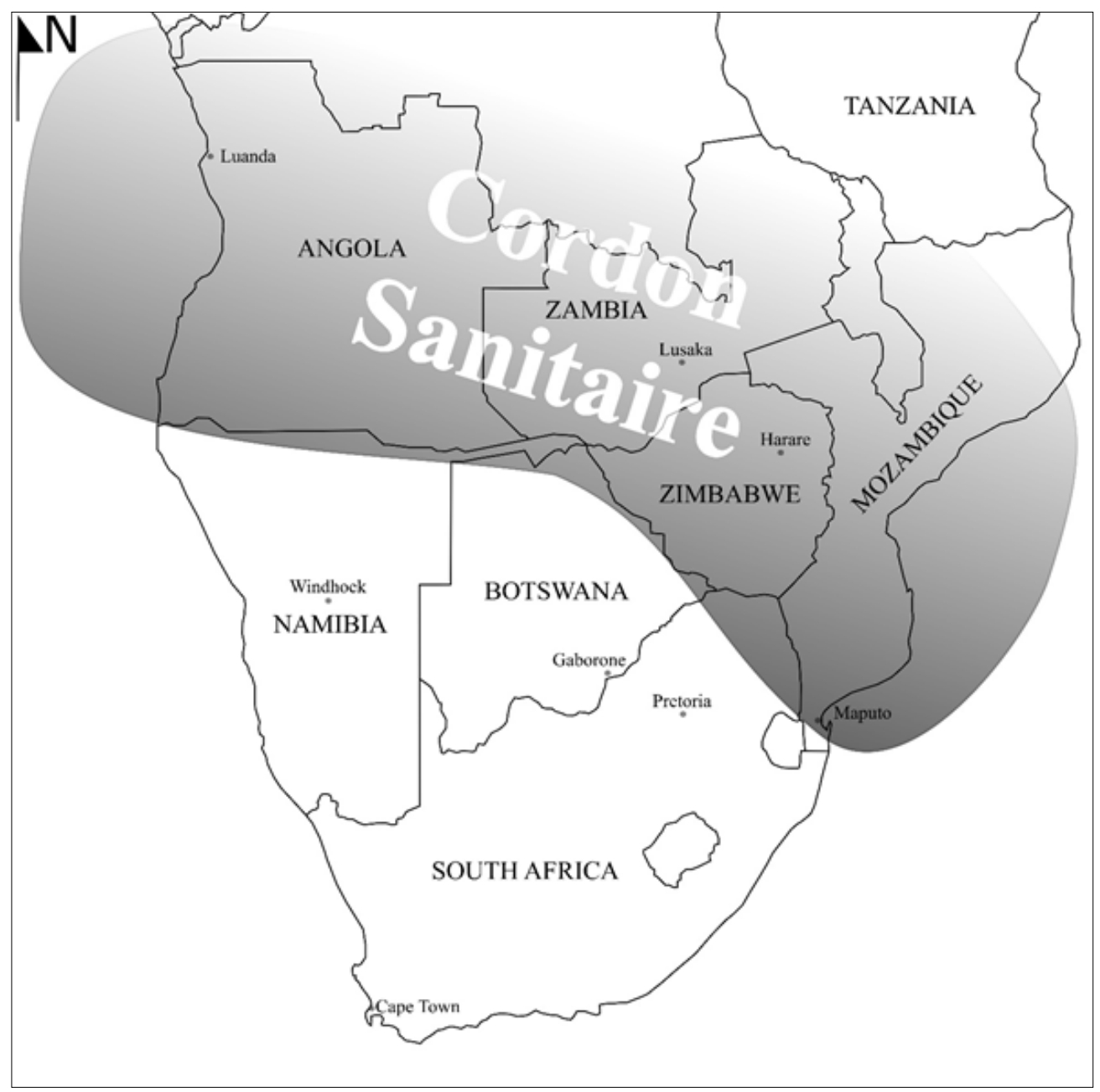

MAP 1 Southern Africa and the cordon sanitaire

In another vein, what is surprising, is that whereas wars usually provide rich material for subsequent political movements to manipulate for their own purposes, often in printed form, this was for the most part not the case for the "Border War". In part, this can probably be explained by the increasing fragmentation of Afrikaner society after 1990 and the thought to harness the "Border War" in a new dispensation, where 
Afrikaner history in its old format is given a wide berth, would not have made much sense. Neither can the current African National Congress (ANC) government lay much claim to the memory of the war (though occasionally they wish to as far as Cuito Cuanavale is concerned) for the simple reason that they were largely absent from the fighting.

While we now know a great deal more about this war, answers to many fundamental questions remain elusive. Why, for example, did South Africa make such a vast commitment in an area of seeming so questionable strategic importance? What did it attempt to do during the twenty-three years of its involvement in Angola? Why, despite the expenditure of billions of Rands, the loss of many lives, the application of growing and increasingly sophisticated armed forces, and the enlistment of the flower of its youth, did the region's only power fail to achieve its ostensible objectives in a war that was deeply frustrating and divisive? At a deeper level, how was this war waged, and what was its nature? And then what was the soldiers' experience from the 'humiliations' of basic training and the development of unit cohesion to the fear, loneliness, and exhaustion of battle? And, not in the least, what have been the consequences for all South Africans, Angolans, Namibians, from this, the region's longest war?

This book seeks to provide some answers to some of these questions and to specifically place South Africa's involvement in Angola in a more nuanced, historical perspective. On 26 August 2016, the Department of History (Arts) and the Department of Military History (Military Sciences) of Stellenbosch University held a symposium on the topic of "The War for Southern Africa; a quinquagenarial reflection". Prominent historians were invited to reflect on their experiences, in several cases as both veterans and scholars. The two keynote speakers were Brig Gen McGill Alexander (retired), a soldier-scholar who completed a $\mathrm{PhD}$ on the airborne concept in the South African armed forces in 2016, ${ }^{16}$ and Professor Gary Baines, author of a reflective, recent book on the Border War. ${ }^{17}$ The event gained traction, and others joined; some were colleagues from related fields, some were past and present postgraduate students. The result is this collection of chapters. The date, 26 August, was chosen as it marked the fiftieth anniversary of the SADF attack on Ongulumbashe in 1966. Those in attendance came from Angola, Namibia, the Russian Federation, and South Africa. That 26 August is also Namibia's national day was duly noted. ${ }^{18}$

The papers offered and those selected for presentation at the symposium were, as expected, diverse in approach and methodology, and this edited collection reflects this diversity of views and approaches. Significantly, the contributions range all three approaches in military history writing: the traditional military history, the new military history, and the war-and-society method. The contributors also base their findings on a variety of sources. Several delved deeply in often newly available, archival material from government and non-governmental sources in Southern Africa and 
part elsewhere. Much of this archival material arrived in 1989 at the Department of Defence Archives, where it was sorted, arranged, catalogued, and has since been rendered steadily accessible. However, too many scholars, working on the Border War and the related conflicts, notably excuse their neglect of this material with claims of inaccessibility, destruction, or loss. ${ }^{19}$ But the material is rich and extensive. In 1992, the Department of Defence Archives held some 35 linear kilometres of files, of that approximately 31.33 linear kilometres, or ninety per cent of the holding at the time, was generated during the period of the Cold War (Figure 1). ${ }^{20}$ With a growing number of scholars following the public access to information route, more and more of this documentation is steadily becoming available. Some scholars, influenced by postmodernist theory, adopt the 'linguistic turn' and contribute to discourses that connect to global trends. These combined efforts, in pursuit of more nuanced understandings of the pervasive and enduring impact of this period of conflict on the processes of political and social change in southern Africa, give us a more complex picture of the dynamics of this war and its legacies.

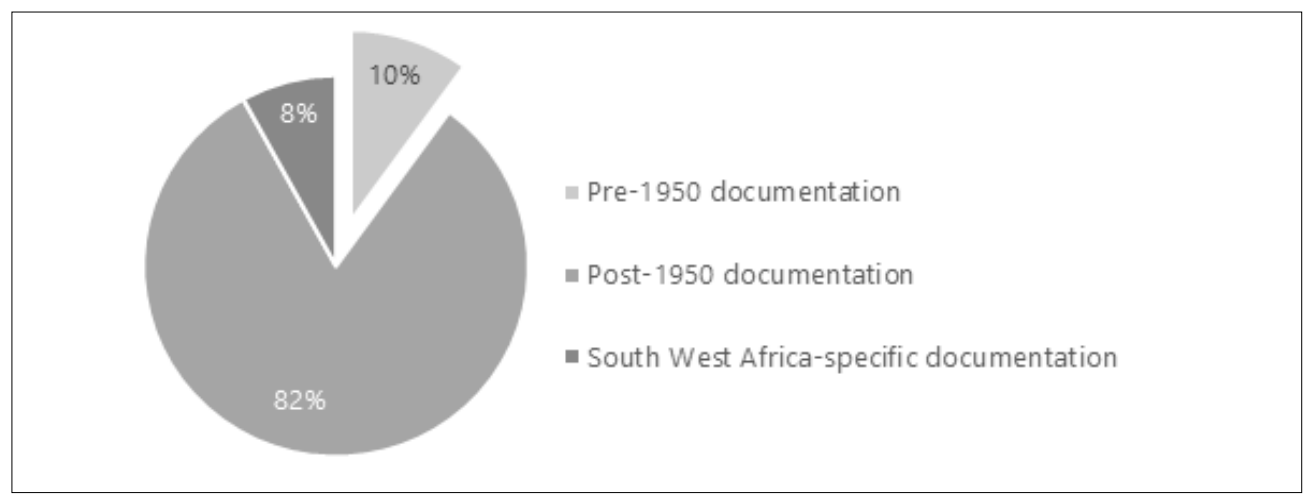

FIGURE 1 Total holding of the Department of Defence Archives (SANDF Documentation Centre), Pretoria, 1993

This book is organised in three parts, each comprising four chapters, a structure that reflects something of the diversity in the approaches of the twelve contributions. In South Africa, much of the history written on this war has a definite focus on the military side of the warfighting. This writing assumed, as much of it continues to do, a traditional approach to military history with a keen interest in diplomacy, military organisation, strategy and tactics, battlefield performance, and, as the matter of Cuito Cuanavale so ably demonstrates, in explaining victory or defeat. Part 1, called 'Places and Events', takes more of this traditional approach.

In Chapter 1, Chris Saunders addresses the question of 'borders'. There were several borders: the old 'imperial border' between the German and Portuguese empires; the international border settled in 1927 between South Africa and Portugal; the veterinary border or 'Red Line' and the so-called kaplyn. These 'borders', always 
porous, meant different things to different people. Saunders concentrates specifically on 'what happened on, along, and across that border during the war'. In Chapter 2, McGill Alexander draws the focus to the events of 26 August 1966, when members of the South African Police (SAP) and SADF attacked an ostensibly insignificant South West Africa People's Organisation (Swapo) base at Ongulumbashe. This clash marks the start of the twenty-three-year conflict. He concludes with some thoughts on the implications of the action at Ongulumbashe for the South African government of the day and their Swapo adversaries, in terms of the widening war and the changing international landscape. The effect of this widening war, specifically on the South African armour, is addressed by Jean-Pierre Scherman in Chapter 3. He argues that, although the SADF won the battles, at a strategic level the decision to escalate the conflict at the end of 1975 was ill-considered and the operation itself - SAVANNAH - was poorly planned and badly timed. These ideas are taken further on the strategic level by James Jacobs. In Chapter 4, he explains the strategic considerations confronting the South African government and the apparent need to manage domestic political reform alongside the creation of a secure environment in which negotiations might take place. He questions whether the escalating war created the buffer zone necessary for the South African government to negotiate the political settlement inside the country. In the end, Jacobs concludes that the Border War was perhaps little more than an expensive foreign adventure. These chapters remind us that victory is a complex business.Victory demands good leadership and command, adequate material resources, and well-trained and resilient troops, who, as a campaign progresses, gain experience and battle-hardiness. And, most of all, victory requires viable political objectives and outcomes.

There are no systematic studies on South African society, and the nature and extent of the social changes brought about by any war in which South Africans fought. The interests of War and Society historians are ranging. As Michael Neiberg has noted, these interests include 'such subjects as the relationships between home fronts and fighting fronts; the differences between history (what happened) and memory (a socially constructed and generally accepted version of that history); tensions between localism and nationalism; and the interactions between war, class, gender and race'. ${ }^{21}$ This approach, in a broader sense, incorporates war as a catalyst of socio-political change. The second part of this volume that emphasises societal systems and the mutually reciprocal impacts between those systems and the experience of the Border War opens up a number of these themes.

One of these themes is the development of nationalism and how communities are imagined and socially-constructed during times of conflict. ${ }^{22}$ Pretoria, realising that the widening war would demand increasing calls on society, and particularly the youth and the national treasure, implemented a sophisticated propaganda programme to steel young men for National Service, convince parents, and influence domestic and 
foreign public opinion. Rodney Warwick tackles this question of the militarisation of 'white' South African society in Chapter 5. The mobilisation of consent, growing rapprochement between English and Afrikaans-speaking white South Africans, and the development of a 'white South African' nationalism were critical pillars underpinning the war effort. However, as Evert Kleynhans explains in Chapter 6, these mechanisms to mobilise support for the war and consent for the changes it would bring were implemented well beyond the imagined limits of 'white society'. A youth movement, constructed on ethnic lines, was created for the Kavango in 1975 'to prevent the spread of communist propaganda, foster a sense of Kavango nationalism, and limit the political influence of ... Swapo amongst the local Kavango youth'. Pretoria harnessed the resources of, amongst other things, the Institute for African Studies at the then Potchefstroom University in their effort to implement a total national strategy that extended beyond the purely military domain into the social, political, economic, and cultural spheres.

A second theme that emerges in part two is society's response to the war and the government programmes associated with it. One of these responses came from the Progressive Federal Party (PFP), the official parliamentary opposition. Chapter 7 addresses this heretofore neglected dimension. The PFP was small, fractured, and lacked substantial power. The party, at times painted as unpatriotic and un-South African, was forced to steer a middle course when it came to many of the controversial and contentious issues of the day, including conscription and the implementation of the tenets of total national strategy. Caught in the crossfire between the government and organisations taking a more active stand against conscription, the PFP had to perform the usual functions of the parliamentary opposition, namely keeping the government accountable. This chapter clearly shows the importance of the oppositional parties, and the roles they played, in deepening our understanding of the impact of this war.

Anneke van Heerden, in Chapter 8, addresses a societal response of an entirely different kind. The Southern Cross Fund (SCF), a civilian, nationwide organisation, was set up and run by mothers and other women concerned about the welfare of the troops. It grew steadily from 1968 to become the largest civilian donor to the SADF. At its height, the SCF had 260 branches, with some 90 per cent of its funds allocated directly to the welfare of soldiers. The SCF was active and visible - at the time some 83 per cent of the white population was familiar with its objectives - and, averaging an annual income of R9 million, it became the second largest welfare organisation in the country. As Van Heerden shows, SCF activities served to unite white society, and particularly white women, as part of a responsive home front.

Part 3 views the war through a third lens - termed 'the soldiers' experience', an approach that has gained in popularity in South Africa as it has done elsewhere. Taking a cue from John Keegan ${ }^{23}$ and Richard Holmes, ${ }^{24}$ these scholars share interests with more traditional military historians, but, markedly, they embrace different 
methodologies and ask different questions. They want to understand the conduct of war and, adopting a 'bottom-up' view, focus on the recruitment and maintenance of soldiers, on how they fight, and on the experience of battle, and the consequences of that experience on themselves as individuals and their societies.

The four chapters - Chapters 9 to 12 - making up part three open up a number of these themes. Gary Baines, in Chapter 9, articulates the relationship between his younger self as a SADF conscript and his present self as both a veteran and a historian of the Border War. His contribution here, that almost takes the form of a life story, traces his personal development as a historian and particularly as a historian of the Border War. Not only did the National Service experience shape his views of and approaches to his writings on the Border War, but the war itself, and his writing about it have come to fashion his identity as an individual, as a veteran, and as a historian. In this way, he argues as a soldier-author, he has perhaps also come to terms with his 'embodiment as a veteran'.

Ian Liebenberg, in Chapter 10, addresses the socialisation of the approximately half a million young, white men, most of whom were conscripted and saw service in Namibia and Angola. Some of the questions resonate with those asked by Warwick in Chapter 5. However, taking an auto-ethnographic and sociological approach, Liebenberg's view is firmly 'from the bottom up'. Using his own experience as a veteran National Serviceman, he describes the process of socialisation and the creation, by a government requiring a reservoir of human resources, of 'a ready warehouse of willing (young) white men available for national defence'. In this way, Liebenberg attempts a wider understanding of the 'militarisation' of state and society.

Again, this went well beyond 'white South Africa'. In Chapter 11, Will Gordon set the context and describes the creation from 1975 of 32 Battalion. Starting as a faction of the FNLA, they were deployed as Bravo Group during Operation SAVANNAH and subsequently incorporated into the regular structures of the SADF as 32 Battalion. From the start, the unit, that comprised soldiers and their extended families, had a distinct character that remained until its disbandment in March 1993. In many ways, '32' was, and perhaps remains, an imagined community of a different kind. Gordon explains how the non-racial training and command methods, which were unusual for the time, innovative leadership and adaptability, and the development of strong smallunit cohesion, made an extremely effective fighting force. However, confronted with the ending of the Border War and then the tedium of township duties in South Africa, the battalion was disbanded, and its members integrated in 1994 into the new South African National Defence Force (SANDF).

The final chapter in the collection, Chapter 12, addresses the matter of leisure, comforts, and military canteens in the SADF. Leisure and consumption are further neglected themes in the historiography of this war. The South African Defence 
Force Institute (SADFI), perhaps better known by its Afrikaans contraction - SAWI (Suid-Afrikaanse Weermaginstituut), was embedded within the SADF. Staffed partly with military personnel, it ran shopping malls on military bases and plied mobile canteens in training and operational areas and provided recreational facilities for members of the SADF from small permissible profits margins. SAWI, therefore, performed other functions of military value for they were one of the mechanisms used to contain and control troops and break the boredom of base life through the donation of sporting facilities and games equipment. The Border War brought rapid growth to what had been a floundering organisation and, in a few years, SAWI had become the primary organisation that managed shops and canteens and sponsored the building and maintenance of recreational facilities.

In Different Times is the first attempt to bring together diverse scholars, using different lenses, to study this Southern African conflict. As a book, it focuses specifically on the SADF experience of the war. Although South Africa is a vastly different country today, the study of the Border War opens a range of questions, also relevant to contemporary deployments such as in Lesotho (1998) and the Central African Republic (2013). It also includes the debate on participation in foreign conflicts; the development, design and preparation of appropriate, modern, armed forces and their use as foreign policy instruments in far-off theatres; on military planning; and, as the historical controversies regarding the battles at Cuito Cuanavale and Bangui illustrate, on the interface between foreign campaigning and domestic politics. 


\section{Endnotes}

1 Fidel Castro, My Life, with Ignacio Ramonet (London: Penguin Books, 2008), 318.

2 John Keegan, War in History: Re-fighting World War II (London: Pimlico, 1995), 30-31.

3 Ian van der Waag, A Military History of Modern South Africa (Cape Town: Jonathan Ball Publishers, 2015), 245-247. See also McGill Alexander, Ch. 2, in this book.

4 Swathes of war-related documents have been declassified in South Africa and the United States; historians still await similar access in the former East Bloc archives. André Wessels, 'Half a Century of South African 'Border War' Literature: A Historiographical Exploration', Journal for Contemporary History, 42(2), 2017, available at: [http://journals. ufs.ac.za/index.php/jch/article/download/3360/3222/], 24-47.

5 The term was coined by Philip Graham, publisher of The Washington Post in the 1960s. Allister Sparks, First Drafts; South African History in the Making (Cape Town: Jonathan Ball Publishers, 2009), xi.

6 This was Willem Steenkamp's Adeus Angola (Cape Town: Citadel Press, 1976). Steenkamp later produced Borderstrike! South Africa into Angola (Durban: Butterworths Publishers, 1983) and South Africa's Border War, 1966-1989 (Gibraltar:Ashanti Publishing, 2016) in addition to a couple of regimental and formation histories, mostly co-authored.

7 Gabriel García Márquez, Operación Carlota: Los Cubanos en Angola El Che Guevara en África. La Batalla contra El Reich Sud Africano (Lima: Mosca Azul \& Horizonte Editores, 1977).

8 Leopold Scholtz, The SADF in the Border War, 1966-1989 (Cape Town:Tafelberg Publishers, 2013).

$9 \quad$ Steenkamp (2016).

10 The official histories include FJ. du Toit Spies, Angola: Operasie Savannah, 1975-1976 (Pretoria: SADF Directorate Public Relations, 1989), and Sophia du Preez, Avontuur in Angola: Die verhaal van Suid-Afrika se soldate in Angola, 1975-1976 (Pretoria: JL van Schaik, 1989).

11 Three early studies registered at South African universities are:W.A. Dorning, A Historical Analysis of the Military Strategic Implications for the Republic of South Africa of Unita's Activities in Angola, 79767983 (DPhil, University of the Orange Free State (UOFS), 1987);

J.C.K. van der Merwe, 'n Ondersoek na die ontstaan en verloop van Insurgensie in Owambo tot 1983 (MA, University of South Africa (Unisa),1985); and M.C. Dempsey, Die Militêre Konflik tussen die Suid-Afrikaanse Magte en Swapo in die Operasionele Gebied, 1974-1980 (MA, UOFS, 1984).

12 The first books published at foreign universities started as theses, for example, Piero Gleijeses, Conflicting Missions: Havana, Washington and South Africa, 1959-1976 (Chapel Hill: UNC Press, 2002); and Edward George, The Cuban intervention in Angola, 1965-1991: From Che Guevara to Cuito Cuanavale (London: Routledge, 2005).

13 Jacqui Thompson, An Unpopular War: From afkak to bosbefok (Cape Town: Zebra Press, 2006). Barry Fowler's Pro Patria (Sentinel Projects, 1995), available at: [http://sadf. sentinelprojects.com/index.html] was an early start but never in the public market.

14 This genre commenced with Jan Breytenbach, Forged in Battle (Cape Town: Saayman \& Weber Publisher, 1986), that initiated a considerable 32 Battalion literature, and led recently to Willem Steenkamp and Helmoed-Römer Heitman's book, Mobility Conquers: The Story of 61 Mechanised Battalion Group, 1978-2005 (Solihull, England: Helion \& Company, 2016). 
15 Early, article-length attempts to address the historiography of this war include Louise Jooste, 'Die Stand van Suid-Afrikaanse Militêre Geskiedskrywing oor die SA Weermag se Betrokkenheid in Suidwes-Afrika en Angola, 1966-1989', Scientia Militaria, 23(2), 1993, available at: [https://www.ajol.info/index.php/smsajms/ article/download/142915/132661], 9-18; and Ian van der Waag and Deon Visser, 'War, popular memory and the South African literature of the Angolan Conflict', Journal of Contemporary History, 34(1), 2009, available at: [https://www.academia. edu/199099/War_popular_memory_and_the_South_African_literature_of_the_ Angolan_conflict], 113-140. Later studies, that have widened the debate on the meaning of the literature, include Danielle Graham, 'Memories of the Border War: An Interpretive Analysis of White South African Defence Force Veteran Perspectives, 1966-1989' (MA, Dalhousie University, 2012), available at: [https://dalspace.library. dal.ca/bitstream/handle/10222/15409/Graham_Danielle_MA_HIST_August_2012. pdf? sequence $=3$ \&isAllowed $=y]$; and, more significantly, C.M.W. Doherty, ${ }^{\text {Bosbefok: }}$ Constructed Images and the Memory of the South African 'Border War" (DPhil, University of the Witwatersrand, 2014), available at: [http://wiredspace.wits.ac.za/ handle/10539/14820], and Gary Baines, South Africa's 'Border War': Contested Narratives and Conflicting Memories (London: Bloomsbury Publishing, 2013).

16 E.G.M. Alexander, 'The airborne concept in the South African military, 1960-2000: strategy versus tactics in small wars' (PhD, Unisa, 2016), available at: [https://core.ac.uk/ download/pdf/141500397.pdf].

17 Gary Baines (2013).

18 Gert van der Westhuizen, 'Práát oor die Grensoorlog', Die Burger, 7 September 2016.

19 However, that there are also real constraints must be recognised. See, for example, C.J. Jacobs, 'Die Problematiek in die Navorsing van Kontemporêre Krygsgeskiedenis in Suid-Afrika', Scientia Militaria, 23(2), 1993, available at: [http://scientiamilitaria.journals. ac.za/pub/article/view/308], 19-26.

20 Ian van der Waag, 'Military Record Preservation in South Africa, 1914-1992: a history of Directorate Documentation Service', Scientia Militaria, 23(4), 1993, available at: [http://scientiamilitaria.journals.ac.za/pub/article/view/291/333], 31.

21 Michael Neiberg, 'War and Society', in Matthew Hughes and William J. Philpott, eds., Palgrave Advances in Modern Military History (Basingstoke, England: Palgrave, 2006), 42.

22 Benedict Anderson, Imagined Communities: Reflections on the Origin and Spread of Nationalism (London:Verso Books, 1991).

23 John Keegan, The Face of Battle (London: Jonathan Cape (Penguin Random House, 1976).

24 Richard Holmes, Acts of War: The Behaviour of men in battle (London: Random House, 1985). 
Part ONE

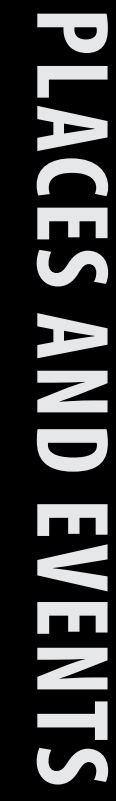




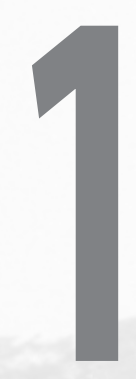

\title{
THE NAMIBIAN/ANGOLAN BORDER
} IN THE NAMIBIAN WAR FOR INDEPENDENCE

\author{
Chris Saunders
}


The war fought in northern Namibia and southern Angola from 1966 to 1989, now sometimes called the 'Namibian war for independence', ${ }^{1}$ was fought across the border between Namibia and Angola. While the term 'border' is often used for a boundary line on a map, it may also be an area adjacent to that line, sometimes also called a 'border region/zone', 'borderland' or 'frontier', the extent of which often remains vague. ${ }^{2}$ In this case, it can arbitrarily be said to be the area stretching, say, twenty miles north and south of the boundary line itself. The line that divides Namibia and Angola was, and is, a long one, made up of different parts. In the west, it begins at the Atlantic Ocean and runs to present-day Zambia, with several distinct geographical and demographic features along the way. In the sparsely populated west, the boundary line passes through what is largely semi-desert. In the central, relatively densely populated portion there is no river to form a natural barrier to movement, and the boundary line separates Oshivambo-speaking people north and south of it. In the east, where the boundary with Angola ends and that with Zambia begins, the border then runs along the area known until recently as the Caprivi, the strip of land that joins the rest of Namibia to the Zambezi River. ${ }^{3}$ A fundamental point about the Namibian/Angolan boundary line is that it was demarcated arbitrarily, drawn by colonial authorities on maps in Europe, ${ }^{4}$ initially to separate Portuguese territory to the north from German territory to the south. In places, the line ran along the Kunene and Kavango Rivers, but elsewhere it was merely drawn along a line of latitude. This line was only finally agreed upon between South Africa, as the country occupying Namibia in terms of a League of Nations mandate, and Portugal in 1927. The line divided people living on both sides, who spoke the same language and shared common allegiances, and it cut through a complex and integrated ecosystem. ${ }^{5}$

This chapter will not explore the history of how the Namibia-Angola border has been defined, nor focus on its geographical and environmental features, except concerning the movement of people across the border during the liberation war. While there are sociological studies of particular places along the border between occupied Namibia and Angola, the history of what happened on, along, and across that border during the war remains largely unexplored, especially in the scholarly literature. ${ }^{6}$ Important questions, such as how much such movement there was, north to south and south to north, remain to be analysed. To the extent that the border area has almost always been looked at from one side in the relevant literature on the war, that of South Africa's involvement in the war. ${ }^{7}$ As the historian must view the past as dispassionately as possible, that means, in the study of any border, viewing it from both sides. In this preliminary survey, I will first sketch some aspects of the role of the border area mainly from the side of South African-occupied Namibia, then from that of Angola, before proceeding to some concluding thoughts about the role of the border in the war and the legacies of that role. 


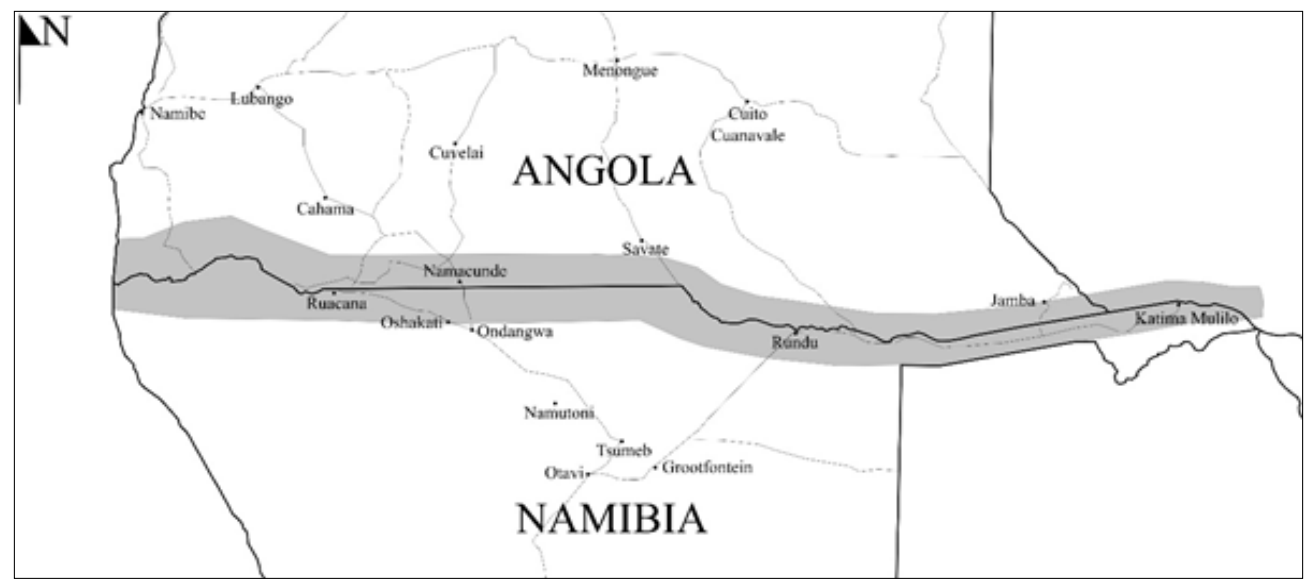

MAP 1.1 The zone of contention along the Angolan-Namibian border

We lack a detailed study of the history of the Namibian/Angolan border similar to one recently completed on another semi-barrier, one to the south of the Namibian/ Angolan border, the so-called Red Line, a veterinary fence that demarcated Namibia's white-owned farming land from African-occupied land to the north. The Red Line, unlike the Namibian/Angolan boundary, did not divide two countries. Its historian, Giorgio Miescher, nevertheless calls it 'an imperial border', suggesting that it marked the extent of South Africa's imperial reach into Namibia and he goes on to claim that the Red Line had 'a greater symbolic and practical significance than any international border' ${ }^{8}$ That did not remain the case once the liberation war had begun, though the Red Line did, in a sense continue to demarcate the zone of the 'Border War', as white South Africans referred to the war that took place north of it. A recent book of reflections by South African soldiers on their involvement in the Border War is therefore titled, North of the Red Line. ${ }^{9}$ However, it was the international border between Namibia and Angola, which South African troops called the 'cut-line' that increasingly became a key line of division, as this chapter will try to show.

The use of the term 'Border War' to refer to the war fought in northern Namibia and southern Angola in the 1970s and 1980s was of course deliberately vague, for it did not specify which border was involved. As Gary Baines has explained, the term was 'used by the apartheid state to perpetuate the fiction that SADF troops were protecting South Africa's border and not fighting on foreign soil'. ${ }^{10}$ When those troops went into Angola in 1975, the entire operation was kept secret for as long as possible because the government needed parliamentary approval to send troops into a foreign country. Some of the South Africans fighting in southern Angola were surprised to hear on the radio the South African government denying that it had any troops in that country. ${ }^{11}$ 
In the white South African imagination, the Namibian/Angolan border became a war against the forces of communism and terrorism, especially after the Popular Movement for the Liberation of Angola (MPLA) came to power in Angola in November 1975. The liberation movement, the South West Africa People's Organisation (Swapo), embodied these 'evil' forces that were both committing acts of violence to try to end the South African occupation of Namibia and seen as Soviet puppet. ${ }^{12}$ To many in Swapo, on the other hand, the political border itself may have been viewed as an artificial and colonial construct. Their goal was the removal of what they saw as a racist and foreign occupation of the country south of the line of territorial division between the country that was hosting them in exile, Angola, and their own country, Namibia.

In the late 1960s, South African military personnel stationed in Angola in support of the Portuguese regime there, were part of a secret military alliance between the South African and Portuguese governments. ${ }^{13}$ After protracted negotiations with Portugal, the white minority South African government signed an agreement in 1969 to build the Ruacana hydro-electric scheme on the Kunene River, with an associated dam at Calueque in Angola. ${ }^{14}$ A pipeline was to be built to deliver water from the Kunene at that point to Ovamboland in northern Namibia. The South African Defence Force (SADF), having taken over responsibility for security in Namibia from the South African Police the year before, initially invaded Angola from northern Namibia in August 1975 to protect its investment in the Ruacana-Calueque scheme, not yet completed, and in particular to secure the Calueque Dam. Then in October that year, South African troops rapidly moved much further north into Angola and in November found themselves up against Cuban forces not far from the Angolan capital, Luanda. Faced with fierce resistance led by the Cubans, the South African forces retreated, and the last of them withdrew back across the border into Namibia in late March 1976. It was then, on the border at Ruacana that secret meetings took place between South African and Angolan officials from mid-1976 onwards, meetings to discuss matters of mutual interest, including continued work on the Calueque Dam. ${ }^{15}$

The next turning point in the war came in May 1978, when the SADF carried out a massive raid into southern Angola, not only by air on the Swapo camp at Cassinga way beyond the border area but also overland across the boundary line to destroy Swapo's nearby Vietnam camp at Chetequera. From that camp, over two hundred Namibian prisoners, only some of whom were members of Swapo's armed wing, the People's Liberation Army of Namibia (PLAN), were taken back into Namibia and held incommunicado for years at Mariental in the south of the country. They were eventually released in 1984, in part thanks to pressure by the International Red Cross on the South African authorities. ${ }^{16}$ For a decade after the so-called Cassinga Raid, the SADF, South West African Territorial Force (SWATF) troops, Battalions 31 and 32 and the militarised police counterinsurgency unit known as Koevoet undertook numerous other raids, some even larger, others small-scale, across 
the border. ${ }^{17}$ A soldier who served in 32 Battalion, which consisted of ex-Angolan guerrillas under white leadership, reported in 1980 as follows:

Our main job is to take an area and clear it. We sweep through it, and we kill everything in front of us ... And Swapo still get[s] by us and cross the cut-line between Angola and Namibia. It's not as if we are stopping them. ${ }^{18}$

From 1975, the South African authorities tried to prevent movement across the border between Ovamboland and Angola by replacing the existing fence with a $450 \mathrm{~km}$ long two-metre-high fence topped with barbed wire. Land on either side of the fence, up to a kilometre wide, was cleared of homesteads, in the process destroying some farming activity. ${ }^{19}$ But all attempts to make the so-called cut-line impenetrable proved ineffective. As movement across the borderline continued, from 1981 South African forces occupied a strip of territory north of it in southern Angola to try to prevent Swapo from operating from Angola into northern Namibia. Occasionally, the SADF negotiated with the Angolans on ways to prevent Swapo operations into northern Namibia. An agreement to that end, reached by the South African and Angolan governments in February 1984 and brokered by the United States, set up a joint monitoring commission: South African troops would withdraw from southern Angola, and in return the Angolan army would prevent Swapo entering the so-called 'area in question', which extended south to the Namibian-Angolan border. After long delays, the last South African troops withdrew from Angola in April 1985, over the border into Namibia as they had in March 1976, but this time with more ceremony. "Led by a brass band playing Clementine", it was reported at the time that:

... 450 South African soldiers and a big white dog that became their mascot left Angola ... General ConstandViljoen, Chief of the South African Defence Force, saluted his men as they rumbled by in dusty, mine-proof vehicles. ${ }^{20}$

From the late 1970 s, the SADF supplied weapons and other support to its ally Unita, whose headquarters were at Jamba in Angola, not far north of the border, and Unita effectively controlled the whole eastern section of the Namibian-Angolan border, preventing Swapo from operating there. ${ }^{21}$ When Unita appeared threatened by the advance of the Angolan army, the SADF struck hard across the border, with troops and from the air, first in 1985 and then again in October 1987, when the Angolan army suffered massive losses near the Lomba River. But then in 1988, negotiations between Cuba, Angola and South Africa began that led to the agreement that brought the war to an end. In part, because of what happened near Cuito Cuanavale (the battle there is not addressed here, because it took place beyond the border area), and because of the Cuban forces moving south for the first time, close to the Namibian border. $^{22}$ At the end of August 1988, the last South African troops moved south from Angola across the border. As in April 1985, there was a small ceremony as they did 
so, and iconic photographs of the withdrawal show vehicles passing under a banner that proclaimed them as 'winners' as ratels of South Africa's 61st Mechanised Brigade crossing a pontoon over the Kavango River. ${ }^{23}$ The following April, on and after the day on which a ceasefire came into effect, South African forces, military and police, were again involved in operations just south of the border against Swapo forces that had crossed the border from Angola. ${ }^{24}$

There was a massive movement of South African troops and their auxiliaries, including San trackers and those conscripted into SWATF, across the Namibian-Angolan border in 1975/76 and again from 1978 to 1988, with troops stationed in bases along the border. Some South African forces - most notoriously Koevoet, whose members were rewarded financially for every Swapo guerrilla they killed ${ }^{25}$ - terrorised the local population. Massive quantities of ivory and rhino horn were brought across the border from Angola, mostly illegally. ${ }^{26}$ These forces caused enormous destruction to the environment, and much of the infrastructure that existed in the border area in southern Angola. Though South African troops had withdrawn from the border area north of the cut-line by the end of August 1988, Koevoet continued to be active in chasing after PLAN combatants across the boundary-line, and that para-military force was only disbanded shortly before the first democratic election in Namibia in November $1989 .{ }^{27}$

If we now turn our attention to the 'other side' in the war, we can turn our focus to Swapo guerrillas in 1965 who, having moved into northern Namibia through the Caprivi, established a base at Ongulumbashe, a little way south of the Angolan border. That base, including its underground tunnels, occupied by only sixteen guerrillas at the time, was destroyed by a South African police unit, aided by military helicopters, in August 1966. ${ }^{28}$ Until 1975, the war in the border area south of the cut-line remained very low-key, with occasionally lobbing mortars at South African facilities. The border itself remained very porous, with people moving easily across it in both directions. ${ }^{29}$ Swapo and Unita were allies at this time, and people easily shifted allegiances between the two movements. ${ }^{30}$

The single most important turning point in the entire liberation war came with the decision of the government of Portugal, after the April 1974 coup d'etat in Lisbon, to withdraw from Angola. Once news of this reached northern Namibia, thousands moved across the border into Angola to escape the oppressive South African occupation and to join Swapo in exile. Marion Wallace writes in her general history of Namibia:

With the end of Portuguese rule in Angola, Namibia's northern border with Angola effectively opened in mid-1974, making it possible to send fighters of ... PLAN directly into the Swapo heartland of Ovambo, where military action escalated from mid-1975. ${ }^{31}$ 
From 1976, Swapo was able to establish bases in southern Angola, some not far from the Namibian border. Taking their orders from the main military headquarters of PLAN at Lubango in southern Angola, guerrillas crossed the border on foot into northern Namibia in platoons. Sometimes they hid amongst cattle driven across the border. ${ }^{32}$ Most PLAN activities took place in the wet season, from December to March, when water was available, and tracks were less easy to follow, and there was more cover from the sparse bushes. ${ }^{33}$ Some PLAN fighters mobilised the local population in Kavango and elsewhere in northern Namibia before returning to Angola, ${ }^{34}$ but most of the combatants who crossed the border to move southwards were either killed or captured. Some of those captured by the SADF were if they refused to switch sides and fight for South Africa, drugged, put on planes and dropped into the sea to their deaths, in what was known as Operation BARNACLE. ${ }^{35}$ From the early 1980s, Swapo could not send its fighters into Namibia via south-eastern Angola because of the presence of Unita there, heavily supported by the South Africans. Instead, elite PLAN units Volcano, then Typhoon, mainly operated into Ovamboland, from where they sometimes moved further south into the white farming areas. ${ }^{36}$

The area immediately north of the Namibia-Angola boundary was transformed in April/May 1988 by the arrival, for the first time, of Cuban forces, who, moving southwards towards the border, quickly rebuilt and expanded the airfields at Xangongo and Cahama, allowing the Cubans to win air-superiority over the entire border area. It was from these airfields that a dozen MIG-23s took off on 27 June 1988 to bomb the South African forces at the Ruacana-Calueque Dam site, in retaliation for a South African offensive against Cuban forces in southern Angola. In this attack, the bridge and sluice-gates at the dam site were severely damaged, along with the pipeline to Ovamboland, while the last bomb dropped killed eleven South African conscripts who were watching the attacking planes. ${ }^{37}$ This incident, and the possibility of further, more deadly clashes, concentrated the minds of the South African, Angolan and Cuban government representatives then involved in negotiating a settlement. That led to the agreements signed between August and December 1988 that provided for the implementation of the process leading to the independence of Namibia. ${ }^{38}$

On 1 April 1989, the day that process began, hundreds of PLAN combatants infiltrated across the Angolan/Namibian border to try to set up bases in northern Namibia, hopefully under the auspices of the United Nations Transition Assistance Group, that was supposed to be in place by that date. Instead, the PLAN combatants found themselves being attacked by South African forces, whom the head of the UN mission in Namibia, Martti Ahtisaari, agreed should be allowed to leave their bases. Over three hundred PLAN fighters were killed and buried in mass graves. Once the settlement process was back on track, from June 1989 tens of thousands of refugees began to return to Namibia from Angola, mostly under the auspices of the UN High 
Commission for Refugees. While most travelled by air, some were transported across the border by land. Amongst the over forty thousand who returned to Namibia were those who had been detained and tortured in the notorious Swapo prison camp at Lubango in southern Angola. Finally in April 1990, the month after Namibia's independence, the last PLAN forces, with their weaponry, crossed the border from Angola back into Namibia in triumph. ${ }^{39}$

We can conclude this section of the chapter by noting that while PLAN activity across the border from Angola into Namibia waxed and waned during the years of war, it continued despite all South Africa's efforts to prevent it, such as the presence of tens of thousands of South African troops in the border area. The militarisation of the border zone increased throughout the 1980s, with South African bases being placed deliberately adjacent to schools in northern Namibia. Support for Swapo amongst the local population remained strong, despite the terror meted out by the occupying forces. They showed this through the school boycotts of 1988 in Ovamboland, that began with a demand that the SADF move the South African bases away from the schools, and also by the overwhelming support given to Swapo by those in the border area who voted in Namibia's first democratic election in November $1989 .{ }^{40}$

With military bases in southern Angola at the time, Swapo carried the war southwards across the border to try to end the South African occupation of Namibia. They wanted to bring about that country's independence, while the SADF and its allies repeatedly crossed the border northwards into Angola in its efforts to defeat the Swapo liberation struggle and prevent Swapo from coming to power in an independent Namibia. This chapter has sought to show how, over 23 years, the border area was central to the war fought between South African and Namibian forces. Throughout the war it remained contested terrain: the outstretched border was never a total barrier to movement, despite the South African efforts to restrict the movement of people across it and to create an effective barrier. Though much of the relevant literature see it from the South African/Namibian side, people moved across it in both directions, and it remained relatively porous. In 1979 to 1980, there were extensive discussions between the South African government, Swapo, the Frontline states, including Angola, and the Western Contact Group, on the modalities of creating a Demilitarised Zone (DMZ) to extend up to $50 \mathrm{~km}$ on either side of the border fence, but could not reach an agreement on how to effect such a DMZ. Despite the fence built along the central portion of the border, the situation along even that section of the border remained fluid, with South African forces unable to prevent Swapo incursions. On numerous occasions, South African forces carried the war into southern Angola, at vast cost in devastation and destruction there. ${ }^{41}$ Though the Swapo attempts to establish 'liberated zones' or bases in northern Namibia failed, in the end, South Africa withdrew from Namibia and Swapo came to power there in 1990. 
The border never became an impermeable barrier to movement: family and ethnic ties ensured that remained the case, as did refugee flows and cross-border traffic in people and goods, but at a much-reduced level when war raged in the area. While those fighting in the war crossed the border, in both directions, for relatively short periods, Namibian refugees spent decades in Angola before returning to Namibia, while perhaps an equal number of Angolan refugees settled in Namibia. ${ }^{42}$ Though the colonial political boundary was an arbitrary one, it socialised people as members of a territorial entity, and the very fact that Swapo was a nationalist movement, fighting for national independence, helped make the boundary between the two countries a key divisive symbol in the consciousness of the local people, who knew it as onhaululi, meaning 'the divide'. ${ }^{43}$ The boundary would anyway have imposed a sense of national identity and exclusivity, based in part on the different colonial languages spoken in the two countries, English and Afrikaans to the south of the border and Portuguese to the north, despite the same indigenous language spoken both north and south of the boundary line. The war for Namibian independence emphasised the sense of difference created by that line.

With the re-igniting of the civil war in Angola from 1992, the border remained unstable, with refugees again crossing from southern Angola, as the Namibian government allowed Angolan forces to operate against Unita immediately north of its territory. ${ }^{44}$ An armed attempt at secession in the Caprivi in 1999 caused further instability in the eastern border area..$^{45}$ After the end of the Angolan civil war in 2002, however, the border remained peaceful, with much-increased interchange across it, more than across any other of Namibia's national borders. ${ }^{46}$ With a new majority government in power in South Africa from 1994, Angola hoped for reparations from that country for the destruction it had caused in southern Angola in the 1980s, ${ }^{47}$ but, to date, none has been forthcoming. Some of the consequences of the war remain visible in the border area to this day, but reconstruction continues, with a new hydroelectric power scheme on the Kunene River planned to go ahead, not at Epupa, as was originally planned, but at Baynes, $200 \mathrm{~km}$ downstream of Ruacana. If built, Namibia and Angola will equally share its 600 Megawatts. ${ }^{48}$ With increasing cross-border trade, there is ever-greater cooperation between the two governments on border issues, some within the context of the Southern African Development Community's TransKunene Corridor initiative, for SADC's goal is freer movement of people and goods. That the war is not forgotten in the era of peace, can be seen in the discovery of more mass graves in northern Namibia, ${ }^{49}$ the erection of war memorials, ${ }^{50}$ and the various forms of what some now call 'war tourism' from Namibia and South Africa across the border into Angola. ${ }^{51}$ 


\section{Endnotes}

1 E.g. Richard Dale, The Namibian War of Independence, 1966-1989. Diplomatic, Economic and Military Campaigns (Jefferson, North Carolina, USA: McFarland Books, 2014).Yves Debay uses the term 'Angola-South West Africa War' in Hanlie Snyman Wroth and Gerry van Tonder, North of the Red Line. Recollections of the Border War by Members of the SADF and SWATF: 1966-1989 (Pinetown: 30 Degrees South Publishers, 2016), 11.

2 There is a large literature on borders in Africa. A recent article is Audie Klotz, 'Borders and the Roots of Xenophobia in South Africa', South African Historical Journal, 68(2), June 2016, available at: [10.1080/02582473.2016.1153708],180-194. Cf. Solomon M. Nkiwane, 'Border Issues and Conflicts in Southern Africa', Peace Research, 25(1), February 1993, available at: [https://www.jstor.org/stable/23607225], 67-76.

3 The classic account by a geographer is John H. Wellington, South West Africa and Its Human Issues (Oxford, England: Clarendon Press, 1959). Caprivi is now the Zambezi Province.

4 For how the boundary line was drawn see, inter alia, Lazarus Hangula, The International boundary of Namibia (Windhoek: Gamsberg Macmillan, 1993); Saki Akweende, International Law and the Protection of Namibia's Territorial Integrity (Dordrecht, Nederland: Martinus Nijhoff Publishers, 1997); Randolph Vigne, 'The moveable frontier. The Namibia-Angola boundary demarcation 1926-1928', in Patricia Hayes, Jeremy Silvester, Marion Wallace and Wolfram Hartmann, eds., Namibia under South African Rule. Mobility and Containment 1915-46 (Athens, Ohio, USA: Ohio University Press, 1998), 289-304. Cf. Gregor Dobler, 'Boundary Drawing and the Notion of Territoriality in Pre-Colonial and Early Colonial Ovamboland', Journal of Namibian Studies, 2008, available at: [https:// www.researchgate.net/publication/259934389_Boundary_drawing_and_the_notion_of_ territoriality_in_pre-colonial_and_early_colonial_Ovamboland].

5 Emmanuel Kreike, Re-Creasing Eden. Land Use, Environment and Society in Southern Angola and Northern Namibia (Portsmouth, England: Heinemann Publishers, 2004).

6 Sociological studies of places on or close to the border include Mattia Fumanti, The Politics of Distinction: African Elites from Colonialism to Liberation in a Namibian Frontier Town (Kingston: Sean Kingston, 2016). Cf. Mattia Fumanti, 'Burying E.S.: Educated Elites, Subjectivity and Distinction in Rundu, Namibia', Journal of Southern African Studies, 33(3), September 2007, available at: [https://www.jstor.org/stable/25065221], 469-483; and on Kaokoland to the west, John T. Friedman, 'Cultivating Ambiguity in (Post-) Colonial Namibia; Reflections on 'History' and Conflict in Kaokoland', The Cambridge Journal of Anthropology, 27(2), 2007-2008, available at: [https://www.jstor.org/ stable/23820814?seq=1\#page_scan_tab_contents], 57-76. For a bibliography of works on the Border War see Gert van der Westhuizen, 'Bibliography on the Border War' in Ian Liebenberg, Jorge Risquet and Vladimir Shubin, A Far-Away War. Angola 1975-1989 (Stellenbosch: African Sun Media, 2015), 165-200.

7 There is now a considerable literature by and about South Africans who crossed the border to fight in southern Angola: memoirs such as Granger Korff, 19 with a Bullet: A South African Paratrooper in Angola (Pinetown: 30 Degrees South Publishers, 2009); collected accounts such as Jacqui Thompson, An Unpopular War: from Afkak to Bosbefok: Voices of South African National Servicemen (Cape Town: Zebra Press, 2006), and accounts by South African military personnel include Jannie Geldenhuys, At the Front. A General's Account of South Africa's Border War (Johannesburg: Jonathan Ball Publishers, 2009) and Willem Steenkamp, Borderstrike! South Africa Into Angola 1973-1980 (3rd ed. Durban: Just Done Publications, 2006). 

(New York: Palgrave Macmillan Publishing, 2012), 201-202.

$9 \quad$ Wroth and Van Tonder (2016). A South African soldier who patrolled the Red Line during the war emphasised to me that it was a more effective barrier than the border itself: Sean O’Sullivan, interviewed by Chris Saunders, Cape Town, March 2017.

10 Gary Baines, South Africa's 'Border War': Contested Narratives and Conflicting Memories (London: Bloomsbury Publishing, 2013), 2. Cf. Christo Doherty, 'Gary Baines, 'South Africa's 'Border War': Contested Memories and Conflicting Narratives', Journal of Contemporary History (JCH), December 2016, available at: [http://journals.ufs.ac.za/ index.php/jch/article/view/715], 273-281; Ian van der Waag and Deon Visser, 'War, Popular Memory and the South African Literature of the Angolan Conflict', JCH, 34(1) 2009, available at: [https://www.academia.edu/199099/War_popular_memory_and_the_ South_African_literature_of_the_Angolan_conflict], 113-140. Cf. Lesley Marx, 'Bodies and Borders:Vietnam/Namibia', Safundi. The Journal of South African and American Studies, 2007, available at: [https://doi.org/10.1080/17533170701295405]; Daniel Conway, 'Somewhere on the border of credibility: the cultural construction and contestation of 'the border' in white South African society' in Gary Baines and Peter Vale, eds., Beyond the Border War: New perspectives on Southern Africa's Late-Cold War Conflicts (Pretoria: Unisa Press, 2008), 75-93.

11 Willem Steenkamp, South Africa's Border War (Cape Town: Tafelberg Publishers, 2016).

12 A South African Air Force song even ran: 'To Strike at dawn that was their task. Against the Swapo swine, to kill the commies in a group. Before they cross the line ...': quoted in Neta C. Crawford, Argument and Change in World Politics (Cambridge: Cambridge University Press, 2002), 378-379.

13 Alcora (Aliança Contra as Rebeliões em Africa); and Aniceto Afonso and Carlos de Matos Gomes, Alcora (Lisbon: Divina Comédia, 2013).

14 The best work on this remains Renfrew Christie's 'White Power in Angola and Namibia. The Kunene River Hydro-Electric Schemes' (BA Honours thesis, University of Cape Town (UCT), 1974), available at: [http://namibia.leadr.msu.edu/files/original/ b3096ae59bc643d8eeb05b4f1ac6b34a.pdf]; and Christie's 'The Political Economy of the Kunene Hydro-electric Schemes' (MA thesis, UCT, 1975), available at: [https://open. uct.ac.za/handle/11427/11770?show=full]; and 'Who Benefits by the Kunene HydroElectric Schemes', Social Dynamics, A journal of African studies, 2(1), 1976, available at: [https://www.tandfonline.com/doi/abs/10.1080/02533957608458173], 31-43. South Africa would only agree to this scheme if Portugal agreed to the Cabora Bassa scheme in Mozambique as well (Christie 1975, 163).

15 Chris Saunders, 'The South Africa-Angola talks, 1976-1984: A little-known Cold War thread', Kronos, 37(1), 2011, available at: [http://www.scielo.org.za/scielo.php?script $=$ sci_ arttext\&pid=S0259-01902011000100007], 104-119.

16 See e.g. Allister Sparks, 'Pretoria Thwarts Suit Seeking Release of Prisoners in Namibia', Washington Post, 3 May 1984. The term Cassinga prisoners were often used for them, but none came from Cassinga, for the SADF operation there was an airborne one and no prisoners could be taken.

17 There is considerable literature on the SADF raids into Angola: see, for example, Leopold Scholtz, The SADF in the Border War (Cape Town: Tafelberg Publishers, 2013). On the formation of 32 Buffalo Battalion, see Jan Breytenbach, Forged in Battle (Pretoria: Protea Books, 2014). Cf. Gerhard J.J. Oosthuizen, 'Regiment Mooirivier and South African Transborder Operations into Angola during 1975/76 and 1983/84', Historia, 49(1), May 2004, available at: [https://journals.co.za/content/hist/49/1/EJC38139], 135-153. For life as a SADF conscript on the border see Anthony Akerman, Somewhere on the Border (Johannesburg: Wits University Press, 2012), a play written in the 1980s. 
19 Gregor Dobler, Traders and Trade in Colonial Ovamboland (Basle: Basler Afrika Bibliographien, 2014), 182-183. Cf. Colin Leys and Susan Brown, eds., Histories of Namibia. Living through the Liberation Struggle (London: Merlin Press, 2005), 56, for the account by Veikko Munyika of how his father's farm was destroyed by the building of the cut-line.

20 United Press International, 'South African soldiers withdraw from Angola', Chicago Tribune, 18 April 1985, available at: [http://articles.chicagotribune.com/1985-04-18/ news/8501220899_1_south-african-defense-force-angola-cape-town].

21 On Jamba, see Justin Pearce, Political Identity and Conflict in Central Angola, 1975-2002 (Cambridge: Cambridge University Press, 2014).

22 Cf. Bernice Labuschagne, 'South Africa's Intervention in Angola: Before Cuito Cuanavale and Thereafter' (MA thesis, Stellenbosch University, 2012), available at: [https://scholar. sun.ac.za/handle/10019.1/1830].

23 The photographs are in the John Liebenberg Collection, Special Collections, University of Cape Town Library, and reproduced in Patricia Hayes and John Liebenberg, Bush of Ghosts. Life and War in Namibia 1986-90 (Cape Town: Umuzi, 2010). Cf. Willem Steenkamp and Helmoed-Römer Heitman, Mobility Conquers: the Story of 61 Mechanised Battalion Group 1978-2005 (Solihull, England: Helion and Company, 2016).

24 Peter Stiff, Nine Days of War and South Africa's Final Days in Namibia (Alberton: Lemur Books, 1991).

25 The success of their operations was measured by the number of ears they took back to their base. Cf. Jim Hooper, Koevoet. Experiencing South Africa's Deadly Bush War (Havertown, USA: GG Books, 2012).

26 Unita and SADF soldiers are thought to have killed more than a hundred thousand elephants and thousands of rhinos in southern Angola in the 1980s: M.E. Kumleben, Report of the Commission of Inquiry into the Alleged Smuggling of and Illegal Trade in Ivory and Rhinoceros Horn in South Africa (The Commission, 1996); Michael Chase and Curtice Griffin, 'Elephants of south-east Angola in war and peace: their decline, re-colonization and recent status', African Journal of Ecology, 49 (3), 2011, available at: [https://www. researchgate.net/publication/230547057_Elephants_of_south-east_Angola_in_war_and_ peace_Their_decline_re-colonization_and_recent_status], 353-361, 357.

SADF soldiers were engaged in large-scale smuggling of ivory and horn: Jan Breytenbach and Peter Stiff, Covert War. Koevoet Operations Namibia 1979-1989 (Alberton: Galago Books, 2004), Ch. 37. South African troops were confined to a base at Grootfontein, south of the border area during the transition period.

Cf. the paper on this operation presented by McGill Alexander to the symposium on the Border War, Stellenbosch, August 2016.

30 V.A. Shigwedha, 'The Relationship between Unita and Swapo:Allies and Adversaries', JSAS, 30(6), 2014, available at: [https://www.tandfonline.com/doi/abs/10.1080/030 57070.2014.967505]. Cf. Patricia Hayes, 'Nationalism's exile: Godfrey Nangonya and Swapo's sacrifice in southern Angola', JSAS, 40(6), November 2014, available at: [https:// www.academia.edu/9936534/Nationalisms_exile._Godfrey_Nangonya_and_SWAPOs_ sacrifice_in_southern_Angola], 1305-13JSAS, 40, 10.1080/03057070.2014.970038.

31 Marion Wallace, A History of Namibia. From the Beginning to 1990 (London: C. Hurst and Co, 2011), 279.

O’Sullivan (2017). 
33 The role of the Namibian/Zambian border during the war deserves a separate study. After an attack on Katima Mulilo from Zambia in August 1978, and retaliation by the SADF into Zambia, Swapo operations from Zambia ceased and the main focus of the war switched to Ovamboland and Kavango. On Caprivi, see Bennett Kangumu, 'A forgotten corner of Namibia: aspects of the history of the Caprivi Strip, c1939-1980' (MA thesis, UCT, 2000), available at: [https://www.academia.edu/28282263/ Final_version_of_this_article_as_published_by_JSAS], Ch. 2; Wolfgang Zeller, 'Neither Arbitrary nor Artificial: Chiefs and the Making of the Namibia-Zambia borderland', Journal of Borderlands Studies, 25, 2010, available at: [https://www.researchgate.net/ publication/239796224_Neither_arbitrary_nor_artificial_Chiefs_and_the_making of_the_Namibia-Zambia_borderland], 6-21. Caprivi was Sector 70 of South Africa's so-called 'operational zone'.

34 Cf. the account of Johannes 'Mistake' Gaomab, describing the three months his platoon spent in Kavango in 1980: Leys and Brown (2005), 64.

See 'Operation BARNACLE', Secret South Africa [website], August 11, 2010, available at: [https://secretsouthafrica.wordpress.com/tag/wouter-basson/]. Details of this emerged in testimony by Johan Theron at the trial of Dr Wouter Basson: see e.g. 'Assassin Exposed Basson', News24, 6 December 2000, available at: [http://www.news24.com/SouthAfrica/ Assassin-exposed-Basson-20001206].

36 Cf. the story of Gaomab in Leys and Brown (2005), 69, but also Oswin Namakulu, Armed Liberation Struggle: Some Accounts of PLAN's Combat Operations (Windhoek: Gamsberg Macmillan, 2004).

Edward George, The Cuban Intervention in Angola: 1965-1991: from Che Guevara to Cuito Cuanavale (London: Frank Cass Publishers, 2005), 245.

38 On the making of these agreements, see Chester Crocker, High Noon in Southern Africa (New York: Oxford University Press, 1992).

39 As can be seen in a moving video on YouTube: Namibia Media Initiative, 'Omakoma e Uya', 3 April 2015, available at: [https://www.youtube.com/watch? $v=8 N 3 t 7$ Gcqdtw]. For a vivid account of a visit to the border area in 1989 see Ben Carton, 'Unfinished Exorcism: The Legacy of Apartheid in Democratic Southern Africa', Social Justice, March 2000, available at: [https://www.researchgate.net/publication/301231924_Unfinished_ Exorcism_The_Legacy_of_Apartheid_in_Democratic_South_Africa].

40 Denis Herbstein and John Evenson, The Devils Are Among Us (London: Zed Press, 1989); Brian Wood, 'Preventing the Vacuum: Determinants of the Namibia Settlement', JSAS, 17(4), December 1991, available at: [https://www.researchgate.net/ publication/248961891_Preventing_the_vacuum_determinants_of_the_Namibia_ settlement], 742-769.

41 Cf. Kumleben (1996); Chase and Griffin (2011), 353-361, 357; Breytenbach (2001).

42 On these, see Inge Brinkman, 'Violence, Exile and Ethnicity: Nyemba Refugees in Kaisosi and Kehemu (Rundu, Namibia)', JSAS, September 1999, available at: [https:// www.researchgate.net/publication/51716819_Violence_Exile_and_Ethnicity_Nyemba_ Refugees_in_Kaisosi_and_Kehemu_Rundu_Namibia], 417-439, 430.

43 Petrus Ndongo, 'The Borderline: 'Onhaululi' in Hayes, Silvester, Wallace and Hartmann (1998), 289.

44 Cf.W.R. Stanley, 'Namibia's Unstable Northern Frontier', Tijdschrift voor economische en sociale geografie, 93, 17 December 2002, available at: [https://doi.org/10.1111/14679663.00210], 369-382. Soon after independence it was decided to move the veterinary fence north to the border with Angola: Peter Amutenya and Eline van der Linden, The Namibia-Angola Border Fence and its Socio-Economic Implications (Windhoek: Namibian Economic Policy Research Unit, June 1993). 

Namibia Scientific Society, 1999); Ndumba J. Kamwanyah, 'The Caprivi Secession Attempt: Is It a Failure of Namibia's Nation-building Project?', Foreign Policy Association [website], August 3, 2010, available at: [http://foreignpolicyblogs.com/2010/08/03/the-caprivisecession-attempt-is-it-a-failure-of-namibia $\%$ E2\%80\%99s-nation-building-project/].

46 Cf. Gregor Dobler, 'From Scotch Whisky to Chinese Sneakers: International Commodity Flows and New Trade Networks in Oshikango, Namibia', The International African Institute: Africa, 78(3), 2008, available at: [https://www.cambridge.org/core/journals/africa/article/ from-scotch-whisky-to-chinese-sneakers-international-commodity-flows-and-newtrade-networks-in-oshikango-namibia/D3921302D17E4AD50FF3B65FA58EE3AC]; and 'Oshikango: the Dynamics of Growth and Regulation in a Namibian Boom town', JSAS, 2009, available at: [https://www.researchgate.net/publication/240524171_ Oshikango_The_Dynamics_of_Growth_and_Regulation_in_a_Namibian_Boom_ Town]; Christiana U. Rodriques, 'Angola's Southern Border: Entrepreneurship opportunities and the State in Cunene', The Journal of Modern African Studies, 2010, available at: [https://www.researchgate.net/publication/231896702_Angola's_southern_ border_Entrepreneurship_opportunities_and_the_state_in_Cunene]; Selma Nanqulah and Ndeyapo Nickanor, Northern Gateway: Cross-Border Migration between Namibia and Angola (Cape Town: Southern African Migration Project, 2005), 3. The latter study, of the busiest border crossing at Oshikango, found that a large number of those who crossed went both ways, engaging in a circular movement from one side to the other. Nearly 20 of those surveyed crossed the border every day, and half said they had family across the border they visited frequently.

47 This was confirmed to me by Ambassador Kito Rodriques of Angola when I met him in Pretoria in 1995.

48 See 'Baynes Hydropower Project', Nampower [website], available at: [http://www. nampower.com.na/Page.aspx?p=222] and John T. Friedman, 'Mapping the Epupa Debate: Discourse and Representation in a Namibian Development Project', in Giorgio Miescher and Dag Henrichsen, eds., New Notes on Kaoko (Basle: Basler Afrika Bibliographien, 2000). Baines (2013), Ch.7.

50 Such as that at Ongulumbashe in northern Namibia, see 'Namibian War Memorials', The Polynational War Memorial [website], August 26, 2013, available at: [http://www. war-memorial.net/Namibian-War-Memorials-1.210].

51 Examples include the road trips from South Africa to Cuito Cuanavale organised by MK veteran Patrick Ricketts, see e.g. Justin Pearce, 'Not Quite the Cuito café', Mail and Guardian, 5 January 2005, available at: [https://mg.co.za/article/2005-01-05-notquite-the-cuito-caf]; the bicycle trip through southern Angola from Cuito Cuanavale back to northern Namibia by a former SADF conscript, Paul Morris (see his Back to Angola. A Journey from War to Peace (Cape Town: Zebra Press, 2014)); and the visit in May 2016 of a group of Namibian survivors of the Cassinga massacre of May 1978 to the site of the massacre, see George Hendricks, 'We will never forget Cassinga - survivors', The Namibian [website], May 12, 2016, available at: [https://www.namibian.com. na/150659/archive-read/We-will-never-forget-Cassinga-\%E2\%80\%93-survivors]; and a documentary film titled, My Heart of Darkness, (Stockholm: Eden Films, 2010), narrated by Marius van Niekerk, follows former soldiers from opposing sides of the war back to Angola. 


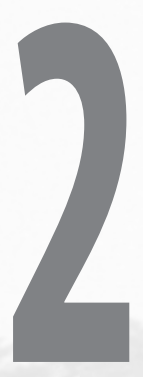

\section{OPERATION BLOUWILDEBEES, 1966: THE HELICOPTER ASSAULT ON ONGULUMBASHE}

McGill Alexander 
There is a growing tendency to refer collectively to the liberation struggles that took place in southern Africa during the second half of the 20th century as the Southern African Thirty-Year War. ${ }^{1}$ Although the belligerents were not part of formal military alliances, the nationalist movements in the various states all had the same aim of casting off the yoke of white oppression, while the security forces in those countries, as instruments of white hegemony, shared the objective of preserving white privilege. So certainly, they were, in a very real sense, all engaged in the same war. Aggressive resistance to white rule reared its head in the Federation of Rhodesia and Nyasaland in 1959, the Mpondo Revolt in South Africa commenced in 1960, and the violent uprising in northern Angola erupted the following year. Complicated by proxy Cold War foreign involvement, the long war reached levels of high-intensity conventional combat in south-east Angola. But it finally faded out with a bewildered whimper with the internecine strife in the townships of South Africa during the early 1990s. The Armed Struggle in Southern Africa, therefore, was indeed encompassed by a period of a little more than 30 years.

However, if the conflict between the South African Defence Force (SADF) and the South African Police (SAP), and the People's Liberation Army of Namibia (PLAN), armed wing of the South West African People's Organisation (Swapo), is seen as one of the campaigns of this war, then it could have commenced on 26 August 1966 - more than fifty years ago. This campaign ended with the blood-shedding that followed the disastrous attempt to implement UN Security Council Resolution 435 in Namibia on 1 April 1989 - twenty-two and a half years later.

In this chapter, an attempt is made to explore what happened on 26 August 1966, based on recently declassified documents in the South African military and police archives, and interviews with some of the paratroopers who participated. The author could not interview any Swapo survivors or South African police officers who participated. The chapter concludes with some impressions of the strategic implications of the action for both the South African government at the time, and for their adversaries, Swapo.

\section{SOUTH WEST AFRICA AND THE WORLD COURT DECISION}

South Africa's trusteeship of South West Africa (SWA) in terms of the mandate that had been awarded at the end of the First World War by the League of Nations, was challenged in 1960. Ethiopia and Liberia had brought a charge to the International Court of Justice (the World Court) that South Africa had violated its mandate and should be compelled to relinquish its trusteeship. It was the same year that Swapo was established - to become the major liberation movement in the struggle for Namibian independence. In 1966, the court finally ruled that the complainants had no legal right or interest in the matter, effectively torpedoing the attempt to eject South Africa from the territory. ${ }^{2}$ 
By then, Swapo had already embarked on its armed struggle. According to SADF and SAP intelligence reports, the first six armed insurgents entered Ovamboland in northern SWA in July/August $1965 .{ }^{3}$ Swapo, however, claims that it had already infiltrated fighters into the territory in $1964,{ }^{4}$ but the year 1965 was subsequently confirmed by one of the insurgents who infiltrated the following year. ${ }^{5}$ Swapo had been making contingency plans should the World Court decision be unfavourable towards them, and this infiltration was a part of these plans. The insurgents lay low inside South West Africa and did not resort to violence, but were in the position to act if things 'did not go well' at the Hague. ${ }^{6}$ The first group established a base in a remote part of Ovamboland (often spelt Owamboland) at a spot called Ongulumbashe (also spelt Ongulumbashe and sometimes rendered as Omugulu gwOmbashe, OmugulugOmbashe or Omugulugwombashe). From this base, concealed on the sandy, sparsely forested plain and undetected by the thinly scattered SAP elements in the territory, they recruited several local youths whom they trained in the basic skills of guerrilla war. ${ }^{7}$ Swapo intended to be ready to launch an armed struggle by targeting all whites, police officers and tribal chiefs who were working with the South African authorities, as soon as they receive the order. When intercepting the second group of ten insurgents, nine of them were arrested, taken to Pretoria and interrogated in March and April 1966, the South African authorities learnt that between 900 and 1200 people had left SWA for military training as members of Swapo. Many of those, according to the captured insurgents, were already on their way back to establish operational bases in various parts of northern SWA. ${ }^{8}$

If Sam Nujoma, the President of Swapo, had foreseen the outcome of the case considered by the World Court, the South African government had not. In terms of the League of Nations Mandate, South Africa could not maintain any military bases inside the territory of South West Africa. ${ }^{9}$ It was for this reason that the only permanent military base was at the Port of Walvis Bay, considered a part of the former Cape Colony and not SWA. Expecting the worst while they waited for the announcement on 18 July 1966, the South African government placed various elements of the Defence Force on standby, ready to be flown to SWA in the event of international military intervention. At 1 Parachute Battalion, the trained senior company had been placed on alert but were ordered to stand down when the court's surprise ruling in South Africa's favour became known. ${ }^{10}$

\section{THE DECISION TO ATTACK THE ONGULUMBASHE BASE}

The band of insurgents at Ongulumbashe was well advanced in their preparations to launch a campaign of violence. But the SAP Security Branch had 'turned' the captured leader of the second band of insurgents, and he had cooperated with them on a two-month-long undercover operation in Ovamboland. They discovered the base at Ongulumbashe and clandestinely reconnoitred it, deciding that the base 
would have to be attacked and destroyed. ${ }^{11}$ The highest level must have discussed the situation, and there can be no doubt that the Justice, Police and Prisons Minister, Advocate B.J. Vorster, was directly involved in the decision to mount an operation. Els implies that Prime Minister Dr H.F. Verwoerd himself gave certain guidelines ${ }^{12}$ and an operation of that nature must have had his approval, particularly as the Defence Force came to be involved. South Africa did not want to 'transgress' the terms of the League of Nations Mandate that she was claiming to still uphold. A military presence, let alone a military action, in SWA could be a significant embarrassment. Ultimately, therefore, Police Headquarters in Pretoria was tasked to carry out this mission. ${ }^{13}$

PREPARATIONS:

PARATROOPERS AND POLICEMEN

The SAP planned to utilise its Riot Unit (also known as the Mobile Unit) to carry out the operation. However, they were neither equipped nor trained for such an action. At a conference between police and military generals in Cape Town, the Commandant General of the SADF, Rudolph Hiemstra, decided that the policemen would need substantial assistance for the operation to succeed. ${ }^{14}$

Accordingly, with political approval, it was agreed that the SADF would provide eight Alouette III helicopters and their crews, three C-130 Hercules transport aircraft and their crews, six three-ton Bedford 4x4 vehicles, three .303 Bren light machineguns, 19 Uzi 9 mm submachineguns, binoculars, radios, maps, aerial photographs and eight paratroopers to train the policemen and accompany them into action. Besides providing a medical officer (doctor) and medical orderly (both paratroopers), a senior paratrooper officer, Commandant ${ }^{15}$ Tommy Renfree was appointed as the SADF liaison officer to the police. ${ }^{16}$ Renfree, at the time an Intelligence Officer at Army Head Quarters, was the senior Army officer involved in the operation and the only one with experience in the use of helicopters. Experience gained during Operation SWIVEL, the SADF action to suppress the Mpondo Revolt in 1960/1961. It had been the first tactical employment of helicopters by the SADF. ${ }^{17}$ Renfree had also seen action as a special force paratrooper with the British in the Second World War. ${ }^{18}$ According to Breytenbach, it was Renfree's idea to use helicopters for the operation. ${ }^{19}$

Renfree, another Army officer and an Air Force officer, accompanied the senior police officers to SWA to conduct aerial reconnaissance and to collect more information. The other ten paratroopers, under the command of Captain Jan Breytenbach, spent almost two weeks training the policemen from the Riot Unit at the SA Police College in Pretoria and a training facility in nearby Elandsfontein. According to Breytenbach, the paratroopers all had to attest as policemen for the duration of the operation. ${ }^{20}$ Even the helicopters of the SAAF had SAP badges painted on their fuselages, together with police serial numbers. ${ }^{21}$ 
The ten paratroopers and 35 riot policemen were then flown to Rooikop Military Airfield at Walvis Bay, together with three Bedford trucks, in the C-130 aircraft. There they waited with the eight helicopters and their crewmen, for the signal to move closer. ${ }^{22}$ On 25 August, the force was flown to the airstrip at Ruacana on the northern border with Angola. ${ }^{23}$

Final orders were issued, and preparations made, but despite the substantial and crucial military involvement, it remained a police action, which meant that suggestions and inputs from the paratroopers were frequently overridden or ignored by the strong personalities amongst the police commanders. But police officers were not trained to carry out military operations, and the paratroopers subsequently admitted to being very frustrated and unhappy with the unprofessional and slapdash way orders were given and preparations made, and particularly with certain aspects of the plan. ${ }^{24}$

Els, who has done considerable research into the operation, unfortunately, produced a somewhat confusing account of what took place. ${ }^{25}$ He appears not to have had access to the reports written by Renfree, which provide essential and comprehensive information. Instead, Els seems to have relied heavily on the memories of some participants in their re-telling of events several decades after the operation. Similarly, the technical inaccuracies of Stiff's account compromised its credibility. ${ }^{26}$

In overall command of the operation was a police officer, Colonel Pat Dillon, the commander of the SAP Riot Unit. A heliborne force of 30 men, divided into six sticks of five men each, with each stick in a helicopter, carried out the assault. The flight engineers were left behind at Ruacana to make room for an extra soldier or policeman in each aircraft. Paratrooper officers Captains Jan Breytenbach and Kaas van der Waals commanded two of these sticks. A seventh stick, commanded by Renfree, remained airborne to act as 'grabbers' should any of the Swapo insurgents get away. The eighth helicopter was used for air control and carried the senior Air Force officer, Colonel Jan Blaauw, a Second World War and Korean War veteran. With him was the police officer who had run the undercover operation, Captain 'Rooi Rus' Swanepoel and an observer from the Army, Major Hans Paetzold. ${ }^{27}$

A reserve force of 14 police officers, four paratroopers (including the medical officer and medical orderly) and an Air Force radio operator travelled off-road in Bedford trucks to a position approximately eleven miles $(17.5 \mathrm{~km})$ east of the Ongulumbashe insurgent base. It seems that the initial plan for this group was to move on foot to the base and form a cordon around it before the helicopters arrived, ${ }^{28}$ but this was certainly not done. Instead, three helicopters would position stop-groups to the east, south and west of the base, while another three would drop three sticks to the 
north, but very close to the base, to carry out the sweep through it. ${ }^{29}$ Of these three, Dillon would command the centre stick, Breytenbach the one on the left flank and Van der Waals the one on the right. Each stick included a paratrooper Bren gunner, several individuals carrying $9 \mathrm{~mm}$ submachineguns and at least one in each helicopter used an FN assault rifle. ${ }^{30}$ Breytenbach claims that the helicopters "put down three assault sticks of paratroopers and about four sticks of stoppers filled with cops". ${ }^{31}$ Breytenbach's claim implies that the paratroopers under his command carried out the attack and that the policemen were merely there to provide back up. His account does not accord with the official documentation, including the passenger lists for the helicopters and the report written by Renfree, who was Breytenbach's superior. ${ }^{32}$ The reverse was true: the paratroopers provided back up for the police.

The police officers reasoned that the insurgents, surrounded, would lay down their arms and surrender. The intention was to give each insurgent a formal warning and arrest him according to SAP procedure. For the policemen, this was simply another police raid on a gang of criminals and the extra hardware provided by the military merely served to cow the crooks into quicker surrender. The paratroopers, trained to deal with insurgents in a very different manner, were sceptical. Dillon reminded everyone that they were not to shoot at anyone without first warning them and that their priority was to arrest the insurgents so that they could appear in court. The paratroopers made no sense of the arrest priority, as it would be quite impossible during a firefight. The doctrinal differences between the police and the military were sharply evident. ${ }^{33}$

According to available intelligence, there were about 16 insurgents in the base, seven of whom trained abroad, and one who was a political commissar. Those using the base at the time of the operation numbered 18, although close to another 30 had already been trained from amongst the youths of the local Ovambo population and had returned to their kraals to await further instructions. Two of the foreign-trained insurgents, however, had left Ongulumbashe to go to the town of Ondangwa for a meeting with Herman Ja-Toivo (also called Andimba Toivo ya Toivo) of Swapo, who owned a shop there. So there were indeed 16 in the base, eleven of them locally recruited and trained. ${ }^{34}$ It transpired that the local population had warned the insurgents that an attack was imminent because the locals had become aware of the suspicious activities of the security policemen posing as civilians during the undercover operation. But an attack from the air using helicopters was completely unexpected and took the insurgents by surprise. ${ }^{35}$ 


\section{THE HELICOPTER ASSAULT}

Almost inevitably, the operation did not go as planned. To start with, the insurgents immediately began firing on the helicopters with their PPSh submachineguns. These shots fired by Swapo were the first in a conflict that was to last almost 23 years. On this occasion, the insurgent reaction immediately put an end to the police notion that they would walk in and arrest the insurgents. As the paratroopers had expected, the sweeper group turned into an assault group that encountered resistance even before it had disembarked from the helicopters. As there had been no rehearsal for this contingency, and because the policemen were not properly versed in military tactics and techniques such as fire and movement and because they lacked battle discipline, the whole operation quickly deteriorated into chaos. The helicopter pilots, nervous of the fire directed at them, placed all six groups down too far away from the base to be able to carry out an immediate attack and made it impossible to throw an effective cordon around the base. Command and control disintegrated as Dillon became embroiled in the fighting rather than running the battle. ${ }^{36}$ But the insurgents realised they had no chance against such a force, and their confusion and disarray exceeded that of the South African security forces. The outcome was a foregone conclusion, and the results documented in the SADF files, particularly the reports by Renfree. ${ }^{37}$

One insurgent was killed (by a paratrooper), ten were captured (one of them seriously wounded), and five escaped. ${ }^{38}$ In the meantime, the helicopters had brought in the reserve force, and in subsequent searches of the area using the helicopters shot dead another insurgent from the air, and captured one. Three got away, all of them foreign trained, with their weapons. There were no casualties amongst the security forces (paratroopers and police officers). Those captured were mostly recruits. It appeared that one of those killed and one of the captured were from the foreign-trained group that had infiltrated, ${ }^{39}$ explaining the recovery of only two submachineguns and two pistols. Only members of this group of six or seven would have had weapons, and three of them escaped, while two were at Ondangwa at the time of the attack. One of the insurgents, desperate and with nothing else at hand, had even shot at a helicopter with a bow and arrow! ${ }^{40}$ The report by Renfree lists an assortment of items collected in the base by the police. This included a large number of documents; over a thousand rounds of ammunition; knives; assegais; bows and arrows; two cameras; a portable typewriter; 37 staves used for rifle drill; flattened poles used for excavating; a pick and spade; two axes; blankets; bags; food; eating utensils; and six bicycles. The base was carefully laid out, with deeply dug trenches and bunkers as well as defensive sand walls. ${ }^{41}$ 
Swapo responded to the attack by claiming that their forces had clashed with the SADF on 26 August 1966 and that the SADF had suffered 15 dead and numerous wounded. ${ }^{42}$ This sparked a propaganda war between Swapo and South Africa that became a concurrent feature of the armed conflict, reflecting the essence of an insurgency, that revolves around the perceptions and support of the people. It was significant that the Swapo propaganda focused on the SADF rather than the police. Though it is unlikely that they would have known of the SADF role, this was irrelevant in propaganda. A battle with the military afforded the insurgents far greater status than a skirmish with the police: it told the world that they were at war. For the same reason, the South Africans preferred to conceal the military involvement; to admit it would indicate an escalation of the situation by Swapo and desperation on the part of the occupying power.

On arrival back at Air Force Base Waterkloof in Pretoria, a senior Security Police officer, the sinister Major General 'Lang Hendrik' van den Bergh, who later headed up the notorious Bureau of State Security (BOSS), met the South Africans who had participated in the operation. ${ }^{43} \mathrm{He}$ greeted and congratulated every police officer individually, but pointedly and openly ignored the paratroopers. ${ }^{44}$ Operation BLOUWILDEBEES was regarded as a police action, and henceforth the SAP went out of their way to play down and even ignore the role of the SADF. But without the SAAF aircraft, Army weapons, paratrooper training and leadership on the ground the operation would have been impossible. Furthermore, including all the aircrew from the C-130s, helicopters and light aircraft as well as the paratroopers and other individuals such as communications experts, there were about 50 SADF personnel involved - approximately the same number as there were policemen.

The scope of the operation was never made public by the South African government, and it was played down in press releases as a mere clash between policemen and a small group of men, leading to the arrest of most of the 'communist-inspired dissidents'. Details to the effect that the encounter had been a helicopter operation were not even released ${ }^{45}$ and, the SADF went so far as to deny SAAF involvement when asked. ${ }^{46}$ The Army, although it could claim no credit for the operation in public, did a comprehensive analysis of what had gone wrong, and the paratroopers applied themselves to correcting the faults in their training. ${ }^{47}$

The report by Renfree also expressed the disillusionment of the paratroopers at the inability of the police to achieve the required level of battle proficiency. Their battle discipline was non-existent; they were unable to use maps, compasses or protractors, so they could not navigate; they had not mastered helicopter drills during the two weeks of training; they did not know first aid, and they were unfit and overweight. ${ }^{48}$ In short, they were not soldiers, and such operations were the job of soldiers. 
The police, unfortunately, did not share the paratroopers' zeal for self-examination and improvement. Instead, they felt self-satisfied, even smug, with their performance in the operation. Captain Swanepoel went on to become recognised in police circles as a leading expert in guerrilla war and eight years later wrote a paper on the abilities of the SAP as guerrilla fighters. In that essay, he made a highly questionable case for police officers, praising their training and skills, which he claimed, made them far better guerrilla fighters than soldiers. ${ }^{49}$

\section{STRATEGIC SIGNIFICANCE}

The action at Ongulumbashe, though messy, confused and exposing the inexperience of both the South African security forces and the Swapo insurgents, contained many of the elements that would, ten years later, be called a 'fire-force' operation. By its offensive nature, it was certainly an advancement on the employment of helicopters in Pondoland during Operation SWIVEL; but was its value merely tactical, or had there been a strategic side to the operation?

There can be no doubt that Operation BLOUWILDEBEES played a major role in the early refinement of tactical thinking regarding airborne operations. Despite its shortcomings, its relatively small force levels and the diminutive size of the objective in terms of the numbers of insurgents it housed, the operation had definite strategic importance, as the height of the level of approval and the maintenance of radio contact throughout the action with the political decision makers in Pretoria and Cape Town showed..$^{50}$

Swapo had established a base inside SWA, ${ }^{51}$ a strategic victory for the liberation movement, regardless of how small and insignificant that base was. But it was not merely a symbolic achievement: Swapo recruited and trained local people from that base, and soon acts of insurrection would have been carried out from it. In terms of the tenets of revolutionary war as propagated by Mao and others, this was an advanced stage of insurgency. The presence of a Swapo base in Ovamboland gave the movement credibility in the eyes of the local population and would lend status to its image internationally. It sent a signal to both the inhabitants of the territory and the outside world that South Africa did not control South West Africa (at the time, the UN had still not recognised the name Namibia). And as with any insurgent war, it is the perceptions and sympathies of the population that determine ultimate victory or defeat, the reason why the primitive and rudimentary base at Ongulumbashe became a strategic target. It thus became of vital strategic importance to the South African government to destroy the base and to terminate the activities of the insurgents.

In annihilating this threat, and mindful of ensuring security, the government had used C-130 Hercules aircraft to transport the force almost $2000 \mathrm{~km}$ via an isolated 
military airfield at Walvis Bay. The employment of helicopters to carry out a vertical envelopment manoeuvre achieved surprise. Had the attack had been carried out by land forces, chances are that the local people could have warned the insurgents of their approach and the insurgents might well have escaped before the attacking force arrived. Destroying an empty base would have been a hollow victory for the South African government and the insurgents could have regrouped and built another base. While it is true that those few men who escaped from Ongulumbashe did regroup with others, and one month later, on 27 September 1966, attacked the homes of administration officials at the border settlement of Oshikango, at no stage did Swapo succeed in establishing another base inside the territory. ${ }^{52}$ Throughout the remainder of the war, the insurgent movement was compelled to operate from bases in sympathetic neighbouring countries and could never in all honesty lay claim to have 'liberated' areas of SWA/Namibia and to have set up an alternative administration. In sharp contrast, in the war in the Portuguese colonies, there were parts, especially in Mozambique, that became 'no go' areas for the security forces. ${ }^{53}$ Even the $i$ Kongo movement, during the Mpondo uprising, succeeded in replacing the government administration for a brief period in most of Eastern Pondoland in 1960, but there is no evidence that Swapo ever accomplished this.

Nevertheless, for Swapo, in one of the ironies so often apparent in insurgency wars, the tactical defeat became a strategic victory. Dobell regards the skirmish, small and one-sided as it was, as a decisive propaganda victory for Swapo. ${ }^{54}$ In October 1966, two months after the Ongulumbashe attack, the United Nations General Assembly voted by 114 to 2 (South Africa and Portugal) in favour of revoking the League of Nations Mandate and South Africa's right to administer South West Africa. The UN thereby assumed sovereign responsibility for the territory, effectively negating the decision of the World Court. South Africa reacted by simply ignoring the Resolution (2145 [XXI]) that the UN was neither willing nor able to enforce. However, the Resolution did, by implication, absolve South Africa from having to adhere to the terms of the mandate. Six months later, on 19 May 1967, the General Assembly created the Council for South West Africa, mandated to administer the territory until it gained its independence. ${ }^{55}$ In practical terms, this meant nothing because as before, South Africa ignored the resolution and continued to govern the territory; but the acrimonious debate raised the Swapo case to prominence on the international stage.

This prominence was a major diplomatic setback for Pretoria because Swapo gained considerable international status from the UN decision, further enhanced on 12 June 1968, when the General Assembly passed Resolution 2372 (XXII), changing the territory's name to Namibia. ${ }^{56}$ In 1971, the International Court of Justice ruled that the continued presence of South Africa in Namibia was illegal and that South Africa was under an obligation to withdraw from Namibia immediately. It also ruled that all member states of the United Nations should refuse to recognise as valid any act performed by South Africa on behalf of Namibia. ${ }^{57}$ 
Predictably, South Africa ignored these decisions, and the insurgency war that had been initiated by the attack on Ongulumbashe continued, albeit initially at a deficient level of intensity. It was on the diplomatic level that Swapo was able to drive its campaign most effectively because of the high profile that South Africa had inadvertently bestowed upon it by the clash at Ongulumbashe. With the image of a heroic, downtrodden people fighting against impossible odds, ${ }^{58}$ Swapo next scored a major diplomatic victory in 1972 when it was recognised as the "sole legitimate representative" of Namibia's people and granted UN observer status by the UN General Assembly. ${ }^{59}$ Ongulumbashe, therefore, for Swapo became an iconic turning point in the liberation war. The post-independence Namibian government has venerated the site of the action to perpetuate its strategic significance to Swapo, with a monument commemorating "the opening engagement of the armed liberation struggle" ${ }^{60}$

After Ongulumbashe, there was a South African crackdown in northern SWA, with a marked expansion of police numbers and activities. Swapo did carry out further infiltrations in 1966, and there were cases of attacks on civilians and intimidation of the local population, while politicisation and recruitment were ongoing. But the Security Police were ruthless in their actions and by April 1967 as many as 200 people, including the entire internal leadership of Swapo, were in detention in Pretoria. These included Eliaser Tuhadeleni, the political commissar who had escaped at Ongulumbashe. ${ }^{61}$ In May 1967, Tobias Hainyeko, Commander in Chief of PLAN, was shot dead when police intercepted the boat in which he was crossing the Zambezi River from Zambia into the Caprivi Strip. ${ }^{62}$ These setbacks led to a military retreat by Swapo and a decrease and almost complete curtailment of insurgent activity for several years. Growing cooperation between the South Africans and the Portuguese made it impossible for PLAN guerrillas to continue crossing Angola from their haven in Zambia to reach the population of Ovamboland. Effectively, the attack on Ongulumbashe and its immediate results ended the war in Ovamboland for the next nine years, making Operation BLOUWILDEBEES an action of strategic importance to South Africa. But it did not end the insurgency - it merely moved it away from the highest concentration of people, thereby handicapping its progress. During those nine years, the focus of the Swapo insurgency shifted to the Caprivi. ${ }^{63}$ For Swapo, this was the only part of Namibia contiguous to a friendly host-country: Zambia.

\section{CONCLUSION}

There were political changes taking place both inside South Africa and internationally, and these impacted further on the war. Ten days after the attack on Ongulumbashe, South African Prime Minister H.F. Verwoerd was assassinated in parliament by Dimitri Tsafendas, a man who was said to be mentally deranged. Fearing that internal disturbances and upheaval might follow, the authorities placed 1 Parachute Battalion 
on one-hour standby for deployment anywhere in the country, but the anticipated unrest did not take place. ${ }^{64}$ John Vorster, the hard-line Police Minister who had overseen Operation BLOUWILDEBEES, succeeded Verwoerd. Giving heed to the police generals, and particularly Hendrik van den Bergh, Vorster, who retained the Police portfolio, increased the role of the SAP in combating the growing insurgency, including the deployment of police units to Rhodesia towards the end of $1967 .{ }^{65}$

But in Namibia, the intensification of the insurgency had to wait for the Portuguese revolution of 1974 and the termination of Portuguese military operations in Angola. The accession to power of the MPLA in that country provided Swapo with the host-country it so sorely needed to enable it to operate in Ovamboland, where close to 80 per cent of the population of Namibia lived. For insurgency to flourish, the insurgents had to gain access to the population from their bases. ${ }^{66}$

Ultimately, the action at the apparently insignificant Swapo base at Ongulumbashe, though untidy and reflecting the inexperience of both sides, signalled the start of an ostensibly local conflict that was to reach unforeseen levels of intensity and involve the armed forces of countries, even from outside the continent. 


\section{Endnotes}

1 The basis of this chapter originally formed part of the author's doctoral thesis for the University of South Africa (Unisa), titled, 'The Airborne Concept in the South African Military, 1960-2000: Strategy versus Tactics in Small Wars', accepted in 2016, available at: [http://uir.unisa.ac.za/handle/10500/23448].

2 Gerald L'Ange, The White Africans: From Colonisation to Liberation (Johannesburg: Jonathan Ball Publishers, 2005), 257, 294.

3 Department of Defence Archives (hereafter DOD Archives): Miscellaneous Documents, Top Secret Interim Report: Operation 'BLOUWILDEBEES', by Cmdt T.J. Renfree (GSO 1 (Int), Army HQ), 7 September 1966; Richard Dale, The Namibian War of Independence, 1966-1989: Diplomatic, Economic and Military Campaigns (Jefferson, New York: McFarland Books, 2014), 76, gives the month when Swapo insurgents first entered Ovamboland as September 1965.

Lauren Dobell, Swapo's Struggle for Namibia:War by Other Means (Basel, Switzerland: P. Schlettwein Publishing, 1998), 35.

5 Helao Shityuwete, Never Follow the Wolf, The autobiography of a Namibian freedom fighter (London: Kliptown Books, 1990), 101.

6 Susan Brown, 'Diplomacy by Other Means: Swapo's Liberation War', in C. Leys and J.S Saul, eds., Namibia's Liberation Struggle: The Two-Edged Sword (London: James Currey, 1995), 20.

7 SADF, Lesse en Foute in die Bekamping van Terrorisme in Suider Afrika, 114 (Pretoria: SADF, Confidential SA Army Publication late 1960s), 13.

8 DOD Archives: Miscellaneous Documents, Top Secret Interim Report: Operation 'BLOUWILDEBEES', by Cmdt T.J. Renfree (GSO 1 (Int), Army HQ),

7 September 1966.

9 Thomas Molnar, South West Africa: The Last Pioneer Country (New York: Fleet Publishing, 1966), 157-158, quoting Article 4 of the terms of the Mandate for German South West Africa.

10 Cpl P.C. Edwards, personal diary, 22 July 1966.

11 SAPS Archives: Citation/Recommendation 'Actions of Lt. P.A. Ferreira and Const. E. Johannes by Capt. T.J. Swanepoel’, 9 December 1966.

12 Paul Els, Ongulumbashe: Where the Bushwar Began (Wandsbeck: Reach Publishers, 2007), 150-151.

13 Michael Morris, Terrorism: The First Full Account in Detail of Terrorism and Insurgency in Southern Africa (Cape Town: Howard Timmins, 1971), 90-93.

14 DOD Archives: Miscellaneous Documents, Top Secret Interim Report Operation 'BLOUWILDEBEES', by Cmdt T.J. Renfree (GSO 1 (Int), Army HQ),

7 September 1966; Els (2007), 128-149.

15 The rank of Commandant was an old Boer term, adopted by the SADF during the 1950s, to replace that of Lieutenant Colonel.

16 DOD Archives: Miscellaneous Documents, Top Secret Interim Report Operation 'BLOUWILDEBEES', by Cmdt T.J. Renfree (GSO 1 (Int), Army HQ), 7 September 1966.

17 DOD Archives: KG Gp [Group] 5, box 322, file KG/GPW/1/5/4, vol.1, Restricted Report 'Pondoland Onluste (Bizana), Operasie SWIVEL:Visit to Bizana: Info Collected by Capt. M.J. le Roux, SAIC', 6 December 1960; and 'Situation in Pondoland by the CG’s Intelligence Section, DHQ', 10 January 1961. 
DOD Archives: Miscellaneous Group, file War Appts Offs: Maint of Records,Seconded Personnel; DOD Archives: Personnel Records Section, 'Personal Wartime File of Lt T.J. Renfree'; Col Tommy Renfree (retired), interviewed by McGill Alexander, Umhlanga Rocks, 28 July 1990.

19 J. Breytenbach, Eagle Strike! The Story of the Controversial Airborne Assault on Cassinga, 1978 (Sandton: Manie Grové Publishing, 2008), 49.

20 Col Jan Breytenbach (retired), interviewed by McGill Alexander, Sedgefield, 28 December 1990.

21 DOD Archives: HVS Gp, box 60, file HVS/203/6/1, vol.1 'Ops: SAP BLOUWILDEBEES', 23 August 1966.

22 Cmdt Wouter Hugo, interviewed by McGill Alexander, Pretoria, during 1990.

23 DOD Archives: Miscellaneous Documents, Top Secret Interim Report Operation 'BLOUWILDEBEES', by Cmdt T.J. Renfree (GSO 1 (Int), Army HQ), 9 September 1966.

24 Renfree (1990); and Brig Kaas van der Waals, interviewed by McGill Alexander, Pretoria, 28 November 1991.

25 Els (2007), 128-149.

26 P. Stiff, The Silent War: South African Recce Operations, 1969-1994 (Alberton: Galago Books, 1999), 36-37.

27 DOD Archives: Miscellaneous Documents, Top Secret Interim Report Operation 'BLOUWILDEBEES', by Cmdt T.J. Renfree (GSO 1 (Int), Army HQ), 9 September 1966; Breytenbach (1990) and Van der Waals (1991).

28 DOD Archives: HVS Gp, box 60, file HVS/203/6/1, vol.1 'Ops: SAP BLOUWILDEBEES', 23 August 1966.

29 Hugo (1990).

30 DOD Archives: Miscellaneous Documents, Top Secret Interim Report Operation 'BLOUWILDEBEES', by Cmdt T.J. Renfree (GSO 1 (Int), Army HQ), 7 September 1966; DOD Archives: HVS Gp, box 60, file HVS/203/6/1, vol.1 'Ops: SAP BLOUWILDEBEES', 23 August 1966.

31 J. Breytenbach, 'A Recce Goes SAS', in J. Pittaway, ed., Special Air Service Rhodesia: The Men Speak (Durban: Dandy Agencies, 2010), 361.

32 DOD Archives: Miscellaneous Documents, Top Secret Interim Report Operation 'BLOUWILDEBEES', by Cmdt T.J. Renfree (GSO 1 (Int), Army HQ), 9 September 1966.

33 Ibid. Also Breytenbach (1990).

34 DOD Archives: Miscellaneous Documents, Top Secret Interim Report Operation 'BLOUWILDEBEES', by Cmdt T.J. Renfree (GSO 1 (Int), Army HQ), 9 September 1966.

35 In a Swapo account it is claimed that there were 17 insurgents in the base. (See O.O. Namakalu, quoted by Catherine Sasman, 'Namibia: Julius Shaambeni Shilongo Mnyika - The Guerilla Fighter (1938 to 2003)', New Era (Windhoek) [online], 27 August 2010, available at: [https://allafrica.com/stories/201008271072.html].

36 Cmdt Snakes Snyman, interviewed by McGill Alexander, Murrayhill, 18 May 1990; and Breytenbach (1990).

37 DOD Archives: Miscellaneous Documents, Top Secret Interim Report Operation 'BLOUWILDEBEES', by Cmdt T.J. Renfree (GSO 1 (Int), Army HQ), 9 September 1966.

38 Snyman (1990); Breytenbach (1990); Van der Waals (1991); and Renfree (1990). 
39 DOD Archives: Miscellaneous Documents, Top Secret Interim Report Operation 'BLOUWILDEBEES', by Cmdt T.J. Renfree (GSO 1 (Int), Army HQ), 9 September 1966. Els (2007), 147, 150, provides slightly different casualty figures, but does not offer sources for his claims. His discussion is confused, and one is left in doubt on the final tally. Swapo sources state: "Some were killed in the battle, and eight were captured". See Sasman (2010).

40 DOD Archives: Miscellaneous Documents, Top Secret Interim Report Operation 'BLOUWILDEBEES', by Cmdt T.J. Renfree (GSO 1 (Int), Army HQ),

9 September 1966. Dobell (1998), 36.

41 See Reg Shay and Chris Vermaak, The Silent War: The Fight for Southern Africa (Salisbury: Galaxie Press, 1971), 171-173.

42 Namibia Today, 1 September 1966.

43 See Mary Braid, 'Obituary: Hendrik van den Bergh', The Independent (UK) [online], 22 October 2011, available at: [https://www.independent.co.uk/news/people/obituaryhendrik-van-den-bergh-1246509.html]; and A.D. Elsdon, The Tall Assassin:The Darkest Political Murders of the Old South Africa (Cape Town: Umuzi Publishers, 2009), for a fictional account of Van den Bergh's alleged role as éminence grise in the apartheid state.

44 Van der Waals (1991). This snub is also related in Els (2007), 156.

45 'Two Infiltrators Shot in Gunfight with Police', Friend, 27 August 1966; 'SWA Intruders Beaten off', Cape Argus, 26 August 1966; 'Tip-off on Guns: Local Ovambos Told Police in SW Africa', Cape Argus, 27 August 1966; 'Die Les uit Terrorisme', Vaderland, 29 August 1966.

46 DOD Archives: HVS Gp, box 60, file HVS/203/6/1, vol.1 'Ops: SAP BLOUWILDEBEES', 23 August 1966.

47 DOD Archives: Miscellaneous Documents, Top Secret Interim Report Operation 'BLOUWILDEBEES', by Cmdt T.J. Renfree (GSO 1 (Int), Army HQ), 9 September 1966; SADF (late 1960s), 13-27.

DOD Archives: Miscellaneous Documents, Top Secret Interim Report Operation 'BLOUWILDEBEES', by Cmdt T.J. Renfree (GSO 1 (Int), Army HQ), 9 September 1966.

SAPS Archives: Highly Secret Paper 'Members of the SA Police as Guerrilla Fighters by Col. T.J. Swanepoel' (SOO), 21 October 1974. Els (2007), 33-134. Dale (2014), 77, states that there were five such bases, although he claimed the Swapo insurgents only occupied one base at a time.

52 Dale (2014), 78.

53 AlVenter, ed., Challenge: Southern Africa within the African Revolutionary Context (Gibraltar: Ashanti Publishing, 1989), 266.

54 Dobell (1998), 36.

55 Ibid.; see also Morris (1971), 99.

56 Wellington W. Nyangoni, Africa in the United Nations System (London: Associated University Presses, 1985), 60. John Dugard, The South West Africa/Namibia Dispute (San Diego: University of California Press, 1973), 453. 
60 Reinhart Kössler, 'Public Memory, Reconciliation and the Aftermath of War', in H. Melber, ed., Re-examining Liberation in Namibia (Uppsala: Nordiska Afrikainstitutet, 2003), 109.

61 Els (2007), 167-168.

62 Morris (1971), 94.

63 Brown (1995), 21-22.

64 Edwards (1966), entries for 6-12 September.

65 Terry Eksteen, The Statesmen (Cape Town: Don Nelson Publishers, 1978), 116-122.

66 Walter Laqueur, Guerrilla: A Historical and Critical Study (London:Weidenfeld \& Nicolson Ltd, 1977), 393-394. Most recognised writers on counterinsurgency deal with the relationship between bases, borders and the local people. See for example, Robert Thompson, Defeating Communist Insurgency: Experiences from Malaya and Vietnam (London: Chatto \& Windus Publishers, 1972); John J. McCuen, The Art of Counter-Revolutionary War: The Strategy of Counter-Insurgency (Harrisburg: Stackpole Books, 1966); and Frank Kitson, Low Intensity Operations: Subversion, Insurgency Peace-keeping (London: Faber \& Faber Publishing, 1971); David Rooney, Guerrilla: Insurgents, Patriots and Terrorists from Sun Tzu to Bin Laden (London: Brassey's Ltd, 2004). See also SADET, The Road to Democracy in South Africa, 2 (1970-1980), 54, referring to comments made by Allister Sparks, The Mind of South Africa (New York: Alfred A. Knopf Publishing, 1990), 300. 


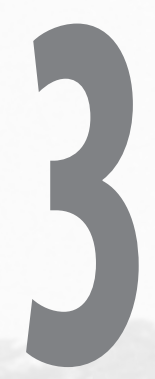

\section{OPERATION SAVANNAH, 1975-76:} THE INITIAL SOUTH AFRICAN ARMOUR DEPLOYMENTS INTO ANGOLA

Jean-Pierre Scherman 
The South African Armoured Corps' (SAAC) philosophy for conventional armour warfare was based on aggressive, offensive actions over a wide front in order to achieve two main aims: firstly, to deny the enemy its freedom of action and manoeuvre and, secondly, to stop and destroy the enemy (especially its armour forces) via direct armour firepower. To achieve these two aims, the SAAC developed two opposite but complementary doctrines that were labelled high-intensity operations (HIO) and high-mobility operations (HMO). Generally, but not exclusively, HIO involves the utilisation of main battle tanks to stop and destroy the enemy at a pre-determined time and place. HMO is considered the domain of the armoured car regiments of the SAAC and as stated above, aim to deny the enemy its freedom of action and space to manoeuvre. ${ }^{1}$

Certain types of missions must be carried out to achieve the goal of denying the enemy its freedom. Firstly, covering large areas while observing from a mobile or static role. Secondly, rapidly concentrating forces in a determined area to bring down effective fire. Thirdly, covering key areas with fire to deny the enemy free use thereof. Fourthly, breaking up and exhausting enemy armoured forces. Fifthly, attacking and destroying selected objectives such as command and control installations, logistical installations, air defence installations, artillery positions and airfields. ${ }^{2}$ The above theory is important to remember as it played a vital role in the decision-making process of the armoured car commanders, utilised during Operation SAVANNAH.

The SAAC on the eve of Operation SAVANNAH consisted of three regular force units: The School of Armour, based in Bloemfontein, was responsible for all leader group training of the SAAC (both Officer and Non-Commissioned Officer or Warrant Officer) up to the rank of Major and Warrant Officer Class 1. The other two regiments of the SAAC, 1 Special Service Battalion (1 SSB, based in Bloemfontein) and 2 Special Service Battalion (2 SSB, based in Zeerust), provided all the training for the bi-annual National Service intake Troopers on the Eland Mk 5 Armoured Car and the Centurion Mk 5A (Semel) ${ }^{3}$ Tanks. They also provided all the operational Armoured Car and Tank squadrons for the South African Defence Force (SADF). An important addition to this organogram was the armoured car squadron that was permanently detached from $2 \mathrm{SSB}$ and placed under the command and control of 2 South African Infantry Battalion Group (2 SAI), located within the South African exclave at Walvis Bay, South West Africa/Namibia (SWA). 


\section{OPERATION BOMBAY}

In 1967, in direct response to repeated Portuguese Armed Forces requests, the headquarters of the Joint Combat Forces, authorised the deployment, codenamed Operation BOMBAY, of various South African Air Force (SAAF) assets, both fixed wing and helicopter, ${ }^{4}$ to deploy to two remote airfields in northern SWA. One at Rundu the capital of the Kavango-East Region, located on the banks of the Kavango River on the border with Angola and the other one at the town of Katima Mulilo, situated in the Caprivi Strip and located on the banks of the Zambezi River. ${ }^{5}$

The absolute remoteness of both these airfields and their proximity to the border soon resulted in an urgent request from the SAAF that ground troops be deployed to protect the airfields. Thus, the Officer Commanding 2 SAI, located within the South African exclave of Walvis Bay, detached two infantry platoons, ${ }^{6}$ northwards to the border. These and subsequent replacement Platoon Commanders' reports soon showed that it was impossible to execute the tasks allocated to them with their allocated force strengths. By 1968, both airfields were protected by a company of infantry from 2 SAI. ${ }^{7}$

\section{OPERATION CRACKER BOX}

But this was still deemed inadequate for the sufficient defence of the airfields. Consequently, on 23 October 1968, Operational Directive No 1/68, instructed the Officer Commanding $1 \mathrm{SSB}$ to place an armoured car troop on standby to support a company from 1 Parachute Battalion, to be deployed to Katima Mulilo. ${ }^{8}$ Codenamed Operation CRACKER BOX, the aim was to protect an electronic eavesdropping station at Katima Mulilo (codenamed Brush), to provide support to the South African Police (SAP) in its counterinsurgency role and to form a mobile reserve within the Caprivi operational area. The force was also to train in the area, in the process getting to know the terrain, and make friendly contact with locals to become conversant with their customs. ${ }^{9}$

$1 \mathrm{SSB}$ readied two troops and moved them to Pretoria to take over new Elands at 81 Technical Stores Depot, twoVA 'Nineties' and two VA 'Sixties' each. One troop was to be airlifted to the Caprivi along with a parachute platoon, while the other was to travel by rail to Grootfontein with the rest of the parachute company for deployment at the Rundu base in the Kavango tribal region. ${ }^{10}$

The armoured car troop, commanded by Second Lieutenant Pretorius, with Sergeant (later Warrant Officer Class 1) I.J. Prinsloo as his second-in-command, arrived at Katima Mulilo and found a SAP base with two Alouette III helicopters, an infantry 
platoon from 2 SAI, a signals element manning the 'Brush' station and a couple of medical orderlies serving at a mission hospital. Pretorius and his crews set up a temporary camp and waited there for the rest of the force - the parachute company headquarters, the third platoon of paratroopers and a section of $81 \mathrm{~mm} \mathrm{M3} \mathrm{mortars.}{ }^{11}$

The armoured car troop's main task was to protect the town at Katima Mulilo, that was laid out in a semi-circle alongside the Zambezi River. For this purpose, they built a usable road for the Elands within the semi-circle, and four guard posts were erected to which the armoured cars were deployed at night, using their searchlights to scan the surrounding area. The troop also carried out area patrols, especially in the vicinity around a shop a few kilometres upstream from Katima Mulilo. They also secured the two local airfields, one for small aircraft at the little town itself and the other for larger craft at Mpacha; this included sweeping the landing strip for mines before the arrival of an aircraft and providing protection while it was on the ground. Convoy protection for the paratroopers or official visitors on the roads around Katima Mulilo was also an SSB task and, on occasion, a sandbagged 3-ton Bedford lorry had to be pressed into service if an Eland was not available (this was, of course, long before the first mineprotected vehicles appeared). ${ }^{12}$

Less than two months after the deployment, on 27 November 1968, the armour's first death in an operational area since the Second World War occurred when an armoured car overturned while negotiating a tricky piece of road between Katima Mulilo and Mpacha, killing its commander, Trooper D.S. Dyer. ${ }^{13}$

After six weeks at Katima Mulilo, Second Lieutenant Pretorius's armoured car troop was relieved in December 1968 by a new armoured car troop, whose members included their energetic Troop Sergeant, Sergeant W.J. Burger, who would later achieve some notoriety within the SAAC. It was from such inconspicuous beginnings that the SAAC involvement in the Border War began.

\section{THE RUACANA-CALUEQUE HYDRO-ELECTRIC WATER SCHEME CRISIS}

On 25 April 1974, in response to the events following the Carnation Revolution in Lisbon, the Portuguese Army Commander in Angola, General Joaquim Franco Pinheiro, withdrew all his forces from the Ruacana-Calueque hydro-electric water scheme and confined them all to base, before their return to Portugal. ${ }^{14}$ An unacceptable move to the South African government, who had invested a huge amount of time and public funds in the scheme's construction. Consequently, on 7 August 1975, the Officer Commanding 2 SAI, Lieutenant Colonel (Commandant) Boy du Toit, was ordered to mobilise his entire Battalion Group for military operations. Four days later, the battalion commander, along with two of his rifle companies, flew to Ruacana. ${ }^{15}$ 
The Eland Armoured Car crews of Delta Squadron, 2 SAI, under the command of Major Toon Slabbert, had also been activated by the Warning Order, dated 7 August 1975, for deployment to Ruacana. At that stage, the troopers were still on a seven-day pass. The Squadron headquarters immediately began the process of contacting everyone to order them to report back as soon as possible - not an easy task considering that only half the squadron lived in SWA, the rest resided in South Africa. Nevertheless, with the men to arrive, the vehicles were prepared, and by 12 August 1975, the entire squadron in their twenty-two Eland Mk V Armoured Cars left Walvis Bay for Ruacana, a road trip of just more than $1000 \mathrm{~km}$, that they completed by $18: 00$ the following day. ${ }^{16}$

Upon their arrival at the airfield in Ruacana, the crews were ordered to maintain their vehicles and weapons. Unfortunately, in a moment of poor concentration, an Eland gunner attempting to unload his co-axially mounted machinegun pulled the trigger at the incorrect stage of the sequence. A burst of fire exploded out of the barrel, with multiple rounds striking Corporal M.C.E. Potgieter, the Crew Commander of the Eland parked next to them. Upon hearing the gunfire, the Troop Commander, Lieutenant André Venter rushed over to assist. As he bent over the seriously wounded Potgieter, the gunner now totally panicking, in an attempt to make his weapon safe again pulled the trigger. A single round shot out, striking and seriously wounding Lieutenant Venter in his lower back. In a matter of a mad minute, Delta Squadron had experienced its first operational casualties, with Corporal Potgieter passing away from his wounds, ${ }^{17}$ and a seriously wounded Lieutenant Venter on his way to the hospital. Command of the Troop now fell upon the shoulders of the Troop Sergeant, Corporal Tank Fourie. ${ }^{18}$

While 2 SAI was still mobilising in Walvis Bay, reports from Calueque arrived that members of Unita were harassing the six South African families still stationed at Calueque. In response, Lieutenant Colonel Gert van Niekerk, the commander of the Owambo Sub Sector, ordered Captain W. Strydom, the commander of Bravo Company, 3 South African Infantry Battalion, ${ }^{19}$ on 9 August 1975 to go and retrieve the South Africans. Captain Strydom, in turn, sent Second Lieutenant Joe Lamprecht, accompanied by two infantry sections $(20 \mathrm{men})$ and two Eland Armoured Cars ${ }^{20}$ the $50 \mathrm{~km}$ north into Angola to Calueque. After a brief exchange of gunfire, which left two Unita soldiers killed, the dam reverted to South African control. With the arrival of 2 SAI in the area on 12 August, headquarters dispatched a Combat Team from the Battalion to Calueque, where they linked up with Lamprecht's force, to protect the area. ${ }^{21}$ 
The prospect of a Marxist MPLA (Movimento Popular para a Libertação de Angola Popular Movement for the Liberation of Angola) victory was unacceptable to the South Africans. So, when Daniel Chipenda (15 May 1931 to 28 February 1996) the leader of the Revolta do Leste - RDL (The Eastern Revolt) sent a delegation southward asking for South African assistance in their fight against the MPLA, he found a willing audience. By pure coincidence, the South African Minister of Defence, P.W. Botha, was on a fact-finding mission in the Operational Area when the RDL request arrived. $\mathrm{He}$ immediately ordered the SADF to begin assisting the RDL in absolute secrecy with both logistical aid (weapons, ammunition, food, etc.) and with training. Consequently, SADF headquarters issued Operational Instruction 8/75 on 28 August 1975, that instructed 1 Military Area to execute the abovementioned mission. After completing their tactical battle appreciation, 1 Military Area headquarters at Rundu issued Operational Order 2/1975, whereby direct SADF aid was authorised to the RDL. The first training group under the command of Lieutenant Colonel J.D. Breytenbach, established on 14 September 1975, $75 \mathrm{~km}$ north-east of Rundu at a small former Portuguese marine base called M'pupa, ${ }^{22}$ would train a battalion of RDL soldiers. ${ }^{23}$

\section{THE WAR AGAINST SWAPO}

While the SADF Focus of Main Effort (FME) had switched to the civil war in Angola, the war against the Swapo (South West Africa People's Organisation)) cadres were not forgotten. Part of Operational Order 2/1975 as issued by 1 Military Area headquarters, ordered the SADF to launch a series of cross-border raids into southern Angola targeting Swapo bases and troop concentrations. They would execute these raids under the command and control of the three subsector headquarters of 1 Military Area located at Oshakati, Rundu and Katima Mulilo. During the night of 25/26 August 1975, the SADF launched Operation SAUSAGE II. These forces (that included the Eland Armoured Cars from Bravo Squadron 1 SSB, who had deployed with two armoured car troops at Ondangwa and a third at Etale), attacked four suspected Swapo camps south of the Angolan hamlet of Caiundo, situated on the western bank of the Cubango River. ${ }^{24}$ Simultaneously two infantry companies from 2 SAI along with Delta Squadron in their Elands crossed the border to protect Calueque. From Calueque, elements of this force spread out northwards along the Kunene River up to Naulila, while a third grouping attacked and conquered the Angolan town of Pereira d'Eça (Ondjiva), the administrative capital of the Cunene Province located only $42 \mathrm{~km}$ north of the Namibian border and the town of Oshikango. ${ }^{25}$ 
Around mid-September 1975, after the completion of the operation, Bravo Squadron, $1 \mathrm{SSB}$ (excluding a troop of four vehicles whose personnel had volunteered to remain behind), returned to Bloemfontein, thinking that they had seen the last of SWA for 1975. ${ }^{26}$ Bravo Squadron was replaced on the border by members from Alpha Squadron, $1 \mathrm{SSB}$, who consequently participated in all the post-Operation SAUSAGE II missions such as Operation HANS I (8-16 October 1975), Operation CUBANGO GALLOP (16-19 October 1975), Operation ROVER ASTEC (20-26 October 1975) and Operations KAREN I and II (November 1975). ${ }^{27}$ It was during Operation HANS I that the SAAC suffered its first National Servicemen fatality due to enemy action on the border. On 12 October 1975, an Eland 60 travelling on the Luiana River Road in south-eastern Angola detonated a landmine. The force of the blast propelled the Crew Commander, Trooper Koos van Zyl and his Gunner, Trooper Lourens Kriel, out of the turret. While badly hurt, both survived and were CASEVAC-ed back to South Africa, for medical treatment. Unfortunately, the force of the blast was so powerful that it flipped the 6-ton armoured car over, killing the driver, Trooper David le Roux, in the process. ${ }^{28}$

\section{THE MISIÓN MILITAR CUBANA EN ANGOLA (MMCA)}

Cuba's military relationship with the MPLA had commenced in the late 1950s with a series of informal contacts between members of both groups. By 1963, Cuban military instructors were providing training to MPLA recruits in Algiers. The first high-level discussions took place on 5 January 1965 in Brazzaville, the capital city of the Republic of the Congo, who had received full independence from France on 15 August 1960. ${ }^{29}$ In attendance was MPLA leader Agostinho Neto and Cuban guerrilla commander Che Guevara. It was during this meeting that the Cubans agreed to assist the MPLA and their ongoing operations against the Portuguese army in the enclave of Cabinda and the FNLA (Frente Nacional de Libertação de Angola - The National Front for the Liberation of Angola) in northern Angola. ${ }^{30}$

In 1972, Cuban Major Manuel Piñeiro Lozada delivered an MPLA memorandum to Raúl Castro, wherein the MPLA reiterated their requests for more training assistance. After the events surrounding the Carnation Revolution, the MPLA's requests became larger and more urgent, seeking economic aid, military training and arms. In early October 1974, the next MPLA request reached Havana, this one asking for five Cuban military officers who could assist in organising the MPLA's armed wing, Fapla (Forças Armadas Populares de Libertação de Angola - People's Armed Forces for the Liberation of Angola). In response to all these requests, two Cuban officials were sent on a factfinding mission to Africa to assess the situation. On 31 December 1974, an MPLA delegation chaired by Neto met in Dar es Salaam with the two Cuban officials, Carlos 
Cadelo (representative for Castro's Central Committee for Angola) and Major Alfonso Pérez Morales 'Pina'. The Major served with the PAIGC (Partido Africano para a Independência da Guiné e Cabo Verde - African Party for the Independence of Guiné and Cape Verde) in Guiné. Upon their return to Cuba, they delivered to their superiors a letter dated 26 January 1975, written by Neto. In the correspondence, Neto asked Cuba to assist the MPLA in establishing, organising and maintaining a military school for cadres. Furthermore, the MPLA needed a Cuban ship to transport war materials from Dar es Salaam to Angola, uniforms and military equipment for 10000 men and financial assistance while the MPLA established and organised themselves. ${ }^{31}$

Cuba dispatched a second fact-finding mission to Angola on 3 August 1975, tasked with assessing the situation in the country, drawing up plans for the training programme as requested by Neto, and handing over 100000 US Dollars. ${ }^{32}$ In a memorandum dated 11 August 1975, the mission leader, Major Raúl Diaz Argüelles, explained the reasons for the visit to Raúl Castro and briefed him of the contents of the talks. He highlighted the military situation facing the MPLA and the development of future actions that could take place until 11 November 1975, the agreed date at which point Portugal would grant Angola its independence. Lastly, Argüelles urged Castro to approve a 94-man military mission to assist the MPLA. ${ }^{33}$

After evaluating the threat against the MPLA, especially the occupation of the Ruacana-Calueque hydro-electric complex by the SADF, the Cubans decided to establish the MMCA (Cuban Military Mission in Angola), under the command of Raúl Díaz Argüelles. He answered to the First Deputy Minister of the FAR (Fuerzas Armadas Revolucionarias - Cuban Revolutionary Armed Forces), General Abelardo Colomé Ibarra, known by his childhood nickname, 'Furry', Ibarra was in overall command of the operation. ${ }^{34}$ Instead of deploying the requested 94-man team, Castro sent 480 Cubans, 390 instructors (of which 284 were officers) ${ }^{35}$ and seventeen doctors. Personnel were supplemented by a small contingent of civilian pilots to fly the MPLA's aircraft and several air-traffic control and cargo handling specialists. The instructor's mission was to train about 4800 Fapla recruits into 16 infantry battalions, 25 mortar batteries and various anti-aircraft units in three to six months. ${ }^{36}$

The MMCA would be subdivided into a headquarters element based in Luanda and amongst four CIR (Centro de Instrução Revolucionária - Centre for Revolutionary Instruction) or military training camps situated in Cabinda, Benguela, Henrique de Carvalho (Saurimo) and at Salazar (N'Dalatando). The CIR in Cabinda accounted for almost half of the total, 191 men, due to the perceived threat posed to it by Zaire (the Democratic Republic of Congo, DRC) while the others had either 66 or 67 men each. ${ }^{37}$ 


\section{ENTER UNITA}

By early September 1975, the MPLA, having consolidated their grip on the towns located along the Atlantic coastline, began to march inland. Their objective - to take control of the Benguela Railway Line and the Unita-controlled city of Nova Lisboa (Huambo) located in the mountainous central area of Angola. Simultaneous to these developments, a series of meetings took place between Jonas Savimbi, the leader of Unita (União Nacional para Independência Total de Angola - the National Union for the Total Independence of Angola) and various South African government officials. Savimbi was quick to emphasise the threat posed to Unita by the deployment of the MPLA's Soviet-supplied armour and the fact that Unita had virtually no armour or anti-armour weapons of their own. ${ }^{38}$

On 24 September 1975, the South African Government, after deliberations, decided to intervene in the Angolan Civil War directly. It approved a four-phase plan of support for both Unita and the FNLA.

$\diamond$ Phase 1 - to provide assistance to maintain control of areas already held by the opposition forces FNLA and Unita.

$\diamond \quad$ Phase 2 - to gain control over the south-eastern corner of Angola, including the towns of Sá da Bandeira (Lubango) and Moçâmedes.

$\diamond \quad$ Phase 3 - to take Benguela, Lobito and Novo Redondo.

$\diamond$ Phase $4-$ a major push against Fapla. ${ }^{39}$

The first South Africans to arrive into the Angolan town of Silva Porto (Cuito), on 24 September 1975, was a five-person SADF-Unita Liaison Team under the command of Lieutenant Colonel Wim van der Waals, who would act as the SADF Liaison officer to the Unita top leadership. A specialist infantry training team, under the command of Major Nic Visser, were the next to arrive - their task to train over 1000 Unita recruits at an old Portuguese prison in Capolo, $62 \mathrm{~km}$ to the south of Silva Porto (Cuito). ${ }^{40}$ The final SADF elements to arrive were a mixed armour-infantry training team. The twelve armoured corps members included four Permanent Force soldiers and eight National Servicemen (four Eland drivers and four Eland Gunners) of the January 1975 intake. The Troopers, all from Alpha Squadron, 1 SSB, had just completed a three-and-a-half-month deployment at Mpacha in the Caprivi. Instead of going on their scheduled post-deployment seven days leave; the eight Troopers along with their four leaders travelled to Pretoria in a Douglas C-47 Dakota. After receiving a briefing at SADF headquarters in Potgieter Street, the twelve had to wait until special parliamentary approval for their deployment, granted on 30 September 1975. The following night, the 12 armour soldiers accompanied by a nine-man infantry training team, along with four SADF Land Rovers armed with Entac anti-tank missiles, ${ }^{41}$ under the command of Major Louis Holtzhausen ${ }^{42}$ were secretly airlifted into Silva 
Porto (Cuito). The twelve SAAC soldiers, under the leadership of Lieutenant Nel van Rensburg, were tasked to inspect and maintain the four Panhard armoured cars that Unita had on their inventory, ${ }^{43}$ while simultaneously giving the Unita armoured car crews some refresher training. It soon became clear that not only were the vehicles in a terrible condition, but Unita had no trained crews whatsoever to operate them. ${ }^{44}$

\section{THE CLASH AT NORTON DE MATOS, 5 OCTOBER 1975}

At the beginning of October, word arrived in Silva Porto (Cuito), that the MPLA had resumed its march towards Nova Lisboa. Eight days after arriving, the 19 South Africans, ${ }^{45}$ including Lieutenant van Rensburg and his men, who had now been ordered to crew the Unita Panhards themselves, went from trainers to active participants. Leaving Silva Porto (Cuito) in a convoy that included: only three Panhards (the 4th cannibalised for spare parts); a SADF Land Rover armed with a $12.7 \mathrm{~mm}$ machinegun; and four SADF supplied Jeeps, armed with the French Entac anti-tank missile systems. ${ }^{46}$ Also on board was a 20 -ton cargo vehicle, carrying the entire teams A1 Echelon supplies, and accompanied by two Unita Land Cruisers, armed with $12.7 \mathrm{~mm}$ machineguns and between 300 to 500 Unita infantry. The convoy reached the town of Nova Lisboa, $140 \mathrm{~km}$ west of Silva Porto (Cuito), on 3 October 1975. Unfortunately, the Panhard 90 of Lieutenant van Rensberg, ${ }^{47}$ suffered a major mechanical breakdown and was abandoned just short of Nova Lisboa. ${ }^{48}$

According to the Unita intelligence reports, the MPLA was advancing eastwards along two routes from the coastal cities of Benguela and Lobito. Considering the northern Lobito route the more dangerous, due to its better road surface, Major Holtzhausen decided to deploy his force along this route. Unita intelligence reported that the MPLA was in the vicinity of the village of Norton de Matos, $165 \mathrm{~km}$ north-west of Nova Lisboa. Leaving Nova Lisboa on 4 October 1975, the entire force (that now consisted of 21 South Africans ${ }^{49}$ moved the $127 \mathrm{~km}$ to an Assembly Area (AA) at the small village of Vila Massano de Amorim. Here, Major Holtzhausen was joined by the local Unita commander, Major Lumumba, and his infantry company. These additions raised the total available Unita forces to 2 infantry companies and one commando, supported by Unita mortars and $106 \mathrm{~mm}$ recoilless rifles. ${ }^{50}$ The men welcomed the addition of these extra forces as another Panhard, this time the Panhard 60 of Sergeant K.D. Strauss, ${ }^{51}$ had become mechanically unrepairable and would have to be left behind at Vila Massano de Amorim.

Leaving Vila Massano de Amorim at 05:00 the following Sunday morning, the force shortened the distance $33 \mathrm{~km}$ west into a Forward Assembly Area (FAA), only $5 \mathrm{~km}$ east of Norton de Matos and just a kilometre away from the bridge over the Balombo River. After a final check of all the weapons and some last-minute coordination 
between the SADF and Unita elements, Major Holtzhausen ordered the force forward to contact. The leading Panhard 90 of Lieutenant van Rensburg quickly reached the bridge over the Balombo River where it halted. The original battle plan had called for the bridge and its immediate surroundings to be secured by Unita forces, but Lieutenant van Rensburg could see that this had not occurred, and he was thus sceptical of crossing the bridge. The vegetation at the bridge was also very dense, limiting observation, while the preceding day's rain had made the entire area extremely soft and muddy and thus not mechanised negotiable (accessible for any vehicles) ${ }^{52}$

While the South Africans tried to track down the missing Unita infantry, a civilian light aircraft overflew the convoy. The crew in the leading Unita Land Rover armed with a $12.7 \mathrm{~mm}$ anti-aircraft machinegun immediately opened fire on the suspected enemy reconnaissance plane. Two signal flares were then spotted by the South Africans on their eastern flank and almost immediately after that the entire convoy began taking fire from rocket, artillery, mortar and small arms. The ambushers drew first blood, when the command jeep of Major Holtzhausen took a direct hit from a large calibre anti-tank weapon. The strike that hit the command vehicle's right rear, flung the Major, his signaller, Staff Sergeant Corrie Maré, Sergeant K.D. Strauss and Trooper A.C. Botha, acting as the command vehicles driver, onto the ground. Only Sergeant Strauss, who had taken shrapnel to his face, was injured.The Angolans, along with their Cuban advisors, had chosen their ambush site well, with dense vegetation and steep terrain channelling the SADF-Unita alliance onto the road (designated killing zone). While the Unita infantry abandoned their comrades in their mad rush to the rear, Major Holtzhausen ordered his South Africans into battle. Lieutenant van Rensburg, in the sole remaining Panhard 90, quickly got his vehicle into a firing position, from where his gunner, Corporal F.J.S. Scheepers, ${ }^{53}$ began to rapidly engage the enemy positions. Simultaneously, the Entac armed Jeep of Staff Sergeants Sid Brown and Jeff Pattison fired one missile at a mortar position they had observed and a second missile at the ambushers' left flank. A second Entac Jeep crewed by Warrant Officers Class 2 Kalahari Jacobs and Piet van der B. Lambrechts hit the enemies' heavily congested right flank with two missile strikes. ${ }^{54}$

Major Holtzhausen realised that to remain on the road within the enemies designated killing zone was foolish, and therefore he ordered his force to withdraw $2 \mathrm{~km}$ back up the road. The Entac Jeep of Staff Sergeants Brown and Pattison covered the withdrawal, by firing two more missiles, one at each flank of the enemies' position. Unfortunately, Lieutenant van Rensburg in his Panhard did not monitor the withdrawal order, so he and Corporal Scheepers continued to fire $90 \mathrm{~mm}$ High Explosive (HE) rounds at the enemy. Realising that they had left Van Rensburg behind; the Major and Sergeant Strauss proceeded forward on foot to go and retrieve them, only to see the lieutenant and his crew returning on their own, the lieutenant correctly assessing the tactical situation. ${ }^{55}$ 
In the interim, fighting had also broken out at the rear of the column. Major Holtzhausen had previously positioned the Jeep of Corporal Bes Bezuidenhout, armed with a $12.7 \mathrm{~mm}$ Browning machinegun, at the rear of his column, with the task of keeping the South Africans escape route clear. While in this position, Corporal Bezuidenhout, his gunner, Trooper Hugh Hulett and driver, Trooper Eddie Young, along with three passengers, Lance Corporal Manus Myburgh, Trooper Barend Liebenberg, and Trooper Wilhelm Swart, suddenly found themselves under attack by an enemy force of approximately 150 men. ${ }^{56}$ The enemy infantry, led by Cuban instructors, had outflanked the South African elements in front and were now determined to cut-off the entire force. Quickly operating the $12.7 \mathrm{~mm}$ machinegun and ably supported by his fellow armoured comrades, Corporal Bezuidenhout lay down a wall of fire that the attacking infantry failed to penetrate. With the attackers pinned down, Major Holtzhausen, also ordered these men back to safety. ${ }^{57}$

After pulling back a safe distance from the fighting, Major Holtzhausen quickly held an impromptu group meeting. Lieutenant van Rensburg reported that he had destroyed one enemy armoured car (most likely a BRDM) ${ }^{58}$ and sent another rearward belching smoke, while the Entac crews reported one mortar destroyed along with multiple enemy casualties inflicted. Major Holtzhausen, worried about the loss of his command vehicle abandoned at the bridge, sent a team forward, in the hope of recovering it. The scouts soon reported back that the entire area was now full of enemy soldiers, who were busy recovering the command vehicle (and both the Unita Land Cruisers, both of which had been abandoned by their crews, immediately after the firing started), back towards their own lines. ${ }^{59}$

Realising that all the vehicles were lost, Major Holtzhausen, leaving behind a Unita covering force tasked with keeping observation on the bridge over the Balombo River, withdrew his force back to Nova Lisboa. ${ }^{60}$ The 12 SAAC members, transferred back to Silva Porto (Cuito), resumed their training of the Unita designated armoured crews. Two weeks later, the 12 were picked up and flown to Rundu. Here they learnt that the SADF had entered Angola and needed them at the front. On 22 October 1975, the men withdrew four brand new Eland $90 \mathrm{~mm}$ armoured cars at the depot in Grootfontein. By month's end, exactly 30 days after leaving Bloemfontein, the 12 men and their four Elands, joined up with Major Toon Slabbert and his Delta Squadron, 2 SAI, at Sá da Bandeira, $408 \mathrm{~km}$ south-east of their last post at Nova Lisboa. ${ }^{61}$

\section{COMBAT GROUP FOXBAT 1: CENTRAL ANGOLA}

The engagement at Norton de Matos, while relatively small, was a catalyst for future SAAC operations, as it demonstrated that the MPLA was indeed effectively utilising armour as part of their forces. ${ }^{62}$ As a direct result, the Officer Commanding 1 SSB, 
Lieutenant Colonel A.P.R. Carstens, was ordered to prepare another Eland Armoured Car Squadron for operational duties in SWA. By combining the remaining personnel from Bravo Squadron, who had volunteered for extra service ${ }^{63}$ and who had just returned from the border with Captain Beyleveldt, with Charlie Squadron, 2 SSB, a new squadron was quickly formed under the command of Captain George Schoeman, 2 SSB. On 9 October 1975, the squadron left Bloemfontein, arriving in Ondangwa, $2400 \mathrm{~km}$ away, four days later. Over the period 17-22 October, all 82 men plus their 22 armoured cars were airlifted by night at tree-top level to Silva Porto (Cuito) in Central Angola. Once there, they joined up with various other SADF groupings in what was to become known as Combat Group Foxbat 1, under the command of Lieutenant Colonel Eddie Webb. ${ }^{64}$

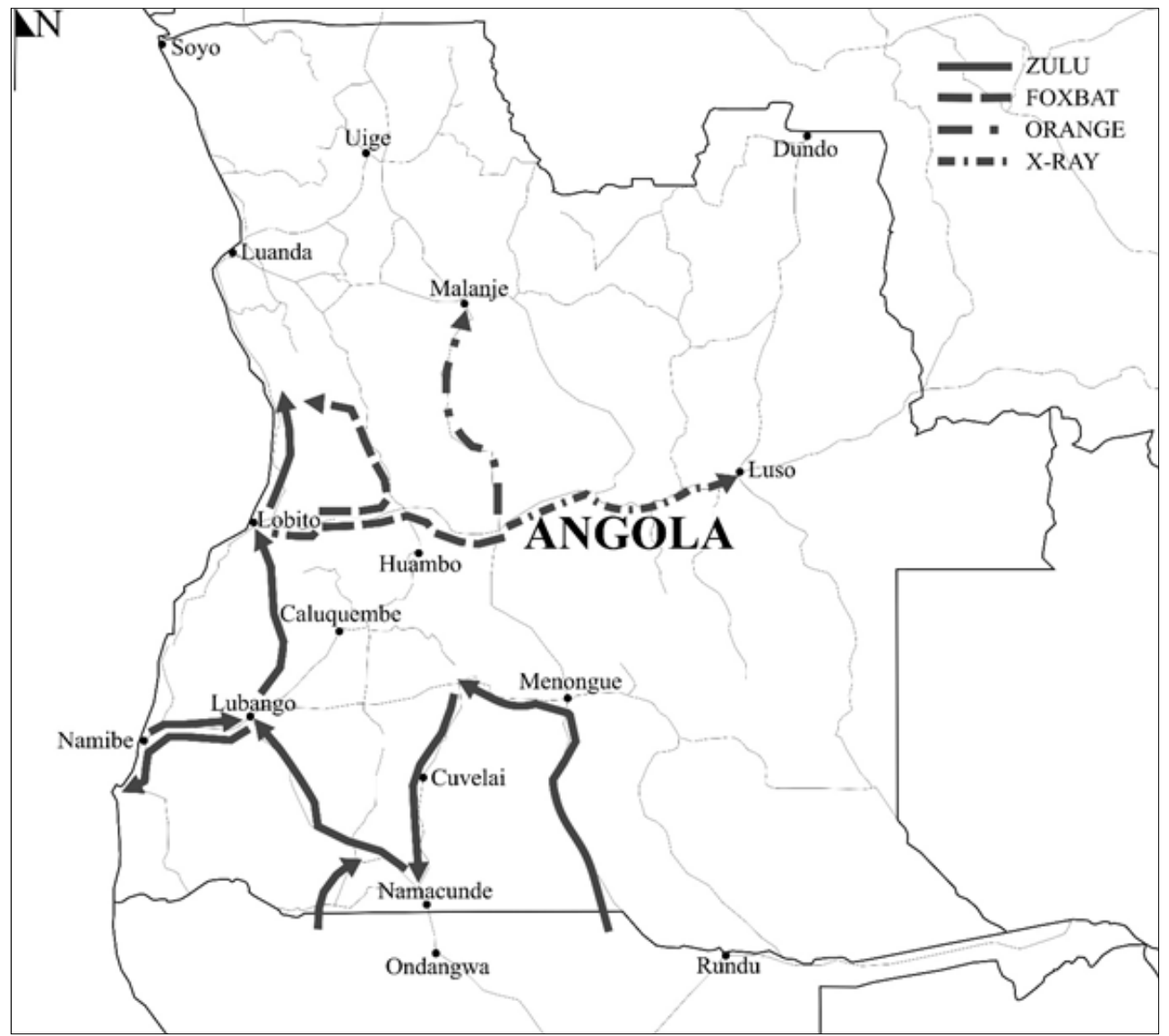

MAP 3.1 Principal SADF movements during Operation SAVANNAH 
While Major Holtzhausen and his men were enduring their baptism of fire, the SADF was forming a new combat formation on the border. Task Force Zulu, under the command of Colonel J.S. van Heerden, ${ }^{65}$ originally consisted of two Combat Groups. The first, Combat Group Alpha, commanded by Lieutenant Colonel Delville Linford, consisted of two companies of ex-Angolan Bushmen soldiers, who had formed the famous Fletcha units in the Portuguese army. The second Combat Group, Combat Group Bravo, was under the command of Lieutenant Colonel Jan Breytenbach and consisted of four companies of FNLA soldiers, whom he had been training in M'pupa. This task force crossed over into Angola at Katuitui on 14 October 1975 and quickly advanced and occupied Caiundo and Serpa Pinto (Menongue). By 16 October, the task force was spending the night at Cuchi. On 17 October, the task force passed through Cassinga, and a last-light assault saw them spend the night in Cuvelai. Two days later, the task force attacked and conquered the MPLA-controlled town of Pereira d'Eca, thereby removing a significant portion of MPLA forces in both the Cuando Cubango and Cunene provinces of Angola. ${ }^{66}$

While Task Force Zulu was busy executing its mission, Brigadier Dawie Schoeman, the commander of 1 Military Area, ordered Lieutenant Colonel D.S. du Toit, Officer Commanding 2 SAI, to attack and occupy Fort Roçadas (Xangongo) with his Battalion Group. Leaving an infantry company and two troops of armoured cars ${ }^{67}$ behind at Calueque, Lieutenant Colonel du Toit successfully attacked and occupied Fort Roçadas on 20 October 1975. The attack was spearheaded by the remaining twelve ${ }^{68}$ Eland Armoured Cars, who by firing both $90 \mathrm{~mm}$ and $60 \mathrm{~mm}$ ordinance into the old fort located just south of the town, quickly eliminated all Fapla resistance. Task Force Zulu, joined up with 2 SAI at Fort Roçadas later on that same day. ${ }^{69}$ The next morning, Brigadier Schoeman informed Lieutenant Colonel du Toit that 2 SAI Infantry was to remain in their current locations, while Task Force Zulu, now reinforced with Major Slabbert's Delta Squadron, as Combat Team Charlie, would continue their advance northwards into Angola. Considering that his command had left behind two troops of Elands at Calueque, ${ }^{70}$ higher command informed Major Slabbert that he would be reinforced with two new troops of armoured cars, ${ }^{71}$ directly sent as quickly as possible from South Africa. ${ }^{72}$

Over the next 27 days (up until 19 November 1975), Task Force Zulu was to blitzkrieg its way across southern Angola, with the Eland armoured cars leading the advance and often proving to be the decisive factor in many of the impending battles. Advancing northwards, a string of settlements soon fell to the Task Force, with Sá da Bandeira, the capital city of the Angolan province of Huila, falling after some ineffective fighting on 24 October 1975. Next, the Task Force struck due west towards the Atlantic coast, with the prized coastal port of Moçâmedes (Namibe) falling to Colonel van Heerden's men by 28 October $1975 .{ }^{73}$ 
After the fall of Moçâmedes, Colonel van Heerden sent Combat Group Alpha back to Sá da Bandeira to protect the city from a possible attack from the north. On 29 October, an Eland Troop under the command of Lieutenant Nel van Rensburg of Norton de Matos fame, who had returned to SWA and been re-equipped in four new SADF armoured cars, reinforced Combat Group Alpha. ${ }^{74}$ Leaving one of the FNLA companies of Combat Group Bravo behind in Namibe as a holding force, Task Force Zulu again struck out north from Sá da Bandeira with Combat Group Alpha in the vanguard. After overcoming relatively light resistance at Cacula, Quilengues, Chongoroi and the Coporolo River, they encountered main Fapla-Cuban defensive positions at Catengue, where 51 Cuban instructors from the CIR Benguela deployed with the MPLA.

Under Cuban leadership, the MPLA had deployed into defensive positions consisting of an Infantry Battalion of approximately 1000 men, dug in along a ridge supported by RPG 7s, two $82 \mathrm{~mm}$ and two $75 \mathrm{~mm}$ guns deployed next to the road. Behind the ridge, the Cuban instructors manned the $82 \mathrm{~mm}$ mortars and approximately four $122 \mathrm{~mm}$ single barrel rocket launchers. ${ }^{75}$ This strong resistance was unexpected, and the first two SADF attacks were unsuccessful. Changing tactics, Colonel van Heerden sent Combat Group Alpha supported by armoured cars to attack the position, while he sent Combat Group Bravo also with armoured car support on a $51 \mathrm{~km}$ wide outflanking manoeuvre via San Christovao and Changongo. ${ }^{76}$

After launching a third assault, led by Captain J.P. Dippenaar with Bravo Company and Captain Gert Grobler's Charlie Company, supported by the Vickers machineguns of the Support Company of Captain James Hill, the MPLA infantry abandoned their positions and began to flee northwards towards the port city of Benguela. Meanwhile, Combat Group Alpha had rejoined the main road towards Benguela, where they set up an ambush site, using their Eland Armoured Cars. No sooner was it in place, when a convoy of vehicles approaching from Benguela entered the killing zone. The first vehicle destroyed by a $90 \mathrm{~mm}$ shell turned out to be a cargo vehicle loaded with artillery ammunition. In total, seven vehicles were engaged and destroyed, including the vehicle transporting a Cuban artillery detachment that was heading for Catengue to provide improved artillery support to the battle there. ${ }^{77}$

\section{OPERATION CARLOTA}

With very little time left before the 11 November 1975 deadline, FNLA leader Holden Álvaro Roberto (12 January 1923 to 2 August 2007) decided the time had come for the FNLA to make its bid for power. Amassing the FNLA, while supported 
by elements of the Zairian Defence Force (ZDF) and the SADF, he struck out for Luanda from the east. To counter this imminent threat to their Centre of Gravity, the Cubans only had available the forces deployed in the original training CIRs. With no other option, the Cubans quickly shut down the CIR at Salazar, only three days after it became operational and redeployed its instructors along with their recruits to Luanda. On 23 October 1975, forty instructors from the CIR at Salazar took part in an unsuccessful assault on an FNLA/ZDF force dug in at Morro do Cal. Five days later, the second group of instructors were in action to the east of Quifangondo (Kifangondo).

The battles at Catengue and Quifangondo and the subsequent loss of life to the Cuban forces deployed in those areas galvanised Havana. The MPLA had continually been harassing the Cubans for more and more aid and on 4 November 1975, their prayers were answered, when Castro decided to deploy an unprecedented Cuban force into Angola. That same day the first plane with 100 heavy weapon specialists left Cuba for Luanda via Brazzaville, arriving in Angola on 7 November 1975. Two days later, the first two Cuban planes landed in Luanda carrying the first company (158 men) of a 652-strong battalion of elite Special Forces of the Ministry of the Interior, tasked with the important mission of protecting Luanda at all costs. ${ }^{78}$ Eighty-eight of the 158 Special Forces were immediately taken to Grafanil, the MMCA military camp on the outskirts of Luanda. There they were issued with weapons, equipment and clothing before being rushed forward to the front. By 08:00 the next morning, the company deployed in position behind the defenders of Quifangondo. ${ }^{79}$

Additionally, they also sent the 100 heavy weapon specialists who had landed on 8 November 1975 to the front at Quifangondo, where they would join up with an 850-man Fapla battalion, a Katanga infantry company of 200 men and one Soviet advisor named Yuri, who was already locked in battle with the FNLA/ZDF ${ }^{80}$ The Cuban defenders at Quifangondo also had access to some heavy weapons (artillery cannons, mortars and most importantly a battery of 6 BM-21 (Katyusha) multiple rocket launchers, that had just arrived from Cuba by ship on 7 November 1975. By the beginning of March 1976, the Cuban military strength within Angola would reach an impressive 36000 men strong force. ${ }^{81}$

The Cubans also commandeered all available ships in their merchant marine to sealift further reinforcements and all the war materials required to Angola, with the first three ships (the Vietnam Heroico, Imías and Océano Pacífico) sailing from Havana on 11 November 1975 and docking in Luanda between 27 November and 1 December 1975, bringing in 1253 Cuban soldiers, primarily members of an artillery regiment. ${ }^{82}$ On 6 December, Fapla would also receive an important shipment of Soviet weapons. The Russian Airforce had transported ten BM-21 multiple rocket launchers, twenty $76 \mathrm{~mm}$ artillery guns and twenty $82 \mathrm{~mm}$ mortars into Luanda. ${ }^{83}$ 
After the unexpected heavy fighting around Catengue, Colonel van Heerden ordered Combat Group Bravo to clear the route of all enemy forces from Catengue eastwards towards Nova Lisboa, to prevent Fapla-Cuban forces from operating in his rear. With Alpha and Charlie Companies leading the way, along with armoured car support, this task was completed by 5 November 1975. Simultaneously, Combat Group Alpha resumed its advance towards the Port of Benguela. After successfully capturing the airport located south-east of the city, Combat Group Alpha became pinned down by accurate $122 \mathrm{~mm}$ rocket and $82 \mathrm{~mm}$ mortar fire, delivered from within the town. The arrival late that afternoon of Combat Group Bravo allowed Colonel van Heerden to launch an assault into the town the next day, that finally resulted in the port falling to the South Africans. ${ }^{84}$

Suspecting that the enemy might abandon the Port of Lobito, located $33 \mathrm{~km}$ north up the coastline on the right bank of the Catumbela River, Combat Group Alpha quickly advanced the next day, 7 November 1975, and by 20:00 that evening, the port was successfully captured ${ }^{85}$ With Lobito in their hands, Task Force Zulu's next target, the port city of Novo Redondo, lay $181 \mathrm{~km}$ further north up the coastline. With Combat Group Alpha again in the vanguard, Task Force Zulu headed north on 10 November 1975. After overcoming light resistance at the Cuula River, $60 \mathrm{~km}$ north of Lobito, the South Africans encountered the enemy's main defensive positions that had been established by the Cuban instructors from the CIR of Benguela, ${ }^{86}$ situated along the high ground overlooking the bridge over the Quicombo River, only $19 \mathrm{~km}$ south of Novo Redondo. When the leading armoured car crossed the bridge, it was engaged and struck by an RPG 7, that disabled the vehicle and wounded two of its crew. The enemy now opened up with artillery, mortars and rockets on the stranded combat group. Luckily for the South Africans, it was already late in the day, and when night fell, they were able to reorganise themselves under cover of darkness. The next morning, making use of a newly arrived $88 \mathrm{~mm}$ artillery battery, the Combat Group successfully managed to force their way over the Quicombo River and continued their advance north. With the Elands leading the way, Novo Redondo was captured intact on 11 November 1975, the same day the Portuguese would have handed over power, according to the Alvor Agreement. ${ }^{87}$

On 14 October 1975, Colonel van Heerden sent Combat Group Bravo north again, their target the important port city of Porto Amboim, $66 \mathrm{~km}$ further north, up along the Atlantic coastline. The combat group made good time, until it came upon the bridge over the Queve River, only $15 \mathrm{~km}$ south of Porto Amboim. Unknown to the South Africans, the second and third companies of the battalion of Special Forces, had arrived in Luanda between 11 and 16 November 1975. Both had immediately been 
sent south to the Queve River, where they linked up with the surviving instructors of the CIR Benguela. Their orders, "hold the line, whatever the cost". ${ }^{88}$

When the South African leading elements reached the bridge they wanted to reconnoitre, they discovered it demolished, and heavy and accurate artillery, mortar and rocket fire hit them. No amount of threatening could convince their FNLA soldiers to cross the river on foot, and so the combat group was forced to pull back to Novo Redondo. ${ }^{89}$

A second attempt by a combat team from Combat Group Bravo, utilising the route to Gabela was also unsuccessful as its bridge over the Queve River had also been destroyed. The Cuban commander of the Central Front, Major Raúl Diaz Argüelles, ${ }^{90}$ had deployed a few men in key locations, such as the four bridges between Porto Amboim and Quibala, while half his force (the Special Forces and the instructors from the CIR Benguela) shadowed the South Africans eastward advance. Major Argüelles was trying to defend a $160 \mathrm{~km}$ long front with a few hundred Cubans and about 400 Fapla soldiers. ${ }^{91}$

Stopped in its tracks and still considering what its next move should be, the task force headquarters received new orders. Leaving behind Combat Group Alpha along with two Eland Troops ${ }^{92}$ as a holding force along the coast, Task Force Zulu headquarters along with Combat Group Alpha and the remaining three troops of Major Toon Slabbert's Eland Squadron were ordered inland towards Cela, where they would be needed. ${ }^{93}$

\section{COMBAT GROUP FOXBAT 1: CENTRAL ANGOLA}

After arriving by air at Silva Porto (Cuito) over the period 17 to 22 October 1975, Captain George Schoeman, 2 SSB, got his 22 Eland Armoured Cars ready for operational use. Unknown to Combat Group Foxbat 1, the MPLA headquarters had decided on 22 October to launch a renewed assault to capture Novo Lisboa. By 25 October, this MPLA advance supported by three armoured cars and two tanks had recaptured Norton de Matos (Balombo), while a second force, supported by nine armoured cars had advanced up to $14 \mathrm{~km}$ north of Santa Comba (Waku Kungo). In response to these reports, Lieutenant Colonel Webb decided to redeploy his combat group from Silva Porto (Cuito) to Alta Hama, located $71 \mathrm{~km}$ north of Novo Lisboa. By nightfall of 25 October, the combat group was at the bridge over the Queve River, $5 \mathrm{~km}$ east of Alto Hama. The next morning, Lieutenant Colonel Webb sent three Eland armoured car troops supported by Unita infantry out on the road westwards towards Norton de Matos. At Luimbale, only $30 \mathrm{~km}$ west of Alto Hama, this force ran into the leading elements of the MPLA advance. Taking in firing positions, the Elands 
quickly engaged the two leading MPLA Armoured Cars, ${ }^{94}$ destroying both and killing all six of their Cuban crews. The rest of the MPLA force hastily withdrew back down to the coast. ${ }^{95}$

To safeguard Nova Lisboa, Lieutenant Colonel Webb realised he would have to patrol and dominate at least three routes into the city; from the east the two routes from Benguela and Lobito and the north, the main road that links Luanda with Nova Lisboa via Quibala and Santa Comba. From 28 to 31 October 1975, various combat teams were sent out on these routes, with clashes occurring on the bridge over the Queve River, $91 \mathrm{~km}$ north of Alto Hama, again at Norton de Matos on the Lobito route, both on the 29th; and at Cuma (Ukuma) on the Benguela route, $89 \mathrm{~km}$ west of Nova Lisboa, on the 31 st. ${ }^{96}$

With Task Force Zulu flying up the coastline, the command decided that Combat Group Foxbat should advance eastwards towards Lobito, thus cutting off the inland escape route of all enemy forces escaping from Task Force Zulu's attack. By the evening of 5 November, the Eland Armoured Car Squadron of Captain Schoeman deployed in ambush positions at the road junction $32 \mathrm{~km}$ east of Lobito. Early the next morning, the first vehicle convoy fleeing Lobito entered the ambush area and the Elands engaged them. By day's end, 18 enemy vehicles were either destroyed or captured, with another 15 on the next day, Friday, 7 November 1975. However, tragedy struck the Eland Squadron early that Friday morning, when Captain Schoeman accidentally stood on a Pom Z-2M anti-personnel mine that severed his left leg just below the knee. Despite being CASEVAC-ed almost immediately by air to 1 Military Hospital in Pretoria, the captain passed away from his wounds two days later. Command of the squadron now fell to his second in command, Lieutenant Chris du Raan. ${ }^{97}$

On 8 November 1975, another combat team from Combat Group Foxbat 1, this one under the command of Captain Johan Holm, who had stayed behind as a holding force at Luimbale, deployed northwards towards Santa Comba. Once command determined that Santa Comba was secured, Lieutenant Colonel Webb made this village his new headquarters position. Over the next ten days various combat teams from Foxbat 1, attempted to reconnoitre all the possible routes northwards from Santa Comba to Quibala, that was designated the combat group's next objective. However, Fapla and Cuban soldiers had destroyed the bridges over the various routes and contested all possible crossings. ${ }^{98}$

\section{ESTABLISHMENT OF 101 TASK FORCE}

By the beginning of November 1975, despite the spectacular successes achieved by both Task Force Zulu and Combat Group Foxbat 1, the South Africans realised that they would not reach Luanda before the 11 November 1975 deadline. A political 
decision was thus required; continue advancing or halt in place. On 10 November 1975, South African Prime Minister Balthazar Johannes Vorster (13 December 1915 to 10 September 1983), gave in to frantic requests by Unita to keep on advancing and thus keeping the pressure on the MPLA-Cuban alliance. The SADF was now re-tasked with capturing as much territory as possible before the upcoming emergency meeting of the Organisation of African Unity (OAU), scheduled to take place in Addis Ababa on 13 January $1976 . .^{99}$

As a new phase of the operation had commenced, command decided that a new command structure was also required. Consequently, 101 Task Force established at Rundu, with Major General André van Deventer in command. The SADF divided the entire northern SWA and Angola into three military areas, each with their headquarters. Military Area 1 consisted of the Ovambo-Kavango-Caprivi areas of SWA, while Military Area 2 covered southern Angola with its headquarters at Cela, with Military Area 3 covering northern Angola, with its Head Quarters at Ambriz; the dividing line being the 90-degree southern latitude line. Brigadier D.F.N. Schoeman was appointed the commander of Military Area 2, with Colonel P.J. Schalkwyk (normally the OC of 81 Armour Brigade) appointed as his Chief of Staff. The headquarters at Cela became operational on 22 November $1975 .{ }^{100}$

In support of the expanded role now facing the SADF, the Chief of the SA Army, General Magnus Malan (30 January 1930 to 18 July 2011) ordered the SAAC to mobilise the regimental headquarters of 1 SSB along with three more complete Eland Squadrons. However, the challenge was the entire National Service intake of January 1975 of the SAAC already deployed in Angola. Either as part of D Squadron, 2 SAI or as members of Alpha and Bravo Squadrons, 1 SSB. All that remained was the recruits of the July 1975 intake, who were less than five months into their year-long training programme. Nonetheless, the crews were needed north as the January 1975 intakes year of service was rapidly coming to an end. With no other choice but to comply, Lieutenant Colonel A.P.R. Carstens, the OC 1 SSB, mobilised his regimental headquarters while simultaneously forming his July 1975 intake into two new Alpha and Bravo squadrons under the commands of Captains Theo Beyleveldt and Fred Rindel. ${ }^{101}$ While the OC 2 SSB, Lieutenant Colonel G.D.M. Coetzee, did a similar exercise by forming his July intake into a new squadron under the command of Major Fido Smit. ${ }^{102}$

\section{COMBAT GROUP FOXBAT 1: BATTLE OF THE EBO RIVER}

On 15 November 1975, Lieutenant Colonel Webb was replaced as OC of Combat Group Foxbat 1 by Lieutenant Colonel George Kruys. The next morning a second Eland 90 Squadron, Alpha Squadron, 1 SSB, under the command of Captain Anton 
Fourie, arrived at Cela, along with a desperately needed $88 \mathrm{~mm}$ artillery battery. The SADF activated the squadron in Bloemfontein on 5 November 1975, to relieve the Eland squadron now under the nominal command of Major W.C.A. Rigaardt, ${ }^{103}$ sent as a replacement for the killed Captain Schoeman. This squadron would need a day or two to acclimatise before it could replace the original Foxbat 1 squadron. However, Lieutenant Colonel Kruys was not in the mood to wait for them. Consequently, with the plan already in place, he ordered his forces forward. ${ }^{104}$

Unbeknown to Lieutenant Colonel Kruys, the Cuban Central Front Commander, Major Argüelles, had anticipated this very movement. After stopping the South African advance over the Queve River, Major Argüelles had relocated part of his force to Catofe, the Fapla-Cuban positions in front of Quibala. After reconnoitring the most likely route the South Africans could take from their headquarters at Cela, Argüelles ordered his subordinate commander, René Hernández Gattorno, to prepare an ambush position along a small wooden bridge that crossed the narrow but deep Mabassa River. Gattorno deployed his force of 70 Cubans, who were manning BM-21 multiple rocket launchers and RPG teams, along the riverbank. He placed the Fapla infantry in a defensive trench system to contest any crossings of the bridge. ${ }^{105}$

The SADF plan called for Combat Group Foxbat 1 to continue advancing from Quissobi north over the village of Ebo towards Condé. The vanguard under the command of Captain Holm would consist of the Eland Squadron of Lieutenant du Raan, while the Elands of Captain Fourie would form the reserve. Captain Holm and the vanguard moved out from Quissobi early on the morning of 23 November 1975. About $21 \mathrm{~km}$ along the gravel road, the leading Elands entered the village of Ebo without encountering any resistance. With Ebo secured, Captain Holm ordered the Elands forward again. About $5 \mathrm{~km}$ north of Ebo, the road dips down to cross the Mabassa River, that flows westwards off two high granite grounds, Dongo and Luanda, situated east of the road. A SAAF light aerial reconnaissance aircraft, flown by Lieutenant K.A. Williamson observed the Angolan and Cuban entrenchments and weapon emplacements, located on the high grounds. In a desperate attempt to indicate the enemies' exact position to the leading Eland Troop under the command of Second Lieutenant J.W. Swanepoel, Lieutenant Williamson flew directly over their positions several times. Second Lieutenant Swanepoel, while aware of the enemies' general location, could not pinpoint their exact location. Observing, a two-lane dirt track leading east off the main road, the Lieutenant redeployed his four armoured cars onto it as he hoped that it would provide better observation northwards. With Lieutenant Williamson providing fire corrections from above, the Troop then fired thirty $90 \mathrm{~mm}$ rounds in the indicated general direction. Besides, the Cubans and Angolans held their nerve and did not give away their position by returning fire. ${ }^{106}$

When Lieutenant Williamson reported observing cargo vehicles parked along the banks of the Mabassa River, 2 to $3 \mathrm{~km}$ further north, the next Troop in line, that 
of Second Lieutenant Johan du Toit moved forward. ${ }^{107}$ As the leading armoured car approached the bridge over the Mabassa River, the Cubans and Fapla soldiers deployed along the river's northern bank, finally opened fire. An anti-tank shell fired from a Russian $76 \mathrm{~mm}$ cannon immediately hit the leading Eland of Second Lieutenant du Toit's Troop and killed the driver, Trooper Neil Lombaard.This Eland left the road and ended up in the river. Soon the three other cars of the Troop were also hit by enemy fire and disabled. Second Lieutenant Swanepoel immediately rushed his Troop forward to assist. As immobilised vehicles blocked the road, the troop approached the river cross country directly north from their previous firing positions. They soon became bogged down in the soft mud, where their stationary vehicles became easy targets for the Cubans manning the artillery. While abandoning his immobilised Eland, Lance Corporal Gerhard Volgraaff was also hit and killed. ${ }^{108} \mathrm{~A}$ third Eland troop under the command of Second Lieutenant A.J. Kriel also moved forward to assist their comrades. By this time, seven Elands had been hit and immobilised. For the rest of the day, the battle raged, with the South Africans fighting to rescue the Eland crews either stuck in their vehicles or in whatever cover they had sought out for themselves outside their vehicles. ${ }^{109}$

Captain Fourie, the commander of the reserve Eland Squadron, was ordered to form two combat teams and deploy them on the Hengo and Tunga roads to protect the withdrawal of the vanguard. Captain Fourie then went forward with the Eland Troop under the command of Second Lieutenant Jan Alberts. Together they successfully recovered the Eland of Corporal G. Botha along with another one from the original troop deployed on the road. While busy with this task, headquarters informed Captain Fourie that he was placed in command of the vanguard's withdrawal, because another mishap had struck the combat group. While Second Lieutenant A.J. Kriel and Corporal J.J. Taljaard were busy offloading mortars from a cargo vehicle for their Eland 60s, Captain Holm stopped alongside them in the Eland that he had commandeered from Lieutenant L. van Niekerk, who was now following in the civilian Honda 4x4 that Captain Holm had been utilising as his command vehicle. As the four discussed the mission, a $122 \mathrm{~mm}$ rocket struck their very position, immediately killing Captain Holm and Corporal Taljaard, while simultaneously wounding the two Lieutenants. ${ }^{110}$

By nightfall, with all the SADF forces withdrawn, concern remained about the missing Eland crews, especially the crews of the two leading Elands destroyed closest to the bridge. The next day, various search teams were dispatched to find the missing SADF soldiers. The teams soon dispatched good news as all were eventually found and reunited with their comrades. ${ }^{111}$

The Cubans had suffered one dead and five wounded. The Fapla infantry deployed in their trenches suffered no casualties at all and had been mere observers of the battle as the SADF never crossed the river. The Cuban ambush commander, Gattorno, estimated that the SADF-Unita alliance had suffered between thirty dead and thirty 
wounded. ${ }^{112}$ Officially, the SADF only had five members killed, three of whom were members of the SAAC. The Unita casualties are not known, but Breytenbach writes about "large numbers" of infantry lost during the battle. ${ }^{113}$ This loss, along with the destruction or capture of seven Eland Armoured Cars, was a bitter pill for the SADF to swallow.

\section{REORGANISATION ON THE CENTRAL FRONT}

Colonel van Heerden and Task Force Zulu, minus Combat Group Alpha who would remain behind on the coastal strip, had left Novo Redondo on 22 November 1975, arriving at Cela on the Central Front the following day, just as the battle at Ebo was unfolding. The original plan had Combat Group Bravo along with reinforcements from South Africa, deploying to Malanje, where Unita was still locked in the bitter struggle for control of the area. The SADF hoped that this force could quickly overcome the MPLA resistance in Malanje, where after they, in collaboration with Combat Team Foxbat 1, could assault Quibala from both the south and the east. The arrival of Combat Group Bravo precisely as the battle at Ebo was unfolding changed this plan as elements of Combat Group Bravo were immediately sent forward to assist their comrades in Combat Group Foxbat $1 .{ }^{114}$

With Combat Group Alpha still deployed on the coast and Combat Group Bravo been utilised on the Central Front at Ebo, it was decided to replace the personnel at the headquarters of Task Force Zulu. Some like Colonel van Heerden was sent back home to South Africa, while others like Lieutenant Colonel S.W.J. Kotzé, the Task Force's second-in-command, were given new assignments within the various combat groups now operating within Angola. ${ }^{115}$

\section{COMBAT GROUP ALPHA: WESTERN ANGOLA}

Lieutenant Colonel Linford and Combat Group Alpha had also been busy since the departure of Task Force Zulu. Not just content to deploy his force south of the Queve River, the Lieutenant Colonel decided to see if he could probe for an alternative route over the river. On 24 November 1975, a patrol under the command of Major C.P. Upton was sent to reconnoitre the Gabela Road up to the bridge over the Queve River. Leading the patrol would be three armoured cars under the command of Lieutenant Alex Nicolaou. Upon reaching the bridge, the patrol discovered a span of $13 \mathrm{~m}$ destroyed. When two Elands were called forward to assist the bridge reconnaissance team, the Cuban and Fapla forces, deployed on the northern bank, opened fire. One of the Elands suffered a mechanical breakdown right in the open. Its Browning machinegun was hit by enemy fire and was disabled. The crew 
commander, Trooper N.G. Obbes then climbed out of the vehicle, where he was shot and killed. The vehicles gunner, Trooper S.P. Janse van Rensburg continued to engage the enemy with $60 \mathrm{~mm}$ mortar fire. When the enemy fire died down, Trooper Janse van Rensburg and the driver, Trooper Wessels withdrew from the vehicle and were picked up by the vehicle of Corporal H.J.B. le Roux. Trooper Janse van Rensburg was awarded the Honoris Crux (silver) for his actions that day. When the enemy fire began to slack later in the day, Lieutenant Nicolaou in the third Eland went forward and recovered the remains of Trooper Obbes. After last light, he went forward again, this time to remove all the salvageable equipment still located on the now destroyed Eland. For his actions on that day, the SADF awarded Lieutenant Nicolaou the Honoris Crux (Silver). ${ }^{116}$

\section{COMBAT GROUP X-RAY: EASTERN ANGOLA}

The 18 Eland 90s and 4 Eland 60s and the crews of the armoured car squadron under the command of Captain Fred Rindel were airlifted to Silva Porto (Cuito) during the night from 24 to 28 November $1975 .{ }^{117}$ Upon their arrival, they were allocated to the newly formed Combat Group X-Ray under the command of Lieutenant Colonel S.W.J. Kotzé, only informed of his new appointment as the leading elements of the squadron, were touching down at the airfield. X-Ray consisted of the squadron, along with an infantry company from 2 SAI under the command of Major Chris Prinsloo, an $88 \mathrm{~mm}$ artillery battery from 4 Field Regiment under the command of Major M.J. Brown and a Field Engineer Troop from 2 Field Engineer Regiment under the command of Lieutenant L.S. Terblanche. ${ }^{118}$

Reports that Unita had suffered a string of defeats in the east meant that the SADF would send X-Ray from Silva Porto (Cuito) with their objective being the capture of the town of Luso (Luena), the administrative capital of Moxico Province, located $399 \mathrm{~km}$ east of Silva Porto (Cuito). Once completed, the combat group was expected to continue advancing eastwards with its ultimate objective the conquest of the town of Texeira de Sousa (Luau), located $313 \mathrm{~km}$ further east on the border with Zaire. ${ }^{119}$

On 29 November 1975, the entire combat group and their vehicles were loaded onto two ancient stream trains and transported the $220 \mathrm{~km}$ further east to the hamlet of Munhango. At Munhango, word was received that the village of Cagumbe, $91 \mathrm{~km}$ up the track had already fallen to the MPLA and that this forces' leading elements were now in the vicinity of Cangonga, only $33 \mathrm{~km}$ away. ${ }^{120}$ With two troops of the 90s leading the advance and two covering the rear, the Eland 60 tasked to protect the echelon, the combat group set off for Cangonga. ${ }^{121}$ Around 16:00, the leading Eland crews observed an enemy armoured car driving up a steep incline that the road crossed over, after passing through Cangonga. When the Eland crews began to 
engage it, the enemy infantry, mortars and artillery deployed on the high ground, retaliated with fire. Nightfall halted all operations for the day with Lieutenant Colonel Kotzé pulling the combat group into a laager, $10 \mathrm{~km}$ back, for the evening. The next morning, 1 December 1975, a quick investigation of the area indicated that the enemy too had withdrawn during the night to new positions. ${ }^{122}$

The $57 \mathrm{~km}$ road from Cangonga to Cangumbe was nothing more than a two-lane path through thick bushveld. When the leading Elands approached Cangumbe, located on a plateau, machinegun and RPG fire hit them from the heights. But, the defenders soon made haste to escape when the Elands began answering their fire with $90 \mathrm{~mm}$ rounds. While the combat group spent the next day in Cangumbe, replenishing and resting, Lieutenant Colonel Kotzé was informed that he was to be replaced immediately by Lieutenant Colonel Hans Möller, as his services were required elsewhere. After the arrival of Lieutenant Colonel Möller on 4 December, the advance could continue the final $89 \mathrm{~km}$ to objective one, the district capital of Luso. ${ }^{123}$

During the night of $7 / 8$ December, the $88 \mathrm{~mm}$ guns of Major Brown were prepositioned within range of Luso, in anticipation for the coming assault. Lieutenant Colonel Möller's battle plan comprised two parts. Firstly, a combat team was to attack directly east into the town using the main road as its axis of attack. Once this combat team had fixed the enemy's attention on itself, a second combat team would attack and capture the airport north of the town, before striking further into the town from the north. After waiting for an entire day for their Unita guides to arrive, the combat team under the command of Captain Rindel sent off for their flanking attack on the airport. The Unita guide, Major Vittoria, however, got completely lost in the dark and the combat team never made it to the airport. The second combat team attacking directly east ran into stiff resistance and were beaten back by the defenders. The next morning, 10 December 1975, Lieutenant Colonel Möller launched a second assault, with both combat teams attacking directly east, with one combat team north of the road (Captain Rindel) and one south of the road (Captain M. Kinghorn). ${ }^{124}$

The Eland armoured cars under Captain Rindel soon penetrated the town's defences forcing a gap between the town and the airport. When the leading armoured cars of Lieutenant Frik van Zyl's troop exploded onto the airport's tarmac from the south, the crews were relieved to see that they had caught the airport's heavily armed defenders napping, as all the defences were orientated northwards, (the original direction of attack). With the Troop of Lieutenant Sakkie van Zyl following close behind and the Eland 60 Troop of Lieutenant Alexander Bischoff, transporting Captain J.H. Laubscher, an $88 \mathrm{~mm}$ battery frontline observer, bringing up the rear, the Elands spread out into an extended firing line. ${ }^{125}$ Suddenly a metal 'monster' appeared out of the bush. "Contact tank right", was yelled over the air. Quickly HE rounds were replaced with $90 \mathrm{~mm}$ HEAT, and the various cars began to engage. With no less than six cars pumping $90 \mathrm{~mm}$ HEAT rounds into it, the monster finally came to a halt. It later transpired that 
the monster was, in fact, a huge tractor, encased in an armoured plate and armed with a $106 \mathrm{~mm}$ recoilless gun and two machineguns. The fall of the 'monster' signalled the end of resistance within Luso itself. ${ }^{126}$

With Luso now firmly under his control, Lieutenant Colonel Möller directed his attention at securing the surrounding area. Over the next ten days, various combat teams were sent out on all the routes radiating out from Luso to drive the MPLA forces out of the Moxico Province. On 20 December 1975, Lieutenant Colonel Möller and the infantry company from 2 SAI were replaced by Lieutenant Colonel A.J.M. Joubert and a new company from 5 SAI. By 22 December, this hand over was complete, and the next day the combat group left Luso heading towards Teixeira de Sousa. On 24 December, the combat group occupied Cassai Gare, situated on the southern bank of the Kasai River. Christmas day was spent repairing the numerous small wooden bridges that had all been destroyed by the retreating MPLA forces. When the combat group reached the small hamlet of Lumeje, on the border of the Parque Nacional da Cameia, Lieutenant Colonel Joubert detached a combat team to reconnoitre and if necessary, destroy the bridge over the Kasai River, $11 \mathrm{~km}$ to their north. Upon reaching the bridge, that was still intact, the armoured car of Staff Sergeant Robert Fletcher crossed over to protect the sappers (combat engineers) tasked to destroy it. Just past the bridge, the Eland detonated a landmine that destroyed the vehicle, but thankfully the crew escaped serious harm. This event was the general signal for the concealed Fapla infantry to begin their attack, that soon pinned down the two sapper officers, Lieutenants C.H. de Wet and J. van der Merwe, who was busy on the bridge. Seeing the two officers in trouble, Corporal K.B. Piccione, an Eland crew commander, grabbed his R1 assault rifle and proceeded the $250 \mathrm{~m}$ on foot to the bridge, where with 11 shots he successfully killed nine Fapla soldiers manning a machinegun position. Lieutenant de Wet, his demolition charges now set, returned to safety under the covering fire of the Corporal. Both Lieutenant de Wet and Corporal Piccione were awarded the Honoris Crux (Silver) for their actions that day. On 27 December 1975, the headquarters at Cela ordered Combat Group X-Ray to return to Luso and then back to Silva Porto (Cuito). On their arrival at Silva Porto (Cuito), the Combat Group's name was altered (to confuse the enemy) to Combat Group Boxer and deployed on a new mission north of Silva Porto (Cuito). ${ }^{127}$

\section{COMBAT GROUP ORANGE: CENTRAL ANGOLA}

The armoured car squadron under the command of Captain Theo Beyleveldt was airlifted into Silva Porto (Cuito) during the night from 26 to 28 November 1975. They, together with the regimental headquarters of 1 SSB would now form part of a new combat group, codenamed Orange. Lieutenant Colonel Dolf Carstens and the rest of the Combat Group Orange arrived by road in Silva Porto (Cuito) on 
5 December 1975. The Combat Group consisted of: a Vickers machinegun element (2 SAI); an $140 \mathrm{~mm}$ artillery battery (14 Field Regiment under the command of Captain P.R.B. du Plessis); a light $20 \mathrm{~mm}$ anti-aircraft troop (10 Anti-Aircraft Regiment, commanded by Lieutenant Billy Malherbe) and a field engineer troop (14 Field Engineer Regiment under command of Lieutenant D. Crafford). After spending three days at Silva Porto (Cuito), mainly because the armoured car troopers still needed time to complete their training programme, the combat group headed northwards, covering $180 \mathrm{~km}$ that first day to the village of Calucinga. ${ }^{128}$

The following day, the combat group, acting on Unita reports that the MPLA was about to attack the town of Mussende, advanced the $105 \mathrm{~km}$ to the town. However, on their arrival there, all they found was a Zairian Infantry Company, neatly dressed and well disciplined. The following morning, 10 December 1975, the advance continued north. When the vanguard was $33 \mathrm{~km}$ north of Mussende the leading Eland Troop, under the command of Lieutenant J. Britz was engaged with small arms, $82 \mathrm{~mm}$ mortar and $122 \mathrm{~mm}$ rocket fire. The armoured cars began to engage those positions visible to them while the infantry deployed off-road on their flanks. Somehow in the ensuing melee, the infantry of the Zairian Company moved in front of the guns of the armoured cars, which resulted in the killing of three by the South Africans. In a fit of rage, their commander threatened to shoot Lieutenant Colonel Carstens. After a lengthy discussion, the Zairian company subsequently decided to turn back to Silva Porto (Cuito), the following day. ${ }^{129}$

The battle against the MPLA-Cuban forces in the meanwhile continued, with the $88 \mathrm{~mm}$ artillery guns firing airbursts over suspected positions. It was only after lunch that the enemy fire began to slack and then cease. A recon of the position late that afternoon showed an extensive trench system, with the South Africans liberating from their previous owners, three different variants of $75 \mathrm{~mm}$ recoilless guns, seven $82 \mathrm{~mm}$ mortars and various other abandoned small arms. The most important find, however, was positive proof in the form of empty packing suitcases of the first deployment by the MPLA-Cubans of the Soviet-designed 9M14 Malyutka (NATO - AT-3 Sagger) wire-guided anti-tank guided missile (ATGM) system. From then on, the Eland crews would have an extra reason to be concerned on the battlefield. ${ }^{130}$

Early the next morning, the Elands were on the road again, their destination being the Ponte Salazar (Salazar Bridge) over the Cuanza River. Completing the trip of $48 \mathrm{~km}$ by 11:00, the armoured cars carefully entered into the Cuanza Valley and approached the bridge. Despite being under mortar and rocket fire from the moment that they entered the valley, a troop of cars succeeded in reaching the kilometre-long bridge, only to discover an entire span demolished. With this news, the combat group was told to withdraw back to Mussende. ${ }^{131}$ 
The combat group was now ordered to redeploy from Mussende due west, over the village of Cariango towards Quibala. Brigadier Schoeman hoped to dislodge the Fapla-Cuban forces deployed across Task Force Zulu's front, by threatening Quibala from the east. By the evening of 14 December 1975, the combat group had completed the $76 \mathrm{~km}$ trek to Cariango. Early the next morning, barely $10 \mathrm{~km}$ from their previous night's laager position, the combat group ran into a brick wall, namely the Pombuige River and its destroyed bridge. A single round mountain, Ulende, dominated the opposite bank from which the Angolan and Cubans had excellent observation over the bridge and its approaches. An Eland troop under the command of Second Lieutenant T. Pike was sent down to the river, but the accurate indirect fire soon forced them back from the river. ${ }^{132}$

In response, Lieutenant Colonel Carstens then attempted to establish a bridgehead on the opposite bank, by sending two infantry companies, one SADF from 2 SAI and one Unita, over the river while his engineers frantically repaired the bridge. A concentrated wall of fire and the total lack of watercraft on the part of the Unita company scuttled this plan. In response to this attempt, the Cubans deployed three T34 tanks on the bridge, with which they then began shelling the South African positions in front. The Elands quickly responded by firing $90 \mathrm{~mm}$ HEAT rounds at the tanks. When one was hit and disabled, the remaining two withdrew to safety. ${ }^{133}$

By Christmas Day, the South Africans had been pinned down behind the river for more than two weeks, with every indication that the Fapla-Cuban position was being strengthened almost daily, with the arrival of fresh troops. On Boxing Day, while the South Africans and their Unita allies tried to think of another plan, small groups of Fapla infantry, many of them led by Cubans, crossed over the river and infiltrated the South-African-Unita lines. The first indication of trouble was when one isolated artillery observation post after another reported being under attack. With no other force available, Lieutenant Colonel Carstens launched his Elands in a desperate counterattack. Anticipating just such a move, the Cubans had set up an ambush site between the South African front lines and Cariango. As the leading Eland entered the pre-determined killing zone, an RPG smashed into its turret seriously wounding its commander, Corporal A.P. Haasbroek. The following Elands counter-attacked, and soon the attackers found themselves under furious attack from all directions by rampaging Eland Armoured Cars. ${ }^{134}$ Not only were RPGs a worry, but the Angolan Air Force even made a brief appearance, with a MiG 'strafing' (shooting at) the South African positions as well. By nightfall, the situation had stabilised, but it had been a close call, with the South Africans suffering one killed and five wounded. After consultation with Brigadier Schoeman, the combat group was withdrawn back to Mussende, that they reached on 27 December 1975. ${ }^{135}$ 
After being placed in command of 101 Task Force in mid-November, Major General André van Deventer felt that the tactical situation was of such a fluid nature, that the establishment of a central reserve would be a wise decision. He decided to locate this reserve at the coastal city of Lobito, $35 \mathrm{~km}$ north of the Port of Benguela, due to its central location, from where it could assist any of the South African combat groups operating further north. ${ }^{136}$

On 5 December 1975, command of this reserve force, renamed Combat Group Beaver, was bestowed upon Lieutenant Colonel Yvor de Bruyn. The forces allocated to Combat Group Beaver began to arrive from South Africa at Grootfontein in Namibia on 6 December 1975. Two days later, the command of Lieutenant Colonel de Bruyn consisted of a mixed infantry company. Two platoons (7 SAI Battalion); one platoon (2 SAI Battalion); an $81 \mathrm{~mm}$ Mortar Fire Group (6 SAI Battalion); a Field Artillery Battery (4 Field Artillery Regiment) and Troop Eland Armoured Car Squadron (2 Special Service Battalion, under the command of Major Fido Smit) made up the company. Additionally, a Signal element (South African Corps of Signals); a medical element, under the command of Lieutenant (Doctor) S.H. Walsh; a Light Workshop Troop; an engineer section; and finally an Echelon with 11 three-ton cargo vehicles, under the control of the Quarter Master (4 Field Artillery Regiment) supported De Bruyn's force. ${ }^{137}$

By midday on 8 December 1975, enough rations, equipment, ammunition and fuel had been loaded by the Echelon to enable the combat group to be self-sufficient for ten days. By sunset on 8 December 1975, Lieutenant Colonel de Bruyn led his convoy of 120 vehicles on the $1184 \mathrm{~km}$ trek northwards towards Lobito, that they reached 48 hours later on the evening of 10 December 1975. The following morning the combat group established themselves at the local golf course as it offered excellent defensive positions while providing an unobstructed breath-taking view over the entire port and the surrounding area. ${ }^{138}$

Besides acting as the reserve for 101 Task Force, Combat Group Beaver was also required to execute a set of military missions. They had to maintain a South African military presence in Lobito, to patrol and dominate the roads leading down towards Silva Porto (Bie), Benguela and Sá da Bandeira and finally to train and thereby enable local FNLA and Unita forces to effectively defend the port and its adjacent airfield from enemy assault. ${ }^{139}$

A few days after arriving, Major Smit was ordered to take a combat team northward to link up and liaise with Lieutenant Colonel Linford and Combat Group Alpha, still deployed at Novo Redondo (Ngunza), $181 \mathrm{~km}$ up the coastline. Major Smit's 
command consisted of an infantry platoon, an armoured car troop and an artillery observation element. While en route, the leading Elands informed Major Smit that they observed two stationary Russian cargo vehicles deployed next to the road. They believed that the vehicles were transporting landmines. Consequently, Major Smit ordered the Elands to destroy both the vehicles, that a few rounds of $90 \mathrm{~mm}$ HE soon accomplished. Not long after that, a lonely vehicle came tearing up the road. Within was an extremely angry Lieutenant Colonel Linford, who informed the bashful major that they had just destroyed two of their cargo vehicles. Nevertheless, they had now established contact between the two South African combat forces. ${ }^{140}$

Besides patrols, the combat group also provided the defence of the port. On both of the occasions during December when the cargo ship Chuabo arrived in port with much needed logistical supplies, two infantry platoons and an armoured car troop deployed to protect from both enemy actions and local looters. ${ }^{141}$

During January 1976, after it had been decided to withdraw South African forces from Angola, Major Smit was once again ordered to take a combat team down to protect the airfield at Sá da Bandeira. Leaving on 4 January 1976 with a force that consisted of an armoured car troop, an infantry platoon and an $81 \mathrm{~mm}$ mortar section, Major Smit was almost at his destination when the leading elements reported seeing signs that a battle was raging on their immediate front. After a quick reconnaissance mission, the platoon discovered that it was an FNLA-Unita clash upfront. Ordering all hatches closed, Major Smit led his force straight down the road and right through the centre of the battle, fortunately without suffering any mishaps. Major Smit and his force would remain at the airfield at Sá da Bandeira until the rest of Combat Group Beaver, who was by then also withdrawing to South Africa, joined him. ${ }^{142}$

\section{TASK FORCE ZULU: THE BATTLE FOR BRIDGE 14}

The departure of Colonel van Heerden resulted in the need for a new commander for Task Force Zulu, who was now in command of two combat groups deployed along the Central Front. Colonel P.J. Schalkwyk appointed Colonel C.J. Swart as the new commander, an appointment ratified by Brigadier Schoeman upon his return from his meeting with Major General van Deventer in Rundu. On 29 November 1975, Colonel Swart received his orders; capture the villages of Ebo and Condé and if this was not possible, pin down all enemy forces along the Central Front as far as possible. ${ }^{143}$

Not only did Task Force Zulu receive a new commander, but so did Combat Group Bravo. Lieutenant Colonel J.D. Breytenbach had commanded this ragtag force of FNLA recruits since the establishment of Combat Group Bravo. In early December, he was withdrawn and placed in command of a section of Special Forces from 1 Reconnaissance Commando, activated for special tasks along the Cela front. 
The newly-promoted Lieutenant Colonel Frank Bestbier took Lieutenant Colonel Breytenbach's place as commander of Combat Group Bravo. ${ }^{144}$

Not only were commanders being shifted around, but the entire force reorganised. The challenge was that all the January 1975 National Servicemen's yearlong service was coming to an end, with most of the 'veterans' that has started SAVANNAH sent back to 'clear out' of the military and were replaced with fresh troops from the Republic - mostly from the July 1975 National Service intake. The forces deployed along the Central Front now consisted out of Task Force Zulu headquarters, with a support element and an armoured car squadron under the command of Major A.C. Slabbert in reserve, all located at Cela. Combat Group Bravo under the command of Lieutenant Colonel Bestbier with an armoured car troop, a machinegun platoon, four $81 \mathrm{~mm}$ mortars and an FNLA infantry company. Combat Group Foxbat 2 under the command of Lieutenant Colonel G. Kruys consisted of an FNLA infantry company a SADF infantry company tasked with protecting two troops of field artillery, an engineer troop, five $81 \mathrm{~mm}$ mortars, two 4.2 inch $(107 \mathrm{~mm})$ mortars and seven troops of armoured cars. ${ }^{145}$ In total, this force amounted to only 724 South African soldiers. ${ }^{146}$

By early December 1975, thanks to the effective interrogation of prisoners, radio communication interception, effective deployment of listening and observation posts and aggressive patrolling, Colonel Swart had a reasonably accurate picture of the enemy deployments along the Central Front. For example, the South Africans were now aware that the enemies' headquarters were located at Catofe, increased in size to that of a battalion. ${ }^{147}$ The dilemma facing the South Africans, however, was how to conquer this identified enemy. The road north from the South African headquarters at Cela towards Condé splits at a Y-junction, with one route going via Tunga and Ebo, while a second more direct route goes via Hengo, Balaia and Panga. The challenge was that the Cubans and Angolans had effectively destroyed all the bridges along both these routes, thereby pinning the South Africans down south at Cela. ${ }^{148}$

On 4 December 1975, observation posts deployed at the destroyed bridge over the Nhia River $(12 \mathrm{~km}$ north of the village of Ebo and $23 \mathrm{~km}$ south of the enemy headquarters at Catofe) reported that they spotted enemy soldiers inspecting the bridge. Colonel Swart estimated that the Angolan-Cuban alliance was preparing to repair the bridge over the Nhia as a prerequisite for an attack southward towards his headquarters. Consequently, he decided to take control of the bridge first, before launching his attack northwards. Colonel Swart decided that while Combat Group Bravo would be responsible for the securing of both of their flanks, Combat Group Foxbat 2 would conquer the damaged bridge over the Nhia River, labelled by the South Africans as Bridge 14..$^{149}$

By the evening of Friday, 5 December 1975, Colonel Swart was ready to present his orders. The first phase of Colonel Swart's plan called for the 430 men in Lieutenant 
Colonel George Kruys' Combat Group Foxbat 2, to attack and conquer the territory between the village of Ebo and the bridge over the Nhia River. Combat Group Foxbat 2 consisted of an infantry company (2 SAI and the Eland Armoured Car Squadron, under the command of Captain Fourie); two Unita Infantry Companies; and 22 Portuguese Freedom Fighters, formed into a loose group under the command of a Captain Ferreira. Phase 2 of the battle plan called for the repair of the bridge over the Nhia in preparation for Phase 3, an assault over the bridge resulting in the conquest of the area north of the river up to the village of Cassamba (Almeida), $5 \mathrm{~km}$ further north.

Early on the morning of Monday 8 December 1975, the South African and their Angolan allies, successfully passed through the village of Ebo and deployed southeast of the bridge over the Nhia River. The infantry then moved forward, while the rest of the force remained hidden behind the high ground. By 17:00, the infantry was in place, that allowed the SADF mortars, artillery and armoured cars to shorten the distance towards the river itself. By sunset, they achieved Phase 1 of Colonel Swart's plan. The following morning (9 December 1975), with the infantry securing the bridge site, Second Lieutenant T.S. Fountain and his engineers began constructing a bridge over the fast-flowing Nhia River. Following the orders that he had received, to prevent the enemy from approaching the Nhia via the mountainous terrain to its north, Captain Fourie had deployed three armoured car troops on tactically important terrain south of the river, leaving him with only two troops. Troop 22 'Papa Troop' under Second Lieutenant Ben Grib and Troop 23 'November Troop' under the command of Second Lieutenant Lou van Vuuren, ${ }^{150}$ to protect the bridge construction site. The enemy only realised what was happening at the bridge at 19:00 the evening of 9 December 1975) and began to fire on the engineers with small arms, grenades and RPGs. The engineers, nonetheless, remained on location, working throughout the night and by sunrise the next morning the bridge was almost completed. For his efforts while under fire, the SADF awarded Second Lieutenant Fountain the Honoris Crux decoration. ${ }^{151}$

The following day, 10 December 1975, the Angolan and Cubans engaged all the South African positions with their accurate mortar and rocket fire. A second infantry assault aimed at the bridge killed Sapper A.R. Willemse. When the vehicle transporting him back, stopped under tree cover at the medical post at Foxbat headquarters, it was hit by indirect enemy fire, that immediately killed Sapper U.K. von Schmettau and wounded three others. Around lunchtime, Lieutenant Colonel Kruys dispatched a fighting patrol from Charlie Company, $2 \mathrm{SAI}^{152}$ to reconnoitre a road that ran parallel with the river towards Quipuco. The patrol began its mission by crossing at the semi-completed bridge. While removing various mines deployed on the road, the enemy ambushed the patrol. Private T. Lotze was killed immediately, while Private D.H.D. Marais suffered a serious stomach wound. The patrol then launched a counterattack, that succeeded in killing five members of the enemy ambush group. They then sought shelter with 
their wounded comrade in a local cattle enclosure, where they were forced to spend the night. A relief force was unable to reach them that night due to continued fighting around the bridge site. The relief team only reached them the following day. Unfortunately, Private Marais passed away due to his injuries. ${ }^{153}$

At last light, around 18:15, the enemy infantry attacked the bridge site for a third time. Artillery, mortar, RPGs and small arms fire supported the attack. The attacking force penetrated the South African positions in such a manner that they now had direct sight on the bridge construction site, while a secondary grouping succeeded in occupying a sandbank in the river, south-east of the bridge itself. Darkness halted all further operations. ${ }^{154}$

After a long night, Colonel Swart had only one thought the next morning, 11 December 1975, and that was to secure the area around Bridge 14 to give the sappers time and space to complete the bridge's construction. While the sappers worked around the clock, the enemy only made their appearance at 11:30, with sporadic rocket and mortar fire onto the South African positions, that drove the sappers back into their trenches. By that afternoon, the sappers reported that the bridge was now strong enough to support the weight of the Eland Armoured Cars. Captain Fourie immediately ordered Papa Troop under the command of Second Lieutenant Grib over the bridge, with orders to eliminate all enemy resistance within the range of their $90 \mathrm{~mm}$ guns. While the armoured cars advanced slowly northwards from the bridge, a rescue force was sent to bring back the infantry patrol still sheltering at the cattle enclosure. By 17:30, this rescue mission was complete and headquarters recalled the Eland Troop as it was under heavy anti-tank fire from mobile RPG teams. ${ }^{155}$

Lieutenant Colonel Kruys believed that the enemies' determination to continue resisting was beginning to falter, and wanted to take control of Bridge 14 with one final push. Consequently, his final plan called for an Eland Troop to cross the bridge at first light the next morning, supported by a Unita Infantry Company. They were then to advance up the road in a herringbone formation, overcoming all enemy resistance, up to Bridge 15 , a small bridge $4 \mathrm{~km}$ further down the road that crosses a dry tributary of the Nhia. Simultaneously, a second Unita Company would advance and occupy the area around the cattle enclosure, while a third Unita Company would advance and occupy a laager area near the village of Cassamba (Almeida), $5 \mathrm{~km}$ north up the road from Bridge 14. The last part of the plan called for the remaining Eland Troop along with infantry support to advance further up the road and capture Cassamba (Almeida). ${ }^{156}$

At 04:00 the next morning, 12 December 1975, with the entire area covered in mist, the three ${ }^{157}$ Eland Armoured Cars of Second Lieutenant Grib and Papa Troop waited for the light to strengthen enough for them to cross over the newly constructed Bridge 14 . Undercover of an artillery barrage courtesy of the South African $140 \mathrm{~mm}$ guns, the 
Charlie Car, followed by the Alpha Car (Troop Sergeant) and lastly the Zero Car (Troop Commander), advanced over the bridge and linked up with the Unita infantry already deployed on the far bank. ${ }^{158}$

The Troop had only advanced a little way and were approaching the first bend in the road when the expected deluge of enemy fire engulfed them. Enemy B10, ${ }^{159}$ RPG and AT-3 Sagger anti-tank missiles fired from prepared positions right of the road about another $400 \mathrm{~m}$ to their front came flying in. It appeared that the enemy had employed a classical L-shaped ambush position with the RPG and Saggers on the long leg to the vehicles right flank, with the heavier B10 anti-tank guns deployed directly ahead of the Troop where the river swung away from the road. To remain on the road would have been suicidal but to leave the road and go cross-country through the mud was also taking a huge risk. Not seeing another option, the Troop Sergeant, Corporal Stephan Fourie ordered his driver, Trooper Eion Gibson, to manoeuvre the 6-ton armoured car off the road. When it became clear that the terrain was holding up the weight of the armoured car, Corporal Fourie contacted Lieutenant Grib and informed him. The Lieutenant, after some convincing by his Troop Sergeant, deployed his three cars right off the road $100 \mathrm{~m}$ apart from each other. This unexpected manoeuvre by the Elands not only got them out of the designated killing zone of the Cuban ambush, but now placed them in a tactically advantageous position to the right of the Cuban positions at an oblique angle to these positions (located as they were next to the road and now orientated away from the Troop). From these positions, the Troop began to engage the Cubans at will. ${ }^{160}$

With the three armoured cars pumping $90 \mathrm{~mm}$ rounds into the Cuban positions, an unexpected incident was to occur that would materially affect the entire outcome of the battle. After firing his first $90 \mathrm{~mm}$ shell at a house located directly ahead of their position, Corporal Fourie accidentally got one of the gloves used for removing the hot $90 \mathrm{~mm}$ empty cartridge shells jammed in the gun's breach, effectively preventing any further loading of the gun. Try as they may, neither Corporal Fourie nor his gunner, Trooper Martin Ziegler, was able to pull the glove loose from the breach. The only option left was to drive up and push the barrel back against a solid object, thus opening the breach. After first attempting the manoeuvre against a post, that the armoured car pushed over, Corporal Fourie decided to advance and try again, this time against the very house they had just engaged with their main gun. The house, located at the top of a rise, had dense bushes behind it. The crew drove there as fast as possible, leaving them quite some distance ahead of the remaining two cars of the Troop. The crew succeeded in pushing the barrel back and retrieving the glove, by using the far studier wall, reloading the gun once again. The crew now manoeuvred their car around the house and into a firing position upon the high ground. From this new position, the crew had an open arc of fire across the entire road, including the entire Cuban position. Corporal Fourie immediately identified a target amongst 
the bushes to their left and shot a $90 \mathrm{~mm}$ HE round at it, causing a huge explosion. It appeared to have been an ammunition truck for the $76 \mathrm{~mm}$ anti-tank guns, deployed in firing positions just below it. ${ }^{161}$

Lieutenant Grib, informed of his Troop Sergeants new location, immediately ordered the remaining two armoured cars forward and onto firing positions upon the ridge. The Cubans, realising that the South Africans had outflanked them, frantically tried to turn their B10s weapons around while simultaneously redeploying their Saggers within a trench network located behind their positions. In response, Corporal Fourie poured a belt of two hundred $7,62 \mathrm{~mm}$ rounds in bursts from his co-axially mounted Browning machinegun into them, neutralising the rocket and missile positions. Next, the crew turned their attention to the four olive green $76 \mathrm{~mm}$ guns with their crews of six scurrying all around them. The Cuban gunners had no idea the Eland was deployed a scant $100 \mathrm{~m}$ to their left above them on the ridge. The lone Eland made short work of them, and when the remaining two Elands arrived the entire Troop deployed along the crest of the rise, with their attention now focused towards targets up on the next rise. From their new firing positions, the Troop had observation upon the enemies' next line of defences; infantry deployed in trenches. With the armoured cars raining $90 \mathrm{~mm}$ HE rounds down onto their positions; the Angolan infantry abandoned their trenches and withdrew backwards over the high ground - the three armoured cars' machineguns enforcing a high butcher's bill on the exposed infantry. ${ }^{162}$

The three cars continued to attack, although headquarters was by now frantically screaming at them on the radio to stop advancing and to take up positions. From the second rise, the Troop had observation over the enemy's third line of defences. A quick scan of the area revealed the location of the Cuban's $120 \mathrm{~mm}$ mortar positions. However, South African artillery counter bombardment had already shot the Cuban weapons and their crews to bits. All that remained of the mortars were their massive yellow-green baseplates, shot into the ground. As for their Cuban and Angolan crews, only bits of body parts hanging over everything with the fresh smell of guts and blood permeating the air remained. ${ }^{163}$

As the crews had been fighting within the cramped confines of their armoured cars since before sunrise, Lieutenant Grib permitted for the crews to climb out of their vehicles quickly, to stretch their legs. Corporal Fourie, who wanted to examine the Cuban positions, left his men and wandered along a small stream surrounded by bushes just north of the mortar positions. Suddenly he heard all the armoured cars start up their engines. Almost immediately after this a group of approximately 12 Cubans broke from cover about $30 \mathrm{~m}$ away from him and began running north. Outnumbered and only armed with his P38 sidearm the corporal let them go. The moment they were past him, he ran back to the Troop who had already formed on the tar road ready to resume their advance. ${ }^{164}$ 
The Troop continued advancing northwards making use of various cuttings through the high ground located to their north. Some small ways, further along, Corporal Fourie was amused to find a set of GAZ tyre tracks coming straight off the side of the road's cutting easily 2 to $3 \mathrm{~m}$ high onto the tarmac with its tyre marked where it hit the tar. A Cuban driver is his haste must have driven straight off the cutting to make a clean getaway. The Troop continued advancing without meeting much resistance until they reached the general area surrounding Cassamba (Almeida), the South Africans final objective for the day. It was at this location that they observed Lieutenant Hans Heinze, ${ }^{165}$ their Squadron Second in Command's armoured car rapidly advancing up the road to where they deployed in their firing positions. The irony of that Eland now travelling unmolested along the tar road not being lost on the Troop members. Lieutenant Heinze had been dispatched north to track down the lost Troop of the Squadron. After receiving a quick feedback report from Lieutenant Grib, he ordered the Troop forward to complete their assault on Cassamba (Almeida). ${ }^{166}$

Papa Troop thus continued to advance northwards along with the tar round until they reached the outskirts of Cassamba (Almeida). Lieutenant Grib stopped the Troop in firing positions in front of an open field located next to the first houses of the village. Suddenly heavy anti-tank fire burst from some bushes ahead of them and the Troop could not advance without infantry clearing the area first. Spotting a section of Unita troops lying prone some distance behind the cars, Corporal Fourie got out of his armoured car to get them moving forward. Repeated shouts of "advance" did not achieve the required result, so the Corporal removed his A39 radio's aerial and commenced laying into the infantry with the aerial to get them to stand up and move forward. Although most had earlier discarded their G3s and picked up captured AK47s they still refused to advance and clear Cassamba of the enemy. ${ }^{167}$

While Corporal Fourie was busy struggling with the Unita infantry, the rest of the Troop continued to slug it out with the defenders of the village. Soon the crews began to report that their ammunition status was approaching critical levels, with the majority of the cars only having extremely limited amounts of $7,62 \mathrm{~mm}$ ammunition remaining for their Brownings, while the remaining $90 \mathrm{~mm}$ rounds now consisted of the anti-tank HEAT rounds, their general purpose HE (High Explosive) rounds already used. As a consequence of their low ammunition status, Papa Troop were ordered back to their echelon area to rearm as quickly as possible, their position being taken over by the four Elands of Second Lieutenant Lou van Vuuren's November Troop, who had crossed over the bridge shortly after Papa Troop. ${ }^{168}$

As Papa Troop started making its way back towards their own lines, an Observation Post $(\mathrm{OP})$ radioed to headquarters that they saw three tanks ${ }^{169}$ advancing towards the South African positions. Lieutenant Colonel Kruys immediately ordered all the Eland Armoured Cars forward into firing positions. Within the withdrawing Papa Troop, 
command decided that the crews of Lieutenant Grib and Corporal Fourie would share the third armoured cars HEAT rounds between them while returning to base to rearm. Along with their remaining HEAT rounds, the two-vehicle commanders were confident that they could hold their own against any approaching Cuban armour. Lieutenant Grib proceeded to position both the cars in a classical hull-down firing position, from where both would be able to engage any armour as it became visible in the cutting ahead of them. ${ }^{170}$

The report of the tanks approaching not only caused some concern within Papa Troop but November Troop as well. Following behind Papa Troop over the river, the four Elands of Lieutenant van Vuuren had stuck in the road. They soon found themselves under a storm of mortar fire. The enemy mortar positions, located within a loop of the Nhia River on a stone embankment, had not been located by prior South African reconnaissance forces. A few well-aimed $90 \mathrm{~mm}$ rounds, quickly caused the Cuban mortar soldiers to abandon their weapons for the safety of their trenches. By rapidly advancing, Lieutenant van Vuuren was thus able to capture all six mortars on position. Three days later, a wounded Cuban mortarman, Alberto Morales Bella, would also be captured on the road to Cassamba - he had hidden in the thick bush near the mortar positions before wandering out onto the road. Behind the mortar position, laid the enemies main defensive positions, occupied by at least a battalion strong infantry force. Between the fire from Lieutenant Grib's troop on the ridge and Lieutenant van Vuuren's fire from the road, the SADF soon drove the enemy from these positions. ${ }^{171}$

When the call went out over the radio of three 'tanks' approaching the South African lines, Lieutenant van Vuuren also took up firing positions with November Troop about a kilometre away from that of Lieutenant Grib, despite his Troop now being completely out of $90 \mathrm{~mm} \mathrm{HE}$ and machinegun ammunition. As the troop moved into the position, a large force of Cuban infantry suddenly appeared out of the dense vegetation and rushed to the vehicles, firing as they came. Lieutenant van Vuuren immediately ordered his crews to close all hatches of the armoured cars as the Cubans clambered aboard. The Lieutenant, previously hit in his right hand, drew his service sidearm with his left hand and systematically began firing at the Cuban infantry through a half-open hatch. In this way, he succeeded in killing some and driving off the rest. Second Lieutenant van Vuuren was awarded the Honoris Crux decoration for this action. ${ }^{172}$

Ultimately, the Elands were not needed as a concentrated artillery barrage succeeded in turning the attacking armour back towards their own front. With November Troop also reporting their ammunition status as critical, Bravo Squadron's commander Captain Fourie ordered his designated reserve troop, Sierra Troop under the command of Second Lieutenant André Freyer to the front to take over the position recently occupied by November Troop. ${ }^{173}$ 
Once it became clear that the tank threat was over, Lieutenant Grib and Corporal Fourie returned to their own lines to rearm. Waiting for them at the Echelon Area, $4 \mathrm{~km}$ south of the bridge, was not only the rearmed Charlie Car but also the fourth vehicle of the Troop, the Bravo Car, whose crew had been monitoring the squadron radio network back at the headquarters at Cela and heard that the battle had started. Quickly obtaining their allocated replacement Crew Commander, the crew had returned as quickly as they could to the front. With the entire Troop rearmed, all four cars returned into the heart of the fight. After proceeding north along the tar road, the Troop crossed a small stream then again managed to manoeuvre off the road. The fighting had died down considerably by this stage, allowing Papa Troop to continue with their advance. After successfully repairing a small mechanical failure on the Alpha Car of Corporal Fourie, the Troop continued to advance up the road. Passing through Cassamba (Almeida), the Troop continued north, even though their original orders named Cassamba (Almeida) the final South African objective of the mission. ${ }^{174}$

Soon the first buildings of Catofe, $23 \mathrm{~km}$ from the Nhia River Bridge and $18 \mathrm{~km}$ north of Cassamba appeared in front of the Troops vehicles. As they approached the first group of buildings on the outskirts of Catofe, the Troop saw soldiers deployed directly in the road, busy working on something that they could not identify. The Elands opened machinegun fire on the soldiers in the road, killing some and sending the survivors running for cover. When the armoured cars reached this location, the crews were surprised and relieved to find dozens of halved assembled AT-3 Sagger anti-tank missiles standing on their green suitcases in the road all pointing directly down the route the Elands has just ridden. More missiles were found heaped upon the steps of the building located next to the road, while inside the largest building, the crews found a fully functional headquarters with many detailed maps on the walls and rows of big radios all crackling away in Spanish. The enemy did not know that the headquarters had fallen yet and was desperately trying to reach them on the radios. The building was also full of the Cubans' kit bags, upon which the mostly bare-footed and equipment-scarce Unita infantry fell upon with a frenzy. Leaving Unita to its spoils of war, the crews mounted their vehicles again in preparation of continuing their thrust northwards along the road towards Quibala, another $16 \mathrm{~km}$ further north. The Troop had just departed Catofe when Lieutenant Heinze ordered them all over the troops' radio network back into defensive positions on the edge of Cassamba (Almeida). The armoured cars rapid advance was out-stripping the rest of the support weapons allocated to the attack, and thus Colonel Swart had ordered them to halt until the rest of the slow-moving Combat Group could catch up. ${ }^{175}$

The challenge facing Lieutenant Colonel Kruys was that it had begun to rain steadily after lunch, that quickly turned the area around Bridge 14 into a sticky muddy mess. He was afraid of getting his command split into two halves, with the artillery unable to cross over the bridge as it was not yet strong enough to support the weight of the 
guns, and the armoured cars unable to cross southwards back over the bridge to safety, due to their inability to travel through extensive muddy terrain. Fortunately for the South Africans, the conquest of Cassamba (Almeida) had already been achieved at 11:45 following a Unita infantry company assault on the town - thus ensuring that they met the entire set of objectives for the day, allowed Lieutenant Colonel Kruys to call a halt to offensive operations for the day. ${ }^{176}$

That evening, however, Captain Fourie sent out Sierra Troop under the command of Second Lieutenant Freyer to set up an ambush on the Cassamba-Sanga Road just north of Quipuco. Just on sunset, a Land Rover with a Browning machinegun mounted on it, approached from the east. The vehicle stopped at the leading vehicle, and a Cuban climbed out, obviously thinking that he was amongst friends. Upon realising his mistake, he drew the pin of a hand grenade and threw it at the vehicle's crew, injuring two. He and three other Cubans, still in the vehicle, were then obliterated by a $90 \mathrm{~mm}$ round, fired at point-blank range into the Land Rover. ${ }^{177}$

Over the next couple of days, while the engineers continued to work, day and night, to strengthen the bridge, the infantry and armour combed the battlefield for stragglers and enemy equipment. Eventually, the South Africans were to capture sixteen $120 \mathrm{~mm}$ mortars, six $75 \mathrm{~mm}$ anti-tank guns, a $14.5 \mathrm{~mm}$ anti-aircraft machinegun, two 7-ton and three 2-ton Russian cargo vehicles, thirteen AT-3 Saggar anti-tank missiles (with control boxes), four 15-ton cargo vehicles loaded with the mortar and small-arms ammunition and a $122 \mathrm{~mm}$ multiple rocket launcher. ${ }^{178}$

\section{WITHDRAWAL}

The successful crossing of Bridge 14 was to be the final offensive action by South African forces. Earlier the previous day, the South African Security Council had decided to withdraw all its forces from Angola, due to the negative international pressure the world asserted upon South Africa. These orders only reached Colonel Swart on the morning of 12 December 1975. Consequently, he ordered Lieutenant Colonel Kruys to take a defensive position and await orders to begin withdrawing his forces. The following day, a high-level delegation arrived at Colonel Swarts headquarters at Cela. The group consisted of Minister of Defence P.W. Botha, Minister of Economic Affairs J.C. Heunis, Lieutenant General Magnus Malan, Chief of the South African Army, Major General C.L. Viljoen, Director of General Operations, and Major General A. van Deventer, Commander of 101 Task Force. They came to see for themselves how the campaign was progressing, while simultaneously informing Dr Savimbi of the Security Council's decision to pull all the South African troops from Angola. ${ }^{179}$ 
By 25 January 1976, the withdrawal was practically completed, with all five Eland Armoured Car Squadrons back across the border. ${ }^{180}$ Soldiers from South Africa's Active Citizen Force protected this withdrawal. They included three Eland Armoured Car Squadrons ${ }^{181}$ and one Centurion-Semel Tank squadron, ${ }^{182}$ mobilised and deployed as part of four combat groups in Southern Angola to protect the Calueque-Ruacana Water Scheme. The last SADF units would, however, only leave Angola almost two months later, on 27 March 1976. ${ }^{183}$

\section{CONCLUSION}

Military terminology defines the required 'end state' as that specified situation at the successful completion of the final phase of a military operation. For the endeavour to be successful, it is the collective goal that all the various military missions within any given campaign must accomplish. If the end state is not identified or poorly articulated, then a situation may arise where a military force wins every battle but loses the war.

Linked to this concept is the military levels of war; tactical, operational and strategic. Each one can have its 'end state', but collectively they must all contribute to the achievement of a national end state. For it is pointless, winning every engagement and battle on the tactical level but failing dismally on the strategic level. I believe such a situation befell the SADF in Angola in 1975/76.

Throughout Operation SAVANNAH, the SADF routinely bested their opponents on the battlefields of Angola. However, on the strategic level, the situation was reversed. South Africa's decision to enter into Angola was not well thought out or even planned. The SADF was in no manner prepared to execute extensive mobile warfare operations hundreds of kilometres from its bases. That so much was achieved was only due to the bravery and dedication of the ordinary soldier and not thanks to the Generals and their political masters in Pretoria.

By launching an extensive campaign so late in the year, the Generals unnecessarily placed huge pressure on field commanders whose troops (by law) had to finish their military service by year's end. No professional army sends home their most experienced soldiers mid-battle and replaces them with half-trained recruits. It is madness.

Furthermore, by not having a well-defined end state (the capture of Luanda, yes or no), the SADF wasted valuable time and resources on other tasks, ultimately giving the MPLA-Cuban alliance just enough time to deploy their forces and stop the SADF advance northwards along the numerous river systems of Angola. 
While the strategic planning and decision-making of the SADF was poor, the SADF on the tactical level proved to be excellent. A large part of the successes achieved on the battlefields was due to the robust and daring utilisation of its armoured car units. In the conclusion of his book on Operation SAVANNAH, Unisa historian Professor FJ. du Toit Spies notes that:

Both Colonel Swart and his opponent Commandant Arnaldo T. Ochoa Sánchez commanded infantry, not properly trained, equipped or motivated. Both sides, due to the lack of infrastructure within Angola, were forced to move their motorised forces along the countries poor gravel roads. Fapla, however, had a firepower dominance. The Fapla support weapons far out-ranged their South African counterparts by such a measure that they could be deployed well outside their effective counter-bombardment ranges. Additionally, the firing tempo of the $122 \mathrm{~mm}$ multiple rocket launchers overshadowed the South African weapons. Finally, the enemy also had more artillery weapons than the South Africans with a Fapla mortar and gun battery having 12 launchers versus only eight in an equivalent South African battery.

However, the one vital area where the South Africans enjoyed an advantage was in the armour department. While South Africans received reports of the Cubans deploying six armoured cars, armed with machine-guns and a few T34/85 tanks on the central front, the South Africans had four squadrons of Eland Armoured Cars (Combat Groups Charlie, Foxbat 2, Orange and Boxer) with a fifth in reserve at Lobito (Combat Group Beaver), armed with mortars, cannons and machine-guns. These armoured cars provided the South African forces with mobility that Fapla, with Angola's chronic shortage of vehicles, never could have matched. The armoured cars were the keys to success in many of the attacks, no more so than during the battle for Bridge 14. Here, Commandant Ocha was forced to maintain an aggressive defensive posture until numerical superiority allowed him the opportunity to go over to the offensive, an opportunity that was ultimately denied him by the armoured car crews of the SAAC. ${ }^{184}$ 


\section{Endnotes}

1 W.J. Wagner et al. South African Army, Armour Doctrine Handbook, 1(1), 41.

2 Ibid., 42-43.

3 H.W. Short, Savannah: Eendrag to Ebo in an Eland: Early South African Armour in Angola (draft copy, personal communication, email, 5 August 2016).

4 Initially the SAAF would deploy 8 Alouette III Helicopters and 4 Cesena 185 Light Aircraft to northern SWA. See Department of Defence Archives (hereafter DOD Archives): H Leer Ops, box 1, file 1/68 Operational Directive, 20 May 1968.

5 DOD Archives: H Leer Ops, box 1, file Operasie Bombay: Beskerming van die Oos-Kaprivi, 9 May 1968.

6 DOD Archives: H Leer Ops, box 1, file Signal from General Officer Commanding (GOC) Joint Combat Forces (JCF) to Chief SA Army, 21 June 1968.

7 DOD Archives: H Leer Ops, box 1, file Letter GOC JCF, Sekerheid van die Kaprivi Strook, 13 September 1968.

8 DOD Archives: H Leer Ops, box 1, file 1/68 Operational Directive, 20 May 1968.

9 DOD Archives: H Leer Ops, box 1, file 2/68 Operational Directive, 9 December 1968.

10 H.W. Short, Black Beret 2 (personal communication, email, 1 December 2015).

11 Ibid.

12 Ibid.

13 Ibid.

14 Anthony Turton, A South African Diary: Contested Identity, My Family - Our Story, Part F: 1975-1986, [online], available at: [http://www.anthonyturton.com/assets/ my_documents/my_files/774_History_1975_-1986_Website_Ready.pdf], [accessed on 24 April 2018].

15 S. van der Berg, Ops Savannah 1975. The Story of Tango 43 Charlie, (unpublished memoir, electronic copy received from author on 1 December 2015), 9.

16 Ibid., 10-12.

17 Corporal Potgieter was not the first SAAC member to be killed on the border by friendly fire. A year earlier (1 October 1974), Staff Sergeant Burghie Burger [the same one from 1968] from the farm Christiaanskuil in the Strydenburg district was killed by his own troops. The troopers had set up an ambush position on Hippo Island, East of Katima Mulilo. Staff Sergeant Burger was not satisfied with the trooper's situational awareness. Without warning any of them, he approached the ambush position from the direction they would have expected Swapo to approach. The troopers activated the ambush and in the process Staff Sergeant Burger was mortally wounded by his own men. See L.J. Bothma, Vang 'n Boer: Die stryd tussen Boer en Ovambo (Windhoek, Namibia: L.J. Bothma, 2012), 290. Ibid., 12 .

19 Then based in Potchefstroom in the Western Transvaal (North West Province).

20 The Eland Armoured Cars were part of Bravo Squadron, 1 SSB, under the command of Captain Theo Beyleveldt, who had been deployed in northern SWA since May 1975.

21 F.J. du Toit Spies and Sophia du Preez, Operasie Savannah Angola 1975-1976, Pretoria: SADF Directorate Public Relations, 1989, 42-43; Bothma (2012), 307.

22 J.D. Breytenbach, The Buffalo Soldiers. The story of South Africa's 32 Battalion 1975-1993, (Germiston: Galago Books, 2002), 20. 
Sophia du Preez, Avontuur in Angola. Die verhaal van Suid-Afrika se soldate in Angola 1975-1976 (Pretoria: JL van Schaik, 1989), 27-28.

Spies and Du Preez (2012), 47.

Ibid., 83.

Erika Gibson, Bravo Squadron 1 SSB Deployment 1975 (personal communication, email, 8 August 2016).

Du Preez (1989), 28.

E. Beetge, Trooper D.B. (David) le Roux, KIA (personal communication, email, 9 August 2016).

Alain Mabanckou, The Lights of Pointe-Noire (Paris: Editions du Seuil, 2013), 175.

Edward George, The Cuban Intervention in Angola. Cass Military Studies (Oxfordshire, England: Routledge, 2012), 287.

Piero Gleijeses, Conflicting Missions: Havana, Washington, and Africa, 1959-1976 (Envisioning Cuba) (Chapel Hill, North Carolina, USA:The University of North Carolina Press, 2011), 22-23.

George (2012), 66.

Ibid., 64.

Ibid., 65.

Ibid., 64.

Ibid., 65.

Gleijeses (2011), 255-256, 265.

Du Preez (1989), 27-30.

Piet Nortje, 32 Battalion: The Inside Story of South Africa's Elite Fighting Unit (Cape Town: Zebra Press, 2010), 27. See also Spies and Du Preez (2012), 86; Du Preez (1989), 30.

Du Preez (1989), 45.

The ENTAC (Engin Téléguidé Anti-Char) or MGM-32A was a $152 \mathrm{~mm}$ French wireguided anti-tank missile with an effective range of between $400 \mathrm{~m}$ and $2 \mathrm{~km}$. Developed in the early 1950s, the weapon entered service with the French army in 1957. By 1969, the SADF had acquired some 500 examples of both French and locally manufactured licence-built missiles. See Victor Moukambi, Relations between South Africa and France with special reference to military matters, 1960-1990 (Doctoral dissertation thesis, Stellenbosch University, 2008), 181-182.

Command of this team was actually entrusted to Lieutenant Colonel Eddie Webb, who was stationed at 2 Sub-Area headquarters. He had however been delayed and thus his second in command had assumed control of the team.

The Unita Panhards were all ex-Zaire Defence Force (ZDF) vehicles, that had been donated to Unita by Zairian President Mobutu Sese Seko.

H.K. Myburgh, Battle of Norton De Matos (personal communication, email, 2 May 2016); H.K. Myburgh, Name list of participants present at the Battle of Norton de Matos on 5 October 1975 (personal communication, email, 1 December 2015).

45 H.K. Myburgh, Memorandum getranskribeer vanuit Maj. L.J. Holtzhausen se oorspronklike handgeskrewe verslag oor die slag van Norton de Matos (personal communication, email, 1 December 2015).

Only three of the Entacs were operational. Major Holtzhausen, thus utilised the fourth missile vehicle as his personal command vehicle. 
As a result of the breakdown of his vehicle, Lieutenant van Rensburg, relocated himself to the Panhard 90 belonging to Corporal Scheepers. With the lieutenant now occupying the crew commander's position, Corporal Scheepers moved into the gunner's seat.

The assigned gunner, Trooper Kobus Gericke, joined Lieutenant van Rensburg's assigned gunner and driver, Troopers Barend Liebenberg and Jacobus van der Westhuizen, in the 20-ton logistics vehicle.

Du Preez (1989), 48.

49 Myburgh (Name list ... 2015).

50 Myburgh (Memorandum ... 2015).

51 Due to this breakdown, Sergeant K.D. Strauss and his driver, Trooper André Botha, joined the crew of Major Holtzhausen's command vehicle. The gunner, Lance Corporal Manus Myburgh, joined the Land Rover of Corporal Nic Bezuidenhout. Myburgh (Memorandum ... 2015).

In 2011, after 42 years of service, Master Chief Warrant Officer (MCWO) F.J.S.

Scheepers, the Warrant Officer of the SANDF, completed his military service and retired.

Willem Steenkamp, Borderstrike! South Africa into Angola 1975-1980 (3rd ed. Durban: Just Done Publications, 2006), 36-38. See also Myburgh (Namelist ... 2015).

Myburgh (Memorandum ... 2015).

56 Ibid.

57 Myburgh (2016).

Major Holtzhausen, in his report to Lieutenant Colonel Van der Waals, notes the armoured vehicle destroyed as a T34 Tank, see Myburgh (Memorandum ... 2015).

Myburgh (Memorandum ... 2015).

60 Ibid.

61 Myburgh (2016).

62 Du Preez (1989), 46-51. See also Myburgh (2016); Steenkamp (2006), 34-39.

63 RSA (Republic of South Africa), 1967, The Defence Amendment Act No. 85 of 9 June 1967 (Pretoria: Government Printing Works). The Act stipulates that it was now compulsory for all 18-year-old white South African male citizens to serve either in the SADF for one year as a National Servicemen, and then undergo annual training for the next nine years in the Citizen Force, or serve in the newly created Commando Reserve for 60 days, with annual training for the following 19 years. However, a concession was made that any National Servicemen who volunteered to complete 18 or 24 months of military service, would have his Citizen Force obligation reduced or nullified. The SADF replaced the 9-month National Service with the 1-year system in 1972.

64 Spies and Du Preez (2012), 82-83, Du Preez (1989), 54.

65 Normally the Officer Commanding 73 Motorised Brigade. See Spies and Du Preez (2012), 86.

66 Spies and Du Preez (2012), 86-101; Steenkamp (2006), 47-56; Nortje (2010), 17-23.

67 Troops 2 and 4 of Delta Squadron, 2 SAI. See Van der Berg (2015).

68 Troops 1, 3 and 5 of Delta Squadron, 2 SAI. See Van der Berg (2015).

69 Du Preez (1989), 70-71.

70 Spies and Du Preez (2010), 92-93.

71 These two troops would be those of Second Lieutenant Alex Nicolaou and Lieutenant Nel van Rensburg, of Norton de Matos fame. 
Van der Berg (2015).

Spies and Du Preez (2010), 93-101; Steenkamp (2006), 61-69; Nortje (2010), 23-27.

Spies and Du Preez (2010), 111; Steenkamp (2006), 69.

George (2012), 75-76.

Spies and Du Preez (2010), 111-117; Steenkamp (2006), 73-81; Nortje (2010), 28-29.

Spies and Du Preez (2010), 117-118; Nortje (2010), 29-31.

George (2012), 77-78.

Gleijeses (2011), 308.

Gleijeses (2011), 311.

Piero Gleijeses, Visions of Freedom: Havana, Washington, Pretoria, and the struggle for Southern Africa 1976-1991 (Chapel Hill, North Carolina, USA:The University of North Carolina Press, 2016), 34.

George (2012), 80-81, 99; Gleijeses (2011), 305.

Gleijeses (2011), 316.

Spies and Du Preez (2010), 118-122; Steenkamp (2006), 83-86; Nortje (2010), 31-32.

Spies and Du Preez (2010), 123; Steenkamp (2006), 86-87.

Gleijeses (2011), 313.

Spies and Du Preez (2010), 124-128; Steenkamp (2006), 88-91; Nortje (2010), 32-34.

Gleijeses (2011), 314

Spies and Du Preez (2010), 124-128; Steenkamp (2006), 88-91; Nortje (2010), 32-34.

When Cuba launched Operation CARLOTTA, Major Argüelles was replaced as the head of the MMCA, by Primer Comandante Leopold Cintra Frias. See Gleijeses (2011), 316.

Gleijeses (2011), 316.

The Eland Troop of Second Lieutenant Alex Nicolaou and Troop 5 under command of Corporal Sakkie Bredenkamp. See Van der Berg (2015).

Spies and Du Preez (2010), 124-128; Steenkamp (2006), 91-92.

Believed to be Russian BRDM-2 (Boyevaya Razvedyvatelnaya Dozornaya Mashina) literally Combat Reconnaissance/Patrol Vehicle. See Steve Zaloga, Modern Soviet Armour: Combat Vehicles of the USSR and Warsaw Pact Today (New Jersey, USA: Prentice-Hall, 1979), 58-59.

Spies and Du Preez (2010), 102-104; Du Preez (1989), 55.

Spies and Du Preez (2010), 105-108.

Ibid., 109-110.

Spies and Du Preez (2010), 177; Du Preez (1989), 124.

Dirk en Johanna de Villiers, $P W-A$ biography of South Africa's President PW Botha (Cape

Town: Tafelberg Publishers, 1984), 266-269.

Spies and Du Preez (2010), 155-158.

Gibson (2016); M. Goller (personal communication, email, 8 August 2016).

Short (2015).

Many sources still have the squadrons original second in command, Lieutenant Chris du Raan, as the acting squadron commander.

Spies and Du Preez (2010), 181; Du Preez (1989), 130.

Gleijeses (2011), 316. 
106 Du Preez (1989), 133-134.

107 Ibid., 134.

108 Short (2015).

109 Spies and Du Preez (2010), 185-189; Du Preez (1989), 134-136.

110 Spies and Du Preez (2010), 189-191; Du Preez (1989), 139-145.

111 Ibid.

112 Gleijeses (2011), 317

113 Breytenbach, p. 112.

114 Spies and Du Preez (2010), 192.

115 Lieutenant Colonel Kotzé was appointed the commander of Combat Group X-Ray.

116 Spies and Du Preez (2010), 246; Du Preez (1989), 97-98.

117 This air bridge was capable of flying in 14 flights per night.

118 Spies and Du Preez (2010), 220; Du Preez (1989), 186.

119 Spies and Du Preez (2010), 219-220.

120 G. Taylor (personal communication, email, 9 August 2016).

121 A. Bischoff (personal communication, email, 10 August 2016).

122 Spies and Du Preez (2010), 221-223; Du Preez (1989), 187-189.

123 Spies and Du Preez (2010), 224; Du Preez (1989), 190-192.

124 Ibid., 224-227.

125 Bischoff (2016).

126 H. du Plessis (personal communication, email, 8 August 2016); Du Preez (1989), 192-196.

127 Spies and Du Preez (2010), 228-232; Du Preez (1989), 196-201.

128 Spies and Du Preez (2010), 233-234; Du Preez (1989), 173-174.

129 Spies and Du Preez (2010), 234-235; Du Preez (1989), 177-178.

130 Spies and Du Preez (2010), 235; Du Preez (1989), 178.

131 Spies and Du Preez (2010), 235-237; Du Preez (1989), 179.

132 Spies and Du Preez (2010), 238; Du Preez (1989), 180

133 Spies and Du Preez (2010), 239; Du Preez (1989), 181.

134 Spies and Du Preez (2010), 240;

135 Spies and Du Preez (2010), 240-242;

136 Brigadier General (retired) Chris Gildenhuys, General Officer Commanding South African Army Armour Formation, interviewed by J.P Scherman, Monument Park, Pretoria, 27 August 2015. See also Spies and Du Preez (2010), 250.

137 Spies and Du Preez (2010), 250.

138 Ibid.

139 Ibid.

140 Gildenhuys (2015). See also Spies and Du Preez (2010), 250-251.

141 Spies and Du Preez (2010), 251.

142 Gildenhuys (2015). See also Spies and Du Preez (2010), 252.

143 Spies and Du Preez (2010), 193.

144 Ibid., 197. 
145 Shortly after the battle of the Ebo, the armoured cars available on the front were reduced when Bravo Squadron, 1 SSB was sent back to Bloemfontein, while Alpha Squadron, $1 \mathrm{SSB}$, under Captain Anton Fourie, remained to continue its duties.

146 Spies and Du Preez (2010), 197.

147 Ibid., 203.

148 Ibid., 196-199.

149 Ibid., 203-206.

150 Erika Gibson (personal communication, email 10 August 2016).

151 Spies and Du Preez (2010), 206-208; Du Preez (1989), 154-157.

152 Goller (2016).

153 Du Preez (1989), 158-160.

154 Spies and Du Preez (2010), 208.

155 Spies and Du Preez (2010), 209; Du Preez (1989), 160-163.

156 Spies and Du Preez (2010), 209-210; Du Preez (1989), 164-165.

157 The fourth car in the troop, the Bravo Car was back in Cela as its Crew Commander, Barry Pretorius, had hurt his arm badly the day before, when his gunner shot the 90 while he still had his arm in the empty cartridge bin removing spent shells.

158 Gibson (2016).

159 The B-10 recoilless rifle is a Soviet $82 \mathrm{~mm}$ smoothbore recoilless rifle. It could be carried on the rear of a BTR-50 armoured personnel carrier and deployed manually using its two-wheeled integrated tripod. It had an effective range of $400 \mathrm{~m}$ and a rate of fire of between 5 and $7 \mathrm{rpm}$. It entered Soviet service in 1954.

160 S. Fourie (personal communication, email, 8 August 2016).

161 Gibson (2016).

162 Ibid.

163 Ibid.

164 Fourie (2016).

165 Later Brigadier General H.J. Heinze, General Officer Commanding Army Support Base Bloemfontein.

166 Fourie (2016).

167 Gibson (2016).

168 Ibid.

169 Later it was clarified that they were not tanks but BRDM-2 Armoured Vehicles.

170 Gibson (2016).

171 Spies and Du Preez (2010), 212.

172 Ibid., 212.

173 Ibid., 213.

174 Gibson (2016).

175 Ibid.

176 Spies and Du Preez (2010), 213.

177 Ibid., 213.

178 Ibid., 213.

179 Spies and Du Preez (2010), 213. 
180 D Squadron, 2 SAI under Major A.C. Slabbert; A Squadron, 1 SSB, under Captain Anton Fourie; A1 Squadron, 1 SSB under Captain F. Rindel, B1 Squadron, 1 SSB under Captain Theo Beyleveldt and A Squadron, 2 SSB under Major H.B. Smit.

181 Two Squadrons from Regiment Mooirivier in Potchefstroom and a Squadron from the Light Horse Regiment in Johannesburg.

182 Charlie Squadron, Natal Mounted Rifles from Durban under the command of Major Bruce Hearn.

183 Spies and Du Preez (2010), 277-292.

184 Ibid., 209. 


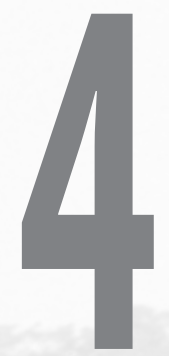

\section{NAMIBIA: EFFECTIVE STRATEGIC BUFFER ZONE OR DRAINING FOREIGN MILITARY ADVENTURE?}

James Jacobs 
The conflict in Southern Africa between the existing order and revolutionary organisations commenced in 1960 when the banned African National Congress (ANC) and the Pan African Congress (PAC) began an armed struggle against the South African government. In Namibia (South West Africa [SWA]), the South West Africa People's Organisation (Swapo), as opposed to South African rule, launched their first military operations in 1966. Namibia became independent in 1990, but the conflict in South Africa lasted until 1994 when the ANC came to power. The war also involved other countries in the subcontinent such as Angola, Zimbabwe and Mozambique, that also influenced the eventual political outcome of events.

The role of the South African Defence Force (SADF) in the Namibian war, 1966-1989, must be understood within the framework of the so-called Forward Defence Strategy that aimed at buying time to find political solutions to conflicts in the region against the background of the Cold War. The core problem this chapter deals with is to determine what role the war in Namibia played in this national security strategy of the South African government and how it influenced the outcome of the events in the subcontinent by 1994. Scholtz ${ }^{1}$ believes that the sacrifices made by South Africans were worthwhile as they eventually forced the Marxist orientated Swapo to accept the result of democratic elections, the drafting of a constitution that guaranteed a democratic dispensation and thus paved the way for the establishment of democratic dispensations in Angola and South Africa.

The question is how vital the continuation of the war in Namibia was, considering the revolutionary struggle in South Africa and the rest of the subcontinent? Did this war not weaken, rather than strengthen the position of the South African government internally and in the region? It is dangerous for a government that faces the possibility of revolutionary violence on its soil to be involved in a foreign military adventure that weakens its hold on the home country and its population. A classic example of this was tsarist Russia that got involved in the Russo-Japanese War (1904-1905) and the First World War (1914-1918). The impact of these wars on the government to effectively govern a vast empire led to the eventual revolutions of 1917, that led not only to the end of the tsarist rule but also the overthrow of a democratically elected government in November of the same year and the establishment of a Marxist dictatorship. ${ }^{2}$

Giliomee $^{3}$ quotes Toynbee, who states that the decline of civilisations was due to human shortcomings such as self-satisfaction and the inability to recognise the burning discontent of the oppressed in society. The Forward Defence Strategy was the result of human decisions up to 1978 and, we must judge it against its inability to prevent the disintegration of the Afrikaner 'empire' by 1994. 
Traditionally South African defence policy since 1910 focused on waging war away from home and preventing violent armed conflict from destabilising the country. The invasion of German South West Africa (SWA) in 1914 can be seen in that light as well as the point of view of the Smuts government in 1939 that East Africa was the Union's first line of defence. ${ }^{4}$

Indeed, one of the factors that enabled the South African government to defeat the first insurgency ${ }^{5}$ campaign of 1960-1965 was the presence of a buffer of friendly states whose armed forces and police intercepted the infiltrators before they reached South Africa proper, making it difficult to wage guerrilla warfare inside the country. The Portuguese were already fighting a counterinsurgency war against indigenous groups inside Angola and Mozambique; Rhodesia was under the white rule; and South African rule in Namibia under the League of Nations Mandate retarded the ability of the military wings of the ANC, PAC and Swapo to make much headway in weakening the position of the government. ${ }^{6}$

In Namibia, the Swapo military cadres, PLAN (People's Liberation Army of Namibia), had difficulties in launching an insurgency in the north of the country. Most infiltrations were stopped by the Portuguese forces in Angola and even the infiltration from Zambia into the Caprivi Strip up to 1962 did not produce significant results. It seemed that the then South African Police (SAP) and from April 1974 the SADF would handle the insurgency with relative ease without drastically escalating the cost of the war. ${ }^{7}$

\section{REVOLUTIONARY WARFARE}

The nature of the threat facing the South African government was revolutionary warfare, the most prevalent form of insurgency against colonial and minority governments during the Cold War era.

This struggle would manifest in different spheres of life. The political dimension would entail establishing an alternative government inside the country, or initially in exile, challenging state authority and demonstrating to the population that the insurgents' ideas would determine the future. The military dimension would consist of guerrilla warfare that aimed to tie down the armed forces of the government, and if it were not possible to defeat these forces, military actions such as ambushes and sabotage would serve as armed propaganda to support other dimensions of the conflict. Revolutionary action could also develop into conventional warfare. Linked closely with the conflict in the political, social and economic dimensions was the struggle for 
cultural supremacy, between the current value systems of society and a new order. The psychological dimension is linked closely to the 'battle for the hearts and minds' of the population. The primary focus of the insurgents was to convince the people that their alternative system would provide them with a better future, and eventually, the ruling elite that the status quo could not be maintained. The international dimension of the struggle would consist of two parts - support of neighbouring states for the guerrillas, providing them with training facilities protected by the armed forces of that state and infiltration routes into the target state. International support in the form of military training and equipment and economic sanctions against the target state was also decisive in the eventual convincing of the target government to end the war, even to the detriment of its political ideals. ${ }^{8}$

As long as South Africa could participate in the international economic system, the revolutionaries would be faced by a population experiencing rising living standards, thus undermining the very fabric of the revolutionary climate needed to mobilise the masses. Therefore, the international community had to be mobilised to introduce sanctions, especially Western countries like the United States of America (USA) and the United Kingdom (UK) that had close economic ties with South Africa. Military support in the form of weapons and training would be forthcoming from Marxist and the Afro-Asiatic bloc of states. ${ }^{9}$ It is important to understand that military operations, even when inflicting heavy losses on the insurgents, can weaken the government in terms of other dimensions of the conflict. It can lead to an increase in economic sanctions and diplomatically isolate the ruling elite even further.

\section{THE COLLAPSE OF THE BUFFER ZONE}

The coup d'état in Portugal in 1974 set in motion a series of events that by 1980 would leave South Africa surrounded by a group of hostile states that provided different levels of support to the ANC, PAC and Swapo.

The Portuguese withdrawal from Angola in 1975, enabled PLAN to activate the insurgency across the whole length of the border between the two countries. The inability of the SADF to utilise the invasion of Angola in 1975 by putting its ally, Unita in power, implied that Swapo now had a sympathetic government in Luanda, the Marxist orientated MPLA enabling it to escalate the insurgency. It also had the advantage that the Ovambo people, the main base of support for Swapo, lived on both sides of the international border, enabling Swapo to re-activate Ovamboland, their main base of support where 46 per cent of the population lived.

The physiography of the border region consists of four main areas - the Northern Namib in the extreme west; the Kaoko Highlands directly east of the Namib; the Etosha Basin, including Ovamboland, in the centre; and the north-eastern Sandveld 
in the east. Along the northern border, the landscape range from sandy Namib dunes in the west; to hills and mountains in the Kaoko Highlands; to plains that stretch from the Etosha Basin to the eastern edge of the Caprivi Strip. Climatically, the first two areas are classified as desert, with the Etosha Basin and north-east Sandveld classified as hot steppe. Rainfall along the northern border is high compared to the rest of the country. The annual rainfall increases progressively from west to east, with the rainfall in the Caprivi Strip the highest of between $600 \mathrm{~mm}$ and $700 \mathrm{~mm}$ per annum. The vegetation of the Etosha basin, where most of the infiltration would take place, is characterised by grasses and widely spaced trees, increasing in density in the woodland areas. Furthermore, the terrain and weather favoured the insurgents, especially during the rainy season when the bush made detection of movement difficult. ${ }^{10}$

These factors soon forced the SADF to launch punitive invasions into Angola to offset the advantages that PLAN enjoyed. By 1977, the insurgency had escalated, and the only way to regain the military initiative was to deny PLAN bases in Angola. ${ }^{11}$ De Vries ${ }^{12}$ describes the area in which most of the fighting took place in Angola as characterised by dense entangled African bush and large areas for manoeuvre. This sand-surfaced vastness would swallow up large conventional formations as well as guerrilla armies. It also differed from the area south of the border in that several rivers would influence the conduct of military operations. It favoured the SADF in that it could use the terrain effectively to fight with smaller mobile forces against larger conventional operations. The reality was that it also took a heavy toll on time and equipment, taking into account the vastness of the area.

Logistically supporting such operations was an even more daunting task. Military operations against PLAN bases soon led to conventional battles with the armed forces of Angola and Cuba and, by 1987, an administrative forward point had to be established at Mavinga. To establish a forward point meant a supply line by bush track, due to the lack of developed roads $-356 \mathrm{~km}$ from Rundu and another $120-150 \mathrm{~km}$ to reach the frontline troops. But that is only part of the story. Keegan and Wheatcroft argue that it was an unpopular campaign at the farthest extremity of South African control, taking into account that the principal means of supply was along the corridor from Upington to Windhoek and from there to Grootfontein, the main supply base in the operational area. ${ }^{13}$ In essence, the battlespace in this war implied that it would be a long, drawn-out war along long lines of communication and quick strategic results would not attainable. One should also take into account the fact that it would be logistically difficult for the SADF to support large tank formations in the event of conventional warfare.

South Africa's military leaders at the time believed that if Swapo gained control of Namibia, it would threaten the north-western part of the Cape Province and the route via Botswana towards the Western Transvaal would make it easier for the military 
wing of the ANC, MK (Umkhonto we Sizwe) to infiltrate South Africa. The fear was that apart from insurgency semi-conventional forces under the guidance of the Soviet Union, East Germany and Cuba would pose a direct threat against the western border of South Africa. ${ }^{14}$

It is imperative to analyse this alternative. Keegan and Wheatcroft state that if South Africa could settle in Namibia, it would improve security by shortening the frontier considerably. ${ }^{15}$ The terrain in the south of Namibia up to the Orange River consists of two parts: along the coast the Namib Desert, and to the east a plateau of sub-desert steppe and arid shrub-grass veld. ${ }^{16}$ One can also describe the area south of the river as semi-desert with mountain ranges stretching from Vioolsdrif on the Orange River southwards via Springbok to Bitterfontein. The area is also thinly populated. ${ }^{17}$ The contrast between this area and the operational area in the north is striking. Apart from operating on much shorter lines of communication, the area can be easier defended using mobile land forces and airpower.

The Namibian infrastructure was also less able to sustain large conventional forces due to the lower capacity of Luderitz and Walvis Bay. Compared to what De Vries describes as the evenly spaced harbours of Luanda, Lobito and Namibe with a large carrying capacity, from where the Soviets and Cubans helped the MPLA government in Angola to build well-developed forward airfields at places such as Lubango, Cahama, Menogue and Cuito Cuanavale. ${ }^{18}$ To duplicate this in the south of Namibia to support conventional forces would take time, and the distribution and density of the population along the Orange River did not favour insurgency operations. Furthermore, between Namibia and Botswana lies the Kalahari Desert and the road and rail systems in the latter were mainly in the eastern part of the country. Thus, a major highway would have had to be built from Windhoek to Gaborone to supply conventional forces or insurgents, presenting a target for the SADF operating from Upington. ${ }^{19}$ This terrain and shorter lines of communication would also have favoured a defence posture relying more on airpower and armour that could produce more decisive strategic results.

The claim that MK would find it easier to infiltrate via Botswana should also be investigated. The area in dispute would be the common border between the Bantustan of Bophuthatswana and Botswana and the Bushveld Savanna of the Northwest Transvaal from Zeerust all along the Limpopo River to an area west of Musina (formerly Messina). It stands to reason that the pressure from Frontline States on Botswana to allow MK to use its territory as a sanctuary for MK would have increased. At this stage, the armed forces of Bophuthatswana were still loyal, but in general terms, one can assume that the population in this region would be more susceptible to ANC political overtures than in the sparsely populated north-western part of the Cape Province. The terrain in this region is described as areas in which trees do not grow 
too close to one another, interspaced with grass. Bushveld is a South African term indicating a higher rainfall than with dry Savanna. ${ }^{20}$ Thus, the terrain would make it impossible to prevent infiltration, but it is less difficult than the north of Namibia and southern Angola.

\section{THE CONFLICT WITH MOZAMBIQUE}

When the Portuguese left Mozambique, they handed over power to the Marxistorientated Frelimo (Frente para Liberação de Moçambique - Mozambique Liberation Front). Initially, the SADF hoped that the close economic ties with South Africa would prevent the Samora Machel government from supporting the insurgency in South Africa. Nonetheless, early in 1975, President Machel declared that the people of South Africa had the right to fight against apartheid and that his country would support this. ${ }^{21}$

Of the buffer states lost to South Africa from 1975 to 1980, this development was the most detrimental from the South African government's point of view. With its long coastline of $2500 \mathrm{~km}$ and good harbours such as Beira and Maputo, foreign maritime powers such as the Soviet Union and Cuba could upset the balance of power in terms of conventional forces in the region. They could do it in a short time by supplying the Mozambique armed forces with key equipment and military advisors, as had happened in Angola. The southern part of the country, with the Maputo harbour, was also geographically the closest area from where the Frontline States could deploy conventional forces to threaten the industrial heartland of South Africa, the PretoriaWitwatersrand-Vereeniging (PWV) complex. It is also relatively close to the DurbanPinetown industrial area. ${ }^{22}$

Furthermore, Mozambique's location posed a threat to escalate the insurgency in Rhodesia, as indeed happened between 1975 and 1979, and the re-activation of the internal front in South Africa. In the border region, the bushveld-type vegetation would retard the detection of groups infiltrating South Africa and the straddling of the international boundaries by different ethnic groups would enable insurgents to easily mix with the local population before the government forces could detect them. It could develop into a rural insurgency, and the proximity of the PWV and DurbanPinetown industrial areas held the potential of activating urban insurrection. ${ }^{23}$ Thus, an ideal situation existed for the large-scale re-activation of the internal insurgency front in South Africa.

Military intelligence reports also indicated that during the period 1975 to July 1977, the Soviet Union and its allies delivered military equipment to the value of R400 million to Mozambique. More and more Soviet, East German and Cuban instructors and technical personnel became involved in the training of the Mozambique armed forces, 
FADM (Forces Armadas de Mozambique) and the maintenance of their equipment. Also taken into account, was the demonstrated ability of the Soviet Union to re-supply their clients with an air bridge during the Yom Kippur War in 1973 and the Marxist government in Ethiopia during 1978. Having Yemen and Ethiopia as client states provided the Soviets with the opportunity to use such an air bridge to alter the force levels in Mozambique in a short time, to the disadvantage of South Africa. ${ }^{24}$

The most immediate threat to the South African government, though, was the re-activation of the insurgency in South Africa. In 1975, the ANC established a political office in Maputo to serve as a reception centre for people that fled South Africa. At the same time, MK cadres moved from Tanzania, and the SADF suspected that they used facilities of the armed forces of Mozambique on route to South Africa. ${ }^{25}$ In November 1976, the first MK cadres infiltrated South Africa from Mozambique via Swaziland, and during the following two years, the feared re-activation and drastic escalation of the insurgency in South Africa followed. As a result of the Soweto riots, thousands of young blacks left the country and joined the ranks of MK and Apla (Azanian People's Liberation Army, formerly known as Poqo, the military wing of the Pan Africanist Congress (PAC)), thus creating an even more favourable climate for the escalation of the conflict. ${ }^{26}$

The first indications of the training of MK recruits in Mozambique raised the concern of repeated escalating insurgency in South Africa that would surpass the situation in Rhodesia where the government forces were struggling to prevent a military collapse. ${ }^{27}$ From 1975 to 1976, a small group of Apla guerrillas cooperated with members of the Mgomezulu people, a community straddling the South African-Swazi border. The SAP crushed this cooperation, but the PAC succeeded in re-establishing underground structures in Johannesburg and East London. ${ }^{28}$

\section{SOWETO AND NEGATIVE INTERNATIONAL EVENTS}

While the struggle against the buffer states escalated, international events also worked in favour of the revolutionary movements in Southern Africa. In 1973, the oil crisis in the Middle East weakened the South African economy that led to dissatisfaction amongst the black population, who experienced the consequent negative impact of these events most, while also realising that the war in the South African neighbouring states was escalating. In 1974, the gold price increased, and the South African economy recuperated, but during the next year, a drastic decline caused the economic growth rate to decrease from 8.3 per cent to 1.3 per cent within a year, and in 1977 , the growth rate was nil. ${ }^{29}$ Two years later, drastic increases in the oil price again stimulated inflation. ${ }^{30}$ The sudden decrease in economic growth caused a phenomenon known as the J-Curve, a situation creating expectations that are suddenly frustrated. 
It emphasised the difference in income between the population groups, and with the escalation of the conflicts in SWA and Rhodesia, the revolutionary climate in South Africa reached its zenith. ${ }^{31}$

In contrast to the situation in 1960 to 1965 , the black population in the cities was ready for insurrection. The government's stance that only the homelands should serve to channel the political and economic aspirations of the black population had failed. In spite of draconian measures to prevent it, urbanisation continued apace, but because blacks, regarded as temporary residents, were not allowed to own property, that had countless negative socio-economic implications. Furthermore, the withdrawal of the Portuguese from Africa and the success of the Civil Rights Movement in the USA created political expectations. In June 1976, when black pupils in Soweto started protesting against inequality in the educational system and the compulsory use of Afrikaans as the medium of tuition, the police opened fire and killed several. Unrest spread throughout the country, and thousands of youths left South Africa to swell the ranks of $\mathrm{MK}$ and Apla. ${ }^{32}$

Since 1965, the government had had ten years to find a political and socio-economic solution that could satisfy the reasonable expectations of the black population in South Africa. However, the unimaginative manner in which the government executed its counter political strategy and regional events aggravated the situation, rather than subdued it. It called for a drastic revision of the government's national security strategy.

\section{THE REFORMULATION OF DEFENCE POLICY}

In government circles, the need for a more aggressive defence posture was already prevalent by the end of 1976. The White Paper on Defence of 1977 identified the enemy of South Africa as International Communism under the leadership of the Soviet Union that wanted to, from a South African government point of view, instigate the so-called liberation movements like the ANC and PAC to wage war against the country and all its inhabitants. The government identified the aim as the overthrow of the current state dispensation and the establishment of a Marxist peoples' republic along the lines of countries such as East Germany and Cuba. It would also coincide with the ideals of Pan Africanism that wanted black people to control all the countries on the continent south of the Sahara. The government identified the grand strategy of the 'enemy' as a 'Total Onslaught' through which the insurgents would try to undermine all the power bases of the state to overthrow state authority within the framework of revolutionary warfare. According to the government, the only viable course of action to counter this was a so-called 'Total Strategy' that also had to protect the power bases of the state. 
Political reform was to be one of the cornerstones of the new approach to address the grievances of the population, linked to draconian internal security measures like states of emergencies to curb internal unrest. The attitude was that this would all be negated if the military dimension of the insurgency spiralled out of control, as in Rhodesia, destroying the legitimacy of the government and forcing the population to choose the side of the perceived winners, the revolutionary movements. Under P.W. Botha's leadership, the State Security Council was reactivated in 1978 as the main organ that had to formulate the government's grand strategy and coordinate the actions of the different state departments to prevent the duplication of government expenditure and win the hearts and minds of the people. ${ }^{33}$

\section{THE FORWARD DEFENCE STRATEGY}

P.W. Botha's foreign policy was to promote international cooperation between the countries in Southern Africa within the framework of a constellation of states. Through this, he hoped to gain international recognition for the independent black homelands, such as the Transkei, and economic integration of the region to offset the hostile attitude of the Frontline States towards South Africa. It would have to be backed up by a defence strategy that had to prevent further escalations of conflict. ${ }^{34}$

Until 1978, the regional strategy of the SADF was based on deterrence of conventional aggression through expanding South Africa's arms industry and creating a credible conventional force. It had to be supplemented by the curbing of insurrection through a counterinsurgency strategy within South Africa and SWA.The SADF supplied limited aid in terms of personnel and equipment to the Rhodesian armed forces and Unita in Angola. Though, in the light of the changed security situation in Southern Africa, it was deemed that this had to be supplemented by a more aggressive intervention in neighbouring states that posed a threat to South Africa. It was to augment the closedefence strategy, as the previous approach was redefined.

Southern Africa was divided into three geostrategic areas:

$\diamond \quad$ Northern Angola, Zaïre, Tanzania, Zambia, Malawi and northern Mozambique The SADF had to be able to collect information in the so-called area of interest and if necessary to conduct punitive operations.

$\diamond \quad$ SWA (Namibia), Southern Angola, Rhodesia, Southern Mozambique, Botswana, Swaziland and Lesotho - The combat/tactical area was the most important region in which the strategy would manifest. The SADF had to be able to influence the governments through diplomatic, economic and military means to adopt a pro-Western, democratic and capitalistic stance. 
$\diamond$ South Africa and the black homelands constituted the vital survival area - From within this region, the SADF had to be able to conduct conventional and counterinsurgency operations in the combat area and punitive expeditions into the area of interest. ${ }^{35}$

South Africa had to keep the Frontline States off balance by dominating the subcontinent up to the Congo River basin. Support to insurgent groups inside the Frontline States implied that attacks against the rail and road networks in these countries forced them to export and import through South African harbours. It had to be used to ensure the establishment of governments in Rhodesia and SWA that would not support insurgency against South Africa and to put pressure on Mozambique to also toe the line. These military actions would also be supplemented by external attacks by the SADF against insurgents in neighbouring countries and against conventional forces if military confrontation proved to be inevitable. ${ }^{36}$ Thus, the strategic military concept was to destroy enemies before they could destabilise South Africa and the black homelands.

\section{CONFLICT WITH MOZAMBIQUE, 1978-1984}

In 1978, the strategic situation in Rhodesia created the impression that this strategy could be successfully implemented. An internal settlement between the Ian Smith government and certain black leaders led to elections and the establishment of a government of national unity under Abel Muzorewa. There was hope that most of the insurgents would support the government and that, what was then called ZimbabweRhodesia, would be recognised by Western countries.

Within the framework of the new strategy, South African military aid to ZimbabweRhodesia increased drastically. The Rhodesians attacked guerrilla bases in Zambia and Mozambique, leading to a large loss of life amongst the insurgents. ${ }^{37}$ Another facet of this approach was the establishment of an insurgent movement in Mozambique by the Rhodesian Central Intelligence Organisation (CIO) with help from the Rhodesian Army. By 1979, the Renamo (Resistência Nacional Moçambicana - Mozambican National Resistance) cadres were conducting a guerrilla war in the central provinces of the country against the Mozambique armed forces, FADM (Forcas Armadas de Mozambique). ${ }^{38}$

The new strategy of the Zimbabwe-Rhodesian armed forces could not stem the tide of the insurgency inside the country and Western recognition did not materialise. British intervention in 1979 led to the Lancaster House agreement, elections in 1980 and the establishment of the Republic of Zimbabwe under the leadership of Robert Mugabe. ${ }^{39}$ Another of the buffer states lost, and the Zimbabwean border added to the area that MK and Apla could use to infiltrate their cadres into South Africa. 
Furthermore, access via Zimbabwe could also lead to the activation of Botswana as a base area for the insurgents. Previously, the location of Rhodesia and the Caprivi Strip in SWA made this difficult. Even worse, intelligence indicated that these events contributed substantially to an increase of support for the ANC amongst the black urban population in South Africa. ${ }^{40}$

To aggravate matters the Soviet build-up of conventional forces in the Frontline States increased unabated, with the probable aim of deterring the SADF from conducting military operations against their armed forces and the insurgents. Soviet involvement in Afghanistan, Ethiopia, Angola and Mozambique also created the impression that they were prepared to support Marxist client states to the hilt to expand their influence in the Third World. ${ }^{41}$

In spite of this, certain international trends favoured the South African government. In 1979, Margaret Thatcher became the Prime Minister of Britain and the next year, Ronald Reagan was elected President of the USA. Both were well known for their anti-Marxist points of view and preparedness to combat the spread of global Soviet influence actively. It would eventually entail American military support to insurgents in self-declared Marxist states. The South African government believed that with internal political reform and its external military actions, they would receive tacit support from the West. ${ }^{42}$

The first component of the military strategy against Mozambique constituted operations by special and air forces against houses in Maputo used by MK as training and transfer facilities from where their cadres could infiltrate South Africa. ${ }^{43}$

During 1981, SADF Special Forces also conducted raids in Lesotho. In December of the next year, a SADF raid in Maseru killed 42 people, more than $20 \mathrm{MK}$ members. ${ }^{44}$ Close cooperation with the Swaziland Defence Force also led to the eventual expulsion of MK cadres from that country. ${ }^{45}$

The support to external insurgent movements in the Frontline States produced the most spectacular military results. After the establishment of Zimbabwe, the SADF moved Renamo to Phalaborwa, close to the South African border with Mozambique, started training their cadres and helped them to infiltrate Mozambique. Most of the time, the insurgents were accompanied by SADF Special Forces to help with planning and guidance. From 1980 to 1983, the civil war in Mozambique escalated to the point that Renamo conducted operations in all but one of the country's provinces and exploded bombs in Maputo and Beira. The FADM could only move in large formations in certain areas. The strategy seemed to be working. ${ }^{46}$ 
The leadership of the ANC took note of the change in government strategy. From 1976 to 1979, several sabotage acts were carried out in South Africa but were pinpricks compared to the military resources the government could mobilise. According to Barrell, ${ }^{47}$ the ANC focus, still too much on the military dimension of the struggle, was rectified only after a visit to Vietnam in 1979. The lessons the ANC leaders learnt on this visit were that the most important aspects were the establishment of underground structures and the mobilisation of the masses. Their focus would also shift to the cities where the discontent amongst the black population was rapidly rising.

Henceforth, military actions would only serve to enhance this process and contribute to the raising of the insurgents' morale. They realised that the South African government would never tolerate the establishment of large military facilities in countries such as Mozambique, Swaziland, Lesotho, Zimbabwe and Botswana. Barrell ${ }^{48}$ claims that after 1979, MK military attacks such as the explosions at Sasol in 1980 and Koeberg in 1982, as well as the Church Street car bomb in Pretoria in 1983, highlighted the ability of MK to conduct sabotage inside the country. The overwhelming reaction of the black population, as measured against the attendance of funerals of MK members killed by government forces and the support to protest actions reflected the effect of the ANC's new strategy. In August 1983, the United Democratic Front (UDF) was established inside South Africa to act as a front organisation for the ANC to facilitate the mobilisation of the masses against all the power bases of the state. ${ }^{49}$

In spite of this, the leadership of the ANC realised that the establishment of liberated areas inside South Africa was still a far way off. In 1982, they decided to deploy an MK brigade inside Angola to fight against Unita, probably to gain military experience in preparation for the future when possibly waging a full-scale guerrilla war in support of the revolutionary struggle..$^{50}$

With the providence of hindsight, it is clear that at this stage, the strategic choices of the South African government should have been re-appreciated. Apart from a drastically needed new political strategy as far as the urban black population was concerned, the military strategy could not prevent the use of Botswana as an infiltration area in spite of the continued South African occupation of Namibia. From bases in Zambia, infiltration was conducted through Zimbabwe and hence Botswana. In terms of the ANC's new strategy, they did not need large military bases in countries such as Zimbabwe, Mozambique and Botswana, only sympathetic governments that would not stop the infiltration into South Africa. The question was, what were the chances of a settlement in Namibia? 
An important development on the diplomatic front was the involvement from 1977 of the big five Western countries - the USA, Britain, West Germany, France and Canada in a search for an end to the war in Namibia. The first significant development was the arrival of their legates on 22 September for further settlement talks in Pretoria. There were rumours that President Carter had drawn up a plan with Tanzania's President Julius Nyerere that required the South African forces to withdraw from Namibia and be replaced by a PLAN contingent as a run-up to independence. Another suggestion, rejected out of hand, was that a small token force of the SADF stays in Namibia, but the PLAN camps on the Angolan side of the border should be left intact, and remain under UN supervision. By 26 September, the talks were suspended, and the only statement was that the representatives would report back to their governments. In the meantime, up to December, the infiltration from Angola escalated. ${ }^{51}$

On 2 December, the representatives returned to Pretoria after consultations with Swapo and the Frontline States. The issue was still the South African troop presence in Namibia, and as long as Swapo demanded total withdrawal of the SADF, they would achieve nothing. Prime Minister John Vorster offered the reduction of personnel to 4000 , including 1500 combat troops, based in two camps under UN supervision. Even before it became clear if Tanzania and Angola could persuade Swapo to moderate its demands, the South African government reacted. The statement was that due to the death of two members of the SADF, there would be a correlation between the tempo of withdrawal and the level of violence. From 1966 until the end of 1977, a total of 88 members of the SADF and SAP had died as well as 363 insurgents, the former figure too high for the South African government's liking.

In the same month, Vorster and his security advisors held a long discussion at his holiday home, where P.W. Botha and the SADF propagated stronger measures. The core argument was that by fighting a defensive war, with the South African forces waiting for PLAN to infiltrate before they could react, would not stop the insurgency. They had to act before crossing the border. Steenkamp ${ }^{52}$ states: "It was a landmark decision, a watershed that would have as great an effect on the Border War as the withdrawal from Angola in 1976, which had presented Swapo with its safe border."

Another important development was the UN enforcement of an arms embargo against South Africa by the end of 1977. They would feel the implication of this severely towards the end of the conflict, especially concerning equipment such as fighter aircraft that South Africa could not manufacture. ${ }^{53}$ 
In February 1978, negotiations between R.F. Botha, Minister of Foreign Affairs, and Sam Nujoma, leader of Swapo, under the guidance of the five Western countries were continued in Windhoek and New York. Nujoma demanded the incorporation of Walvis Bay into a future independent Namibia and the deployment of 1500 members of the SADF near Karasburg in the south. The Western countries and South Africa wanted them at Grootfontein and Oshivelo in the north. On 28 February in a television interview, Nujoma denied that his organisation was guilty of any atrocities, murders or intimidation. He claimed that the landmines that killed civilians had been laid by the SADF and that the SADF had the habit of firing indiscriminately at civilians and then reported the casualties as being PLAN members. He promised that once in power, his organisation would 'do away' with Namibians that served in the SADF, as well as puppets serving in anti-Swapo political parties. He concluded that the question of black majority rule was out, that they were not fighting for this, but to seize power in Namibia. It destroyed any hope of a peaceful settlement.

International peace talks continued and, on 25 April, South Africa formally accepted the Western countries' proposals for a settlement. It would include a ceasefire and a reduction of SADF troops, the holding of an election and the formation of a constituent assembly. But Swapo rejected the proposals, and the UN General Assembly started a 10-day special session scheduled to attack South African intransigence and inflexibility and to call for unconditional withdrawal. On 28 April, a group of 100 PLAN members infiltrated from Angola. Attempted attacks on Ovambo tribal leaders and the planting of landmines took place. On 3 May, Nujoma delivered a speech at the UN special session where he stated that Swapo would intensify the struggle. On 4 May, the SADF launched Operation REINDEER that dealt PLAN a severe blow from a military point of view. ${ }^{54}$ Scholtz ${ }^{55}$ asks the question if the South African government had forfeited an opportunity for a peaceful solution to the problem.

On the other hand, the attitude of the Swapo leadership created the impression that an election under UN supervision would not be free and fair and would lead to retributions and bloodshed and the establishment of a Marxist dictatorship such as in Angola. REINDEER was a successful test to the new approach of the SADF of using external military operations to make it difficult for PLAN to infiltrate Namibia. It also set the pattern for military operations until the end of the war.

The SADF kept a watchful eye on the Namibian election process. Swapo refused to participate, and as expected, the UN rejected the results in which the Democratic Turnhalle Alliance (DTA) won and took over most of the governmental functions. ${ }^{56}$

Early in 1979, there was optimism as the negotiations were resumed. The PLAN attack on the Nkongo base, $15 \mathrm{~km}$ from the border, however, led the South African government to send a protest note to the UN Secretary General Kurt Waldheim asking that Swapo indicate if they accepted the Western proposals and if UN troops 
would arrive before the end of the month to set the independence process in motion. Waldheim could give no such assurances and blamed South Africa for the delay in the peace process. Besides, Nujoma's talks with UN representative Martti Ahtisaari led to the announcement that in the event of a settlement, they would not restrict PLAN to their bases and SADF troop strength had to be reduced, irrespective of whether a visible peace should come about. The South African answer to this to withdraw no soldiers until PLAN stopped its acts of violence. Consequently, both sides escalated their military actions.

In October 1979, the Western contact group proposed that the SADF be allowed to retain five bases within $50 \mathrm{~km}$ from the Angolan border, that from there to the border a demilitarised zone (DMZ) be established, patrolled by UN forces. They wanted to retain the bases for the first three months of the independence process, excluding PLAN forces from the DMZ. Swapo was lukewarm to the proposals, but the South African government accepted them, subject to certain conditions. On the military front, the SADF was achieving substantial success. By the end of the year, according to SADF sources, 915 PLAN members were killed compared to 50 on the South African side. The number of incidents had increased from 500 in 1978 to more than 900 in $1979 .{ }^{57}$ Thus, the pattern of both sides escalating the conflict to improve their positions continued.

During 1980, the situation would become even more complicated. The proposed UN Task Force Commander (Untag) General Prem Chand visited Luanda, while the Unita leader, Jonas Savimbi, wrote a letter to P.W. Botha, demanding that they include him in the peace talks. By this time, South African aid to Unita, together with external military operations, further escalated the conflict. On 1 May 1980, the South African government extended home rule to Namibia and in August the South West African Territory Force (SWATF) was established involving all the population groups in the country, but in the same month, the first clashes between the SADF and the Angolan Armed Forces (Fapla) occurred.

In June 1980, negotiations resumed. The South African government proposed a reduction in SADF bases from 40 to 20 south of the DMZ, but PLAN had to be disarmed seven days after the elections and relinquish claims to bases in Namibia. Furthermore, Waldheim had to stop declaring that Swapo was the legitimate representative of the people of the country. It seemed as if Waldheim agreed and Angola and Zambia proclaimed that they would guarantee the acceptance of election results by Swapo. Also, if South Africa agreed to the concept of the DMZ, the UN would not insist on PLAN having bases in Namibia after the ceasefire.

Against the background of these events, the SADF was conducting external operations as far north as Chitando and Evale in southern Angola (Operation SCEPTIC). Two weeks after seemingly reaching an agreement, Waldheim launched a verbal attack 
against South Africa because of Operation SCEPTIC. The military results caused a decline in incidents in Namibia, but another chance to end the war was forfeited. Furthermore, the effects were temporary. As soon as the SADF withdrew from Angola, PLAN re-occupied the area and rebuilt their bases.

Consequently, in 1981 the SADF would again have to launch operations into Angola..$^{58}$ Thus, a new strategic pattern emerged. To keep PLAN infiltration at acceptable levels of external operations into Angola and support for Unita was vital, but this led to armed combat with the Angolan armed forces and more international condemnation.

In January 1981, it seemed as if the negotiating process had come to a grinding halt. In Genève, Switzerland, the delegates engaged in a shouting match and achieved nothing. On 30 January, the SADF attacked MK bases in Maputo, leading to international condemnation. In August, the SADF launched its largest external raid of the war against PLAN, Operation PROTEA, followed by Operation DAISY in November. The battles involving clashes between the SADF and Fapla had at the same time drastically increased as the latter proceeded to protect PLAN. At the same time, Unita also stepped up its operations against Fapla in a drastic escalation of the war. The other consequence of PROTEA was that the SADF started maintaining a semi-permanent presence in the Cunene province of Angola. In the UN Security Council, the USA vetoed a resolution condemning the South African actions. The stance of the Reagan administration on the war favoured South Africa, but PLAN was not defeated..$^{59}$

The first development on the diplomatic front was in June 1981 when R.F. Botha announced that the withdrawal of the Cuban forces from Angola had to happen first, before the implementation of Resolution 435, the UN plan for a settlement. The interests of South Africa and the Reagan administration were now closer than ever. During talks in New York in July, Angola categorically stated that the Cubans would only withdraw after Namibia became independent and all SADF forces had withdrawn from the territory. In exchange, the Cubans undertook to stay north of the 14th parallel ( $240 \mathrm{~km}$ north of the border), and PLAN would be confined to bases no closer than $350 \mathrm{~km}$ from the Angolan border. On 29 July, R.F. Botha asked for a ceasefire date, 15 August, and agreed that the Cubans did not have to leave before the implementation of Resolution 435. Swapo did not agree and stated that South Africa had brought back the precondition that the UN monitor PLAN bases in Angola and Zambia. However, the Frontline States persuaded Swapo to accept this, but then the South African government demanded that they disarm and that the UN provide a specific timetable for the Cuban withdrawal from Angola. On 30 August, the Angolan Minister of Foreign Affairs rejected the linkage between the Cuban and South African withdrawals. In a letter to the Frontline States, President Reagan made it plain that he regarded the continuing presence of the Cubans as the main obstacle to a settlement. 
Another proposed ceasefire date, 15 September 1981, came and went. It was clear that the opposing parties were not yet prepared to compromise enough to settle. The SADF stayed in southern Angola, Fapla improved their anti-aircraft defences and PLAN continued infiltrating Namibia. From December 1981 to August 1982, the SADF conducted three operations in Angola, Operations MAKRO and MEEBOS I and II. Consequently, Swapo called the efforts of the Western countries to mediate peace a diplomatic charade.

In August 1982, media reports indicated that the Frontline States recognised the importance of the Cuban withdrawal for the USA. Also reported was the USA's possible recognition of the Angolan government and aid provision, if South Africa would stop its attacks on Angola and its support of Unita and that the USA would hold South Africa to this promise. Also stated was that if South Africa did not accept this, it was not serious about ending the conflict.

On 8 December 1982, negotiations resumed between South Africa and Angola at the Cape Verde Islands, but nothing was achieved except a joint declaration to continue with talks. During the same month, the SADF launched attacks in Lesotho against MK facilities. During a General Assembly debate, the Western contact group was condemned for its cooperation with South Africa and specifically the US delegates for their government's stance that there should be a link between the Cuban withdrawal and the implementation of Resolution $435 .^{60}$

During January 1983, the South African government reiterated its statement on the linkage between the withdrawal of the Cuban forces and the implementation of Resolution 435 and in February further talks produced nothing, due to this issue. At the same time, PLAN launched a massive infiltration into Namibia, so much so that members of the South African parliament questioned whether the SADF was winning the war. On the other end of the equation, Unita now controlled 25 per cent of Angola, and its military strength was more or less 35000 men. They were also receiving help from other African countries, apart from South Africa, such as Zaire and Zambia. The area occupied by Unita in Southeast Angola implied that PLAN could not activate the full length of the border and the insurgency was confined to Ovamboland, making the task of the SADF much easier. On the other hand, Soviet and Cuban aid to Angola also drastically increased.

In November 1983, the new Secretary General of the UN Perez de Cuellar visited South Africa, Namibia and Angola, where he had discussions with Angolan leaders and Nujoma. The Frontline States met on 13 November and condemned the USA and South Africa about the link between the Cuban withdrawal from Angola and the implementation of Resolution 435. At the same time, the Soviet government issued South African delegates at the UN a stern warning that they would not tolerate the South African occupation of Angola and support to Unita and that the US would not 
achieve a withdrawal of Cuban troops before the implementation of Resolution 435 . In the background, South African attacks against air defence installations in Angola escalated. In December, new proposals were tabled, drawn up by R.F. Botha and Chester Crocker, Assistant Foreign Secretary in the Reagan administration. According to these, the SADF would disengage all troops from Angola by 31 January 1984, and Angola had to restrain their armed forces and ensure that Swapo and the Cubans did not exploit this. Nonetheless, both the SADF and PLAN escalated military operations.

In January 1984, during the attack on Cuvelai, elements of the SADF encountered T54/55 tanks in a mobile role. In the intense battles that ensued, the SADF prevailed. While mopping up operations continued, Swapo handed a letter to the Secretary General of the UN, asking for renewed negotiations. Despite this, the UN General Assembly passed a resolution calling for punitive sanctions against South Africa. In the Security Council, it was vetoed by the USA with the UK and France objecting to some of the wording in the document.

When the SADF withdrew on 15 January 1984, it was clear that the SADF has severely disrupted PLAN operations and destroyed a large number of Fapla tanks. It proved that even being outnumbered, the SADF could beat a conventional force through better tactics and battle handling. But the aggressive reaction of the Fapla and Cuban forces indicated that the days of relatively easy external operations were over and, for the first time, Russian personnel also participated in the fighting. Another reality was that South Africa's semi-permanent presence in southern Angola had turned into an intolerable political burden and the economic costs also escalated. ${ }^{61}$

\section{THE JOINT MONITORING COMMISSION AND NKOMATI}

After lengthy negotiations, South Africa and the Angolan government signed the Lusaka Accord. A joint monitoring committee consisting of members of the two defence forces had to determine if all SADF elements had withdrawn south of the Angolan border and if Fapla and Cuban forces did not occupy this area. Swapo exploited the situation to escalate the conflict, and the Fapla and Cuban forces reinforced their conventional force capability. Therefore, South Africa withdrew from the commission. ${ }^{62}$

In Mozambique, the Forward Defence Strategy results became even more spectacular. Renamo had by March 1984 activated all the provinces in Mozambique, and the SADF Chief of Staff Intelligence Division reckoned that Renamo would be able to wrest political power from Frelimo by $1985 .{ }^{63}$

Certain Western media, however, used South Africa's destabilisation of the subcontinent to tarnish the name of the South African government, and in so doing, contributed 
to the increased isolation of the country from the international community. The argument was that South Africa's regional actions had become an embarrassment to the Reagan administration. ${ }^{64}$ At the same time, South African efforts to promote Renamo as a viable alternative to Frelimo in the West met with only limited success. ${ }^{65}$ President Machel realised that the Soviet Union would not be able to bail out his government in a conflict with South Africa. It also became clear that the USA did not want to overthrow the governments of Angola and Mozambique, but was using Unita and Renamo respectively to move them away from Marxism towards democratic and free-market dispensations. ${ }^{66}$ Since 1981, the Mozambique government liaised with the USA, that had the clear message that MK could not escalate the war in South Africa to full-scale guerrilla war and, as long as the Frontline States supported insurgency against South Africa, they should not expect help from the West. ${ }^{67}$ The Nkomati Accord between South Africa and Mozambique was signed on 16 March 1984. In exchange for Mozambique's undertaking to cease support to MK, South Africa agreed to halt its support to Renamo. ${ }^{68}$

The Nkomati Accord was a temporary setback for the ANC. Simultaneously it became known that Swaziland had a secret agreement with the South African government to act against $\mathrm{MK}$ in its territory. The result was MK cadres, hastily deployed in South Africa, and a sudden rise in casualties inflicted by the SADF and the SAP. Despite maintaining armed activity for a short time in South Africa after that, the outbreak of a new wave of protest in September 1984, they could not supplement it with a full-scale guerrilla campaign, due to the loss of military facilities in Swaziland and Mozambique. At the same time, infiltration routes through Zimbabwe and Botswana had not been developed. To aggravate matters, dissatisfaction with the circumstances in which MK members had to fight in Angola led to a mutiny in some MK camps. ${ }^{69}$

In a secret meeting between P.W. Botha and Machel, they agreed that South Africa would continue to provide non-military aid such as agricultural implements, seed and medical support to Renamo. It could then be used to facilitate negotiations between Renamo and the Frelimo government to create a government of national unity. ${ }^{70}$

\section{THE FINAL PHASE, 1985-1989}

In spite of the diplomatic setback of the failure of the Joint Monitoring Commission to end the wars in Angola and SWA, on face value it appeared that the Forward Defence Strategy allowed the South African state to survive. But it was soon proved that appearances were misleading.

The nature of the war in Angola and Namibia changed. Although counterinsurgency against PLAN continued, the main focus of the SADF became a support to Unita, after Fapla, the Cubans and Swapo started building up forces to destroy Savimbi's 
hold on southeast Angola. During 1985 and 1986, Fapla launched military offensives against Unita that were beaten off by a limited SADF presence. ${ }^{71}$ It seemed as if South Africa was winning the military side of the conflict in SWA. ${ }^{72}$ The Unita guerrilla war against Fapla still enabled the SADF to limit the insurgency to Ovamboland, and the PLAN losses increased dramatically. ${ }^{73}$

In spite of this, MK infiltrated from Zambia via Zimbabwe, Botswana and Swaziland in 1985 and planted landmines in the border region on the South African side. ${ }^{74}$ On 14 July, the SADF and SAP attacked MK underground structures in Botswana and killed 12 people. ${ }^{75}$

In January 1986, Major General Justin Lekhanya led a military coup d'état in Lesotho. He favoured closer relations with South Africa, and it led to the deportation of ANC members and specifically MK operatives. As MK had used Lesotho to infiltrate into the Eastern and Western Cape, the Transkei and, to a limited extent, the PWV area, this was a serious blow to the ANC.7 ${ }^{76}$

Strategic realities proved the above to be only temporary gains. In 1985, Keegan and Wheatcroft ${ }^{77}$ warned that the position of the South African government was vulnerable, as the following four years would demonstrate. According to them, the war in Angola and SWA had become a drain on the South African economy. They saw part of the solution a disengagement from this war, as it would ease international pressure and burden South Africa's enemies with the logistic problem of fighting a war with long lines of communication. A glance at the map of Southern Africa indicates that after the creation of Zimbabwe in 1980, SWA lost its value as a buffer zone. The argument that a Swapo government in Windhoek would allow infiltration into the north-western part of the Cape Province and via Botswana does not take into account the fact that infiltration through the latter could from then on anyway proceed via Zimbabwe. Also, the semi-desert nature of the border with Namibia and its resultant lack of large population concentrations in that area defeats the argument that Namibia, as a strategic buffer, was still vital for national survival. Also, according to L'Ange, ${ }^{78}$ by 1988 , it became obvious that Swapo was winning the contest for the loyalty of the population, as they had the political support amongst most black Namibians, especially the numerically strong Ovambo people in spite of the extensive communication operations amongst them by the SADF.

In Mozambique, the problem was the failed efforts to facilitate negotiations between Frelimo and Renamo. Also, by signing the Nkomati Accord, the South African government had for the first time officially acknowledged its support of Renamo. The civil war escalated and, in desperation, Machel used the continued limited aid to Renamo to accuse South Africa of breaking the accord. His death in a plane crash on 19 October 1986 aggravated this. Mozambique, the Soviet Union and the Western media created the impression that the South African government was responsible for 
the accident and used the accusations of continued support to Renamo to depict South Africa as the regional bully. ${ }^{79}$ It neutralised the temporary diplomatic advantage gained by South Africa, and during 1985, MK and Apla had again started using Mozambique as an infiltration route. ${ }^{80}$ The Mozambique government had outmanoeuvred its South African counterpart within the diplomatic dimension of the war.

The war in Angola escalated as Fapla, supported by the Soviet Union and Cuba, from 1986 to 1988 launched large-scale offensives against Unita. The South African contribution had to increase accordingly. The SADF-Unita forces achieved spectacular success on the Lomba River in 1987, but then got bogged down in a war of attrition near Cuito Quanavale. Still, the South African government could not afford the impression that it had caved into Marxist pressure due to right-wing accusations of a sell-out of the white people. The deadlock was eventually broken in 1988 when the Soviet Union approach the USA government, indicating that it wanted to end its military commitments in Africa and also put pressure on its clients such as the ANC to negotiate with their political opponents. ${ }^{81}$ Ultimately the South African withdrawal from Cuito Quanavale, the implementation of UN Resolution 435 and the independence of Namibia established the situation recommended by Keegan and Wheatcroft, but only in 1989 , four years later. ${ }^{82}$

The South African government did not escape unscathed from this conflict. They, and the SADF, never understood the importance of propaganda in war. The events at Quito Quanavale were used to create the impression that the SADF was defeated and that South African diplomats negotiated from a position of weakness. ${ }^{83}$ The effect of this on the election in Namibia and the subsequent political victory of Swapo are aspects that will have to be examined by historians as well as the PLAN invasion of Namibia early in 1989 as the UN forces started to deploy. The UN requested South Africa to re-mobilise its forces and countered this military action and the PLAN cadres were defeated. It only demonstrated that the SADF could not curb the actions of Swapo and the Cubans only withdrew after Namibia became independent in 1990, in spite of Western diplomatic efforts and South African military actions from 1977. The only difference this time around was the involvement of the USA and the Soviet Union, providing some guarantee that the Cuban forces in Angola would not interfere with the implementation of Resolution 435 in Namibia. ${ }^{84}$

In 1985, Keegan and Wheatcroft ${ }^{85}$ also warned that the government's internal policies were not working and that they should find alternatives quickly. Since 1983, the UDF synchronised a coalition of anti-apartheid organisations that included labour movements, educational, youth, civic, women's, religious and political organisations in mass actions against the government. The government's efforts to placate black political and economic aspirations through the homelands, local government participation in the urban areas and the Tricameral Parliament again aggravated rather than defused the situation. In September 1984, large-scale mass protests started in the urban areas that 
even spread to certain rural regions. MK and Apla membership increased drastically, and some authors reckon that the country was on the verge of full-scale civil war. ${ }^{86}$

Hough $^{87}$ thought that by 1988 the ANC had to admit setbacks in their attempts to transform unrest into insurrection. The government's counter-measures such as states of emergency and, in certain cases, addressing the immediate causes of discontent stemmed the tide. MK and Apla could not convert any area in South Africa into liberated areas, but the government could also only stay in power through emergency legislation and brute force. Also, international pressure and sanctions further isolated the country. That set the stage for the dramatic events of 1990 that would resolve the conflict.

\section{THE ECONOMIC DIMENSION}

In Revolutionary Warfare, the cost for the government mostly leads to a collapse of will to carry on with the struggle. Not to mention the negative influence of world economic events such as drastic rises in the oil price again. The influence of economic factors on South Africa, as far as Namibia is concerned entailed two components: The foreign perception was that, apart from being a buffer against the infiltration of guerrillas, Namibia was important for South Africa because of its mineral wealth. ${ }^{88}$

The reality was that the South African economy, to a large extent, supported that of its neighbour. The annual contribution of the South African government to keep the railways in Namibia running was R70 million. During 1982, South Africa provided R60 million for drought relief, and since 1973 Namibia was provided with loans and direct financial contributions totalling more than R2 billion. ${ }^{89}$

The other component was defence expenditure. Official figures on the cost of the war in 1985 were R2 million per day on average, ${ }^{90}$ while only the ammunition used during the 1987/88 book year cost R328 million. Other figures are somewhat contradictory. Geldenhuys ${ }^{91}$ states that defence expenditure as a percentage of state expenditure declined from 18.4 per cent in 1977-1978 to 14.4 per cent in 1986-1987, while defence expenditures as part of the Gross Domestic Product (GDP) declined from 4.8 per cent (1977-1978) to 4.2 per cent (1986-1987). According to him, the war in Namibia cost R580 million per year but with a defence budget being less than 5 per cent of the GDP, compared with other countries, USA (6.5 per cent), Britain (5.4 per cent), Israel (14.8 per cent) and Mozambique (10.8 per cent). According to Giliomee, ${ }^{92}$ military expenditure between 1985 and 1986, and 1988 and 1989, increased with 25 per cent against constant pricing and constituted 17.7 per cent of state expenditure. The latter figures were probably indicating the effect of the conventional battles in Angola from 1986 to 1988. See these expenditures against the background of the growing sanctions campaign against South Africa from the 
Western World. The South African economy was not on its knees, but lack of foreign investment would have inhibited the government's ability to curb unemployment, that would have led to an intensification of the revolutionary climate. ${ }^{93}$ The problem is that the money spent on the war in Namibia and Angola could have been used for the execution of a counterinsurgency strategy in South Africa. After all, what is the use of pumping millions of Rand into the Namibian economy while the people in Soweto did not have running water and electricity?

\section{CONCLUSION}

The main lesson learnt from the Rhodesian bush war was that if the South African government forces lost the military struggle, they would have to negotiate from a position of weakness. The Military strategy, therefore, had to win time for the government by preventing an escalation of the conflict in South Africa to become a full-scale people's war. To achieve this was imperative, to prevent the insurgents from using neighbouring states and eventually liberated areas in the country from where to conduct guerrilla warfare. After all, to win the military dimension of the conflict avails to nothing if the political struggle, in the end, is lost.

The time gained between 1960 and 1975 were not exploited, and the loss of Angola and Mozambique as buffer states to the revolutionary onslaught contributed substantially to the Soweto riots that were an indication of the futility of the government's internal policies.

From 1976 to 1980, the Forward Defence Strategy furnished the government with a strategy that could buy time to find answers to the internal problems of the country, but the loss of Rhodesia and the escalation of the conflict in Angola and SWA were serious blows, that called for an even more aggressive posture. From 1980 to 1989, the SADF achieved spectacular military results, but it was not decisive enough, and on the diplomatic and economic fronts, the South African government could not win the war.

The government again failed to capitalise on the security umbrella to find an answer to the most pressing political question, the design of a constitutional system that would address the aspirations of the majority of the people in the country. Thus, the ruling elite found themselves overtaken by world events such as the end of the Cold War in 1989 and the mounting support for the ANC in the West. The inability to find a way out of the conflict in SWA and Angola only aggravated the situation. The result was that the SADF got dragged further into an unwinnable war of attrition, while time and money, possibly better used in the struggle against the ANC and PAC inside South Africa, were wasted. 
After 1989, the only positive result of the continued war in Namibia and Angola from a South African government point of view, was that MK had to vacate their training bases in Angola and move to Tanzania and Uganda, following the final agreement between the warring parties. ${ }^{94}$ It was to the advantage of Unita, but it is debatable whether this had much influence on the war inside South Africa. All the fighting and diplomacy could not get the Cubans to leave Angola before elections in Namibia, and the final PLAN invasion into the country not prevented.The population demography ensured a victory for Swapo anyway.

As for the Cold War, the South African involvement in Namibia and Angola did contribute towards the eventual demise of the position of the Soviet Union and Cuba in Africa. Crocker ${ }^{95}$ described the situation by 1980 as one in which the Soviets had developed the means for further expansionism into the region, while South Africa had developed the means and rationale for military intervention beyond its borders. The Soviet approach to the USA in 1988, indicating a willingness to disengage and support negotiated settlements, constitute a victory for the West and supports Scholtz's argument for sustainable peace in the subcontinent.

In the revolutionary war, military dimensions can only achieve limited success. By 1989, the government was losing the war on all fronts, except for its military power in comparison with the Frontline States and the revolutionary movements. The end of the Cold War created the circumstances for a new political strategy that would not have been possible had the government also lost the military dimension of the conflict. But, the strategic focus was wrong. The main focus should have been the counterinsurgency campaign in South Africa, implying an imaginative plan to satisfy the aspirations of the majority of the country's population. It is where the South African government lost the war.

An earlier withdrawal from Namibia would not have been without risks. However, it is difficult to see how that would have enabled MK and Apla to repeat the Rhodesian scenario by using military bases in Namibia and Botswana to escalate the conflict in South Africa to the level where the insurgents were also winning the military dimension of the war. Conventional operations with mobile forces along shorter lines of communication would be logistically less taxing. If the Soviets and Cubans got involved, they would have faced a bigger logistic burden: the distances from Angola to Luderitz and Walvis Bay, and from there to the Orange River and over the breadth of Botswana, from west to east to build up forces against South Africa. Operating on such long lines of communication could also have led to these Marxist forces overextending themselves, making it unnecessary to counter this threat on the Cunene River rather than on the western border of South Africa.

The war in southern Angola had the risk that the SADF with its limited ability to sustain large armour formations could have been decisively defeated in conventional 
battles if the Soviets and Cubans quickly increased the scales of such forces in the region. It was quite possible taking into account the earlier arguments of South African defence planners about the ability of the Soviet Union to establish an air bridge via Ethiopia to Southern Africa. South Africa also ran the risk of the Soviets and Cubans using the infrastructure in Mozambique to tip the balance of power even further against South Africa and create a protective cordon around MK and Apla bases. It would have provided a firm platform for the drastic escalation of the insurgency in South Africa.

The geographic factors, in the event of a withdrawal from Namibia, were also far less favourable for infiltrating insurgents. MK did not need to win the war primarily with military means, like in Rhodesia, and the South African presence in Namibia did not prevent the infiltration of small groups via Zimbabwe or Botswana to support the internal uprisings in the South African cities after 1984.

The impact of the war in Namibia was perhaps not as dramatic as that of Tsarist Russia's foreign military adventures, but the result was the same - the loss of political power and the risks involved if the Soviets and Cubans wanted to escalate the conflict. Keegan and Wheatcroft summarised it well in 1986:

South Africa's problem is war on too many fronts. There is a draining conflict for the protection of Namibia, battles to preserve an economy over-reliant on the gold price, a constant need to police an increasingly unworkable racial policy, and a never-ending struggle to preserve contacts - personal and commercial with an increasingly hostile outside world. Fighting on all fronts, she is winning on none: problems which are containable in isolation become insuperable in combination. The root cause is the ceaselessly rising tide of internal violence, which calls into question the capacity and wisdom of political leadership. ${ }^{96}$

All the efforts of the South African government from 1966 to 1989 in Namibia and Angola could not provide the ideal situation for the political climate in Namibia to favour the anti-Swapo parties in a UN-supervised election. South Africa never overcame the unwillingness of Swapo to keep to agreements, and the population demography of Namibia virtually guaranteed them a political victory. Withdrawing from the conflict in 1989 did not run fewer risks than, say, in 1978, 1980 or 1984, but the effect on all the dimensions of the revolutionary struggle by 1989 had a detrimental outcome on the position of the South African government in the region and especially in the country itself. Scholtz ${ }^{97}$ refers to SADF military intelligence reports of 1981 that states that the Soviet Union instructed Swapo to draw South Africa into a war of attrition in Namibia, in support of an internal uprising in South Africa. This strategic 'fixing' succeeded. 


\section{Endnotes}

1 Leopold Scholtz, Die SAW in die Grens-Oorlog, 1966-1989 (Cape Town:Tafelberg Publishers, 2013), 464.

2 Marian Kamil Dziewanowski, A History of Soviet Russia (Englewood Cliffs, New Jersey: Prentice-Hall, 1979), 89-90.

3 Pieter Geyl and Arnold Toynbee, Can we know the Pattern of the Past? (Bussum: FG Kroonder, 1948), 21, as discussed in Hermann Giliomee, Die Laaste Afrikaner-Leiers, ' $n$ Opperste toets van mag (Cape Town:Tafelberg Publishers, 2012), 254.

$4 \quad$ Ian van der Waag, A Military History of Modern South Africa (Cape Town: Jonathan Ball Publishers, 2015), 95, 175.

5 Insurgency refers to a localised armed conflict between forces of a constituted government and other forces originating within the same national territory. The form may or may not be that of guerrilla warfare. If the conflict is internal but not localised, then it is a revolutionary war, Edward Luttwak, $A$ dictionary of modern war (London: Penguin Books, 1972), 116.

6 Francis Toase, 'The South African Army: the campaign in South West Africa/ Namibia since 1966' in Ian Beckett and John Pimlott, Armed Forces and modern counterinsurgency (London: Croom Helm, 1985), 194-198.

7 Scholtz (2013), 11-13.

8 John Baylis, 'Revolutionary warfare' in André Beaufre, An introduction to strategy (London: Croom Helm, 1965), 132-152.

9 Jackie Grobler, A decisive clash? A short history of black protest politics in South Africa, 1875-1976 (Pretoria: Acacia, 1988), 149-151.

10 Abel Esterhuyse and Evert Jordaan, 'The South African Defence Force and Counterinsurgency, 1966-1990', in Deane-Peter Baker and Evert Jordaan, eds., South Africa and Contemporary Counterinsurgency (Cape Town: University Cape Town Press, 2010), 107-108.

11 Scholtz (2013), 58-59.

12 Roland de Vries, Eye of the Firestorm (Paarl: Naledi, 2013), 151-165.

13 John Keegan and Andrew Wheatcroft, Zones of Conflict: An Atlas of Future Wars (London: Jonathan Cape, 1986), 71. They have the core of the argument right, but claims that the supply route from Windhoek to the Caprivi Strip ran through Botswana, which does not make sense. It ran from Windhoek to Grootfontein from where all supplies were distributed to the different bases.

14 Gen C.A. Liebenberg, Chief of the SADF, Speech to senior officers, Voortrekkerhoogte, 17 September 1991.

15 Keegan and Wheatcroft (1986), 71.

16 Esterhuyse and Jordaan (2010), 108.

17 Barnie Barnard, Philippus Smit and J.A. van Zyl, Suid-Afrika. Die land en sy streke (Cape Town: Nasou, 1972), 333.

18 DeVries (2013), 162; [http://ports.com.browse/africa/namibia] and [http://ports.com/ browse/africa/angola], accessed 1 August 2016.

19 Keegan and Wheatcroft (1986), map next to page 70.

20 August Sycholt, Eco Guide to South African destinations (Pretoria: Briza, 2009), 22.

21 H.J. van Aswegen and Grietjie Verhoef, Die geskiedenis van Mosambiek (Durban:

Butterworth, 1982), 152. 
23 Department of Defence Archives (hereafter DOD Archives): DST Collection, file ST/311/1/18/2, Altar Part 1, CSI to CSADF, Report 'SADF support to the RNM', 27 May 1980.

Gen Constand Viljoen, Chief of the SADF, Presentation 'ISSUP Strategic Review: The Conventional Threat to the RSA and SWA', Pretoria, June 1983.

Maj Gen J.F. Huyser, former Director Military Strategy, Chief of Staff Operations Division, SADF, interviewed by James Jacobs, Pretoria, 30 August 1990; DOD Archives: OAMI Group 3, box 405, file MI/205/10, Military Intelligence Report 'The Military Threat against the RSA', 30 May 1979.

26 Howard Barrell, MK: The ANC's armed struggle (London: Penguin Books, 1994), 36-37. DOD Archives: OAMI Group 6, box 59, file MI/203/2/7, CSI to Mil Attaché Lisbon, 3 June 1978.

28 Tom Lodge, 'Soldiers of the storm: A profile of the Azanian People's Liberation Army' in Jakkie Cilliers and Markus Reichart, eds., About turn (Halfway House: Institute for Defence Policy, 1995), 106; DOD Archives: OAMI Group 3, box 405, file MI/205/10, Military Intelligence Report 'The Military Threat against the RSA', 30 May 1979. James Barber and John Barrett, South Africa's foreign policy, the search for status and security, 1945-1988 (London: Oxford University Press, 1990), 177-178.

30 Grietjie Verhoef, 'Suid-Afrika se ekonomie in die 20ste eeu' in Fransjohan Pretorius, ed., Geskiedenis van Suid-Afrika: van voortye tot vandag (Cape Town:Tafelberg Publishers, 2012), 477. R.J. Greyling, Terrorisme: die feite (Pretoria: J.L. van Schaik, 1985), 60.

32 John Kane-Berman, Soweto, black revolt, white reaction (Johannesburg: Ravan Press, 1978), 106-107.

RSA (Republic of South Africa), 1977, White Paper on Defence and Armament Production, Department of Defence (Pretoria: Government Printing Works), 4-8.

Philip Frankel, Pretoria's Praetorians (Cambridge: Cambridge University Press, 1984), 35-37.

35 DOD Archives: OAMI Group 13, box 23, file AMI/303/3 DID, TNSD 3/78 Nasionale Belange, Opdragte, Take en Beleide, 25 July 1978.

Paul Moorcraft, African Nemesis: war and revolution in Southern Africa, 1945-2010 (London: Brassey's, 1990), 166-167.

Ian Beckett, 'The Rhodesian Army: Counter-Insurgency, 1972-1979', in Ian Beckett and John Pimlott, eds., Armed Forces and Modern Counter-Insurgency (London: Croom Helm, 1985), 166-168, 178-179; DOD Archives: OAMI Group 3, box 405, file MI/205/10, Military Intelligence Report 'The Military Threat against the RSA', 30 May 1979.

38 David Martin and Phyllis Johnson, 'Mozambique:To Nkomati and Beyond', in David Martin and Phyllis Johnson, eds., Destructive Engagement. Southern Africa at War (Harare: Zimbabwe Publishing House, 1986), 3-10.

Paul Moorcraft and Peter McLaughlin, Chimurenga:The War in Rhodesia, 1965-1980 (Johannesburg: Sygma, 1982), 234.

40 DOD Archives: OAMI Group 3, box 405, file MI/205/10, Military Intelligence Report 'The Military Threat against the RSA', 30 May 1979.

41 DOD Archives: OAMI Group 3, box 405, file MI/205/10, Military Intelligence Report 'The Military Threat against the RSA', 30 May 1979.

Barber and Barrett (1990), 274-276. 
43 White Paper on Defence (RSA, 1984), 3.

44 Barrell (1994), 48-49.

45 Joseph Hanlon, Beggar your Neighbours, Apartheid Power in Southern Africa (London: CIIR, 1986), 138.

Huyser (1990); DOD Archives: DST Collection, file ST/310/4/Piki/5/4. DST to CSI, Memorandum ‘Operation PIKI: Monthly Report, January 1984', 22 February 1984.

Barrell (1994), 36-38.

48 Ibid., 38-39.

49 Ibid., 51

50 Stephen and Tsepo Sechaba, Comrades against Apartheid, The ANC and South African Communist Party in Exile (London: James Currey Ltd, 1992), 131.

Willem Steenkamp, South Africa's Border War, 1966-1989 (Gibraltar: Ashanti, 1989), 69-71.

52 Steenkamp (1989), 71.

53 Scholtz (2013), 68.

54 Steenkamp (1989), 74.

55 Scholtz (2013), 100.

56 Van der Waag (2015), 269.

57 Steenkamp (1989), 85-87.

58 Ibid., 93-94; Scholtz (2013), 120-122.

59 Scholtz (2013), 159-161.

60 Steenkamp (1989), 103-107; Scholtz (2013), 166.

61 Steenkamp (1989), 115-117.

62 Helmoed-Römer Heitman and W.A. Dörning, ‘The Joint Monitoring Commission', Scientia Militaria, 18(1) 1988, 3-5.

63 DOD Archives: DST Collection, file ST/310/4/Piki/5/4, DST to CSI, Memorandum 'Op Piki Monthly Report: March 1984', 27 March 1984.

64 'Halfway Mark; Africa: Namibia, Aid and Ideology', The New York Times, 25 January 1983.

65 Huyser (1990).

66 Chester Crocker, High Noon in Southern Africa, Making Peace in a Rough Neighbourhood (Johannesburg: Jonathan Ball Publishers, 1992), 243.

67 Norman Macqueen, 'Mozambique's widening foreign policy', The World Today, 40(1) January 1984, 23-26.

68 Brand Fourie, Brandpunte: agter die skerms met Suid-Afrika se bekendste diplomat (Kaapstad: Tafelberg Publishers, 1991), 198.

69 Barrell (1994), 53-54.

70 Brig C.J. van Niekerk, interviewed by James Jacobs, Pretoria, 7 December 1990.

71 Leo Barnard, "n Historiese oorsig van die gewapende konflik op die noordgrens van SWA/Namibië, 1966-1989', Acta Academica, 23(1), 1991, 122.

72 Toase (1985), 216.

73 Leopold Scholtz, 'The Namibian Border War: An Appraisal of the South African Strategy', Scientia Militaria, 34(1), 2006, 39.

74 Barrell (1994), 99. This was not with the consent of the Botswana government. During the conflict, the authorities used to arrest and deport MK operatives from the country.

75 Hilton Hamann, Days of the Generals: The untold story of South Africa's apartheid-era military generals (Cape Town: Zebra Press, 2001), 133. 
76 Tsepe Motumi, 'The Spear of the Nation - The recent history of Umkhonto We Sizwe (MK)', in Jakkie Cilliers and Markus Reichardt eds., About Turn: The Transformation of the South African Military and Intelligence (Halfway House: Institute for Defence Policy, 1995), 99.

77 Keegan and Wheatcroft (1986), 71.

78 Gerald L'Ange, 'Countries in the Cross-Fire', Challenge: Southern Africa within the African Revolutionary context (Gibraltar: Ashanti, 1989), 346.

79 Moorcraft (1919), 177.

80 Ronnie Kasrils, Armed and Dangerous, My Undercover struggle against Apartheid (Oxford: Heineman, 1993), 244. In an interview with Gen Jannie Geldenhuys in 2008, he stated that the SADF again started supporting Renamo in 1986 when it became clear that the Mozambique government did nothing to stop MK from using their territory to infiltrate South Africa, Giliomee (2012), 272.

81 Giliomee (2012), 277.

82 Greg Mills and David Williams, 7 Battles that shaped South Africa (Cape Town: Tafelberg Publishers, 2006), 186-187.

83 Castro Kwhela, 'Umkhonto We Sizwe's Contribution to the Defence of the African Revolution in Angola', Journal for Contemporary History, 28(2), 2003, available at: [http:// journals.ufs.ac.za/index.php/jch/article/download/372/355], 117; Leopold Scholtz, 'Cuitio Cuanavale:Wie het werklik gewen?', Scientia Militaria, 28(1), 1998, available at: [http://scholar.ufs.ac.za:8080/xmlui/bitstream/handle/11660/9108/contemp_v34_n1_ a17.pdf?sequence=1\&isAllowed=y], 51 . Philip Nel, A Soviet Embassy in Pretoria? (Cape Town:Tafelberg Publishers, 1990), 32.

85 Keegan and Wheatcroft (1986), 71.

86 Barrell (1994), 70-72; Motumi (1995), 87.

87 Michael Hough, 'Revolt in the Townships', Southern Africa within the African revolutionary context (Gibraltar: Ashanti, 1989), 406-408.

88 Keegan and Wheatcroft (1986), 71.

89 Steenkamp (1989), 109.

90 Defence Diary, 1985, 19; Leo Barnard, 'n Historiese oorsig van die gewapende konflik aan die noordgrens van SWA/Namibië, 1966-1989', Acta Academica, 23(1), 1991, 103; Steenkamp (1989), 158.

91 Jannie Geldenhuys, Die wat gewen het:feite en fabels van die bosoorlog (Pretoria: Litera, 2007), 247.

92 Basing his calculations on Sean Archer, 'Defence Expenditure and Arms Procurement', in Jacklyn Cock and Laurie Nathan eds., War and Society: The Militarization of South Africa (Cape Town: David Phillip, 1989), 244-259. See also Giliomee (2012), 277.

93 Giliomee (2012), 330-331.

94 Castro Kwhela, 'Umkhonto We Sizwe's Contribution to the Defence of the African Revolution in Angola', Journal for Contemporary History, 28(2), 2003, available at: [https://uncensoredopinion.co.za/wp-content/uploads/2019/03/Umkhonto-WeSizwe-and-Angola.pdf], 122. Crocker (1992), 36.

96 Keegan and Wheatcroft (1986), 70.

97 Scholtz, 54. 


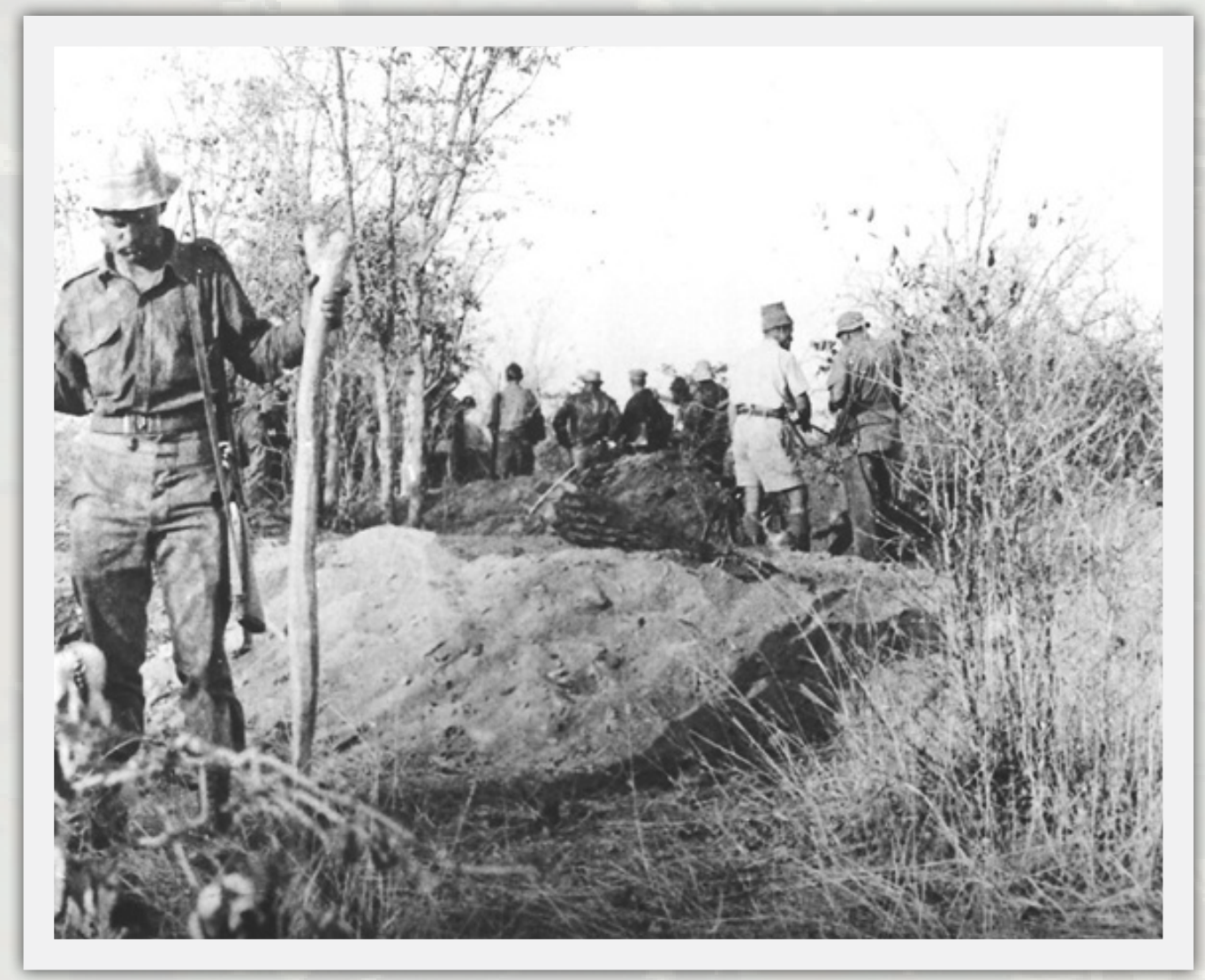

Mopping up the base at Ongulumbashe after the helicopter assault

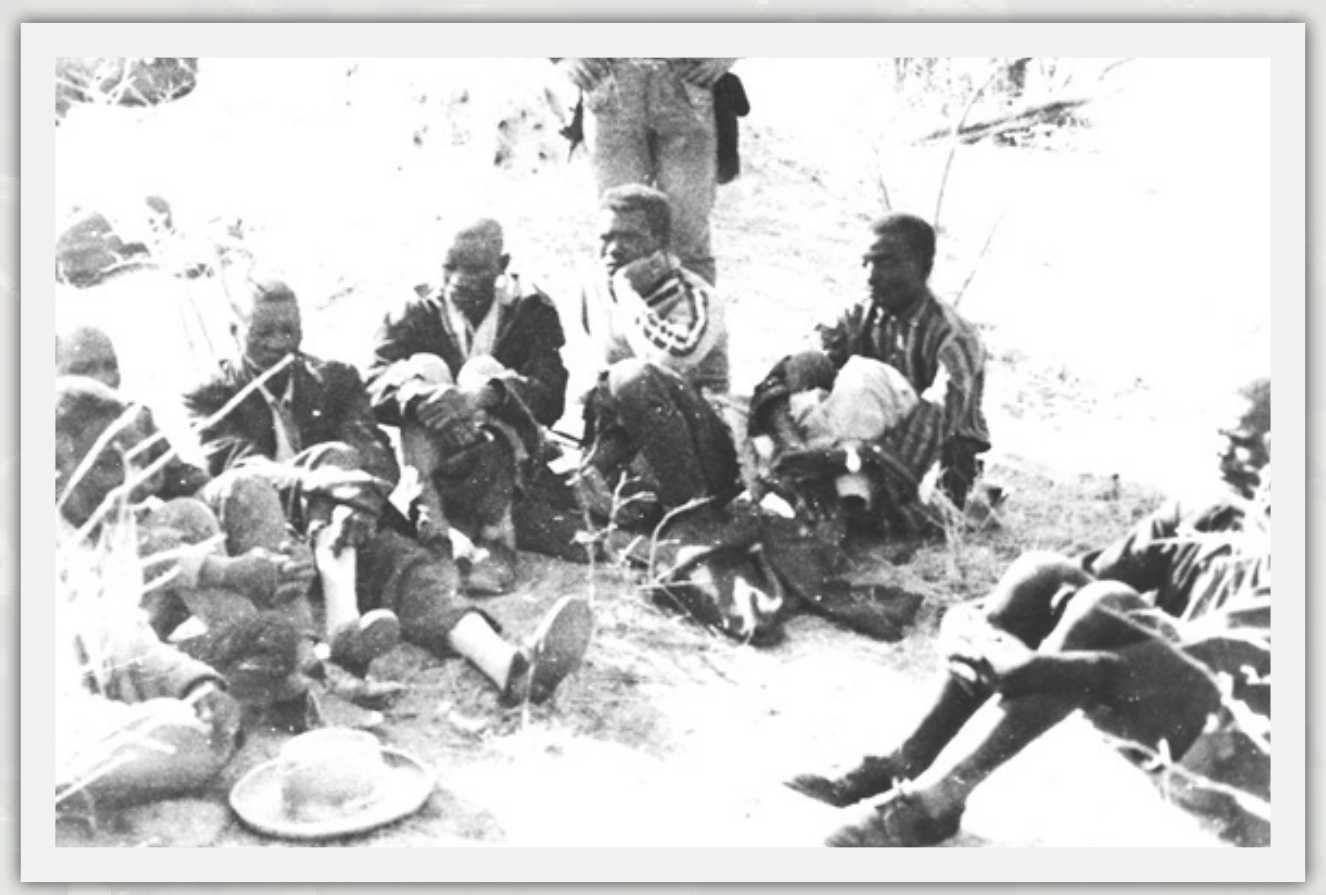

SWAPO prisoners under guard after the action at Ongulumbashe 


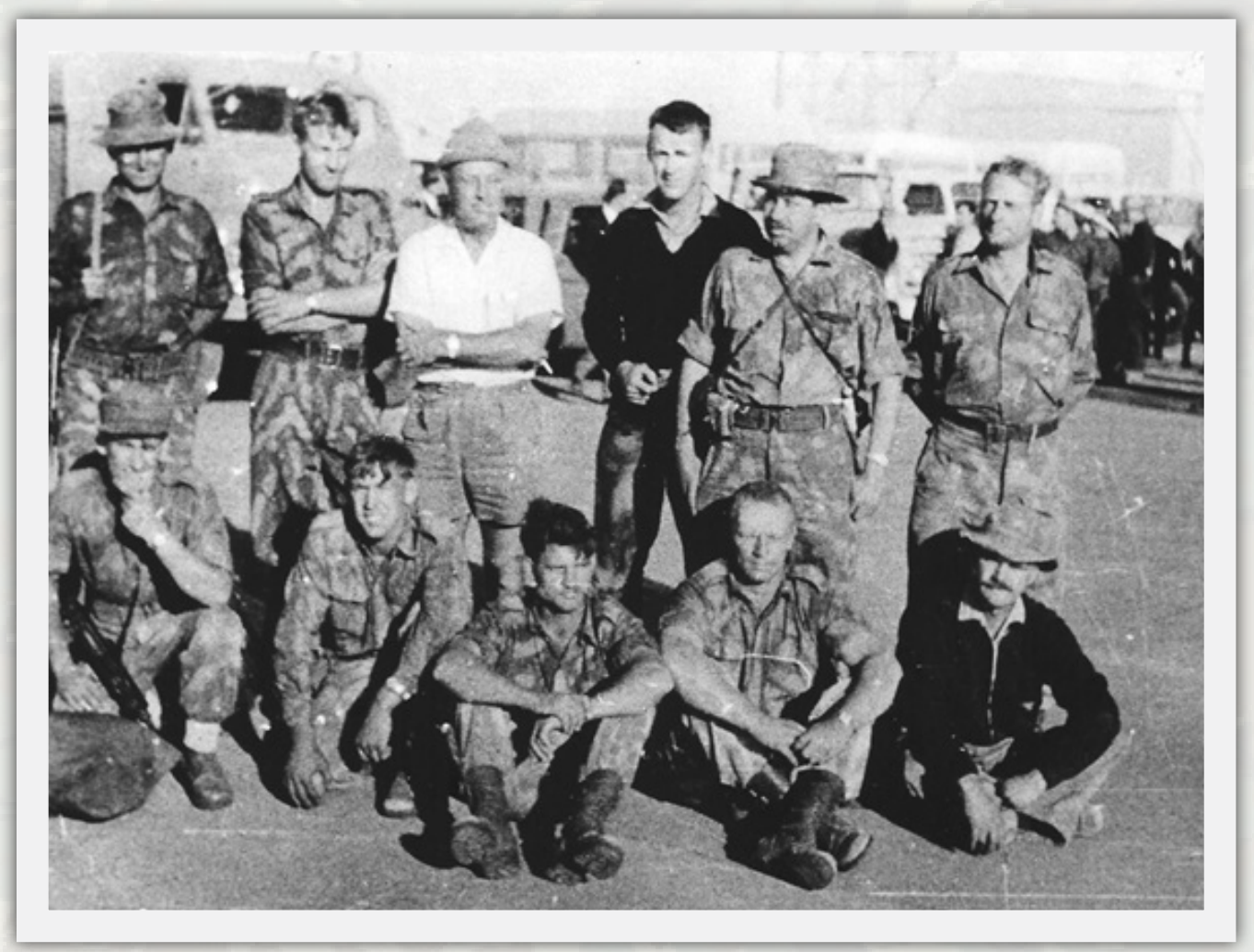

The raiders of Ongulumbashe

Standing (L to R): Capt Jan Breytenbach, Sgt Wouter Hugo, Cmdt Tommy Renfree, Sgt Ray Burgess, Cmdt Willem Klomp, Sgt Yogi Potgieter

Front (L to R): Capt Kaas van der Waals, Cpl "Snakes" Snyman, Sgt Tilly Smit, Sgt "Ouboet" Kruger, Sgt Lionel Slade

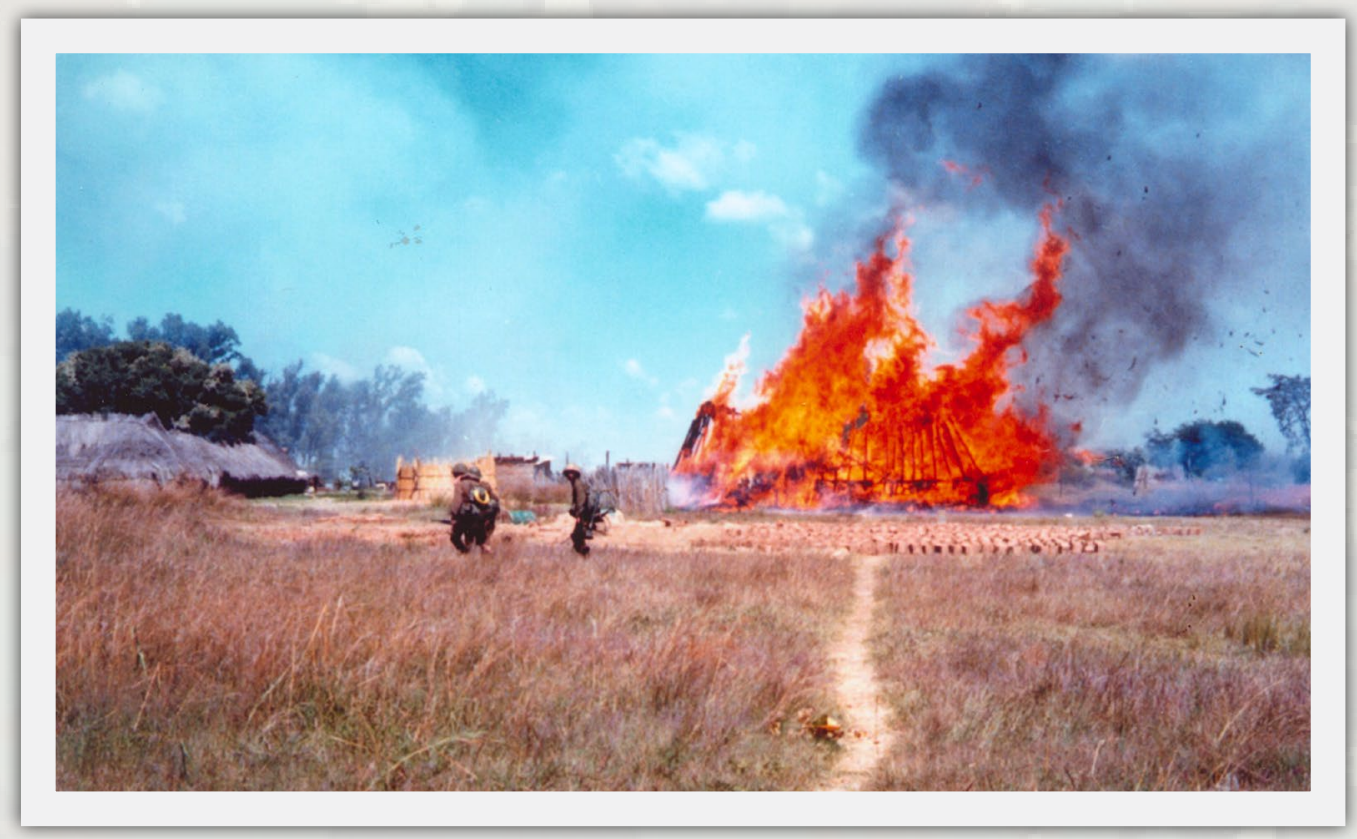

Cassinga, burning after the South African attack 


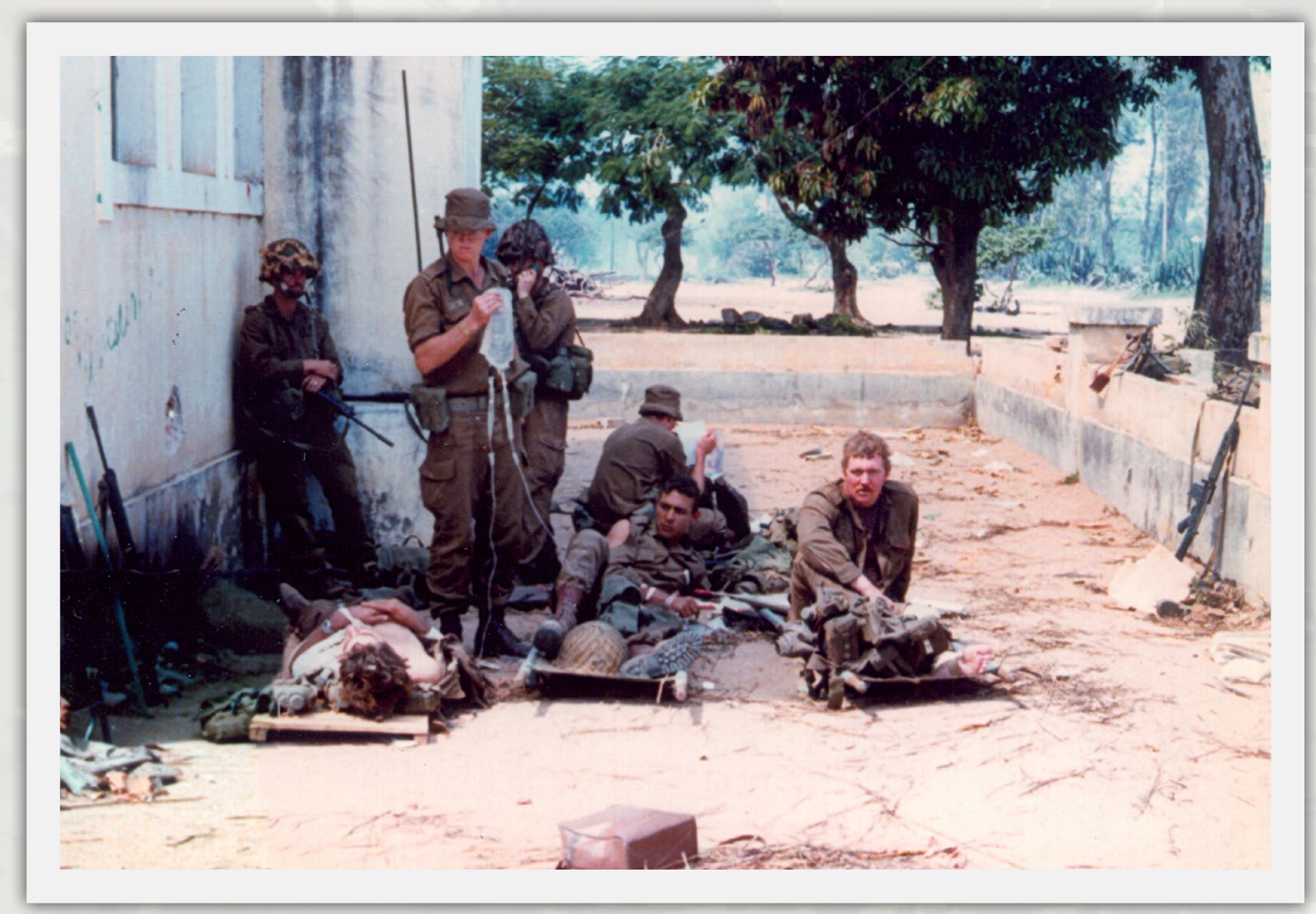

SADF casualties sustained during the attack on Cassinga

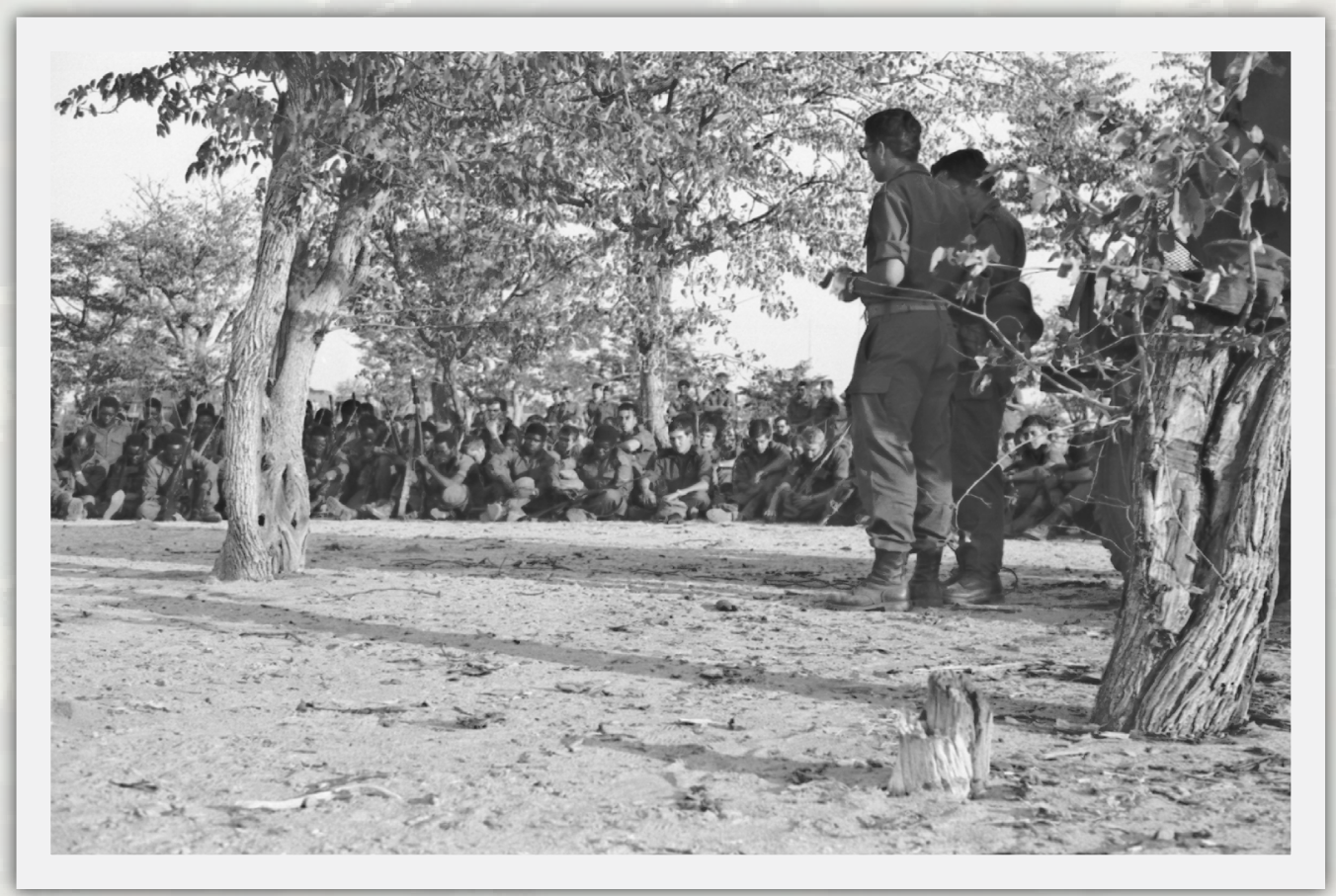

The battle for the mind, body, and soul - an SADF church parade being held prior to a cross-border operation 


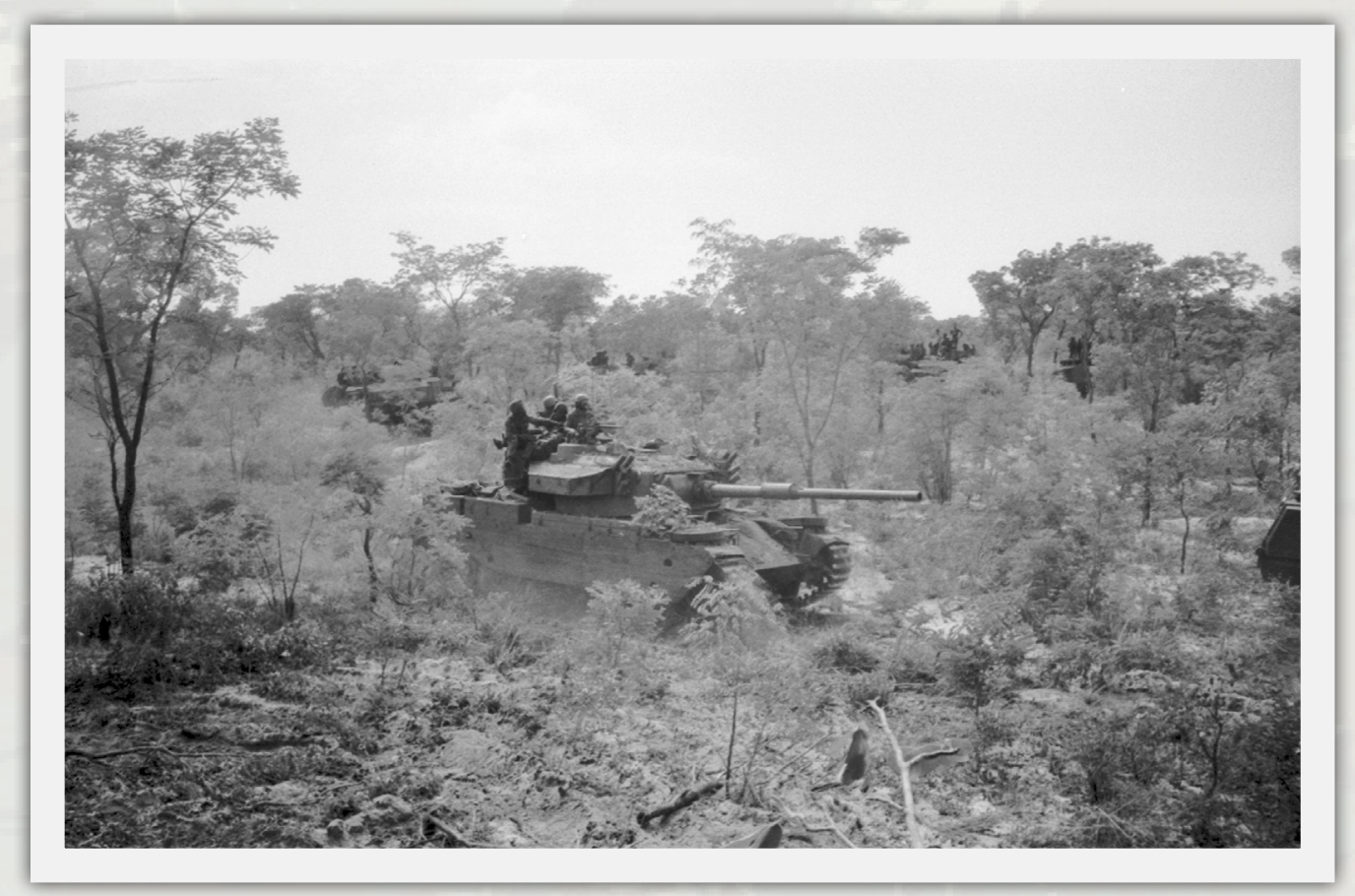

The Angolan bush, largely considered as 'untankable'

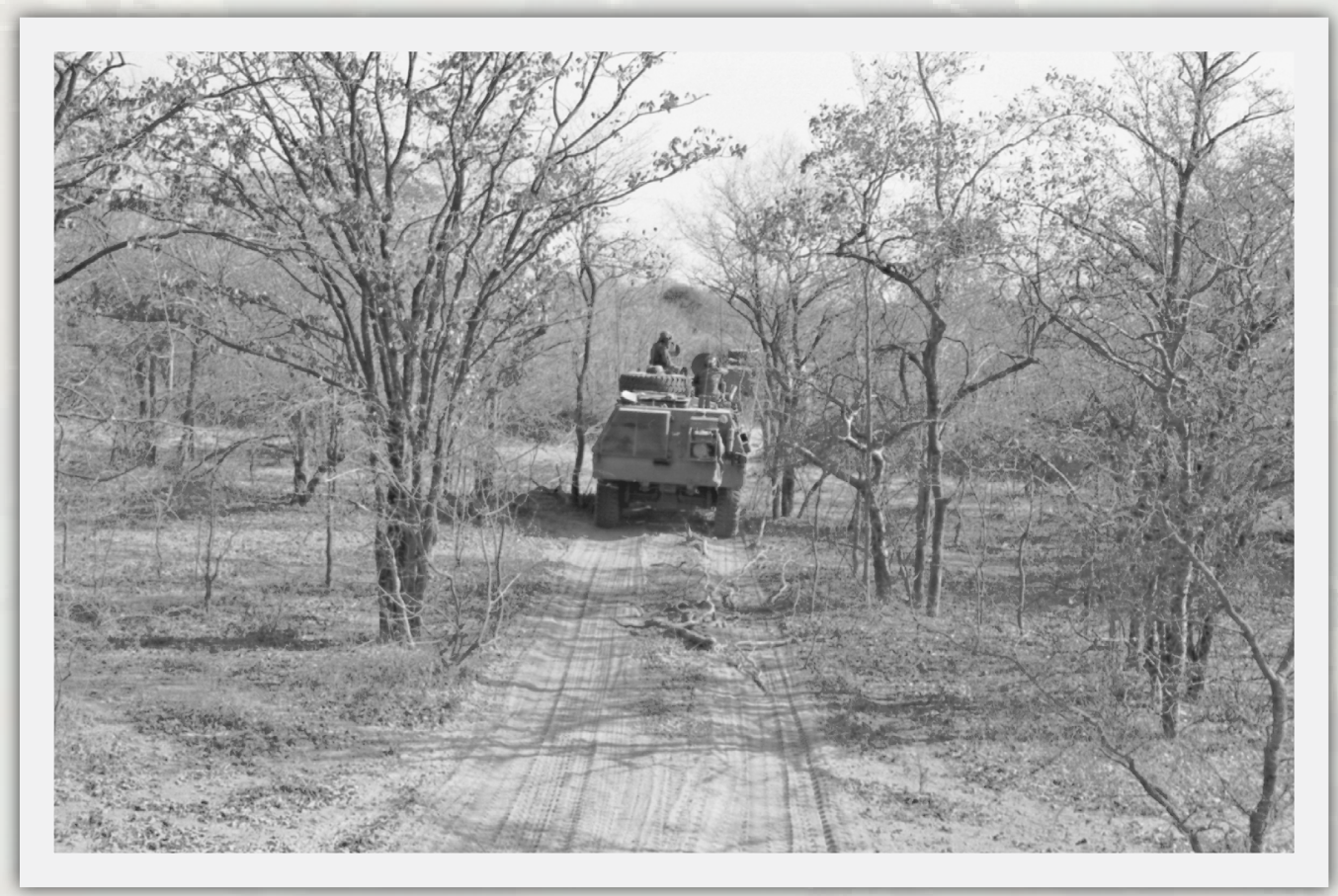

An SADF Ratel IFV navigating the dense Angolan bush during a cross-border operation 


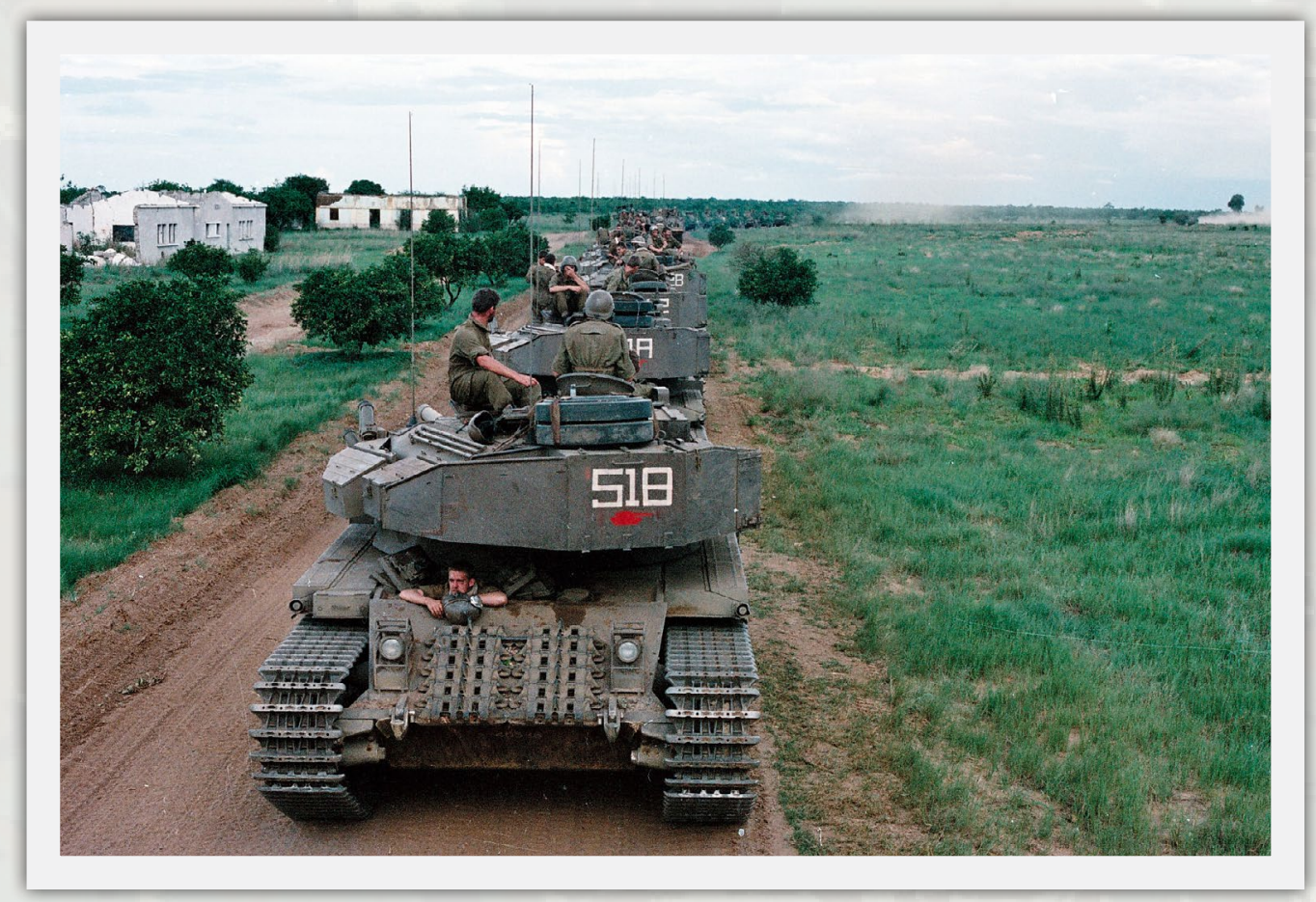

South African tanks moving out of Mavinga in a line-ahead formation
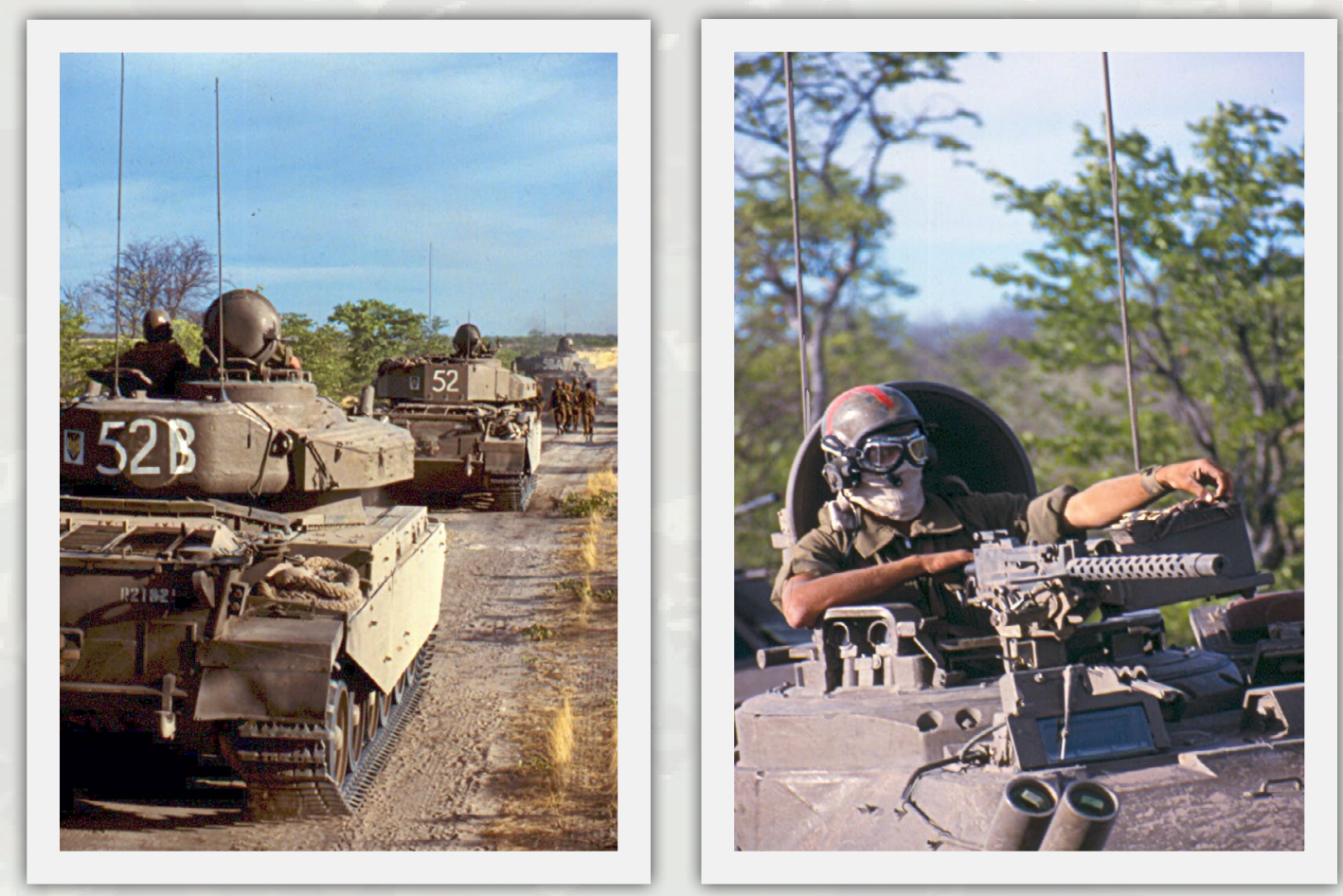

South African armour was deployed on a number of occasions during the conventional phase of the Bush War 


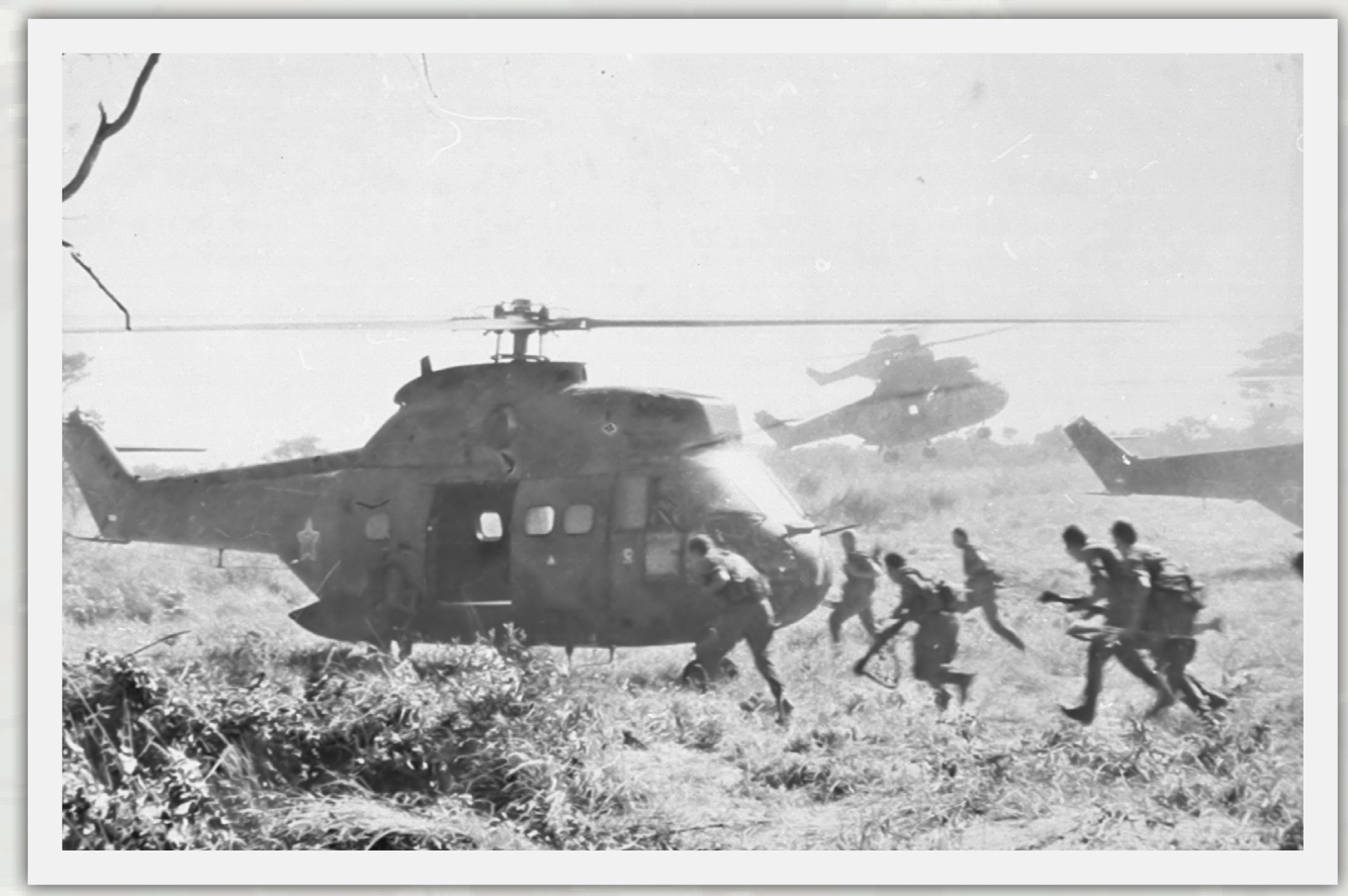

South African infantry being extracted from the battlefield by a Puma helicopter

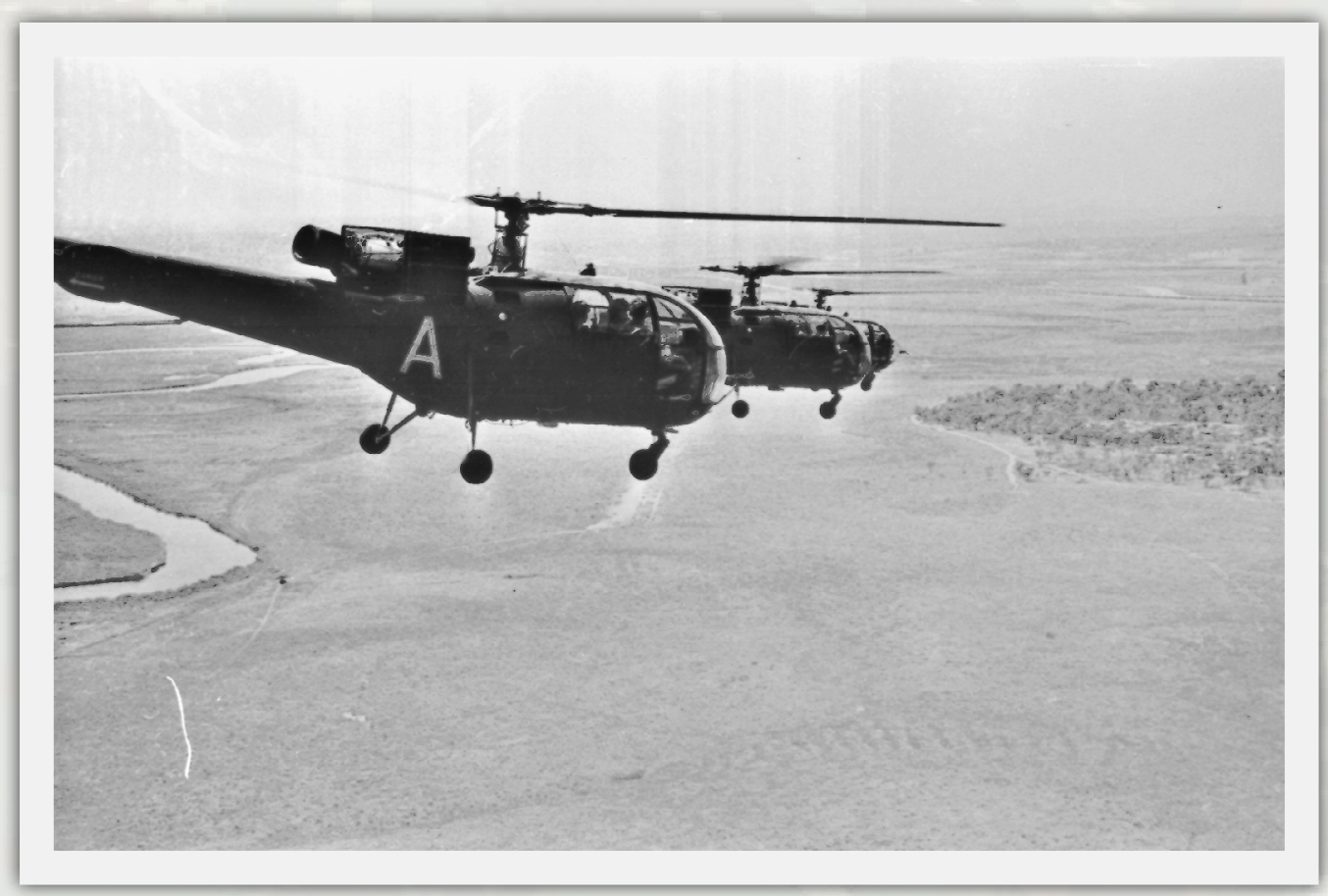

SAAF Alouette gunships - a notable force multiplier during a firefight 


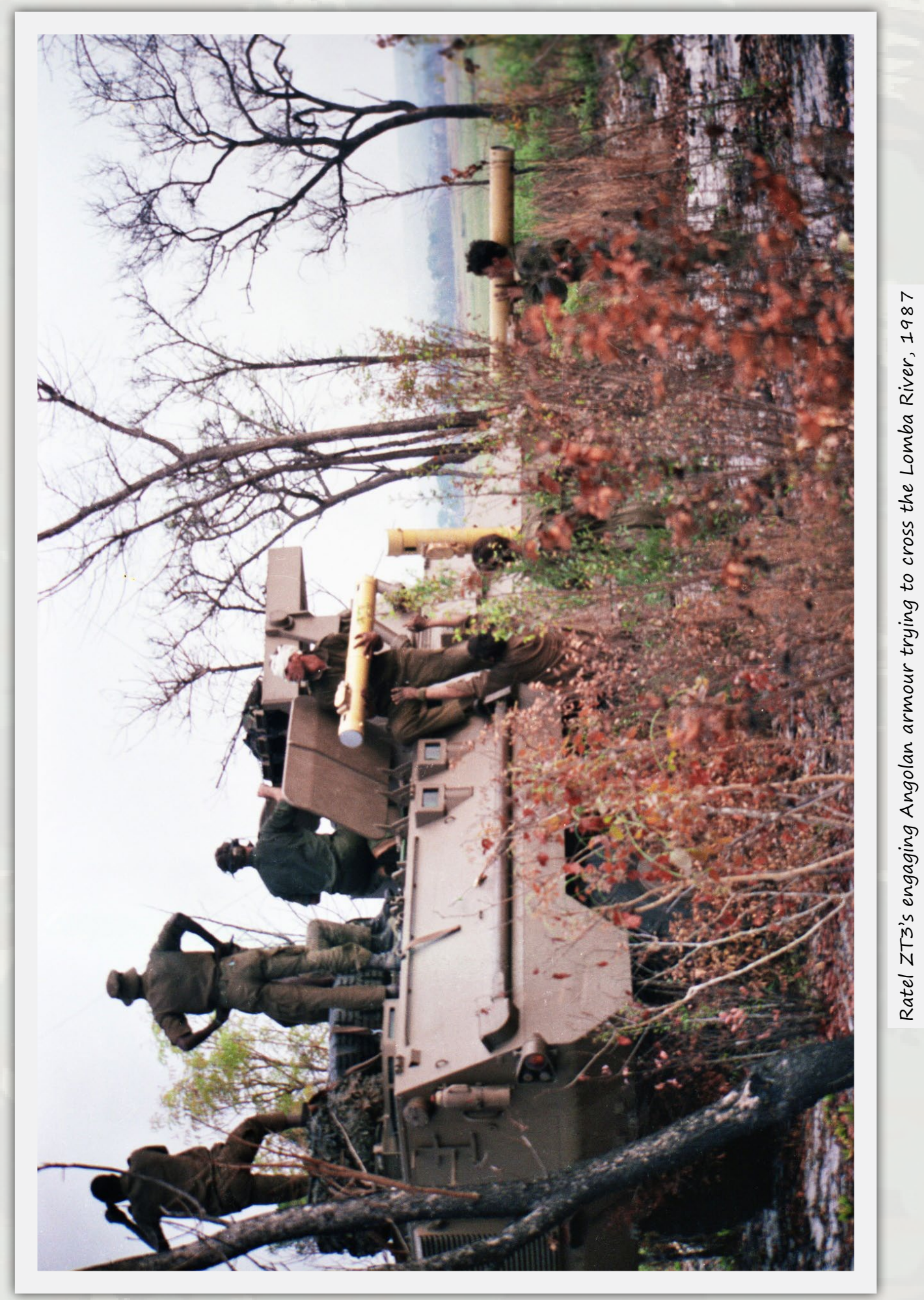




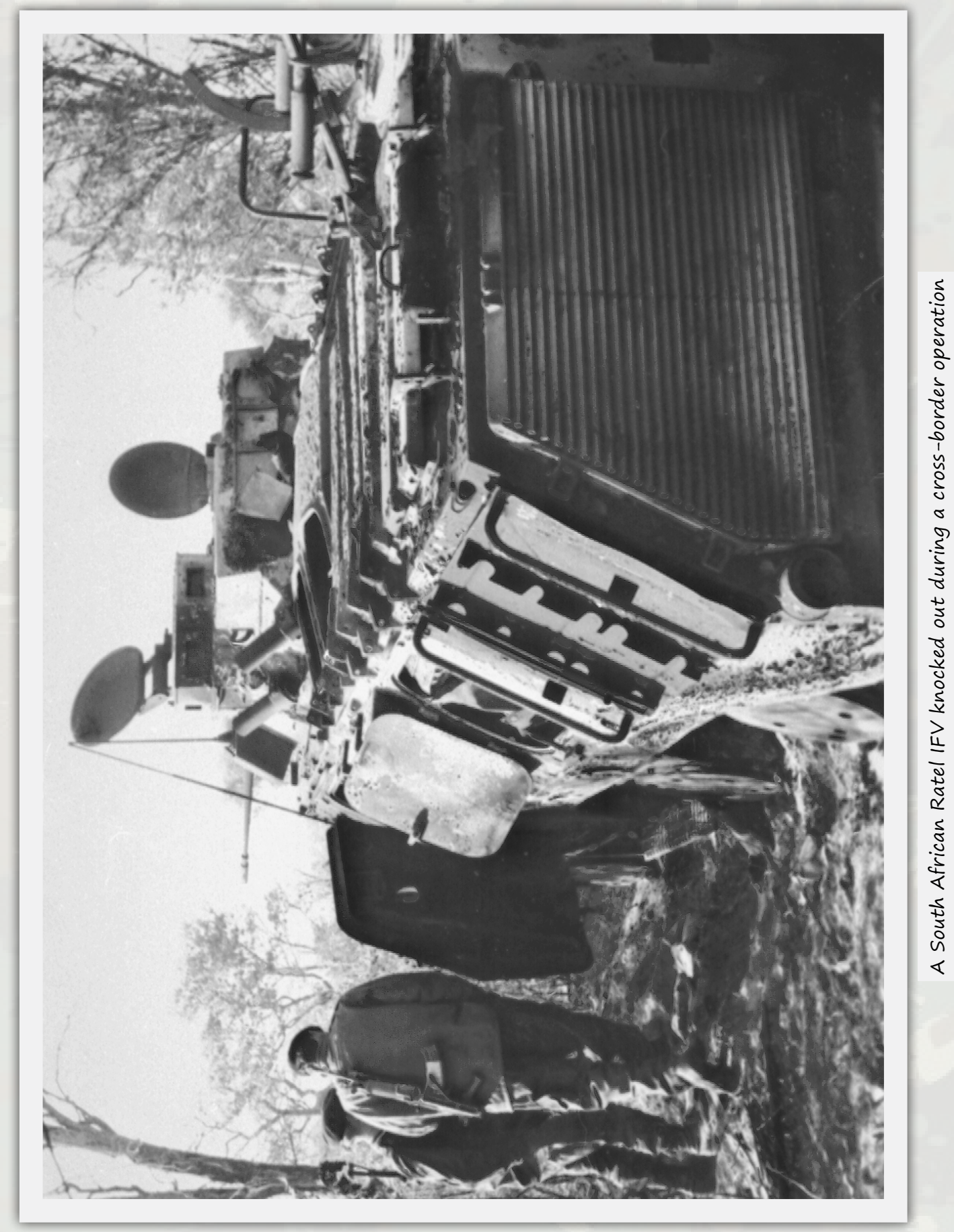


The faces of war...

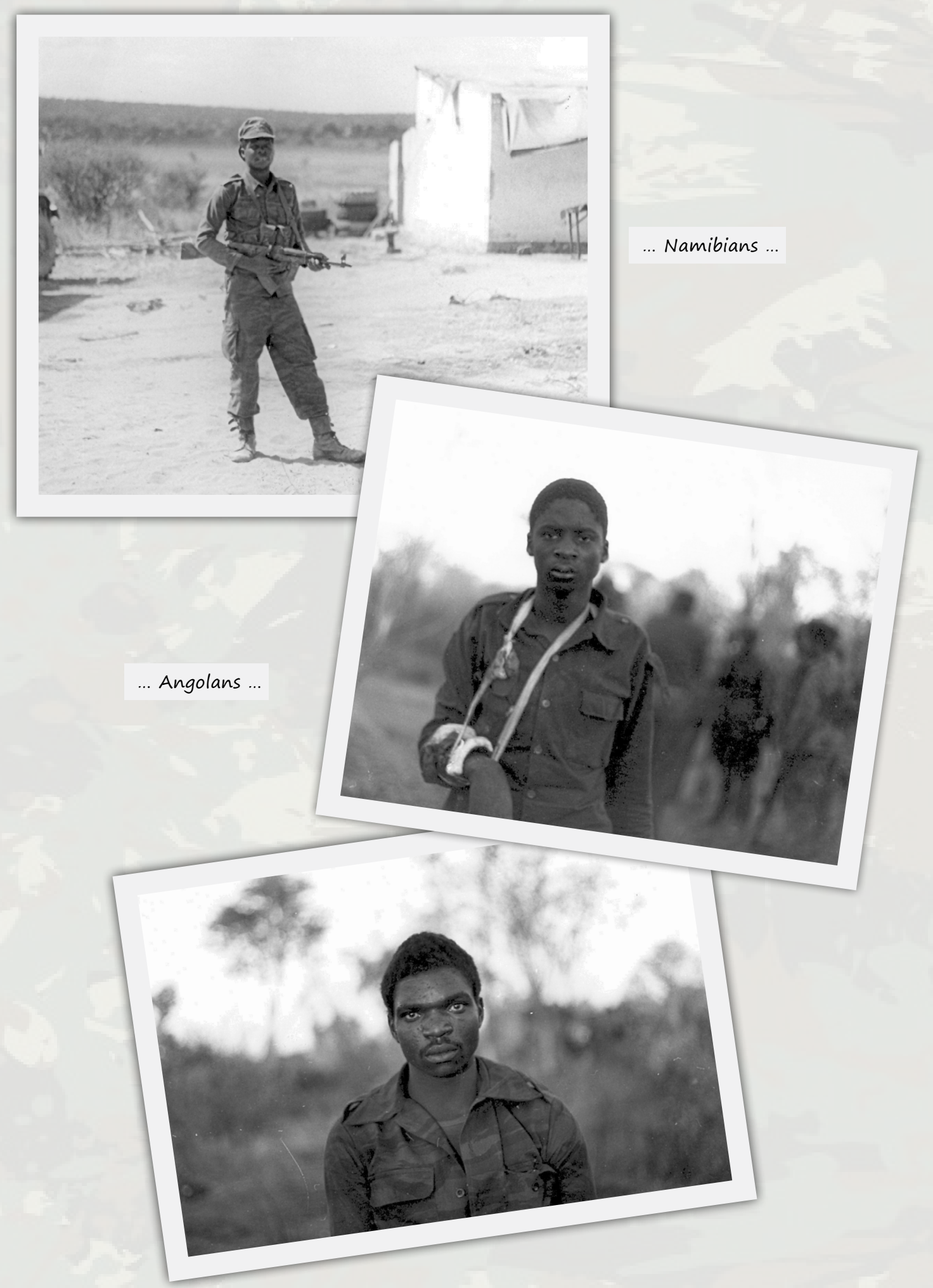




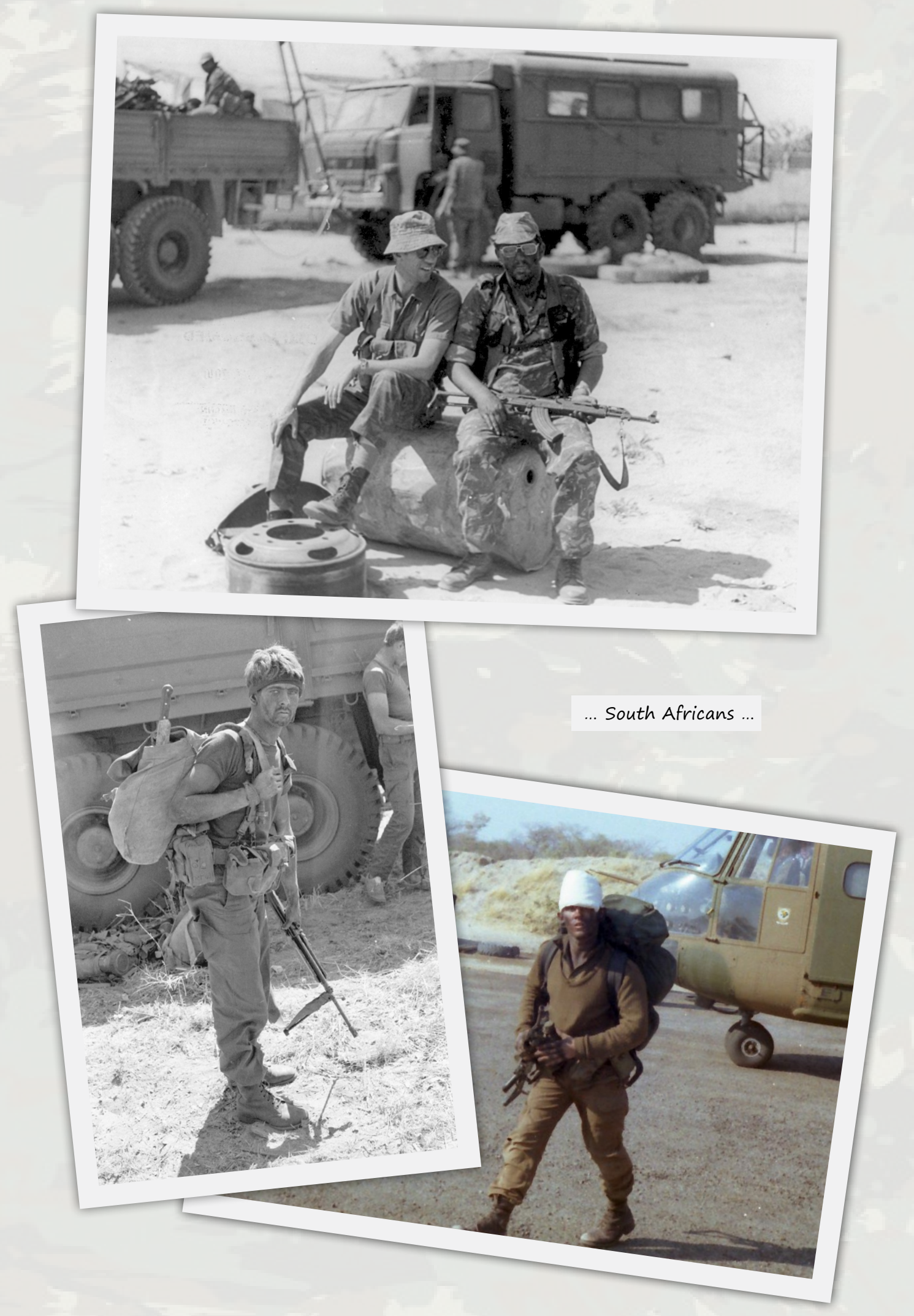




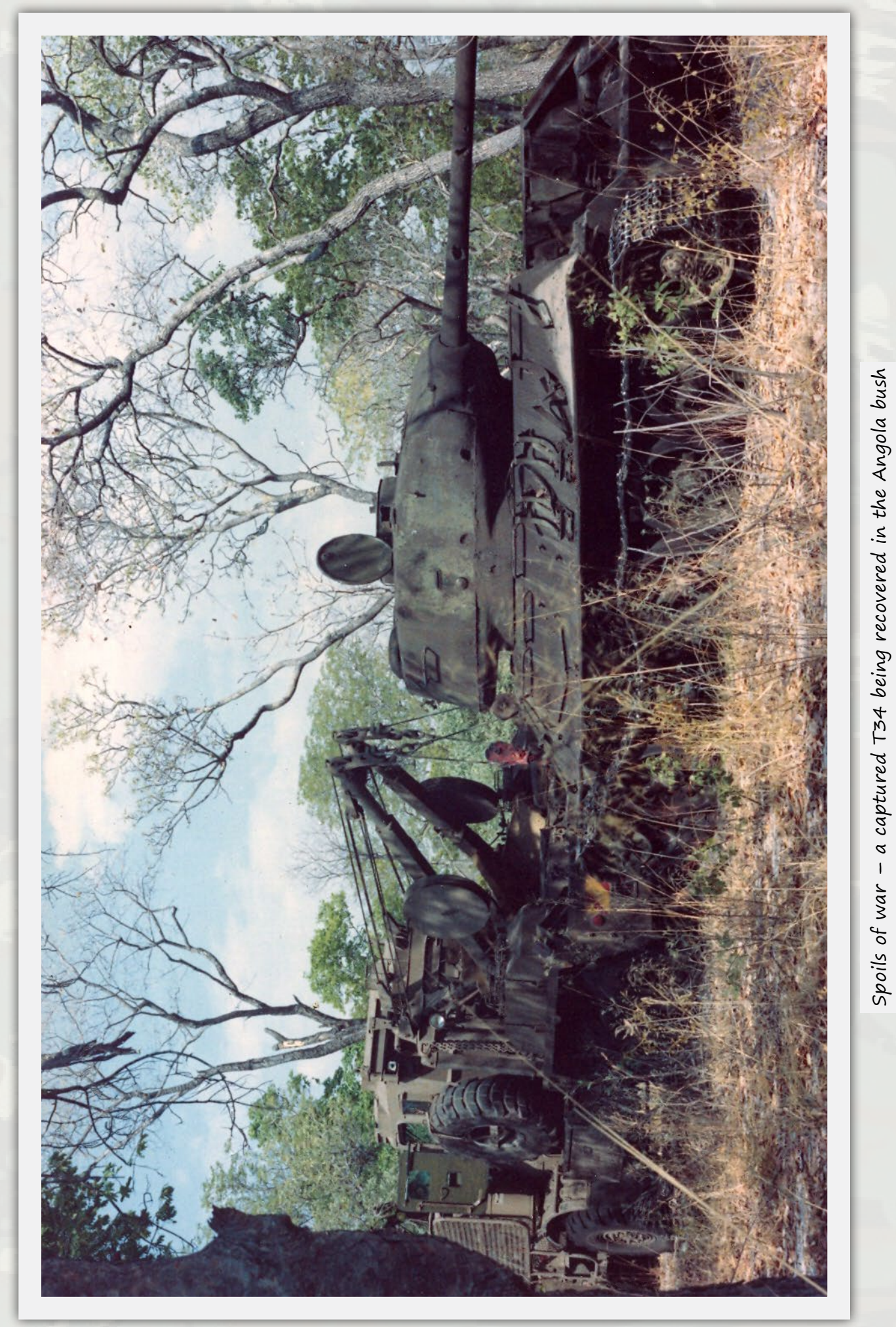




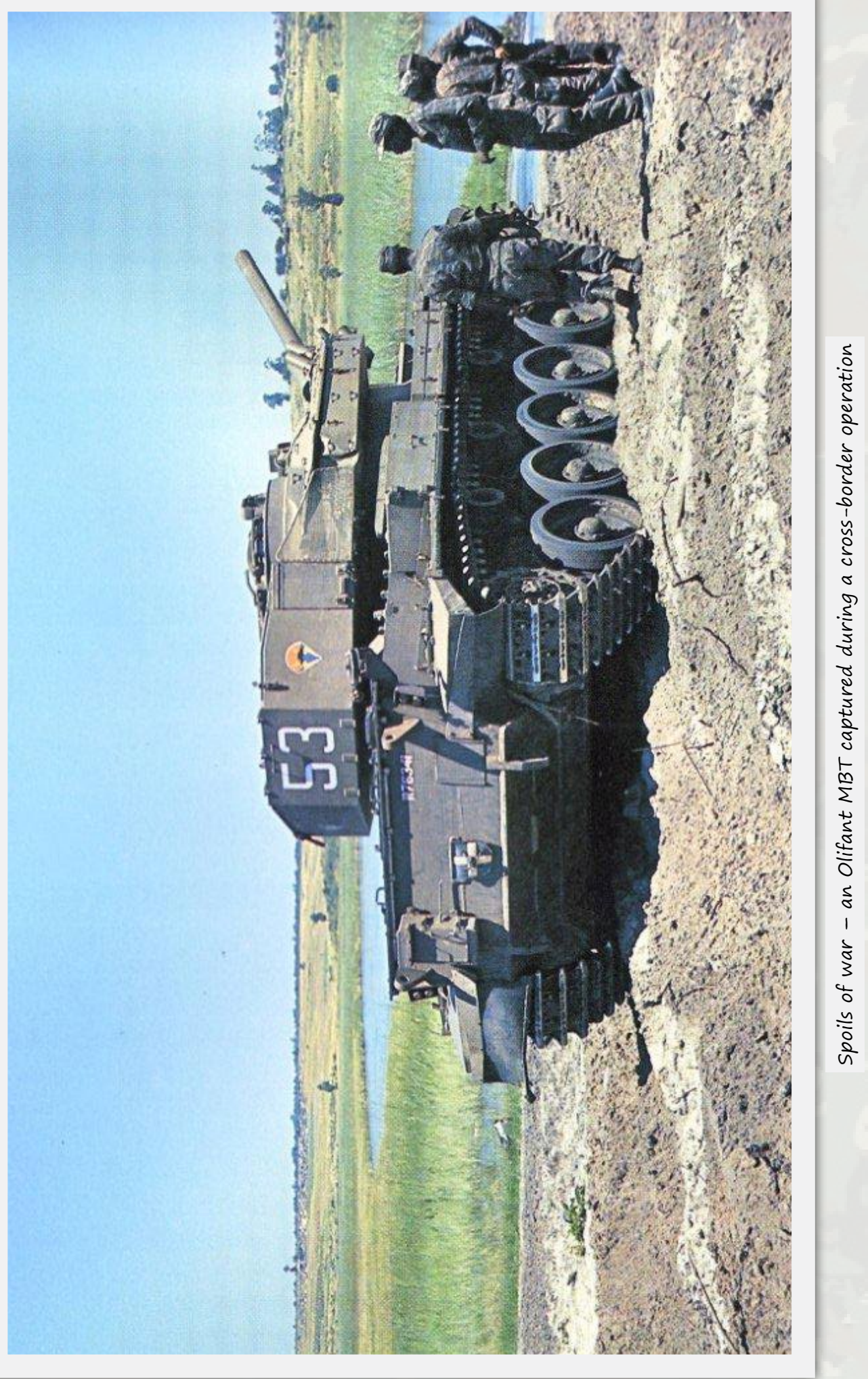



Part TWO

$$
\begin{aligned}
& \text { 跤 } \\
& \text {. } \\
& \sigma \\
& \theta \\
& \text {. }
\end{aligned}
$$

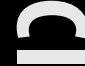

$$
\begin{aligned}
& \text {. } \\
& \text {. } \\
& <
\end{aligned}
$$




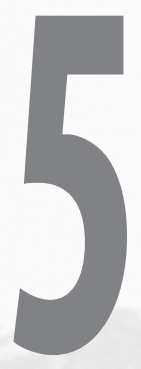

\section{THE SADF AND THE MILITARISATION OF WHITE SOUTH AFRICAN SOCIETY}

Rodney Warwick 
During the 1960s, the SADF operated as part of a beleaguered white community: traditional allies Britain and the USA enforced the United Nations' arms embargo; MK attacks and Poqo murders occurred; the Rivonia trial and its aftermath took place; the arrests and trials of African Resistance Movement (ARM) members, including station bomber John Harris and leading SACP fugitive Bram Fischer, occurred. The press devoted considerable attention to all of this. Mobilising the consent of white South Africans regarding conscription occurred alongside the SADF's task to counter perceived armed threats to the state - external and internal - which meant that the SADF worked within National Party (NP) post-republic strategy. This involved stressing loyalty and fear commonalities within the largely split white South African identity, while still retaining Afrikaner nationalist political control. It presented challenges pertaining to both the Afrikaner and white English-speaking (WESSA) groupings in their collaboration with the SADF projecting itself as a highly visual and important component of the white community.

Neither the SADF commanders nor defence minister Jim Fouché could have anticipated the effects of 1960s prosperity on Afrikaners, or how it might influence their and other whites' attitudes to compulsory military service. Urgent planning against assumed threats included widening conscription, but this also meant having to cope with drastically increased trainee numbers from 1962. In this, SADF preparation lacked in a wide range of infrastructural and instructional personnel issues, concerning suitability, numbers and programmes. This resulted in numerous complaints from parents and trainees, well reported in a local media that was, in general, markedly supportive of the SADF. Fouché also gave a new political direction to the Permanent Force (PF) core that included members buoyant with Afrikaner nationalist confidence, while others remained explicitly professional. Nationally, although more strident Afrikaner nationalism was slowly waning, it found some important common cause with the largely conservative WESSAs regarding defence, despite surprise and outrage in both communities regarding aspects of their sons' management by the SADF.

\section{FOUCHÉ APPOINTED DEFENCE MINISTER}

Numerous SADF changes affirmed the NP's republic goal during the 1950s, but defence remained a rather low government priority. Frans Erasmus's portfolio as defence minister was not particularly prized, and neither were defence issues central to NP apartheid legislation. However, as African nationalism accompanying decolonisation ignited alongside the intensifying, globalising Cold War, it brought the SADF more urgently under government scrutiny and public attention. A wide range of security 
threats were perceived: black insurrection, communist subversion, and guerrilla warfare possibilities. ${ }^{1}$ Even a conventional warfare 'African threat' was seriously mooted with intimations thereof accompanied by Third World, UN and Superpower military support. ${ }^{2}$ After the early 1960 post-Sharpeville State of Emergency and the SADF's Citizen Force (CF) call-up, Verwoerd was concerned about the military's capacity to assist in maintaining order. Significant mobilisation and operational problems had occurred, ${ }^{3}$ while the defence force's capacity needed appraising and stiffening to defend against conventional or guerrilla attacks. ${ }^{4}$

Appointed in January 1960, Fouché also worked explicitly within the government's belief of communism being at the root of all dangers facing South Africa, which the West, he explained, did not fully understand. ${ }^{5}$ Undoubtedly favoured by Verwoerd for his diplomacy, Fouché set about to repair $\mathrm{SADF} /$ government distrust and smoothing SADF English/Afrikaans conflicts. Erasmus's politically motivated meddling had impacted negatively on the SADF's image; across the white community, respect for it was at a low ebb. Fouché appealed that the SADF be spared from ridicule:

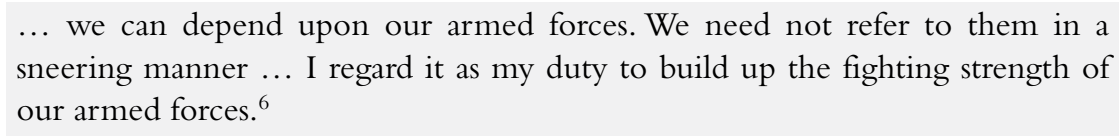

In overseeing a more trusted and effective SADF, Fouché was heavily dependent on the SADF General Staff, for within senior Afrikaner nationalist political ranks there was a complete dearth of military experience. He was assisted by some remaining competent senior officers with significant war experience. These included Commandant General (CG) Pieter Grobbelaar, a committed Afrikaner nationalist, and SA Navy Chief, Rear Admiral Hugo Biermann, a more apolitical professional, as was Major General Charles Fraser, Army Chief from 1965 and Joint Combat Forces Chief from 1967. 7 During a Military Academy passing-out parade in December 1960, Grobbelaar announced that South Africa could be isolated and urgently needed to build up its forces against any enemy. ${ }^{8}$ Extended conscription for all white school-leaving males had long been called for by the ambitious Major General Rudolf Hiemstra, the Inspector General position incumbent in 1960 - effectively the third top-ranking SADF officer. Hiemstra had outraged with withering contempt the outgoing CG Stephen Melville by writing that "there [in the SADF] was a lack of authoritative policy ... so that circumstances were now bordering on chaos". 9

Despite the political, historical, economic, cultural and social divisions between Afrikaners and WESSAs, the SADF had been identified as an important environment for facilitating a common 'white nationhood'. Fouché, therefore, followed the 1960s republican goal, adopting its mildly convincing part-reconciliatory approach or ruse, akin to the 1920s-30s Hertzog 'two-stream policy', but retaining explicit Afrikaner control. 
This contrasted with the Anglo-Afrikaner 'South Africanism' of the United Party (UP) Second World War government era - a supposedly sincere equal collaboration between the two language groups, but more Anglo than Afrikaner its opponents maintained.

Where Erasmus had been reckless, divisive and incompetent, Fouché had to repair and build bridges in the SADF and maintain Afrikaner hegemony. From 1960, the SADF publication, Commando, paid attention to reporting successful 'cooperation' between the two language groups at all three services gymnasiums, including publishing a percentage breakdown according to the recruits' language, education, province and religious denominations "to illustrate how the gymnasium trainees are representative of the different white population and language groups", generally aligned 60-40 in favour of Afrikaners. ${ }^{10}$ Addressing a predominantly Afrikaans Bloemfontein crowd during the 1960 Union Festival celebrations, Fouché commented on the SADF's post-Sharpeville mobilisation:

... it was ... an extremely hopeful and gladdening sign to see how in all the Provinces the various English and Afrikaans ... Citizen Force units rallied to the cause of national security ... a praiseworthy spirit of unity for a common cause ... of self-preservation.... the armed services set a fine example ... and it will be a good day for all of us ... [that] our entire nation could [emulate]. ${ }^{11}$

Likewise, at the conclusion of a national school cadet competition, Fouché reflected on the respective white language groups' heritages regarding young white South African male historical heroes:

Let the Dick Kings and Dirkie Uys's ... offer each other a brotherly hand on the road to a great future. When you return to your different schools remember that you coexisted here as future Afrikaans and English citizens of this country ... and competed ... in a spirit of unity. Make the effort to build upon this. ${ }^{12}$

Often, the SADF was also present whenever the white "reconciliation" theme was performed in public: the 11 July 1964 unveiling of the Spioenkop Burger Memorial epitomised the popularised concept of the Afrikaner nationalist Republic projecting English and Afrikaner as one. State President C.R. Swart referred to the urgency of a common white nationhood:

We are no longer Boer and Brit - we are South Africans ... we honour the graves on Spioenkop, but we must direct our eyes towards the future. ${ }^{13}$

Accompanied by much publicity, Fouché made a bold move in 1962 to "restore" WESSA confidence in the SADF by announcing 130 promotions, "warmly received in the Defence Force ... many English-speaking officers are involved". ${ }^{14}$ Fouché's facilitating the re-inclusion of the alienated Defence Force WESSAs was a consistent refrain when interviewing English-speaking former PF members. SADF white 
nation-building was reiterated in 1963 during a speech by Stellenbosch University Rector, Professor H.B. Thom, at the annual Military Academy passing-out parade. He referred to the combining of WESSA and Afrikaner military traditions, while acknowledging that Afrikaners felt until comparatively recently that the Defence Force was not "theirs". An aggressor would therefore had to reckon with the "full, combined potential of both the English-speaker and Afrikaans-speaker". ${ }^{15}$

Wherever practical, the SADF continued to strongly endorse components of Afrikaner traditionalism. Scenes in a 1964 Department of Information film affirmed as much: a farmer on a tractor staring appreciably upwards at South African Air Force (SAAF) Sabre jets flying low overhead, with the film's closing scene showing a soldier guarding the Voortrekker Monument against a sunset backdrop. The CG had ordered that SADF assistance be given to the filmmakers with the production, fitted into regular training programmes. ${ }^{16}$ Significant SADF involvement occurred at Afrikaner commemorative ceremonies such as the provision of troops for the annual Day of the Covenant commemoration in December 1965. Commando remarked on the soldiers' movement from their Ladysmith base to the Blood River site:

5 SA Infantry Battalion transported the guard of honour easily within fastmoving troop carriers ... to the historic terrain. This modern unit possesses the same inspiration ... as the wenkommando of Pretorius, which shall echo if the call ever comes again. ${ }^{17}$

While Erasmus was in his last ministerial months, the UP war veteran MPs escalated their attempts to demonstrate government defence mismanagement. One particularly heated debate included accusations of SADF political favouritism, resulting in the furious trading of insults and accusations of cowardice and fraud. ${ }^{18}$ However, once Fouché took over during the turbulent African and international circumstances, with defence matters perceived as linked to the Cold War ideological struggle, the mostly WESSA-supported UP faced a dilemma in opposing the NP on defence without wanting to appear unrealistic regarding security. While insisting it viewed the country's security as a top priority, the UP struggled to convince the electorate majority that the NP's defence management was lacking, discovering rather that its space to be critical was reduced. During parliamentary defence debates, the NP was seldom particularly uncomfortable, despite the UP highlighting strategic problems regarding the country's increasing isolation, aggrieved conscript and parental concerns, and SADF operational problems.

Although he had assured politically-motivated SADF appointments was a thing of the past, Fouché still at times continued with Erasmus's practice, ${ }^{19}$ either as a compromise for NP unity or because of his own convictions that those positioned on merit had to be counterbalanced by others "deployed" according to NP preference. ${ }^{20}$ Hiemstra's grooming for CG is undoubtedly the best example. 
An SAAF pilot in the late 1930s, Hiemstra had self-suspended his career by declining on political grounds to take the African Oath whereby Union Defence Force (UDF) members consented to war service anywhere on the continent. Hiemstra supported the NP position that South Africa should remain neutral in any war between Germany and Britain. He resigned after pressure from hostile fellow officers.

Following the 1948 NP election victory, Hiemstra returned to the military and, initially bolstered with Erasmus's political patronage, renewed his career accompanied with a zeal to 'Afrikanerise' the UDF. ${ }^{21}$ In 1949, he was invited to join the Broederbond. ${ }^{22}$ Hiemstra was an almost unique civil servant at the NP government's disposal. While hardly the only Afrikaner nationalist senior SADF member, he was the most brash in political rhetoric and action, audaciously playing out a public "soldier/ nationalist politician" role, clearly with NP endorsement. This, and his lack of war service, meant that Hiemstra's career was fraught with controversy, drawing regular adverse comment from the English-language press, parliamentary opposition and amongst some PF personnel. ${ }^{23}$

In August 1958, Hiemstra strengthened direct Afrikaner nationalist political involvement within the SADF by initiating the creation of the Afrikaanse Kultuurvereniging Volk en Verdediging (AKVV), accepting the position as its first chairman. ${ }^{24}$ Established to ostensibly promote Afrikaans as a military language and to strengthen the relationship between Afrikaners and the military, ${ }^{25}$ the AKVV ensured that Afrikaner nationalist commemorations were endorsed with a military presence. The AKVV's existence is some measure of the extent to which the SADF became compliant to NP political designs. Cultural and commemorative activities perceived as "too English" received much less or no SADF patronage. ${ }^{26}$ The AKVV's SADF profile remained high throughout the early to mid-1960s, positioning itself to the right of the growing verligte or verkrampte NP struggle. By mid-1965, just before Hiemstra assumed his partyintended CG position, the AKVV ensured that the most strident right-wing variation of Afrikaner nationalism enjoyed institutional security and influence. In mid-1965, during an address to the civilian ATKV, the AKVV demonstrated how threatened it perceived Afrikanerdom to be. The speech, published in Commando, was paranoid and manic, an attitude that must have found traction amongst many personnel working with conscripts:

The struggle around us is fierce. There are those who seek our demise with violence and economic pressure ... they scream for our blood. There is even a more subtle attack against us ... even within Afrikaner ranks, who want to break down our volk on the cultural front and deliver us to those who seek our demise. In our literature, in our churches, and at every cultural level ... They gnaw at our soul, because a volk's soul is its CULTURE! A VOLK'S CULTURE is its 
POWER! Its POWER and CULTURE are born out of its love for those things that are its own - Its GOD, its LAND, its LANGUAGE, its TRADITIONS, and its MORAL VALUES... The Afrikaner culture was always the salvation of the white national element in South Africa.${ }^{27}$ [capitalisation in the original]

Commando covered Verwoerd's death by referring to the slain Premier as being the 'Father of the Republic' and 'A Giant Amongst our Heroes'. ${ }^{28}$ Commando subscribers were encouraged to purchase copies of a recently published study of Verwoerd's life. At the October 1966 funeral of former Ossewabrandwag leader, Hans van Rensberg, the SADF provided a guard of honour and pall-bearers. ${ }^{29}$

In December 1960, Hiemstra progressed to Deputy CG, alongside sustained personal acrimony with newly-appointed CG Grobbelaar dating back from the 1940s. ${ }^{30}$ Hiemstra continued to advocate conscription for all white males from their 18th year, resulting in bitter clashes with Erasmus and Hiemstra's two CG predecessors. ${ }^{31}$ When Fouché passed the CG baton to Hiemstra in October 1965, it was a reward for his wartime NP loyalty and assiduously promoting Afrikaner nationalism within the SADF - "serendipitously" endorsed by the increased white public interest in defence. Hiemstra, who had never even been SAAF Chief, would have battled to secure CG, had merit been the sole criteria. ${ }^{32}$

The achievement in 1968 of full white conscription was Hiemstra's most important career achievement, and while pursuing it, he never received any resistance from Fouché and enjoyed full support from the post-1967 defence minister, P.W. Botha. Until his retirement in March 1972, Hiemstra indulged himself with public political rhetoric. ${ }^{33}$ However, by the end of the 1960s, some of the more extreme SADF political posturing had diminished, with Commando providing much less space for AKVV activities. The organisation lost impetus after Hiemstra, following his CG appointment, resigned the organisation's chairmanship - a severance which Hiemstra described as one of his regrets. ${ }^{34}$

\section{AFRIKANERS AND THE SADF}

By the early 1960s, Afrikaner perceptions of the formal military had changed considerably, yet some negativity still lingered. Thousands living, remembered the traumatic Second World War intra-Afrikaner disputes. In contrast to WESSA war veterans, Afrikaner ex-servicemen were never honoured within any Afrikaner cultural or institutional forums. ${ }^{35}$ However, the government had already long given notice of military preparation being one of its highest priorities. Die Burger stressed that the "southward advance" of decolonisation meant that the white community needed to accept that defence planning involved increased public spending and participation: "[W]e have little time to put our political, economic and military houses in order." 36 
Within the post-war SADF PF, Afrikaners dominated the army, increasingly so within the SAAF, although not in the navy ${ }^{37}$ while Afrikaner and WESSA war veterans were still fairly common at senior and middle rank levels. During the previous decade, it was not unknown for still-serving war veterans to be viewed with contempt by other Afrikaner soldiers whose service dated from before and after 1945. This was in response to marked suspicions held during the war years within the UDF and UP government towards suspected or known Afrikaner nationalist armed forces members. Even post-1948 Afrikaner recruits could be mocked in the street as "khaki's". ${ }^{38}$ In 1962, Afrikaner nationalist historian Scholtz wrote:

the [negative] relationship that a considerable section of the Afrikaans-speakers have maintained towards the Defence Force ... [caused] many Afrikaners to stand apart regarding (the SADF). ${ }^{39}$

A critical component of Fouché's task was the "mobilization of white consent" amongst Afrikaners and WESSAs, to facilitate or persuade them to accept the SADF becoming a periodic and potentially very intrusive part of their lives. During the 1950s, thousands of Afrikaner males had participated in the reinvigorated skietkommando's and newly established Afrikaans CF units. Skietkommando's offered a community experience compatible with volk heritage, memories and traditions, rather than any direct Afrikaner consent to formal militarisation. However, the skietkommando's also enacted a culturally comprehensible military socialisation, assisting in forging a later conscription acceptance.

Another key factor in garnering full Afrikaner conscription consent was the position of Afrikaans churches. During 1960, the Hervormde Kerk leaders had corresponded directly with Verwoerd to influence Hiemstra's appointment to $\mathrm{CG}^{40}{ }^{40}$ but the position went instead to Grobbelaar with his wartime combat experience. During December 1960, the Dutch Reformed Church and other Afrikaans denominations had come under severe pressure from Verwoerd. Alongside most Afrikaner intellectuals, the majority of dominees understood the Republic's defence to be a "God-given national calling". ${ }^{41}$

Hiemstra was determined to inculcate an authentic Afrikaner military image: burgerkommando members comprised a heritage befitting a citizen who should also be 'naturally' affirmative to formal army service. ${ }^{42} \mathrm{He}$ had noted changes placing Afrikaners twixt country and town; fitting neither the nineteenth-century rural Boer image nor a street-wise urban proletariat. Hiemstra used this to further endorse extended conscription, referring to young men with little practice in skietkuns being no longer "children of the veld". However, they were also not "children of the street" either and would also require training in the art of urban-warfare. ${ }^{43}$ 
Hiemstra reminded his audiences how their forefathers had willingly served to ensure the current generation's existence. Because of the "Afrikaner warrior's" militia mindset from Free Burger to armed and mounted Boer, he was "the most outstanding citizensoldier of his time". ${ }^{44}$ However, the armed and mounted Boer image, long part of community collective memory and schools teaching, was not necessarily integrated into the priorities of growing numbers of Afrikaner suburban families enjoying the economic boom, consumerism pleasures and ambitions for their children. Since 1948, Afrikaner socio-economic diversity had changed markedly, but was still behind the WESSA community in terms of education levels, university graduates and incomes. ${ }^{45}$ In December 1962, Hiemstra drew attention to comparative white prosperity during a speech for graduating officers, advising them to respect and seek advice from those older officers and non-commissioned officers who had been less privileged. ${ }^{46}$

Increased numbers of Afrikaner males were entering university and Hiemstra was a regular guest at Afrikaner Studente Bond (ASB) events, his well-received speeches inevitably following a hard AKVV-type political line. The Pretoria University ASB clearly perceived his opinions as bolstering their own. ${ }^{47}$ Emphasis was placed on "Afrikaner survival" facing threats from "Liberalism, Communism, Jingoism and Roman Catholicism", but also on the need to build prosperity amidst a world of revolution and dramatic change. ${ }^{48}$ Students were strongly cautioned to resist influences undermining Christian-National principles. ${ }^{49}$ When invited on Republic Day in 1964 to the same university, he reiterated the above, finding a resonance amongst the Tukkies student leaders, ${ }^{50}$ but no doubt at other Afrikaner tertiary institutions, too.

While Hiemstra's popularity shows that a strong core of Afrikaner youth readily accepted a senior nationalist SADF officer's explanations of 'threats', NP political support at Pretoria University did not necessarily translate into a mass student military enthusiasm. When appointed CG, Hiemstra received an obsequious letter of congratulations from the Regiment Pretoria University's Commanding Officer, Commandant J. A. Vorster:

For seventeen years this regiment has looked forward ... when the SADF would be led by a full-blooded South African son. ... [the] regiment that has stood firmly by these (Afrikaner) ideals ... now requires security regarding its future. ${ }^{51}$

In 1964, out 10000 students and 800 lecturers, the unit had just 315 members of whom only about thirty percent were actually lecturers, students, or even past students. Some Afrikaners clearly also viewed Hiemstra's CG ascendancy as opportunistic, still anticipating political favours supposedly done away with under Fouché. Lt Gen W.P. Louw, appointed army chief in 1968 with Broederbond membership from 1962, also enjoyed a meteoric career rise like Hiemstra and was perceived by some colleagues as "Hiemstra's man". ${ }^{52}$ But Vorster also demonstrated that there was no overwhelming interest from students in a university military unit, a trend likely to have been replicated 
at other Afrikaans universities. There was scant interest by young educated Afrikaners for an SADF career - it provided little motivation to shift away from plans to secure high paying occupations. Even Commando permitted correspondents to point out the SADF failure to effectively market itself: a young officer severely criticised a planned military tattoo based around an unimaginative theme of "Physical Education through the Ages". ${ }^{53}$

The navy, in particular, struggled with technical manpower shortages, but recruitment was also low in the army, and this was severely criticised in parliament. The UP attributed it to low salaries and poor management: a provision existed for 20000 officers, yet Fouché acknowledged the air force and navy were short by 1755 and 1537 officers respectively, while the army lacked 2492 officers, 25 percent of the approved SADF strength. ${ }^{54}$ It is not difficult to see that the state's push for full conscription was also motivated by an acute manpower need, just as Hiemstra had always claimed. By the mid-1960s, the SADF's efficiency in all aspects was also not all what it seemed, including the SAAF - the military's best public show-piece. ${ }^{55}$

\section{THE SADF AND WESSAS}

While Fouché appealed for white unity, his party's 1961 severance of the British connection helped undermine any WESSA identity developing, comparable to that of their historical kin in Australia or New Zealand. Constant nationalist baiting of all that was British had also edged WESSAs to relinquish, forget or ignore their colonial past as one defining component of identity. Yet, notwithstanding the Erasmus years and Afrikaner nationalist state dominance, the 1960s WESSAs were not generally hostile to the SADF, with most accepting government explanations regarding the State of Emergency call-up and SADF external threat perceptions and mobilisation. These, along with Fouché's reforms, were largely supported or reinforced by the Englishlanguage press. ${ }^{56}$

'Republican unity' was partly a white racial compromise for national defence. WESSAs were never seriously drawn into the Afrikaner volk structures - neither grouping demonstrating any particular interest in it - nor was the civil service ethos adjusted to make WESSAs feel the state sector was culturally more accepting of them. ${ }^{57}$ However, NP appeals to defend "white civilisation" were more readily heard by WESSAs than concerns for "white nationhood". Political activists to the left of the essentially conservative WESSAs were not complimentary. Alan Paton caustically referred to English South Africans as "half-willing, half-wry prisoners, moved by selfinterest and the desire for security rather than by that quaint relic known as British fair play". ARM activist Rudolf Vigne believed the white English community had undergone some "moral collapse". ${ }^{58}$ Hyslop describes the loyalty of English South 
Africans to the Afrikaner-controlled state as never particularly strong, or at least it was weaker than Afrikaner loyalty. ${ }^{59}$ Did figures like Hiemstra assume or intended that compulsory military service would in time help "Afrikanerise" WESSAs, which the Broederbond intimated should be a broader cultural objective? ${ }^{60}$ Even Anton Rupert, a leading Afrikaner businessman whose opinion the government took seriously, asserted exclusive Afrikaner leadership, sweepingly maintaining that "English settler culture" had not developed any bond of national identity and that it was an Afrikaner responsibility to set the pace and course of "nationhood" by the "activation of the younger and significantly divergent elements of the population". ${ }^{61}$ This would have to include the new generations of WESSAs and Afrikaans males conscripted to the SADF.

By 1960, the NP was also hoping to draw more of the 'English' vote as whites observed the Congo/Algeria racial violence and resultant panic-stricken white exodus, in turn influencing a growing WESSA perception that Britain was betraying both them and white Rhodesians: "whiteness" had become more important to WESSAs than their "Britishness" and they now increasingly "sought to preserve their position as part of a privileged white minority by accepting an implicitly racist consensus with Afrikaner nationalism". ${ }^{62}$ Seen another way, most WESSAs felt enough (white) South African patriotism to be explicitly counted on regarding defence.

The 1963 Rhodesian Federation collapse prompted the Afrikaans press to appeal that the prosperous middle-class WESSAs shift their voting support behind the NP, as their identity and class kinsmen, the white Rhodesians, were doing regarding Ian Smith's Rhodesian Front. ${ }^{63}$ In fact, more WESSAs adopted a 'local Rhodesian UDI-type mindset' and at least tacitly supported the Afrikaner-led republic. Certainly, this was some shift away from the WESSA 1939-45 intense hostility towards the NP. Numerous regimental histories written during the 1960s record the enthusiasm and pride with which 'English' CF regiments performed their post-war dutiess.

WESSAs seeking a military career also had the option of joining the Rhodesian Armed Forces. In August 1960, with the SA government's blessing, visiting Southern Rhodesian army representatives recruited men in Durban, Cape Town and Johannesburg for new regular all-white army units formed in the wake of the Congo events. ${ }^{64}$ Good pay was an incentive, ${ }^{65}$ but WESSA considerations joining the Rhodesian Light Infantry (RLI) also included the Afrikaner dominance in the SA Army, with the larger number of recruits drawn from Natal. ${ }^{66}$ The RLI troops during the early to mid-1960s mostly comprised South Africans. Rhodesian military intelligence had surmised that they would resist a post-UDI British invasion. ${ }^{67}$

Young WESSA and Afrikaner males encountered one another regularly in school sports, compulsory military service and innumerable other contexts. The communities had historically lived cheek by jowl, with many interacting at the deepest social levels around urban and rural areas. But undoubtedly this occurred less so than the opposite, 
where the two groupings lived separate lives and could (and did) harbour jaundiced views of the other. Politically disempowered, WESSAs might arguably have been more resentful than most Afrikaners regarding military service. But WESSA commitment to defence obligations also manifested strongly through an interest in local military affairs, stimulated by SADF-sympathetic defence press correspondents, writers of military histories and contemporary commentaries, together with connections to the culturally familiar CF 'traditional' regiments and ex-servicemen organisations such as the Moths, Sappers Association and SA Legion. ${ }^{68}$ World War veterans often held prominent positions in business and politics, Harry Oppenheimer ${ }^{69}$ and De Villiers Graaff $^{70}$ being two obvious examples.

WESSA boys' schools had cadet detachments often a century or more old, besides educational cultures retaining the lingering legacy of preparing young men to serve the British Empire, a component ensuring them to be ideal training grounds for imbuing respect regarding military conformity. ${ }^{71}$ Community memory long anticipated military service and it held a place as time honourably spent with respected sacrifices within family histories and community and cultural entities, where a longstanding community cultural construct also existed whereby military service was accepted as a masculine rite of passage. ${ }^{72} \mathrm{~A}$ strong social culture of war remembrance existed regarding the world wars, with constant reminders thereof through memorials scattered amongst schools, churches, universities and city or town public places. Unlike Afrikaans universities, 'English' universities allowed an academic depth and freedom equating their Western counterparts, but WESSA schools and communities were much more conservative than reflected in UCT/Wits SRCs or Arts and Social Science faculty staff and students. ${ }^{73}$ A growing minority of WESSAs had supported the NP during the republican referendum and the 1966 general election ${ }^{74}$ and, as with their political choices, WESSAs were also hardly homogenous. Conscription meant drawing WESSAs from different sections - public and private schools, class distinctions, rural and city, church denominations and religions, including Jews and Jehovah's Witnesses. ${ }^{75}$

Just as the NP government after 1948 was determined to ensure preferential opportunities for Afrikaners in state employment, creating work environments sometimes perceived by WESSAs as culturally uncongenial, by 1960, numerous WESSAs viewed the regular military likewise. Although there were still WESSAs seeking careers in the navy and air force, comparatively few entered the army, which received the bulk of the compulsory trainees. But "traditional' regiments received their share of men, ensuring a new lease of life for WESSA military involvement.

Some SADF military intelligence reports expressed concern that balloted nonAfrikaners could include subversive elements. In April 1963, a confidential report noted that this might include those who would welcome "UN interference" and 
become active in the spreading of subversive propaganda. ${ }^{76}$ Urban white Afrikaners were "part-quarantined" through separate educational, cultural and commercial organisations, ${ }^{77}$ but if conscription presented challenges from potential sedition, it also provided an opportunity for stressing government political imperatives to WESSAs.

From 1968, the reinforcing of communism's role in military, civil, moral and social threats became even more apparent during Botha's defence ministership. Judging from press letters, journalistic comment and the opinions of parliamentary opposition members, it is clear that WESSAs were also committed to understanding the Cold War as being explicitly Soviet driven, with South Africa the chief target of communist designs in Africa.

With Afrikaner social structures being culturally more autarkic and authoritarian, there was less of the conflict-filled generation attitudinal gap existent then across the Western world and already marginally discernible amongst young WESSAs. Afrikaner national servicemen, most particularly in the army, entered a military environment better tailored for them through a largely Afrikaner officer/non-commissioned officer corps. However, it is unlikely that many WESSA national servicemen felt the desperation of acclaimed writer J.M. Coetzee to the prospect of military service during $1960 .{ }^{78}$

As WESSAs felt the early-1960s white anxieties of African internal revolution and racial violence, it tended to also mute any loud objections that may have been felt against the government increasing its conscription demands in 1962 and 1968. The forced republican change of military titles and insignia did not dull enthusiasm within CF 'English' units. ${ }^{79}$ The Cape Town Highlanders, for example, were pleased to hear that Fouché had no intention of interfering with their British originated traditions ${ }^{80}$ and received their new colours from Hiemstra ${ }^{81}$ whom its members would have openly despised two decades earlier. Lt Gen Gleeson, who attested in 1953, remarked that during the 1960s, republican changes upset some, but on the whole the "main officer group ... got on with the job". ${ }^{82}$ Within the republic context, WESSA military traditions continued virtually unchanged.

After initial "republic hesitations", the English-language press displayed a different tone on defence to that of the 1950s, for example, the Cape Times reported enthusiastically on the local 1962 trainees' experiences:

There are boys from Bishops Court and boys from Woodstock; English-speaking youths from the cities and Afrikaans-speaking from the platteland, working and living together in the rugged, healthy atmosphere of the army camp. ${ }^{83}$

With the mooting of further extended compulsory service for all school-leaving white males of age, the media projected the WESSA community as supportive: 
High-school youths of call-up age ... interviewed by the Cape Times yesterday endorsed the general agreement among industrialists, businessmen, school principals and defence experts that the proposed '100-per-cent call-up' was preferable to the present ballot system for the $\mathrm{CF}^{84}$

English-language newspapers reflecting their white readers views and even wary of differing from the government on defence issues, took a generally conservative and supportive view. ${ }^{85}$ At the end of 1965, the Cape Times published two lengthy articles by the military historian, Neil Orpen, an influential 1960s military analyst read in government and SADF circles. Orpen showed identification and empathy with the Boer struggle against British Imperialism, comparing it with white South Africa, Rhodesia and the Portuguese territories facing current African and world hostility. ${ }^{86}$ Orpen's views reinforced the government's 'backs to the wall' philosophy, demonstrating that whites were aware of the military's growing prominence. ${ }^{87}$ In 1967 , inspired by the history of Boer guerrilla forces during 1900-1902, Orpen published a book titled Total Defence, ${ }^{88}$ collated articles he had written concerning his envisaged role of the SADF commandos in the event of a foreign invasion.

\section{AFRIKAANS/WESSA RELATIONS: SOME OBSERVATIONS}

To illustrate whites drawing closer through conscription, the SADF published selected letters in Commando affirming its successes. Emphasis was placed on 'English' servicemen successfully integrating and developing a better understanding of the Afrikaans community, ${ }^{89}$ without ever any hint suggesting the reverse. Confirmation of military service 'benefits' purportedly even came from within components of the 'English' academic environment. It was reported to the CG that, at UCT's medical school, a professor had stated that students having undergone military service turned out better doctors and citizens, while a proposal by the University's 'Medical Association' to approach the government for medical students' military exemption had been defeated. ${ }^{90}$ In the same year (1963), the Pretoria University rector, Professor Rautenbach, expressed serious misgivings about military training occurring between school and university, an issue sensitive enough for Fouché to challenge him immediately, resulting in the University administrator quickly retreating. ${ }^{91}$ Clearly, political pressure had 'corrected' Rautenbach, however, non-political dissension with military service was a reality Fouché and his officials had to come to terms with.

Fouché's SADF "nation-building" had not received unanimous Afrikaner approval; antipathy remained in certain contexts and circumstances. By early 1962, white urbanisation and the white nation-building theme contributed to the establishment of 25 English-language commando units, ${ }^{92}$ prompting a badge amendment. The single word 'Kommando' was replaced by 'Unitas'. Three years later, Ventersdorp Commando's 
OC, Commandant Frans Cronje, complained angrily via his MP about this 'undermining' of Afrikaner Commando identity to appease the 'English'. According to Cronje, the reason why defence authorities had changed the badge was to ensure that "we [Afrikaners] dare not offend our 'English friends' ... Commandos remind them of the English war and how the Boer Commandos mowed them down". ${ }^{93}$ Insisting that, during a 1964 conference, the attending Commando Officers had in unison supported restoration of the original badge, Cronje also reminded SADF officialdom that he was a Boer War general's grandson, and slated WESSAs supposed reluctance to accept symbolic changes accommodating the republic: "Somewhere within the SADF, there was violent opposition that was putting this 'thing' aside ... We Afrikaners have to throw away all our traditions to win the goodwill of the English-speakers." 94

On a similar theme, the wife of an Afrikaner SADF member received a stinging response when she suggested that it would be preferable if two separate Defence Force wives organisations existed for English and Afrikaans members, with a possible future single organisation uniting both under the common embracement of Afrikaner culture. ${ }^{95}$ The above examples are unlikely to have been exceptions. Clearly not all intra-white tensions had been smoothed over by Fouché's appeals, and conscripts from both language groups entered an organisation still rife with such attitudes.

In contrast, former trainee correspondents (except one) ${ }^{96}$ recalled relations between English and Afrikaans troops as good, with all remembering their understanding the country's threats as "communist-inspired". The religious denomination divergence of servicemen had obvious implications for any project attempting to mould a common "white-nation". Although the permanent force chaplaincy was dominated by the $\mathrm{DRC}^{97}$ in terms of worship facilities, time and diet, the SADF dutifully covered all denominations and the Jewish faith. ${ }^{98}$ Some groupings such as Anglicans were already strongly critical of government racial policies, but only towards the late 1970s were there louder objections from them and other 'English churches' towards the political controversies surrounding National Service. ${ }^{99}$

Inevitably, tension regarding "white cooperation" also existed within the NP. Albert Hertzog's insulting of WESSAs constituted one of the reasons given by John Vorster for Hertzog's 1969 expulsion from the party. ${ }^{100}$ The SADF persisted with their promotion of a 'white nationhood' through the repeated emphasis on 'English' and Afrikaner conscripts working successfully together as one 'nation'. by the end of the 1960s, some of the ultra-nationalistic promotion of Afrikaner symbolism within the SADF had become slightly more toned down. 
Military Intelligence (DMI) attempted to assess the white population's capacity to respond effectively to military threats, both conventional and guerrilla. Some appraisals (1963) reported that it was not entirely certain if whites could face potential sustained enemy subversion: "There are indications that the volk's will to succeed and willingness to accept necessary suffering is not as strong as is generally presumed." There were risks of frustrations predominating, ultimately creating an outlook (amongst whites) "that at some or other stage they (the 'revolutionary forces') will get what they want. This aspect should be further investigated." ${ }^{101}$ Because all attempts to combat subversion were essentially defensive, it implied that this could result in frustration and a defeatist attitude. ${ }^{102}$ There was speculation about a conservative component of the volk not viewing possible assistance from neighbouring states (Portuguese or Rhodesia) as necessary, with potentially negative consequences. ${ }^{103}$ The suggestion was that some Afrikaners were complacent and lacked insight regarding local military threats.

How such deductions were determined was not explained, but one fear was that volkseenheid and nationalism were waning. As Afrikaners increasingly consolidated around their urban identity, new 'dangers' 'lurked' - phenomena perceived as disseminated readily from within the city environment: "Atheism; Internationalism; Liberalism; Materialism". ${ }^{104}$ The NP understood these issues as directly connected with the 'communism' supposedly behind military threats. With many Afrikaner conscripts coming into the SADF from the same cities as their WESSA counterparts, the military showed growing concerns about a decadent misguided youth. Commando reported on a parade containing members from the final balloted draft during 1967:

The public enjoy military parades ... not only [to] stimulate national pride ... but also [to] counter the despondency that has grown over the beatniks, hippies and other human oddities that prowl our city streets and haunt coffee bars. ${ }^{105}$

'Materialism' had also not escaped the concerns of military chiefs - already in May 1961, the SA Navy Chief-of-Staff, Rear Admiral Hugo Biermann, referred to his perceptions of young whites' priorities:

... concentrated training in the armed forces could only be of benefit ... Modern youth in South Africa has too many bioscopes, too many Elvis Presleys and too much money ... ${ }^{106}$

Reflecting during a 1959 Day of the Covenant speech upon the marked distance between the increasingly 'indulged' 1960s volk and his generation, Hiemstra lashed out at parents who assumed military service was the panacea for difficult sons in an era of new fashions and anti-social trends such as the 'ducktail' cult: "The lost young 
people of today are the responsibility of their parents and it is misguided to think that the Defence Force ... can correct what these parents have spoilt." ${ }^{107}$ Hiemstra was referring to a persistent popular assumption within the military, political and public domains that 'army life' straightened out anti-social behaviour. Early 1962, a reporter, interviewing an instructor staff sergeant, wrote the following about Oudtshoorn trainees:

I [the reporter] was assured that 'ducktails' and 'milkbar cowboys' presented no problems in camp. They arrive here ... but ... soon have the nonsense knocked out of them - usually by the trainees themselves, ... For them, it is a period of abstinence and rigid discipline. What mother and the coloured servant did for them before, they now have to do themselves. ${ }^{108}$

'Milk bars' were popular 1960s white urban youth 'hang-out' locations and it prompted the perception that military experience might rehabilitate young men who displayed bad behaviour. In June 1964, J.F. Schoonbee, the NP MP for Pretoria District, claimed that idle youths and gangs should be conscripted into the army, where "scum was eliminated, and ducktails were turned into decent people". ${ }^{109}$ Justice Minister Vorster mooted the 1930s Special Service Battalion concept of a youth battalion rehabilitating young white male offenders, emphasising the need for military discipline being enforced upon young white men between the ages of 18 and 30, further expressing concern that, compared to just 47 white woman prisoners nationally, there were about 60000 white male prisoners, who should "sweat out their penalties on the parade ground". ${ }^{110}$ Schoonbee went so far as to state his concerns in a non-racial commonality:

Whether black, brown or White, youths should not be allowed to run wild and grow ripe for communism. Even if they were given nothing more than to clean the guns they should be kept off the street. ${ }^{111}$

While military conscription constituted one component whereby the state exerted some control over forging a degree of white political and cultural uniformity, ${ }^{112}$ but this compulsion to serve also created resentment and enthusiasm from within both white WESSAs and Afrikaners. A uniform reaction from either cannot be generalised, although the dominant joint response was certainly conformity with the law.

\section{BALLOT CONSCRIPTION EXEMPTION GRIEVANCES}

Amongst many prospective trainees and their parents, there was no end of efforts to legally evade or postpone call-ups, usually without success. Both language groupings exhibited confidence in their parliamentary representatives' capacity to influence. ${ }^{113}$ 
However, only the exemption board possessed the necessary legal power, insisting that even a ministerial recommendation required support by "relevant facts". ${ }^{114}$ University candidates had to complete military obligations first, causing consternation amongst parents anxious that their sons' post-matric study should not be interrupted. Future teachers received special exemption if willing to undergo a school cadet officer's course. ${ }^{115}$

The SADF responded to the numerous exemption applications with lecturing letters explaining the impracticality of making exceptions; how critical the country's defence was; and that the military dealt with scores of such applications. Rejecting a university study application followed a standardised process. J.F. du Plessis's example typically demonstrates the resentment felt by some families: his mother rationalised that military service might malign her son's study habits and expressed indignation at just receiving a 'rolled-off' refusal letter. When her representations failed, she wrote directly to Verwoerd, pleading that 'JF' intended qualifying as a chemical engineer. She inquired why teachers received exemption and whether their profession was more important than "science". ${ }^{116}$ Her detailed and personalised response from the Defence Secretary contained the predictable content - thousands of identical applications were received and any policy exceptions would set a "dangerous precedent" - followed by a lesson on patriotism. ${ }^{117}$

Ballot administrative dogmatism was mixed with clumsiness, for example, three future chartered accountants complained that, although never balloted at school, they had all received later call-ups making it difficult for them to complete their professional internships. ${ }^{118}$ An anonymous complainant in a similar position detailed spending his period of service living in a tent, unable to study properly by candle-light, enduring poor food, unhygienic toilets, uncurbed stealing, inadequate leave and abusive officers. ${ }^{119}$

Medical exemptions could also be managed in a tardy, insensitive style: UP MP Van der Byl reported a case of a recruit who had been declared medically unfit and whose elder brother by tragic coincidence had been shot while doing training. No official inquest had been held nor any form of compensation granted to the family, but the younger brother, despite a medical certificate posted three months earlier, had still been informed to report for duty. Van der Byl wrote that this was "typical of the slackness ... in replying to correspondence". Although the said soldier eventually received the exemption, he was kept waiting for three months, leaving him and his family "in anxiety". ${ }^{120}$ Yet, in selective situations, the SADF could also be pragmatic; farmers might be disadvantaged if a needed son was called up: After being denied leave, M.J. de Kock deserted after six months to assist his ill father on their farm. This matter was considered important enough for the CG to be kept informed, and documentation consulted suggested SADF sensitivity and fairness, but also caution regarding the Afrikaner farming constituency. ${ }^{121}$ 
With the readjusted 1962 ballot resulting in greater trainee numbers, MPs received very substantial grievance representation appeals regarding poor treatment, inadequate facilities and boredom; already Tempe had achieved particular notoriety with complaints of inadequate water. ${ }^{122}$ The press also reported on scores of incidents concerning alleged assaults and the general brutal treatment of conscripts. A significant letter, directed privately to the defence minister, came from J.A. Fourie, principal of Afrikaanse Hoër Seunskool (AHS), based upon communications with numerous ex-students. Fourie affirmed support for military service, but challenged Fouché on concerns regularly expressed by numerous complainants:

\begin{abstract}
Almost without exception, the boys explain ... that they waste a great deal of time; ... that they are often involved ... in paltry things like washing dishes for several weeks; ... I get the impression that there is not a proper plan for instruction over the entire period of training ...

A second issue ... are complaints about the non-commissioned officers who have to give instruction, and where it is done in such a manner that (it causes) undermining of respect and authority ... the above allegations are so regularly forthcoming that truth could well be hidden therein, and I feel our Defence Force ... is developing a reputation that is unworthy, and it cannot. ${ }^{123}$
\end{abstract}

In 1965, AHS drew its boys from amongst families that included senior politicians, professionals and civil servants, like then Justice Minister John Vorster. ${ }^{124}$ Conceivably, Fourie was also describing frustrations demonstrating the increasing class divisions amongst white Afrikaners. Such allegations threatened to mar the public's view of both SADF and military training, subverting the country's largely citizen-based defence.

UP parliamentarians wrote regularly on behalf of their constituents, repeatedly stressing they would not assist anyone perceived as attempting to evade military service. UP MP Gay reported in parliament that parents were "ringing up Defence headquarters ... say[-ing] they are not prepared to let their sons go ... under conditions such as those exposed in the Press". ${ }^{125}$ Headmaster Clarke of Rondebosch Boys' High School, through De Villiers Graaff, confirmed Fourie's deductions that later stages of training were marked by poorly utilised time. Conclusively, it seemed the SADF was not sufficiently organised to properly occupy the trainees or even accommodate them properly:

The general slackness in the latter part of the training period has been raised from many quarters and all we can get from the Minister [off the record] is that while he has not yet adequate facilities for intensive training during the whole period of service, he feels compelled to hold trainees for the full period so as to have a large force underarms for security reasons. This, of course, is not public property and we cannot get him to say it publicly at the moment. ${ }^{126}$ 
Fouché had stated in 1960 that training existed principally to deal with internal security, but this was amended by later defence appraisals outlining potential external threats. ${ }^{127}$ Maintaining large trained troop numbers with resultant problems was directly connected to SADF threat appraisals. The increased call-ups and service duration implemented from 1962 had been intended to ensure the constant availability of trained troops within 'Full-Time Force' units. ${ }^{128}$ The SADF was severely criticised for poor management: UP MP Vause Raw accusing Fouché of over-conscripting, despite PF personnel being unable to cope with unsatisfactory training in consequence - three months "square-bashing, three months training" with the last three months "wasted because of excessive ... numbers. 16000 men were drawn out [of] the economy but without proper utilization; companies commanded by lieutenants, during the winter over 1964 men in Bloemfontein were not issued with their winter clothing". ${ }^{129}$ Another complaint pattern concerned the trainees' enthusiasm stunted by poor management and abusive instructors. ${ }^{130}$ An anonymous parent wrote undated complaints about her son's experiences in the navy, including lack of control in Lourenço Marques; trainees visited a brothel and were ordered to receive 'VD injections'. This complaining mother inquired why the "boys" were not properly supervised: "[T]hey are not yet permanent force - nor are they adult." 131 Other complaints were lack of responsibility by officers and non-commissioned officers while on watch duty and cruelty towards the ship's dog. ${ }^{132}$

These views are in stark contrast to what Lt Gen Dutton, who commanded a Bloemfontein training unit during the mid-1960s, expressed concerning its programmes. The distance between the commander and his men can be considerable in terms of training experiences, but the many archived complaints from the public may have been less apparent in Dutton's camp:

From the point of view of discipline, I was at all times most satisfied with our standard. I had a large staff of officers, WOs and NCOs, all of whom were well trained, experienced and reliable. ${ }^{133}$

In 1965, Fouché formally addressed public complaints regarding the SADF and trainees through the Groenewoud Committee. ${ }^{134}$ Additionally, MPs were requested to submit their complaints to a Commission of Inquiry. Two years later, the committee resolved to support Hiemstra's call for military national service being extended to all white male school leavers.

\section{COMPLAINTS REGARDING ASSAULTS}

Parent complaints of brutality and cruelty inflicted upon their sons by instructors were the most serious fielded by an SADF increasingly alerted to protect its reputation. By example, an NP SWA MP went to considerable trouble to intervene 
on behalf of Josef Davids, a 19-year-old rejected for PF service on the grounds of civilian court convictions. The SADF pointedly informed Davids that they did not want impressionable young conscripts mixed alongside PF members with dubious reputations. ${ }^{135}$ A correspondent, balloted for service in Walvis Bay during 1962, remarked on his disillusionment with non-commissioned officers boasting about their dagga smoking to trainees. ${ }^{136} \mathrm{~A}$ father wrote a particularly strong letter about his son's experiences at the Air Force Gymnasium where he had been injured during training, describing recruits having their faces pushed into their own vomit and cartilage damage caused to several men due to brutal drilling. ${ }^{137}$ Such bad conduct, suggesting ill-suited personalities given instruction duties, is corroborated by many other accounts. In a 1961 "Memorial Album" for the Air Force Gymnasium, some of the photos provide glimpses of the institutional culture, one illustrating a recruit having to drink a 'doctored' cold drink during 'Boeresport'. ${ }^{138}$ The NP MP for Wolmaransstad confirmed that his colleagues received numerous trainee complaints and demanded that bad language be eradicated in the SADF and that soldiers should not fear their superiors. ${ }^{139}$

Equally serious grievances came from the father of a 1964 ballotee describing an abuse level which was unlikely to have been an exception. The complainant, who held a "very senior position in a well-known scholastic institution", ${ }^{140}$ related a series of events witnessed or endured by his son during training at Diepkloof. Allegations included physical assault on a trainee by a PF corporal, the victim also being compelled to run along cattle kraal walls with full pack throughout the morning. At the end of the exercise, this man was further punished by being "placed under close arrest" and forced to run with sandbags after refusing to get into a hole the corporal had threatened to bury him in. Later, when the troops drove through a "coloured reserve," a corporal ordered them to "arrest" a "coloured bystander" and several children from nearby houses. Some soldiers participated, while others refused. Eventually, at their camp all of the captives were released, although they were "shot at with blank ammunition" as they ran away. During a night attack exercise later, instructors allegedly assaulted one recruit and threw stones at others. The trainee's company did not receive breakfast on three occasions during the exercise as punitive measures for allegedly not cooperating. The report concluded by stating that nothing came out of the above man's arrest. ${ }^{141}$

It is notable that many trainees and parents showed faith in the parliamentary constituency system's role of representing citizens grievances, expressing outrage that the SADF could be a place where violence against conscripts seemed to be prevalent and increasing. Also intimated in these complaints was a willingness to support military service, but with expectations of appropriate instruction. However, it is also notable that the majority of Van der Byl's complainants insisted to remain anonymous. During the same year (1964), Fouché received correspondence signed by Grobbelaar concerning similar complaints about instructors. A board, appointed to investigate, 
found six incidents where ballotees' complaints were verified and accepted evidence, supporting four incidents concerning swearing and bad language alongside eight incidents of assault. One instructor was found guilty of blasphemy, while disciplinary steps were being taken against an officer, a warrant officer and six non-commissioned officers. Grobbelaar reported to the Minister that because of previous complaints he had appointed a senior officer board to investigate certain aspects of training, and particularly the issue of time being allegedly wasted. ${ }^{142}$

One of the clear problems during the 1960s was that, although the SADF also utilised CF instructors, much of this work was under junior PF members' control. There was not only a shortage of PF instructors, but a dearth of quality, particularly amongst non-commissioned officers. Later, army chief Magnus Malan remarked during the early 1970s that "if he could not have an army of good permanent force sergeants, then it would be better to have an army of good national service corporals". ${ }^{143}$ The inference was of problems that dated back to the 1960 s.

Yet, despite complaints, the SADF continued to become pervasive within white South Africans lives. By mid-1966, new Minister of Defence P.W. Botha was capitalising on that. Addressing the Rapportryers Club in Porterville, Botha made specific references to employers needing to support their workers' SADF obligations. More specifically, Botha emphasised that the white youth should view military service as a patriotic duty that promoted the "physical and spiritual well-being" of the nation. The view of compulsory military service had shifted since 1960; it now possessed a louder nationalistic purpose as opposed to army duty for internal defences. Within six years, Botha was making grandiose statements such as: "South Africa has a right to expect enthusiasm for her Defence Force from every patriotic citizen", ${ }^{144}$ a considerable change from 1960 when Die Burger cautioned that the government should carefully approach the issue of extending national service. By the late 1960s, the SADF senior officer mindsets were shifting towards understanding revolutionary and counterinsurgency warfare, following Major General Fraser's important study on that, closely read and approved of by Botha. ${ }^{145}$

THE 1960s SADF IN PUBLIC:

ENTERTAINMENT, PRIDE, PROPAGANDA AND REASSURANCE

Military prowess was projected as an important manifestation of republican nationhood by a supportive media that reported on military displays, showcasing the SADF as a force to be reckoned with. Future trainees and parents imbibed the patriotic atmosphere associated with these shows, accompanied by numerous other whites in very large numbers, motivated by a mixture of national pride and entertainment expectations, and also because family members participated. 
A very significant example occurred two months after the March 1960 unrest at the main training area outside Bloemfontein. A 70000 white crowd witnessed the firepower of tanks, field artillery, aircraft, and an infantry battalion, followed by a braaivleis and display of "searchlight aerobatics". ${ }^{146}$ This SADF spectacular reassured white insecurities during a nationally unsettled period. The event's importance was emphasised by the presence of Verwoerd accompanied by his cabinet, making his first public appearance after an assassination attempt. ${ }^{147}$ The frequency of SADF exhibitions and live ammunition demonstrations definitely increased after $1960,{ }^{148}$ public viewing of new arms arrivals, particularly ships, were guaranteed to draw big crowds and usually received front page publicity. When the last of the navy's new frigates docked in Cape Town on 26 September 1964, people lined Signal Hill and surrounding heights to observe it met by four other warships and several aircraft formations. Die Vaderland spoke of "the biggest demonstration of South Africa's maritime strike power yet seen."'149

SADF chiefs clearly comprehended the usefulness of military spectacles and exploited the SADF's capacity to stage them, bolstering further public interest, patriotism and the incipient 'popularisation' for the SADF, while arms acquisitions were open to inspection by white tax-payers. Various civic organisations regularly called upon the SADF to perform on supposedly notable occasions. Many requests had to be rejected, like one from the Harrismith Municipality in June 1964, asking for a display of jet fighters to mark the occasion of the opening of a new tar road to the Rand. ${ }^{150}$ When Hiemstra addressed the exclusive Durban 'Wings' Club, the accompanying show, including a huge SAAF aerial display, were watched by 180000 people. ${ }^{151}$

With the SADF often the dominant presence at large commemorative and national occasions, businesses also saw profit in associating themselves with the growing SADF public presence. The South African Mutual Life Assurance Company produced a well-carried full-page advertisement, portraying three of the SAAF's new Buccaneers jets. ${ }^{152}$ A June 1967 BP advertisement presented a display feature titled 'BP Salutes our Fleet', ${ }^{153}$ and popular magazines increasingly ran lengthy, informative and admiring articles on the SADF. ${ }^{154}$

\section{THE SADF'S ROLE IN THE 1966 REPUBLIC DAY FESTIVITIES}

The most spectacular SADF public display occurred in Pretoria during the fifth republic anniversary celebrations in May 1966. Hiemstra wanted a parade that would compare to the Bastille Day equivalent, and in posterity wrote that it had signalled to "black nations of Africa who had thought ... they could take us over ... not after that day". ${ }^{155}$ Thousands watched a march-past of nearly 20000 troops, columns of several armoured vehicles, trucks and artillery, while dozens of aircraft thundered across 
the sky. ${ }^{156}$ It was an impressive military display intended to confirm to whites the Republic's success and security. The celebrations finale centred round the Voortrekker Monument, recalling its triumphant opening in 1949:

Before sunrise, already thousands of people were huddled around camp fires ... the air was thick with smoke and the aroma of coffee. Flags fluttered in the breeze, a carnival atmosphere prevailed, and the military organisers worked hard to control the arriving crowds. ${ }^{157}$

The military proceedings easily dominated other programme items and an admiring national press responded accordingly: "On parade for peace" wrote the Cape Times editorial with a bold front-page headline: "S.A. Shows World her Might". The press intimated that Verwoerd's intention was peace, shared by "all South Africans", 158 while the parade was also a white celebration of militarised nationalist fervour. ${ }^{159}$ Verwoerd's speech was focused on white unity and resolve in the face of outside, particularly African, hostility. ${ }^{160}$ The Star spoke of the spectacle grandeur, headlining it as "South Africa Shows Might in Vast Parade". ${ }^{161}$ The Cape Times reported on hundreds crowding to board the new navy frigates at the city docks, ${ }^{162}$ giving the SADF further prominence in a 'Festival Supplement' that commented favourably on the organisation's marked growth since 1960/1961. ${ }^{163}$ The 1966 Republic Day parade was an effective public relations exercise as compulsory full white male military conscription loomed.

Callistair deduced that by 1967 national service was one under sufferance by some, citing comments by the retiring Chief of the Army, General Jacobs, complaining of substantial trainees entering the military "in a spirit of resistance". ${ }^{164}$ This point is valid in that, for many, the military was for varied reasons perceived as a much resented intrusion into their personal lives. But there was also no significant wide public resistance - SADF 'popularisation' had in fact triumphed. By 1966, the Cape Times referred optimistically to changing public attitudes:

Another important change ... has come into the attitude of the ordinary man in the street towards the armed forces. Previously he was inclined to look down upon them. This was all changed and now he takes a real interest. ${ }^{165}$

Afrikaner nationalists from the 1960s started likening their historical struggle to that of Jewish Zionist aspirations to protect Israeli independence. ${ }^{166}$ After the Six-Day War in 1967, it was discussed how small, determined states with a "dedicated citizen army" and "economic and technical strength" could survive against "overwhelming odds". Articles on the Israeli armed forces became more prominent in Commando. Like the IDF's assimilation of Jews from different traditions and diaspora regions, the SADF arguably performed a similar role with Afrikaans and WESSA trainees and, by the decade's conclusion, the SADF had part-successfully overhauled its public image. 
This compared to the "sneers" Fouché referred to in 1960, while the SADF remained "captured" by the NP, ensuring national service obligations were blended with a loud patriotism definition, strictly within this political party's terms and objectives. Whether whites during the 1960s would have fought en mass against an invader to maintain political control is not clear. ${ }^{167}$ However, this was likely, considering the conformism of the time and the interest, besides involvement in the military, by large sections of the community. The mobilisation of South African white consent for the SADF during the 1960s was prompted by deliberate policy decisions and there is also no doubt that whites in general were receptive rather than obstructive. 


\section{Endnotes}

1 Rodney Warwick, White South Africa and Defence, 1960-68: Militarization, Threat Perceptions and Counterstrategies (PhD thesis, University of Cape Town, 2009), available at: [https:// open.uct.ac.za/handle/11427/8258], Ch. 1.

2 bid., Ch. 3.

3 Boulter outlines a range of SADF deficiencies in Roger Boulter, F.C. Erasmus and the Politics of SA Defence 1948-59 (PhD thesis, Rhodes University, 1997), available at: [http:// agris.fao.org/agris-search/search.do?recordID=AV2012092989], 86-88. Magnus Malan, Magnus Malan: My Life with the SA Defence Force (Pretoria: Protea Books, 2006), 39.

4 Warwick (2009), Ch. 3-4.

5 Commando (official magazine of the Union Defence Force and the SADF - December 1949 to October 1970), November 1960, 1; Department of Defence Archives (hereafter DOD Archives): KG Group 5, box 200, file KG/GC/5/1 Rolprentvervaardiging Vesting in Die Suide, Secretary of Defence to Secretary of Information, 20 July 1962; DOD Archives: KG Group 5, box 200, file KG/GC/5/1, Commandant General to Director of Military Intelligence, 1 August 1962.

6 RSA (Republic of South Africa), Hansard Parliamentary Debates (hereafter Hansard) 1 (3rd Session, 12th Parliament, 15-22 January 1960), 227.

7 Considered an expert regarding revolutionary warfare, Warwick (2009), 281-282, 390-392.

$8 \quad$ Cape Times, 9 December 1960, 15; Die Burger, 10 December 1960, 18.

9 DOD Archives: KG Gp 5, box 326, file KG/GPW/2/1/2 Verdedigingsprobleem en Oplossing:Waardering deur Veggenl. R. C. Hiemstra, 22 June 1960.

10 Commando, March 1960, 32; Commando, September 1961, 5.

11 Commando, July 1960, 3.

12 Commando, 43.

13 Commando, August 1964, 66-67.

14 Cape Times, 5 April 1962.

15 Prof Thom, speech in booklet (Stellenbosch: Department of Development, University of Stellenbosch, 1963), 4, 8-10.

16 Raymond Hancock, dir., Bastion of the South (Afrikaans: Vesting van die Suide) (Department of Information, Pretoria: South African Screen Productions, 1963); DOD Archives: KG Group 5, box 200, file KG/GC/5/1, Commandant General to Director of Military Intelligence, 1 August 1962.

17 Commando, April 1966, 41.

18 Hansard 103, (3rd Session, 12th Parliament, 15 January to 4 March 1960), 'Union of South Africa House of Assembly Debates (about defence)', entry 10 March 1960.

19 Boulter (1997), 69-70.

20 Dawid Grobbelaar, interviewed by Rodney Warwick, Constantia, 21 December 2006.

21 Colonel Jan Breytenbach left the UDF in 1953 for the UK armed forces, principally because of political interference; rejoining in 1961; he discussed recollections of the early 1950s UDF atmosphere where some members spoke of attaining 'revenge' against those who had served enthusiastically in WW2; Jan Breytenbach, interviewed (telephone) by Rodney Warwick, 26 June 2008.

22 Ivor Wilkens and Hans Strydom, The Super-Afrikaners (Johannesburg: Jonathan Ball Publishers, 1978), A50. 
Lt Gen Ian Gleeson (personal communication, email, 28 and 31 October 2007); Warwick (2009), 109-110.

Rudolph Hiemstra, Die Wilde Haf (Cape Town: Human \& Rousseau, 2001), 274-275.

Louisa Jooste, F.C. Erasmus as Minister van Verdediging 1948-1959 (MA thesis, University of South Africa (Unisa), 1995), 57-58.

Boulter (1997), 244.

Commando, July 1965, 43.

Commando, October 1966, 7-10.

John D'Oliveira, Vorster - The Man (Johannesburg: Ernest Stanton, 1977), 207-208.

Warwick (2009), 96-99.

Ibid., 117-127.

Lt Gen Dennis Earp, interviewed (telephone) by Rodney Warwick, 6 January 2008.

Paratus, October 1971, 58-59.

Hiemstra (2001), 307.

Die Burger, 18 February 2012.

Die Burger, 28 February 1962, 12.

Warwick (2009), 318-319.

Breytenbach (2008); Magnus Malan, interviewed by Rodney Warwick, Durbanville, 10 August 2007.

G.D. Scholtz, Die Republiek van Suid-Afrika en die nuwe Wêreld (Johannesburg:Voortrekker Press, 1962), 62-63.

DOD Archives: MVV, box 119, file MV 72, Ds. Oosthuizen to Verwoerd, 25 February 1960.

Hermann Giliomee, The Afrikaners (Tafelberg Publishers Likited, 2003), 527-529.

Commando, July 1959, 32.

Die Burger, 11 June 1960,1.

Hiemstra (2001), 289-290.

Giliomee (2003), 542.

Hiemstra (2001), 291.

Ibid., 285-287.

Ibid., 293-294.

Giliomee (2003), 547.

Hiemstra (2001), 293-294.

DOD Archives: KG Group 5, box 419, file KG/ADM/16 Gelukwensing, Simpatisering, Cmdt J.H.Vorster to Hiemstra, 30 July 1965.

52 Maj Gen Daan Hamman, interviewed by Rodney Warwick (telephone), July 2007; Gen Jannie Geldenhuys, interviewed by Rodney Warwick, (telephone) 14 November 2007; Wilkens and Strydom (1978), A69.

Commando, June 1964, 5.

Hansard 13-15 (4th Session, 2nd Parliament, 22 January to 18 June 1965), entry 25 May 1965.

Warwick (2009), 235-237, 248-252.

Cape Argus, 25 April 1960, 1. 

1983), 133-136; Boulter (1997), 67-68.

58 Alan Paton, 'The Second Quinquennium', in Liberal Opinion, 4(5) June 1966; Sunday Tribune, 29 May 1966, quoted in Vigne Randolph, Liberals Against Apartheid A History of the Liberal Party in South Africa, 1953-68 (London: McMillan Press, 1997), 213. Jonathan Hyslop, 'Shopping during a Revolution: Entrepreneurs, Retailers and 'White' Identity in the Democratic Transition', Historia, 50(1) May 2005, available at: [http://wiredspace.wits.ac.za/handle/10539/7858], 175-177.

Peter Randall, Little Englands on the Veld:The English Private School System in South Africa (Johannesburg: Raven Press, 1982); referring to both Ernie Malherbe, Education in South Africa, 2, (Cape Town: Juta, 1977), 679; Wilkens en Strydom (1978), 140-156. Huisgenoot, 27 May 1966, 17.

62 John Lambert, From British to South Africans: the evolution of a white English-speaking identity in South Africa until 1961, unpublished article, 2004, 18. 'Rhodesië se les vir SA se Engelstaliges', Vaderland, 26 October 1964, 12.

64 Natal Mercury, 17 August 1960, 3.

65 Natal Mercury, 9 November 1960, 10.

66 'Hobo' Hobson from Durban, a member of the 1960s RLI (personal communication, email: 14 January 2007); McGill Alexander, 'The Militarization of White South African Society, 1948-1990', Scientia Militaria, 30 (2), 2000, available at: [http://scientiamilitaria. journals.ac.za/pub/article/download/178/224], 283-284.

Paul Moorcroft and Peter McLaughlin, Chimurenga: The War in Rhodesia, 1965-1980 (Johannesburg: Sygma Books), 1982, 16; also Alexander Binda, The Saints: The Rhodesian Light Infantry (Pinetown: 30 Degrees South Publishers, 2007), 20.

The SA Legion publication, Springbok, during the 1960s referred regularly in a positive way to current SADF activities as did other ex-servicemen organisations publications.

69 Anthony Hocking, Oppenheimer and Son (Johannesburg: McGraw-Hill Book Company, 1973).

70 De Villiers Graaff, Div Looks Back: The Memoirs of Sir De Villiers Graaff (Cape Town: Human \& Rousseau, 1993).

71 John Lambert, 'Munitions Factories ... Turning Out a Constant Supply of Living Material': White South African Elite Boys' Schools and the First World War', South African Historical Journal, 51, 2004, available at: [https://www.researchgate.net/ publication/232967752_'Munition_Factories_Turning_Out_a_Constant_Supply_of_ Living_Material'_White_South_African_Elite_Boys'_Schools_and_the_First_World_War].

72 John Lambert, 'Their Finest Hour' English-speaking South Africans and World War II, 2007 (online), available at: [https://www.researchgate.net/ publication/232860330_'Their_Finest_Hour'_English-speaking_South_Africans_and_ World_War_II].

73 See Dennis Worrell's remarks in André de Villiers, (ed.) English-Speaking South Africa Today, Proceedings of the National Conference July 1974 (New York: Oxford University Press, 1976), 208-209.

74 Giliomee (2003), 525.

75 Gerhard Vermaak, who was balloted in 1962 serving at Walvis Bay, recalled widespread resentments regarding Jewish trainees especially being flown back to the republic for ten days during religious holidays (personal communication, correspondence, August 2007). 
76 DOD Archives: Adjutant Generaal (AG), Group 4, box 4, file No. AG 672/2,

Memorandum 'Inligtingswaardering opgestel deur die Direkteur van Militêre Inligting', 1 April 1963, 5-6.

77 Albert Grundlingh and Hilary Sapire, From Feverish Festival to Repetitive Ritual? The Changing Fortunes of Great Trek Mythology in an Industrialising South Africa, 1938-1988, South African Historical Journal, 21, 1989, available at: [https://www.tandfonline.com/ doi/abs/10.1080/02582478908671645], 33-34.

78 John Maxwell Coetzee, Youth (London: Random House, 2002), 39-40.

79 Neil Orpen, The Cape Town Highlanders 1885-1970 (Cape Town:The Cape Town Highlanders History Committee, 1970), 343.

$80 \quad$ Ibid., 343.

81 Ibid., 346

82 Gleeson (2007).

83 Cape Times, 20 January 1962, 13.

84 Cape Times, 1 October 1966, 9.

85 Gerald Shaw, author of The Cape Times: An Informal History (Cape Town: David Philip, 1999), interviewed (telephone) by Rodney Warwick, 6 April 2008.

86 Daan Prinsloo, Stem uit die Wildernis: 'n Biografie oor oud-pres P.W. Botha (Mossel Bay: Vaandel Uitgewers, 1997), 63; Commando, September and October 1968, 15; Cape Times Weekend Magazine, 27 November 1965; 4 December 1965. Ibid.

88 Neil Orpen, Total Defence (Cape Town: Nasionale Boekhandel, 1967).

89 I. Freese, Letter, Commando, November 1962, 9.

90 DOD Archives: KG Group 5, box 421, file KG/ADM/20D Navrae, Voorstelle en Klagte deur Publiek, Secretary of Defence, J.H. Badenhorst to the Commandant General, 18 November 1963.

91 Ibid.

92 Commando, March 1962, 1.

93 DOD Archives: KG Group 5, box 420, file KG/ADM/20C, vol.2, Navrae Voorstelle en Klagtes Deur die Publiek, Cmdt Cronje to Mr J.C. Greyling MP, 1 May 1965.

94 Ibid.

95 Commando, March 1962, 2; Commando, May 1962, 3.

96 This correspondent was insulting towards all language or population groupings besides Afrikaners.

97 André Wessels and Izette Bredenkamp, 'Military Chaplaincy in the SADF', Journal of Contemporary History, 34(1), February 2009, available at: [https://scholar.ufs.ac.za/xmlui/ handle/11660/4462], 335.

98 Jack Dutton (personal communication, email, 1 June 2006).

99 André Wessels and Izette Bredenkamp, 333-336.

100 Giliomee (2003), 558.

101 DOD Archives: Adjutant Generaal (AG), Group 4, box 4, file AG 672/2, Memorandum 'Inligtingswaardering opgestel deur die Direkteur van Militêre Inligting', 1 April 1963, 5.

102 Ibid., 6.

103 Ibid.

104 Grundlingh and Sapire (1989), 33. 
105 Commando, November 1967, 31-33.

106 Cape Times, 15 May 1961.

107 Commando, January 1959, 25.

108 Cape Times, 20 January 1962, 13.

109 Cape Times, 5 June 1964, 7.

110 'Spesiale bataljon beoog vir jeugdige oortreders', Vaderland, 2 October 1964.

111 Cape Times, 5 June 1964, 7.

112 Hyslop (2005), 175-177.

113 The CG Group at the Pretoria DOD has a large number of boxes containing exemption applications.

114 DOD Archives: KG Group 5, box 421, file KG/ADM/20D Navrae, Voorstelle en Klagte deur Publiek, Secretary of Defence, J.H. Badenhorst to Mrs J. du Plessis, Bloemfontein, 20 November 1963.

115 Ibid.

116 DOD Archives: KG Group 5, box 421, file KG/ADM/20D Navrae, Voorstelle en Klagte deur Publiek, Mrs J. du Plessis to H.F. Verwoerd, 16 November 1963.

117 DOD Archives: KG Group 5, box 421, file KG/ADM/20D Navrae, Voorstelle en Klagte deur Publiek, Secretary of Defence, J.H. Badenhorst to Mrs J. du Plessis, Bloemfontein, 20 November 1963.

118 United Party Archives (Unisa) (hereafter UP Archives): Defence, Correspondence 37.1, M. Friedman, D. Kretzmer and B. Glass to Major Piet van der Byl, 23 September 1965.

119 UP Archives: Defence, Correspondence 37.1, Anonymous correspondent to Major Piet van der Byl, 21 September 1965.

120 UP Archives: Defence, Correspondence 37.1, Major Piet van der Byl, 29 September 1965.

121 DOD Archives: KG Group 5, box 421, file KG/ADM/20D Navrae, Voorstelle en Klagte deur Publiek, Adjutant General to Commandant General, 15 December 1963.

122 Hansard (11 Feb 1965), 922-923.

123 DOD Archives: KG Group 5, box 422, file KG/ADM/20F Navrae, Voorstelle en Klagte deur die Publiek, J.A. Fourie to Secretary, Department of Defence, 15 June 1965.

124 D’Oliveira (1977), 209-210.

125 Hansard (17 June 1965).

126 UP Archives: Defence, Correspondence 37.1, De Villiers Graaff to Mr Clarke, Headmaster of Rondebosch Boys' High School, 4 February 1964.

127 Hansard (11 Feb 1965), 922-923.

128 Ian van der Waag, A Military History of South Africa (Johannesburg: Jonathan Ball Publishers, 2015), 241; Jack Dutton (personal communication, correspondence, 30 January 2007).

129 Van der Waag (2015), 219-220.

130 UP Archives: Defence, Correspondence 37.1, Piet van der Byl to The Secretary, Committee of Inquiry, 29 September 1965.

131 UP Archives: Defence, Correspondence 37.1, Anonymous correspondent to Major Piet van der Byl, 1965.

132 Ibid

133 Dutton (2006). 
134 Graeme Callistair, Compliance, Compulsion and Contest:Aspects of Military Conscription in South Africa, 1952-1992 (MA thesis, Stellenbosch University, 2007), available at: [https://scholar.sun.ac.za/handle/10019.1/2451], 62.

135 DOD Archives: KG Group 5, box 421, file KG/ADM/20D, Adjutant General to Commandant General, 26 March 1964; DOD Archives: KG Group 5, box 421, file KG/ADM/20D Navrae, Voorstelle en Klagte deur Publiek, J. von Moltke MP to Commandant General, 22 November 1963.

136 Gerhard Vermaak, Nylstroom (personal communication, email, August 2007).

UP Archives: Defence, Correspondence 37.1, Piet van der Byl to The Secretary, Committee of Inquiry, 21 September 1965.

138 Capt. T.F. Prinsloo, ed., Air Force Gymnasium Memorial Album, 1952-1977 (Pretoria: Promedia Publishing, 1977).

139 Cape Times, 5 June 1964, 7.

140 UP Archives: Defence, Correspondence 37.1, Piet van der Byl to The Secretary, Committee of Inquiry, 29 September 1965.

141 UP Archives: Defence, Correspondence 37.1, Anonymous correspondent to Major Piet van der Byl, n.d.

142 DOD Archives: KG Group 5, box 419, file KG/ADM/20A Navrae, Voorstelle en Klagtes deur die Publiek, CG Grobbelaar to Fouché, 13 October 1964.

143 Vice Admiral Martin Trainor, interviewed (telephone) by Rodney Warwick, 2 July 2007.

144 Cape Times, 20 August 1966, 7.

145 Warwick (2009), 281-282, 390-392; Pop Fraser, Revolutionary Warfare: Basic Principles of Counter Insurgency: Being a revision of 'Lessons Learnt from Past Revolutionary Wars' (Pietermaritzburg: 4 Survey and Printing Regiment, probably 1980s).

146 Commando, July 1960, 4, 6.

147 Hiemstra (2001), 281.

148 This can be ascertained, working through all Commando issues from 1949 to 1969.

149 Die Vaderland, 3 October 1964, 3; Chris Bennett, Three Frigates - The South African Navy comes of Age (Durban: Just Done Productions Publishing 2006), 57.

150 DOD Archives: KG Group 5, box 459, file KG/SER/10 Militêre Deelname: 75-jarige bestaan: Belfast; $S A W$ deelname: aerial display: official opening of tarred road from Harrismith to the Rand.

151 Hiemstra (2001), 285, 303.

152 Cape Times, 30 May 1966, 5.

153 This advertisement was also prominent in the press, see Commando, June 1967.

154 See Die Huisgenoot, 11 October 1963; Die Huisgenoot, 20 May 1966.

155 Hiemstra (2001), 310-311.

156 Commando, July 1966, 6-11.

157 Cape Times, 1 June 1966, 1.

158 Cape Times, 1 June 1966, 12.

159 Commando, July 1966, 6-7.

160 Cape Times, 1 June 1966, 3.

161 The Star, 1 June 1966.

162 Cape Times, 16 May 1966, 1.

163 Cape Times Festival Supplement, 30 May 1966. 
164 Callistair (2007), 46.

165 Cape Times, 2 May 1966, 12.

166 Al Venter, The Zambezi Saliant (Cape Town: Howard Timmins, 1974), 157-159; Barber, 147, 214-215. Alexander (2000), 281-282.

167 Alexander (2000), 281-282. 


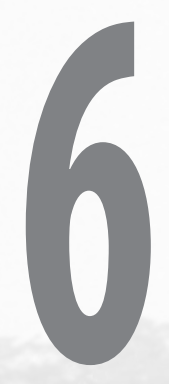

\section{THE KAVANGO JEUGBEWEGING} AND THE SOUTH AFRICAN COUNTERINSURGENCY CAMPAIGN IN NAMIBIA

Evert Kleynhans 
The Kavango Department of Education, at the behest of the government of South West Africa (SWA), ordered the creation of a local youth movement during 1975. The primary aim of the Kavango Jeugbeweging (youth movement) was to prevent the spread of communist propaganda, foster a sense of Kavango nationalism, and limit the political influence of the South West Africa People's Organisation (Swapo) amongst the local Kavango youth. The Institute for African Studies (IAS) at the then Potchefstroom University for Christian Higher Education (PU for CHE) played a crucial role in the formative years of the movement, by providing key sociocultural knowledge on the 'human terrain' of the Kavango people to the government of SWA. The creation of this movement coincided with the start of the conventional military involvement of the South African Defence Force (SADF) in the Angolan Civil War during 1975, as well as with the escalation of the Swapo insurgency in northern SWA. The South African Government hence developed a total national strategy to combat these threats in the military, social, political, economic and educational spheres. The Kavango Jeugbeweging formed an integral part of this strategy in the Kavangoland.

There has been an exponential increase in revolutionary wars and insurgencies in Africa since the end of the Second World War. These insurgencies, often referred to as the wars of decolonisation, were mainly waged by African liberation movements intent on securing their independence from European colonial powers. As such, some European counterinsurgency campaigns were waged across Africa before the former colonies gained their independence. ${ }^{1}$ An insurgency is defined as:

... an organised, violent and politically motivated activity conducted by non-state actors and sustained over a protracted period that typically utilises several methods, such as subversion, guerrilla warfare and terrorism, in an attempt to achieve change within a state. ${ }^{2}$

Insurgencies may have many aims, the most common being to gain control of territory, pursue the resolution of a grievance or to seek the overthrow of the existing political authority. The origins of insurgencies may be ideological, religious, ethnic, sectarian, class-based, or more generally, a combination of all these factors. Counterinsurgency, on the other hand, is defined as:

... [the] military, law enforcement, political, economic, psychological and civic actions taken to defeat an insurgency, while addressing the root causes. ${ }^{3}$

In counterinsurgency operations, the front lines are often blurred; there is no distinguishable enemy and often no clear end. It is a war waged amongst the people. The success of counterinsurgency operations is also often difficult to measure, and the results slow to be realised. ${ }^{4}$ 
According to historian Leopold Scholtz, South Africa fought three distinct wars during apartheid. The first war was fought against the African National Congress (ANC) insurgency within South Africa, with limited cross-border operations by South African security force personnel into Botswana, Zimbabwe, Mozambique, Swaziland and Lesotho to thwart the movement and its armed wing, Umkhonto we Sizwe (MK). The second was the counterinsurgency war fought against Swapo in SWA and Southern Angola. The SADF directed the mainstay of the South African security force operations in this war against the armed wing of Swapo, the People's Liberation Army of Namibia (PLAN). The third was a conventional war waged by the SADF against the People's Movement for the Liberation of Angola (MPLA) and its armed forces, the People's Armed Forces of Liberation of Angola (Fapla). The SADF became involved in this war in 1975 when it intervened in the Angolan Civil War. ${ }^{5}$ The focus of this chapter is however on the counterinsurgency war fought against Swapo in northern SWA and southern Angola by the South African security forces.

Abel Esterhuyse argues that the very nomenclature surrounding the South African military involvement in SWA and Angola remains extremely problematic. According to him, the labels 'Border War' or 'Bush War' are often used interchangeably, although there is a clear distinction between the two wars. Esterhuyse further states that the South African counterinsurgency war against Swapo was unconventional, and primarily fought inside SWA with some pre-emptive and follow-up operations into Angola and Zambia. This war is more commonly referred to as the Border War. The initial South African military involvement in support of the National Union for the Total Independence of Angola (Unita) in the Angolan Civil War, in contrast, was largely conventional in orientation and had an explicit strategic defensive purpose. It was also primarily directed against Fapla and their Cuban military allies within Angola. This war is more commonly referred to as the Bush War. He argues that the majority of the available literature on the South African involvement in both of these wars are also problematic, in that they romanticise South Africa's role in both wars, and often seek ideological justification for the country's involvement in them. He concludes that these works also clearly disregard the complex nature of both wars, by actively ignoring the participation of the Angolans, Namibians, Cubans and the Soviets in the conflict. ${ }^{6}$ Two of the most recent South African works that appeared on these wars are South Africa's 'Border War': Contested Narratives and Conflicting Memories ${ }^{7}$ written by Gary Baines, and A Far-Away War: Angola, 1975-1989 ${ }^{\circ}$ edited by Ian Liebenberg amongst others. These two publications are refreshingly liberal in outlook, and despite some flaws provide a counterpoint to the mainly conservative, and at times hagiographic, 'drum and trumpet' or campaign histories on the South African military involvement in SWA and Angola.

Despite those mentioned above, the South African counterinsurgency war in northern SWA has received some scholarly attention over the past thirty years. Some of the 
more notable works include those authored by Francis Toase, ${ }^{9}$ John Turner, ${ }^{10}$ Anita Gossmann, ${ }^{11}$ Abel Esterhuyse and Evert Jordaan, ${ }^{12}$ Kersti Larsdotter, ${ }^{13}$ Richard Dale, ${ }^{14}$ and Leopold Scholtz. ${ }^{15}$ The majority of these scholarly works are, however, primarily focused on the South African security force operations against PLAN insurgents, and have measured the conduct of the war against well-established counterinsurgency theories. As such, one often overlooks the social, political, economic and administrative elements of counterinsurgency warfare. Lieneke deVisser, on the other hand, challenged the more conservative approaches to the study of the counterinsurgency operations in northern SWA. ${ }^{16}$ In an article, she argued that:

the overall direction of a counterinsurgency war belongs with the civilian power, and the armed forces are but one of many instruments at its disposal. ${ }^{17}$

In doing so, she demonstrated that there was a complete lack of unity of purpose and effort in the counterinsurgency war in northern SWA, and that this had a detrimental effect on the South African, and in particular SADF, efforts at winning the hearts and minds (Wham) of the local population in the operational area.

Military forces have historically used and abused both anthropology and ethnography for their gain during times of war. ${ }^{18}$ The most recent example is the Human Terrain System Programme of the United States (US) Armed Forces, which was established by the US Army Training Doctrine and Command between July 2005 and August 2006 amidst substantial controversy. ${ }^{19}$ In the South African context, Lindy Heinecken and Donna Winslow, as recently as 2010, have debated the value of 'Human Terrain', ipso facto cultural intelligence, and the possible lessons it might hold for the South African National Defence Force in modern counterinsurgency operations. ${ }^{20}$ The Namibianborn anthropologist Rob Gordon was one of the first individuals to alert academia on the extensive cooperation between the SADF, security police and some Afrikaner academics during the counterinsurgency war in SWA. ${ }^{21}$ This element of the South African counterinsurgency campaign in SWA, including the involvement of PU for $\mathrm{CHE}$ in the establishment of the Kavango Jeugbeweging, has received no real scholarly attention. Two postgraduate studies from the University of the Western Cape have discussed elements that are in part related to the Kavango Jengbeweging during the period in question, although both Herberth Karapo and Michael Akuupa have failed to address the reasons behind the establishment of the movement. They have also failed to take the South African counterinsurgency strategy in northern SWA into account. Both authors clearly do not understand the military environment, nor the complex and multi-dimensional nature of counterinsurgency warfare, especially during the Swapo insurgency in SWA. These studies do, nonetheless, provide unique insights into the later functioning of the movement, how the community viewed it, as well as its eventual demise. ${ }^{22}$ 
This chapter has three specific aims. First, to investigate the reasons behind the establishment of the Kavango Jeugbeweging in 1975, by providing a brief historical background to the South African counterinsurgency campaign in northern SWA. Second, to explain the nature, extent and the development of this youth movement between 1975 and 1987, with a specific focus on the role that the IAS at the PU for CHE played in the formative years of the movement. Lastly, the chapter will evaluate the effectiveness of this youth movement, as a counterinsurgency tool, within the framework of the broader South African counterinsurgency strategy deployed in northern SWA during the Border War. To elucidate the background, nature and development of the Kavango Jeugbeweging, the author draws from a myriad of primary archival sources, from both governmental and private institutions, as well as private and official correspondence, along with a host of secondary sources. In doing so, the chapter uncovers an aspect of the South African counterinsurgency campaign in SWA that has received little or no scholarly attention to date.

\section{BACKGROUND TO SOUTH AFRICA'S BORDER WAR}

The SA Government became involved in a major counterinsurgency campaign in SWA from 1966. During that year, the United Nations (UN) General Assembly revoked the South African mandate over SWA, granted in 1920. By June 1968, the UN General Assembly renamed the territory Namibia and called for its independence. The International Court of Justice, furthermore, declared the South African presence in Namibia illegal during July $1971 .{ }^{23}$ During the same time, the nationalist movements within the territory started to threaten the South African presence increasingly. The largest military and political threat to South Africa Government in SWA was Swapo. Soon after its establishment in April 1960, Swapo decided to use force in its quest to gain the independence of Namibia. The first batch of PLAN insurgents infiltrated SWA during 1965 and established bases in Ovamboland. Ovamboland consequently formed the nerve centre of the Swapo insurgency, as the Ovambo people formed the party's major support base. ${ }^{24}$ During August 1966, South African security forces attacked the Swapo camp at Ongulumbashe and killed some PLAN insurgents. Swapo regarded the attack on Ongulumbashe as the opening of the 'final phase' of its liberation struggle. The attack on Ongulumbashe forced Swapo to relocate its in-country bases within SWA to the relative safety of Zambia. The Swapo bases in Zambia, geographically removed from their primary target area of Ovamboland, naturally hampered the insurgency. The PLAN insurgents were therefore forced to infiltrate SWA via two distinct routes that stretched over vast distances. ${ }^{25}$ The first route was via south-eastern Angola, under Portuguese control. Since 1961, operations against an insurgency backed by various nationalist movements kept the Portuguese military involved in counterinsurgency. The SADF supported the Portuguese counterinsurgency operations in Angola from 1968 under the auspices of Operation 
BOMBAY. The major Angolan nationalist movements involved in this insurgency were the MPLA, the National Front for the Liberation of Angola (FNLA) and Unita. The second route was via north-eastern SWA and the Caprivi Strip where the SADF had a few military bases. ${ }^{26}$

PLAN insurgency intensified between 1966 and 1974. In the military sphere, small groups of insurgents infiltrated SWA through southern Angolan and the Caprivi Strip with the explicit aim of conducting sabotage and harassing the SA security forces and the local civilian population. In the political sphere, Swapo sought to politicise the SWA people in an attempt to gain popular support, while concurrently working to establish a viable political structure within the territory. The South African Police (SAP) was initially the main protagonists in the counterinsurgency campaign in SWA, with the SADF merely acting in a supporting role. The SAP attempted to prevent the infiltration of Swapo insurgents by blocking their infiltration routes from Zambia and Angola into SWA through a series of regular patrols and combined operations. The SADF launched these operations from M'pacha in the Caprivi, Ondangwa in Ovamboland and Rundu in Kavangoland.The Security Police furthermore monitored internal political activities of Swapo and detained suspected Swapo adherents within SWA. ${ }^{27}$ These measures met with some success, as Swapo was unable to gain a political foothold in SWA, while the actions of its military wing PLAN were negligent. The South African Government subsequently pressed ahead with the findings of the Odendaal Commission and incorporated SWA into the Republic as a de facto fifth province. By May 1973, the two largest homelands in SWA, Ovamboland and Kavangoland, also gained a level of independence as self-governing territories within the territory. ${ }^{28}$

By 1974, the general security situation in southern Africa drastically changed following the overthrow of the Portuguese Government during a coup d'état in April of that year. Angola, along with Mozambique and Portuguese Guinea, gained its independence from Portugal in November 1975 after the signing of the Alvor Agreement, whereafter the country spiralled into a civil war. The diminished cordon sanitaire created a situation conducive to the Swapo insurgency. Swapo was hence able to establish bases in the southern part of Angola, and could, in theory, infiltrate SWA along its entire $1600 \mathrm{~km}$ long northern border. The main PLAN infiltration route was via the $280 \mathrm{~km}$ long border between Ovamboland and Angola, which was geographically featureless and largely porous due to the overwhelming Ovambo support for Swapo. ${ }^{29}$ By 1974, Swapo intensified its armed struggle, with operations extending to the Caprivi Strip, Ovamboland, Kavangoland and the white areas in the so-called murder triangle around Grootfontein-Tsumeb-Otavi. Coincidentally Swapo had also declared 1974 as 'the year of the kill'. ${ }^{30}$ Despite the initial counterinsurgency successes of the SAP, the deterioration of the security situation along the northern border of SWA between 1974 and 1975 compelled the SADF to assume overall 
responsibility for all counterinsurgency operations along the northern border of the territory. It forced the SADF to adopt a comprehensive counterinsurgency strategy from 1974, that brought with it fundamental changes to the South African policy within SWA. This new strategy focused on the military, political, social and economic dimensions of counterinsurgency warfare as a counter to the intensification of PLAN insurgency. The so-called 'Total Strategy' was a multi-component strategy based on the experiences of other countries in counterrevolutionary warfare and low-intensity conflict. The SADF largely based their strategy on the writings of the French General, André Beaufre, and an American Army Colonel, John McCuen. Militarily, the SADF was forced to check the influence of Swapo within SWA for the political, social and economic initiatives of the SA Government to be implemented. By June 1974, the South African military strength within SWA was gauged at 15000 men. By early 1976, this number had escalated to 45000 men as Pretoria continued to devote a significant portion of its military resources to the defence of SWA. ${ }^{31}$

The SA Government sought to deliver a crushing blow to both Swapo and the MPLA by intervening in the Angolan Civil War during 1975. In conjunction with Unita, the SADF was able to destroy several Swapo bases in southern Angola as part of Operation SAVANNAH. These locations were revealed to the SADF by Unita who had shared some of these bases with Swapo before the start of the Angolan Civil War. The SA Government, politically isolated and logistically overstretched, was forced to end Operation SAVANNAH and withdraw its troops from Angola between January and March 1976. Swapo, as a result, soon re-established itself in southern Angola with the backing of the MPLA government. ${ }^{32}$ The South Africans were thus forced to reconsider their counterinsurgency approach towards PLAN insurgency and developed a new approach, based on four key elements. Firstly, the South Africans wished to exploit any political divisions within Swapo to their benefit and cause a political rift within the organisation. Secondly, desertions were encouraged from amongst the PLAN cadres through a dedicated propaganda campaign. Thirdly, the SADF aimed to destroy the in-country organisational efforts of Swapo. Fourthly, the SADF established a civicaction programme amongst the local inhabitants in the northern border areas of SWA. Pretoria sought to use the SADF as a development agency of sorts in its civic-action programme, and the military became increasingly involved in rendering agricultural, educational and medical assistance as part of the counterinsurgency campaign. ${ }^{33}$ It is against this backdrop that the SADF first conceptualised and established the Kavango Jengbeweging.

\section{THE ORIGIN AND ESTABLISHMENT OF THE KAVANGO JEUGBEWEGING}

During July 1975, Elrick Pretorius, in his capacity as the Youth and Culture Organiser of the Kavango Department of Education, was tasked to establish an indigenous 
youth movement amongst the Kavango people to prevent the spread of communist propaganda, to foster Kavango nationalism, and limit the influence of Swapo amongst the local Kavango youth. ${ }^{34}$ At the end of that month, Pretorius contacted the IAS at the PU for CHE to seek assistance with the conceptual implementation of the Kavango Jengbeweging. He supplied a detailed confidential report on the problems facing the establishment of a youth movement in Kavangoland. The report in part states that a mere 400 teachers taught approximately 13000 school children in Kavangoland in only 150 schools. There were hardly any extramural activities on hand, and very few teachers were qualified to oversee leisure time and sports activities. A then recent survey had established that approximately 600 children no longer attended school and that some children had joined the various terrorist organisations across the Cubango River in Angola. Evidence even suggested that some children were receiving training with these groups in Zambia. During 1974, Swapo had held a meeting at Calai in Angola during which they organised a loose-knit political organisation amongst the secondary school learners of the Kavangoland. Some of the learners also attended an interdenominational Christian rally at Döbra near Windhoek, where Swapo openly preached its propaganda. The report concluded that it was evident that the Kavango youth had become politicised by Swapo, and that drastic measures had to be taken to stem this influence. ${ }^{35}$

Towards the end of August 1975, Prof Hennie Coetzee, the Director of the IAS and a trained anthropologist, replied to Pretorius confirming the IAS's willingness to render assistance with his request. For a start, the IAS pledged to provide Pretorius with some useful literature on communism and its 'intrusion' in Africa. Coetzee further suggested that the Malawi Young Pioneers, as well as its sister movements in Zambia and Ghana, should act as the theoretical blueprints for the establishment of the Kavango Jeugbeweging. ${ }^{36}$ These movements, Coetzee argues, were prime examples of youth movements that were established to nullify the spread and influence of communism amongst the young people of Africa. A chapter written by A.W. Wood carries this argument. He states that these movements were part of large-scale governmental youth training programmes or national youth services, that had:

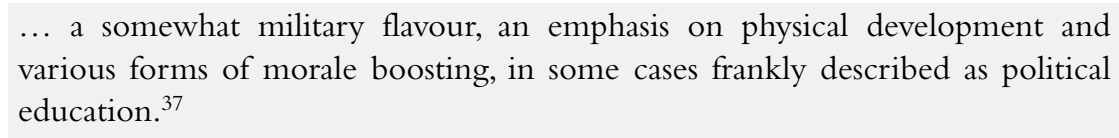

It is of interest to note that these organisations were established under the auspices of the Israeli government during their constructive engagement with Africa, starting in the 1960s. The young pioneers' movements in African were modelled on the Israeli Gadna programme. The Gadna programme was established with the sole purpose of preparing young people for military service with the Israeli Defence Force, while it also served as a tool for political education. The programme dated back to 1949 
and was established soon after the founding of the state of Israel the year before. The Gadna programme to this day focuses on discipline, as well as military and physical training, and falls under the command of the renowned Nahal Infantry Brigade. ${ }^{38}$

Both Pretorius and Coetzee realised that before establishing a youth movement in practice, a detailed study of the culture, history and languages of the Kavango people was a necessary prerequisite. ${ }^{39}$ By the end of August, Coetzee sent Pretorius copies of some radio talks that he had presented for the Tswana service of the South African Broadcasting Corporation on communism, and that he believed could be generalised for use and distribution amongst the Kavango youth. ${ }^{40}$ During October, Coetzee also posted Pretorius a copy of a publication on the Malawi Young Pioneers, as well as more information on Swapo and a pamphlet titled The Christian Mission in the Communist World. ${ }^{41}$ By the end of the month, Pretorius once more wrote to Coetzee, emphasising the urgency of the training of youth leaders, and requested his professional help in the drafting of a basic training programme for the Kavango Jeugbeweging. The changing security situation within Kavangoland brought about by the relocation of Swapo bases to southern Angola between 1974-1975, as well as the start of Operation SAVANNAH was a concern to Pretorius. It enticed him to secure the cooperation of the SADF, who promised the services of some of its professional personnel alongside Coetzee and his colleagues. ${ }^{42}$

By the end of November, Coetzee once more wrote to Pretorius and gave his views on the confidential report sent to him in July on the establishment of the Kavango youth movement. He suggested that he and his colleagues needed to visit Kavangoland in-person to examine the existing situation first-hand and to meet Pretorius to discuss the proposed structure of the Kavango Jeugbeweging. He further suggested that it would be particularly useful to meet at Rundu. He also provided Pretorius with an initial analysis based on the confidential report of the Kavango Jeugbeweging. He addressed factors such as the need for a youth movement in Kavangoland, as well as the risk associated with the establishment thereof. Coetzee's greatest fear was that the youth movement might become a weapon of the very elements that it was trying to subvert - Swapo. In principle, Coetzee suggested that sport and leisure time activities would form the initial backbone of the organisation and that the key to success would be the direct and continued involvement of the Kavango Government. ${ }^{43}$

During February 1976, Coetzee and Dr Hendrik van der Wateren, a fellow anthropologist, were invited by the Kavango Department of Education to visit the region for a fact-finding mission. The urgent need for their visit was once more emphasised by Pretorius, as he desired to start the training of Kavango youth leaders as soon as possible. ${ }^{44}$ The visit to Kavangoland occurred from 24 to 29 March 1976 and coincided with the end of Operation SAVANNAH. ${ }^{45}$ During their visit, Coetzee and Van der Wateren called at various Christian missions and schools, but failed to attend 
the inaugural Hompa Leevi youth leaders camp at Mbunza. They spent the majority of their time in talks with the military staff at the headquarters of 1 Military Area (1MA) at Rundu, as well as the command element of the Kavango Battalion (202 Battalion). ${ }^{46}$ The headquarters of 101 Task Force, which oversaw Operation SAVANNAH, was located at Grootfontein, approximately $240 \mathrm{~km}$ south of the border with Angola. There were two operational areas under the command of 101 Task Force: 1MA with its headquarters at Rundu in Kavangoland, and 2 Military Area (2MA) with its headquarters at Oshakati. The SADF operations in Kavangoland and Western Caprivi was run by $1 \mathrm{MA}$, while $2 \mathrm{MA}$ conducted all military operations in Ovamboland and the Kaokoveld. The Eastern Caprivi fell under 13 SubArea, which was a sub34division of $1 \mathrm{MA}$ but operated as a separate command. ${ }^{47}$

On 10 May, Coetzee wrote to thank Pretorius for their visit. He attached a detailed report on the Kavango Jeugbeweging and their findings. They also circulated their report to the Kavango Secretary of Education, who was also coincidentally Pretorius' father in law, and the Commissioner General of South West Africa. ${ }^{48}$ The report revealed several interesting elements. The name and motto of the movement translated into diligence from the Kwangali dialect of the Kavango and had great significance as it related to the goals of the Kavango Jeugbeweging. The Kavango Jeugbeweging was to establish a national consciousness amongst the Kavango youth to shift the political, cultural and economic awareness of this group from that of traditional clan-based loyalties to one of a national character. 'Kavango unity', they argue, would prevent Swapo from using the Kavango Jengbeweging to its advantage and fostering anti-white feelings amongst the Kavango population. Both Coetzee and Van der Wateren stressed the importance of writing up the history of the entire Kavango and its people, to promote the national character and instil a sense of national pride. The Kavango Jeugbeweging as an organisation, they stated, was a first of its kind within the South African sphere of influence and was thus not allowed to fail. They further argued that Pretorius would have to nominate and train a Kavango understudy to take over the leadership of the organisation, as this would emphasise the fact that the movement was for the benefit of the Kavango people. The success of the youth movement, they argued, would be dependent on the operation thereof. At first, the focus would be on the training of leaders for the movement; whereafter the focus would shift to sport and leisure time utilisation as a means of combatting idleness and boredom amongst the Kavango youth. After that, the movement's focus would gradually change to issues such as family relations, good citizenship, political education, discipline, and establishing a purified Christian Kavango culture. ${ }^{49}$ The end goal of the Kavango Jeugbeweging was the establishment of an effective training programme that would ensure that the Kavango youth became goal-orientated, staunch nationalists and good Christian citizens. The state could then recruit future Kavango police officers, soldiers, firefighters and civil servants from the ranks of this movement. ${ }^{50}$ 
At the request of Defence Headquarters, Coetzee once more travelled to Kavangoland during June 1976 to address approximately 500 teachers on the importance of Kavango nationalism. ${ }^{51}$ In July, Pretorius wrote to Coetzee and requested his professional assistance in the drafting of a manual, titled Burgerleiding, for use in the training of the regional leaders of the Kavango Jengbeweging. Pretorius also suggested to Coetzee that he wished to contact academics at other South African universities to help with the writing of the manual. ${ }^{52}$ One can deduce that this did not sit well with Coetzee, as communication between him and Pretorius immediately broke down. Henceforth, only Van der Wateren corresponded with Pretorius. By the beginning of August, Van der Wateren suggested that several Potchefstroom academics would contribute chapters to this manual. These chapters focused on a variety of topics such as international political relations, the independence struggle in Africa, communism, terrorism, South Africa's relations with the Kavango, patriotism, nationalism and culture. ${ }^{53}$ Pretorius agreed to the suggested outline of the manual, ${ }^{54}$ and Van der Wateren promised to deliver the manual by March 1977. ${ }^{55}$ The promised chapters of the manual were only provided to Pretorius in April 1977, whereafter Van der Wateren intimated that he and Coetzee wished to visit Kavangoland once more in June 1977. This trip never materialised. ${ }^{56}$ By October 1977, the final correspondence between the IAS and Pretorius occurred, because Pretorius had failed to acknowledge receipt of the Burgerleiding manual. It signalled the end of the constructive engagement between the PU for CHE and the Kavango Department of Education. ${ }^{57}$

Be that as it may, there is some evidence that suggests that the Kavango Jeugbeweging continued to operate in an unabated form until about 1987, when the movement ended abruptly. By 1978, the main camp of the Kavango Jeugbeweging at Shambyu, more commonly known as Ekongoro, was upgraded to a fully-fledged cultural centre, managed by Pretorius. The cultural centre comprised a museum, botanical garden, dormitories, kitchen, dining hall and administrative office block. The centre operated according to ten laws, to which anyone who wanted to be part of the Ekongoro activities had to conform. ${ }^{58}$ By the mid-1980s, the Kavango Jengbeweging concerned itself primarily with the organising of a sangfees (a song festival) amongst the local Kavango youth. The various district leaders of the movement had to oversee teacher training and workshops on the activities of the sangfees and help to compose a sangbundel (songbook). The finale of the sangfees occurred at Ekongoro, where the various student groups performed selected songs from the sangbundel. These songs included the Kavango anthem, Christian hymns and other local folk songs. The soldiers from 202 Battalion became increasingly involved in the sangfees from the mid1980s, despite widespread disapproval from the local community. Akuupa, an anthropologist, argues that though the sangfees was organised to preserve the culture and tradition of the Kavango people, it increasingly became a politicised space where the SADF actively discredited Swapo and spread South African propaganda. He also argues that 
the continued presence of soldiers at the sangfees was an indirect measure from the SADF to emphasise their authority within the Kavango. The Kavango Jeugbeweging and the sangfees continued until Pretorius was recalled to South Africa somewhere between 1985 and 1986. It seems as if Pretorius' disagreement with senior military officials and education administrators, who felt that he had to promote the Kavango Jeugbeweging during the sangfees for various political and military means, hastened his departure. Pretorius vehemently opposed this strategy. After it became apparent that several teachers were unwilling to cooperate with Pretorius, the SADF removed him from his position. A certain Jan Bradley replaced Pretorius in 1987 and became the last Youth and Culture organiser of the Kavango Department of Education. During his tenure, the sangfees became increasingly dominated by the soldiers of 202 Battalion, amidst mounting pressure from the local community to halt the pseudo-cultural activities at the Ekongoro camp. ${ }^{59}$

\section{THE KAVANGO JEUGBEWEGING AS A LENS TO THE BROADER COUNTERINSURGENCY CAMPAIGN}

The Kavango Jeugbeweging provides an interesting lens through which to analyse the South African attempts at Wham amongst the local SWA population, the growing 'namibianisation' of the counterinsurgency war, and the unprincipled use of academics by the SADF during the Border War. In doing so, the section also discusses the broad course of the South African counterinsurgency campaign in SWA.

De Visser argues that the SADF sought to gain the cooperation of the local SWA population in several ways. It included the provision of socio-economic help, instilling respectful attitudes towards the population amongst the South African soldiers, and through a sustained propaganda campaign aimed at undermining local support for Swapo and at the same time instilling a positive attitude towards the SA government. The purpose of the SADF Wham campaign was:

to obtain intelligence and deny the insurgents food, shelter and intelligence ... [and] ... to cultivate a positive attitude towards the authorities ... to make the population less susceptible to enemy propaganda and more receptive to psychological action by the SA authorities. ${ }^{60}$

Esterhuyse argues that the SADF Wham campaign was more successful in Kavangoland and the Caprivi as opposed to Ovamboland, mainly due to Swapo having more support in the latter. ${ }^{61}$ The Kavango Jengbeweging was a pseudo-cultural organisation established with the explicit aim of Wham of the local Kavango population, and to develop a positive attitude towards the South African regime. Herbert Karapo argues that the youth movement was further used to indoctrinate the local Kavango youth 
with anti-Swapo ideologies and that its organisation was not really as cultural as it sounded, but rather used as a strategy to achieve the political-military agenda of the SADF and to foster an overarching Kavango nationalism. ${ }^{62}$

Akuupa also states that the Kavango Jeugbeweging was not a one-of-a-kind organisation but that similar pseudo youth movements functioned in Hereroland and Ovamboland during the Border War. These youth movements were used to counter the radical politicisation that Swapo advocated. ${ }^{63}$ According to Akuupa, the Kavango Jeugbeweging did not, however, have a universal appeal across Kavangoland. In the uKwangali District, near modern-day Nkurenkuru, the general perception of the inhabitants towards the SADF and the youth movement was negative. It was, in part, due to the unprecedented number of PLAN combatants who operated in the district and who were able to actively counter the anti-Swapo propaganda and mobilise popular support for the insurgency. The youth camp, supposed to be established at Katara in this district, also never materialised due to the ongoing threats posed by the presence of PLAN cadres. ${ }^{64}$ One finds this hard to believe, as there is overwhelming evidence suggesting that Swapo, and PLAN for that matter, hardly had a foothold in Kavangoland after 1978. A closer investigation of the evolution of the South African counterinsurgency campaign confirms this.

Between April 1975 and March 1977, fighting in Ovamboland, Kavangoland and East Caprivi lead to the killing of a total of 231 insurgents, 33 security force personnel and 53 local inhabitants. According to South African intelligence reports, there were roughly 300 Swapo insurgents active in Ovamboland by October 1977, with a further 2000 and 1400 insurgents located across the border in Angola and Zambia respectively. Reports showed that roughly 100 'contacts' between the security forces and insurgents per month. By 1978, Swapo had a significant number of forward operating bases located in Angola within striking distance of northern areas of SWA. The security that Angola offered Swapo was all but relative and extremely short-lived. The Angolan Civil War continued unabated after the culmination of Operation SAVANNAH in March 1976. It had particularly severe consequences for Swapo. From 1976, there was a vast number of MPLA/Cuban forces deployed to southern Angola to counter Unita rebels and to prevent further SADF incursions. South Africa, in turn, provided Unita with direct military assistance, which made it an enemy of Swapo. ${ }^{65}$

The South African defence analyst, Helmoed-Römer Heitman, argues that the immediate result of the relocation of Swapo bases to southern Angola was the planning of a very large PLAN incursion into SWA during 1978 to disrupt the elections scheduled for that December. The SADF realised that a pre-emptive strike against the Swapo bases in southern Angola was necessary to stop the impending incursion of PLAN insurgents. The SADF subsequently launched Operation REINDEER, which was both the first South African major cross-border operation against Swapo as well as the first operation directed against Swapo bases deep inside Angola. ${ }^{66}$ 
Overall, Operation REINDEER was quite successful, despite a few setbacks. During the operation, 859 experienced PLAN cadres were killed, 202 captured and at least 340 wounded, with valuable intelligence gained from the seizure of high-level Swapo documents at Cassinga. The SADF lost six soldiers who were killed and effectively halted the planned large-scale PLAN infiltration of SWA. ${ }^{67}$

The SADF planned two further pre-emptive cross-border operations in 1979 after it became known that Swapo had recovered from the previous year's attacks, and that PLAN was preparing for a new large-scale infiltration of Ovamboland. Swapo was also in the process of opening up the Caprivi as an active front. The SADF launched Operation REKSTOK against Swapo targets in southern Angola and Operation SAFRAAN against Swapo targets in the south-west of Zambia. These two operations met with some success, although the SADF mainly encountered evacuated Swapo camps and only inflicted some casualties. The planned Swapo infiltration of the Caprivi never materialised, and as a result, the movement was forced to step down operations in northern SWA. An important outcome of Operation SAFRAAN was that Zambia hence denied Swapo to launch incursions from their territory. The year 1980 thus marked a turning point in the Border War, after which Swapo attacks in Ovamboland drastically declined. The SADF soon realised that pre-emptive crossborder attacks against Swapo bases were not the answer. The new strategy adopted by the SADF called for the launch of spoiling attacks with the explicit aim of disrupting Swapo efforts to prepare and support infiltrations, and to disrupt their infrastructure in southern Angola. ${ }^{68}$ As part of the SADF strategy of disruption, they conducted several cross-border operations from 1980. These operations prevented Swapo from rebuilding its forward staging areas near the SWA border and forced the movement to relocate its bases deep into Angola. The most notable operations include SCEPTIC, PROTEA, DAISY, SUPER, MEEBOS and ASKARI. The external South African operations persuaded the MPLA to protect the Swapo bases in the south of Angola. It did not perturb the SADF, and they decided to engage any Fapla forces who attempted to interfere with their cross-border operations against Swapo. The South Africans also felt obliged to establish dominance in the area to the north of the AngolaOvamboland border. The direct result of this South African strategy was a sudden, sharp, sustained decline in Swapo activity in Ovamboland. ${ }^{69}$ It ultimately led to the signings of the Lusaka Agreement in 1984, which called for the withdrawal of the SADF from southern Angola and for MPLA to prevent Swapo from establishing bases in the area. The Lusaka Agreement, however, totally failed, as the MPLA government did not enforce the agreement and Swapo was allowed to re-establish its bases in southern Angola. ${ }^{70}$

After the failure of the Lusaka Agreement, the SADF decided to step up its support for Unita. Through this, they hoped to achieve two aims. Firstly, Unita dominance of south-east Angola would seal off the Caprivi and Kavangoland from direct Swapo 
cross-border infiltrations. It would dramatically reduce the length of the border that would require full protection. Secondly, a Unita insurgency would force the MPLA government to reconsider its support and protection of Swapo. It would allow the SADF to attack Swapo bases with relative ease. These operations included the 1987/1988 campaign of Operations MODULER, HOOPER, PACKER and DISPLACE. The Unita dominance of southern Angola successfully prevented the Swapo infiltration of the Caprivi and most of Kavangoland. The majority of Fapla and Cuban forces in the south of Angola was tied up in operations against Unita, which led to little or no forces to protect and support Swapo. The MPLA government further required Swapo to provide troops to help fight the Unita insurgency. By the mid-1980s, nearly one-third of the total strength of Swapo was allocated to security and counterinsurgency tasks in south-eastern Angola, leaving preciously few forces for raids into Ovamboland. ${ }^{71}$

The intention of Swapo to have waged a classic insurgency failed dismally. The movement failed to move beyond acts of agitation, propaganda and terrorism, and never had the capability of conducting a conventional war against the SADF by itself. The Swapo campaign in northern SWA failed because of no real support in the Caprivi, especially after the success of Operation SAFRAAN in 1978. In Kavangoland, Swapo found it increasingly difficult to win popular support amongst the local population, particularly after the SADF started to conduct 'external operations' into Angola to stem the insurgency through pre-emptive measures. The South African pro-active support of Unita after the breakdown of the Lusaka Agreement of 1984, successfully denied Swapo from establishing a permanent presence in southern Angola. The SADF further maintain that there were only 30 PLAN fighters in Ovamboland, 23 in Kaokoland and practically none in Kavangoland by the end of 1984. Heitman argues that the inability of Swapo to gather support in Kavangoland and Caprivi was largely thanks to a dislike and distrust of the organisation by the local population, rather than the result of the South African counterinsurgency strategy in northern SWA. ${ }^{72}$

The Kavango Jeugbeweging was in its essence nothing more than a pseudo-cultural organisation, established with the sole purpose of countering Swapo propaganda, kerbing the exodus of Kavango youth from joining Swapo in exile, and supplying the South African security forces with strategic human capital for it counterinsurgency operations in northern SWA. De Visser, however, states that by 1989, the underlying assumption that civic and psychological action could affect a change in attitude in the ideological mindset of the population was proved to be largely unsuccessful in Ovamboland. According to Visser, this region was never under complete South African control, and Swapo was able to capture 92 per cent of the total votes cast during the 1989 election. In contrast, the results in Kavangoland and Caprivi regions that were firmly under South African control, seemed better. Swapo only managed to capture 52 per cent and 45 per cent of the votes in Kavangoland and the Caprivi respectively. 
The Kavango Jeugbeweging may have played an insignificant role in achieving these results in Kavangoland. ${ }^{73}$

The establishment of the Kavango Jeugbeweging furthermore ties in with a crucial, but often overlooked, part of the South African military campaign in SWA - the policy of the 'namibianisation' of the counterinsurgency war. Pretoria, in general, sought to transfer the military burden, and indeed ownership, of the counterinsurgency operations in SWA to the local inhabitants of the territory. Initially, only white South West Africans were considered for combat roles, while non-white soldiers were confined to support roles. This policy, however, drastically changed after 1974, and they adopted a new racially inclusive military system in SWA.The SADF subsequently launched a recruitment campaign amongst all inhabitants of SWA that invariably led to the raising of military units on an exclusively ethnic basis. As such, they formed army battalions from the San in 1974, and the Ovambo, Kavango and Caprivi peoples during 1975. ${ }^{74}$ By 1977, the SADF centralised the command and control of all military activity in Windhoek and established the South West Africa Territorial Force (SWATF) in August 1980. The SADF subdivided the entire SWA into seven sectors who each fell under the command of SWATF headquarters in Windhoek. Of the seven sectors, the SADF was responsible for the defence of Sector 10 (Kaokoland and Ovamboland), Sector 20 (Kavangoland, Boesmanland [Bushman's land] and Western Caprivi) and Sector 70 (Eastern Caprivi) ${ }^{75}$

Richard Dale maintains that Pretoria localised the counterinsurgency campaign in SWA from 1974 to 1980 through the creation of 'apartheid-like' military structures in Ovamboland, Kavangoland and the Caprivi. The local battalions, created in each homeland under the guise of SWATF, held two main attraction for the South African defence planners. ${ }^{76}$ First, the burden of the casualties in the Border War shifted from South African soldiers to that of locally recruited SWATF soldiers. Second, to comply with the UN Security Council Resolution 435 adopted on 29 September 1978, which called for the withdrawal of South African troops from SWA, the SWATF could fill the void left by the SADF and continue the counterinsurgency operations against Swapo. ${ }^{77}$ From 1982, local forces such as 202 Battalion in Kavangoland accounted for nearly 60 per cent of all operational forces in SWA. ${ }^{78}$ It is, in turn, evident that the Kavango Jeugbeweging served as a recruitment pool for the SADF from 1976, and that the various youth camps were aimed to empower the young people with semi-military skills while developing an interest in the South African security forces. According to Karapo, the majority of the Kavango youth who joined the SADF or Koevoet, the renowned SAP counterinsurgency unit, were graduates from the five youth camps ${ }^{79}$ established at Mbunza, Shambyu, Ukwangali, Gciriku and Mbukushu. ${ }^{80}$ The Kavango Jeugbeweging thus provided the SADF, and by extension the SWATF, with the necessary local human capital with which to wage the counterinsurgency war in northern SWA. ${ }^{81}$ 


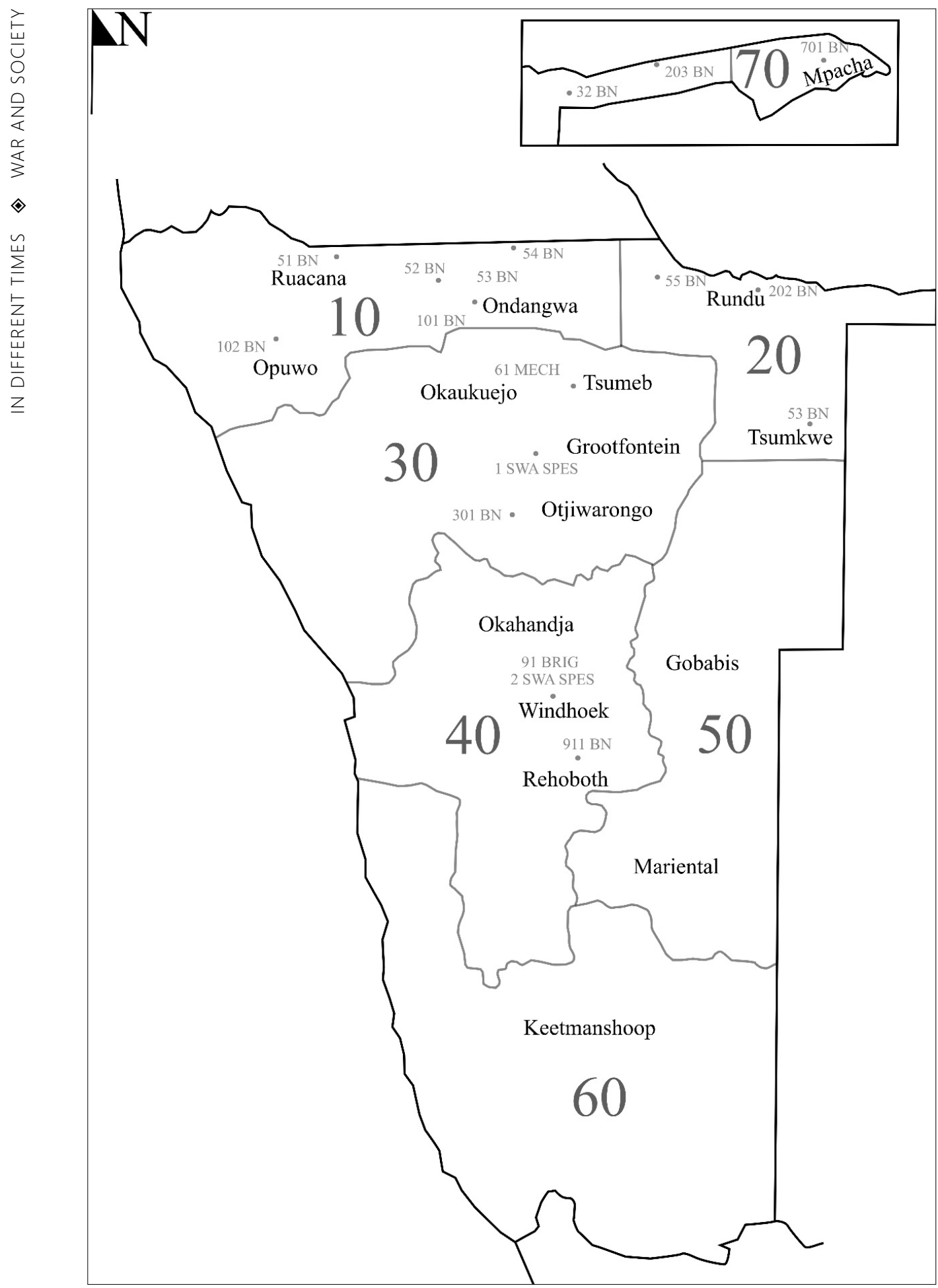

MAP 6.1 The military sectors in South West Africa/Namibia during the Border War 
The Kavango Jeugbeweging lastly provides a rare, though limited, insight into the various, and at times perverse, roles that some South African academics rendered to the SADF during the counterinsurgency operations in SWA. The establishment of the Kavango Jeugbeweging during 1975 happened to coincide with the creation of a dedicated ethnology section in the SADF. The SADF sought the specific skills of anthropologists and ethnologists in order:

to provide ethnological knowledge not only for strategical and tactical operations but also to 'improve race relations' both within the SADF and between the SADF and the black population that bore the brunt of military operations. ${ }^{82}$

These academics were thus mainly concerned with Wham, as perverse as some of their plans and programmes were, as part of the broader South African counterinsurgency strategy in SWA. Gordon argues that this section formed part of the larger civicaction programme of the SADF, organised around the assumption that victory in the counterinsurgency war was 20 per cent military, and 80 per cent political and civil. Consequently, the SADF became the single largest employer of anthropologists and ethnologists during apartheid, with the majority of graduates drawn from Afrikaans-language universities and their Anthropology departments that offered a uniquely South African 'social anthropology'. ${ }^{83}$ Coetzee and the IAS also had various dealings with the SADF between 1975 and 1977, and Coetzee was, on more than one occasion, summoned to Pretoria and Rundu to deliver lectures to military personnel and teachers on communism, nationalism and various non-military aspects of counterinsurgency. The SADF use of academics stretched far beyond mere ethnologists and anthropologists and included geographers, political scientists, psychologists, pedologists, historians and horticulturalists to name but a few. ${ }^{84}$ The fact that the ethnology section of the SADF comprised of 16 Permanent Force staff members by March 1977, may in some way explain the breakdown in communication between Coetzee and Pretorius during that year. One might venture that the specific brand of anthropology that Coetzee preached did not sit well with Pretorius and that the SADF at that stage offered an in-house ethnological service with dedicated personnel deployed to SWA that negated the services of Coetzee and the IAS. ${ }^{85}$

\section{CONCLUSION}

The Kavango Jeugbeweging was established in 1975 with the explicit aim to prevent the spread of communist propaganda, to foster a sense of Kavango nationalism, and to limit the political influence of Swapo amongst the local Kavango youth. The youth movement furthermore provided the SADF with strategic human capital in the counterinsurgency war, by acting as a recruitment pool for amongst others 202 Battalion, based in Kavangoland. The impact of the Kavango Jeugbeweging in 
the larger counterinsurgency war in SWA may be negligible, but when limited to the Kavango it makes for an interesting lens through which to analyse the Wham campaign, as well as the eventual 'namibianisation' of the South African Border War. One must somewhat disagree with Gordon, for in the end it was military feet on the ground, and not so much the civic-action programmes of the SADF, that bestowed some measure of success in the South African counterinsurgency war in SWA from 1975 to 1989. The Kavango Jeugbeweging does, after all, offer a mere glimpse into the role that academics played during the counterinsurgency war in SWA. The full extent of the role and functioning of the ethnology section of the SADF, especially regarding its contribution to the counterinsurgency campaign in SWA, is yet to be researched and written up. 


\section{Endnotes}

1 Thean Potgieter, 'Counterinsurgency in Africa:The Colonial Experience' in DeanePeter Baker and Evert Jordaan, eds., South Africa and Contemporary Counterinsurgency: Roots, Practices, Prospects (Claremont: University of Cape Town Press, 2010), 68.

2 Deane-Peter Baker and Mark O'Neill, 'Introduction: Contemporary South Africa and Counterinsurgency' in Baker and Jordaan (2010), 2.

3 British Ministry of Defence, British Army Field Manual - Countering Insurgency (Warminster: Colonel Warfare Development, 2009), 1(10), 1-6.

4 Anita Gossmann, 'Insurgency and Counterinsurgency: An Introduction' in Baker and Jordaan (2010), 33.

$5 \quad$ Leopold Scholtz, 'Lessons from the Southern African Wars: A Counterinsurgency Analysis', Journal for Contemporary History (JCH), 36(2), 2011, available at: [http://scholar. ufs.ac.za:8080/xmlui/handle/11660/7236], 202.

6 Abel Esterhuyse, 'The Strategic Contours of the South African Military Involvement in Namibia and Angola during the 1970/1980s', JCH, 34(2), 2009, 16-17.

7 Gary Baines, South Africa's 'Border War': Contested Narratives and Conflicting Memories (London: Bloomsbury Academic, 2014).

8 Ian Liebenberg, Jorge Risquet and Vladimir Shubin (eds.), A Far-Away War: Angola, 1975-1989 (Stellenbosch: African Sun Media, 2015).

9 Francis Toase, 'The South African Army: The campaign in South West Africa/ Namibia since 1966', in Ian Beckett and John Pimlott, eds., Armed Forces and Modern Counterinsurgency (New York: St. Martin's Press, 1985), 190-219.

10 John Turner, Continent Ablaze: The Insurgency Wars in Africa, 1960 to the Present (Johannesburg: Jonathan Ball Publishers, 1998).

11 Anita Gossmann, 'The South African Military and Counterinsurgency: An Overview', in Baker and Jordaan (2010), 83-104.

12 Abel Esterhuyse and Evert Jordaan, 'The South African Defence Force and Counterinsurgency, 1966-1990', in Baker and Jordaan (2010), 104-124.

13 Kersti Larsdotter, 'Fighting Transnational Insurgents: The South African Defence Force in Namibia, 1966-1989', Studies in Conflict E Terrorism, 37, 2014, available at: [https:// www.researchgate.net/publication/268038585_Fighting_Transnational_Insurgents_The_ South_African_Defence_Force_in_Namibia_1966-1989], 1024-1038.

14 Richard Dale, 'Melding War and Politics in Namibia: South Africa's Counterinsurgency Campaign, 1966-1989', Armed Forces E Society, 20(1) 1993, available at: [https://www. researchgate.net/publication/240719027_Melding_War_and_Politics_in_Namibia_ South_Africa's_Counterinsurgency_Campaign_1966-1989],7-24.

15 Leopold Scholtz, 'The Namibian Border War: An Appraisal of the South African Strategy', Scientia Militaria, 34(1) 2006a, available at: [https://www.researchgate.net/ publication/260387320_The_Namibian_Border_War_An_Appraisal_of_the_South_ African_Strategy], 19-48; Scholtz (2011), 193-215.

16 Lieneke de Visser, 'Winning Hearts and Minds in the Namibian Border War', Scientia Militaria, 39(1), 2011, available at: [https://www.researchgate.net/ publication/269867658_Winning_hearts_and_minds_in_the_Namibian_border_war], 85-99.

17 De Visser (2011), 86. 
18 The most infamous was Project Camelot and Project Phoenix that was used by the US Army during the Vietnam War as part of the Civil Operations and Revolutionary Development Support (CORDS). For more on this see Jacob Kipp, Lester Grau, Karl Prinslow and Don Smith, 'The Human Terrain System: A CORDS for the 21st century', Military Review, 9, 2008, available at: [https://www.researchgate.net/ publication/277873517_The_Human_Terrain_System_A_CORDS_for_the_21st_ Century], 9-10; Oliver Blecher, ‘The Best-Laid Schemes: Postcolonialism, Military Social Science, and the Making of US Counterinsurgency Doctrine, 1947-2009', Antipode, 44(1) 2012, available at: [https://onlinelibrary.wiley.com/doi/full/10.1111/j.14678330.2011.00948.x], 258-263.

19 Roberto González, 'Human terrain': Past, Present and Future Applications', Anthropology Today, 24(1) 2008, available at: [https://rai.onlinelibrary.wiley.com/doi/abs/10.1111/ j.1467-8322.2008.00561.x], 21. During the Vietnam War; Roberto González, 'The Rise and Fall of the Human Terrain System', Counterpunch:Tells the Facts, Names the Names, 29 June 2015, available at: [http://www.counterpunch.org/2015/06/29/the-rise-andfall-of-the-human-terrain-system/], accessed 19 January 2017.

20 Lindy Heinecken and Donna Winslow, 'The Human Terrain:The Need for Cultural Intelligence', in Baker and Jordaan (2010), 197-208.

21 Rob Gordon, 'Anthropology and Apartheid - The Rise of Military Ethnology in South Africa' in Cultural Survival Quarterly Magazine, 11(4), 1987a, available at: [https:// www.culturalsurvival.org/publications/cultural-survival-quarterly/anthropology-andapartheid-rise-military-ethnology-south], accessed 19 January 2017; Rob Gordon, “Ethnological Knowledge is of Vital Importance':The Martialisation of South African Anthropology', Dialectical Anthropology, 12(4) 1987b, 443-444.

22 Herbert Karapo, 'Living Memory in a Forgotten War Zone: The Ukwangali District of Kavango and the Namibian Liberation Struggle, 1966-1989' (MA thesis, University of the Western Cape, 2008), available at: [http://etd.uwc.ac.za/xmlui/handle/11394/3765]; Michael Akuupa, 'The Formation Of 'National Culture' In Post-Apartheid Namibia: A Focus On State Sponsored Cultural Festivals In Kavango Region' (PhD Dissertation, University of the Western Cape, 2011), available at: [http://etd.uwc.ac.za/xmlui/ handle/11394/3045]; and Michael Akuupa, National Culture In Post-Apartheid Namibia: State Sponsored Cultural Festivals and their Histories (Basel: Basler Afrika Bibliographien, 2015).

23 Larsdotter (2014), 1027; Dale (1993), 9-10.

24 Esterhuyse and Jordaan (2010), 109.

25 Scholtz (2006a), 26-27; Esterhuyse and Jordaan (2010), 104-111.

26 Kaas van der Waals, Portugal's War in Angola: 1961-1974 (Pretoria: Protea Books, 2012), 224-231; Toase (1985), 200-202.

27 McGill Alexander, 'The Cassinga Raid' (MA Dissertation, Unisa, 2003), 74-75; Leopold Scholtz, 'Die Ontwikkeling van die SA Leër in die Grensoorlog, 1966-1989', JCH, 31(3), 2006b, available at: [http://journals.ufs.ac.za/index.php/jch/article/download/541/521], 113; Scholtz (2006a), 27.

28 The Bantu Authorities Act of 1951, and the Bantu Self-Government Act of 1959 in particular, underpinned the creation of the so-called homelands within South Africa and SWA.The homelands, such as Ovamboland and Kavangoland, were self-governing, quasi-independent states, and formed part of the apparent 'enlightened' approach to apartheid. RSA (Republic of South Africa), 1951, The Bantu Authorities Act No. 68 of 17 July 1951 (Pretoria: Government Printing Works) and RSA, 1959, The Bantu Self-Governing Act No. 46 of 19 June 1959 (Pretoria: Government Printing Works); Toase (1985), 202-203; Larsdotter (2014), 1027. 

Toase (1985), 204-207; Alexander (2003), 75.

31 De Visser (2011), 94-95; Esterhuyse (1996), 27-28; Chris Alden, Apartheid's Last Stand: The Rise and Fall of the South African Security State (London: MacMillan Press, 1996), 38-46; Baines (2014), 141.

Scholtz (2006a), 28; Larsdotter (2014), 1028.

Toase (1985), 209-211; De Visser (2011), 86-88.

North-West University Institutional Archive (hereafter NWU Archive):

Privaatversameling - Prof. J.H. Coetzee, file Onderwerpslêers Kavango Jeugbeweging, Brief van Mnr. E.W. Pretorius aan Prof. C.F. van der Walt, 30 Julie 1975.

35 NWU Archive: Privaatversameling - Prof. J.H. Coetzee, file Onderwerpslêers Kavango Jeugbeweging,Vertroulike Verslag aangaande Kavango Jeugbeweging, 30 Julie 1975. NWU Archive: Privaatversameling - Prof. J.H. Coetzee, file Onderwerpslêers Kavango Jeugbeweging, Brief van Prof. J.H. Coetzee aan Mnr. E.W. Pretorius, 20 Augustus 1975.

A.W.Wood, 'Developing Educational Alternatives: Some New Ways for Education in Rural Areas', in Philip Foster and James Sheffield, eds., World Yearbook of Education 1974: Education and Rural Development (London: Routledge Publishers, 2006), 140.

38 Joel Peters, Israel and Africa: The Problematic Friendship (London: British Academic Press, 1992), 5-6; Shelly Paz, 'Gadna pre-army program tries to restore IDF's appeal', The Jerusalem Post, 13 April 2008, available at: [http://www.jpost.com/Israel/Gadna-prearmy-program-tries-to-restore-IDFs-appeal].

NWU Archive: Privaatversameling - Prof. J.H. Coetzee, file Onderwerpslêers Kavango Jeugbeweging, Brief van Prof. J.H. Coetzee aan Mnr. E.W. Pretorius, 20 Augustus 1975. NWU Archive: Privaatversameling - Prof. J.H. Coetzee, file Onderwerpslêers Kavango Jeugbeweging, Brief van Prof. J.H. Coetzee aan Mnr. E.W. Pretorius, 28 Augustus 1975.

41 NWU Archive: Privaatversameling - Prof. J.H. Coetzee, file Onderwerpslêers Kavango Jeugbeweging, Brief van Prof. J.H. Coetzee aan Mnr. E.W. Pretorius, 2 Oktober 1975. NWU Archive: Privaatversameling - Prof. J.H. Coetzee, file Onderwerpslêers Kavango Jeugbeweging, Brief van Mnr. E.W. Pretorius aan Prof. J.H. Coetzee, 22 Oktober 1975. NWU Archive: Privaatversameling - Prof. J.H. Coetzee, file Onderwerpslêers Kavango Jeugbeweging, Brief van Prof. J.H. Coetzee aan Mnr. E.W. Pretorius, 24 November 1975.

44 NWU Archive: Privaatversameling - Prof. J.H. Coetzee, file Onderwerpslêers Kavango Jeugbeweging, Brief van Mnr. E.W. Pretorius aan Prof. J.H. Coetzee, 11 Februarie 1976. NWU Archive: Privaatversameling - Prof. J.H. Coetzee, file Onderwerpslêers Kavango Jeugbeweging, Brief van Prof. J.H. Coetzee aan Mnr. E.W. Pretorius, 1 Maart 1976; NWU Archive: Privaatversameling - Prof. J.H. Coetzee, file Onderwerpslêers Kavango Jeugbeweging, Telegram van Mnr. E.W. Pretorius aan Prof. J.H. Coetzee, 17 Maart 1976. NWU Archive: Privaatversameling - Prof. J.H. Coetzee, file Onderwerpslêers Kavango Jeugbeweging, Program i.v.m. die Besoek van Instituut vir Afrikanistiek.

47 Alexander (2003), 30-32.

48 NWU Archive: Privaatversameling - Prof. J.H. Coetzee, file Onderwerpslêers Kavango Jeugbeweging, Brief van Prof. J.H. Coetzee aan Mnr. E.W. Pretorius, 10 Mei 1976; NWU Archive: Privaatversameling - Prof. J.H. Coetzee, file Onderwerpslêers Kavango Jeugbeweging, Brief van Prof. J.H. Coetzee aan die Kavango Sekretaris van Onderwys, 10 Mei 1976; NWU Archive: Privaatversameling - Prof. J.H. Coetzee, file Onderwerpslêers Kavango Jeugbeweging, Brief van Prof. J.H. Coetzee aan KommissarisGeneraal vir die Naturellevolke in SWA, 10 Mei 1976. 
49 NWU Archive: Privaatversameling - Prof. J.H. Coetzee, file Onderwerpslêers Kavango Jeugbeweging,Vertroulike Verslag i.s. Kavango Jeugbeweging na aanleiding van die besoek van Prof. J.H. Coetzee en Dr. H. van der Wateren aan Kavango vanaf 24 tot 29 Maart 1976.

50 NWU Archive: Privaatversameling - Prof. J.H. Coetzee, file Onderwerpslêers Kavango Jeugbeweging; Akuupa (2011), 142-143.

51 NWU Archive: Privaatversameling - Prof. J.H. Coetzee, file Onderwerpslêers Kavango Jeugbeweging, Nota aangaande telefoniese gesprek tussen Maj Muller van Verdedigings Hoofkwartier en Prof. Coetzee se sekretaresse i.v.m. besoek aan Kavango, Mei/Junie 1976.

52 NWU Archive: Privaatversameling - Prof. J.H. Coetzee, file Onderwerpslêers Kavango Jeugbeweging, Brief van Mnr. E.W. Pretorius aan Prof. J.H. Coetzee, 14 Julie 1976.

53 NWU Archive: Privaatversameling - Prof. J.H. Coetzee, file Onderwerpslêers Kavango Jeugbeweging, Brief van Dr.Van der Wateren aan Mnr. Pretorius, 11 Augustus 1976.

54 NWU Archive: Privaatversameling - Prof. J.H. Coetzee, file Onderwerpslêers Kavango Jeugbeweging, Telegram van Mnr. Pretorius aan Prof. Coetzee, 23 August 1976.

NWU Archive: Privaatversameling - Prof. J.H. Coetzee, file Onderwerpslêers Kavango Jeugbeweging, Brief van Dr.Van der Wateren aan Mnr. Pretorius, 15 Februarie 1977.

56 NWU Archive: Privaatversameling - Prof. J.H. Coetzee, file Onderwerpslêers Kavango Jeugbeweging, Brief van Dr.Van der Wateren aan Mnr. Pretorius, 22 April 1977.

NWU Archive: Privaatversameling - Prof. J.H. Coetzee, file Onderwerpslêers Kavango Jeugbeweging, Brief van direkteur Instituut vir Afrikanistiek aan Mnr. Pretorius, 12 Oktober 1977.

Akuupa (2011), 137-145.

Akuupa (2011), 135-145.

60 DeVisser (2011), 86-87.

61 Esterhuyse (1996), 31-32.

62 Karapo (2008), 122-124.

63 I, unfortunately, could not find further information on similar youth movements in Hereroland or Ovamboland. That is not to say that information about these youth movements do not exist. The National Archives of Namibia along with the National Archives of South Africa likely may preserve some primary sources dealing specifically with the distribution and functioning of these youth movements across SWA. Akuupa (2011), 116.

64 Karapo (2008), 124-125.

65 Alexander (2003), 29-32; Larsdotter (2014), 1027-1029.

66 Helmoed-Römer Heitman, 'The Other Edge of Asymmetry: South Africa's Bush War Strategy',JCH, 34(1), 2009, available at: [https://journals.co.za/content/contemp/34/1/ EJC28477], 2-4; Alexander (2003), 12, 80-95.

67 Leopold Scholtz, "n Strategiese en Operasionele Beoordeling van die Suid-Afrikaanse Weermag (SAW) se Oorgrens-Operasies in Angola, 1978-1988', JCH, 34(1), 2009, available at: [https://journals.co.za/content/contemp/34/1/EJC28474], 64-67; Heitman (2009), 4.

68 Heitman (2009), 4-5; Larsdotter (2014), 1028-1029, 1033.

69 Dale (1993), 12; Esterhuyse and Jordaan (2010), 113-117; Heitman (2009), 5-8.

70 Scholtz (2009), 72; Scholtz (2006b), 126. 
Ian van der Waag, A Military History of Modern South Africa (Cape Town: Jonathan Ball Publishers, 2015), 269-272; Scholtz (2011), 209-212.

72 Heitman (2009), 1; Scholtz (2009), 67-77.

73 De Visser (2011), 87-88.

74 Toase (1985), 207-209.

75 Esterhuyse and Jordaan (2010), 110.

76 The South African homelands had similar 'apartheid-like' military structures, styled as the defence force of each nominally independent Bantustan. They were the Transkei Defence Force, Ciskei Defence Force,Venda Defence Force, and the Bophuthatswana Defence Force.

Dale (1993), 12.

Toase (1985), 217.

79 Karapo (2008), 99, 123-124, 149; Akuupa (2011), 128.

80 Akuupa (2011), 134.

81 Van der Waag (2015), 269.

82 Gordon (1987a).

83 Gordon (1987b), 443-445; Baines (2014), 143.

84 NWU Archive: Privaatversameling - Prof. J.H. Coetzee, file Onderwerpslêers Kavango Jeugbeweging, Nota aangaande telefoniese gesprek tussen Maj Muller van Verdedigings Hoofkwartier en Prof. Coetzee se sekretaresse i.v.m. besoek aan Kavango, Mei/Junie 1976

85 Gordon (1987b), 443-445. 


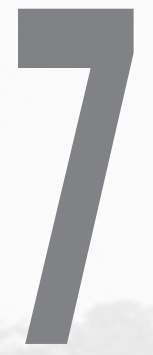

\section{CAUGHT IN THE CROSSFIRE: THE PROGRESSIVE FEDERAL PARTY AND DEFENCE POLITICS DURING THE 1980s IN SOUTH AFRICA}

Albert Grundlingh 
As far as military matters during the 1980s were concerned, South Africa's Border War has dominated. Not surprisingly the historiography has reflected this and grown exponentially from initial forays describing campaigns and battles to analyses of the different frameworks explaining the reasons for the war, the nature of civil-military relations, the war in international affairs, the experiences of ordinary soldiers and the ways popular memory expresses the afterlife of the war. What happened away from the war zone, also came into focus for example in work dealing with gender, the activities of civic organisations and analyses of the anti-conscription campaign. ${ }^{1}$ This chapter also addresses an additional dimension - how oppositional parliamentary politics played out under duress and how the role players mediated divergent points of views.

\section{PARAMETERS}

The stark realities of militarisation in South Africa during the 1980s could not but infuse the nature of political discourse. As the official parliamentary opposition for most of the period, the Progressive Federal Party (PFP) was not in a position to define the terms of the debate as the agenda was being set by the National Party (NP) under P.W. Botha. Botha, a long-standing Member of Parliament and Cabinet Minister served as Defence Minister from 1967, was chosen as Prime Minister in 1978 and became President in 1983 under a new constitutional dispensation. He and his handpicked Minister of Defence, General Magnus Malan, assiduously promoted defence force interests.

At the heart of the ideology of militarisation was the notion of a 'Total Strategy' to counter what was perceived to be a 'Total Onslaught' emanating from South Africa's enemies. These enemies were first and foremost communists - the Soviet Union and its satellite state, Cuba - that used Angola as a base and a springboard for incursions into the South African controlled South West Africa (SWA), currently Namibia. South Africa, it was argued, stood largely alone in this struggle as the liberal West was perceived to be too pusillanimous to assist. Conveniently underplayed in this outlook was that apartheid in itself was a major destabilising factor that attracted negative worldwide attention. ${ }^{2}$

The idea of a Total Onslaught seeped into the very fabric of white society and inevitably resonated in party political terms. The PFP, as the opposition to the left of the NP, was concerned with its pervasive effect. Colin Eglin, a senior PFP parliamentarian, believed in 1983 that:

Every attack on South Africa, every criticism of its policy or actions, every move to exclude or boycott, every proposal to disinvest is seen as a part of the Total 
Onslaught. Foreign governments, international organisations, church bodies, trade unions and political activists who criticise or act against South Africa are seen to be part of the Total Onslaught whether as initiators, agents, allies or simply as dupes in the Total Onslaught strategy. ${ }^{3}$

The PFP tried to mediate the Total Onslaught approach by seeking to separate 'legitimate security considerations' from 'wholesale panic that bordered on paranoia'. It was not convinced that in terms of realpolitik the Soviet Union had grand designs of per se imposing communist rule on Southern Africa, but considered the Soviets to be opportunistic in trying to take advantage of targets that may present themselves to increase their spheres of influence. ${ }^{4}$ Such a more nuanced understanding, while it might have had a certain appeal in rarefied political circles, was difficult to convey effectively in the rough and tumble of everyday politics. Especially at a time when Cubans amassed on the northern frontier of SWA, bombs exploded in public spaces in South Africa and the country seethed with black unrest that called for the government to decree several states of emergencies. Neither were matters helped by the African National Congress (ANC) in exile making blood-curdling pronouncements that in order to advance their cause, it is necessary to develop a 'hatred of the enemy' and claiming, reaching back into history, that one of the reasons 'our forefathers fought so heroically against the enemy was that they hated them'. ${ }^{5}$ It was within these prickly political parameters that the PFP had to operate.

\section{PARLIAMENTARY SKIRMISHES}

Given the pre-eminent place accorded defence matters in white society, the PFP was careful not to convey an image in parliament and also further afield that it was intent on the outright rejection of the role of the military. On the contrary, Harry Schwarz, a noted PFP member and one who was particularly hawkish on defence issues, made it clear that the South African Defence Force (SADF) had a legitimate task and that it should be supported:

If you are a South African, if you believe in peace and if you seek protection against violence and terror from our Defence and Police forces, you must be prepared to assist in that defence. ${ }^{6}$

Similarly, Philip Myburgh, PFP spokesperson for defence matters in 1983 argued that as far as the military is concerned; “... the greatest possible measure of agreement should be reached, and that the security and defence of South Africa are one of our prime considerations." 7 
Apart from the personal convictions of these speakers, this point of departure was also meant to portray the PFP to the public as a party that was not 'soft' on security as the NP members often averred. ${ }^{8}$ It was a point that the PFP needed to repeat often. In May 1987 before the general election, Brian Goodall, then PFP spokesperson for defence, made it clear that it was 'nonsense' for the government to pronounce that the PFP refused to acknowledge the threat against South Africa. Even if the PFP was in government, he continued: "... there would still be a threat. We would, however, deal with it much more effectively than this government has." Such a message was essential for the PFP to try and establish its credentials with the voting public as well as to create manoeuvring room in parliament. Otherwise, it could far too easily be side-lined based on perceived 'disloyalty'.

Frederik van Zyl Slabbert, PFP leader from 1979, started soon after the beginning of his parliamentary career in 1974 to exploit the available space to extract information on military matters. His concern had a personal angle to it as his half-brother, Shamus Taylor, was one of the conscripts involved in the ill-fated incursion into Angola in August 1975. Slabbert was one of an official parliamentary delegation to the border in January 1976, when they received the news of the Angolan invasion. He was not only perturbed about the possible fate of Shamus but aghast at what he considered the foolhardiness of invading Angola in what turned out to be a futile attempt to influence local politics. This attack meant that the principle of non-interference in the affairs of other countries South Africa advocated for so long, was violated. As information of the incursion was classified, Slabbert was not allowed to raise the issue in parliament, but he nevertheless tried to circumvent the restrictions by posing a hypothetical scenario of where conscripts should be allowed to be deployed. ${ }^{10}$

As the ideology of 'Total Onslaught' gained greater traction, the dividing lines between the state and the party became more porous. Slabbert was concerned that what started as a 'Total Strategy' was in the process of becoming a 'Totalitarian Strategy'. ${ }^{11}$ The incident that sparked off this remark was a report that was leaked to the Sunday Times newspaper in March 1980, revealing a plan by the SADF to try and manipulate the news media to counteract the opposition's criticism of P.W. Botha. In parliament, Botha viewed the matter of minor concern and was loathe to admit that the SADF has transgressed the fine line between state and party by trying to shield him from PFP criticism. ${ }^{12}$ Slabbert stated that the Defence Force should be very careful not get involved in partisan party politics and that if the idea took root that the "Defence Force is simply the NP in uniform; he feared this country would split from top to bottom". ${ }^{13}$ In a lengthy critique of the leaked document, Slabbert consistently argued for a clear and rigorously observed division between party and state.

It is a moot point whether Slabbert believed that there was in the first place, such a substantial difference between the party and the state. There was some criticism that he was naive in even thinking that there was anything to choose between the 
two entities. ${ }^{14}$ The political reality though might well have been that in line with PFP general strategy it was publicly necessary to bring to the fore such a divide, as it provided a way of drawing the NP into the debate and keeping the government accountable. Jannie Geldenhuys, Chief of the Defence Force in 1985, later stated that Slabbert's opinion did indeed carry some weight in certain government circles. ${ }^{15}$

Debates on defence matters could derail easily. In response to Slabbert's comments on the revelations of the SADF's involvement in party politics, the irascible Botha described Slabbert's speech as a 'tirade' and likened him to a 'young rhinoceros bull'. Slabbert's response was measured: he regretted that a senior member of the house with years of service should speak to a junior member in such a manner and he hoped that he would not ever have to stoop to the level at which Botha had addressed him. ${ }^{16}$ Relations between Botha and Slabbert remained strained. A senior NP member later allowed it to slip that the root cause of the animosity was: "Slabbert is too clever; PW hates him." ${ }^{17}$

It could, furthermore, not be taken for granted that when the leader of the opposition addressed the House on military matters that suitable attention would be paid. In 1985, while speaking on the complexities of conscription, Slabbert found himself rudely interrupted by two NP members who for some unknown reason started to argue amongst themselves - the one calling the other 'dikkop' (blockhead) - and they first had to be reprimanded by the speaker before Slabbert could continue. ${ }^{18}$

For most of the time, Slabbert preferred to shy away from name-calling or ridiculing his opponents. There were exceptions, though. Malan's stonewalling tactics or what Slabbert regarded as the Minister of Defence's hypersensitivity to criticism of the SADF, could occasionally become exasperating. He compared Malan to a turkey that he had encountered on the farm of his youth. When teased, the turkey would start cackling, and after a while, the turkey had become so conditioned that as soon as he sees someone approaching, he would start cackling without even being provoked. It, Slabbert said, was the 'cackling politics' of the Minister of Defence. ${ }^{19}$

Despite such exchanges, not all was lost in parliament. Through diligent committee work, the PFP at times did succeed in changing or watering down more extreme NP defence proposals. Thus a 1983 Bill on Conscription was changed in several respects, after PFP interventions, amongst others, that religious objectors should be given the option to buy themselves out of further military service after they had completed their first stint. The PFP argued that this would privilege the rich and that nobody should be exempted from service just because they could afford it. ${ }^{20}$ 


\section{FRICTIONS AND FACTIONS}

While the PFP sought as far as possible to maintain a united front in parliament, defence issues in the turbulent 1980s spilt-over into the deliberations of the party. These mainly revolved around the question of compulsory military conscription and conscientious objection and since late-1984 the deployment of troops in black townships.

The terms of who qualified for military exemption on religious grounds were narrowly defined and did not leave much latitude for those who objected to the draft based on the assumption that the conflict was an 'unjust war'. Moreover, the penalties for those who refused to do military service were severe and could include a jail sentence of up to six years. As the country became more militarised, the government extended the periods of military service accordingly. Compulsory military service for all white males first introduced in 1967 with a stretch of nine months, then extended to twelve months in 1972 and subsequently in 1977 to two years of compulsory duty. In tandem with these obligations, the lengths of time one had to spend doing camps after the initial spell also increased: in 1972, it was 19-day camps for five years; in 1977, this rose to 30-day camps for eight years; from 1983, each member was required to serve a further 720 days spread over 14 years.

It was not the end yet: afterwards, the conscript, transferred to the Active Citizen Reserve Force, he was expected to serve twelve days annually for another five years. He could also be called up to the age of 55 before finally placed on the national reserve for a further ten-year period..$^{21}$ The stringent call-up regulations could, in theory at least meant that all white males were for most of their adult life, beholden to the Defence Force. The scope and extent of these demands catapulted the issue of conscription right into the centre of the political arena. Conscription was no longer a minor issue of young men being called up for a limited period; in the 1980s, it started to assume the form of mass mobilisation.

The deployment of white troops under state emergency regulations in black townships where unrest occurred was an equal quantum leap for the Defence Force. Although there is evidence that some black people preferred the troops to the police in the townships - the latter regarded as more vindictive and ill-disciplined ${ }^{22}$ - overall the impression now gained currency that South Africa was descending into civil war. The border was no longer north of the country but has moved south into the towns and cities of the country itself. Once the Defence Force had moved into the townships to help quell anti-apartheid protests, it compromised its claims, debatable as they might have been, to neutrality. These developments added a sharper edge to how political parties positioned themselves. 
It was against this background that Slabbert opened the PFP Federal Congress in Durban in 1985. He stated frankly:

Defence issues have always been controversial within the PFP, and rightly so, because they involve matters of life and death. I prefer a controversial, heated but honest debate to the kind of pseudo-patriotic posturing which so often typifies political comment on these matters. It has been stated I --- am too uncritical or even 'jingoistic' in speaking on behalf of the PFP on defence matters. I disagree with such sentiments. ${ }^{23}$

In general terms, without always being mutually exclusive, there were three groupings on defence issues within the PFP. In the middle, there was some consensus on the need for political reform instead of increased defence spending as the preferred manner to ensure stability. Besides, there was a fair measure of agreement that a larger professional Defence Force consisting of career soldiers as opposed to a preponderance of conscripts was desirable. To the left, a grouping with anti-militarist tendencies with distinct undertones of disapproval of military culture in general and associated actions held sway. On the right, there was a more sympathetic stance towards the need for conscription and a greater willingness to accept the government's assurances of why the Defence Force should play a central role in South African affairs, with the proviso that this should not become an end in itself and meaningful political reform should accompany it.

The position of shadow Minister of Defence in the PFP had the reputation that it was one of the more controversial major portfolios in the party and it was here that underlying tensions surfaced. ${ }^{24}$ Defence spokespersons frequently vacated the hot seat as they followed each other in rapid succession: Harry Schwarz, Roger Hulley, Myburgh, Slabbert himself, Brian Goodall, Peter Gastrow and, before the end of the decade, Nic Olivier.

Those parliamentarians to the left of the party included people like Helen Suzman, Graham McIntosh and Alex Boraine. (One of Boraine's sons was on the run from the Military Police for failing to report for camp duty. ${ }^{25}$ More to the right was Harry Schwarz, Myburgh, Alf Widman, Dave Dalling and Reuben Sive. It is probably no coincidence that three of these had some actual military experience that might as well have influenced their outlook. Schwarz, whose family came out to South Africa as Jewish refugees from Nazi Germany in 1934, felt deeply loyal to South Africa as the country providing them with opportunities at a time of need. ${ }^{26} \mathrm{He}$ served in the South African Air Force in the Second World War. Myburgh volunteered for army service in 1958, and some of his immediate family also served during the Second World War. Sive carried the title of Major for service in the Union Defence Force.

Internecine clashes could at times be unedifying. McIntosh in particular, who at one time refused to report for military duty, was at loggerheads with Schwarz. Schwarz regarded 
it as the duty of every South African to obey the law and that included McIntosh. The latter retorted:

I don't take his [Schwarz's] comments very seriously. Mr Schwarz has a political erection every time anybody mentions the Defence Force, and with that, his rationality disappears completely. ${ }^{27}$

McIntosh was somewhat of a stormy petrel when it came to defence issues. Slabbert also berated him for implying that there was no or little difference between the SADF and terrorists. "Hyperbole, exaggeration and emotional utterances," Slabbert cautioned, "are detrimental to a satisfactory and constructive debate on defence matters and cause alarm." 28

The issue of conscription specifically caused considerable debate within PFP circles. While not all that urgent during the 1970s, the question assumed greater political proportions with the dramatic increase in the length of military service during the early 1980s and the more prominent role of the Defence Force. Heated arguments for and against conscription became a hallmark of PFP congresses and had the effect of clouding the practicalities of what was possible at the time. It caused Myburgh to resign as defence spokesperson. He considered the idea put forward by the leftwing of the PFP that conscription should be abolished immediately as impractical and irresponsible. It could not be done without having a suitable alternative in place and without that the Defence Force would be seriously weakened, precisely at a time when it needed as a shield behind which political reforms could take place under peaceful circumstances. ${ }^{29}$

Slabbert had to step in as defence spokesperson, buffeted from all sides. At one point, he even threatened to resign as party leader should the caucus fail to resolve the controversy. ${ }^{30}$ Gradually tempers did become less frayed, but whether that was because of Slabbert's threat or perhaps just enough time to reflect more calmly on the issue, is hard to say. Eventually, Slabbert was able to pass a resolution, described as a 'personal triumph' for him, to the effect that:

$\ldots$ as the expansion of the fulltime non-racial professional Defence Force and volunteer reserve arm progresses, so also progress can be made with the phasing out of conscription as part of the military organisation until it is no longer necessary. ${ }^{31}$

With this formulation, Slabbert tried not only to appease the warring factions of his party, but it was also an attempt to provide a firm directive on the issue of conscription. He furthermore made it clear that the party was in "no way going to oppose military service actively, nor in any way undermine the role of the Defence Force". At the same time, he was alert to the fact that, while it seemed that conscription was a burning issue, it was also the way the military used troops that sparked negative reactions. ${ }^{32}$ 
It was particularly the case with the deployment of conscripts in black townships. The military argued that their role in the townships was not to arrest ringleaders but to protect innocent people who preferred to stay out of politics. It was only in extreme cases of conflict that they were supposed to intervene. ${ }^{33}$ It was, however, a very thin line. Slabbert could not but observe:

I do not think it helps to say the Defence Force will only be involved in a supportive capacity. The temptation to go further and intervene is inescapably great. ${ }^{34}$

While the prescriptions on the military in the township might have been difficult to observe and easy to transgress, the situation also had worrisome policy implications for the PFP as it militated against the view that the SADF should be an impartial guardian. The Defence Force itself had now in effect become a key player and could be perceived as promoting the status quo. As a result, Slabbert noted, it will be "impossible to present it [the Defence Force] as a neutral shield behind which orderly reform can take place". ${ }^{35}$ With this development, the credibility of a much peddled PFP argument came under severe strain.

To add to Slabbert's woes, the SADF kept on conducting cross-border raids into Mozambique, Botswana and Lesotho. He experienced a sense of déjà vu, similar to how he was deceived by the military at the time of the incursion into Angola in the mid-1970s. Under the cloak of confidentially, he as leader of the opposition was bypassed and left in the dark while the usual parliamentary protocol was to inform the leader of such developments. He could barely conceal his resentment:

If the ... Minister of Defence and his department do not trust me or my Party, let them say so clearly and not inform me confidentially about anything. I will learn to live with that, but I prefer that to being lied to. ${ }^{36}$

It is not surprising that Slabbert had started to lose faith in the military. It became clear to Myburgh who, to establish a better working relationship, had arranged for informal meetings between Slabbert and senior military personnel. Slabbert only attended two of these meetings and then decided to decline further invitations. ${ }^{37}$

Steadily then during the 1980s as military matters started to loom large, the PFP had to position themselves on two fronts. The party had to counter the government's view of a Total Onslaught without appearing as 'soft' on security by the voting public.

Moreover, it had to contend with divergent points of departures on military matters within its ranks. It fell to Slabbert to steer this ship through treacherous seas with a squabbling crew. And as if this was not enough of a challenge, there gathered on the horizon new clouds in the shape of another organisation with its sights set on military matters. 
The ECC, founded in 1983, stated its aims as follows: to pressurise the government to terminate conscription; to stimulate awareness of the extent of South Africa's militarisation; to oppose the presence of the SADF in SWA; to campaign for alternative forms of National Service; and to work for peace and justice in South Africa. Of these, the main thrust was to object to compulsory military service. In doing so, it sailed legally close to the wind as it was punishable by law to encourage men to refuse service. It, therefore, claimed that it merely provided conscripts with 'accurate' information about SADF activities, allowing them to make up their minds. ${ }^{38}$

Such a fine distinction was, nonetheless, not always observed in practice. Not surprisingly, the organisation was on a collision course with the government. Over and above attacks in the press, it also had to deal with some underhand 'dirty tricks' and harassment aimed at discrediting the campaign. ${ }^{39}$ The government banned the ECC in 1988; inasmuch because the state thought that the ECC improperly influenced young men and thereby transgressed the law, as it was aware that certain members worked underground for the banned ANC. At the time, the ECC for understandable reasons sought to deny ANC linkages, but that these connections indeed existed emerged after $1994 .{ }^{40}$

There is a tendency in the historiography of oppositional forces in the 1980s to give some prominence to the ECC as a significant player in the politics of the day. ${ }^{41}$ Without wishing to deny its uniqueness, one also has to bear in mind that over time, its influence can easily be exaggerated. Just because, as it subsequently turned out, in the post-1994 era the ECC happened to be on the 'right' side of history, does not necessarily mean that it was all that important in the 1980s. As a matter of fact, at its peak, it had no more than between 1580 active members in nine regions. Its restricted organisational reach, in major cities only, failed to make significant inroads into Afrikaans campuses - at Stellenbosch University it only had a 2.1 per cent following. In the English-speaking community its support base was mainly drawn from the middle-class liberal intelligentsia, church organisations and civic bodies like the Black Sash, which had a hand in establishing it in the first place. Although many people made much of its supposed success in influencing men not to enrol, it is hard to prove that the ECC was, except in highly publicised cases, actually instrumental in refusals. Men also stayed away for reasons other than the political objections the ECC advanced. Overall, despite some minor fluctuations, reporting figures stayed relatively constant. ${ }^{42}$ What the ECC lacked in actual influence, they made up for in a highly visible and creative counter-culture drive, including mocking cartoons and posters of the SADF, which had the effect of considerably raising their public profile. ${ }^{43}$ 
It also raised the ire of General Malan who did not take kindly to the lampooning of the SADF. He moreover claimed that funding for the ECC came from abroad and that the organisation was less concerned about conscripts than they were about undermining the SADF that, according to him, served as a bulwark against revolution. ${ }^{44}$ Besides, he sought clarity about the attitude of the PFP towards the ECC.To his mind, the party was too circumspect. "Why does the PFP not clearly state that they reject an organisation like the ECC?" he asked. "Is this another one of the PFP albatrosses?"45

While the ECC might not have quite been an albatross for the PFP, it did put the party on the spot and presented it with an explicit challenge from the extra-parliamentary white left. Some ECC members considered the PFP's view that conscription can only be phased out once a viable alternative was in place, as a vote for the continuation of apartheid. ${ }^{46}$ Along similar lines, Max Ozinsky, later to become prominent in the ANC in the Western Cape, recalled that he and other like-minded youths in the 1980s regarded the PFP stance as hypocritical as the party was quick to criticise but not prepared to make any real sacrifices to end apartheid. He had joined the ECC and later Umkhonto we Sizwe, the armed wing of the ANC. It stood in contrast to what he considered the "'fake liberals of the PFP' in the 1980s who had become completely irrelevant to a generation of white youth who were expected to sacrifice their lives [in the SADF] so that their parents could continue enjoying the benefits of apartheid." ${ }^{4}$ Although not cast in the same strident tone, the PFP youth wing at the time also edged closer to ECC rhetoric. It started questioning the validity of the claim that conscription can only be phased out gradually as well as the idea that the Defence Force was a shield behind which politicians could bring about the necessary reforms. ${ }^{48}$

The PFP sought to inject what they considered to be a measure of realism into the debate. Myburgh recalled that the ECC was more intent on publicity and less concerned about finding working alternatives. The military authorities he claimed, although they had to act against the ECC, was not given to unseemly and running public squabbles with a section of the country's youth. As a result, in certain cases, it was possible to come to a compromise solution with young men who had serious qualms about armed service insofar that they were allowed to serve in non-combatant capacities. The ECC, on the other hand, did not buy into this as such men, despite their non-combatant status, were still seen to be part of the 'apartheid war machinery'. ${ }^{49}$

Slabbert, notwithstanding his increasing disillusionment with the military, had as he said in 1985, "not yet lost all my idealism". ${ }^{50} \mathrm{He}$ did his best to hold the official PFP line and at the same time also expressed his misgivings about the ECC. In public debates, he berated them for targeting the Defence Force without providing an alternative. All such a strategy did, he argued, was to provide ECC supporters with "... a kind of moral superiority that allowed them to call other people bad names". ${ }^{51}$ Although he could, on certain points, agree with the organisation, especially as far as the presence of troops in the township was concerned, overall he considered its position too glib, even 
"dangerously romantic, extraordinarily naïve and counterproductive". ${ }^{2}$ He explained that the ECC vilified the Defence Force more than understanding the complexities of the matter. He found it:

... totally illogical to use the issue of conscription in order to in fact attack the SADF, and the role it plays in South Africa. The Defence Force can do away with conscription tomorrow completely (which no doubt would help a great many morally anguished and privileged White South Africans), but would in no way affect the negative and counter-productive role that the Defence Force can play if not called to account or controlled in society. ${ }^{53}$

He said that it was easy for the ECC to polish 'platitudes in front of a supportive mass rally', but another matter to try and engage the top echelons of the SADF with realistic alternatives. ${ }^{54}$ Slabbert's reservations about the ECC also echoed on the Stellenbosch University campus where similar concerns about the organisation were raised. The demeanour of and the arguments advanced by ECC spokespeople also piqued some Afrikaners who considered the tone to be "enveloped in a haze of intellectual and moral superiority". ${ }^{5}$

The arguments of the ECC and the PFP despite their divergent points of departure were, however, in a way locked into a binary position. Both considered the issue of conscription as of paramount importance and the touchstone of defence politics. What was at stake here, though, were different political views of conscription, but the origin of their conflict had its roots in a single source, namely the policy as decreed by the government. It meant that both bent the knee before the imperatives of high politics.

In doing so, they ignored a whole swathe of interested parties. While the pro and anti-conscription political arguments, including positions in between, were well represented, those that belonged to neither of these camps and were outside the media and political spotlight hardly featured. These were the troops who were politically apathetic or whose political views were not considered worth canvassing or considering. In all likelihood, they formed the bulk of conscripts and were the silent majority.

Although there was some fusion between civic patriotism and the willingness to do military service, this did not necessarily translate into boundless enthusiasm on the part of conscripts. Even P.W. Botha himself thought that only between 20 and 30 per cent of National Servicemen were highly motivated. ${ }^{56}$ The majority merely sought to survive military service unharmed; they were more animated about the prospects of the conclusion of their duty than the service itself. ${ }^{57}$ In a way then for both the PFP and the ECC, partly at least because they fixated on the implications of policy, actual conscripts stayed under the radar. These conscripts have moreover, also stayed outside the ken of general historiography, that tends to deal with the more dramatic and exclude that which on the surface may appear as mundane. 
The very nature of the PFP's position as official parliamentary opposition determined the extent to which it could influence military matters during the turbulent 1980s. As it lacked substantial power, its reach was accordingly limited. Its strategy was to steer a middle course on issues such as conscription, one of the vexed issues of the day. The party was caught in the crossfire: the government, on the one hand, was quick to describe the opposition as unpatriotic and anti-South African, and on the other hand was the ECC with strident if not very carefully considered calls for an immediate end to conscription. The position was not only invidious but also impacted on the internal dynamics of the party.

In all of this, Slabbert as leader of the opposition had to try and straddle different positions. He had to make a real effort to keep a government who was intent on usurping more power accountable, he had to cauterise wounds inflicted by the internecine strife in his party, and then he had to deal with a rumbustious ECC. At the same time, keeping the greater picture in mind and considering the long-term effects of the government's Total Onslaught ideology.

It is common practice in war and society studies to investigate how societies react to war and to focus on the general tensions that emerge amongst different layers of society. ${ }^{58}$ As this primarily calls for a social history approach with a focus on ordinary people, the impact on more formalised parliamentary developments runs the risk of being side-lined. On the other hand, those writing more explicitly on politics and war tend to focus generally on ruling parties. This chapter has hopefully demonstrated that if we wish to move to a more rounded understanding of the impact of war, there are benefits to be gained by also setting our sights on oppositional parties, often dealing with their unique problems. In addition, while work on high politics during this period has its advantages, one should also be aware of the silences or blind spots that such an approach may contain. 


\section{Endnotes}

1 For an excellent list of sources on the Border War see Ian Liebenberg, Jorge Risquet and Vladimir Shubin, A Far-away War, Angola 1975-1989 (Stellenbosch:African Sun Media, 2015), 165-200.

2 Albert Venter, 'Mededingende politieke paradigmas oor die Grensoorlog, 1966-1989', Journal for Contemporary History, 34, February 2009, available at: [https://hdl.handle. net/10520/EJC28475], 40-42.

3 Colin Eglin, 'South Africa in a Southern Africa and International Foreign Policy Perspective', South Africa, a chance for liberalism?: Papers presented during a seminar of the Friedrich Naumann Foundation in December 1983 (Schriften der Friedrich-Naumann-Stiftung) (hereafter Naumann Papers) (Berlin: Liberal Verlag, 1985), 268. See also Frederik van Zyl Slabbert, The system and the struggle (Johannesburg: Jonathan Ball Publishers, 1989), 125.

4 Philip Myburgh, 'Security defence issues in Southern Africa' in Naumann Papers, 261. See also Venter (2009), 50.

5 Tsepo Sechaba, 'Our armed offensive: military strategy in South Africa', Sechaba, March 1986, 19-20.

6 RSA (Republic of South Africa), Hansard Parliamentary Debates, House of Assembly Debates (hereafter Hansard), 25 March 1980, 3445.

7 Hansard, 21 March 1983, 3551.

$8 \quad$ Philip Myburgh, interviewed by Albert Grundlingh, Stellenbosch, 25 April 2016.

9 University of the Witwatersrand, Historical Papers: PFP Archives, file AG 1977/H 7 , Speech B Gooddall, May 1987.

10 Frederik van Zyl Slabbert, White Parliament (Johannesburg: Jonathan Ball Publishers, 1985), 39-42; Hansard, 5 February 1976, 671-672.

11 Hansard, 25 March 1980, 3424.

12 Kenneth Grundy, The Militarization of South African Politics (Berkeley: University of California Press, 1983), 63.

13 Hansard, 25 March 1980, 3446-3447.

14 Grundy (1983), 64-124.

15 Hermann Giliomee, Die Laaste Afrikaner-Leiers, 'n Opperste toets van mag (Cape Town: Tafelberg Publishers, 2013), 220.

16 Hansard, 25 March 1980, 3456.

17 A senior NP member quoted in Ray Swart, Progressive Odyssey (Cape Town: Jonathan Ball Publishers, 1991), 157.

18 Hansard, 29 May 1985, 6472.

19 'Cackling politics', Deurbraak, March 1984.

20 'Defence breakthroughs', Deurbraak, April 1983.

21 Philip Frankel, Pretoria's Praetorians: Civil-military relations in South Africa (Cambridge: Cambridge University Press, 1984), 91.

22 Myburgh (2016).

23 University of the Witwatersrand, Historical Papers: PFP Archives, file 44.11.8, Speech FvZ Slabbert to PFP Federal Congress, 10 August 1985. Frankel (1984), 128-129.

Alex Boraine, $A$ life in transition (Cape Town: Zebra Press, 2008), 117.

Boraine (2008), 130. 
'Schwarz will ignore what McIntosh said', The Citizen, 21 September 1987.

Hansard, 29 May 1985, 6465.

'Sword drawn in PFP defence force row', Rand Daily Mail, 21 November 1984.

'Neglecting the art of the possible', Eastern Province Herald, 21 November 1984.

'Conscription', Deurbraak, December 1984.

'My view', Rand Daily Mail, 21 November 1984.

Hermann Giliomee in gesprek met Generaal Jannie Geldenhuys, Die Suid-Afikaan, Herfs 1985, 32-34.

University of the Witwatersand, Historical Papers: PFP Archives, file Ac 1.13, Speech by FvZ Slabbert to the PFP Federal Congress, 10 August 1985.

Ibid.

Hansard, 28 May 1985, 6571.

Myburgh (2016).

Laurie Nathan, 'Marching to a different beat:The history of the End Conscription Campaign' in Jacklyn Cock and Laurie Nathan, eds., War and society: The militarisation of South Africa (Cape Town: David Philip, 1989), 310.

Liebenberg (1989), 124-126; Nathan (1989), 317-319.

'Minister gives his reasons', Weekly Mail, 26 August to 1 September 1988; 'ECC ontken bande met ANC', Die Matie, 20 August 1987; 'The End Conscription Campaign and the power of refusal', Business Day, 30 September 2009.

See, for instance, Nathan (1989), 305-308.

Merran Willis Phillips, The End Conscription Campaign, 1983-1988: A study of white extraparliamentary opposition to apartheid (MA thesis, Unisa, 2002), available at: [http://hdl. handle.net/10500/15771], 224; On Stellenbosch, see Hermann Giliomee, 'Afrikaner politics 1977-87: from Afrikaner nationlis rule to central state hegemony' in John Brewer, Can South Africa survive? (Cape Town: Macmillan Press, 1989), available at: [https://www. researchgate.net/publication/312679579_Afrikaner_Politics_1977-87_from_Afrikaner_ Nationalist_Rule_to_Central_State_Hegemony], 132.

Deidre Pretorius and Marian Sauthoff, 'Challenging apartheid: Posters from the United Democratic Front and the End Conscription Campaign', in Image and Text - a journal for design, 3, 2011, available at: [https://www.researchgate.net/publication/279258013_ Challenging_apartheid_posters_from_the_United_Democratic_Front_and_End_ Conscription_Campaign], 23-32.

'Herman Giliomee in gesprek met Generaal Magnus Malan', Die Suid-Afrikaan, Winter 1988; 'ECC se geld kom van die buiteland', Die Burger, 13 May 1988.

'The direct enemy of the SADF', Citizen, 14 April 1987.

'Battle lines drawn over conscription', Sunday Tribune, 9 June 1985.

'Fake liberals of PFP supported apartheid', Cape Argus, 14 June 2013.

'PFP youth pressures party leaders', The Star, 4 March 1985;'PFP youth call for radical policy stand', Rand Daily Mail, 4 March 1985; 'End call up say PFP youth', Cape Times, 4 March 1985.

Myburgh (2016); 'Dienspligvoorwaardes', Die Matie, 20 August 1987; 'Beswaardes behandel met deernis', Die Burger, 22 March 1983.

'Battle lines drawn over conscription', Sunday Times, 9 June 1985.

Ibid.

'ECC drive on call-up naïve - Slabbert', The Star, 15 June 1985. 
53 University of the Witwatersrand, Historical Papers: Slabbert Papers, file 44.11.8, Slabbert to D Runciman, 12 June 1985.

54 University of the Witwatersrand, Historical Papers: PFP Archives, file Ac 1.13, Speech by FvZ Slabbert to PFP Federal Congress, 10 August 1985.

55 'Pasop vir mooi morele retoriek', Die Matie, 14 May 1985. For the views of white English speakers, see Frankel (1984), 138-140.

56 Frankel (1984), 134-135.

57 Francois Verster, Omega, Oor en uit (Cape Town:Tafelberg Publishers, 2016), 139.

58 One of the classic texts in this respect is Arthur Marwick, War and social change in the Twentieth Century: A comparative study of Britain, France, Germany, Russia and the United States (London: Macmillan Press, 1974). 


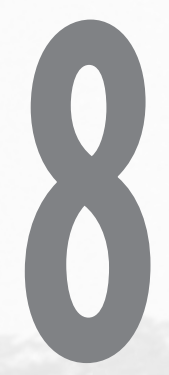

\section{"EK HET IEMAND OP DIE GRENS":}

THE SOUTHERN CROSS FUND AND MOBILISATION OF WHITE SOUTH AFRICAN SOCIETY

Anneke van Heerden 
Elizabeth Albrecht led the establishment of the Mozambique Soldiers' Fund in 1968. The presence of the Portuguese military forces in South Africa's neighbouring states motivated Albrecht. While providing humanitarian support for the Portuguese, the organisation quickly became aware of the presence of South African troops. Within months of creation, the Mozambique Soldiers' Fund changed its name to the Southern Cross Fund (SCF) (Afrikaans: Suiderkruisfonds) and extended its services to providing aid, supplies and comforts to the South African Defence Force (SADF). The organisation mostly consisted of white members of the civil society, and in cooperation with the SADF, the SCF strived to serve the basic needs of the soldiers involved in the conflict in Mozambique and Angola and of troops later deployed in the violent townships in South Africa. The duration of the support from the SCF equalled the length of the deployment of South African soldiers, therefore suggesting to the SADF's possible dependence on civilian mobilisation. Through its support of the troops, the organisation also strived to serve as a morale builder. This secondary role surpassed the immediate environment of the military base and penetrated the civilian sphere. Through a thorough analysis of the image of the SCF in the media, as well as veterans' recollections of the support rendered by the organisation, this chapter endeavours to determine the impact of the SCF on both military and civilian spheres. It is especially the personal viewpoints of the veterans that can give insight to the level of significance of the organisation. This insight allows us to ascertain whether the SCF could have softened the impact of military service on civil society, created unity and served to build morale.

The South African Army, until its crossover to the South African National Defence Force (SANDF), had relied on conscription to meet its manpower requirements. The conscription system had expanded by the late 1960s as the threat on South Africa's border increased. ${ }^{1}$ The South West African People's Organisation (Swapo) wanted independence for South West Africa (SWA), then under South African administration and the independence of Angola caused a civil war between different factions for control over the former Portuguese colony. With the support of Russia and Cuba, the takeover of Angola by a socialist guerrilla faction, the Popular Movement for the Liberation of Angola (MPLA), further threatened South Africa's position in Southern Africa. By 1974, South Africa launched its first cross-border operation, Operation SAVANNAH, into Angola. It was the first operation of the Border War. ${ }^{2}$ A country's civil society harbours the need to provide domestic facilities to soldiers on the battlefront during times of war. War serves as the motivation for society to organise to provide support to soldiers. South Africa is no exception. 
During the First World War, the Governor Generals Fund provided for South African soldiers and their dependents. In 1919, a Whippet tank toured from Cape Town through Mossel Bay to Uitenhage with four young ladies astride the war's newest weapon, armed with bags tied to sticks to collect money for the war effort. For $\mathcal{E}^{1} 1$, a lucky passenger could buy a ride. ${ }^{3}$ By the Second World War, the National War Fund had replaced the Governor Generals Fund to support soldiers and their families. The Fund sent glory bags to soldiers during the war with articles like scarves, gloves, balaclavas, socks, razors, ropes, handkerchiefs, writing pads, envelopes, pencils, cigarettes, sewing kits and, in 1940, even a letter from Mrs Smuts. ${ }^{4}$ In both wars, the Union Defence Force Institute supported the South African Army - a mobile canteen with refreshments and other items at low prices. ${ }^{5}$ The Southern Cross Fund was built on this tradition. With the country's participation in the Border War, the public again needed to provide for its army.

\section{HISTORIOGRAPHICAL BACKGROUND}

Arthur Marwick presents the mobilisation of civil society to support the state and its national army in times of war as integral to the success of war:

The success of the war would not depend on the strength and the organisation of the army alone; it would depend directly upon the efficient organisation of the public forces, on the organisation of the community. ${ }^{6}$

The definition of 'mobilisation' can be the organisation and participation of the public in the production and preparation of the requirements for war. ${ }^{7}$ Various historians have researched this form of mobilisation as a process of the consequences of war within society. The threat to a country cannot be measured objectively and does not necessarily lead to conflict but can still lead to a defensive attitude and influence the mobilisation of society. With the encouragement to mobilise and the extended role of the army in society, the public develops a political mindset. It then creates the context for mobilisation.

Marwick further categorises mobilisation into two areas: unguided and guided mobilisation. Guided mobilisation refers to the purposeful attempts by the government and national army to gain the support of society. Unguided mobilisation, in turn, is the independent reaction, with or without state support, by society to create an interaction with the government or army. ${ }^{8}$

Patrick Regan concludes that this process becomes self-sustainable within the political paradigm that encourages the mobilisation of society. ${ }^{9}$ Because the preparation for war forms part of the mobilisation process, the status of society changes to that of a militarised society. The definition of 'militarisation' is the extension of military 
influence on the civilian sphere. ${ }^{10}$ Due to this influence of the defence force on society, society becomes more than just participators in war; they come to represent the war:

A society in which the institutions and the men who hold military, economic and political power have become so dependent on one another; in which their goals and interests are so complementary, and in which the traditional boundaries between military and civilian spheres have broken down to such an extent, that the very conception of civilian versus military control has no meaning. ${ }^{11}$

At the forefront of the organisation of the public during the Border War was the Southern Cross Fund.

\section{RESEARCH}

Research on the SCF proved problematic. According to Colonel Pieter van der Walt, last national president of the SCF, all documentation relating to the SCF was handed over to an unknown Director of Fundraising in 1995. The documentation, minutes and agendas of meetings, financial states, has not been preserved in any of the national archives, and, after many inquiries, unfortunately, seems lost. Possible reasons may include negligence, damage or even deliberate destruction. ${ }^{12}$ Documentation at the SANDF Documentation Centre contains references to the Southern Cross Fund. Throughout the decades, the media advertised the activities of the SCF.

Oral sources served of great value during research. The author interviewed Van der Walt (second and last president of the SCF); Lieutenant General Raymond Holtzhausen (National President of the South African Army Fund for eight years); Ds Jan Venter (served on the Council of the Southern Cross Fund as Provincial Head of the Orange Free State branch); and Dr Carl Albrecht (son of Elizabeth Albrecht, who established the SCF). Albrecht also kindly provided access to his mother's diaries and privatelyowned recorded interviews. The author also interviewed veterans via social media.

\section{THE POLITICAL CONTEXT OF THE SOUTHERN CROSS FUND}

According to an article in Rapport, 1974, the defence of the country was 20 per cent military and 80 per cent social. ${ }^{13}$ The apparent 'Total Onslaught' was, therefore, not just aimed at the battlefront, but also at the home front. According to Holtzhausen:

To get an even better understanding of the environment in which the Southern Cross Fund functioned; one must also consider the National Conscription system. Without conscription there would be no justification for the Fund's existence. Without this system the army would not have been able to execute their operations. ${ }^{14}$ 
Of the 600000 white men who received military training, 320000 served on the South West African border. South Africa also had a strong military presence in SWA with strategically placed military bases in Ruacana, Rundu, Ondangwa, Katima Mulilo, Oshakati, Oshivelo and the Caprivi Strip. Annually, 40000 South African troops manned the border and 60000 served within SWA in a support capacity. This military presence stretched from 1975 to $1989 .{ }^{15}$ Despite this presence, they also required social participation in the war effort.

Anna Wolf honours the role of society during wartime: "The home is at all times the nation's first line of defence". ${ }^{16}$ Organisations like the Southern Cross Fund took a prominent role in the society's support of the state and army. Admiral Ronnie Edwards supported this notion, stating:

The Republic is involved in a full-scale war that is fought on various fronts. The front least talked about is the home front that has to bear the consequences of the total onslaught. In fact it is the home front that protects the army. ${ }^{17}$

In Organising Societies for War, Regan asks: "Does violent foreign policy feed the process that leads to a society organised around the goals and missions of the military?"18 The mobilisation of the home front during war depends entirely on the political context in which the state functions. A country's foreign policy reflects the international context and serves as the basis for the defence policy. A country cannot construct the defence policy without considering the international context and the state's position within that context. In turn, the defence policy serves as the context for the mobilisation of the home front as it influences the political disposition of the public. ${ }^{19}$ The mobilisation of the South African home front and therefore the Southern Cross Fund should be viewed against the backdrop of South Africa's international political context.

During the 1950s, South Africa's political context was characterised by strong support for the West during the Cold War, as seen in conflicts like the Korean War, and a positive relationship with Western countries with a strong presence in Africa. However, by the late 1950 s, the international context started to change as countries like Great Britain and France began to grant independence to their African colonies. ${ }^{20}$ By the 1960s, South Africa also began to withdraw from the international community as the condemnation of the country's apartheid system increased. ${ }^{21}$ Although, it would be Portugal's changing political context that would have the most profound influence on South Africa's mobilisation process.

Due to South Africa's withdrawal from the international community, South Africa's defence policy became a reaction to domestic upheaval and threats on the country's border and focused on the country's protection. The legitimacy of these threats is subjective and is therefore not relevant. The defence policy and consequential civilian 
militarisation and mobilisation are reactions on this perceived threat. Defence policy is a dynamic and powerful instrument that can adapt to a changing international context. South Africa's defence policy empowered the Defence Force to change its role according to the changing international context, and with Portugal's withdrawal from Angola, the SADF could play a role outside of South Africa's borders, mobilising the public to support this role. ${ }^{22}$

For the South African government, the fight against the perceived threat was not to be limited to the military forces. Despite Swapo's activities in SWA, it was the communist presence in Angola that served as the greatest threat to South Africa. South Africa's involvement in the Korean War solidified its support for the West, but the country's withdrawal from the international community meant that the communist threat in Southern Africa became South Africa's responsibility to face alone. ${ }^{23}$ An article in Die Burger, November 1975, points to the implication of this threat and states that the "great danger of Communism", with its associated "chaos and disorder", "has reached South Africa's borders". "It must be stopped, not just for South Africa's sake, but for the Free World." ${ }^{24}$

Within the context of the Cold War, Neil Orpen argues that the change in Angola would lead to the inevitable involvement of communist countries in the form of a proxy war as well as the involvement of pro-Western countries like South Africa. ${ }^{25}$ Under the guise of the 'total onslaught', the National Party government successfully sold this threat to the South African public - a public already conscious of the country's foreign and defence policy:

Because we face an onslaught so total in extent, our defence should naturally also be total in its nature. In other words, it is not a matter which should be left to the State alone but one in which every right-thinking citizen, irrespective of language, faith or culture, is joined, or in which he should be joined, even though it merely be in the precepts of his daily life. ${ }^{26}$

Therefore, the SCF within this context joined the 'total defence' of South Africa against the 'total onslaught'.

Even though the SCF was representative of the society at this time, it should be clear that it was not representative of society as a whole. The End Conscription Campaign (ECC) and others strived to put pressure on the government and army to end conscription, to make society aware of the army's role in everyday life and to extend resistance against militarisation. ${ }^{27}$ Despite objection to conscription, the SCF still became the most significant civil donor to the SADF. 
During a conversation about communist infiltration in Southern Africa in January 1968, journalist Ken Anderson asked Elizabeth Albrecht: "What are you going to do for the Portuguese?" 28 Albrecht was the only child of Ds W. de Vos of the Dutch Reformed Church in Ladysmith. After completing school, she gained a Degree in Journalism from King's College in London. During the Second World War, she returned to South Africa and began working at the Cape Times. During this time, she became a member of the Maria van Riebeeck Club where she gained valuable skills in fundraising and organisation. With her interest in the Portuguese heightened by the conversation with Anderson, Albrecht spoke to experts in the field of political science and the Communist threat. Following her research, she travelled to Angola and Mozambique to investigate the needs of the Portuguese army. A need for equipment and medical help in hospitals surfaced, leading Albrecht to call a meeting on 24 January $1968 .{ }^{29}$

In attendance at this meeting was Elizabeth's husband and prominent businessman, Rudolph Albrecht, Ken Anderson, Dr Vaz Pereira, the Portuguese Consul General, a few of Albrecht's friends and members of the South African Portuguese Society. A committee was formed consisting of Elizabeth Albrecht, President; Isabel Venter, Vice-President; Johan Fourie, Secretary; a Mr Liebenberg, Treasurer; and Lynn Moolman, first member. ${ }^{30}$ The organisation, christened the Mozambican Soldier's Fund, approached Telma Valente, President of the Movimento Nacional Feminico, a Portuguese women's charity organisation based in Lourenço Marques, to work together. ${ }^{31}$

With the help of General Kualza d'Arriaga of the Portuguese Army, they determined the needs of the Portuguese Army to heed immediate assistance in the form of hospital beds, equipment, ambulances, medicine and first-aid equipment. ${ }^{32}$ To determine the needs of the soldiers, members visited military bases in Mozambique and Angola. Because of the popularity of the Mozambican Soldier's Fund, the Portuguese shared information with them and gave them access to various bases on the battlefront. During these visits to military bases, the involvement of South African troops in the conflicts in Angola and Mozambique became evident. During a visit to a base in Cazambo, Angola, a Mrs Pam Hansen was warned by a South African lieutenant about the sensitivity of the information she possessed. According to his report about the visit, it was clear to him that members of the SCF possessed information about the movement of troops and the involvement of South African forces. ${ }^{33}$

Despite the warning, a written proposal was sent to Prime Minister John Vorster to suggest an extension of the SCF's activities to include South African troops and setting new goals for the $\mathrm{SCF}^{34}$ They changed the name of the organisation to the Southern Cross Fund and registered as a welfare organisation. Its new purpose and 
activities included funds for South African forces on and across the border from 1968, humanitarian help to the Portuguese army until 1974 and humanitarian aid to the Rhodesian forces until 1979, which included and was limited to ambulances and medicine. ${ }^{35}$ Albrecht summarised the goals of the SCF as follows:

[The Southern Cross Fund is] the channel between the people and the forces, who receive in this way not only recreational equipment, but also the assurance of the gratitude and moral support of the people at home. ${ }^{36}$

To ensure this channel remained uninterrupted, the government solidified the SCF as the only certified fundraising organisation that could raise funds for and in the name of the SADF through the Fundraising Act, 107 of $1978 .{ }^{37}$ This law served to prevent a negative influence on the fundraising attempts by the SCF of fundraising projects by other organisations. It consequently allowed the SCF greater success on a national level and served to appease the public; their money went to a legitimate organisation and used for the welfare of the soldiers. ${ }^{38}$ With the extension of the SCF's activities, its committee and membership also grew. In the Cape Province alone, there were a total of 127 branches and 71 branches in the former province of Transvaal. Over the years of its existence, the SCF had more than 260 branches in South Africa. ${ }^{39}$

\section{COOPERATION WITH THE ARMY FUND}

To ensure a successful contribution of the Southern Cross Fund to the war effort and the welfare of soldiers, fruitful collaboration with the Defence Force was required. Both organisations gave their full cooperation in this endeavour. ${ }^{40}$ In 1969, the Brandwagfonds was established to handle all donations from the public to the army after a call by P.W. Botha, then Minister of Defence, that "the public should not forget our men on the border". ${ }^{41}$ In that year, the Brandwagfonds made its first donation: R3000. By 1 July 1976, the Brandwagfonds had changed its name to the South African Army Fund (hereinafter Army Fund) with the approval to also raise funds independently. By 1978, documentation of the Army Fund attested to a shortage of funds available for the welfare of South African soldiers as the activities of the army on and across the border increased. Cooperation with the Southern Cross Fund thus became invaluable. ${ }^{42}$ The motivation to work together and the protection of the law proved successful, with an estimated total of R 5 million donations from the SCF from 1968 to $1978 .{ }^{43}$ 
Necessarily, the SCF had to maintain a positive relationship with the SADF to ensure the continued success of the SCF. In an interview with Beeld, Elizabeth Albrecht emphasised the role of the SCF:

We have to accept that the state can't serve all the needs of its soldiers who are fighting far from home. This is the case all across the world. While we are constantly trying to improve the situation, it is the people of South Africa who, through the Southern Cross Fund, donate facilities like swimming pools, films, books, sporting equipment, etc., to improve life on the border, especially around Christmas. $^{44}$

Communication between the two organisations was imperative. The Army Fund would inform the Southern Cross Fund about the requirements of the soldiers, and the SCF would, in turn, update the public about the desires of the army to raise the necessary funds. The list of needs would include the requested items and amount to guide the fundraising efforts of the organisation. Funds raised would then be transferred to the army. ${ }^{45}$

Even though cooperation between the SCF and the Army Fund was constructive, it soon became apparent that the soldiers were not aware of the work of the organisation because the army bought the facilities. A misconception existed amongst conscripts that the goods they received came from the military and that the SCF was not delivering on their promises. This misperception was brought home with them. To prevent this affecting the contributions by the public, they addressed the issue in the media and added the Southern Cross Fund-emblem to their products. ${ }^{46}$

Donations by the SCF to the Portuguese and Rhodesian forces lasted until 1974. These donations totalled R353000 and R250000, respectively. Donations to the SADF and South African Police (SAP) lasted until the dismantlement of the SCF.The organisation's total annual income averaged R1000000 of which 70 per cent was spent on the army and the rest was paid to the Police. Administrative costs averaged 4,97 per cent and never exceeded 8 per cent. ${ }^{47}$

\section{Christmas gift packs and Going-Away gift packs}

The primary goal of the SCF was to donate facilities and gift packs to those soldiers fighting on and across the border. The Fund emphasised that they made donations to all members serving South Africa, not just white members of the Defence Force and Police. It was the handing out of gift packs by members of the SCF to soldiers that lead to their lasting nickname: The "Dankie-tannies" (translated to the 
'Thank-you-Aunties'), as every soldier thanked the mostly female volunteers. The soldiers consequently dubbed the gift packs "Dankie-tannie-pakkies" ('Thank-youAuntie packs'). ${ }^{48}$ According to Elizabeth Albrecht, the gratitude went both ways, describing the reason for the Christmas gift packs as such: "To thank the young men who are willing to sacrifice their Christmas on the border for our safety." ${ }_{49}$

The primary receivers of the Christmas gift packs were the soldiers who were stationed very far from home, therefore containing luxuries that would make Christmas more pleasant. They included the following items in the parcels sent at Christmas: a memento of their service, a Christmas card, key holder, diary, bubble-gum, cigarettes, snacks including biltong, nuts, dried fruit, raisins, condensed milk and even a T-shirt. ${ }^{50}$

The Going-Away gift packs were released soon after the positive response to the packs sent at Christmas. Where the Christmas gift packs included luxuries, the Going-Away gift packs included necessities every soldier might require during his service. To assure the concerned parents of conscripts that the SCF would donate specific necessities to their sons, the organisation advertised the contents of the packs in the media. An article in Rapport, 'Hoe lyk die pakkie grens toe', described the contents of the packs: writing pad with envelopes, postcards and a pen, a knife, can opener, nail clipper, lip balm, a shaving bag with mirror and razors, shoelaces and a sewing kit. ${ }^{51}$ The army, the SCF and inputs from conscripts determined the contents. The contents were handed over in an artificial leather pouch with the Southern Cross emblem on the front. The emblem also featured on some of the included items such as the T-shirt, pen and writing pad. They also sold the knife, the most popular item, to the public at fundraising events. The knife and poach, both durable items, were kept by most conscripts after their service period had passed. ${ }^{52}$

According to Van der Walt, the most important item in the gift pack was the letter, in Afrikaans, from the National President to the conscripts. The purpose of the letter was to remind the soldier that the donation came from home, but, above all, that these services were delivered by the SCF. The letter from 1977 read as follows:

Liewe vriend,

Hierdie pakkie wat aan $u$ gestuur word met die goeie wense van die Suiderkruisfonds en al $u$ volksgenote, is ' $n$ blyk van ons belangstelling en dankbaarheid. Onthou ons staan bankvas agter $u$ ! Die Suiderkruisfonds, 'n geregistreerde fondsinsamelinsorganisasie, werk nou al nege jaar vir die welsyn van Suid-Afrika se veiligheidsmagte, en al die fondse wat ons insamel - nou reeds meer as R2 miljoen - word oorbetaal aan die Suid-Afrikaanse Weermag en Suid-Afrikaanse Polisie. Dit word bestee aan geriewe soos sport- en musiek-items, projektors, yskasmasjiene, ekstra Kersrantsoene ensovoorts, asook hulp aan afhanklikes en bystand aan verminktes.

Met hierdie pakkie word u egter op tasbare wyse deur ons gegroet.

Mag God u seën, bewaar en veilig terugbring. ${ }^{53}$ 
From 1972 to 1984, the amount spent on the contents of the gift packs rose from R12000 a year to R200000. By 1987, the SCF was spending R280000 on the gift packs. ${ }^{54}$

\section{Facilities at military bases}

By 1969, reports collected from various military bases attested to the following conditions experienced by soldiers: minimal or no recreational facilities were available for use and morale and discipline was at a significant low. Conscripts were described as dirty, unshaven and aimlessly wandering around during free-time, bars were open later than permitted, and chaplains were complaining about immoral activities on base. ${ }^{55}$ The lack of recreational facilities consequently had to be addressed, not only to keep conscripts busy but to pacify the public who had been complaining that conscripts were not utilising their time in the army productively. ${ }^{56}$

The Fund identified the following facilities for acquisition: concert halls or a bioscope with a film projector, a lounge area or restaurant with piano, a reading room, darts room or billiard room with billiard tables and a table tennis room with tennis tables. ${ }^{57}$ The sporting facilities needed to include a tennis court with equipment, snooker tables, dart boards and sets, soccer or rugby balls, swimming pools, trampolines and chess sets. Military bases were also in need of everyday facilities to simplify life for the conscripts and provide entertainment. These facilities included automatic washing machines, air conditioners, televisions, video machines, films, books, newspapers, Bibles, musical instruments and cassette players and tapes for diving boats and attack vehicles. Cooking and kitchen facilities required by the army included a mobile field kitchen, stoves, freezers, refrigerators, warm water tank, cold water machines and ice machines. ${ }^{58}$ The Fund aimed to provide these facilities to as many bases as possible. ${ }^{59}$

\section{Monetary donations by the Southern Cross Fund}

As mentioned previously, the SCF made its first donation to the Army Fund in 1969 with a sum of R3000. By 1971, the amount donated had grown to R10000 and R15000 the following year. In 1973, the amount doubled to R30000. ${ }^{60} 1978$ was a fruitful year for the SCF with a donation of 11 field kitchens worth R13000 each for the SAP and facilities for the base at Ondangwa worth R17340. ${ }^{61}$ By 1980, the total monetary donation by the organisation over its 12 years of existence was an unprecedented R6 million. In 1982, the SCF donated R500000, of which they spent R350000 on facilities. ${ }^{62}$ Administrative problems, unfortunately, did occur. Martin Foster, the Tactical Reaction Group officer at Oshivelo, recalls an incident where he discovered that donations by the SCF never reached the troops but were taken by, what he called the 'Socks and Jam', administrative clerks. ${ }^{63}$ 


\section{Visits to military bases by the Southern Cross Fund}

Visits to military bases by members of the SCF occurred with the handing out of parcels or by invitation of the army. The reason for the SCF's visits to the military bases was twofold: firstly, to determine the needs of the soldiers first hand and to show the support of the public, and, secondly, to give feedback to the public about the living situation of soldiers. ${ }^{64}$ Members also made scheduled visits to No 1 (Voortrekkerhoogte) and No 2 (Wynberg) Military Hospitals. They were involved with projects to donate the following facilities, equipment and luxuries to conscripts, hospitalised here: a hydro-therapeutic swimming pool; a rehabilitation centre; donations for psychological or therapeutic help; overnight sleeping facilities for families; ${ }^{65}$ and Hospital gift packs that included reading material and music, treats, PJs and underwear, soap, razors, towels, toothbrushes, toothpaste and shampoo. The members of the SCF looked after the patients until their family members arrived. ${ }^{66}$

\section{Assistance to SADF dependents}

The Fund not only served to provide support to the armed forces but also their relatives. The Fund aimed to assist the dependents of soldiers in need financially. They donated money to those families identified for assistance to be used for rent, water and electricity bills, petrol, insurance, food, clothes and school fees ${ }^{67}$ By 1980 , the SCF was supporting 246 families; by 1984, the organisation spent an average of R260 000 annually on this assistance. Dependents were encouraged to contact the SCF for assistance when it was needed. It was especially done to prevent the concern over their families to affect the service of the conscripts. ${ }^{68}$

\section{The Ride Safe project}

The Ride Safe project was an initiative by the SCF that relied on the charity of the public to give a lift to conscripts on leave. They used slogans such as 'Help Johnny comes marching home' and 'Give our country a lift' to promote the campaign. ${ }^{69}$ Between 1976 and 1977, 232 conscripts were involved in accidents relating to privatelyowned vehicles, thus inspiring this project. ${ }^{70}$ The Fund sponsored the telephone bills and provided shelter at pickup points. By 1983, the SCF had built 43 shelters in the Transvaal, 5 in Pretoria, 15 on the Witwatersrand, 48 in the Cape Province, 17 in Natal, 17 in the Orange Free State and 9 in SWA. ${ }^{71}$

\section{Assistance in black townships}

By the mid-1980s, the activities of the armed forces had been extended to service inside the country. With the deployment of soldiers in the townships in 1984, the support of the SCF was also affected. The content of border gift packs was cut to 
provide funds for support inside South Africa. In 1987, the SCF spent R142000 on ablution facilities for soldiers' use in places of protest. They equipped temporary bases, set up in strategic areas throughout townships, with luxuries including televisions, pool tables, playing cards, darts and dartboards, and domino sets. ${ }^{72}$ This changing role of the SCF would eventually contribute to its end.

\section{THE SOUTHERN CROSS FUND AS A WOMEN'S ORGANISATION}

One can label the SCF as both a women's organisation and a civic organisation. The connection between the SCF and the image of a women's organisation is apparent from its nickname, "Dankie-tannies". This image is also supported by various academic works that refer to the SCF as a women's organisation: S.M. Fourie in 'Die impak van Militêre Aktiwiteite op die Vaaldriehoekse samelewing' calls the organisation a "vroueorganisasie". ${ }^{73}$ Jacklyn Cock's Colonels and Cadres also discussed the SCF under the chapter, 'Women's organisations' ${ }^{74}$ and in Masculinities, Militarization and the ECC, Daniel Conway generalises it as a 'women's group'. ${ }^{75}$ This image is most likely the result of twenty years under the leadership of Elizabeth Albrecht, who also served as the face of the organisation. Paratus, the mouthpiece of the SADF, that regularly reported on the SCF's activities, wrote the following about Albrecht:

Being a true woman, she has over the past ten years worked herself up to a level of absolute stability and has shown unshakable solidarity. She maintains these principles according to strict discipline and demands respect from all who get into contact with her. In the best tradition of femininity the Southern Cross Fund bears the prestigious past with dignified pride and a modesty characteristic of the remarkable woman she is. ${ }^{76}$

Brigadier Lets Kok remarked that the woman formed the home front and was responsible for the emotional preparedness of society for war:

The South African woman does not have to be in uniform to serve the army. The woman's attitude towards her husband or son's conscription affects the quality of their service to their country. ${ }^{77}$

Lorraine Boyard de Volo argued that one of the reasons why women play such an important role during wartime, besides their influence as mothers, is that they can be presented as apolitical. ${ }^{78}$ Colonel van der Walt credits the role of the mother and or wife as the success behind the SCF. He claims the Army focused on their role for two reasons: To turn possible resistance into active participation and, secondly, to keep them 'busy' with fundraising events during their husband's absence. In that way, the SCF served as a 'lightning conductor' - defusing a possible threat to the war effort. ${ }^{79}$ 
However, not everyone supported or appreciated this role. In Rocky Williams' poem, 'Cuito Cuanavale: For Gary 1987', he opposes the Border War and suggests that women did not always understand the sacrifice made by conscripts until they were affected by it themselves:

And his mother and Pat Carr
were at one with the love
that crucifies itself between the armour
of the Southern Cross
although she would halt in her giving
when the stories exploded in her chiffon living room. ${ }^{80}$

Focus nonetheless fell on the contribution of this women's organisation to the war effort. During the existence of the SCF, Albrecht was awarded for her service by numerous organisations. In 1976, she became the first woman to receive the South African Toastmasters International Communications and Leadership Prize. In 1978, she again became the first women to be awarded the Order of the Star of South Africa in the Officer's class, and a year later she became the first women to receive the rank of Honorary Colonel in the SAP. In 1983, Albrecht won the Paul Harris Prize from the Rotary Club. Recognition for her service was not just limited to South Africa. The Movimento Nacional Feminico, the Portuguese women's organisation who worked alongside the SCF during the early years, honoured Albrecht with a golden necklace for her service to the Portuguese armed forces in Angola and Mozambique. ${ }^{81}$

As a women's organisation, the SCF therefore represented the participation and mobilisation of women in the course of the Border War and filled the expected traditional role of women on the home front. De Volo argues that the traditional role of women creates the misperception that the state initiates and maintains the mobilisation of women due to the contribution of mobilised women to the war effort. De Volo concludes that women mobilise out of their initiative. ${ }^{82}$ Organisations, like the SCF, challenge the passive support of women and transform it into active support. The women had to be active in support of their country's safety. Even though women were limited to the home front, it was an active home front that formed part of the war effort and was not just limited to the support of the traditional role of men during wartime. ${ }^{83}$

\section{THE SOUTHERN CROSS FUND AS A CIVIL ORGANISATION}

Initially, the reaction from the public in support of the SCF was lukewarm due to the limited operations by the army. With the increase of military activity, the public's support grew. ${ }^{84}$ By 1981, a poll showed that 83 per cent of the public was familiar with the work of the SCF ${ }^{85}$ They raised funds on both the national and local level. Branches regularly worked with the army to raise funds. 
Fundraising events organised by the SCF included, for instance, a Debutant Ball, music concerts, Bonanza competitions with a Ford Granada as the 1st prize, blikskud, and various sporting events. Branches throughout all the provinces of South Africa also organised their fundraising projects. The income from fundraising events, divided into the different provinces, is as follows: the Transvaal, 58 per cent; the Cape Province, 25 per cent; the Orange Free State, 10 per cent; Natal, 5 per cent; and SWA, 2 per cent. ${ }^{86}$ Projects for fundraising ranged from 'Klimtolle vir Suid-Afrika' ${ }^{\text {' } 7}$ to exhibitions at the Forces' Festival, the selling of the Southern Cross Fund diary and two cooking books, Trakteer die Troepe and Resepte van Heinde en Ver. Mementoes included in the "Dankie-tannie-pakkies" and also sold to the public at Forces' Festivals were, for example, knives, pens, flags, ties, scarves and writing pads. ${ }^{88}$

Various South African companies donated large amounts to the SCF's cause. These companies included Sanlam, the Department of Correctional Services, ${ }^{89}$ the Magnis Company, ${ }^{90}$ the Italian Veteran Prisoner of War Bond, ${ }^{91}$ the Episcopal Church in Texas who donated $\$ 260,{ }^{92}$ Krygkor and Anglo American. ${ }^{93}$ The annual ball held at the Castle in Cape Town was the most popular event, attended by many politicians and prominent businessmen. ${ }^{94}$

To maintain the support offered to the fighting forces, the SCF had to call on the public on a regular basis. The role of the public was emphasised time and again in the media to gain their cooperation and funding:

The Southern Cross Fund is an important organisation in the South African life. It is born from the people and reaches out one hand to the fighters on the border and the other to the people back home. ${ }^{95}$

The Fund was advertised as a dynamic organisation and recognised channel for public support. ${ }^{96}$ They annually advertised the gift packs, handed out at Christmas and to departing conscripts. "Basics can't be all that bad, not with the useful packages handed out by the Southern Cross Fund." ${ }^{77}$ Southern Cross Fund products sold to the public, in turn, contained feedback from soldiers attesting to the SCF's contribution to their welfare and recreational time spent on military bases: "It means so much to us that there are people back home who think of us. It helps to drive the loneliness away and turns a normal day into a good day." 98 Again the SCF served its purpose as a channel between the public and the conscripts.

Despite the success, there were cases of failure and opposition. By 1988, the profile of the SCF, membership numbers and funds raised decreased, and projects were postponed and even cancelled. A weaker economy and a decrease in military activity could accredit for this. ${ }^{99}$ From 1990 to 1992, the income and donations of the SCF decreased with as much as 35 per cent. ${ }^{100}$ The organisation also endured several blows to its image. In 1980, the model Liz Shai withdrew from a Fund project due to the 
SCF's support of the armed forces outside of military bases: "I will have no option but to bow out. Black people are sensitive when it comes to defence, and I do not want them to see me as willing to help in this regard." ${ }^{101}$ In one isolated event, black nurses were forced to donate to the SCF. Their employer subtracted the donation from their salary, and they were not informed about the intentions of the donation. ${ }^{102}$ Four years later, one member of the SCF, Di Bishop, made negative comments about the attitude of conscripts after a visit to military bases, claiming conscripts were uninformed about the political situation in SWA. ${ }^{103}$ Opposition to the organisation reached a climax in 1985, when the SCF's headquarters became the target for a bomb attack by the ANC. The bomb did not cause much damage, and no one was hurt. ${ }^{104}$

Nevertheless, the SCF became the largest donator of funds to the armed forces and a representative of the participation of society to the war effort. The foreword of the SCF's cookbook, Trakteer die Troepe, emphasises this: "Throughout the country more than 260 Southern Cross branches have been working with dedication for our men on the borders, thus underlining their involvement in the struggle against terrorism." 105

\section{THE MEANING OF THE SOUTHERN CROSS FUND: MORALE BUILDER AND CREATOR OF UNITY}

Regarding the definition of a militarised society, organisations like the Southern Cross Fund become integral to the militarisation of civil society. The goal of the SCF was therefore extended from its primary goal, to serve the needs of the armed forces, to an expected secondary goal: by eliciting support for the army, the organisation indirectly carried over the values and ideals of the army to the public, thus supporting the militarisation process: ${ }^{106}$

We believe in you, we love you, you are our men, our sweethearts, our sons; we expect much of you. You must meet the challenge of this time with faith in yourselves, in your leaders, in God. The bravery and loyalty of our South African soldiers have been proven on a hundred battlefields. They have never failed us, we expect you, their sons, to keep faith. ${ }^{107}$

This idealisation of the role and duty of the conscript in the media represents the military values upheld by the public.

Regan argues that, while war influences a country on a political, economic and social level, it is the social aspect of a war that can derail the war effort, specifically referring to the presence of conscription in society. If a society does not accept this system, support for the state and army will decrease. ${ }^{108}$ As the biggest donator of funds to the welfare of conscripts, the public held the SCF responsible for their well-being and had high expectations. An emotionally loaded letter from the mother of a conscript and 
addressed to the establisher of the SCF, Elizabeth Albrecht, attests to the passionate involvement of white South African women at the time and their concern for the conscripts:

The war is no longer that faraway war to the north of South West Africa, it's here. For example, a mother says to you, 'You give parcels for the man in Ondangwa, my son is in Soweto and he is in as much danger as they are, if not more. And what are you going to do about it?'109

The concerns of the mothers were exasperated by military censorship: "What I remember best is the crying of parents. I don't think they were crying because their sons were going away, but rather because they did not know where they were going." 110

Reports from the SCF after visits to conscripts often answered these concerns. These reports were regularly published in the media to reassure the public:

The boys are tanned, healthy and glad that their parents don't have to worry about them. The conscripts are full of life and motivated in their task. Recreational facilities are adequate and include everything from swimming pools to dartboards and tennis courts. Some of the bases even have electricity in every tent. The soldiers are definitely not bored and free time is organised. The Southern Cross Fund is happy with how the money is spent. ${ }^{111}$

A similar report on the conditions at military bases aimed directly aimed at the mothers of conscripts: "Mothers can be assured that their sons are well looked after and the Southern Cross organisation has done a lot for our boys." 112 Some reports encouraged the support of the public by referring to the 'total onslaught' faced by the country, therefore directly merging the values of the army with those of society:

We have no right to expect our men in uniform to endure suffering and hardship if we at home do not manifest a strong belief that our cherished values and traditions are worth defending. ${ }^{113}$

The feedback from a civil organisation that represented society brought home the condition of the conscript's military service and served to comfort the public. This was done mainly through the media. As this quote from The Citizen shows:

Just as they are united in combating infiltration and attacks, so we, on the home front, must also unite since union still ensures and guarantees strength. The Southern Cross had succeeded laudably in impressing on people the concept of a continuous consolidated front from up-country to the border, from the home front to the battle front. ${ }^{114}$

Therefore, the emotional involvement of the public was turned into communal support. The Fund thus served to ensure the high morale of society, not just concerning victories or defeats, but also the deaths and absence of their loved ones. 
Historians such as Jonathan Fennell and James Alexander Ulio argue that, even though the army can provide for its soldier's basic needs, clothing, food and shelter, it is not enough to ensure the high morale of its troops. We must give equal attention to the soldier's environment. Albrecht believed that the country's most important weapon is the morale of society and its soldiers. ${ }^{115}$ Politicians regularly emphasised the role of the SCF in the building of morale. Magnus Malan, former Minister of Defence, supported this role of the SCF:

By providing funds to members of the South African Army for their welfare and facilities, the Southern Cross Fund is contributing to the high morale of the defending forces - that unmissable quality without which we cannot win the war. ${ }^{116}$

Through its activities, the Southern Cross Fund aimed to reach the following goals: firstly, to prove to the South African conscript that the civilians cared about and would actively work to contribute to their welfare and, secondly, to improve the morale of the conscripts through recreational equipment. ${ }^{117}$ An article in Die Oosterlig supported this sentiment:

A soldier's preparedness doesn't just depend on his weapon and what the army provides for him - a soldier must also be spiritually combat-ready; that is where his strength lies. It means a lot for a soldier's morale when he receives a Southern Cross gift pack in the loneliness of the border area. ${ }^{118}$

Magnus Malan took this opinion further and implied that the conscripts could not fulfil their task without the help of the SCF: "The tangible presence of the home front and the people back home in the form of articles provided by the Southern Cross Fund, serves as a much-needed morale boost without which the army cannot operate." 119

The contribution to the morale of soldiers by the SCF was held by the organisation to be very successful. Albrecht regularly remarked that the SCF received many letters of gratitude from conscripts and published selected letters in Southern Cross Fund products such as the cookbook, Trakteer die Troepe: "As a soldier, I was made aware of the unity built by our people back home. It kept our morale high." 120 This was also evident from the interviews with veterans, adding that " $[t]$ he Dankie-tannies had hearts of gold"; "I think it especially meant a lot for the troops who were still very young to know a mother figure cared about them"; and "The bubble gum definitely helped to better the taste of malaria pills". ${ }^{121}$ 


\section{THE SOUTHERN CROSS FUND DISSOLVES}

With the evacuation of troops from Angola and South West Africa in 1988, the services of the SCF seemed to no longer be needed. Troops were still being deployed in townships, therefore, changing the role of the SCF in 1990. ${ }^{122}$ Support continued, but the early 1990s was a time of change. After several meetings in 1995, they decided that the political situation no longer called for the existence of the SCF. ${ }^{123}$ At the national conference held that year, they decided that the organisation would dissolve. ${ }^{124}$ The organisation still followed normal procedures. The Fund paid all remaining funds out to the military bases like Ysterplaat, Saldanha and Pretoria, and a final external audit with all documentation were handed over to the Director of Fundraising on 28 February 1996. Twenty-eight years after the SCF formed, it dissolved. ${ }^{125}$

\section{CONCLUSION}

The Southern Cross Fund was an all-encompassing organisation. Due to a lack of sources, it is difficult to determine the precise membership figures, however, available statistics do attest to the size of the organisation. At its culmination, the SCF had 260 nationwide branches, 90 per cent of its funds were allocated to the welfare of soldiers, 83 per cent of the population was familiar with the SCF, and the organisation averaged a national income of $\mathrm{R} 9$ million per year that made it the second biggest welfare organisation. ${ }^{126}$ The grandeur of the SCF ensured that its impact reached the majority of the population - military as well as civil. Participation in the activities of the SCF served to unite the white society as an active home front.The relationship that the SCF built and maintained between the public and the troops was a constructive relationship that brought comfort to both parties.

We should not look at the work of the organisation and its donations as part of the debate surrounding the justification of the war. The conflict and legitimacy of the 'Total Onslaught' cannot be measured objectively, and the SCF did not serve to justify the war, but it did indirectly contribute to society's participation in the war. Therefore, the SCF should be studied in the context of the mobilisation of society and as a product of its time.

In 2001, South African forces were deployed in the Democratic Republic of the Congo. A volunteer support network, formed by civilian and veterans working together in Pretoria to support the deployed soldiers and their families, send gift bags and mail. Businesses, community organisations and volunteers donated various luxuries. ${ }^{127}$ Forty-three years after the birth of the SCF, the mobilisation process repeated itself in the tradition of the support of the troops of South Africa by the public. 


\section{Endnotes}

1 Cameron Blake, Troepie:Van Blougat tot Bosoupa (Cape Town: Zebra Press, 2009), 263.

2 Willem Steenkamp, Suid-Afrika se Grensoorlog (Rivonia:Ashanti Uitgewers, 1990), 20, 32-36.

3 'War tank: John Inggs tells how the Whippet came to Uitenhage', Eastern Province Herald, 2 Junie 1981, 17.

4 'Army gift parcels critic criticised', The Friend, 16 Augustus 1978, 8; Henry Moolman, 'Jan Christiaan Smuts and the Union of South Africa', The American Scholar, 12(4), 1943, available at: [https://www.jstor.org/stable/41204616?read-now=1\&seq=1\#page_scan_ tab_contents], 399.

5 Ian van der Waag, 'A history of the South African Defence Force Institute', Scientia Militaria, 21(4), 1991, available at: [http://scientiamilitaria.journals.ac.za/pub/article/ download/338/375], 27-29; Rebecca Gill, 'The Rational Administration of Compassion: The Origins of British Relief in War', Le Mouvement Social, 227, April-June 2009, available at: [https://www.cairn.info/revue-le-mouvement-social-2009-2-page-9.htm\#], 9-10.

6 Arthur Marwick, War and Social Change in the Twentieth Century (London: Macmillan Press, 1974), 34.

7 Patrick Regan, Organising Societies for War: the Process and Consequences of Societal Militarization (Westport: Praeger Publishers, 1994), 6, 28, 60.

$8 \quad$ Marwick (1974),12-13.

9 Regan (1994), 22, 31.

10 Ibid., 4.

11 Dylan Craig, 'Total Justification: Ideological Manipulation and South Africa's Border War' in Gary Baines and PeterVale, Beyond the Border War: New Perspectives on Southern Africa's Late-Cold War Conflicts (Pretoria: Unisa Press, 2008), 59.

12 Colonel P. van der Walt (personal communication, email, 9 January 2013).

13 'Terrorisme kan hier nie saad skiet', Rapport, 16 June 1974, 5.

14 Ibid.

15 Tim Ramsden, Border-Line Insanity: A National Serviceman's Story (Alberton: Galago Publishing, 2009), 78; David Williams. Springboks, Troepies and Cadres: Stories of the South African Army, 1912-2012 (Cape Town:Tafelberg, 2012), 133, 137; Catholic Institute for International Relations (CIIR), Out of Step:War Resistance in South Africa (London: CIIR, 1989), 30.

16 Anna Wolf, 'The Home Front in Wartime', Journal of Educational Sociology, 16(4), December 1942, available at: [https://www.jstor.org/stable/2262955?seq=1\#page_scan_ tab_contents], 202.

17 'Suiderkruisfonds kan groter rol speel', Die Vaderland, 23 June 1978, 9.

18 Regan (1994), 2.

19 Ibid., 22, 31; B.J. Olivier, The Strategic significance of Angola (Pretoria: Institute for Strategic Studies, University of Pretoria, 1984), 1-2.

20 Graeme Callister, Compliance, Compulsion and Contest: Aspects of Military Conscription in South Africa, 1952-1992 (MA thesis, Stellenbosch University, 2004), available at: [https://core.ac.uk/download/pdf/37321643.pdf], 47-48; Rodney Warwick, 'Operation SAVANNAH: A Measure of SADF Decline, Resourcefulness and Modernization', Scientia Militaria, 40(3), 2012, available at: [https://www.researchgate. 
net/publication/269867490_Operation_Savannah_A_Measure_of_SADF_Decline_ Resourcefulness_and_Modernisation], 355 .

21 John de St Jorre, 'South Africa up against the world', Foreign Policy, 28, 1977, available at: [https://www.researchgate.net/publication/273084908_South_Africa_Up_against_the_ World], 57.

RSA (Republic of South Africa), 1957, The Defence Act 44 of 10 June 1957 (Pretoria:

Government Printing Works), available at: [http://www.dod.mil.za/documents/ documents.htm]; 'SA Defence Policy', Paratus, April 1975, 26(4), 6.

Gerrit Olivier, Die Grondslae van Suid-Afrika se Buitelandse Beleid (DPhil thesis, University of Pretoria), 1973, 278.

'SA skiet 10 terroriste na soldaat se dood', Die Burger, 11 November 1975, 1.

Neil Orpen, Total Defence: The Role of the Commandos in the Armed Forces of South Africa (Cape Town: Nasionale Boekhandel, 1967), 1.

W.C. du Plessis, South Africa in the World: Lectures delivered at the annual general meeting of the Suid-Afrikaanse Akademie vir Wetenskap en Kuns in July 1969 in Pretoria on the subject of South Africa in the World (Cape Town:Tafelberg Publishers, for the Suid-Afrikaanse Akademie vir Wetenskap en Kuns, 1969, 71.

Laurie Nathan, 'Marching to a different beat: the history of the End Conscription Campaign', in Jacklyn Cock and Laurie Nathan, War and Society: The Militarization of South Africa (Claremont: David Phillip Publisher, 1989), 308-310.

Colonel Pieter van der Walt (personal communication, email, 9 January 2013). Dr Carl Albrecht, interviewed by Anneke van Heerden, [Eversdal, Cape Town], 21 January 2013; 'Die vrou agter Suiderkruis', Die Transvaler, 5 September 1984, 15.

Colonel Pieter van der Walt (personal communication, email, 9 January 2013; 8 February 2013; 13 May 2013).

31 Ibid., 9 January 2013; SABC Archives: 'Interview with E. Albrecht', Nuus om Nege (recording), 14 June 1972.

Van der Walt (9 January 2013); SABC Archives (14 June 1972).

Department of Defence Archives (DOD Archives): BGGGM, box 106, file 302/6/1

Operation War Diaries, Verslag oor die besoek aan basis deur Mev Hansen, November 1969.

Van der Walt (9 January 2013).

35 Kirkwoodse Suiderkruisfonds, Trakteer die Troepe / Treat the Troops (Roodepoort: CUM Books, 1983), 227; 'Sy woeker vir ons land', Die Volksblad, 3 February 1979, 11.

Daniel Conway, 'Somewhere on the Border - of Credibility: The Cultural Construction and Contestation of 'the Border' in White South African Society', in Baines and Vale (2008), 80.

RSA (Republic of South Africa), 1978, Fund-raising Act 107 of 20 June 1978 (Pretoria: Government Printing Works), available at: [http://www.historicalpapers.wits.ac.za/ inventories/inv_pdfo/AG1977/AG1977-A10-5-1-001-jpeg.pdf], accessed 13 May 2013. Lieutenant General R.F. Holtzhausen (personal communication, email, 8 March 2013). Van der Walt (9 January 2013); DOD Archives: CSADF, box 6A, file 507/2/1, Funksionering van die Suiderkruisfonds, June 1982. Van der Walt (9 January 2013). 'Die SAW Brandwagfonds', Paratus, February 1972, 24(2), 24.

'Defence fund to be disbanded', The Argus, 22 February 1979, 6; 'SAW Fonds hou eie Fondsinsameling', Paratus, July 1982, 33(7), 79; 'Die SAWF', Paratus, December 1977, 28(12), 20; DOD Archives: Minister of Defence (MVV), box 285, file MV/B/62/10, Vryetydsbesteding, Hulpverlening met sport en oriëntasiedienste, June 1979. 
'R5 miljoen is Suiderkruis se blink ster', Die Vaderland, 21 August 1978, 12.

'Elkarien Fourie:Weermag eer mev. Albrecht vir Suiderkruis-diens', Beeld, 3 November 1978, 4.

Suiderkruisfonds (1983), 228; DOD Archives: MVV, box 285, file MV/B/62/10, Letter from A van Vuuren re Vryetydsbesteding, May 1979.

Suiderkruisfonds (1983), 228; 'SCF Celebrates', Paratus, August 1978, 29(8), 41; 'Fonds se beeld opgeknap', Beeld, 11 October 1979, 11.

'Sue Garbett: Soldiers have her to thank', The Star, 31 January 1978, 11; DOD Archives: CSADF, box 6A, file 507/2/1, Funksionering van die Suiderkruisfonds, June 1982.

Van der Walt (9 January 2013); 'Elizabeth Albrecht op Melkbos oorlede', Die Burger, 22 March 2001, 3.

'Kerspakkies', Paratus, December 1972, 24(12), 18.

'Die SAW Brandwagfonds', Paratus, February 1972, 24(2), 24; Van der Walt (9 January 2013; 13 May 2013).

'Hoe lyk die pakkie grens toe', Rapport Tydskrif, 14 April 1974, 6.

'Die SAWF', Paratus, December 1977, 28(12), 20; Van der Walt (13 May 2013;

9 January 2013); Revision of commentary by veterans on questionnaire, Facebook, Group: Grensoorlog/Border War, Questionnaire, 23 May 2013.

'Die SAWF', Paratus, December 1977, 28(12), 22.

Albrecht (14 June 1972); ‘SKF skenk R40 766,17’, Paratus, April 1974, 25(4), 19;

'Weermag kry R30000', Die Vaderland, 24 March 1984, 3; 'Suiderkruisfonds werk vir veilige SA', Die Transvaler, 18 March 1987, 10.

DOD Archives: BGGGM, box 106, file 302/6/1 Operation War Diaries, Klagtes oor kroegtye, 1969; DOD Archives: BGGGM, box 106, file 302/6/1 Operation War Diaries, Verslag oor toestand van basis, November 1969.

DOD Archives: MVV, box 285, file MV/B/62/10, Memorandum Besoek van Weermagpersoneel aan basisse (Vryetydsbesteding), April 1973.

Ibid.

'Soldiers have her to thank', The Star, 31 January 1978, 11;'Gerda Klopper:

Suiderkruisfonds help eintlik waar nood is', Die Oosterlig, 21 April 1980, 6; 'Verdere korrupsie beweer', Rapport, 17 July 1983, 1; 'Kittie Vermaak: R 5 miljoen is Suiderkruis se blink ster', Die Vaderland, 21 August 1978, 12; 'Johan Gagiano: Bull skakel tussen publiek en Suiderkruis', Die Transvaler, 12 September 1980, 4; 'Suiderkruisfonds doen skenkings', Hoofstad, 16 October 1978, 5; 'Polisie kry mobiele kombuis', Beeld, 14 July 1984, 4; 'R516 915 aan Weermag bestee verlede jaar', Die Oosterlig, 19 September 1984, 5; SABC Archives: 'Interview with E. Albrecht', Nuus om Nege (recording), 23 November 1979; Facebook (23 May 2013).

Die Transvaler (18 March 1987).

SABC Archives: 'Interview with E. Albrecht' (recording), Nuus om Nege, 17 July 1973; 'Die SAW Brandwagfonds', Paratus, February 1972, 24(2), 24.

61 Die Vaderland (21 August 1978); 'Suiderkruistak gee R7 000 aan Weermag', Die Vaderland, 1 February 1978, 10.

Die Transvaler (12 September 1980); DOD Archives: CSADF, box 6A, file 507/2/1, Funksionering van die Suiderkruisfonds, June 1982.

Facebook (23 May 2013).

64 DOD Archives: MVV, box 285, file MV/B/62/10, Memorandum Besoek van Weermagpersoneel aan basisse (Vryetydsbesteding), April 1973. 
65 Van der Walt (9 January 2013); 'Kolonel nuwe voorsitter van Suiderkruisfonds', Die Burger, 2 March 1989, 13; Die Transvaler, 18 March 1987.

66 'SKF besoek No. 1 Militêre hospitaal', Paratus, June 1982, 33(6), 61; Van der Walt (9 January 2013; 13 May 2013).

67 Van der Walt (9 January 2013); Suiderkruisfonds (1983), 241-242.

68 'R331 000 bestee aan geriewe by grens', Die Oosterlig, 16 March 1982, 4; 'Lloyd Bodill: R30000 given by funds to help border soldiers', Evening Post, 19 August 1981, 6; Suiderkruisfonds (1983), 242; Van der Walt (9 January 2013); Stephanus Fourie, Die Impak van Militêre Aktiwiteite op die Vaaldriehoekse Samelewing in die Tydperk 1974-1994 (PhD thesis, Potchefstroom University for Christian Higher Education, 2002), available at: [https://dspace.nwu.ac.za/handle/10394/14075], 298.

69 Michael Drewett, 'The Construction and Subversion of Gender Stereotypes in Popular Cultural Representations of the Border War' in Baines and Vale (2008), 97; Fourie (2002), 301.

70 DOD Archives: MVV, box 285, file MV/B/62/10, Vryetydsbesteding, Rygeleenthede vir Nasionale Dienspligtiges, May 1979.

71 Suiderkruisfonds (1983), 249; 'Jannie Coetzee: Onderdak kom vir soldate wat wag om huis toe te gaan', Die Transvaler, 10 February 1982, 5; 'DP-skuilings oorweeg', Die Volksblad, 16 February 1982, 4;Van der Walt (8 February 2013); Jacklyn Cock, 'Manpower and militarisation: women and the SADF', in Cock and Nathan (2008), 52; DOD Archives: MVV, box 285, file MV/B/62/10,Vryetydsbesteding, Rygeleenthede vir Nasionale Dienspligtiges, May 1979.

72 'Con Botha neem SKF onder sy vlerk', Tempo, 14 March 1991, 7; Die Transvaler (18 March 1987); SABC Archives: 'Interview with E. Albrecht', Nuus om Nege (recording), 20 March 1986.

73 Fourie (2002), 200.

74 Jacklyn Cock, Colonels and Cadres:War and Gender in South Africa (Contemporary South African Debates) (London: Oxford University Press, 19 May 1994), 106-109.

75 Daniel Conway, 'Masculinities, Militarisation and the End Conscription Campaign: War resistance in apartheid South Africa' in African Affairs, 112(448), July 2013, available at: [https://www.academia.edu/1815128/Masculinities_Militarisation_and_the_End_ Conscription_Campaign_War_Resistance_in_Apartheid_South_Africa], 83. 'Southern Cross Fund Celebrates', Paratus, August 1978, 29(8), 40.

77 Gabrielle Malan, Ek het Iemand op die Grens (Cape Town:Verenigde Protestantse Uitgewers, 1981), 65.

78 Lorraine Bayard de Volo, 'Mobilizing Mothers for War', Gender and Society, 18(6), December 2004, available at: [https://www.academia.edu/2001031/Mobilizing Mothers_for_War_Cross-National_Framing_Strategies_in_Nicaraguas_Contra_War], 715-716.

79 Van der Walt (8 February 2013).

80 Gary Baines, 'Blame, Shame or Reaffirmation? White Conscripts reassess the meaning of the Border War in Post-Apartheid South Africa', Interculture, 5(3), October 2008, available at: [https://www.academia.edu/350467/Blame_Shame_or_Reaffirmation_White_ Conscripts_Reassess_the_Meaning_of_the_Border_War_in_Post-Apartheid_South_ Africa], 218.

81 'Elizabeth Albrecht op Melkbos oorlede', Die Burger, 22 March 2001, 3; 'Southern Cross Fund has new head', The Citizen, 23 February 1989, 10; “Dankie-tannie' groet na 20 jaar', Die Burger, 8 March 1989, 11; 'Albrecht made a colonel', Pretoria News, 28 May 1979, 5; 'Elizabeth Albrecht ontvang Ster', Die Transvaler, 14 November 1979, 3; 
'Weermag eer mev. Albrecht vir Suiderkruis-diens', Die Beeld, 3 November 1978, 4;

'Grensfonds se stigter vereer', Die Beeld, 9 June 1983, 4.

82 Bayard de Volo (2004), 720.

83 Loraine Maritz, 'Afrikanervroue se politieke betrokkenheid in historiese perspektief met spesiale verwysing na die Women's National Coalition van 1991 tot 1994' (DPhil thesis, Stellenbosch University, 2004), available at: [http://hdl.handle.net/10019.1/1188], $13,53$. 'Janine Stein: End of an era for fund founder', The Citizen, 7 March 1989, 18; "Dankietannie' groet ná 20 jaar', Die Burger, 8 March 1989, 11.

DOD Archives: CSADF, box 6A, file 507/2/1, Funksionering van die Suiderkruisfonds, June 1982.

86 'Suiderkruisfonds oorskry rekord', Die Vaderland, 1 August 1984, 3.

“Klimtolle vir SA' moet Suiderkruis se fonds styf', Hoofstad, 13 June 1979, 6. 2007), 1. 3 December 1983, 11.

113 'Home fires', The Natal Witness, 31 January 1984, 6.

114 'Transvaal tops Southern Cross' contributions', The Citizen, 11 Augustus 1984, 4. 
115 'Arms not enough - Treurnicht', The Star, 12 March 1979, 7; 'Ada Nelson: Peetma van SA soldate', Suid-Afrikaanse Oorsig, 23 February 1979, 11.

116 'Ons sal meer van onsself moet gee!', Paratus, December 1981, 32(12), 25.

117 Van der Walt (9 January 2013).

118 'Dit is 'n eer om die troepe te dien', Die Oosterlig, 19 September 1984, 5.

119 'Fonds het soldaat se behoeftes gesien', Hoofstad, 4 November 1978, 1.

120 Suiderkruisfonds (1983), 226.

121 Facebook (23 May 2013; 7 June 2013).

122 'Suiderkruisfonds se rol het verander', Die Oosterlig, 23 September 1990, 3.

123 Van der Walt (9 January 2013).

124 Ibid.

125 Ibid.; Ds Jan Venter, interviewed by Anneke van Heerden, [Bloubergstrand, Cape Town], 4 June 2013.

126 'Soldiers have her to thank', The Star, 31 January 1978, 11; Fourie (2002), 316; DOD Archives: CSADF, box 6A, file 507/2/1, Funksionering van die Suiderkruisfonds, June 1982; 'SKF skenk R500 000', Paratus, October 1981, 32(10), 85.

127 “Dankie-tannies' herleef', Beeld, 4 June 2001, 5. 



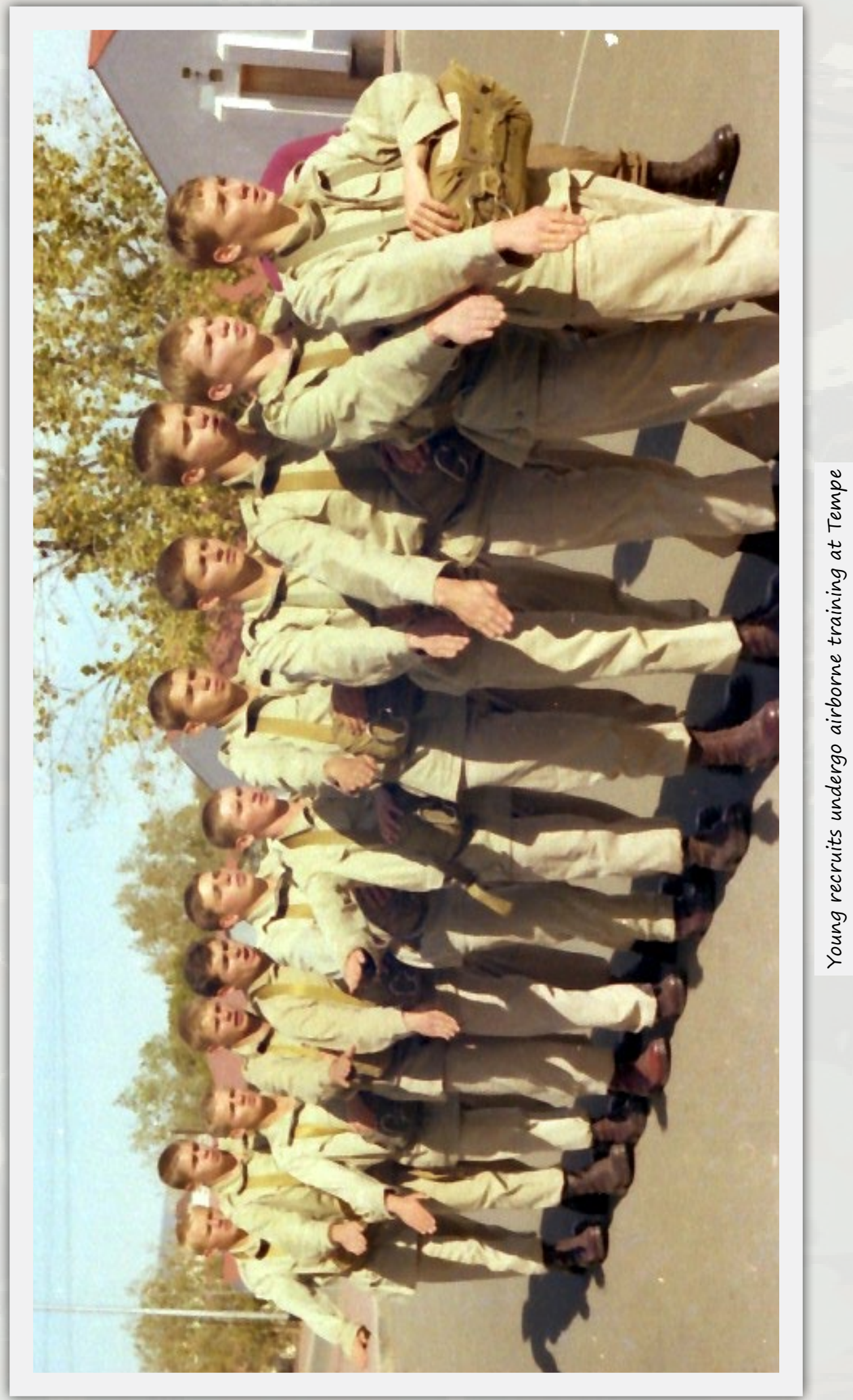




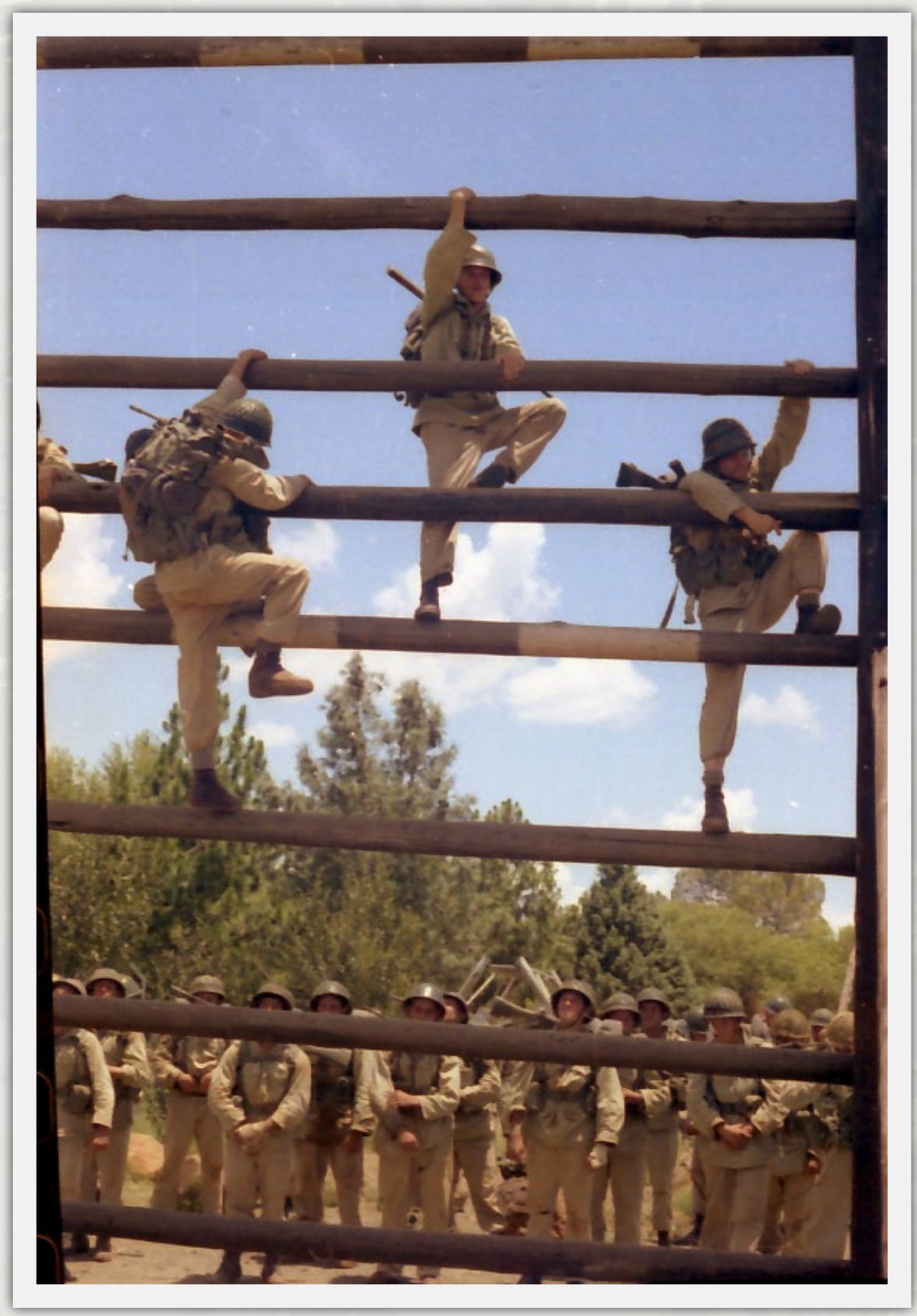

Young recruits undergo airborne training at Tempe 


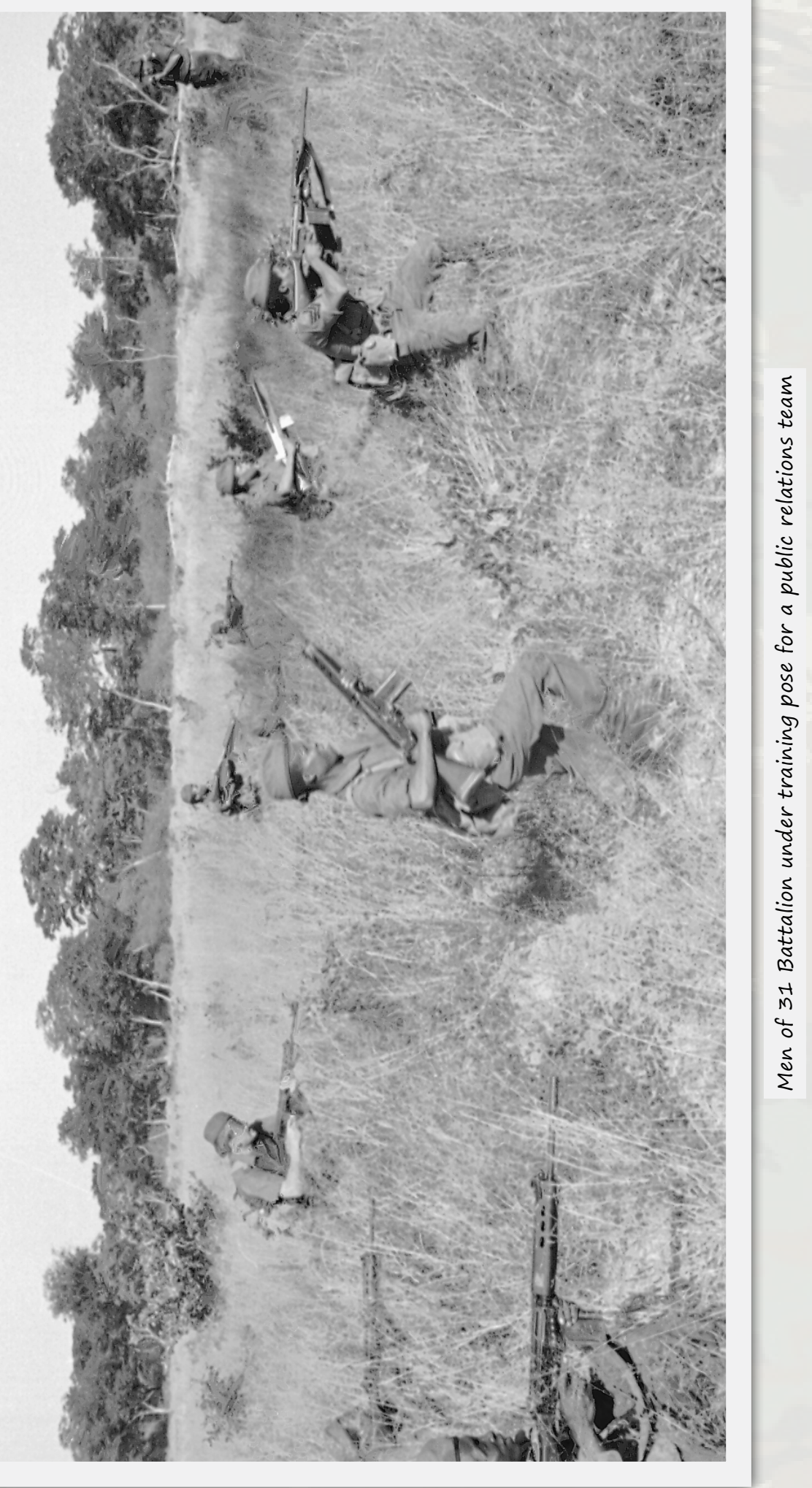




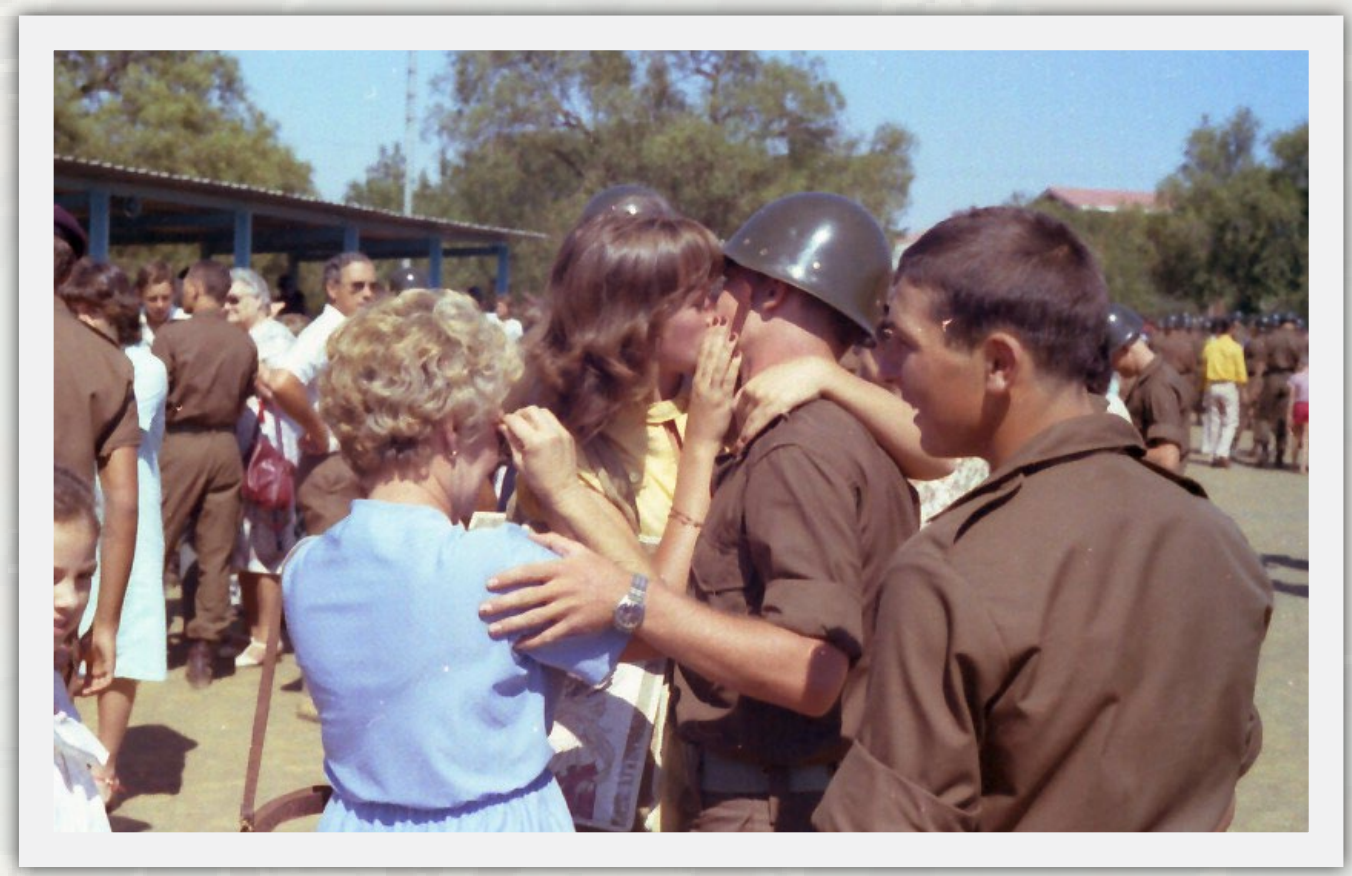

A warm embrace from a girlfriend on parents' day at a training camp

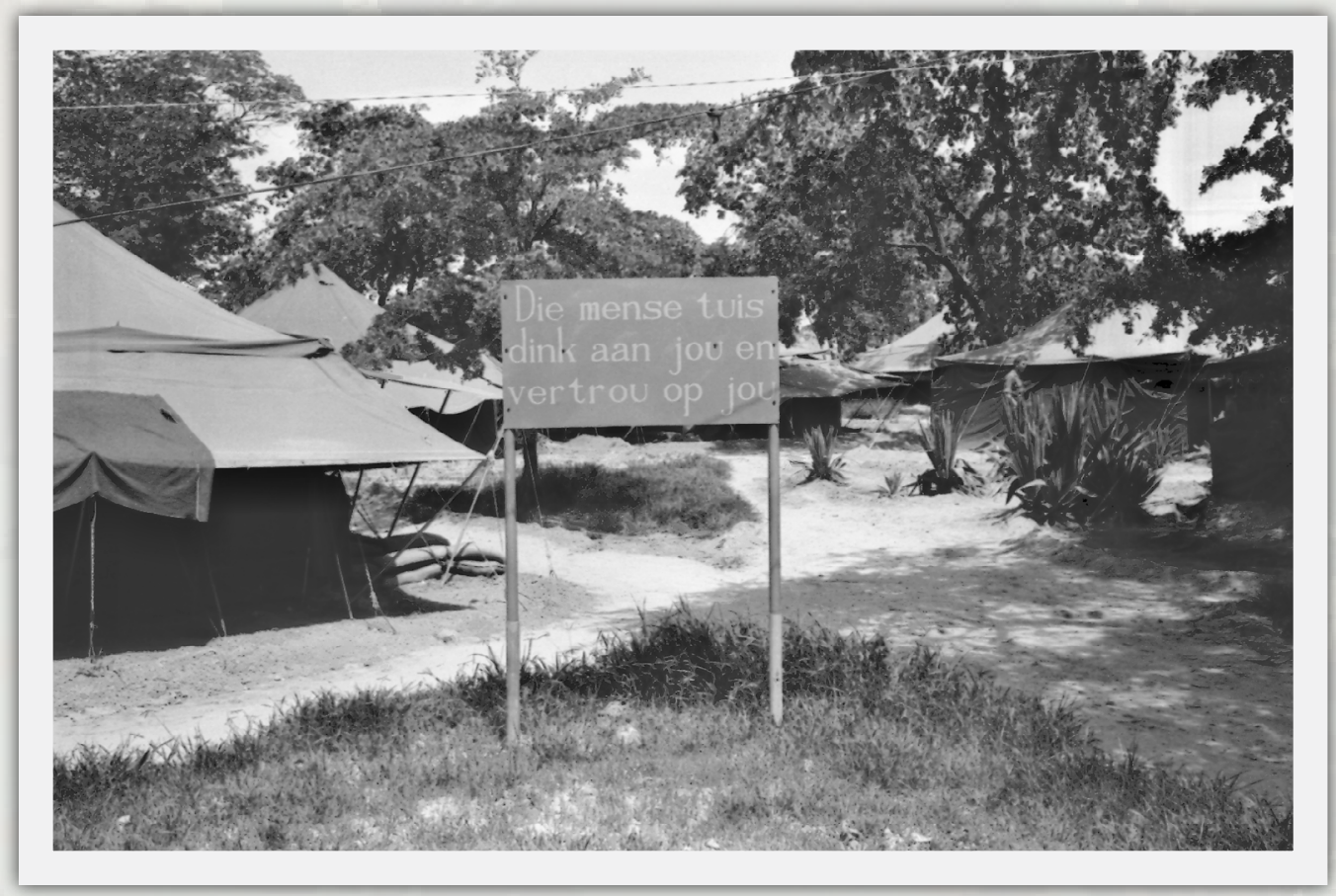

A reminder of the connection between the home front and The Border 


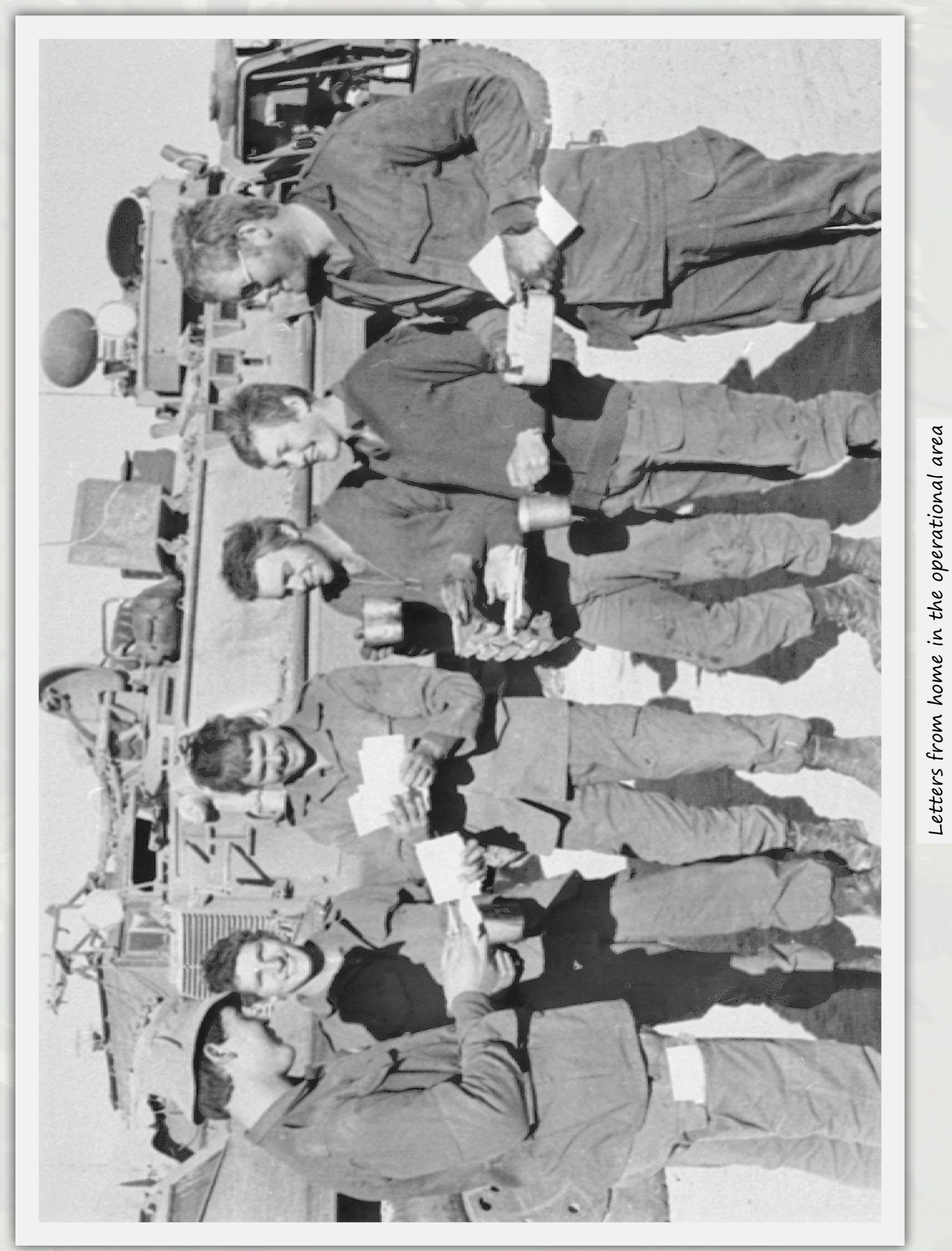




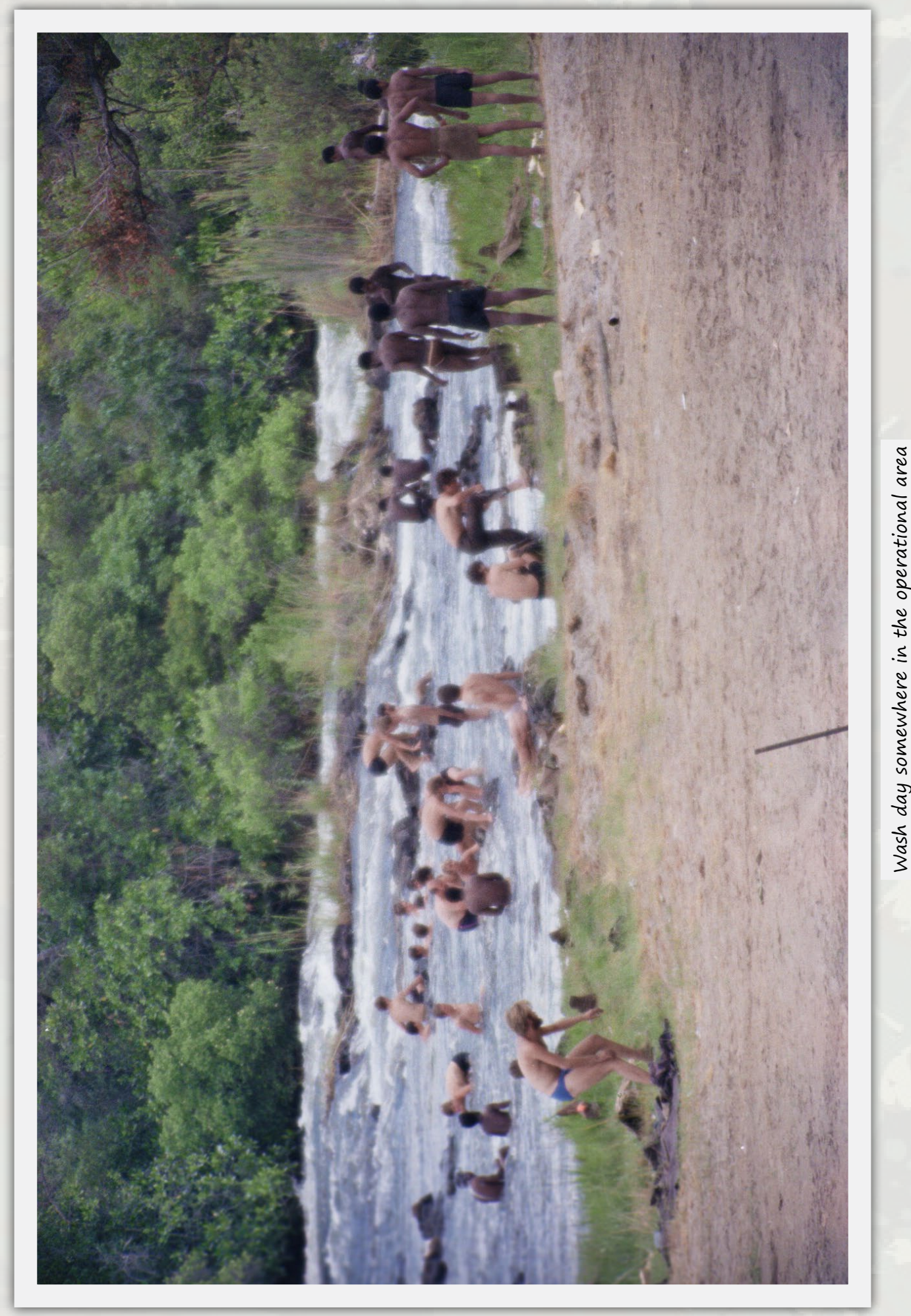




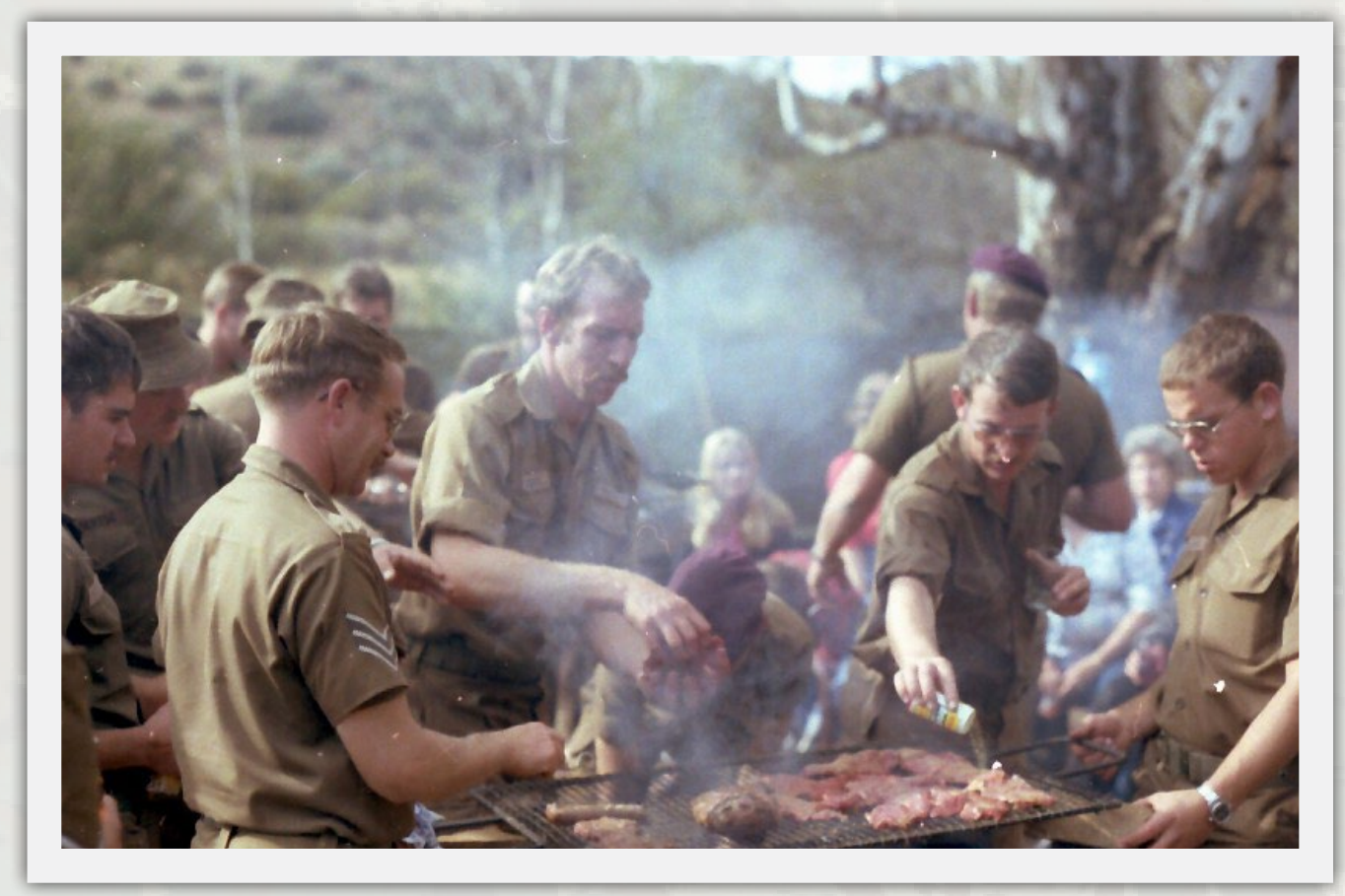

Always an excuse for a braai

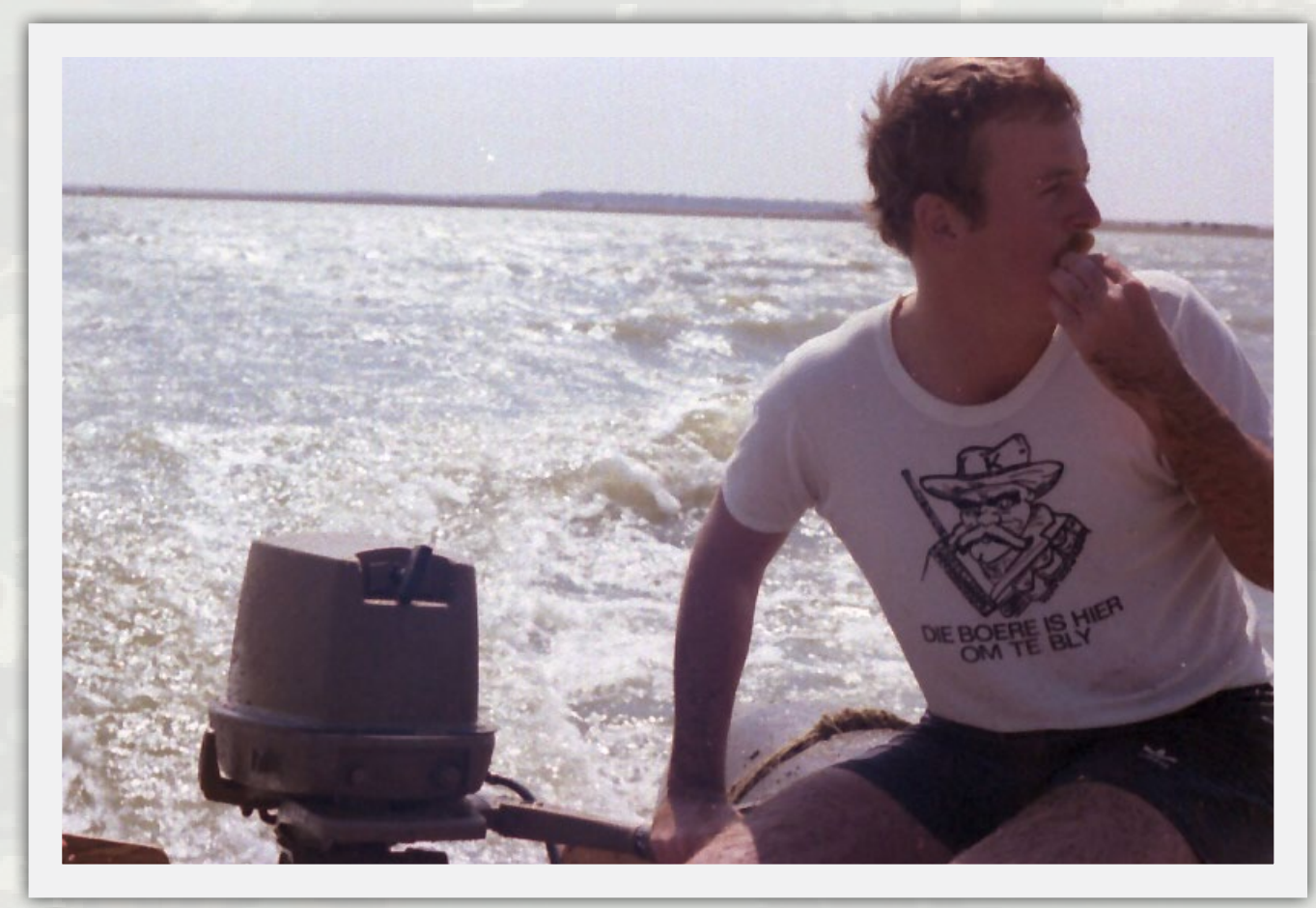

The battle for hearts and minds on the home front 


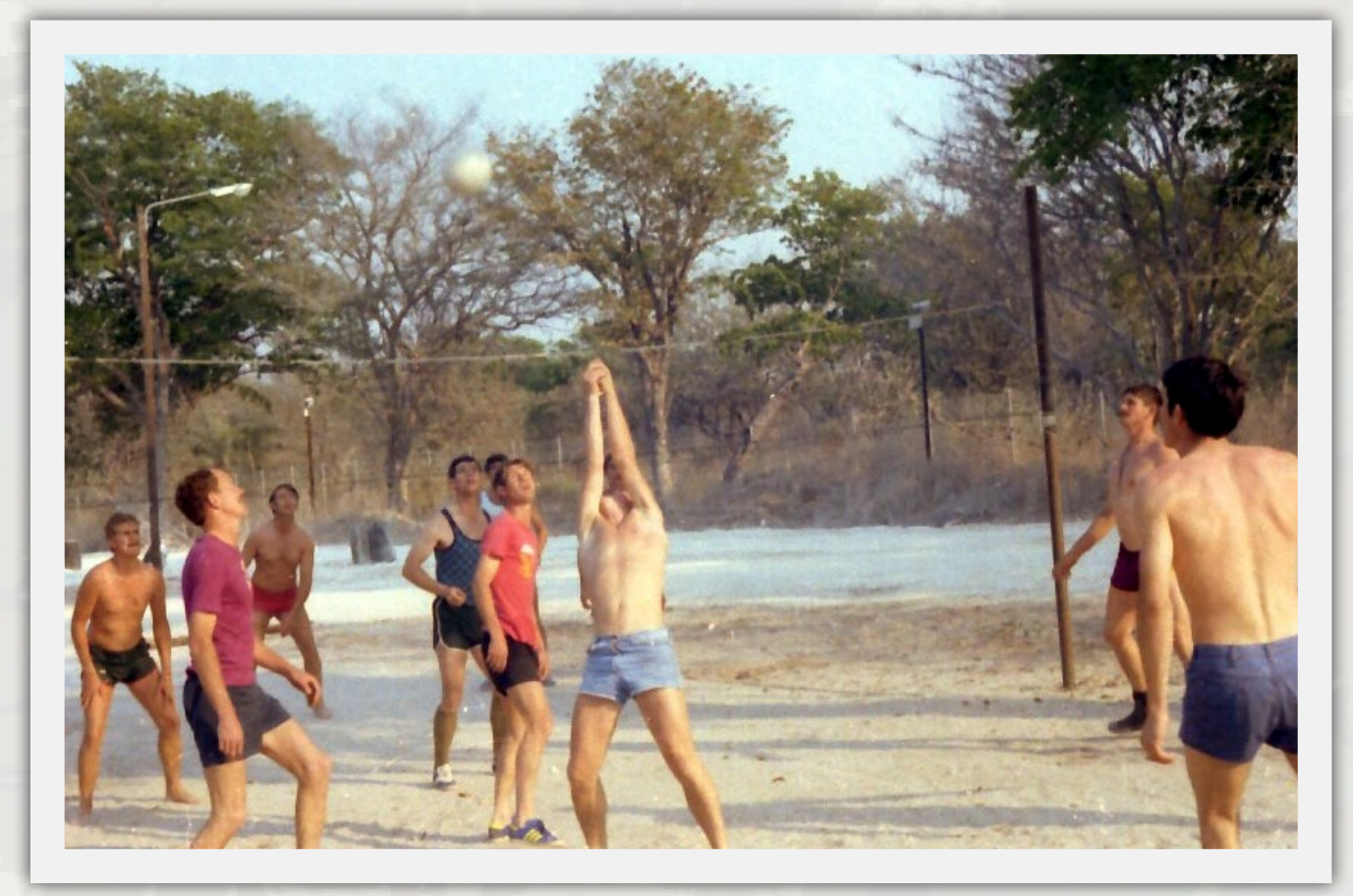

Leisure time utilisation - volleyball on The Border

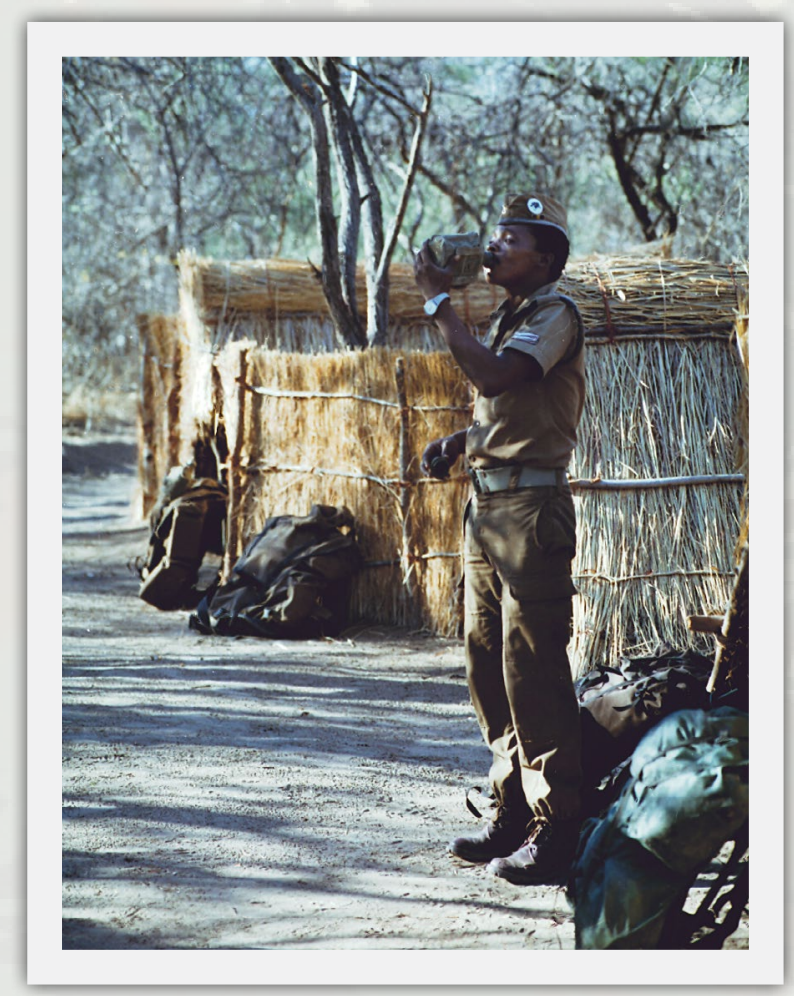

A corporal in the kimbo at the Omega base of 31 Battalion 


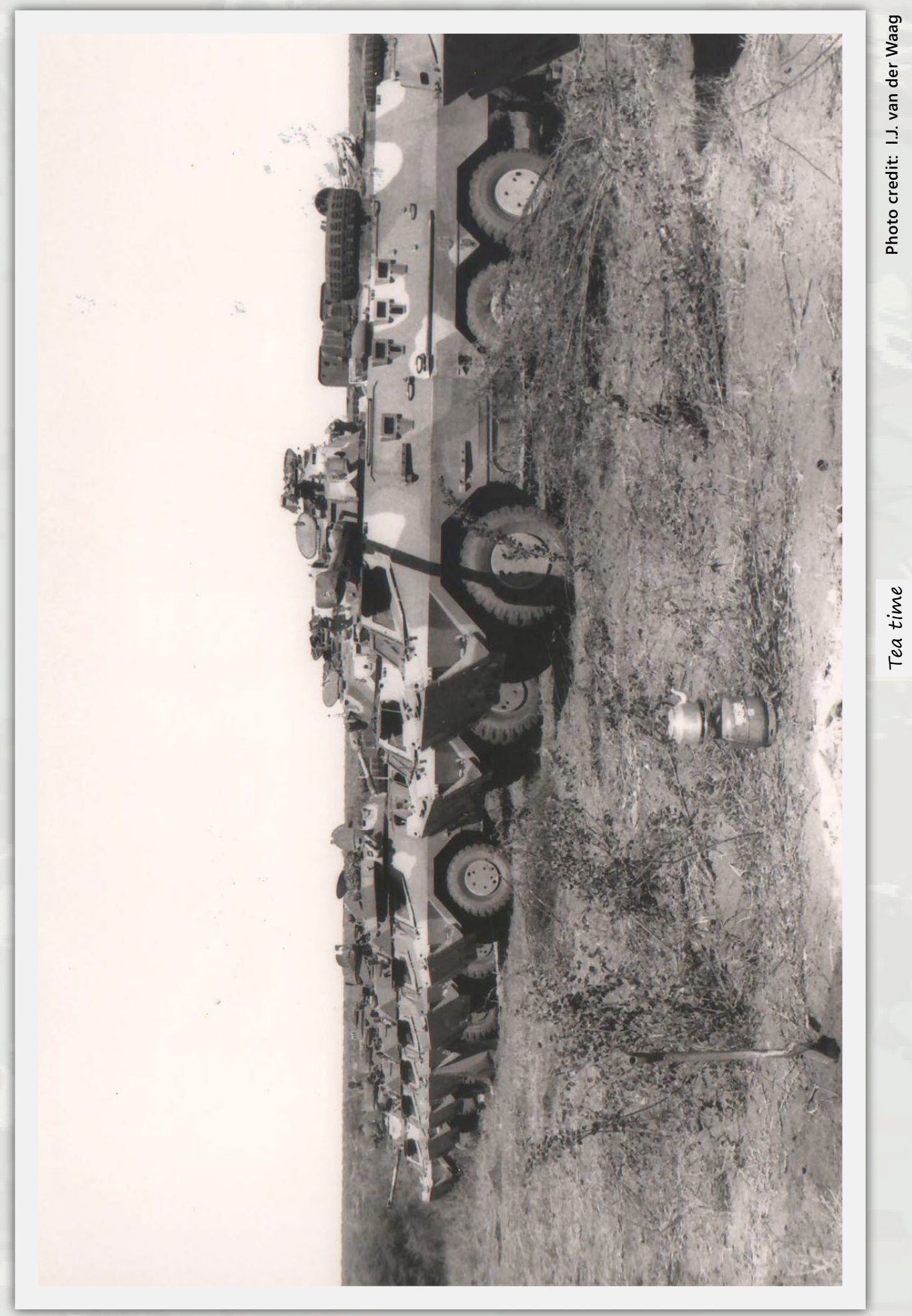




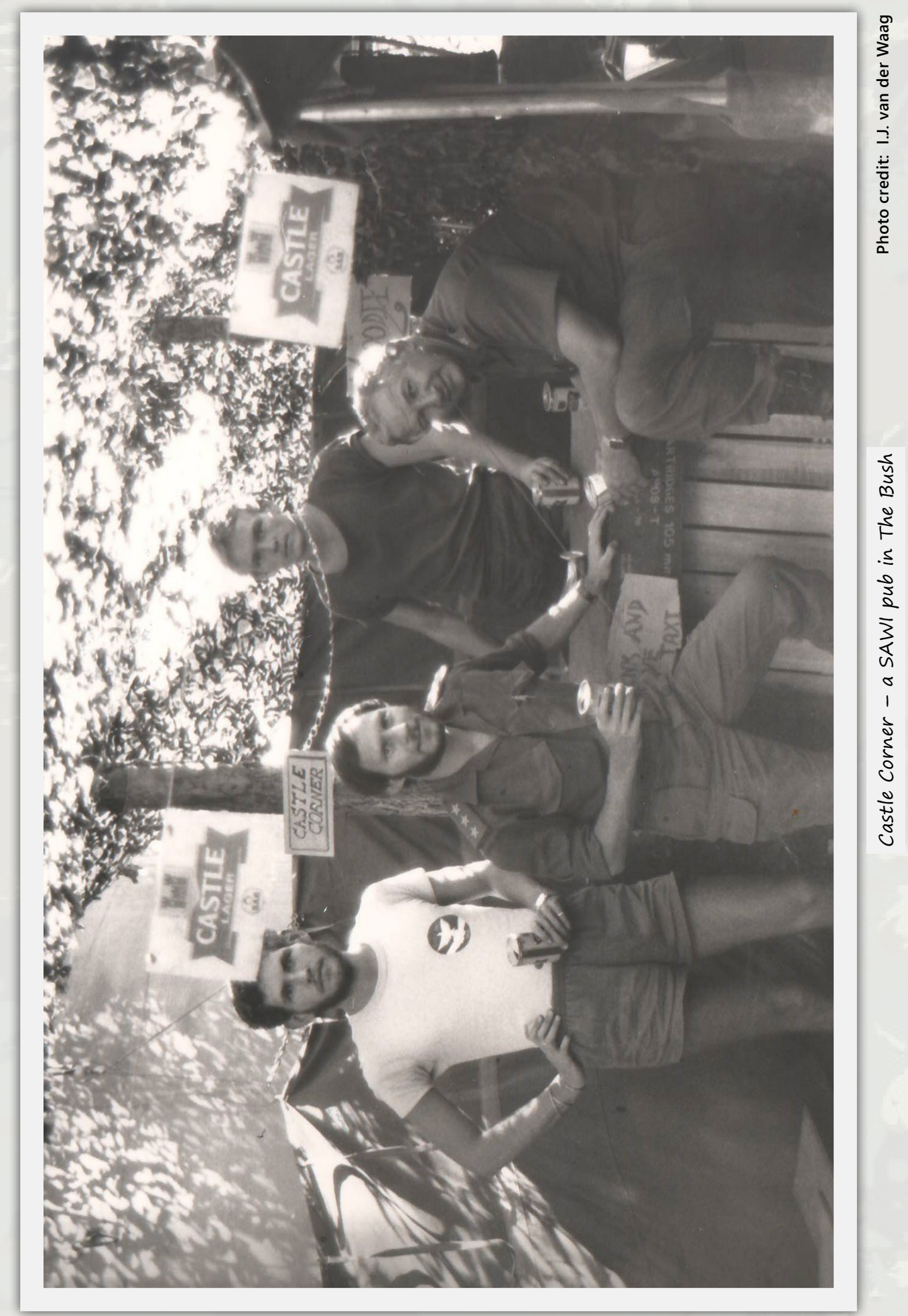




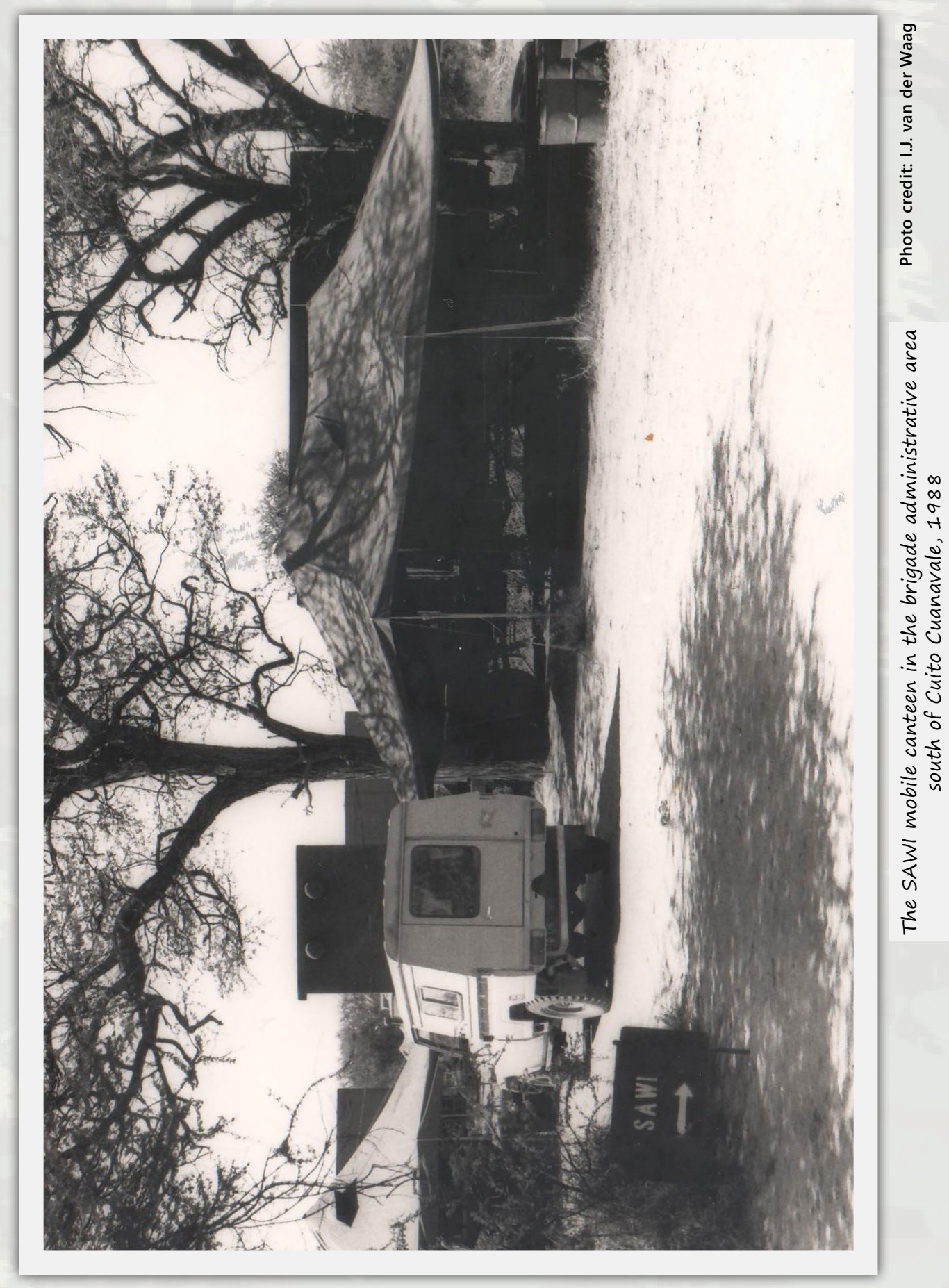




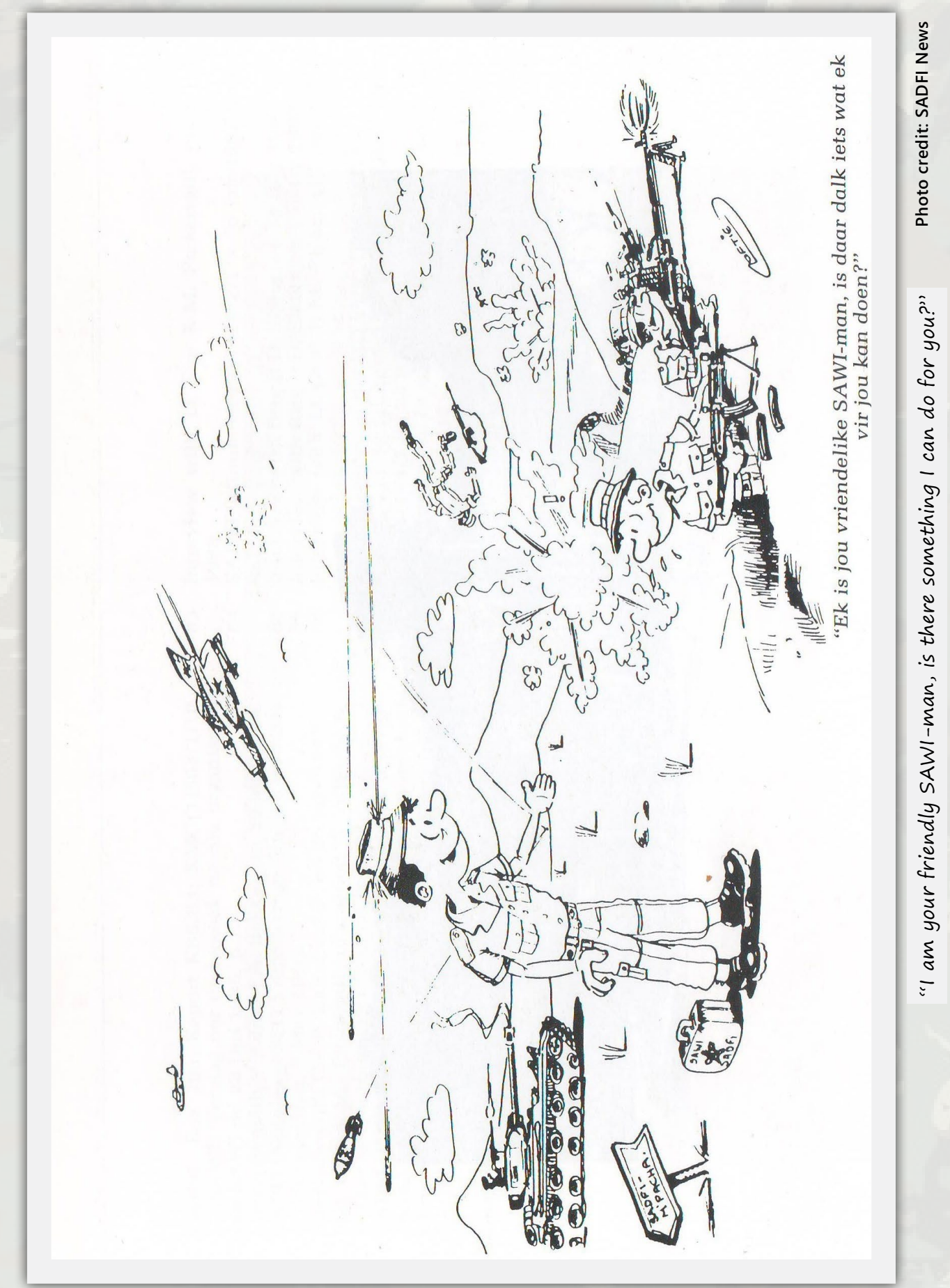



Part THREE 


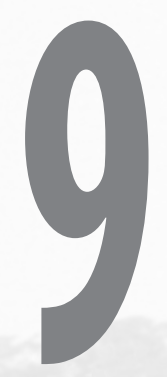

\section{CONFESSIONS OF A CONSCRIPT, DISCLOSURES OF A HISTORIAN:} AN AUTOBIOGRAPHICAL ESSAY ABOUT THE BORDER WAR

Gary Baines 
In the preface to my book, South Africa's Border War: Contested Narratives and Conflicting Memories, ${ }^{1}$ I proffered the following statement:

For the sake of full disclosure, it should be noted that I am a former South African Defence Force (SADF) conscript and hence a veteran. I make no claim to speak on their behalf though. In fact, many of my opinions are at odds with those of large segments of this 'community of remembrance'. Nor did I set out to write myself into this (hi)story. But it would be disingenuous or dishonest to deny that I have something personal invested in this project.

To reference my prior statement as a point of departure for this chapter might well be deemed self-indulgent or solipsistic. But my intention of repeating it here is to problematise this articulation of the relationship between my younger self as a SADF conscript and my current self as a veteran and historian of the Border War. When someone first asked me whether I wrote myself into the (hi)story of the War, I demurred. My training as a historian prompted me to take recourse in the largely discredited notions of objectivity and impartiality. But I soon realised that, while I might not have been fully aware of it at the time, my personal experience of the military informed my approach to writing about the Border War. While I acknowledged as much in my book, I did not explore my epistemological assumptions and how these influenced my historiographical practices. I propose to do so here.

Practising historians seldom articulate their epistemologies, and I am no different, partly because the theories of how we acquire and create knowledge seem abstract or abstruse to historians trained in the tradition of empiricism. Suffice to say I have forsaken the view that we have direct access to reality and come to accept that language and genre - in the sense of the codification of discursive practices - mediate the past. Hence historical knowledge is not simply derived from observation of the evidence and the inference of its meaning. Rather, I have come to accept that the meaning of historical narratives are not discovered in the events but reconstructed from subjective traces of the past. I subscribe to a 'soft' version of constructivism that allows for the existence of an independent reality that sets limits to what meaning(s) may be gleaned from texts; they cannot simply mean what we want them to mean. History, then, is a discourse based upon a set of rules that define how 'truth' is arrived at and how it is (re)presented and (re)produced. ${ }^{2}$ My postmodernism - if that's what it is - has made me more self-reflexive about the practice of history. It behoves me to recognise that my epistemology defines my positionality as a scholar and underpins this venture into auto-historiography. ${ }^{3}$ 
The confession is a model of autobiographical writing. It has its origins in Christian ritual but subsequently became literary genre exemplified by the writings of the early Christian father, St Augustine (397-400 C.E.). Although secularised, the confession has retained its form as a series of self-disclosures that amount to the recounting of a transformative or conversion expeience. The French philosopher Jean-Jacques Rousseau's 'foundational autobiography' The Confessions (1782) ${ }^{4}$ serves as "serious exploration in the limits of truthful self-representation". ${ }^{5}$ The confession reveals the narrator's fears and foibles to the reader; it renders the subject vulnerable to being criticised, judged, misunderstood, or even not believed. Confessional narratives crafted as intensely subjective explorations of the self are mainly concerned with the ethical dimensions of growth. ${ }^{6}$ The conventions of the confession are evident in memoirs and other forms of life writing.

The confession is usually regarded as being an altogether different genre from historical writing. Whereas the confession risks exposing the inner self to scrutiny, the academic essay is designed to establish distance between the subject matter and the self. Thus, when writing about war, the normative social discourse of scholarship requires me to disavow the embodied self of a veteran. ${ }^{7}$ However, I regard this as untenable as I have come to share Simon Schama's viewpoint that "all history tends towards autobiographical confession". ${ }^{8}$ In what follows, I suggest that my positionality as a historian of the Border War was shaped by my experience as a SADF conscript that is, in turn, contingent upon my memory as a veteran.

Memory is not merely stored in the brain as a series of snapshots of the past. Instead, it is constantly reconstructed to make sense of our experience and knowledge in the here and now. We tend to align and fashion our memories according to how we define ourselves in relation to others; according to our understanding of self within a group or social context. In other words, the intersection of collective and autobiographical memory shape our identity. Geoffrey Cubitt notes that autobiographical memory refers to "any recollection of past events or circumstances that carry a trace of autonoetic (or self-knowing) awareness". ${ }^{9}$ If my autobiographical memories reveal something significant about my identity and essential truth about the self, ${ }^{10}$ then they are tantamount to confessions even when appearing in the guise of life history.

The confession is thus a mode of life writing that takes the form of testimonials that recount personal experiences that provide a version of past events from the perspective of someone who directly experienced them. Those that testify assign responsibilities to others and assume as much for their conduct - unless the confession is deliberately evasive or self-serving to shift blame for reprehensible deeds such as human rights violations or atrocities. It might take the form of an ordinary soldier insisting that his 
conduct was justified as he was following orders, or it might take the form of an officer attributing his conduct to conformity to institutional authority. The subordination of individuality to the institution and its corollary, the denial of personal agency, is seldom absolute. There are always some choices to make, even if circumscribed in the case of conscripts.

At the age of 18, the SADF conscripted me. I went reluctantly, opting to render National Service straight out of school rather than defer it until after university. My service was wholly undistinguished. I never volunteered for anything and did not rise above the rank of rifleman. Following my training, I was deployed in the so-called 'operational area' on the Namibian/Angolan border but did not experience combat. Instead, I became a casualty of war as a result of a near-fatal vehicle accident towards the end of my stint of 'border duty'. ${ }^{11}$ I spent several months recuperating in military hospitals from serious injuries before being discharged. After being declared fit enough to resume my military commitments, I was transferred to Donkin Commando in Port Elizabeth (where I was teaching). When my Citizen Force Unit was deployed to quell 'unrest' in the local townships, I refused to comply, and the SADF charged me for refusing to obey orders. But the officer commanding my unit preferred not to make a public spectacle of my case, especially when it turned out that I was one of several troops who objected to having to 'police' the townships.

Consequently, I was permitted to perform my duties in the stores in the unit's headquarters. In the official records of the SADF, neither of these episodes is mentioned (although the first incident was reported briefly in the press). When I accessed my file in the Department of Defence Documentation Centre, I found no trace of either of the events. What I did discover was a medical report concerning my injuries and treatment following surgery in 1 Military Hospital, as well as a detailed register of the hours spent issuing uniforms and equipment to members of Donkin Commando. I found this archival 'silence' somewhat disconcerting as there seemed to be no official confirmation of my acts of recklessness and defiance.

Nonetheless, my recall of these episodic memories suggests that my military experience impacted profoundly upon my social consciousness and political awareness. I abhorred being treated as a cypher by an institution that sought to break down and then remake me in its mould. I developed a deep-seated resentment of the arbitrary authority abused by non-commissioned officers (NCOs) and officers who did not earn respect but demanded it based on their rank. While I did not directly challenge the opinions of instructors for fear of being victimised, I resisted the SADF's indoctrination in other ways. For instance, I had the gumption to submit a piece to the base rag of 2 South African Infantry Battalion in which I drew an analogy between the futility of fighting the desert sand infiltrating Walvis Bay and the South West Africa Peoples' Organization (Swapo). An officer berated me as a 'communist' for my troubles. Deployment in Namibia and the performance of 'border duty' made me question the 
legitimacy of the SADF's occupation of that country. Subsequently, during my years at university, I came to regard my service in the SADF with misgivings and the war in Angola and Namibia as morally indefensible. I could not identify with those who came to regard their time in the SADF with fondness, who evinced a nostalgia that I found nauseating. Like Second World War military veteran and scholar, Paul Fussell, who adopted the persona of "the pissed-off infantryman in the guise of a literary and cultural commentator", ${ }^{12}$ I became a bitter veteran indignant at having had to defend an unjust system. In some respects, my Border War project seeks to recuperate my sense of self-worth or, at the very least, affirm my humanity.

\section{MY BORDER WAR PROJECT}

My reading of several conscript memoirs piqued my scholarly interest in the Border War. Their publication punctured the conspicuous silence in the public sphere about the subject. I attributed this largely to the need to observe political correctness and circumspection in a climate of national reconciliation. SADF veterans who had been on the 'losing side' of history adopted a wait and see attitude towards the new dispensation. As the new ruling party, the African National Congress (ANC) consolidated its position as the premier liberation movement and constructed a triumphalist 'Struggle' narrative. The ANC regarded the Angolan/Namibian War as only a sideshow in the anti-apartheid struggle, but Umkhonto we Sizwe (MK)'s armed struggle accorded pride of place in the official narrative. ${ }^{13}$ School curricula and history textbooks were revised, memorials erected, commemorative stamps issued, and a pantheon of heroes and martyrs was constructed to legitimise the new regime. Notwithstanding the ANC's use of history to validate its rule, the party has entrenched a constitution that safeguards freedom of speech and so allows counternarratives to circulate in the public sphere. The existence of divisive memory regimes allowed SADF apologists to claim control over the SADF's institutional memory by the dissemination of their narratives. Meanwhile, in the private sphere, SADF veterans shared their stories with compatriots and family members. An inability to come to terms with their trauma, or the burden of guilt and shame, cause reticence on the part of former combatants to do so. Thus personal inhibitions and public constraints combined to produce a relative silence rather than amnesia. ${ }^{14}$

In the new millennium, SADF veterans found their voices and the silence well and truly shattered. I have suggested elsewhere ${ }^{15}$ that their renewed self-belief was made possible by the belated discovery of post-traumatic stress disorder (PTSD) and the appropriation of victimhood. It also owed much to the advent of the internet that provided an unregulated (cyber)space that enabled veterans to air their views and relate their stories. Indeed, the internet has provided them with a ready audience that is not particularly demanding as to accurate historical contextualisation nor discerning 
when it comes to the literary qualities of their output. The Border War has also been the subject of a stream of commercially and privately published personal narratives; a documentary film series screened by the Kyknet television channel; a revived anti-war theatre production; a musical; popular songs; art; photographic exhibitions; media installations; and so on. The market for Border War cultural artefacts and memorabilia has been saturated in the last decade or so.

My monograph seeks to understand the 'afterlife' of the Border War. I employ a framework that focuses on collective memory and cultural production that shapes the representation and remembrance of war. The book traces the forms and practices of the transmission of such memory by mnemonic communities, particularly SADF veterans. It also has a comparative dimension, as it draws on insights gleaned from the literature that examines the legacies of wars waged by the German Wehrmacht, the US military in Vietnam, French forces in Algeria, and the Israeli army against its Arab neighbours. This transnational approach enabled me to make a study of common cross-cultural themes in the depiction of 'war' in an array of representations including literature (imaginative and non-fictional), photographs, theatre productions and memorials. It also allowed me to move beyond the parochialism of South African historiography and narrow focus of traditional military history.

I accept the premise that cultural memory shapes social understandings of the war as much if not more than published history - including books like my own. It is because products of memory are increasingly validated as the veridical representation of the war. The meanings of the war produced by veterans through memory work (such as writing memoirs), memorialising practices (such as erecting makeshift and permanent sites of memory), returning to Angolan battlefields, and so on, has resulted in narratives that resonate with the National Service Generation (NSG). As I have already pointed out, many of these veterans have taken to the internet to share their experiences with others of the NSG where they have created virtual bunkers or discursive laagers. ${ }^{16}$ In the anonymity of cyberspace, some veterans have become cyber warriors, re-fighting the war with their keyboards. One of the objectives of my project is to destabilise the sometimes racist and recidivist discourse that passes for discussion of the legacy of the Border War.

My pluralist credo as a historian recognises the 'messiness' of past reality and leaves the way open for multiple readings of the past - "none claiming any special privilege, but each providing some illumination from its perspective". ${ }^{17}$ It does not imply that all claims are true, but that they should be judged in terms of the evidence they marshal and the coherence of their argument.

With this in mind, my project avoids constructing a (grand) narrative that offers a singular political and ideological explanation of the Border War. I fully appreciate that my approach runs the risk of being regarded as 'relativistic', because it frequently 
juxtaposes conflicting narratives rather than endorsing a particular version of the past. Some may well see this as a failure of commitment, even the resort of a coward because I do not take a stand. I do not avoid making judgements as I employ common language that is far from being value-free so that the very terms I use implies political positioning. My criticisms of the conduct of the military hierarchy in refusing to admit its poor record of and condonation of human rights abuses have earned me a reputation for being 'anti-SADF' in certain circles. In this regard, I part company with most (military) historians who steer clear of moral judgements and tend to explain violence and aggression as an ineradicable aspect of human nature and so regard the harm caused by conflicts as unavoidable.

This type of military history (with which I take issue) appears located within a technicist paradigm. Its primary concern is with military strategies and tactics, as well as with the lessons of history. It avoids having to make moral judgements by invoking a commitment to impartiality and objectivity. ${ }^{18}$ Neither does it have much truck with the Keeganesque Face of Battle school or the so-called 'new military history' that pays more attention to the experience of ordinary soldiers than the decision-making of commanders in the field. ${ }^{19}$ Nor does it have much time for the linguistic and cultural turns in war studies. Not only is this chapter indebted to the last-mentioned approaches, but also the writings on war and remembrance by scholars such as Jay Winter. ${ }^{20}$ Thus my approach to the legacy of the Border War is informed by an eclectic - but not random - an array of paradigms, underpinned by the understanding that historians are never free from effect as sensory and somatic stimuli are as many filters of knowledge as intellectual ones. ${ }^{21}$

\section{WRITING WAR EXPERIENCE}

Embodied or lived experience is effective, and my recollections of the military were often emotionally charged. It became evident when I was moved to tears by the stories recounted to me by certain of my informants who confided details that they had not previously shared even with loved ones. There is little doubt that I was deeply affected by the experience of revisiting my own and others' repressed memories. Many historians might feel uneasy about the capacity of intimacy and emotion to evoke the past as they aspire for objectivity and truth. I share this discomfort to some extent as I believe that historians are still bound to be responsible for the evidence and people of the past. But what we know about war is always mediated by knowledge and feeling. Therefore I think that it might be prudent to heed Christine Sylvester's advice that:

To access [the myriad] experiences [of war] requires that the researcher takes a close look at himself or herself; that $\mathrm{s} /$ he engages in self-reflexivity; that $\mathrm{s} / \mathrm{he}$ relates to moods, feelings and attitudes or the affective. ${ }^{22}$ 
Accordingly, war scholars are giving increasing attention to the relationship between war and the body, or what Kevin McSorley calls the "corporeal turn". ${ }^{23}$ It lends credence to Sarah Bulmer and David Jackson's claim that "the struggle to articulate embodied experience is the key problem for research on war". ${ }^{24}$

War is visceral and physical. Elaine Scarry has noted that war is "the most radically embodying event in which human beings ever collectively participate". ${ }^{25}$ Accordingly, some scholars admit the impossibility of addressing the topic adequately, of making sense of wartime experience. Others place a premium on the first-hand experience and hold that veterans have earned the right to write about war by having been there. ${ }^{26}$ But does this necessarily disqualify historians who have not participated in war from writing about it with authority? Readers of war stories tend to accept at face value the authenticity of the first-hand experience; they routinely regard experiential knowledge as more credible than the historian's expertise. But is this warranted? Are there hierarchies of knowledge when it comes to writing about war? Why is it assumed that the war memoirist has direct access to past reality, whereas the historian has to defend his/her expertise when s/he lacks military experience?27 I contend that memoirists' claim to authenticity and veracity does not diminish the historian's authority to write about war. It is not a zero-sum game. Personal narratives and histories do not compete with one another. They are discrete genres of literature, each of which adds value to our knowledge of war. For the knowledge of war is acquired from the body and the mind, from feelings and words.

As literature of lived experience, memoirs are assumed to have been written by people who have been through the events that they relate. But given that they are based on personal memory and written retrospectively, memoirs depict remembered experience. Nonetheless, as participants, memoirists are regarded as having privileged knowledge of the events in which they are involved. The historian, typically, holds that being experientially distanced or removed from the event better positions him or her to "piece together the confused, desperate, and sometimes contradictory accounts by participants into a plausible whole". ${ }^{28}$ Historians tend to adopt the position of omniscient narrators who use the third person, whereas the memoirists appear as the protagonist in their stories and use the first person. Memoirs tend to be judged by their fidelity to the 'real', by their veridicality and veracity, whereas the rules of the discipline bound histories or share certain, albeit seldom articulated, epistemological assumptions. Although histories and memoirs bear close family resemblances, they are distinct discourses about the past to be evaluated on their terms. ${ }^{29}$

The war memoir is a well-established genre. ${ }^{30}$ In his survey of personal narratives titled The Soldiers' Tale, war veteran and scholar Samuel Hynes champions the veterans' voice, but does not do so unreservedly. He reminds us that personal narratives are not history ${ }^{31}$ and that comprehensive knowledge of a historical event - especially of one as complex as war - is beyond the subjective experience of any one person. 
Eyewitness accounts are necessarily partial, as conflicting accounts of battles often demonstrate. John Keegan points out that the ordinary soldier's battle is a microcosm of the war, offering a limited or keyhole perspective on the overall situation. ${ }^{32}$ It is not to argue that his experience is any less valid than his commanding officer, but to suggest that the view from the foxhole is different from that of the operations room. However, access to past reality is beyond our grasp by the very nature and limitations of language as it is an inadequate and arbitrary means of communicating the ineffable. ${ }^{33}$ Indeed, no-one's account of war; though faithful to the actual events can enable the reader to (re)live the experience of war. If we construct lived experience culturally and socially as remembered experience (as I believe it to be), then the subject is constituted through such experience. The memoirists' narrative provides internal coherence and ascribes meaning to the experience of the individual; it does not guarantee the veracity of the text. In respect of the American experience of the Vietnam War, Brendan Boyle rather pointedly notes that "if the veteran author knows the 'truth' about the war, then there would only need be one novel, memoir, play film, or history; these representations being interchangeable and all following the first, redundant". He adds that "the biographical, "truth-telling' power of the veteran should not be privileged over those who do not claim veteran status". 34

In his discussion of Great War memoirs, Dominic Harman notes that "narratives exist as [a] discourse rather than lived experience, [and they] can never bring us to a full understanding of war...". ${ }^{35}$ As language is unequal to the task of describing warfare, there exists a gap between life and literature, or experience and its representation. ${ }^{36}$ Memoirs work towards bridging this gap by attempting to transcend the obvious limitations of language. As such, they "offer colour commentary on history" 37 and so add extra dimensions and layers of meaning to the reader's understanding of war. But they also suffer from inherent weakness: namely, a loss of overall perspective due to an intense focus on the singular lived experience. Memoirs that examine unremarkable events and quotidian experience from the perspective of the individual soldier often lose sight of the bigger picture or the overall context that frames and gives meaning to the soldier's conduct during war.

Veterans are wont to assert that their participation in combat and proximity to the enemy accords them special knowledge of war - even though the majority of those in uniform do not experience fighting. ${ }^{38}$ Their premise is that individuals' sensory experiences produce knowledge of war that is the preserve of the soldier. It is, above all, the bodily experience that is deemed to be crucial for knowledge of something as visceral as war. Accordingly, only those who Yuval Harari calls "flesh witnesses" are qualified to speak about war. ${ }^{39}$ Furthermore, this intimate knowledge cannot be passed on by narration; it cannot be acquired second-hand. A soldier might relate what he (and occasionally she) experiences, but to know what s/he knows, someone would also have had to live through it. In other words, 'you had to be there'. ${ }^{40}$ It has become the veterans' mantra invoked as a catchphrase in much war writing. Indeed, 'being 
there' is widely regarded by veterans and their readers as a prerequisite for providing a credible account of the Border War.

A collection of writings by SADF veterans compiled by its former chief, General Jannie Geldenhuys, first published in Afrikaans as Ons was Daar and translated into English as We were there, typify this prerequisite of "being there". ${ }^{41}$ The title of Geldenhuys's volume is an assertion of authority based on participation in the conflict, of knowledge derived from being on the battlefield. In his preface, Geldenhuys calls the contributors to the volume "real-life participants" who "relate the real history of the war". ${ }^{42}$ They would appear to believe that they alone are qualified to relate accounts of combat and other war experiences; that their experience affords them special knowledge of the Border War. The implication of this is that only witnesses and participants are authorised to speak about war; 'experts', including historians, are according to this view, mere pretenders to knowledge. ${ }^{43}$ Thus scholars and armchair critics are confronted by the rhetorical question: 'How can you understand?' Followed by the dismissive retort: 'You were not there...' ${ }^{4}$ This amounts to a strategy aimed at asserting a hierarchy of knowledge and silencing those who venture to produce alternative accounts of the Border War. The 'retired generals' are regarded as the epitome of the received wisdom of the conflict. It assumes that their authority cannot be challenged. But this is not the case.

\section{BORDER WAR STORIES}

Some argue that a poor literary tradition in the SADF exacerbated by a censorious approach to the dissemination of information curtailed the production of personal narratives by veterans. ${ }^{45}$ While the bulk of the literature on the Border War is in the form of campaign and battle histories, unit and regimental histories, ${ }^{46}$ there has been a burgeoning of autobiographies, biographies and prosopographies, memoirs, as well as fiction and other imaginative literature of late. ${ }^{47}$ It seems safe to say that veterans produce much of this literature for fellow veterans or military buffs. A few well-written personal narratives or memoirs provide something approaching canonical accounts of the Border War. On the other hand, some of these memoirs have little historical or literary value as they are clichéd and unoriginal. Their significance, if any, lies in the fact that they confirm that "the lived experience of war is culturally constructed". ${ }^{48}$

SADF veterans' memoirs have a limited range of storylines and narrative structures. Some are coming-of-age stories suffused with nostalgia for the 'good old days' when National Service was a rite of passage whereby boys became men. For some memoirists, the Border War was a just and necessary war, while others express the conviction that they were betrayed by the older generation that sent them to wage an unwinnable war. $^{49}$ Some are stories of life-long male friendships that have resulted from National Service on account of the bonding occasioned by the camaraderie of training and 
battle. Still, others narrate subversive strategies pursued during National Service to make life easier by 'jippoing' (avoiding duty) or to test the resolve of the military authorities to discipline armed troops and 'naafi' (no ambition and fuck-all interest). Veterans are inclined to relate stories with considerable candour and unflinching honesty. Whatever their mode of narration - tragic or traumatic, nostalgic, ironic, comic - the authors invariably follow the traditional literary-confessional conventions of the memoir form. ${ }^{50}$

The majority of memoirs published by English-speaking conscripts constitute a corpus that Christo Doherty has described as a genre of trauma and anti-heroic narratives. ${ }^{51}$ He holds that Rick Andrew's Buried in the Sky (2001) ${ }^{52}$ established the trend of anti-heroic accounts with its portrayal of the boredom and inaction experienced by three-month 'campers' on the Border. This was followed by Clive Holt's At Thy Call We Did Not Falter (2005), ${ }^{33}$ Steven Webb's Ops Medic: A National Serviceman's Border War (2008), ${ }^{54}$ Frank Nunes' Altered States (2008), ${ }^{55}$ Tim Ramsden's Border-Line Insanity: A National Serviceman's Story (2009), ${ }^{56}$ Peter Tucker and Marius van Niekerk's Behind the Lines of the Mind: Healing the Mental Scars of War (2009), ${ }^{57}$ Granger Korff's 19 With a Bullet: A South African Paratrooper in Angola (2009), ${ }^{58}$ and Anthony Feinstein's Battle Scarred: Hidden Costs of the Border War (2011). ${ }^{59}$ Given that these memoirists are mainly 'ordinary soldiers' from the lower ranks, who served as infantry or riflemen, artillery gunners, junior officers and medics in the SADF, suggests that they are representative of a cross-section of experience. But what has gone previously unnoticed or remarked upon is that, whereas in earlier wars the quintessential wounded veteran displayed physical injuries, the wounds of the Border War seldom inscribed on veterans bodies.

So, for instance, Korff's narrator-protagonist, a gungho paratrooper, is the very incarnation of the grensvegter (literally, 'border fighter'). Although Korff's account is replete with descriptions of acts of the derringdo with boastful bravado, the admission that he was traumatised, tempers it. Haunted by memories of committing or being a party to heinous acts, Korff recounts how he suffered a breakdown, diagnosed with PTSD at a Veterans' Centre in Los Angeles. The trope of trauma seems to be a common denominator in the abovementioned memoirs. Trauma narratives have become almost de rigueur in SADF conscripts' narratives. Feinstein's In Conflict was revised and re-published as Battle Scarred. ${ }^{60}$ It relates several episodes that reveal the deep emotional and psychological scars incurred by those involved in the fighting in Ovamboland. For instance, Feinstein tells of the security policeman who, following an ambush in which he failed to overcome his fears, experienced nightmares during which he regressed into a state of childhood. And Behind the Lines of the Mind depicts Van Niekerk's attempts to manage his inner turmoil stemming from his attempts to confront his culpability for atrocities he committed while deployed as a paratrooper in Angola. The titles of Feinstein and Van Niekerk's texts both bear the word 'scar' which alludes to their self-diagnosed psychic wounds. Both frame their stories within 
a PTSD paradigm - the first because he is a psychiatrist and the second because he familiarised himself with the discourse after viewing TV documentaries about the treatment of USVietnam veterans.

Like Doherty, I have previously noted the trend that SADF soldier-authors have taken to framing their war stories as trauma-cum-healing narratives. ${ }^{61} \mathrm{I}$ would attribute this to the de-stigmatisation of PTSD. The psychologist, Lynne Jones, holds that PTSD has come to signify the moral, social and political suffering of war. She has observed:

... the growing hold that this one diagnosis, PTSD, had on the professional and public imagination. PTSD appeared to be taking hold of the professional and public imagination even when it did not apply. Perhaps it was because PTSD was a diagnosis without a stigma. The rise of biological psychiatry and its focus on mental illnesses as 'brain diseases' had failed to remove the taint of moral and personal failing associated with the majority of psychiatric disorders. But here was a disorder that came packaged with a clear-cut cause that was obviously not the patient's fault, and which set them in the sympathetic and dramatic light of victimhood. Here was a diagnosis that could be taken as a badge of suffering. ${ }^{62}$

In the South African context, the Truth and Reconciliation Commission (TRC) arguably laid the platform for the de-stigmatisation of PTSD, although this went largely unacknowledged by military veterans at the time. In any event, the TRC Report encouraged them "to share their pain and reflect on their experiences". ${ }^{63}$ The Report also advocated raising public awareness about the reality and effects of PTSD and suggested veterans seek "help to tell and write their stories". ${ }^{64}$ The broadcast of the television news programme, Carte Blanche's feature 'The War Inside' on M-Net in 2001, raised the public profile of PTSD. The feature, produced in response to the publicity generated by Andrew's Buried in the Sky, categorised the author as a PTSD sufferer although he did not claim that he displayed the characteristic symptoms of the malady in his memoir or during the programme. But the (non-medical) diagnosis of PTSD offered former Koevoet operatives who appeared on the programme a sympathetic hearing and even a kind of exculpation for their nefarious deeds. ${ }^{65}$ It is little wonder that soldier-authors such as Holt andVan Niekerk have pursued narrative therapy in the belief that the writing of their memoirs might prove cathartic and assist with their healing processes.

The American historian Jerry Lembcke argues that PTSD is a socially constructed category, its meaning only partly derived from its medical context and that it has mutated from a diagnostic category to a social trope. He contends that the seductiveness of PTSD caused some US veterans to embrace it as an identity and their comrades to assign it as a badge of honour. ${ }^{66}$ Accordingly, they were viewed not only as 'victims' but as 'heroes'. This badge was worn by those who were said to have fought hard and experienced 'real' war. PTSD, no longer regarded as the mark of failed masculinity, but rather that of the brave soldier who had been on the frontline in perhaps the 
ultimate display of typically heteronormative masculinity. Whether victims or heroes, returning soldiers adopted the symptoms of PTSD and a war-story biography that conformed to what they thought family and friends would expect to see and hear. ${ }^{67}$ Lembcke's scepticism concerning PTSD as a medical category in the post-Vietnam American context has a degree of resonance in post-apartheid South Africa. Here the veteran-as-victim and anti-hero have decentred the narrative of the SADF soldier as the grensvegter and hero. Possibly the best example of a Border War story written in the anti-heroic vein is Johan Vlok Louw's ironically titled novel, Eric the Brave, ${ }^{68}$ not a memoir.

\section{CONCLUSION}

Like the soldier-authors, my military experience has followed me my entire adult life. But, unlike them, I have not seen fit to write a memoir. ${ }^{69}$ Instead, I have produced a monograph, numerous articles and now this essay. None of this work is a substitute for fully-fledged autobiographical writing, yet they offer clues to my identity as a historian and veteran. Like Jaume Aurell, I am convinced of "the futility of separating personal experience from intellectual activity", of disentangling my personal and professional identities. And given that "autobiographical style mirrors historical style - and vice versa", I am equally convinced that "reading academic historical texts through the prism of autobiographical narratives extends the possibilities of historical interpretation". ${ }^{70}$ Thus I have re-read my monograph as a revelation of personal issues, imbricated in disciplinary discourse. And I have undertaken this exercise in autohistoriography that has revealed my identity, not merely represented, but enacted or performed in the process of writing.

In this essay, I have sought to come to terms with my embodiment as a veteran, to confront the memories that define my experience of National Service and attempt to ascertain how these might have influenced my subsequent development as a historian of the Border War. To that end, I have divulged personal recollections of my time in uniform, acknowledged my personal relationship to the subject of study, and reflected upon the linkages between my veteran-historian identities. My attempt to don two hats simultaneously, to conjoin my veteran and historian selves, is in recognition of the fact that my personal experience is inseparable from my intellectual activity. This exercise in auto-historiography or life writing has enabled me to venture outside of my comfort zone, to tear down the ramparts of my ivory tower, and deconstruct the premises of my profession. I have entered a liminal space or no-mans-land where veteran and historian meet. It has been a difficult terrain to negotiate, for "like history, life writing is a discourse that generates considerable insight, and sometimes anxiety, about its generic and literary status, about the limits between 'life' and 'writing'." 71 But the risk has been repaid as it has earned me some self-respect and validation. 


\section{Endnotes}

1 Gary Baines, South Africa's 'Border War': Contested Narratives and Conflicting Memories (London: Bloomsbury, 2014), vi.

2 Alun Munslow, 'Introduction', The Routledge Companion to Historical Studies (Routledge Companions to History) (London: Routledge, 2000), 1-20.

3 I have borrowed this term from Jaume Aurell, Theoretical Perspectives on Historians' Autobiographies: From Documentation to Intervention (New York: Routledge, 2016).

4 Jean-Jacques Rousseau, The Confessions, 1978 (Wordsworth Editions, revised ed. 1996).

5 Christopher Crowley, 'Introduction: What is a Philosophy of Autobiography' in Christopher Crowley, ed., Philosophy and Autobiography (Chicago: University of Chicago Press, 2015), 1-2, cited in David McCooey, 'The Limits of life Writing', Life Writing, 14(3) 2017, available at: [https://www.researchgate.net/publication/318240794_The_Limits_ of_Life_Writing], 277.

6 Martin J. Murray, Commemorating and Forgetting: Challenges for the New South Africa (Minneapolis: University of Minnesota Press, 2013), 185.

7 Sarah Bulmer and David Jackson, "You do not live in my skin': embodiment, voice and the veteran', Critical Military Studies, 2(1-2) 2016, available at: [https://ore.exeter.ac.uk/ repository/handle/10871/18644], 25-40.

8 Simon Schama, The Embarrassment of Riches: An Interpretation of Dutch Culture in the Golden Age (Berkeley, Los Angeles: University of California Press, 1988), xiii.

9 Geoffrey Cubitt, History and Memory (London: Manchester University Press, 2007), 69-70.

10 John Maxwell Coetzee, 'Confession and Double Thoughts' in John Maxwell Coetzee and David Attwell, ed., Doubling the Point: Essays and Interviews (Cambridge: Harvard University Press, 1992), 282 cited in Michiel Heyns, 'The Whole Country's Truth: Confession and Narrative in Recent White South African Writing', Modern Fiction Studies, 46 (1), 2000, available at: [https://www.researchgate.net/publication/236694879_ The_Whole_Country's_Truth_Confession_and_Narrative_in_Recent_White_South_ African_Writing], 42-66.

11 'Grensmanne Vorder Goed na Ongeluk', Die Burger, 17 December 1974.

12 Paul Fussell, 'My War', Harper's (January 1982), 40, cited in Pat C. Hoy II, 'War Elegy' in Alex Vernon, ed., Arms and the Self: War, the Military and Autobiographical Writing (Kent, Ohio: The Kent State University Press, 2006), 173.

13 By 'official', I mean state-institutionalised or sanctioned narratives. For example, the South African Democracy Education Trust (Sadet)'s Road to Democracy project established at the behest of (then) President Mbeki. Unisa Press has to date published 10 volumes, see Bernard Mbenga, ed., The Road to Democracy in South Africa, (Pretoria: Unisa Publishers, 2015), available at: [http://www.sadet.co.za/road_democracy.html], 1-7.

14 For a more expansive treatment of this: Gary Baines, 'SADF Soldiers' Silences: Institutional, Consensual and Strategic', Acta Academica, 47(1) 2015, available at: [https:// www.researchgate.net/publication/283521604_SADF_soldiers'_silences_Institutional_ consensual_and_strategic], 78-97.

15 Baines (2014), 173-188.

16 Roland Leikauf's notion of virtual bunkers created by American Vietnam veterans bears a striking resemblance to that of discursive laagers first employed by Theresa Edlmann in 'Negotiating Historical Continuities in Narrative Terrain: A narrative-based reflection on the post-apartheid psychosocial legacies of conscription into the South African Defence 
Force' (PhD thesis, Rhodes University, 2014), available at: [https://scholar.google. co.za/citations?user=i-XQjKQAAAAJ\&hl=en]. See Frank Usbeck's review of Roland Leikauf, 'Welcome to My Bunker:Vietnamkriegserfahrung im Internet' (H-Soz-u-Kult, H-Net Reviews [online], January, 2017, available at: [http://www.h-net.org/reviews/showrev. php?id=48944], accessed 17 February 2017.

Beverley Southgate, History, What and Why? Ancient, Modern, and Postmodern Perspectives (New York: Routledge, 1996), 8.

18 Albert Venter, 'Mededingende Politieke Paradigma oor die Grensoorlog 1966-1989', Journal for Contemporary History (JCH), 34(1) February 2009, available at: [https://hdl. handle.net/10520/EJC28475], 36-56.

19 Ian van der Waag and Deon Visser, 'War, Popular Memory and the South African Literature of the Angolan Conflict', JCH, 34 (1) 2009, available at: [https://www. academia.edu/199099/War_popular_memory_and_the_South_African_literature_of_ the_Angolan_conflict], 127.

20 See, especially, Jay Winter, Remembering War:The Great War Between Memory and History in the Twentieth Century (New Haven:Yale University Press, 2006) and Jay Winter, War Beyond Words: Languages of Remembrance from the Great War to the Present (Cambridge: Cambridge University Press, 2017).

21 Christine Sylvester, War as Experience: Contributions from International Relations and Feminist Analysis (London: Routledge, 2013).

22 Christine Sylvester, 'Pathways to experiencing war' in Christine Sylvester, ed., Experiencing War (London: Routledge, 2011), 129.

23 See, for instance, Kevin McSorley, 'War and the body' in Kevin McSorley, ed., War and the Body: Militarization, Practice and Experience (London: Routledge, 2012), 13.

Bulmer and Jackson (2016), 27.

25 Elaine Scarry, The Body in Pain:The Making and Unmaking of the World (Oxford: Oxford University Press, 1987), 71.

26 Kate McLoughlin, 'War and Words' in Kate McLoughlin, ed., The Cambridge Companion to War Writing (Cambridge: Cambridge University Press, 2009), 15-24.

27 The eminent military historian John Keegan felt obliged to defend his bona fides in The Face of Battle (London: Pimlico, 2001), 15-22.

28 Gordon S. Wood's review of Simon Schama's Dead Certainties/Unwarranted Speculations (New York: Random House, Vintage, 1990), 333, in Gordon S. Wood, 'Novel History', New York Review of Books, 27 June 1991, 14.

29 Gabriel Motzkin, 'Memoirs, Memory, and Historical Experience', Science in Context, 7(1) 1994, available at: [https://www.researchgate.net/publication/231898262_Memoirs_ Memory_and_Historical_Experience],103-119.

30 Yuval Harari distinguishes between war memoirs and military memoirs by suggesting that civilians might author the former whereas only combatants write the latter. See his 'Military Memoirs: A Historical Survey of the Genre from the Middle Ages to the Late Modern Era, War in History, 14(3), 2007, available at: [https://www.jstor.org/ stable/26070708?seq=1\#page_scan_tab_contents], 289-309. For a treatment of the different genres of war memoirs and military autobiographies, see the 'Introduction' to Vernon (2006), 1-40. See also Philip Dwyer, 'Making Sense of the Muddle:War Memoirs and the Culture of Remembering' in Philip Dwyer, ed., War Stories: The War Memoir in History and Literature (New York: Berghahn Books, 2016), 1-26. The Japanese use the word jibunshi (self-histories) for the tradition of veterans writing memoirs. See Aaron W. Moore, 'A Cog in the Machine of History? Japanese Memoirs of Total War' in Dwyer (2016), 115. 
Samuel Hynes, The Soldiers' Tale (New York: Pimlico, 1998), 16.

Keegan (2001), 48.

Hynes (1998), 25.

Brendan M. Boyle, 'Introduction:The War Stories We Tell' in Brendan M. Boyle, ed., The Vietnam War:Topics in Contemporary North American Literature (London: Bloomsbury, 2015), 8.

Dominic Harman, “The Truth About Men in the Front Line': Imagining the Experience of War in Memoirs of the Western Front', University of Sussex Journal of Contemporary History, 2, 2001, available at: [https://www.sussex.ac.uk/webteam/gateway/file. php?name $=2$-harman-the-truth-about-men-in-the-front-line\&site $=15]$.

Kate McLoughlin, Authoring War: The Literary Representation of War from The Illiad to Iraq (Cambridge: Cambridge University Press, 2014), 20.

Ian Isherwood, 'British Memoirs and Memories of the Great War' in Dwyer (2016), 105. Vernon (2006), 2-3.

Yuval Harari, The Ultimate Experience: Battlefield Revelations and the Making of Modern War Culture, 1450-2000 (Basingstoke: Palgrave Macmillan, 2008) explains why the writings of soldier-authors have attained this status.

Stephen Morillo with Michael F. Pavkovic, What is Military History? (Cambridge: Polity Press, 2013, 2nd ed.), 54.

General Jannie Geldenhuys, We Were There:Winning the War for Southern Africa (Pretoria: Kraal Publishers, 2012).

Ibid., 16.

Morillo with Pavkovic (2013), 54-55.

Facebook, Group ‘Grensoorlog / Border War 1966-1989’, available at: [https://www. facebook.com/groups/grensoorlog/].

Van der Waag and Visser (2009), 126.

For a sprawling and sketchy survey of the historiography of the Angolan/Namibian War, see Van der Waag and Visser (2009).

The most comprehensive bibliography that includes works of fiction and non-fiction is Gert van der Westhuizen, 'Bibliography on the Border War' in Ian Liebenberg, Jorge Risquet and Vladimir Shubin, eds., A Far-Away War: Angola 1975-1989 (Stellenbosch: African Sun Media, 2015), 165-200.

Harari (2007), 307.

Henriëtte Roos, 'Writing from Within: Representations of the Border War in South African Literature' in Gary Baines and PeterVale, eds., Beyond the Border War: New Perspectives on Southern Africa's Late Cold War Conflicts (Pretoria: Unisa Press, 2008), 141-148.

Vernon (2016), 23.

Christo Doherty, 'Bosbefok: Constructed Images and the Memory of the South African 'Border War' (PhD thesis, University of the Witwatersrand, 2014), 38-71. See also his 'Trauma and the Conscript Memoirs of the Border War', English in Africa, 42(2) September 2015, 25-56.

2 Rick Andrew, Buried in the Sky (Johannesburg: Penguin Random House, 2001).

Clive Holt, At Thy Call We Did Not Falter (Cape Town: Zebra Press, 2005).

4 Steven Webb, Ops Medic: A National Serviceman's Border War (Alberton: Galago Publishing, 2008).

55 Frank Nunes, Altered States (Durban: Just Done Publications, 2008). 
56 Tim Ramsden's Border-Line Insanity: A National Serviceman's Story (Alberton: Galago Publishing, 2007).

57 Peter Tucker and Marius van Niekerk's Behind the Lines of the Mind: Healing the Mental Scars of War: The Story of a South African Parabat (Published by authors, 2007).

58 Granger Korff, 19 With a Bullet: A South African Paratrooper in Angola (Pinetown: 30 Degrees South Publishers, 2009).

59 Anthony Feinstein, Battle Scarred: Hidden Costs of the Border War (Cape Town: Tafelberg, 2011).

60 Doherty (2015), 48.

61 See Gary Baines, 'Memoir Writing as Narrative Therapy: A South African Border War Veteran's Story' in Dwyer (2016), 252-276.

62 Lynne Jones, 'Each Scar is Different', Aeon Magazine, 22 May 2014, available at: [http:// aeon.co/magazine/psychology/does-everyone-who-suffers-trauma-have-ptsd/], accessed 10 July 2015.

63 Truth and Reconciliation Commission of South Africa Report (hereafter TRC Report), 4 (Cape Town: Juta \& Co, 29 October 1998), 221.

64 TRC Report (1998), 242.

65 Doherty (2014), 66-67.

66 Jerry Lembcke, PTSD: Diagnosis and Identity in Post-Empire America (Kentucky: Lexington Books, 2015), xi, 18-19.

67 Ibid., 10.

68 Johan Vlok Louw, Eric the Brave (Cape Town: Umuzi [Random House], May 2012).

69 If I were to write my own memoir, I would be inclined to highlight a combination of choices that I made during my military service that set me at odds with the authorities. It would have to be written in an ironic vein. I might have been inclined to title such a putative memoir Slegtroep! My Stint in the SADF or perhaps The SADF: My Part in its Demise. For readers unfamiliar with the allusions, my first title parodies that of the exculpatory military memoir by Magnus Malan, My Life with the SA Defence Force (Pretoria: Protea Books, 2000) whereas the second plagiarizes Spike Milligan's Adolf Hitler: My Part in his Downfall (London: Michael Joseph, 1971) with its characteristic absurd humour and irreverence for military authority.

70 Aurell (2016), 263-264.

71 McCooey (2017), 280. 



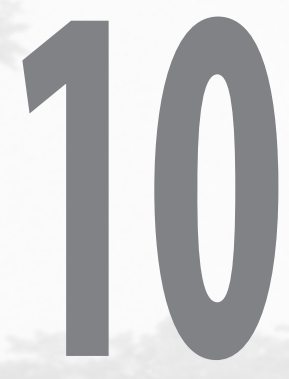

SOCIALISED TO SERVE:

\section{AN AUTO-ETHNOGRAPHICAL} EXPLORATION OF THE MAKING OF THE (CITIZEN) CONSCRIPT

IN SOUTH AFRICA

Ian Liebenberg 
What is known today as the 'Border War' in South African parlance was, to a large extent, a war fought by young foot soldiers extracted from the white minority of citizens. The vast majority of these men were conscripts. The exact number is not certain but estimated at roughly half a million young white South African men, who went through National Service (Nasionale Diensplig) under the apartheid regime, and a relatively large number of these young men saw deployment in Namibia and Angola. This study deploys a qualitative and auto-ethnographic approach in looking at the socialisation of the conscripted or National Servicemen (Nasionale Dienspligtiges). In this contribution, it is assumed that qualitative research can enrich contemporary South African military historiography. Socialisation is a process from the cradle to the grave and occurs in all societies and therefore influences the course of history. The state needed people with a specific socio-political attitude to uphold the white Christian Nationalist minority regime of apartheid. These correctly socialised men were to provide a reservoir of manpower to uphold the repressive system inside the country, but also to act as an enabling mechanism for the system to ensure an aggressive projection of power outside the borders of the Republic of South Africa and its assumed 'fifth province', South West Africa (SWA) (today Namibia). Apartheid's survival meant that the government had to have a ready warehouse of willing (young) white men available for national defence. Without such a body of registered human units, the apartheid politicians and generals would hardly have been able to leave the parameters of Pretoria at the time.

For this reason, a look at the conscript phenomenon is not only advisable but necessary to understand the social dynamics of apartheid rule and the war on the 'border'. Through this approach, a wider understanding of the militarisation of state and society in (white) South Africa is possible. By having used a qualitative research framework in conjunction with auto-ethnographic insights to conduct the research, I can address the individual male and his pre-conscription, conscription and post-conscription military career socialisation as part of a white nation in arms within a certain historical epoch namely the rule of the apartheid regime. The chapter also touches on the extent to which this socialisation process contributed to the apartheid state's military projection into Namibia and later Angola (or what some authors refer to as the Angolan War). The contemporary socio-political outcomes of such a militarised socialisation process also deserve attention.

\section{INTRODUCTION}

This contribution to South African literature about the Border War falls squarely in the broad realm of qualitative research. Qualitative research can be defined generically as a field of enquiry in its own right and as a research approach that crosscuts disciplines, 
fields and subject matter. ${ }^{1}$ As Denzin and Lincoln argue that the researcher "becomes a bricoleur", a personal tool of research dedicatedly sourcing from many disciplines. ${ }^{2}$ I assume here that qualitative research can enrich the writing and understanding of history - in this case, the controversial Border/Angolan War with its social-economic after-effects still felt in South(ern) African communities. ${ }^{3}$

Qualitative research encompasses more than the traditional boundaries of disciplines, and aims at immersion into a subject without taking a positivistic (or assumed objective) distance: ${ }^{4}$

Qualitative research is a situated activity that locates the observer in the world. Qualitative research ... means that qualitative researchers study things in what is known as their natural settings ... it is a set of interpretive material actions that make the world visible and interpret phenomena in terms of the meanings people bring to them. ${ }^{5}$

As Carolyn Ellis observed, qualitative research in its broadest terms aims 'to paint a larger, sometimes more intense and human picture' while sharing and soliciting knowledge at the same time. ${ }^{6}$ In this sense, auto-ethnography can contribute to understanding partially historical events, large or small.

In the course of an evolving research process, the representations, field notes, diaries, interviews, conversations, personal archives of the research participants, photographs and other imagery, related newspaper and other media reports, recordings, memos and solicited and unsolicited materials do not only add value. They form an integral part of the research process as an exploration of the setting at the time and the participants therein.

Given the then (historical) social setting of conscripts within a highly ideologically mobilised society under apartheid, a qualitative research approach can unearth a dearth of human data that provides a close and intimate understanding of the life and world of the National Serviceman under apartheid during the era of the Border War. In many ways, it brings the experience of the serviceman up close and personal. After a lapse of 40 or 50 years, a qualitative approach can bring 'alive' and provide a 'feeling for' what happened at the time. To an extent, qualitative research and, more so, auto-ethnography intend to 'show', not only 'tell' the story ${ }^{7}$ - in this case, the story/ stories of conscripts under apartheid in a more personal, intimate, grit-touching and embodied way. It aims to immerse the researcher, research participants (subjects as referred to in more positivist terms) and the audience in a world of real-life experience within the setting of the time, be it one of diesel, oil and dust, Savlon and the view and smell of a dead body, blood, cordite, or the odour of a stinking waterhole or a burning vehicle or kraal. 
The simple answer would be that the time is right. There is a place for more research on what transpired during the Border War from new angles. The Border War, or Grensoorlog in Afrikaans, is a generic term for the drawn-out counterinsurgency and later (semi-)conventional war from 1966 to 1989 between apartheid forces and their contestants in northern Namibia; a war that spilt over into Angola. The story of the conscript so far has been told mostly in descriptive studies or through individuals that opted for fiction or semi-fiction. While some ex-conscripts took to the pen, current non-fiction publications on the Border War more often than not tell the story from the (old) South African side from the top and not 'bottom-up'. Others chose to share the history of resistance to conscription (mostly in MA studies) or disillusionment with a militarised and abusive state, frequently in fictional terms. The life, times and experiences of the individual conscript such as myself and the collective of conscripts between 1968 and 1990 are relatively under-researched and qualitative research together with elements of auto-ethnography opens new angles on the (veteran) conscript experience.

Auto-ethnography forms part and parcel of qualitative research and has gained in stature over the past two decades, to the extent that despite earlier criticism, it is currently seen as a research approach in its own right and utilised in several disciplines and subdisciplines.

Auto-ethnography is "an alternative form of writing falling somewhere between anthropology and literary studies". ${ }^{8}$ It can arguably make for uncomfortable reading. Neville-Jan is correct in this. However, he could have also mentioned that auto-ethnography has surfaced over the past decade or more in disciplines such as psychology, (military) sociology, the sport sciences, health sciences, communication sciences, business and management sciences, political science and theology. ${ }^{9}$ "Qualitative research is used in many disciplines (and) ... it does not belong to one discipline".${ }^{10}$ The same applies to the use of this approach in South Africa. ${ }^{11}$

Arguably, for some this research approach amounts to writing against the grain. It tends to come up close and personal in its attempt to share time, experience, context and atmosphere - collectively known as the setting - with the reader. Qualitative research in its evolution, amongst others, to auto-ethnography, brought to the fore notions of story and life, (shared) lived experience, narrative practice, life stories and narrative environments and the active involvement of the researcher. In this chapter, the story is told from the perspective of the 'I' as the author and through the immersion with others in the then world of conscription or National Service. 
It is not only about the 'I', but also the 'us' - the latter not to be construed as a single muscular body of men necessarily in unison in thought, belief and action, but all with a shared experience. I consciously refrain from a post-modern approach here as human life experience is not a dream, and military life is real and not imagined.

\section{METHODOLOGY}

In this chapter, I do not intend to go into the nuances and the in-depth developments of qualitative research over the past decades. ${ }^{12}$ The qualitative research approach is not new elsewhere. It holds for South Africa in which case some early approaches were taken by researchers at the South African Human Sciences Research Council (HSRC) during the late 1980s and early 1990s. In South Africa, a single supervisor, Prof Willem Schurink, delivered more than 70 PhDs and MAs by 2019; the majority of these auto-ethnographies and many of these studies were in business, health, management and administrative sciences. Current students of this supervisor come from NGO backgrounds, the business environment, and the world of work (labour), theology and psychology. In this chapter, military sociology, amongst others defined by Paparone ${ }^{13}$ and numerous others before him, ${ }^{14}$ is relevant.

The methodology that I used for this study included auto-ethnography (my story) and related areas, such as narratives (the story of others, 'fellow travellers'), stories of the self, reflective images, personal archives, confirmed anecdotes (double-checked with other sources), oral history, articles of a critical social nature (accredited, non-accredited or international, magazine articles and relevant newspaper reports from the era, government or party-political media, photos sourced from participants or unsolicited photos, cartoons, posters and drawings). The visual element plays an important part in sharing the knowledge - or more precisely, in conveying the experience and real-life world of the then conscripted. Sadly, the visual cannot be fully represented here due to lack of space, whether it was an Instamatic or box camera (or the more expensive types such as Nikon), Polaroid, film, video, digital images including YouTube and Facebook imagery. The latter two would have assisted in taking us back to the exact atmosphere, the dirt, dust and flies in the face. At the time, there was no YouTube or Facebook. As for the then conscript, only the boldest of the bold would smuggle in a camera as doing so amounted to the transgression of military regulations and per se constituted a punishable offence. Some did so, nonetheless. Images of whatever sort may have assisted in qualitative research and auto-ethnography, but the fuller picture may still elude one. More so, in most journals and even in web-accessible publications, the space allocated does not always allow for the plethora of images needed to provide a full picture. A lot, as in the past, still depends on the power of mindful retelling of the human experience (shall we call the latter oral tradition?). 
In preparation for this chapter, I delivered a paper at a symposium on the Border War at the Department of History at Stellenbosch University, which initiated this event on the 40th anniversary of the Border War that started in earnest in 1966 in northern SWA. I engaged the audience with all the above. For this presentation, I had prepared files (brownish files, similar to the colour of the then official military files) with newspaper clippings from that time, personal photos by conscripts, pre-selected military documents of the time sourced in various ways, and examples of Paratus, the official military magazine of the time (editions between 1975 and 1983 were selected). To add to this, I had selected a few editions of the National Party's mouthpiece, Pro Nat, which at the time was widely distributed (this specific selection of Pro Nat came from the 1970s when the Total Onslaught ideology started and grew in influence). I had also prepared a slide show that I shared with the audience interactively. About half of the audience consisted of ex-conscripts and permanent force members of various ages that saw border duty between 1975 and 1988. The rest of the audience comprised persons interested, for academic reasons; current service men or women; and those with a personal interest, many of them because it involved their parents in some or other way at the time. I took along a long-time friend, now a well-known journalist, who saw action during one of the larger-scale operations into Angola in the early 1980s. In a real sense, he became a fellow traveller over many years. He wrote several articles on the war and contributed chapters to books. Moreover, he saw deployment in Angola while I saw deployment only in northern Namibia (Sectors 10, 20 and 70), but we shared similar experiences even though his border stint was two years later than mine and at a time that trans-border operations into Angola escalated.

The research process for this study involved the actual (re-)immersion of the researcher as one of the tools of the research but was not limited to the researcher and linked up with other participants or fellow travellers. The research framework was not rigid or per positivist recipe.

The process enlisted the narrative, the visual and other elements, but rigour was not compromised. Qualitative research is not an easy way out to investigate and explore human experience and social questions; it is and should remain rigorous and focused. I suggest that the building blocks in qualitative research, specifically auto-ethnography within the military realm, should abide by the building blocks I identified in earlier research. ${ }^{15}$

\section{SOCIALISATION}

In exploring this topic, I simultaneously brought in the concept of socialisation. Socialisation is a powerful phenomenon and frequently a political tool deployed by government and state. ${ }^{16}$ It is rightly said that socialisation is a process from the cradle 
to the grave. In highly mobilised societies, the process is set in motion against a specific socio-political background or paradigm-in-practice - thus, what we call ideology, the latter being a political or religiously inspired action-orientated worldview. Socialisation according to the norms, narrative and the (imposed) system of values is intense, and its products (the citizens or citizen-soldiers) carry the results thereof with them for a long time, even into the grave.

The apartheid state, when it comes to socialisation and the institutions involved as socialisation agents, was no different. The incumbents of an ideologically mobilised state that believed itself to be beleaguered by a communist onslaught (the 'Total Onslaught') required a citizenry that could fulfil their role as advocates and defenders of a (white) nation in arms. More so, this applied to the security arms of the state, namely the police and the military:

Political socialisation can be latent or manifest. In the case of manifest politicisation, there is a definite attempt to socialise the individual in a specific direction, an attempt for instance made by a state. ${ }^{17}$

Political socialisation links to the political culture and beliefs about the prevalent political system and:

...can be understood as the process whereby a person becomes part of a political culture and a way in which a society carries the political norms of behaviour and political beliefs from one generation to another - it is a lifelong process. ${ }^{18}$

Apartheid socialisation amongst white people, together with the role of the apartheid state and system, provides a telling example. ${ }^{19}$

\section{AGENTS OF SOCIALISATION}

Volumes have been written on socialisation in disciplines such as sociology and to an extent political science. ${ }^{20}$ In the world of sociology, the term is not new and has been in use for a while. ${ }^{21}$ While the term socialisation as a definition is more recent, socialisation is a lived experience and practice as old as (the organised) human community itself, stretching from hunter-gatherer communities in defence of territory or scarce resources such as water, and later on the military as an organised entity. ${ }^{22}$

Let us contemplate for a moment the socialised warrior such as the ancient Egyptian and Nubian armies, the Spartan soldier, the kingdom of Shaka Zulu and the well-trained impis, the warrior class in ancient China ${ }^{23}$ and the samurai in Japan. ${ }^{24}$ Or think about the ideologically mobilised soldiers of Nazi Germany, the Soviet Union or militarised Japan before and during the Second World War, or perhaps the modern-day 'noble warriors' fighting on behalf of their ruling political elites' self-declared 'war on terror'. 
Patrick Wright, in his excellent work on the evolution of the tank, points out how socialisation through digital gaming is preparing future generations for war. The USA is a case in point. Advancing to simulators and 'distributed interactive simulation' could assist an aggressive state in a 'new wave of warfare' with, by the way, cyber-consultants on standby. ${ }^{25}$ As the then Chief of Armour School at Fort Knox, Kentucky, put it in an interview with Wright: "The kids who have done a lot of video games have exactly the right kind of eye-hand coordination ... Nintendo has done great things for this generation [sic]." ${ }^{26}$ In this habitus of globalised 'digitisation', socialisation will remain to play an important role from generation to generation. Indeed, it will do so in the form of socialisation where children now socialise their parents, and children socialised in a way that benefits war and assisting 'the Other' into their graves. Endless movies from Hollywood and associates on such soldier and citizen heroism - from Vietnam to the elimination of 'terrorist states' such as Iraq, Afghanistan, Libya and others and lately any conceivable critic of the USA - play a role to socialise people to uphold Western capitalism, euphemistically called 'Western civilisation'. Examples of how media discourse assisted power-hungry elite are, for example, Ronald Reagan's and George H.W. Bush and son George W. Bush's the 'Axis of Evil' and 'you can run, but not hide' and, earlier, a 'bomb them back to the stone ages' mentality. (Did Lyndon Johnson or Richard Nixon say that?) By the way, the aforementioned mentality mirrors that of apartheid, albeit on a much larger and more destructive scale.

In the process of (re-)producing the ideal citizen or warrior, numerous socialisation agents come into play. Amongst these are the family, peers, schools and other educational institutions, religious organisations, youth movements, sports bodies, political parties, the state system, the media, paramilitary institutions and military institutions. Needless to say that the socialisation process is underpinned by abidance to norms, imposed social consensus, 'positive enforcement' and various levels of sanctions. ${ }^{27}$

Particularly important are the stages of socialisation across the life of a person, namely childhood socialisation, adolescence socialisation, socialisation through young and middle adulthood, late adulthood, old age and even the environment of death ${ }^{28}$ or the conclusion of the life cycle. ${ }^{29}$ Throughout all the above stages, agents of socialisation are at play.

\section{MILITARISATION OF STATE AND SOCIETY IN AN APARTHEID SOCIETY}

Public utterances by politicians, for example, a Minister of Defence of a country, explain a lot about both internal and foreign policy and how the state form public opinion. Public perceptions, in turn, stem to a large degree from socialisation, including how the state frame things through the usage of language or the world view facilitated. Perception confirmed or strengthened through statements calling up images of the world or how it should be; the latter calling for action - thus ideology as a programme 
of action. In 1950, the Minister of Defence of South Africa, F.C.Erasmus, declared: "Every attack by Communists on Africa will immediately be seen as an attack on South Africa." ${ }^{30}$ Apartheid South Africa started arming itself early on. Naval craft, jet-aircraft and modernisation of equipment totalled $\mathcal{f}_{40}$ million by 1955 , by rough calculation.

The phenomenon of socialisation of the individual through various stages in a militarised South African society is relevant here.Authors commented on the evolution of South Africa under apartheid from a state kept in power with the support of the South African Police (SAP) and the Security Police (1955-1976) and after that a shift in focus to primary dependence on the military, the evolution of the security state. ${ }^{31}$

Within the international community, the Non-Aligned Movement (NAM) and the United Nations General Assembly (UNGA) criticised against apartheid. Coupled with the deep-seated fear of communism, further underpinned by the awareness of the 'black danger' (Afrikaans: Swart Gevaar), the ruling National Party and its cultural cohorts such as the Afrikaner Broederbond and the white Afrikaans religious community saw itself as beleaguered. (The 'black danger' was inherited from the times of white Western settlement in South Africa.) The politicians often spoke about 'the winds of change' in Africa, meaning the liberation of African states from colonial rule either by a peaceful transfer of power or by armed struggle, furthered the tendencies towards a garrison state. The white nation, dominated by Afrikaners, started arming itself against enemies from outside and inside. On 24 May 1972, the State Security Council (SSC) was established in South Africa through the Security Intelligence and State Security Council Act 64 of 1972. This act triggered the further militarisation of South African society. On an annual basis, the military budget increased by leaps and bounds. The notion of a Total Onslaught (Afrikaans: Totale Aanslag) from communist countries, specifically the Soviet Union became a salient part of the political discourse, part of the everyday government jargon and eventually a mantra to be infused into the white population. ${ }^{32}$ The Total Onslaught became a political mantra for the mass mobilisation of white society. Such mobilisation included military aspects such as the cadet system, conscription and the Citizen Force (CF) (the latter becoming the home units of previous waves of annual conscripts).

Interesting to read is what P.W. Botha, leader of the South African government, made of the Total Onslaught in his foreword to the 1973 White Paper on Defence:

Like the rest of the Free World, the RSA is a target for international communism and its cohorts - leftist activist, exaggerated humanism, permissiveness, materialism and related ideologies ... the RSA has been singled out as a special target for the byproducts of their ideologies, such as black racialism, exaggerated individual freedom, onemanonevote, and a host of other slogans employed against us on the basis of double standards. ${ }^{33}$ 
At a symposium presented in 1983 by the Institute for the Study of Marxism at Stellenbosch University, Prof Mike Hough from the University of Pretoria and the then head and Commissioner of the South African Security Police, Lt Gen P.J. Coetzee, expanded ad nauseam on the Total Onslaught and its links to what they called 'terrorism' and support for national liberation movements. ${ }^{34}$ Military intelligence at the time partly funded the Institute (Afrikaans: Instituut vir die Studie van Marxisme).

Between 1983 and 1988, the already militarised country experienced rising levels of militarisation that were visible. ${ }^{35}$ The military locus of state power under Magnus Malan, P.W. Botha (Minister of Defence, later Prime Minister and eventually Executive President of the apartheid state), and the so-called (military-dominated) securocrats moved to the centre of the decision-making process. The locus of power within the state machinery under P.W. Botha and close confidantes such as Malan were shifting away from the (white) parliament and the previous guardians of state security, namely the SAP and security police. They described this phenomenon as 'the changing locus of decision-making' in South African politics. ${ }^{36}$ The changing locus of state power should not be equated with praetorianism as Nordlinger ${ }^{37}$ and others understand it. I prefer to refer to the growing influence of the security-minded with the South African military (SADF) in tow as 'praetorianism of a special type'. The military in apartheid South Africa did not take power through a coup d'etat or even a planned salient rise to protect the state or the vision of the ideal state. They were invited into politics by the then politicians and eventually absorbed into the political status quo in South Africa. This changing locus of power and decision-making impacted civilmilitary relations that represented a onesided process from above, socialisation of the citizenry and, especially, foreign policy and the latter's effect on defence posture and projection.

\section{WHAT TO WRITE AND WHAT NOT TO WRITE}

It is not the place to enter the debate or the long traverse of the theoretical-historical debates on the place and standing of military autobiographies and truth claims or what the exact differences are between autobiography and auto-ethnography. Kleinreesink and Soeters addressed these matters eloquently in an earlier article. ${ }^{38}$ Neither is it the place to entertain in detail a discussion on the trials, temptations and tribulations of the 'from an eyewitness to flesh-witness' notion, albeit relevant. I also do not enter the intense debate on projecting the self. ${ }^{39}$ I had numerous fellow travellers over the years and historical materials on the era under discussion, even more so since the South African Border War became a heated and not yet exhausted debate, marked by sharp personal and ideological differences, some nostalgia and lots of ex post facto rationalisations - sometimes to the extent of spin-doctoring. 
I had to reflect seriously on what to write and what not to write. Over the years, I had amassed hundreds of clippings, photos, military magazines (especially South African), posters, propaganda materials, documents and much more. Then classified materials have been declassified and the viewpoints of other actors in the war such as the South West African People's Organisation (Swapo) and its armed wing, People's Liberation Army of Namibia (PLAN), the Angolan forces, the Cubans and the Russians (the then-Soviets) have been put on paper increasingly. I was fortunate to have access to some declassified archival material from the Department of Defence Documentation Centre. More publications continue to appear, and daily a broader picture evolves not without contestation though. The author on past military affairs in South Africa has a field day, or year or decade(s) when it comes to the Border War.

I still have fellow travellers, some in agreement, others not. Through others' stories published or documented by people I knew or did not know I can weirdly enough state that I even have fellow travellers that have passed away already. Fellow travellers from the grave? Strange idea? But such is life.

I had to choose how I share the material with the audience, reader and prospective student, although I used declassified materials. The reason is that people and individuals matter. I do not have contact with all those that were fellow travellers, some as far back as 45 years ago, and can in no way hope to reach them to ask for consent. In research ethics, the 'do not harm or hurt' approach applies for good reasons. Hence, I chose not to name any person or disclose anything personal about them if I did not have their explicit approval. To that extent, I applied personal censorship. That knowledge remains in the stored memory and will stay there.

In criticising past political and military leadership, I do share strong - even bitter opinions openly and attach names to them as I then did. These matters are part of current dialogues and (much-heated) debates - as it was then - and, as such, in the public domain. And it should remain in this domain in reflecting on the past and projecting ideas for a better South African society in the future. History and for that matter democratisation of state and society and the reconciliation of the citizenry of a previously deeply divided society is, like history, a discussion without end and so are insights into the then leadership responsible for the ongoing conflict.

\section{CHILDHOOD AND FAMILY SOCIALISATION: FROM THE CRADLE TO THE GRAVE, IN STAGES WE SHALL DELIVER YOU}

Imagine two boys aged two-and-a-half and three-years-old with military helmets aiming airguns and shooting at an imaginary enemy. Loading the airgun, since it was spring operated and the 'neck has to be broken' before the next shot, required 
some skill - as was hitting a target of roughly any size at that age. A foot could assist where the young arms were not up to 'breaking the neck' of the spring-loaded gun or a somewhat older cousin, father or uncle could assist. (There are more ways than one to break a neck.) After a few demonstrations, young children could do this and reload successfully - or at least some of them if not the majority in Afrikaner society, with here and there perhaps a split lip or a slight injury to finger or face. These boys imitated what they saw and dreamt about firing larger rifles. At that impressionable age, many of their fathers, friends of the family, or older brothers and uncles and a not so an insignificant number of mothers and their daughters knew how to use a rifle or were at the very least understanding the application of a personal firearm or rifle to be used. Men were on 'border duty' or just returned from a 'stint' at the border or an interior training camp (either in the CFs or Commandos) and cemented the social fabric (the term now used by ideologues in post-apartheid society is 'social cohesion'). Such social experiences and imagery solidified a social consensus within the apartheid ideology.

The scene of the young boys described above is not a dream; it happened in many families. Father and uncle taught son; in turn, son and cousin taught cousin or niece and nephew. Mothers mostly observed with enthusiasm, apprehension or (dis-)interest. In other cases, with deep-seated dedication, some moms taught the young boys and girls to shoot or to be ready to shoot. (Females were allowed to become part of the Commando system voluntarily. My mother was one of them.) I have to add that military socialisation in South Africa's white community was not confined to Afrikaner people or, for that matter, men. In the English-speaking community, with some qualifications, the same applied, especially in rural areas.

Socialisation in highly ideologically mobilised and militarised society was not necessarily only masculine or patriarchal. It was part of a social paradigm, call it a Weltanschaung and the daily practice of being in what Pierre Bourdieu described as habitus, namely an environment of being that is created through a social process rather than an individual one, is relevant here. "Habitus can be understood as enduring and transferable patterns, neither a result of free will, nor (only) by structures that condition our perceptions." ${ }^{40}$ The then historical habitus amounted to a white (Afrikaans) society under perceived siege. Ideology as a social programme influenced society, mobilising the people or citizenry towards an imagined ideal world. Values were distilled and re-legitimised through an interplay of power, agency and structure - including the state system and the power the state holds over its subjects, i.e. young people, the worker, clerk, conscript, permanent force member in the military, or citizens and their loved ones.

The same applies to imagery and the media in an ideologically mobilised community such as the apartheid society. Media and state structures not only interface, but also tend to reinforce each other. The SAP, earlier on, and the military, later on, received 
ample attention in newspapers, receiving the freedom of the town, march passes and exhibitions at agricultural shows (Afrikaans: landbouskoue). Early childhood socialisation was real, not imagined in apartheid society. In the meantime, the Border War escalated, and with South Africa illegally occupying Namibia, the war was to spread into Angola. ${ }^{41}$ The escalation of the conflict was a reality. As Andre du Pisani so pointedly argue about the Pax Pretoriana's military's role: the SADF under apartheid politicians moved beyond the barracks and assumed the role of a frontier army with an aggressive posture to be readily enacted far outside the borders of the South African state. ${ }^{42}$

\section{TEENAGER AND SECONDARY SCHOOL SOCIALISATION IN THE APARTHEID HISTORICAL CONTEXT}

Imagine walking into the school on a particular day, all 16yearold boys called over the 'intercom' to the school hall where uniformed men sat with registration papers behind desks. On that day, you would be registered for future military service and within three months receive an official letter with your force number; the force number reflecting the year of registration at high school, i.e. 76436252 for a young man that was registered in 1976 (in this case), meaning that, if you completed matric (Grade 12), the army was waiting for you. Should you have chosen or be forced by financial circumstances to leave school earlier, i.e. Standard 8 (now Grade 10), you would have joined the army sooner. It was not imagination; it was a real experience for those involved. Ideology may be a dream, but ideology in practice becomes real, an objectified dream that set ideals in action, action into practice - becoming an embodied programme of action. Upholding ideology and spreading the programme, bodies are needed whether thinking or forced, being used as (more hyperbolically stated) the unknowing useful idiot.

A mentality, such as described, calls for the mobilisation of defence and, when needed, offence (authoritarian regimes opt by their acquired constitutional instinct for offence inside or outside their borders). For those boys (male learners) that chose to study at universities or colleges first, the call-up would again revisit them on completion of studies. The legislation was strict, and the only way out was to emigrate or to be declared unfit or, in a minority of cases, to be declared 'key personnel' in another state department. A real (not imagined) option, was to leave the country or to simply face a sixyear prison service.

Growing up in a militarised society was not imagined. It was real, both for the called upon and those that suffered the results. ${ }^{43}$ 
The state introduced a system of school cadets at white schools. An estimated 500 cadet units came into existence all over South Africa. It implied that all secondary schoolboys had to participate in school cadet activities. Uniforms, berets and a designated cadet corps badge were issued. Usually, cadet periods took place on Thursdays with the majority drilling and a minority selected for shooting teams that would compete at inter-school, inter-regional, provincial and national levels. Participation in the cadet system, in this case mostly drilling and parade work, was open to girls voluntary.

Cadet weekend camps also took place that widened the activities to map-reading, fieldcraft, shooting, drilling and fitness exercises. During winter holidays (June/July), two-week-long cadet camps regularly took place. While not enforced, schoolboys were motivated to partake in these as such cadet camps provided a useful introduction to military life and prepared them for their National Service soon to follow. With the use of the system, they installed regimental rules, military discipline and the values of patriotism. Cadet training was the continuation of a process whereby the apartheid state consolidated a reservoir of bodies for future military use and enacted the principle of a nation-in-arms. Photos and other images can best illustrate the above. This system furthered childhood socialisation for school-going children in their teens. A Christian-Nationalist social consensus, pre-emptively enacted, upheld the state and status quo.

\section{YOUTH MOVEMENTS SUCH AS THE VOORTREKKERS AND TO A LESSER EXTENT THE BOY SCOUTS}

Youth movements in South Africa, usually voluntary, also played a socialisation role. In the case of South Africa, two movements were pertinent. The Boy Scouts (and much later, Girl Scouts), mostly English-speaking in orientation, had its origins in 1908 after it was established as a movement for all countries under British rule and later the British Commonwealth. One of Robert Baden-Powell's first actions after initiating and establishing the Scout movement (sometimes referred to as Pathfinders), was to write Scouting for Boys. The Scout experience aimed at outdoor activities to contribute to character development, health, nurture citizenship, instil a sense of adventure and service orientation, getting to know nature and enhance intergroup skills and loyalty to the country. The movement grew rapidly in the British Commonwealth to become the world's largest youth organisation. 
Baden-Powell advocated that the Scout is to be loyal to the Queen (or King), his country, his fellow Scouts, parents, employers and those under his leadership. As part of the Scouts' attitude and honour, they advised courtesy, obedience, neatness, friendliness and a caring attitude to nature. ${ }^{44}$ They formed Scout branches in various cities and provinces in South Africa, and by 1916, Provincial Councils. By 1930, the Imperial Scout Headquarters granted independence to the Scouts in South Africa. Initially segregated by race, the Scout Movement in South Africa under international pressure became a multi-racial organisation around the late 1970s. Implementation was hampered in practice by apartheid laws and separate living areas and to an extent, racial attitudes or perceived cultural differences. Baden-Powell implanted the idea that a Scout should "prepare himself [sic] to be a good citizen of his country and the world". ${ }^{45}$ The terms "standing shoulder to shoulder for your country" and "[the] sinking of your differences" are voiced, and Baden-Powell suggests that "a Scout should think of your country and the good that your work is going to do to other people". ${ }^{46}$ The Scouts remained separated under apartheid as the "independent homelands'Transkei, Ciskei and Bophuthatswana had separate movements. The Scouts only announced full inclusivity in 1995. The body then became known as Scouts South Africa.

Given the divided history of South Africa, one may assume that amongst white Scouts and Scouts of other races, different perceptions existed regarding loyalty to one's country and the meaning of citizenship. Unfortunately, little research has been done about this. Arguably, within the white community of Scouts and perhaps some of colour, a measure of South African patriotism was developed and made Scouts susceptible to the apartheid ideology and the paraideologies of (limited) reform and repression (the latter pivoted on the Total Onslaught syndrome). If the Scout experience in South Africa had some effect on political socialisation, the studies by Gagiano and Booysen ${ }^{47}$ on student attitudes at South African universities may, to an extent, account for more liberal attitudes yet high trust in the military and security apparatus of the state amongst white students at English-speaking universities. I will address this to some extent later. Until new research proves otherwise, it seems that Scout socialisation played some role in maintaining the status quo.

The roots of the Voortrekker Youth Movement (Afrikaans: Voortrekkers) are closely identified with the rise of Afrikaner nationalism. The organisation, initiated by Dr C.F. Visser and established in Bloemfontein on 11 December 1920, just seven years after the National Party that was to rule South Africa from 1948 to 1991 had been established. The growth of the organisation was initially stunted and sporadic, but a second initiative followed, and it became a country-wide organisation in September 1931 after cultural advocates, Afrikaner church leaders and educationists started a drive to broaden the movement. ${ }^{48}$ The movement, since its establishment, catered for boys and girls. The organisation based its ideals and vision on the notion of 
the Afrikaner people as an independent volk, a nation in its own right; a commitment to the country; a particular language; and a Christian orientation (as then understood). They upheld the values of patriotism, common nationhood and the love of the land (fauna and flora included). The movement from the beginning, in the context of the rising Afrikaner nationalism, was a whites-only and paramilitary institution and importance attached to parades, drills and ceremonies. ${ }^{49}$

During the consecration of the Voortrekker monument in 1948, large numbers of Voortrekkers took part in the proceedings, including torch marches. Ten years earlier in 1938, the centenary of the Great Trek (Groot Trek in Afrikaans) was celebrated. Centenary treks from all corners of South Africa (ox wagons, Voortrekker clothes for women and men from the past) converged on Pretoria where the cornerstone of the Voortrekker monument was to be laid. In the Gedenkboek van die Ossewaens op die Pad van Suid-Afrika, $1940,{ }^{50}$ there are photos of Voortrekkers leading a convoy of ox wagons in the Worcester-Robertson areas in what is now the Western Cape Province. Likewise, other photos demonstrate Voortrekker parades in Koeroeman (today Kuruman/Kudumane) in the north-western part of the Cape Province saluting the passing wagons en route to Pretoria. ${ }^{51}$ In Zoutrivier (today Soutrivier) close to Cape Town (today ensconced in Cape Town), a large commando of Voortrekkers formed a guard of honour for the Cape wagons on their departure to Pretoria. ${ }^{52}$ Ten years later, members of the youth movement (no gender discrimination) were present in large numbers at the consecration of the Voortrekker monument (an ode to the Afrikaner and its long struggle to gain nationhood as a separate entity) at Voortrekkerhoogte (earlier on called Robinson's Heights, today Thaba Tshwane).

On 31 May 1966, the Republic of South Africa celebrated its first five years of independence. South Africa left the British Commonwealth (others may say they were unceremoniously kicked out) and after a whites-only referendum declared its independence and became a republic (RSA) ruled by a white minority. The family magazine, the Ster (the Star), ${ }^{53}$ included a supplement in August 1966 paying tribute to the fifth birthday of the new republic and showing interesting imagery. Apart from military parades, including tanks, armoured cars, self-propelled artillery and flypasts by the air force, the supplement mentioned that as 17000 infantrymen marched past, the crowd at the (note!) Voortrekker monument counted more than a 100000 people. The supplement also featured a torch parade by the Voortrekker youth movement - in this case, Penkoppe and Drawwertjies, boys and girls up to the age of twelve. On 11 October 1975, during the inauguration of the Afrikaanse Taalmonument (monument for the Afrikaans language) in Paarl, 600 Voortrekkers symbolically carried torches from the monument to the Gideon Malherbe House, where one of the fathers of the Afrikaans language used to reside in 1875 when the Afrikaans language movement started. ${ }^{54}$ In uniform, the road to a new South Africa was laid; it was a trek of liberation that recalled past battles and readiness for new battles, and so contributed to new 
battles to be fought in trenches and borders twice removed from Pretoria by 1975. By 1985, the war moved into South African townships when the military was called in to support the AP.

As a movement with a close association with the culture and the politics of Afrikanerdom, the Voortrekker youth movement played some role - however difficult to quantify - to imprint Afrikaner political values in the participating members and served a role as the carrier of collective historical consciousness. By the 1970s, there were numerous cases where military instructors from nearby bases, when requested, supplied camping equipment or drill instructors and, on occasion, the opportunity for Voortrekker boys and girls to get acquainted with the use of a pistol or military rifle.

In preparation for the festival at the inauguration of the Taalmonument, Voortrekker Kommando's participated in carrying torches from cities, towns and rural areas to the inauguration in Paarl (roughly 40 kilometres from Cape Town). One can safely venture that the Voortrekker movement played an important role in the socialisation of Afrikaner youth. It needs saying that not all Afrikaans-speaking young people were enthusiastic about the movement and various (derogatory) nicknames from those that did not belong to the Voortrekker movement were not uncommon (some of these nicknames were not very innovative, yet best not to be mentioned in an academic contribution!).

\section{THE ROLE OF YOUTH PREPAREDNESS AND VELD SCHOOLS (AFRIKAANS: VELDSKOLE)}

Veld schools, as part of the youth preparedness programmes (Afrikaans: jeugweerbaarheid), were offered during secondary school holidays. Amongst others, the children listened to lectures on South African politics (from the reigning perspective) and the threats against South Africa. Basic field skills were taught. Veld schools were more prevalent in the then Transvaal Province and to some extent the Orange Free State (Afrikaans: Oranje-Vrystaat). South Africa, after the making of the Union of South Africa, became a unitary state with four provinces, namely the Cape Province (previously the Cape Colony), Natal (also a previous British colony) and the defeated Boer Republics, the Transvaal and the Orange Free State. Given the historical background and national government seated in Pretoria (Transvaal Province), it could be expected that veldskole were dominantly present in Transvaal and the Orange Free State. However, the state introduced youth preparedness classes (to be distinguished from the school cadet system discussed earlier) in all-white schools during the 1970s. It needs little imagination to comprehend the role of such systemic educational exercises on childhood socialisation in apartheid South Africa. Arguably Cadets, Voortrekkers and Veldskole played a role in what Booysen later described as the "Afrikaner youth's manipulated political consciousness". 55 
Just like all other agents of socialisation, media in whatever form is a strong agent for transferring information and immensely powerful as a tool of political socialisation and (re-)affirming political culture. Television came to South Africa in the late 1970s and the South African Broadcasting Corporation (SABC) (Afrikaans: Suid-Afrikaanse Uitsaaikorporasie - SAUK) was under government control from the start. As far as radio broadcasting and television were concerned, the government set the agenda. Therefore, the ruling elite ${ }^{56}$ could decide what could be shared and highlighted or, if need be, twisted or spin-doctored to suit the ruling ideology, and what had to be kept away from the listener or viewer. ${ }^{57}$ Add to these, strong media regulations under a variety of security laws,${ }^{58}$ and the scene was set for a very onesided socialisation process.

Media socialisation is much older than television. Newspapers, whether national or local, and radio programmes played a major part in the socialisation of white South Africans of all ages, as in other societies. In a single personal collection, I have more than 350 articles, the majority in Afrikaans and about 25 per cent in English, and roughly 1000 photos in printed media covering the era 1965-1988 related to (civil-)military affairs. At the time, I did not cover or trace electronic media such as radio and television, nor did I trail current Border War veteran websites (the latter a demonstration of continuous apartheid military socialisation; such a research enterprise will remain for others).

From these photos, images and representations, it is abundantly clear how much time and energy, needless to add funding, went into providing suitable reportage and imagery to socialise South Africans, including those growing up in the then social setting that benefitted the apartheid and militarised status quo. Whether it was family magazines, photo storybooks (a well-known genre at the time), 'girly' magazines and newspapers (daily and weekly) as well as dedicated magazines, i.e. Defence Force publications or party-political bulletins, the scene was set to justify and maintain a minority state. I did not attempt to quantify the available data from my archives as a personal archive is of small comparison to the national Afrikaans and English media coverage of the time. I did not utilise any documentaries or recordings of old radio and television broadcasts, compare them or quantitatively exploit them. News broadcasts and actuality programmes are especially relevant here. This rather imposing challenge remains for other researchers. Just unearthing and comparing the then news broadcasts and printed media would probably comprise a $\mathrm{PhD}$ or more. 
At this stage, it is necessary to mention that the school curricula under apartheid selectively reflected Afrikaner Nationalism and its isolationist worldview. It contributed to white school children - even students in some cases - being educated in a knowledge vacuum where very little was shared with them, for example about the history of struggles for independence on the continent. It also happened with regards to South Africa's liberation struggle with the collective description of the political contenders as terrorists or communist-inspired useful idiots without supplying a broader historical context. And, schools are indeed a strong agent for socialisation as most children will spend ten to 12 years at school. ${ }^{59}$

When registered at age 16 at your school, you would have received your 'call-up' papers some months before you had to report to a military unit attached to a specific military muster. National Service intakes were in January and June. If you left school in Grade 10 (Standard 8), as many did due to financial reasons, the SADF would already have called you up when leaving the safer boundaries of your school. As elsewhere in the world, the working class happened to be first in the firing line.

One option to postpone military service was to first go for further studies at a Technicon or University. However, after your studies, you would have to comply with the requirement of becoming a National Serviceman - albeit with the prospect of an automatic officer's rank. Other options 'out' were to volunteer for service in the SAP or use contacts to manipulate a transfer to the SAP. In certain cases, some individuals together with their managers in state institutions, such as the post and telecommunication services, organised a declaration of being 'key personnel' and, because of that, would be exempted from military service. The men who were about to enter National Service, or who were busy with it, or who had completed it, sometimes regarded those who became key personnel or did their service in the SAP as 'copouts'. It is, however, difficult to say how pervasive such views were as no one has researched this. At the time, the state would not have permitted such research in any case due to the plethora of security legislation. ${ }^{60}$ To prevent their children from serving in the 'fighting forces' such as the infantry, armour and artillery, some better-positioned families used their contacts to arrange for callups to the Navy. It happened to be close to Cape Town or Durban and anyway not directly involved in the Border War.

Related to National Service, a category was later created for universal religious conscientious objectors. It was, however, somewhat punitive as the alternative service required was four years or a large fine. This matter falls outside the ambit of this research. ${ }^{61}$ 
Conscript training? In the fighting forces, you were trained to kill. This training influenced the mind and mentality. It is a given that such training desensitises the individual regarding the value of human life, at least in my experience. It was an intense socialisation process in a nearly fully institutional world where groupthink, obedience, discipline and respect for higher authority, the norm. Uniformly in uniform. A serviceman was part of what (military) sociologists describe a total institution and the latter leading to confined thinking and socialised through groupthink with high potential to absorb authoritarian structures. That in turn, in the long run, has great potential to create authoritarian personalities or uncritical conformists. ${ }^{62}$

Border duty intensified socialisation. During 'basics', all conscripts were trained to be soldiers, more so those designated to the infantry corps, artillery and the armoured corps. The so-called 'fighting forces' included those who underwent parachute training and became known as the 'parabats' and those trained as pathfinders or pioneers, infantrymen specifically trained in tracking and reconnaissance.

Border deployment for the fighting forces furthered shared experiences such as becoming battle-ready and reinforced and deepened the socialisation of the individual and group. For those that saw combat (or 'contacts', as they referred to skirmishes with guerrilla forces), the process grew in magnitude - especially in cases where comrades were wounded or killed or where the person in the engagement saw people killed or killed people themselves (the enemy, the 'terrorists'). Regular call-ups for border duty entrenched the military socialisation and solidified a shared warrior experience. When simply talking to these men even 40 years later, one discovers how deep the socialisation and bonding was, whether people experienced it negatively or positively. I recall a case during an evening in a pub in Pretoria circa 2004 when someone shouted: "Which of you remember your force numbers?" Immediately, eight of 12 white males aged 40 plus stepped forward and without hesitation called out their force numbers from memory. I made a video of the instance, but it was unfortunately lost. I wish I still had this video, because it was a clear demonstration of how deeply the military experience was edged into the memories of former conscripts.

Cross-border operations of semi- and fully conventional operations further cemented the experience, as can be seen from numerous veteran websites, some established by conscript veterans and other sites that see daily contributions by exservicemen. And frequently, the images and attitudes of the past are strongly mirrored in the present.

\section{AFTER NATIONAL SERVICE}

Following their initial six months' training - later expanded to one year and later two years (1978 onwards) - National Servicemen were transferred to CF Units, Commandos or, in the case of universities, a University Military Unit (UMU). For the 
next six to eight-odd years, they were due to serve a further one month a year and in the following year two or three months. Again, such service included border stints or to be called up for major cross-border operations such as Operation RHEINDEER (today commemorated in Namibia as Cassinga Day or Heroes Day due to a large number of lives lost especially amongst civilians during the airborne attack deep inside Angola).

Leaving the CF still implied being available for a call-up for Commando Service. It applied to both working-class men and students at tertiary establishments. For example, in my case, I was transferred from Infantry School in Oudtshoorn (conscript and junior officer) to Kimberley Regiment in the Northern Cape, my area of birth. Soon after that, I was to be transferred to the University Stellenbosch Military Unit (USMU), since I chose to study at Stellenbosch University. In Afrikaans, it was known as the Universiteit Stellenbosch Militêre Eenheid (USME), soon ironically dubbed 'Use-Me'. In short, you did not follow the army; the army followed you wherever you went.

Some CF Units, distributed throughout the country, had long histories and set traditions as far back as the Anglo-Boer War (1899-1902). Amongst these were Kimberley Regiment, the Transvaal Scottish, Cape Town Highlanders, Natal Carabineers and others. CF members served in cohesive units and frequently saw further border deployments either routine or during semi-conventional operations in Angola, such as RHEINDEER, ASKARI, PROTEA, SMOKESHELL, MODULER, HOOPER and PACKER. From 1985 onwards, others found themselves deployed in townships in South Africa during the tumultuous 1980s under an almost permanent state of emergency. Indeed, here we find a socialisation process with a long shelf life, with 'the border' coming home...

Commandos in South Africa are not to be confused with the meaning of the word in the British military sense. Commandos were bound territorial forces organised and equipped as units to operate in their immediate and local areas. Their task was to assist the SAP and where necessary the military in home defence, restraining unrest, road blockades and guard key-points and, when so called, to assist in patrols and farm protection. Commandos formed an integral part of the broader defence system even if sometimes referred to as oumanne (old men), 'Dad's Army' or skietpiete (roughly translated as 'shooting Johns'). Where commando activities between 1950 and the late 1960s merely implied attending regular shooting exercises (skietoefeninge) equipped with the dated Lee Enfield Mk II rifle, the SADF modernised these units during the 1970s, instilled more discipline, and created new urban and rural units. The weapons issued became modern, such as the semi-automatic R3 rifle, and included light support weapons such as light machineguns (LMGs). Commando Officers were motivated to attend regular courses to sharpen their skills and enhance their qualifications at 11 Commando, a unit dedicated to this purpose in Kimberley, Northern Cape. 
Commandos, spread over the length and breadth of South Africa, demonstrated further proof of a process of military socialisation from cradle to near-grave. As far back as 1976, To the Point reported that South Africa's defence budget rose from roughly R333 million (South African Rand) in 1969-1970 to R1350 million in 1976. Reportedly, South Africa had up to 400000 soldiers ready, including the Commandos, if so needed. ${ }^{63}$ At the time, the number of National Servicemen or conscripts increased from a few thousand per year to 20000 ; later, call-ups amounted to two per year with as many as 40000 men being called up. For example, in 1978, 43000 men were called up. In 1979, the number was more than $45000 .{ }^{64}$ In keeping with the continuous training and expansion of forces and arming them, the defence budget rose annually, "therefore increasing its share of total government expenditure from 10,5 per cent in 1970 to 17,6 per cent in $1980 " .{ }^{65}$ While people of all ages were socialised to accept the defence of the Republic and the war up north as normal, rising costs put stress on the economy. ${ }^{66}$ The Armaments Corporation of South Africa (Armscor) and its affiliates also employed thousands of staff and contributed to the acceptance of a system of arming South Africa against outside threats. ${ }^{67}$ The arms industry and the imagery created around it further contributed to the socialisation of the citizen in a militarised South Africa. Armscor, established in 1964 and refined in 1976, grew rapidly. An innovative format brought the public and private sector together in the endeavour to produce and acquire weaponry. Eventually, more than 400 companies were reliant on defence contracts from footwear to sophisticated equipment. ${ }^{68}$ All over South Africa, white families had men either in uniform or working for Armscor, or both. The socialisation effect of this speaks for itself.

\section{TO WHAT EXTENT WAS SOCIALISATION SUCCESSFUL?}

During 1989, the Institute for Democracy in South Africa (Idasa), a pro-democracy think tank and activist institute, undertook an extensive survey on Afrikaans and English university campuses related to political attitudes of white students. The survey covered all white-dominated universities. As Director of the then Research Unit of Idasa, I coordinated the project. Two of the principal investigators were from the Stellenbosch University and the Randse Afrikaanse Universiteit (RAU) (today, the University of Johannesburg). Jannie Gagiano was affiliated to the Department of Political Science at the Stellenbosch University and Susan Booysen to the Department of Political Studies at RAU. ${ }^{69}$ The study, the largest of its kind ever undertook in South Africa, saw a response rate of 47 per cent (4321 out of 8747 questionnaires sent out).

If the then prevalent student attitudes were anything to go by, the socialisation process in the military environment of the apartheid state was successful. Years of indoctrination enforced groupthink to a large extent. One may argue, somewhat 
provocatively, that historical prisons confined young South Africans. Arguably, one can assume, as Gagiano did, that the findings of the study rest on the reality of 'then':

The white segment (of university society) is constituted as a community by virtue of the rules of operation of the rules of the political regime that gives them differential and superior access to the levers of state in society. ${ }^{70}$

Some examples will suffice. Support for the security establishment of the minority state stood at 62.9 per cent overall.Very sympathetic towards the security establishment, Afrikaans students (Likert scale used) stood at 84,6 per cent and English-speaking students at 33,5 per cent. However, on closer scrutiny, even with only 62 per cent indicating sympathy with the security apparatus of the state, both Afrikaans and English students indicated that they harboured a deep dislike for the liberation movements. Only 16,3 per cent indicated that they would welcome (3,4 per cent) or accept it. Looking at the high levels of institutional trust, it is not surprising that with Afrikaans campuses' repression potential, Afrikaans-speaking students agreed to suppression any left-wing activism (even peaceful protest) at 88,2 per cent. English students came in much lower at 49,4 per cent. However, the overall figure still stood at 72 per cent on white campuses. Likewise, the protest potential (the willingness to physically protest, underwrite a campaign or sign a petition against the ruling political order) on Afrikaans campuses was extremely low. At Afrikaans universities, 87,9 per cent of students saw no need for or had no interest in protests - on the contrary, they felt (strong) antagonism towards it. On English campuses, the protest potential was somewhat higher, but some 70 per cent of English students saw no need for open protest. ${ }^{71}$ Small percentages on Afrikaans- and English-speaking campuses were indeed willing to protest openly, and even far smaller numbers of students felt alienated from the state. Considering the above, it seems clear that apartheid socialisation worked and that, presumably, the military socialisation process proved more than successful. The belief in the Total Onslaught featured strongly at both Afrikaans universities (much so) and English universities (lesser so), Booysen, in her contribution to the same report, argues that white students were "paradigmatically constrained due to selective exposure to media, debate and access to broader information". ${ }^{72}$ She further argues: "Political exposure and accompanying socialisation processes are critical in establishing what people believe, feel committed to or are prepared to venture upon in the political arena." 73

The research found a close correspondence between parental political attitudes and that of the students, including support for institutional parties and a general distrust in liberation movements or internal extra-parliamentary bodies. ${ }^{74}$ Given the access to socialisation agents at the time, namely pro-government newspapers, a state-run broadcasting corporation and restrictions on alternative media, Booysen argues that low levels of potential re-socialisation were prevalent; in short, the paradigmatic prison 
translated into groupthink with little space for exit or resistance. Some difference amongst the more conservative attitudes of Afrikaans students related to their exposure to Afrikaans newspapers and the SABC that was unashamedly pro-government, as well as supportive of the security apparatus. Add to this the pro-state filtered framework of educational institutions such as primary and secondary schools, and one can grasp the magnitude of an ideological grip that the ruling state had on its subjects.

English-speaking students were somewhat more critical, although not enough to threaten the state. It could hardly be expected. The reading of the slightly more liberal English press, amongst others, presumably led to these more liberal attitudes of students on English-speaking campuses. The English press in South Africa mostly favoured the parliamentary opposition, but not the liberation movements and were frequently sceptical of extra-parliamentary organisations. While some journalists and perhaps a sub-editor here and there may have harboured sympathy or empathy with the liberation movements, it was not possible to articulate this due to restrictions on the press, and I suggest the attitudes of the readers and sponsors. Other perspectives than those of the institutional media organisations were left to the so-called alternative media or alternative newspapers. These had a smaller support and distribution structure, fewer readers and were under constant pressure of the state, because they were regarded as subversive (interestingly enough, the 'subversive' media appeared in both English and Afrikaans). ${ }^{75}$

Alternative media, mostly distributed in urban areas and at universities, were often dependent on smaller budgets. In some cases, these papers were mere newsletters, locally printed and distributed. Of these, many did not reach universities, being steadily discredited by national news media.

Both Afrikaans- and English-speaking students reported rather low levels of reading newspapers left of the parliamentary system. Newspapers representing the black viewpoint and 'alternative' newspapers saw a readership of between 3 and 10 per cent, depending on the campus. ${ }^{76}$ Booysen's findings, like Gagiano's, confirmed that there was little love lost for extra-parliamentary political movements and the banned liberation movements, with English-speaking students somewhat more sympathetic to these movements than the Afrikaans speakers. Quite clearly, the majority of white students at Afrikaans- and English-speaking universities supported either the National Party or the 'liberal' parliamentary opposition and demonstrated majority support or at least acceptance of state institutions.

One definite shortcoming of the study was that no surveys were done amongst young white working-class men and women as opposed to students, as working-class attitudes may have been even more conservative and hard-lined (after all, these men and women did not have the privilege of tertiary 'liberal' education). As a research team (with me as coordinator), we failed in this regard. Thus, our study restricted itself 
to students, who can arguably be seen as an elite in themselves. In the middle of the 1990s and as part of a social identities project under auspices of the Human Sciences Research Council (HSRC), I interviewed groups of white secondary school students. These focus groups were held in smaller towns and included working-class children. In analysing the findings of the study, the attitudes reflected a strong inclination to conservatism and anti-communism and distrust in the new majority government after the transition to democracy, which is perhaps to be expected with parents socialised this way. ${ }^{77}$

It is clear that, with socialisation on various levels in a highly mobilised society that underwent a shift towards the militarisation of state and society, opportunities for breaking out of the rather static and rigid political discourse were limited. The status quo was either not challenged or only slightly challenged by the large majority, even if some people were sceptical about political developments.

Liebenberg and Visser ${ }^{78}$ identified how limitations on discourse developed over the years on one university campus (Stellenbosch University). The authors provide numerous examples of unbalanced exposure that furthered selective frameworks and worlds of reference and thus contributed to growing tensions on this campus. Limited space prevents discussion of these examples here, however informative they may be. The findings of the research by Liebenberg and Visser nonetheless provide a useful platform for further research on a case-study basis. ${ }^{79}$

Later conscript veterans were to speak out in books and contributions to the media. Some still believed in the Total Onslaught and the 'righteousness' of the struggle against communism, and that the SADF won the Border War or Angolan war, as did the late General Jannie Geldenhuys. Some were openly critical of apartheid militarisation early on, others in retrospect. ${ }^{80}$ Decades after the war, some veterans demonstrate an openness to perspectives other than that of the ruling elite of yesteryear. In reviewing work on the Angolan War, one South African veteran said: "This must be the toughest book I had to review so far!" He then engaged with the material in an open-minded, honest way, although the views were conceivably disconcerting and called up strong emotions. To do so, I think, means you have 'steel in the soul'. His relevant conclusion is that such views should be read and reflected upon while knowing well that doing so will steer a debate or dialogue in a new direction and unleash strong emotions. ${ }^{81}$

\section{CONCLUSION}

History is indeed a discussion without end. The story related here provides but a glimpse of a setting of the past that still reverberates in debates and is reflected in social attitudes today. ${ }^{82}$ In this chapter, I only touched on the role of socialisation of the media and virtually not at all on the role of religious organisations (Afrikaans and 
English Christian Churches). ${ }^{83}$ That is a topic for another day. I did not discuss the music of the time, inspirational radio talk programmes or films with a proSADF slant. Nor did I touch on the role of the Chaplain Services that were viewed by some as positive, while others saw Chaplains being used (sometimes enthusiastically so) as types of religious-political commissars to enhance the status quo. As in some other militaries, the Chaplain Servicemen within the apartheid SADF were in uniform and all had to have security clearance. Some publications, brochures and pamphlets published by the Chaplain Services touched on topics that could be regarded as propagandistic, others as indoctrination (even if by 'hidden curricula'). On this aspect, the narrative is far from being concluded and much more research is needed.

On the one hand, the socialisation of the South African citizen-soldier from a young age was intense, spread over many years, had a lasting influence on political attitudes, and impacted social tolerance. In some cases, such attitudes still bedevil social reconciliation in South Africa. While a small minority of those socialised by the apartheid state, liberated themselves from the historical prison of apartheid and resisted the system, the majority remain caught in a past that constrains human interaction in the current South Africa. ${ }^{84}$

On the other hand, in the broader South African society there is a significant lack of understanding the lifeworld and experiences of the then white youth, especially the conscripts. Those conscripts were then and are now often confused with the role of the SAP (including the security police) inside the country and as a SAP counterinsurgency unit like Koevoet (in Namibia). There is little understanding of the immense socialisation pressures on this generation of white males, and they are frequently glibly described as apartheid soldiers, without understanding the complex social dynamics of the time. On all sides, a lack of historical knowledge and understanding of the socio-political dynamics under an authoritarian and militarised state inhibit constructive dialogue on the past with social reconciliation as the main objective. In my view, there is much need for an ongoing reconciliatory, non-racial dialogue and a broadening of insight into our past, including the Border War, by all South Africans. 


\section{Endnotes}

1 Norman Denzin and Yvonna Lincoln, 'The discipline and practice of qualitative research' in Norman Denzin and Yvonna Lincoln, eds., The SAGE Handbook of Qualitative Research (Singapore: Sage Publications, 2011), 3.

2

Ibid.

3 For an excellent and recent summary on Border War literature, consult André Wessels, 'Half a Century of South African 'Border War' Literature: A historiographical exploration', Journal for Contemporary History, 42(2) 2017, 24-47.

4 In an insightful work, Norman Dixon argues that in writing on war one should be aware that "the interdependence between (things) necessitates keeping an open mind, however much one may like or disbelieve single trees [or singular research approaches] postponing judgement until the wood is seen in its entirety". Dixon thereby suggests that writing on the success and follies of war, the trials and tribulations of history and a politics of violence, other approaches can be useful besides leaving history to be written only by historians and soldiering to be described by soldiers, or for that matter generals and colonels. In short, he advocates a critical but inclusive and holistic approach in understanding and writing history, see Dixon, On the psychology of military incompetence (London: Pimlico, 1994), 24.

5 Denzin and Lincoln (2011), 3.

6 Carolyn Ellis and Arthur Bochner, 'Auto ethnography, personal narrative, reflexivity' in Denzin and Lincoln (2000), 733-768.

$7 \quad$ Ellis and Bochner (2000), 734.

8 Ann Neville-Jan, 'Encounters in the world of pain: An auto-ethnography', American Journal of Occupational Therapy, 57(1), 89.

9 Denzin and Lincoln (2011), 6; Ian Liebenberg, Truth and reconciliation processes and civil military relations: A qualitative exploration, Unpublished DLitt et Phil dissertation, Unisa, 2008, 20.

10 Denzin and Lincoln (2011), 6.

11 Liebenberg (2008), 20.

12 At least eight moments of this multi-layered approach is identified by Denzin and Lincoln (2011), 3.

13 Chris Paparone, The sociology of military science (New Delhi: Bloomsbury Publishers, 2013).

14 See several military sociologists mentioned in Liebenberg (2008).

15 Liebenberg (2008); Ian Liebenberg, 'Evolving experiences: Auto-ethnography and military sociology - a South African immersion' in Helena Carreiras and Celso Castro, eds., Qualitative methods in military studies: Research experiences and challenges (Oxon: Routledge, 2013), 50-67.

16 Cf. Ann Freedman and P.E. Freedman, The psychology of political control (New York: St Martin's Press, 1975); also see Michael Hughes and Carolyn Kroehler, Sociology: The core (New York: McGraw-Hill, 2nd ed., 2005), 21-21, 77-77, 87-89, 358-359.

17 Cornis van der Lugt, 'Worlds of difference' in Ian Liebenberg and Cornis van der Lugt, eds., Worlds of difference: The political attitudes of white students in South Africa, an IDASA

Research Report (Mowbray: Idasa, 1990), 3.

18 Ibid.

19 Cf.Van der Lugt (1990); Jannie Gagiano, 'Ruling group cohesion in South Africa: A study of political attitudes among white university students' in Liebenberg and Van der Lugt (1990), 9-34; Susan Booysen, 'Cohesion, dissension and contradiction 
in the political world of South Africa's white student youth' in Liebenberg and Van der Lugt (1990), 35-62; Ian Liebenberg and Deon Visser, 'Afrikaner nationalism, tertiary military education and civil discontent: Student attitudes at an Afrikaans university from apartheid's beginnings to the end of the Angolan War, 1950-1989' in Matteo Paesano and Paolo Alberini, eds., Military conflicts and civil populations (Rome: Commisione Italiana di Storia Militare, 2009), 675-692.

20 Doyle Paul Johnson, Sociological theory: Classical founders and contemporary perspectives (Singapore: John Wiley and Sons, 1981), 387, 409, 440; Freedman and Freedman (1975); Harry Johnson, Sociology: A systematic introduction (7th Edition. London: Routledge and Kegan Paul Ltd, 1971), 53-55,110ff; R.M. MacIver and Charles Page, Society: An introductory analysis (London: Macmillan Publishers, 1969), 623-624; Hughes and Koehler (2005), 70, 87ff, 98-99, 358-359.

21 Ely Chinoy, Society: An introduction to sociology (New York: Random House, $2^{\text {nd }}$ ed. 1967); Harry M Johnson, Sociology: A systematic introduction (London: Routledge and Kegan Paul, 1962), 53, 55, 122-132, 110-144) and Jackson Toby, Contemporary society: An introduction to sociology (Toronto: John Wiley \& Sons, 1971). Cf. John Hackett, The profession of arms (London: Sidgwick \& Jackson, 1984), 9. Ralph Sawyer, The seven military classics of ancient China (New York: Basic Books, 1993). Mitsuo Kure, Samurai:An illustrated history (Tokyo:Tuttle Publishing, 2001). 2000), 410ff).

Wright (2000), 411.

Hughes and Kroehler (2005), 70-72.

For a child to see a brother, uncle or parent buried by military honour is a social and political force multiplier (building resilience in the jargon of military Chaplains in support of their Generals). Those attending such an occasion will repeat the story; with oral tradition again as new impetus for socialisation, (re-)asserting the socialisation process and embodying the ruling ideology from cradle to grave. Accompanying photos and media reports also further socialisation in this regard.

29 Hughes and Kroehler (2005), 97.

30 Piet Cillie, 'Die Nasionale Party regeer weer' in A.J. Boeseken, D.W. Kruger and A. Kieser, eds., Drie eeue: Die verhaal van ons vaderland (Cape Town: Nasionale Boekhandel, 1953), 253-308, 264.

31 Philip Frankel, Pretoria's Praetorians: Civil-military relations in South Africa (Cambridge: Cambridge University Press, 1984); Kenneth Grundy, The Militarization of South African Politics (Oxford: Oxford University Press, 1988); Deon Geldenhuys, The diplomacy of isolation: South African foreign policy making (Johannesburg: Macmillan Publishers, 1984); Annette Seegers, The military in the making of modern South Africa (London: IB Taurus, 1996); James Selfe, 'The state security apparatus: Implications for covert operations' in Charl Schutte, Ian Liebenberg and Anthony Minnaar, eds., The hidden hand: Covert operations in South Africa (Pretoria: HSR C Publishers, 2nd ed.1998), 127-136; Hermann Giliomee and Heribert Adam, Afrikanermag: Opkoms en toekomst (Stellenbosch: University Publishers, 1981); Ian Liebenberg and Francois de Wet, 'Militarised politics, economic consequences and the implosion of state legitimacy under apartheid' in Thean Potgieter and Ian Liebenberg, eds., Reflections on war: Preparedness and consequences (Stellenbosch: African Sun Media, 2012), 65-90.

32 Seegers (1996), 179, 180; Liebenberg and De Wet (2012); Ian Liebenberg, 'The arms industry, reform and civil-military relations in South Africa' in Calvin Manganyi, Ian Liebenberg and Thean Potgieter, eds., South Africa and Romania:Transition to democracy and 
changing security paradigms (Durban: JD Publications, 2012), 241; Richard Dale, The Namibian War of Independence, 1966-1989: Diplomatic, economic and military campaigns (Jefferson, North Carolina: McFarland \& Company, 2014), 51, 102, 121, 130. James Selfe, Democracy and militarization: The national security management system (Paper delivered at a National Student Conference organised by Idasa, Stellenbosch Office, Winelands Hotel, June 1987).

34 Mike Hough, 'Sowjetbetrokkenheid in Suidelike Afrika: Implikasies vir die RSA' in Die Marxisme en die RSA: ' $n$ Toekomsblik 1 (Stellenbosch: Ismus, University of Stellenbosch, 1983), 30-50; Johann Coetzee, 'Terrorisme en die toekoms van die RSA' in Die Marxisme en die RSA (1983), 51-64.

35 Grundy (1988); Frankel (1984); Ian Liebenberg, 'The militarisation of South African society 1972-1988' in Ian Liebenberg, Jorge Risquet and Vladimir Shubin, eds., A faraway war: Angola 1975-1989 (Stellenbosch: African Sun Media, 2015), 41-56.

Frankel (1984); Grundy (1988).

Eric Nordlinger, Soldiers in politics: Military coups and governments (Englewood Cliffs: Prentice-Hall, 1977).

38 Esmeralda Kleinreesink and Joseph Soeters, 'Truth and (self) censorship in military memoirs. Current Sociology, 64(3), 2016, available at: [https://www.researchgate.net/ publication/282054847_Truth_and_self_censorship_in_military_memoirs], 373-391.

Cf. Mariolina Graziosi, 'Projecting selves: From insecurity to reflection?' Current Sociology, 63(2), 2015, 182-197.

40 Pierre Bourdieu, Distinction: A Social Critique of the Judgment of Taste, translated by Richard Nice (Cambridge: Harvard University Press, 1984).

41 In a work of some historical importance, even if somewhat biased, the experience and consequences of the war in Angola and South Africa's role therein is described from the perspective of the new regime that came to power in 1975 in Angola, see Michael Wolfers and Jane Bergerol, Angola in the Frontline, (London: Zed Press, 1983).

André du Pisani, Beyond the barracks: Reflections on the role of the SADF in the region (Johannesburg: SAIIA, 1988).

43 Liebenberg (2015), 41-55. See also Grundy (1988); Frankel (1984) and Richard Leonard, South Africa at War: White Power and the Crises in Southern Africa (Craighall: AD Donker Publishers, 1985), 198ff.

Robert Baden-Powell, Scouting for Boys (London: C. Arthur Pearson for The Scout Association, abridged ed. 1963).

Baden-Powell (1963), 178.

46 Baden-Powell (1963), 179.

47 Gagiano and Booysen (1990).

48 Die Voortrekkers (n.d.); Die Voortrekkers (1973), 4-6.

J.M. Buys, Voortrekker-plegtighede (Bloemfontein: Nasionale Pers, 1936) 6-7;

Die Voortrekkers (1974), 3.

50 ATKV (1940).

51 ATKV (1940), 513

52 ATKV (1940), 703.

53 E. van Heerden, 'Die Republiek se Eerste Fees', Ster, 5 Augustus 1966, 49-68.

54 Hou Koers, Kwartaalblad vir Voortrekkeroffisiere en Staatmakers, 4, 1975, 185-187.

55 Susan Booysen, 'The legacy of ideological control: the Afrikaner youth's manipulated political consciousness' Politikon, 16(2), 1989, 87-101; Booysen (1990). 
56 For the concept of 'elite', see 'elite' and 'elitism' in John Schwarzmantel, The state in contemporary society (Singapore: Harvester-Wheatsheaf, 1994), 21, 33, 68-69, 114-113, 214-216. For 'state elite', see Schwarzmantel (1994), 13-15, 103, 109-111, $186 \mathrm{ff}$.

57 On the role of media (and government and political elite) in setting the political and policy agenda, consult Wayne Parsons, Public policy: An introduction to the theory and practice of policy analysis (Cheltenham: Edward Elgar, 1999), 106ff, 112ff.

58 For some insight on legislation related to state security and to curb political opposition, see John Dugard, Human Rights and the South African Legal Order (Princeton: Princeton University Press, 1978), 178.; Anthony Matthews, Freedom, State security and the rule of law: Dilemmas of the apartheid society (Cape Town: Juta Publishers, 1986) as well as Muriel Horrell, Race relations as regulated by law in South Africa: 1948-1979 (Johannesburg: SAIRR, 1982).

59 See Ian Liebenberg, Ideologie in konflik (Bramley: Taurus Publishers, 1990), 24ff, 30ff, 32, 37, 40; Hanneke du Preez, Africana Afrikaner: Master symbols in South African school textbooks (MA thesis, Unisa, 1982); and Ian Liebenberg, 'Tussen vryheid en massamoord in Hornkranz-skadu', Beeld, 5 Mei 2018, 10.

60 Cf. Horrell (1982) on the extensive range of security legislation that affected the social life of each South African citizen on virtually all levels of society.

61 With regard to religious objection to war in South Africa under apartheid, see Gert van der Westhuizen, Ian Liebenberg and Tienie du Plessis, 'National service and resistance to conscription, 1969-1989' in Liebenberg, Risquet and Shubin (2015).

In his ground-breaking work, Dixon (1994) points out how closed systems (total institutions) that run on authoritarian lines create Authoritarian Personalities. Such people become myopic, intolerant to criticism, obsessive and unable to escape the extremities of group think. In Dixon (1994, 256-279) he concludes that authoritarian personalities (through socialisation in a charged and ideologically laden context) lead military operations and their civil followers to disaster. He supplies ample examples. His main argument here is that "there is a close relationship between authoritarianism and obsessive traits that (plays) a significant part in (creating) military incompetence", see Dixon, On the Psychology of Military Incompetence (London: Pimlico, 1994), $273 \mathrm{ff}$.

In contemplating why South Africa could not conclude the Border War successfully in fact on reflecting why the SADF went there in the first place - it is worth recalling Dixon's arguments mentioned above.

'What will happen if South Africa is attacked?' To the Point, 5(50), 7.

Liebenberg and De Wet (2012), 65-90.

65 Liebenberg and De Wet (2012), 83.

66 More recent research demonstrates that the amounts spent on keeping apartheid in power were far in the excess of the defence budget at the time. The use of secret funding and secret projects through 'unofficial means' was beyond the scope of the white parliament, auditors' general and even legality (see Hennie van Vuuren, Apartheid, guns and money: A tale of profit (Auckland Park: Jacana Media, 2017).

Liebenberg and De Wet (2012), 65-90.

68 Seegers (1996), 217. 
Booysen (1990), 45ff.

In referring to alternative media, names such as Grassroots, New Nation and Vrye Weekblad as well as Afrikaans publications such as STET comes to mind. Booysen (1990), 49.

One of the extremely worrying developments in post-apartheid South Africa in terms of education, especially in the field of historiography, is that history and our past (including the war in Angola) receives so little attention. The result is that the youth are growing up in a historical vacuum with little knowledge of the immense dehumanising consequences of apartheid and its military projection into neighbouring countries of which Angola bore the brunt. This does not bode well for an informed citizenry of the future, with meaningful and informed social dialogue, and may invite further tensions and misunderstandings in a country where relationships are already strained and to frequently build on glib stereotypes of the 'Other'. Liebenberg and Visser (2009).

79 Ibid.

80 Some examples are Anthony Feinstein, In conflict (Windhoek: New Namibia Books, 1998); Bertie Cloete, Pionne (Hermanus: Hemel en See Boeke, 2009) and a variety of others. The source list compiled by the historian and journalist, Gert van der Westhuizen, for Liebenberg, Risquet and Shubin (2015), 199-200, include a list of novels, short stories and poems critical of the war. More recent work is Hans Pienaar, Die Generaal (Cape Town:Tafelberg Publishers, 2018). These literary works are important sources for historiographers to get a feeling for the 'then' setting, it provides an 'against-the-grain' peep into the attitudes of 'now' and 'then'. This is important because history, 'what happened then', speaks to us in the 'now and present' discourse and has an effect on 'what is to come' (the future). For an article worth reflecting on - an interview with Hans Pienaar, conscript veteran of 1975-1976 - see Gert van der Westhuizen, 'Die (Grens)oorlog wat nog steeds in ons koppe woed', Netwerk24, 8 February 2019, available at: [https://www.netwerk24.com/Stemme/Aktueel/die-grensoorlog-wat-nog-steeds-inons-koppe-woed-20190207], accessed 12 March 2019.

81 Johan Schoeman says amongst others: "Had I learnt of the Russian support for Boer Forces in the Anglo-Boer war at school, it may have changed the perception I had of them while growing up". Further: "The last chapter on resistance to conscription in South Africa was the biggest eye-opener of them all". He felt that reading the work would be disconcerting, but that this is necessary for those growing up with static interpretations of the past. His careful review invites an important ongoing dialogue, see Schoeman's review on the War In Angola (General Forum, Post 1684) website about The Far-Away War: Angola, 1975-1989War in Angola (website), available at: [http://www. warinangola.com], accessed 3 March 2016).

82 For an outsider's perspective on the lasting effect of this war in the collective psyche, see Fred de Vries, 'Ons sal lewe, ons sal sterwe: Pijnlike geskiedenis De Zuid-Afrikaanse Grensoorlog', De Groene Amsterdammer, 31, 29 July 2009, available at: [https://www. groene.nl/artikel/ons-sal-lewe-ons-sal-sterwe].

83 Marius Brill observes that Pope Urban II "was the first pontiff to openly cross from the state ethereal to real estate". His observation links a grab for land, domination of the 'Other' and organised violence for these causes. He argues that religion provided a rationale (or perhaps rather a proto ideology). "With that he launched the Crusades and authorized a return to the savageness of the Huns, Goths and Vandals. But this time the genocidal slaughter was right, because God said it was" (Brill, Making Love: A Conspiracy of the Heart (London: Black Swan Books, 2004), 22). Dawid Bosch observes how within Afrikaner values the concepts 'volk', 'nation', and '(apartheid) religion' became a civil 
religion that formed the basis for white domination - if needed with violence (Bosch, 'The Roots and Fruits of Afrikaner Civil Religion' in Johannes Hofmeyer and Willem Vorster, eds., New faces of Africa: Essays in Honour of Ben Marais (Pretoria: Unisa Publishers, 1984)). The work of Bill de Klerk, The Puritans in Africa: A story of Afrikanerdom (London: Rex Collins Press, 1975) is also informative here. See also Liebenberg (1990, 36-40) on the role of the (white) Afrikaans churches in moulding a nationalist (and eventually) militarist state under apartheid. The interesting thing is that political theorists today use a term such as 'Political Islam' glibly - if not mantra-like. A whole corpus of quasi-science (if not an ideological paradigm masqueraded as science) on the topic evolved. Ironically one has not heard the term 'Political Christianity' and its role in the past or present being discussed in the global 'war on terror'.

84 Small wonder that the Afrikaans sociologist and political practitioner, the late Frederik van Zyl Slabbert, in answer to why he resigned from the white parliament in 1986 and followed an extra-parliamentary road to facilitate transition-through-negotiation titled his work, The Other Side of History: An anecdotal reflection on political transition in South Africa (Cape Town: Jonathan Ball Publishers, 2006). When asked in one of the last interviews before his death on why he chose this route, he said: "I had nothing to fall back on, but my own moral convictions ... I did precisely so." 


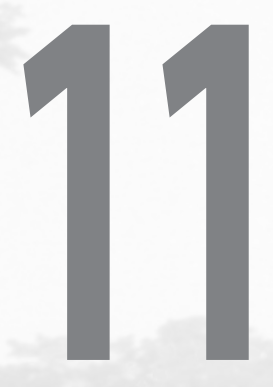

\section{THE EVOLUTION OF 32 BATTALION: FROM RENEGADE GUERRILLAS TO TOWNSHIP TROOPERS}

Will Gordon 
During the Angolan Civil War, South Africa and the West supported parties that proclaimed anti-communist sentiments, notably the National Union for the Total Independence of Angola (Unita) and the National Front for the Liberation of Angola (FNLA). However, with Soviet support, the Popular Movement for the Liberation of Angola (MPLA) emerged as the stronger contender to govern post-colonial Angola, with weak leadership, logistics and supply shortages plaguing both Unita and the FNLA. The South African Defence Force (SADF) took over command of a leaderless faction of the FNLA and deployed them, as Bravo Group, during Operation SAVANNAH, the South African offensive in Angola in 1975-1976. After withdrawing from Angola, Bravo Group was incorporated into the regular SADF structures as 32 Battalion and deployed against the People's Liberation Army of Namibia (PLAN), but the distinct character of the unit remained intact. 32 Battalion was characterised by unusual, non-racial training and command methods, alien to apartheid South Africa. Different Officers Commanding (OCs) imparted different influences on the role of the unit, but the innovative character and adaptability of the soldiers meant that it continued to be an effective fighting force that was able to provide the SADF with many unique skills and opportunities. After the Border War, 32 Battalion was relocated to Pomfret in the north-western part of South Africa's Cape Province (now the Northern Cape) and deployed on township duties. This new role, less militaristic, was not ideally suited to the unit and problems that arose from it contributed to the disbanding of 32 Battalion in 1993.

The clash between the South African Police (SAP) and the South West Africa People's Organisation (Swapo) at Ongulumbashe on 26 August 1966 is generally accepted as the start of the Border War. South Africa was still largely unprepared for a higher intensity war nine years later. At the start of Operation SAVANNAH in 1975, the majority of the infantry component of the South African forces consisted of hastily trained foreign troops under South African leadership. These troops were to become the nucleus of 31 and 32 Battalion of the SADF. The experiences during SAVANNAH made it clear to the SADF that its doctrine and equipment would have to be re-evaluated and adapted. This chapter traces the evolution of 32 Battalion from its inception during Operation SAVANNAH as irregular infantry using whatever weaponry and equipment could be pilfered, acquired, and appropriated, through the days of pseudooperations and guerrilla warfare, to a conventional infantry battalion armed with some of South Africa's latest doctrine and cutting-edge equipment by the end of the war. The post-war changes necessary for the transition from a combat infantry role to a township policing role are also examined. Throughout this period, the SADF also went through a process of evolution; from the hastily assembled battle groups 
of Operation SAVANNAH to one of the most modern armies in Africa. Therefore, comparisons are drawn between the different roles of 32 Battalion and the perceived requirements of the SADF.

Piet Nortje's comprehensive history of 32 Battalion, The Terrible Ones, ${ }^{1}$ and, to a lesser extent, Jan Breytenbach's The Tempered Sword ${ }^{2}$ are used to construct the historical narrative. Primary sources from the South African Department of Defence Documentation Centre that neither Nortje nor Breytenbach reference are used both to confirm the accuracy of their accounts and to enrich and motivate the contentions about the evolution of 32 Battalion. The chapter does not attempt to renounce or replace existing narratives, or even to be a comprehensive historical narrative itself, but rather focuses on and analyses a specific aspect of the fighting history of one of South Africa's most active units during the Border War. In doing so, it addresses one of the voids in the extant literature on 32 Battalion. With the notable exception of The Terrible Ones, the corpus of 32 Battalion literature comprise almost exclusively memoirs, recollections and apologetics. ${ }^{3}$ Nortje, on the other hand, has written a regimental history, of sorts. All these works, however, are either satisfied with providing an uncritical historical narrative or using the narrative to justify the actions of the author (and the author's perception of the actions of 32 Battalion) during the war.

\section{OPERATION SAVANNAH}

South Africa was already involved in the Civil War in Angola when Luanda declared independence in 1975. The MPLA deemed the least desirable of the three nationalist organisations competing for power, and the SADF was keen to support either the FNLA or Unita. The latter organisations both approached South Africa for assistance in their fight against the MPLA and the SADF assisted to a greater or lesser extent. Unfortunately for South African strategists, the FNLA proved an unreliable ally and an ineffective fighting force, despite the material and advisory assistance from South Africa and the USA. The rapid state of deterioration of morale and equipment within the FNLA indicated this. A March 1975 newspaper report that states: "FNLA soldiers have a neat uniform, modern arms, good pay and allowances, efficient transport and their discipline and behaviour are excellent," 4 contrasts markedly with the first impressions that the South Africans had of them at M'pupa in August of the same year:

The base was in a filthy state. The approaches were through a several hundredmetre-wide minefield of human excrement [...] the stench was all-pervading $[\ldots]$ all of the men showed signs of starvation [...] none of them had decent footwear. $^{5}$

It left Unita as the only viable opposition to the MPLA unless support to the FNLA was increased dramatically and to a more practical level. Besides, South Africa was not 
well prepared for a large-scale conflict in Angola. Conscription was still in its infancy, and the Citizen Force pool was not as large as it would be when the SADF planned and executed the later large cross-border operations. To compound the problem, Army Headquarters had, on 19 March 1975, concluded that there was "... geen konvensionele militêre aanslag teen die RSA nie [no conventional threat to the RSA]". ${ }^{6}$ It meant that the SADF focused planning on low intensity, low manpower, counterinsurgency (COIN) warfare, rather than conventional operations in a foreign country. South Africa required manpower if they were to increase their influence in Angola without a great mobilisation effort in the Republic, which was curtailed both by time constraints and potential political repercussions.

Daniel Chipenda played a crucial, though unintentional, part in assisting the SADF to fill this manpower void. A former member of the MPLA, Chipenda had fallen out with Agostinho Neto, MPLA leader, and joined the FNLA as assistant secretarygeneral in 1975..$^{7}$ Although some of the MPLA support base - approximately 2000 soldiers - followed Chipenda to the FNLA, they did not espouse their new organisation wholeheartedly and remained a faction within the FNLA. One of the first acts of Chipenda's faction was to establish a presence in southern Angola under Oginga Odinda, ${ }^{8}$ something the FNLA had been unable to do effectively up to that point. ${ }^{9}$ The FNLA had approached South Africa House in Trafalgar Square for aid in the war effort against the MPLA as early as 28 February $1975,{ }^{10}$ during the period when American aid was still sufficient to keep the movement in the field, but by May, Chipenda had apparently come to the conclusion that South African aid had become crucial. In an attempt to secure this for his faction, he visited Rundu on 24 May and Windhoek on 28 May. ${ }^{11}$ Perhaps disheartened by Pretoria's decision to limit FNLA support to supplying Holden Roberto with military hardware, rather than his own faction, Chipenda left the next meeting with the South Africans to Odinda, who on 8 July informed the South Africans at Calais of the presence of about 300 ChipendaFNLA troops at M'pupa, about $60 \mathrm{~km}$ to the north. Odinda promised that, with South African help, these men would take the fight to Swapo inside Angola. ${ }^{12}$ At a follow-up meeting initiated by Chipenda's brother-in-law, Pilisso, on 11 July, they presented the South Africans with a more accurate picture of the situation at M'pupa: there were only about 150 men who, between them, only had 15 rifles. ${ }^{13}$ Besides, Chipenda was no longer taking an active part in the leadership of this part of his FNLA faction. The SADF quickly realised that this situation could be turned to their advantage, identifying the Angolan soldiers as a potential SADF proxy force.

Major General Constand Viljoen, then Director General of Operations at Army Head Quarters, tasked Col Jan Breytenbach to move to Angola and commence a training programme. Breytenbach, given 11 Reconnaissance Commando (Recce) operators to assist him with the task, ${ }^{14}$ arrived at Rundu in 1 Military Area (1 MA) in Namibia on 28 August 1975. The next day, Breytenbach met with Brigadier Dawie Schoeman 
(Officer Commanding $1 \mathrm{MA}$ ), Commandant (Lieutenant Colonel) M. Knoetze (South African Military Intelligence) and representatives from the FNLA to establish a training programme. In an attempt to keep South African involvement in Angola a secret, they told the FNLA delegates that the white SADF personnel that would be in charge of the training programme was a mercenary force employed by the South African government. ${ }^{15}$ Although this deception was successful in keeping SADF activities secret for a few more months, the epithet 'mercenary' would stay with 32 Battalion for the remainder of its existence. Nonetheless, a detailed training plan was drawn up, ostensibly based on FNLA reports of their strength and capabilities at M'pupa. Although Breytenbach's recollections of the training indicate a haphazard, makeshift approach, ${ }^{16}$ the events that he recalls digress only slightly from the training plan that he submitted to Brigadier Jannie Geldenhuys, Director Operations at Army Headquarters, on 3 September $1975 .{ }^{17}$

When Breytenbach arrived at the FNLA base at M'pupa on 5 September 1975 on a fact-finding mission, he discovered that even the more realistic image, sketched by Pilisso on 11 July, had significantly overstated the reality of the situation at M'pupa. Breytenbach is scathing in recollecting his initial impression of the troops ${ }^{18}$ but applied himself and his small core of South African officers and NCOs to the abbreviated training that they had planned. After addressing the most immediate concern feeding the starved FNLA troops - Breytenbach organised them into two rifle companies of three platoons and a support company with mortar, machinegun and anti-tank platoons. The training focused on physical fitness, section and platoon drills, weapons training and offensive drills. ${ }^{19}$ The actual training differed from the planning only in the addition of the anti-tank platoon, not initially envisaged and added by Breytenbach only because the SADF supplied him with 3.5" rocket launchers and an ex-Portuguese army soldier, by then part of Chipenda's FNLA, claimed to be an anti-tank expert. ${ }^{20}$ True to the reputation that he had acquired and was fast developing, Breytenbach did not let the opportunity, however improbable, of adding additional firepower to his makeshift force slip through his fingers. The agreement between the SADF and the FNLA envisaged that the latter would gradually provide additional troops for training at M'pupa until the force under Breytenbach's command came up to battalion strength. ${ }^{21}$ In reality, it rather was the news of the improved conditions now prevalent at M'pupa under South African leadership that inspired enough 'recruits' to turn up to enable Breytenbach to establish a third rifle company. ${ }^{22}$ Although this third rifle company lagged behind the other two in training that was already cut down to a minimum, they would still, contrary to the initial planning, be deployed during Operation SAVANNAH. This lack of training, knowledge and discipline had regrettable consequences when Task Force Zulu's Bravo Group, as Breytenbach's command was now known, ran into a People's Armed Forces for the Liberation of Angola (Fapla) ambush near M'pupa during the initial stages of Operation SAVANNAH. In the confusion of battle, Charlie Company established 
positions on either side of a road, after that the two parts of the company started firing on one another. Two soldiers of Charlie Company were wounded, and one of them later died of his wounds. ${ }^{23}$ Because of this incident, Breytenbach kept Charlie Company in reserve for the rest of the campaign. In turn, this meant that Charlie Company never acquired the combat experience of the first two companies, Alpha and Bravo, while under Breytenbach's command. At the battle of Ebo, when Charlie Company detached to Battle Group Foxbat, Charlie Company's inexperience cost them dearly when confronted by a well-prepared, well-executed Fapla ambush. ${ }^{24}$

Perhaps due to the inexperience of the SADF in using proxy forces, or due to the poor track record of the FNLA, the equipment provided to Breytenbach's men was almost exclusively inferior and of Second World War vintage, except the FN/R1 rifles. ${ }^{25}$ The 3" mortars, with an effective range of around 1000 metres, were hopelessly outclassed by the more modern Soviet $82 \mathrm{~mm}$ mortars of Fapla that could fire up to 3000 metres. At first glance, the water-cooled Vickers machineguns seemed prehistoric alongside the Fapla RPDs and PKMs. The Sten submachineguns (SMGs) that were used as personal weapons by the support platoons might have gained a brutal reputation in townships in South Africa, particularly at Sharpeville in 1960, but were of arguable use against a well-equipped opponent. From the outset, the Stens were unpopular with the support weapons platoons ${ }^{26}$ and were eagerly exchanged for Soviet PPSh SMGs as soon as they seized these during Operation SAVANNAH. ${ }^{27}$ Possibly due to security concerns, the SADF recalled all the FN/R1 rifles, issued to Bravo Group shortly after the start of Operation SAVANNAH, but it was impossible to exchange them for AK47s, as proposed by 1 Military Area Headquarters, with Bravo Group actively deployed. ${ }^{28}$

Despite the challenges facing him and the men under his command, Breytenbach succeeded in moulding an effective fighting force from his demoralised FNLA troops. Three aspects that would become hallmarks of 32 Battalion in later years stood out in the fighting efficiency of Bravo Group. Firstly, the innovative use of whatever equipment they had at hand increased the efficiency of obsolete weapons. The most obvious examples of this kind of innovation were the mounting of eight Vickers machineguns on the back of a flat-bed truck and using this in broadside offensives against Fapla strongpoints $^{29}$ or mounting machineguns on Land Rovers and using these vehicles as armed scout cars. ${ }^{30}$ Secondly, superior tactical awareness and application negated many of the advantages that the Fapla superior weapons and tactically defensive positions gave them. It is evident from the organisation of Breytenbach's column during the advance into Angola: the Land Rovers led the way, followed by the machinegun and mortar companies. The rifle companies formed the rear of the column. ${ }^{31}$ In this way, Bravo Group was able to bring very heavy fire to bear on any enemies that they encountered, in a short space of time. It also positioned the mortars further towards the front of engagement, thereby enabling them to have some effect on the outcome 
of the battle despite their limited range, though endangering the mortar crews in the process. Thirdly, Breytenbach did not hesitate to appoint non-white, anti-SADF personnel in key positions. It was partly due to a shortage of SADF leaders, but astute judgement in these appointments gave the FNLA soldiers both a sense of continuity and importance. Initial planning had strongly suggested that white South African leadership would be essential to achieve success. It was the contention of both the SADF, with Breytenbach stating that:

die sukses van die operasie [hang] af van goeie beheer tot op lae vlak, d.w.s. wit Suid-Afrikaanse beheer ... [... the success of the operation is dependent on good control at low level; in other words, white South African control.... $]^{32}$

and the FNLA, who requested:

... dat ons hulle moet bystaan, nie alleen met opleiding nie, maar ook met die fisiese beplanning en beheer van operasies. [... that we assist them not only with training but also with the actual planning and control of operations. $]^{33}$

Nonetheless, when it became apparent that enough 'white, South African' personnel were not available and that elements of the FNLA command structure were, in fact, capable leaders, Breytenbach deviated significantly from his planning brief to make optimum use of the forces at his disposal. Operation SAVANNAH showed the importance of leadership by example, that was absent in the FNLA, and the men chosen by Breytenbach formed the nucleus of the permanent leadership of 32 Battalion.

\section{INTEGRATION AND EARLY DEPLOYMENT}

Although Operation SAVANNAH was a tactical success, with South African battlegroups advancing more than $3000 \mathrm{~km}$ into Angola in little more than a month, ${ }^{34}$ Pretoria's strategic decision to withdraw to southern Angola left Bravo Group with no immediate prospects of employment. A large part of the white leader group, already evacuated because of malaria, and Brigadier Schoeman of 1 Military Area Headquarters planned to withdraw the remainder and replace them with newly arrived South Africans. However, Breytenbach realised that Schoeman's proposal would be problematic because: the FNLA troops were unlikely to take kindly to leaders who had not proved themselves and the South Africans would probably underestimate the value of the FNLA troops. Fortunately, the bonds, forged during Operation SAVANNAH, proved strong enough, and Breytenbach and the remainder of his leadership group took a firm stance: if they came back to Namibia, the Angolans under their command came with them. ${ }^{35}$ With the MPLA assuming power in Luanda, the future looked bleak for their opponents, who had opposed them as 
part the FNLA and the SADF. Common sense prevailed, and unofficial arrangements were made for the troops of Bravo Group to reconvene at M'pupa and Calais in January 1976, following a period of leave for the South Africans. ${ }^{36}$ By that time, the influence of the FNLA had diminished considerably, effectively leaving Unita as the only viable opposition force in Angola. It meant that former FNLA supporters had nowhere to go within Angola, as Unita was as much an enemy as the MPLA, resulting in a large number of refugees trying to enter Namibia. The South Africans made the most of this situation, handpicking the best of the former FNLA troops from amongst the refugees to join Bravo Group. ${ }^{37}$ In addition to the soldiers recruited in this way, skilled civilians from amongst the refugees were also informally attached to Bravo Group. ${ }^{38}$ Breytenbach then set about getting official SADF recognition for his new force. The focus of the SADF had by now returned to a counterinsurgency role aimed at combating PLAN infiltrations into Namibia, rather than direct action against Fapla. South African intelligence had established that the Angolan government was supporting Swapo and PLAN, ${ }^{39}$ providing them with bases of operation inside Angola, and the USSR had promised to provide PLAN with arms and ammunition to continue their fight against the $\mathrm{SADF}^{40}$ Reports of increased PLAN activity in southern Angola and Ovamboland had also started coming in from November 1975, and South Africa's Chief of Staff Intelligence (CSI) was under the impression that:

... operasies in S [Suid-] Angola slegs in 'n mindere mate Swapo se operasionele beplanning beinvloed [sic] het [... operations in s [Southern] Angola only influenced Swapo's operational planning to a limited extent]. ${ }^{41}$

Breytenbach, therefore, envisaged that the former FNLA soldiers could be employed as a guerrilla force in the south of Angola, recreating something of the cordon sanitaire that PLAN forces would have to cross to infiltrate Namibia. To achieve this, he requested logistical support from 101 Task Force (101 TF) Headquarters, ${ }^{42}$ that had been established in November 1975 to provide a more effective command structure over the increasingly large theatre of operations of the SADF. ${ }^{43}$ They duly complied and authorised for the training of 1000 men. During Operation SAVANNAH, the SADF had repeatedly denied that South African forces were operating in Angola until Fapla paraded captured South African prisoners of war (POWs) in front of the media. Perhaps in a bid to avoid a repeat of this embarrassment, Bravo Group was to be equipped with captured Soviet PPSh SMGs for their new counterinsurgency role, rather than the standard SADF FN/R1 rifle that they had used during Operation SAVANNAH.${ }^{44}$ It added a layer of protection to the SADF, but also made sense for a force set to operate inside enemy territory. The Chief of the Army (C Army), Constand Viljoen, authorised the withdrawal of Bravo Group, now recognised as a quasi-South African force, as well as that of their families, to Namibia together with the rest of the South African forces. The last South Africans were officially set to leave Angola by 27 March $1976 .{ }^{45}$ This decision initiated the move to Pica Pau (Woodpecker), 
in the Caprivi, and later Buffalo, the home of the unit for the next 13 years. The first group of Bravo Group soldiers and civilians arrived at Pica Pau on 2 March. ${ }^{46}$ Surplus equipment from the Second World War was given a new lease of life, with $15^{\prime} \times 15^{\prime}$ tents used as housing for the soldiers. ${ }^{47}$ Civilians had to make do with what they could find. On 2 March 1976, the SADF agreed to start paying salaries to the Angolan soldiers, the first sign of formal integration, at an annual rate of R60 for riflemen, R120 for lance corporals and R180 for corporals. ${ }^{48}$ On 15 July, Breytenbach requested a review of the salary scale, indicated in Table 11.1. ${ }^{49}$

TABLE 11.1 Breytenbach's proposed salary scale for black soldiers

\begin{tabular}{|l|l|}
\hline Role & Proposed Annual Salary \\
\hline Trainee Rifleman & R120 \\
\hline Rifleman & R300 \\
\hline Section Leader & R360 \\
\hline Platoon Sergeant & R420 \\
\hline Platoon Leader & R480 \\
\hline
\end{tabular}

For comparative purposes, it is notable that, earlier in the same year, the Owambo Cabinet indicated to 2 Military Area (2 MA) that they were willing to "spend R100 000 per annum for the employment of 500 Home Guards", ${ }^{50}$ that equates to R200 per guard per year. Although it is unclear whether this amount was earmarked exclusively for salaries, Breytenbach's proposed salary scale seems to be in greater sync with the prevalent socio-economic climate than the initial SADF allocation. Additionally, the fact that Breytenbach refused to rest on his laurels following his successful campaign for getting official recognition for his unit appears to indicate a genuine concern for the well-being of his men and their families.

After the rushed training programme at M'pupa, the frenetic pace of Operation SAVANNAH and the struggle to get SADF recognition for his former FNLA troops, Breytenbach now found time to reflect on the composition of his unit. He realised that he had black men from at least seven different tribes as well as white men from vastly different backgrounds and cultures under his command. ${ }^{51}$ Nonetheless, encouraged by the potential shown by Bravo Group, he started to foster an esprit de corps amongst his soldiers. Recognising that the reasons for which his men had become soldiers in the first place - the desire for an independent country in which to live - was no longer a motivating factor, Breytenbach embraced the motto of the French Foreign Legion: Legio Patria Nostra, The Legion is Our Fatherland. The inherent mentality within the unit would not be that black Angolan troops are fighting a white, apartheid, South African government's war, but rather that they are fighting for the unit itself. In return, 32 Battalion would provide a haven for them and their families. Because the MPLA government in Angola was starting to refuse entry into Angola to refugees that wished to return, ${ }^{52}$ the value of a guaranteed home increased significantly. 
However, Breytenbach could only achieve this if the white South Africans in the unit embraced his philosophy with the same vigour as the blacks. From the outset, the white leaders were regarded as part of the unit, rather than elite instructors. At the time, the SADF intelligence was concerned about the fact that black Namibians in the Caprivi were resigning from the SAP, because of inequality between them and their white counterparts. ${ }^{53}$ Junior white officers of 32 Battalion quickly came to realise that their black senior NCOs had a wealth of information and experience to impart to a 19-year-old platoon commander, and the ingrained South African division between black and white soon diminished, at least when members were at Buffalo and or Pica Pau. A former resident of the Kimbo - the area where civilians associated with 32 Battalion lived - recalls that he was not aware of any racism at Buffalo, although he did experience racism after the unit's move to South Africa in 1989. ${ }^{54}$

Because 32 Battalion Head Quarter's location at Rundu, the need arose for a transit camp there. The construction of this camp indicated that the greater SADF was not yet comfortable with the desegregated views of 32 Battalion and in 1979 the General Commanding South West Africa Command (SWA Command) specifically instructed the SWA Engineer Squadron to pay attention to the construction of segregated ablution facilities at Rundu. ${ }^{55}$ It indicates that SADF members who felt unable to embrace the attitude of equality within 32 Battalion would find a more comfortable fit in other, more traditional, SADF units, and they were soon reassigned, either by their design or that of senior 32 Battalion officers. ${ }^{56}$ The use of Angolans as NCOs filled a manpower void and ensured a measure of continuity, both along the chain of command and when SADF officers left.

Bravo Group, destined to become known as 32 Battalion in October, shortly before Lieutenant Colonel Gert Nel assumed command, received their official tasking from 101 TF on 18 May 1976. Their primary task was:

... om 'n strook van ongeveer $50 \mathrm{~km}$ Noord van die SWA grens aan Swapo te ontsê deur klandestiene optredes ... [... to deny Swapo an area of 50 kilometres north of the South West African border using clandestine operations]. ${ }^{57}$

They were specifically instructed to avoid contact with Fapla and the armed forces of other neighbouring countries. ${ }^{58}$ This directive necessitated two developments: establishing a training facility - done at Dodge City in the eastern Caprivi ${ }^{59}$ - and establishing an operational base at Omauni in the east of Ovamboland since Buffalo was too far from the theatre of operations. Dodge City was chosen as a training facility because the area around Pica Pau was not big enough for the more intensive training that was now taking place at 32 Battalion. ${ }^{60}$ To execute the directive, Breytenbach requested more contemporary weapons for Bravo Group, including RPG7s to replace the 3.5" rocket launchers and $40 \mathrm{~mm}$ grenade launchers, which he considered ideally suited to the task that 101 TF had assigned Bravo Group. Besides, because he could 
now train his men in its use, he requested equipment, such as camouflage nets, to use in training at Dodge City as well as on deployment. ${ }^{61}$ Following their official recognition, Bravo Group was better equipped, though still not to the standard of a regular SADF infantry battalion. At least, Second World War equipment had given way to more contemporary weaponry. It included captured Soviet AK47s and Portuguese FN G3 rifles, FN MAG light machineguns and South African $60 \mathrm{~mm}$ and $81 \mathrm{~mm}$ mortars, though the machineguns and mortars were in very short supply and the SADF seemingly ignored Breytenbach's request for RPGs and $40 \mathrm{~mm}$ grenade launchers. ${ }^{62}$ Initially, 32 Battalion deployments were similar to those of regular SADF infantry units, although 32 Battalion patrols took place inside Angola and over periods considerably longer than other SADF patrols, typically lasting six weeks, and were led by more junior officers than elsewhere in the SADF. It was an initial cause for concern within $101 \mathrm{TF}{ }^{63}$ but the combination of South African training and Angolan experience proved sufficient. The nature of the 32 Battalion deployments, in which forces were seldom larger than a platoon, led Nel to assign platoon commanders usually white South Africans - and platoon sergeants - normally black Angolans - the responsibility for training their platoons ${ }^{64}$ Although junior officers and NCOs were also responsible for platoon training in the rest of the SADF, the training at 32 Battalion was different in the fact that platoon commanders functioned autonomously and did not, as in the regular SADF, operate according to a set training plan. It meant that it was left to the platoon leaders to decide on which areas of training to focus within their particular platoons as well as, if the need arose, develop training methods and drills to improve the combat effectiveness of their platoons. Although the SADF informally had a culture of decentralised command, with lower-ranking officers given a large degree of freedom in which to operate, in 1977 the idea that black soldiers were capable of leading and training South African forces differed radically from the views of the apartheid government.

Nonetheless, this training method nurtured the innovative spirit of 32 Battalion, established from necessity during Operation SAVANNAH, and was an effective way to increase the level of training and combat effectiveness of the Angolan troops. Ironically, the SADF took the diametrically opposite view. The office of C Army compiled a document titled "Lesse geleer gedurende Op SAVANNAH [Lessons learnt during Op SAVANNAH]" that states:

The command and control structure of the SADF has been designed to function efficiently not only during peacetime but also during wartime. To change this organisation and operate on an ad-hoc basis during an operation not only results in confusion among lower formations but, as has been proved during SAVANNAH, also causes uncoordinated [sic] action and ineffective control. We must stick to our existing organisations and doctrine. ${ }^{65}$ 
It seems to disregard the successes achieved by units functioning on the very ad hoc basis, reviled in the document. Nonetheless, the caveats that $\mathrm{C}$ Army issues are poignant when viewed in the light of later command and control failures that had disastrous results, particularly in the case of 32 Battalion. ${ }^{66}$

\section{PSEUDO OPERATIONS AND RECONNAISSANCE WING}

Driven by the lack of intelligence on Swapo, Breytenbach came up with the idea of pseudo-operations late in 1976. Intelligence gathering was, at the time, a hot topic in the SADF, as the realisation started to dawn that South Africa was probably now involved in a protracted war in Namibia and Angola. After studies done on both the philosophy and praxis of intelligence gathering, in typical army fashion, the SADF established guidelines for efficiency. ${ }^{67}$ They based the concept on the Rhodesian Selous Scouts, and the idea was that a group of black 32 Battalion soldiers could masquerade as Swapo cadres, hopefully gaining the trust of the local population and gathering intelligence from them. ${ }^{68}$ Breytenbach again exhibited his willingness to use the assets at his disposal by appointing an Angolan sergeant, who had undergone guerrilla training in the USSR and China while serving in the FNLA, together with two other black Angolans and two South Africans as instructors. ${ }^{69}$ The Battalion trained thirty soldiers but selected only ten for the first pseudo-operation, an infiltration of the Opepela area. The group successfully contacted the local population who accepted them as Swapo cadres after spending some time amongst them. After nearly a month of posing as Swapo insurgents, the group withdrew. Because of a communication breakdown between 32 Battalion, 101 Task Force and SADF Army HQ, the operation had taken place without the knowledge of the SADF. When they became aware of it, further operations of such nature were prohibited. ${ }^{70}$ Soon after that, on 16 February 1977,,$^{71}$ an OC Conference was hosted by 101 TF followed by another, on $12 \mathrm{March}$, at $2 \mathrm{MA} \mathrm{HQ}$, specifically emphasising the importance of intelligence gathering as a whole but, to an even greater extent, intelligence gathering be done in the prescribed, army way. ${ }^{72}$ Intelligence Instruction 4/76, discussed at these conferences, states explicitly:

Dit is van kardinale belang dat daar die grootste mate van samewerking en vertroue heers tussen die onderskeie inligtingstawwe [It is of the utmost importance that the greatest degree of cooperation and trust prevails between the different intelligence staffs]. ${ }^{73}$

It is not a large leap of imagination to envisage 101 TF, chagrined at Breytenbach's independent attempts at intelligence gathering, pre-empting further such attempts at these conferences. Although Breytenbach (or any other delegate from 32 Battalion) did not attend these conferences, pseudo operations ceased to form an integral part of 
32 Battalion activities. Pseudo operations, therefore, only formed a small part of the fighting history of 32 Battalion but are indicative of their adaptability and willingness to embrace new challenges. The fact that the Battalion effectively implemented the concept of pseudo operations without the knowledge of Army HQ also illustrates the efficiency of the leadership in conceiving and implementing novel approaches to warfare.

The 32 Battalion Reconnaissance (Recce) Wing was also born from the need for accurate, uptodate intelligence. SADF intelligence doctrine of the time placed a premium on the rapid dissemination of intelligence and information, to the extent that it was considered worthless after a sufficient time lapse. ${ }^{74} \mathrm{Nel}$ recognised that the Reconnaissance Commandos (Recces) of the SADF would never be a large enough group to provide intelligence for the whole of the SADF and set out to provide his own. ${ }^{75}$ The first training of the Recce Wing commenced in 1978 and closely resembled that of the existing Recces. As with the Recces, training started with a selection phase, designed to eliminate soldiers that lacked either the physical prowess or the mentality to become members of the Recce Wing. Those that were selected then embarked on an intensive programme that included intensive navigation, bushcraft, tracking and minor tactics training in addition to a strenuous physical fitness regime. ${ }^{76}$ Soldiers that completed both the selection phase and the Recce Wing training were then based at Omauni, closer to 32 Battalion's area of operations than Buffalo and therefore quickly able to deploy when the need arose. They were organised into teams of five: a white team leader (usually a second lieutenant), a white NCO (usually a corporal) as the team's second in command, and three black troops (some of which had the rank of corporal). The rigidity of the composition of the teams, when compared to normal 32 Battalion platoons, was because the Recce Wing training attracted National Servicemen (NSM) from outside 32 Battalion. These newcomers could not always comprehend the fluidity of the command structures within the unit, and a more traditional approach to the Recce Wing went some way to alleviate the concerns of some potentially invaluable NSM. ${ }^{77}$ The ability to gather intelligence from within their ranks significantly reduced the time it took for 32 Battalion to act on such information. The success and efficiency of the Recce Wing soon led to it acquiring something of an elite status within 32 Battalion and it was eventually deployed for reconnaissance duties in other SADF units in addition to providing intelligence for internal operations.

\section{CONVENTIONAL OPERATIONS}

By October 1977, 32 Battalion was rapidly gaining experience in the guerrilla warfare aspects of patrolling and dominating an area but had not deployed in a conventional role since the makeshift days of Operation SAVANNAH. The availability of SADF 
officers and NCOs also continued to be a problem, to the extent that $101 \mathrm{TF}$ accused 32 Battalion of 'grapping [sic: grabbing]' two second lieutenants en route to $1 \mathrm{MA}$ at Rundu. ${ }^{78}$ Such unconventional 'recruiting' tactics not only did nothing to endear 32 Battalion to the rest of the SADF but compounded the command and control issues that already existed. Operation KROPDUIF, the assault on a Swapo base at Eheke, executed in concert with the Recces, was 32 Battalion's first attempt at conventional warfare as formal SADF troops and vividly illustrated their leadership crisis. ${ }^{79}$ Although Swapo forces were successfully engaged, the large number of casualties suffered by a casualty-shy SADF led the operation to fail. The main reason identified for the failure of Operation KROPDUIF was a lack of command and control, at all levels and at all times. ${ }^{80}$ Potentially, due to security concerns, little information about the operation was given to 32 Battalion during the planning phase. Considering that the Angolan soldiers had no formal SADF training in conventional warfare, this lack of detail seriously hampered training for Operation KROPDUIF. The Angolan soldiers were used to guerrilla patrols, and the warfare needed for this operation differed a lot. Also, close cooperation with other units, in this case, the Recces, was alien to the 32 Battalion way of war up to that point, which was waged almost exclusively at platoon level. To minimise the risk of friendly-fire casualties, it was custom for different 32 Battalion platoons on patrol to actively avoid each other's area of operations. Finally, while adhering to a given timetable was key to the success of a conventional operation such as KROPDUIF, the patrolling with which 32 Battalion was familiar was much less time-critical. These factors combined in costly fashion to highlight the inexperience of 32 Battalion in conventional operations, despite $101 \mathrm{TF}$ attempting to improve command and control by transferring soldiers from 32 Battalion to the Recces $^{81}$ and temporarily returning Recce operators, who had been part of Bravo Group, to 32 Battalion. ${ }^{82}$

Fortunately for the SADF, the men of the unit, though stunned by experiences of KROPDUIF, were not deterred from attempting future conventional operations, but were rather motivated to improve their capabilities in this regard. The minor part in Operation REINDEER, ${ }^{83}$ the controversial assault on Cassinga, provided some more conventional experience, but it was only with the arrival of Colonel Deon Ferreira as OC on 9 January 1979 that 32 Battalion became thoroughly proficient at conventional warfare. Tasked by Constand Viljoen to "strike a balance between Breytenbach, who only wanted to shoot, and Nel, who only wanted to write", Ferreira had an operational focus from the outset. ${ }^{84} \mathrm{He}$ quickly identified several problems in his new command, mainly centred around a lack of experience, training and planning. To rectify this, Ferreira initiated an intensive eight-week retraining programme as well as an evaluation of the - mostly black - permanent leader group, which had the additional effect of enhancing discipline within 32 Battalion. ${ }^{85}$ 
Regardless of whether Ferreira had an inkling of what was to come, or whether he just happened to provide the right kind of influence at 32 Battalion at the right time for the SADF, his time as OC saw an increase in their conventional deployment. It culminated in Operation TIRO-TIRO, an attack on a Fapla base at Savate in support of Unita from 17 to 24 May 1980. Drawing on experience gained from smaller deployments since Operation KROPDUIF, as well as Ferreira's influence on the morale and outlook of his troops, planning for Operation TIRO-TIRO was thorough to a fault. ${ }^{86}$ The Battalion did extensive reconnaissance and intelligence gathering beforehand that, although not flawless, was a vast improvement of the confusion during KROPDUIF. ${ }^{87}$ 32 Battalion suffered heavy casualties during Operation TIROTIRO, but this time it could not be attributed to a lack of experience, planning, training or coordination. The Unita forces that were supposed to support 32 Battalion did not live up to the expectations of the $\mathrm{SADF}^{88}$ but Ferreira was able to effectively adapt his battle plan, and effectively communicate this to his subordinates, to compensate for the Unita lack of support.

In addition to enhancing the conventional capabilities of 32 Battalion, Ferreira also introduced 'air-mobile sweep operations' or 'butterfly operations', similar to the Rhodesian 'fire-force' concept, ${ }^{89}$ that required the coordination of three or more companies and, at times, artillery support, with helicopters from the South African Air Force (SAAF). Butterfly operations took place concurrent with the normal COIN patrols. Ferreira significantly increased the command and control structures and capabilities of 32 Battalion, which in itself gave them a greater conventional capability. The soldiers' conventional combat effectiveness had increased dramatically coupled with the increased standards of training and experience gained during smaller parts in operations. At the end of Ferreira's tenure as OC at 32 Battalion, training of black leaders was a firmly established priority at the unit. Specialised courses, specifically for black platoon sergeants and section leaders, were officially acknowledged as one of the key goals that would contribute to future success, ${ }^{90}$ culminating in the commissioning of black members of 32 Battalion as some of the first black officers in the SADF.91

\section{LATE WAR}

Colonel Eddie Viljoen, who had taken over command from Ferreira in 1982, had seen the typical deployment of 32 Battalion change from patrols to deny Swapo access to southern Angola to the support of Unita against Fapla. The MPLA was giving ever greater support to Swapo, and the distinction between Fapla and PLAN combatants was becoming less clear. Pretoria also increasingly realised that it was impossible for the SADF and South West Africa Territorial Force (SWATF) to effectively patrol the whole of the Angolan/Namibian border and that they needed Unita as a buffer 
between Namibia and Fapla/PLAN. Unfortunately for the South African strategists, Unita was not able to offer effective resistance to Fapla on their own and had to rely heavily on South African support. South Africa was able to provide Unita with equipment, but international political pressure made it difficult to intervene directly on their behalf. Because the majority of the soldiers of 32 Battalion was black and spoke Portuguese, they became the natural choice when a direct intervention was deemed essential. Pretoria was better able to deny involvement when confronted with evidence of black SADF troops aiding Unita than with whites. As a result, 32 Battalion took on an increasingly conventional role and, by April 1986, Viljoen was able to assess the role of the unit in a letter to SWATF HQ as:

... die voer van ops konvensioneel sowel as TEIN in SWA en transgrens $[. .$. performing operations, conventional as well as COIN, in SWA and cross-border]. ${ }^{92}$

Major General M.J. du Plessis from the office of C Army, two brigadiers, nine colonels, two lieutenant colonels and a major met at Army HQ on 3 April 1986. ${ }^{93}$ The meeting directly resulted in the attachment of Ratel 90 and Ratel ZT3 anti-tank IFVs, Ystervark anti-air vehicles and multiple rocket launchers to the unit, in anticipation of a Fapla offensive against Unita whom South Africa would support. The unwillingness of the SADF, in 1977, to change the name of the unit from Bravo Group to 32 Battalion Group, on the grounds that the addition of the word 'group' implied the attachment of artillery, armour and other fighting elements, ${ }^{94}$ now only served to illustrate to what a great extent 32 Battalion had outstripped the role originally envisaged for them. They were the first unit to deploy the Ystervark operationally, and their ability to adapt and innovate, put to good use in developing the most effective drills to use on this type of weapon system. They were also able to suggest modifications to the system, such as the use of a different type of radio antenna, to the SADF to increase operational effectiveness ${ }^{95}$ and point out shortcomings, such as the susceptibility of South African manufactured ammunition links to stoppages. ${ }^{96}$

For the rest of the war, 32 Battalion was, in some capacity, involved in the majority of SADF operations. They had established their competence in unconventional warfare and intelligence gathering and reconnaissance early in the war and had expanded their conventional capabilities under Ferreira and Viljoen. The SADF was, therefore, able to use them, in piecemeal fashion or otherwise, to fill the myriad of gaps that the increasing intensity of the war brought about. Although the 32 Battalion of 1989 was almost unrecognisable from the Bravo Group of 1975, the spirit of camaraderie that Breytenbach initiated, and subsequent OCs had fostered, had stood the test of time. Censor reports for 1988 indicate that the vast majority of 32 Battalion soldiers had positive experiences of the morale within the unit. Notably, most of these letters would have been written by white members, resulting in a somewhat distorted image, but the consensus is undeniable (see Table 11.2). 
TABLE 11.2 Frequency of reference to morale in letters from 32 Battalion soldiers

\begin{tabular}{|l|c|c|c|c|}
\hline Month (1988) & $\begin{array}{c}\text { Total letters } \\
\text { censored }\end{array}$ & $\begin{array}{c}\text { Mention of } \\
\text { negative morale }\end{array}$ & $\begin{array}{c}\text { Mention of } \\
\text { positive morale }\end{array}$ & $\begin{array}{c}\text { Percentage } \\
\text { negative }\end{array}$ \\
\hline March $^{97}$ & 367 & 21 & 316 & $5.72 \%$ \\
\hline June $^{98}$ & 338 & 66 & 215 & $19.53 \%$ \\
\hline July $^{99}$ & 268 & 17 & 88 & $6.34 \%$ \\
\hline August $^{100}$ & 230 & 12 & 40 & $5.21 \%$ \\
\hline September $^{101}$ & 291 & 22 & 128 & $7.56 \%$ \\
\hline October $^{102}$ & 289 & 23 & 64 & $7.96 \%$ \\
\hline November & 103 & 12 & 134 & $6.06 \%$ \\
\hline Total & 198 & 173 & 985 & $8.73 \%$ \\
\hline
\end{tabular}

The unusually high percentage of negative comments about morale in the unit during June can probably be attributed to 32 Battalion's involvement in Operation PACKER, the finale of the contentious MODULAR/HOOPER/PACKER trilogy of operations around Cuito Cuanavale, ending on 30 April 1988. ${ }^{104}$ Soldiers would, therefore, have had time to reflect on the operations and the indecisive outcome would undoubtedly have galled a unit that had become used to unequivocal results, if not successes. Even taking this into account, an average of one negative comment in more than 11 letters does not seem excessive.

\section{TOWNSHIP OPERATIONS}

With the withdrawal of the SADF from Namibia in 1989, they relocated 32 Battalion to Pomfret, in the north-western part of the Cape Province. The unit's perennial leadership problem now suddenly evaporated. From very few white South Africans willing to join the unit during the Border War, the availability of white leaders now outstripped vacancies. ${ }^{105}$ It seemed that white South Africans was more willing to join a racially integrated unit, not almost continuously deployed in a combat capacity. This new influx of white officers and NCOs created some tension within the ranks of 32 Battalion, with the black soldiers loath to accept untried white newcomers and the existing leadership group also viewing them with suspicion. Internal matters such as these did not influence the operational readiness of the unit and, although the SADF planned to initially deploy them to the South African borders with Zimbabwe and Botswana, urban warfare training started soon after their arrival at Pomfret. ${ }^{106}$ The SADF rightly recognised that rural COIN operations, such as those undertaken on South Africa's borders, would be a natural continuation of the northern-Namibian COIN operations in which 32 Battalion excelled. Despite the enmity of white farmers in the area, border operations were generally successful, but on the other hand, urban deployments were a greater challenge. The SADF reasoned that the 
Portuguese speaking, Angolan soldiers of 32 Battalion would be ideal for township duty because they were black but did not share the political views of the majority of black South Africans. The men of 32 Battalion were, indeed, less politically motivated than the rest of South Africa, including the other SADF units and the SAP, and were successfully deployed - effectively as a police force - to curb unrest on many occasions between 1989 and 1992. ${ }^{107}$ During initial deployments, the SADF was at pains to establish whether 32 Battalion was effective and efficient in their new role. For the most part, the feedback was positive and seemed to underscore the SADF thinking in their deployment of 32 Battalion on township duty. The Greytown Municipality, for example, reported that:

Die meerderheid inwoners verwelkom blykbaar die teenwoordigheid van 32-Bataljon
angesien dit die enigste effektiewe manier is om die onrus in die woongebied te beheer.
My raad het geen klagtes ontvang dat die lede van 32-Bataljon nie onpartydig is in die
uitvoering van hul pligte nie [The majority of the inhabitants welcome the presence
of 32 Battalion, as it is the only effective way of controlling unrest in the area. My
council did not receive any complaints about members of 32 Battalion not being
impartial in the discharge of their duties].

But the fact that 32 Battalion was, to a large extent, used to operate by their own rules in a context somewhat isolated from society was bound to haunt them. While stationed at Buffalo, enforced discipline punished the transgressor, without limiting combat effectiveness. Corporal punishment and hard labour were key components of a 'punish and move on' mentality that was no longer suitable to a more structured, and sensitive, South African society. ${ }^{109}$ The change of disciplinary procedures led to several charges being brought against members of 32 Battalion, though very few were ever prosecuted. For the most part, South African society seemed to echo the thoughts of the Greytown inhabitants, though on occasion enquiries about the actions of 32 Battalion escalated. Understandably, South African politicians were concerned about the actions of, essentially, a foreign force within their borders and occasional ministerial enquiries were justifiable. The continued escalation of charges against members of 32 Battalion to this level, after some of the initial enquiries successfully defended, still seems excessive, though. ${ }^{110}$ It is, therefore, perhaps not a pure coincidence that the final withdrawal of 32 Battalion from township duties, and therefore from a role of useful contribution to South African society, was due to an investigation into the Phola Park incident, where charges of brutality were brought against 32 Battalion members. ${ }^{111}$ Although no criminal proceedings were initiated against them, the SADF decided to accept the advice of the Goldstone Commission, who investigated the incident and withdraw 32 Battalion from township duty. ${ }^{112}$ 


\section{CONCLUSION}

From the earliest moments of 32 Battalion, when Breytenbach started to train the FNLA troops at M'pupa, improvisation was necessary to achieve success. After Operation SAVANNAH, Breytenbach recognised that he needed a focal point for the loyalty of the men under his command. He, therefore, consciously and actively fostered a culture of loyalty towards the unit, rather than the political or military structures controlling it. Less apparent, though, was the evolution of the culture of innovation that had germinated during Operation SAVANNAH. Aided by the attitude of decentralised command prevalent within the SADF, 32 Battalion became adept at rapidly adapting to the changing nature of the Border War. In some cases, they started to address problems that the SADF had not yet recognised as such and put invaluable resources at the disposal of the SADF, such as the Recce Wing.

In addition, the unusual, from a SADF perspective, circumstances and experiences of 32 Battalion added valuable expertise to the SADF repertoire. By way of example, in July 1977, $101 \mathrm{TF}$ was able to request that WO Pep van Zyl be detached to Windhoek for 14 days to assist with the training of (presumably white) instructors for six non-white companies. With this request, $101 \mathrm{TF}$ tacitly acknowledged that 32 Battalion was the prime authority of the SADF on the "... metodiek van opleiding van swartes [... training methodology for black soldiers]". ${ }^{113} 32$ Battalion continually adapted existing and developed new ways of soldiering to increase effectiveness as a fighting force, making optimum use of the resources at their disposal. 


\section{Endnotes}

1 Piet Nortje, The Terrible Ones: A Complete History of 32 Battalion, 1-2 (Cape Town: Zebra Press, 2012).

2 Jan Breytenbach, The Tempered Sword: Forged in Battle Revisited; Operation Savannah and the Birth of 32 Bn (Sandton: Bushwarrior.com, 2011) [e-book].

3 Cf. Louis Bothma, Die Buffel Struikel: 'n Storie van 32 Bataljon en sy mense (Bloemfontein: Handisa Media, 2006); Marius Scheepers, Striking Inside Angola with 32 Battalion (Solihull, England: Helion and Company, 2012); Jan Breytenbach, The Buffalo Soldiers: The Story of South Africa's 32-Battalion 1975-1993 (Alberton: Galago Books, 2002); Justin Taylor, A Whisper in the Reeds: 'The Terrible Ones': South Africa's 32 Battalion at War (Solihull, England: Helion and Company, 2013).

4 As quoted by FJ. du Toit Spies, Die Angolese Burgeroorlog, 1975-1976, 12 (Pretoria: Militêre Informasieburo, n.d.), 187.

5 Breytenbach (2011), 22-24.

6 Department of Defence Archives (hereafter DOD Archives): 32 Battalion (32 Bn), box 14, file G/OPS 3/3, 1, Focus Aanhangsel B by Operasionele Instruksie No 1/75, 1975.

$7 \quad$ Nortje $(2011,1), 49$.

8 Sometimes written "Odinda Odinda".

9 DOD Archives: Hoof van Staf Operasies (HS Ops), Gp [Group] 1, box 9, file $\mathrm{HS} / 1 / 3 / 14$, 1, Waardering oor die moontlike gebruik/aanwending van Chipenda/ FNLA tot voordeel van RSA.

10 Spies (n.d., 1), 296.

11 Spies (n.d., 1), 299.

12 Nortje $(2011,1), 60$.

13 Spies (n.d., 1), 312.

14 Breytenbach (2011), 16-17.

15 Spies (n.d., 1), 315.

16 Cf. Breytenbach (2011); Breytenbach (1993).

17 Spies (n.d., 1), 317.

18 Cf. Breytenbach (2011); Breytenbach (1993).

19 Nortje $(2011,1), 71$.

20 Breytenbach (2011), 41.

21 Spies (n.d., 1), 316.

22 Cf. Breytenbach (2011), 27-37; Nortje (2011, 1), 68-72.

23 Nortje $(2011,1), 78-79$.

24 Breytenbach (2011), 215-223.

25 Breytenbach (2011), 66-68.

26 Breytenbach (2011), 35.

27 Nortje $(2011,1), 87$.

28 DOD Archives: 1 Militêre Gebied (1MG), box 82, file G/Ops/3/3/Bravo 1, Bravo, Message 004/222/0830 From 1 MA to 101 TF, n.d.

29 Nortje $(2011,1), 71$.

30 Nortje $(2011,1), 77$.

31 Breytenbach (1993), 40. 
Breytenbach as quoted by Spies (n.d., 1), 317.

As quoted by Spies (n.d., 1), 317.

Leopold Scholtz, Die SAW in die Grensoorlog 1966-1989 (Cape Town:Tafelberg, 2013), 19.

Nortje $(2011,1), 127-128$.

Breytenbach (2011), 240-241.

Nortje $(2011,1), 144-153$.

DOD Archives: 32 Bn, box 9, file Log/Ops/3/16/13/4, Portugese/Angolese, Indiensneming: Portugese.

DOD Archives: 32 Bn, box 8, file G/INT/5/1 Inligting Samevatting, 'Insam 20/76, 250600B-010600B, 28', October 1976.

DOD Archives: 32 Bn, box 8, file G/INT/5/1 Inligting Samevatting, 'Onderhoud met Raphael Shoopala alias Lucky'.

DOD Archives: HS DG Ops, H Leër D Ops, box 19, file G/Ops/3/3, 2HLM, EVAL/315 'Hoër In, Signal from HIS to HSAW (Suidwes-Afrika Hoofkwartier Operasies (SWA HK (Ops), December 1975.

Nortje $(2011,1), 155$.

Spies (n.d., 2), 554.

Nortje $(2011,1), 155$.

Spies (n.d., 2), 932.

Nortje $(2011,1), 159$.

DOD Archives:, 1 MG, box 82, file G/Ops/3/3/Bravo, 1, Bravo Message 022/106/1230 From 1 MA to 101 TF, n.d.

Nortje $(2011,1), 161$.

DOD Archives: 32 Bn, box 14, file G/Ops/3/3, 1, Budgie - B Group Salarisskaal: B Groep, n.d.

DOD Archives: 32 Bn, box 7, file G/Ops/3/3/Letta, 1, Signal Ops/555 Deel drie van drie, August 1976.

Breytenbach (2011), 279.

DOD Archives: 32 Bn, box 7, 1, file G/Ops/3/3 Letta, Bravo Group Higher in Sitrep from 101 TF to C Army.

DOD Archives: 32 Bn, box 8, file G/INT/3/2, Inrap 518/76 from 101 TF to C Army, November 1976.

Anonymous 32 Battalion dependant, interviewed by Will Gordon, Centurion, 17 March 2019.

DOD Archives: 1 MG Sektor 20, box 78, file 302/6/C63, 1, Projek Carpenter Letter from GC SWA Cmdt to C Army, 13 June 1979.

Breytenbach (2011), 279-289.

DOD Archives: 32 Bn, box 14, file G/Ops/3/3, Bevelsdirektiewe Bevelsdirektief 15/76 Ops 34, n.d.

Nortje $(2011,1), 168-169$.

Nortje $(2011,1), 166-168$.

Nortje (2011, 1), 169-171.

DOD Archives: 32 Bn, box 14, file G/Ops/3/3, 1, Budgie - B Group, Points submitted for discussion at OC's Conference, n.d. 
Nortje (2011, 1), 170.

DOD Archives: 32 Bn, box 14, file G/Ops/3/3, 1, Budgie - B Group, Higher Inrep from 101 TF to C Army, n.d.

Nortje (2011, 1), 253.

DOD Archives: 32 Bn, box 41, file 309/1/51, Savannah, 1, Lesse geleer gedurende Op Savannah, n.d.

Cf. Chapter on 'Conventional Operations', 7.

DOD Archives: 32 Bn, box 7, file G/Ops/3/3, 1, Konferensies 'Voorvereiste vir die veiligheid van die staat, n.d.

Nortje (2011, 1), 274.

Nortje $(2011,1), 274-275$.

Nortje $(2011,1), 275-276$.

DOD Archives: 32 Bn, box 7, file G/OPS/3/3, 1 Konferensies, Opvolging van punte bespreek op Bev Konf te 101 TM HK, 16 February 1977.

DOD Archives: 32 Bn, box 7, file G/Ops/3/3, 1 Konferensies, Notule van Bevelvoerderskonferensie gehou te 2 MG HK Oshakati om 10h30, 12 March 1977.

DOD Archives: 32 Bn, box 7, file G/Ops/3/3, 1 Konferensies, Inligtingsinstruksie 4/76 'Insameling van informasie en inligting', n.d.

DOD Archives: 32 Bn, box 7, file G/Ops/3/3, 1 Konferensies, Inligtingsinstruksie 4/76 'Die beginsels van inligting', n.d.

Nortje $(2011,1), 332-333$.

Nortje $(2011,1), 335-340$.

Nortje $(2011,1), 380$.

DOD Archives: SWA HK (Ops), box 7, file 309/1, 1, 32 Bn, Signal from HQ 101 TF to $1 \mathrm{MA} / 32 \mathrm{Bn}, \mathrm{Q} / \mathrm{Ops} / 151$, July 1977.

Cf. Nortje $(2011,1), 302-321$.

Nortje $(2011,1), 304$.

DOD Archives: SWA HK (Ops), box 7, file 309/1, 1, 32 Bn, Signal from 32 Bn to 101TF, Q/OPS/428, September 1977.

Ibid. 'Signal from $101 \mathrm{TF}$ to $2 \mathrm{MA}, \mathrm{Q} / \mathrm{OPS} / 457$ ', August 1977.

Cf. Nortje (2011, 1), 355-359.

Nortje $(2011,1), 377$.

Nortje $(2011,1), 386$.

Cf. Nortje (2011, 1), 493-502.

Nortje (2011, 1), 497-502.

Nortje $(2011,1), 531$.

Nortje (2011, 1), 557.

DOD Archives: 32 Bn, Gp 2, box 260, file 522/1, 1 Konferensies, Kongresse, Seminare, Simposiums en Vergaderings / Konferensie 'Aanhangsel B by 32BN/522/1', February 1982.

91 Anonymous 32 Battalion soldier, interviewed by Will Gordon, Pretoria, 14 December 2018.

2 DOD Archives: SWS 3, box 52, file 309/1, 1, 'TD Plan ter Onts van 32 Bn', 29 April 1986. 
93 DOD Archives: SWS 3, box 52, file 309/1, 1, 'Notule van 'n vergadering gehou by Leër HK (D Ops) 0310H30 mbt 32 Bn’, April 1986.

94 DOD Archives: SWA HK (Ops), box 7, file 309/1, 1, 32 Bn 'Signal from 101 TF to SSO Ops 32 Bn, OPS/364', June 77.

95 DOD Archives: SWS 3, box 52, file 309/1, 1 'Signal from 32 Bn to C Army and SWATF, Ops/327/29', May 1986.

96 Ibid.

97 DOD Archives: SWA HK GM OATI), box 105, file SEK/202/02732, 1, DTI, Censor Report 01/03/88 to 31/03/88 (Suidwes Afrika Gebiedsmag Hoofkwartier Onderafdeling Teeninligting), March 1988.

98 DOD Archives: SWA HK GM OATI), box 105, file SEK/202/02732, 1, DTI, Censor Report 01/03/88 to 31/03/88 (Suidwes Afrika Gebiedsmag Hoofkwartier Onderafdeling Teeninligting), May/June 1988.

DOD Archives: SWA HK GM OATI), box 105, file SEK/202/02732, 1, DTI, Censor Report 01/03/88 to 31/03/88 (Suidwes Afrika Gebiedsmag Hoofkwartier Onderafdeling Teeninligting), July 1988.

100 DOD Archives: SWA HK GM OATI), box 105, file SEK/202/02732, 1, DTI, Censor Report 01/03/88 to 31/03/88 (Suidwes Afrika Gebiedsmag Hoofkwartier Onderafdeling Teeninligting), June/July 1988.

101 DOD Archives: SWA HK GM OATI), box 105, file SEK/202/02732, 1, DTI, Censor Report 01/03/88 to 31/03/88 (Suidwes Afrika Gebiedsmag Hoofkwartier Onderafdeling Teeninligting), September 1988.

102 DOD Archives: SWA HK GM OATI), box 105, file SEK/202/02732, 1, DTI, Censor Report 01/03/88 to 31/03/88 (Suidwes Afrika Gebiedsmag Hoofkwartier Onderafdeling Teeninligting), October 1988.

103 DOD Archives: SWA HK GM OATI), box 105, file SEK/202/02732, 1, DTI, Censor Report 01/03/88 to 31/03/88 (Suidwes Afrika Gebiedsmag Hoofkwartier Onderafdeling Teeninligting), November 1988.

104 Nortje $(2011,2), 1049$.

105 Nortje (2011, 2), 1120.

106 Nortje $(2011,2), 1112$.

107 Cf. Nortje $(2011,2), 1116-1161$.

108 DOD Archives: 32 Bn, Gp 3, box 54, file 309/1 Spesifieke Operasies, Letter 'From Greytown Town Clerk to Maj Fourie, n.d.

109 Anonymous (2019).

110 DOD Archives: 32 Bn, Gp 3, box 160, file 509/1, 2 Ministeriële Navrae m.b.t. personeelaangeleenthede, Enquiry: shooting incident and alleged harassment: members $32 \mathrm{Bn}$, n.d.

111 Nortje $(2011,2), 1149-1154$.

112 Nortje (2011, 2), 1156.

113 DOD Archives: SWA HK (Ops), box 7, file 309/1, 1, 32 Bn, Signal from 101 TF to 32 Bn, Q/Ops/356, July 1977. 



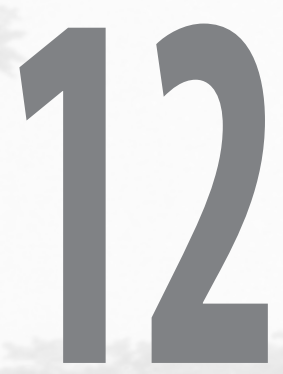

\section{SAWI! LEISURE, COMFORTS AND MILITARY CANTEENS IN THE SADF}

Ian van der Waag 
Soldiers get up to all kinds of mischief. Whether on a campaign or in the barracks, there are accusations of alleged looting and scrounging, of illicit sexual encounters, and even murder. Leisure-time programmes are now designed to keep young men, adventurous and emboldened by a sense of power endowed by the profession of arms, in camp and under military discipline. For millennia, the physical and emotional well-being of the soldier was no specific organisation's official concern. Loot and plunder all too often supplemented inadequate or non-existent rations, while soldiers also fell victim to traders - the sutlers immortalised by Bertolt Brecht in Mother Courage - who followed armies and adjusted prices according to the intensity of the campaign and the temperature of battle. Things changed gradually. Regular pay and embryonic medical and chaplain services were instituted in most European armies from the Thirty Years War, although the improvement of living conditions for soldiers and the provision of comforts, refreshments and small luxuries - to supplement those sparse and mediocre rations - would wait at least another two hundred years. The canteen organisations created during the latter half of the nineteenth century were dependent on the goodwill of senior officers and the raising of public awareness. Their chequered history in the British Army continued until 1900, when Lord Roberts, the British Commander-in-Chief in South Africa during the Second Anglo-Boer War, established the South African Garrison Institute (SAGI) as a unified canteen facility to offer goods and services at reasonable prices to Imperial troops on campaign in South Africa. The Union Defence Force Institute (UDFI) and the South African Defence Force Institute (SADFI) (Afrikaans: Suid-Afrikaanse Weermaginstituut - SAWI) were direct successors to SAGI and aspired from 1916 to continue this tradition in service of the South African armed forces. ${ }^{1}$

The British canteens have been the focus of ongoing work, often by men and women long associated with SAGI and the Navy Army Air Force Institute (NAAFI) of the British armed forces. Sir John Fortescue, historian of the British Army and Royal Librarian at Windsor, wrote the first history of the British canteens. He approached this from the early sutlers through to the reforms, undertaken by his brother, that led to the creation of the Canteen and Mess Society and its successors, SAGI (1900) and NAAFI (1921). Fortescue's book, published in 1928, was followed by several publications at different intervals during the twentieth century. ${ }^{2}$ Much less has been done in terms of the canteens in the South African armed forces. ${ }^{3}$ Fransjohan Pretorius analysed the questions of supply and leisure within the Boer Commandos during the Second Anglo-Boer War ${ }^{4}$ and James Bourhill has done the same for the 6th South African Armour Division in Italy during the Second World War. ${ }^{5}$ Neil Roos, working on the same period, reasoned that leisure, sex and the social control of white South African volunteers was a critical concern of the defence authorities in 
Pretoria, highlighting the close relationship between recreation, canteen and military discipline. ${ }^{6}$ The entertainment units of the Second World War have been the separate focus of two journal articles and an MA thesis. ${ }^{7}$ However, despite the wealth of archival material on funds and institutions related to the SADF, there has been little, deeper-level historical analysis of these issues. This chapter seeks to fill something of the historiographic gap, by analysing the role and function of SAWI - known better by the Afrikaans acronym - and examining the measures taken to provide canteen and shopping facilities and leisure activities to South African troops and military families during the Border War era.

\section{MILITARY EFFICIENCY, THE 'TROEPIE' AND SOCIAL CONTROL}

The watchword in all armed forces is military effectiveness. ${ }^{8}$ This refers to the combat readiness of the soldier individually and within the organisation as a whole. Anything that compromises that effectiveness is combatted through regulation and the application of firm military discipline. Nevertheless, soldiers historically have presented their commanders with a complexity of problems. Military service - and conscription, introduced in South Africa in 1967 - served as a rite of passage into adulthood. It brought freedom from the parental home, uncertainty but the promise of hardship, and initiation into the military as experienced by older relatives and friends. Geographical remoteness and social isolation introduced an unnatural environment, with often empty hours. The SADF organised leisure activities, laid on sporting equipment and games, and supplemented rations in a variety of ways.

There has been very little historical analysis on leisure and consumption in the South African armed forces; with the regimental histories tending to follow the battle and emphasising camaraderie and deeds of valour. ${ }^{9}$ There are a small, but growing number of references in the recent Border War memoirs, which can be supplemented by the vast archives generated by the SADF on institutions and funds, canteens, and sport. The SADF faced several unfavourable factors on 'The Border'. A low ratio of force to space facilitated breakthroughs in the battlespace but imposed severe logistical problems, made worse by the climate and the nature of the terrain. Large river systems and flooding in the semi-arid south of Angola during the rainy season (February to April) combined with the poverty of the country, fewer bridges and roads, more unpaved tracks, and less cleared growth and thicker vegetation, exacerbated these supply difficulties. ${ }^{10}$ Food was a factor, the bush of the war zone offered little, and all requirements had to be brought forward by the SADF.

Notwithstanding, complaints - about the quantity, quality and lack of variety of food - regularly feature in the writings of soldiers. Food, Richard Holmes argues, has a marked effect on a soldier's performance, shortages doing 'more than merely make 
men hungry, dispirited and increasingly ineffective'. ${ }^{11}$ However, battle rations could be improved and varied and might include chocolates and cigarettes, and supplies and small luxuries might also be bought from a SAWI whenever one was in the area.

But canteens play other roles too. Healthy young men, removed from the normal female company and home surroundings, are housed in a barracks environment. Whether in training camps or combat zones, they are often limited to female contact that may verge on promiscuity if not professional prostitution. This comes as no surprise. Throughout the history of armed forces, sexual liaisons, ranging from romantic passion to cold commerce, was widespread and entailed rapture and abuse on both sides of the gender divide. Casual sex and prostitution, and corresponding bouts of sexually transmitted diseases, flourish during times of conflict, when sexual behaviour is freer and pleasure-seeking and intemperance is fostered by the horror of war and notions, often very real, about the brevity of life. The rate of admission for venereal diseases in the Dominion armies during the First World War was 24 per thousand troops in France and 32 per thousand in Egypt. ${ }^{12}$ The Second World War presented similar statistics, but in Korea, the South African rate per thousand shot up to 130 per thousand in March 1953. ${ }^{13}$ Regular medical inspection of personnel; lectures on STDs and preventative measures; the running of prophylactic centres (the 'Blue Light Depots'); and abundant well-organised sporting and recreational facilities, all removed from the influences of local towns, formed part of the military solution. Primarily, it remains a hidden history, "an aspect perhaps best forgotten", and no statistics are presently available for the SADF troops during the Border War.

The South African involvement in the broader war for Southern Africa lasted from 1966 to 1989 . It would be naive to presume that the near half-million young men conscripted from 1967, as well as the older Permanent Force personnel of the SADF, had no sexual contact over this 23-year period along a "Border" that was geographically, logistically, and psychologically a long way from home. ${ }^{14}$ The recent writings of former National Servicemen sometimes reveal sordid tales: of alleged rapes, ${ }^{15}$ group sex, ${ }^{16}$ and heavy drinking, ${ }^{17}$ the feeding of prostitution, and the circulation of Scope, a soft-porn magazine, ${ }^{18}$ and screening of 'blue movies' ${ }^{19}$ Some units were more affected than others. A National Service Medical Officer records that nearly all the soldiers of 32 Battalion had a venereal disease: "...the gonococcus has found a home here in Ovamboland, the chaos of war offering the perfect environment." 20 This "Border", and military service more generally, was a rite of passage into manhood. Rituals might involve the consumption of alcohol and drugs, exposure to pornographic material, and perhaps sexual behaviour and even violence that would be frowned upon or deemed unacceptable at home. The need to contain and control the troops, and so minimise any mischief, perhaps particularly on the part of young National Servicemen, enjoyed paramount importance. The SADF mitigated the isolation of the Border and the boredom of base life in various ways. 
They provided sporting equipment, distributed games, dug swimming pools, built tennis courts, revitalised 'rat packs', and opened shops and canteens on military bases and in military towns. Soldiers were thereby encouraged to spend leisure time within unit lines, removed from the allure of neighbouring suburbs and towns, and remained safely under military discipline. SAWI was the primary organisation that managed these shops and canteens, ran the mobile canteens in the operational area, and, from the proceeds of the business so conducted, sponsored the building and maintenance of recreational facilities.

\section{PUTTING THE RIGHT FOOT FORWARD: STRUCTURE, MANAGEMENT}

SAWI has had something of a chequered history. Starting as the UDFI in 1916 it performed this task, for the most, quite adequately, supplying members of the Union Defence Force (UDF) with canteen facilities in South West Africa (SWA) during the First World War and then serving South African and Allied servicemen and women in no fewer than five theatres during the Second World War. Fragmentation of the business within South Africa during the interwar years led to the emergence of local institutes, in the form of the Pretoria Garrison Institute, the Cape Peninsula Garrison Institute, and the Algoa Bay Garrison Institute, until re-amalgamation and a name change in 1957 to SADFI.

The organisation underwent far-reaching changes from 1916, changing from a mainly civilian organisation into a military unit. However, poor management and a lack of business acumen led to an extremely pitiable public image. Several inquiries into the affairs of the Institute followed - in December 1939, September 1952, and February 1961 - and, on each occasion, insufficient remedial action compounded matters. The Institute was at times charged with the abuse of its credit system, condemned as a social evil, and for making victims of the military families buying goods on credit. Customers accused the Institute of inflating prices to cover losses, maintaining an inadequate stock, having an officer-preferential policy and delivering a generally poor, often-grudging service. As a result, many members of the UDF who could afford to take their custom elsewhere did so. Opinion gauged during the inquiries (perhaps at best a perception within only a small portion of the military community) was that the Institute no longer justified its existence as it no longer fulfilled the function of supplying the soldier cheaply and expeditiously. Such negative threads were not continuous or ubiquitous, and the Institute cannot be judged solely from the 'negative overload' in the archival 'residue' of the Institute, which was of course the result of SADFI's specific documentary process. It is also true that few businesses would have survived the vicissitudes of the five decades preceding 1968 when the SADF took the Institute out of the purely business arena. 
However, this is only part of a complex story. The 1952 board of inquiry found that the convenience of a nearby shop for married members of the UDF living on military bases where they could not obtain necessities at reasonable prices justified the continued existence of the Institute. During the implementation of several changes and an improvement in the finances of the organisation, the Institute remained burdened with the most significant problem which had been haunting it since 1916. It was the fact that the Institute remained an attempt to run a civilian shopping organisation inside the SADF for members of the SADF. In 1968, the General Staff decided to take the whole structure out of the purely business arena and adapt it to suit the military environment. South Africa was slowly being drawn into a war on her borders and, as a result thereof, the Institute's activities were re-evaluated with a view towards the growing need for an effective field canteen system. This involved a shift on the part of SADFI from retail trade to operational trade.

Massive changes followed in 1968, the year of the first National Service intake. Brigadier Larry Hopkins was appointed as general manager, with a new Permanent Force management team to run the Institute, under the overall control of the Quartermaster General. ${ }^{21}$ In peacetime, SADFI, confined to the Republic of South Africa, was divided into two regions for effective control: the Cape and the Transvaal. For the first time in the history of the Institute, the managers formed a management team, and the different branches were run as one organisation. Militarisation brought about an immediate re-assessment and a reorientation of attitude by many senior officers. Hopkins's appointment gave SADFI new status and authority both within the Defence Force and in negotiations with trading associates. SADFI now was no ordinary trading concern, but an integral and vitally important part of the SADF, promising enormous benefits if adequately supported..$^{22}$ "For the first time", according to Brigadier Brian Slater, who would succeed Hopkins in 1976, "the soldier felt that the soldier was controlling SADFI to the benefit of the soldier". ${ }^{23}$ Militarisation brought other benefits. The entry of a large number of civilians and delivery vehicles to units and military bases was averted. All problems regarding institutions and funds, such as the non-payment of accounts, could be settled within the organisation so as not to tarnish the image of the SADF. And, with time, SADFI established itself as the sole supplier of all commodities required by units. It not only introduced uniform prices but saved the individual institutions money and manpower. By the end of the 1970s, the Institute had established a productive Citizen Force element able to supply canteen services at isolated places at short notice.

The condition of SADFI improved dramatically after 1968. Between June and November 1968, the Institute achieved an overall price reduction of approximately $17.5 \%$ throughout the Transvaal, with smaller reductions in the Cape. 'Sticking stocks' were disposed of in the Transvaal and replaced by a wider variety and a greater range of new stocks at competitive prices. Customer support increased by more than $60 \%$ 
between August and November 1968 and soon adverse criticism was almost entirely restricted to factors arising from the struggle to offer a modern shopping service in obsolete shops and stores. Relationships with military units also improved given a growing understanding of and increasing support for the new SADFI based on the NAAFI model. While the Institute could not meet all unit requirements at better prices than elsewhere, the average prices level per unit was unquestionably lower. Army units as far afield as Kimberley, Bloemfontein, Potchefstroom, Middelburg and Nigel began to purchase many of their requirements from SADFI Voortrekkerhoogte voluntarily. ${ }^{24}$ The trading accounts for the six months ending on 31 August 1968 reflected, for the first time in two years, a small profit in the Transval. With growing support and increasing turnover, the Institute rehabilitated to such an extent that the Director General of General Administration could report to the Defence Staff Council: "There is no way in which a meaningful comparison can be made between the disreputable and bankrupt SADFI of early 1968 and new SADFI." ${ }^{25}$ As activities of SADFI expanded, and beyond official expectation, Hopkins held the hope that SADFI might develop as NAAFI of the SADF and that all unit institutions would become SADFI outlets. ${ }^{26}$

SADFI, as an enterprise, achieved some stability by 1974. Surplus assets, excluding buildings and major equipment, exceeded R650000 and was invested in stock that realised an average turnover of R500 000 per month. Although sufficient for wholesale buying, this fell far short of the amount needed to finance long-term development programmes essential for future growth. The reversal of inherited debt, the reduction of loans, and the financing of growth of about 475\% between 1968 and 1974 largely absorbed trading profits. The financial problem, compounded by the late payment of credit sales, in April 1974 caused the Chief of the SA Defence Force to instruct all formations, units and sections to pay their SADFI accounts within 30 days. Furthermore, and much to Hopkins's indignation, the assets of the SADFI Trust Fund, that would have settled all outstanding loans, were instead spent on a residence for the commanding officer of SWA Command. ${ }^{27}$ The lack of trading capital was certainly slowing growth..$^{28}$

Hopkins won other battles. On one front were the shops and canteens run by individual units for their benefit. They represented a motley crew, and no real improvement had taken place since the introduction of National Service. The reasons for this were equally multifarious: some unit commanders showed little interest and gave little direction and guidance, others did not have the time to set aside for the unit shop, and all battled with small ranges and erratic supply. Importantly, these unit shops did not keep pace with the needs of large numbers of National Servicemen. ${ }^{29}$ As a result, SADFI became the preferred wholesaler, and all units were instructed to purchase all goods and services from the Institute. In August 1973, Admiral Hugo Biermann, the Chief of the SA Defence Force, decided that all institutions, sports clubs and funds 
do likewise. Biermann accepted the position that SADFI would not always be able to quote the lowest price but would be the lowest most of the time. Moreover, whereas civilian suppliers were in business for profit, SADFI was an integral part of the SADF, ploughing back profits to improve and extend services for the benefit of military units and members of the SADF and their families. ${ }^{30}$ Notwithstanding, he and Magnus Malan, then Chief of the Army, and others believed that the Institute ought to obtain support through persuasion rather than compulsion. ${ }^{31}$ In this, they were seemingly proved correct. Units, at first somewhat cautiously, later wholehearted gave support to SADFI. ${ }^{32}$

Hopkins consolidated matters before his retirement. A difficult process, he had listed several 'demands for continued service' in a letter to the Chief of the SA Defence Force. It resulted in the provision of additional trading capital and the review of the management and control structure. As general manager of SADFI, Hopkins now also became Director of Institutions on the Quartermaster General's staff, while an assistant general manager was appointed and additional Permanent Force personnel were allotted to the Institute. ${ }^{33}$ Liaison between the general manager and senior representatives of the Arms of Service became more effective and more frequent following the disbandment of the old SADFI Board of Control and the creation of a liaison committee comprising representatives from all of the Services. ${ }^{34}$ Trading restrictions were relaxed to allow unit shops to supply all of the needs of National Servicemen confined to their respective military areas and lacking the freedom to buy from the shops in town during business hours. ${ }^{35}$ These steps enhanced the status of SADFI and SADFI interests, and vastly improved the service given by direct SADFI outlets as well as unit shops. They also confirmed the important place the shopping facilities and field services of SADFI had assumed in the SADF ${ }^{36}$ These functions the larger shopping facilities and the mobile field service - will be dealt with in turn.

SHOPPING FACILITIES:

\section{MILITARY TOWNS, GARRISONS, UNITS}

By 1974, growth had taken place at such a rate that reference in policy to 'branches' of SADFI had become mostly meaningless. ${ }^{37}$ SADFI was initially permitted to provide services where it had a shop or a 'branch'. However, in preparation for possible wartime mobilisation and in compliance with the direction to "provide a service to units and troops under arms anywhere within or outside the Republic wherever they may be', SADFI developed a network of approved suppliers throughout South Africa. With this, the Institute met the needs of units it could not, for practical reasons, serve directly. These 'approved suppliers' became SADFI 'branches'. ${ }^{38}$

At first, SADFI mainly restricted attention to the Transvaal. This region and Pretoria, in particular, had been identified as the most profitable point for growth after 1968 . 
In fact, during the 'rescue years', the management, facing the genuine possibility of liquidation, had little choice. Having to convince higher authorities that the position of SADFI was redeemable and that the Institute was capable to make a profit, ${ }^{39}$ Hopkins focused on the only region capable of rapid growth. "Nothing", he noted, "was expected from the Cape other than they keep their heads above the water." 40 However, once he consolidated the Institute's position and the Transvaal had enjoyed the incredible growth of 1973/74, the growing demand for SADFI services elsewhere could not be satisfied. The most significant problem facing the Cape business was the dispersion of the few training bases for National Servicemen situated in the Cape province, the largest element being the Navy - the smallest of the Services - and Naval Headquarters moved from Simon's Town up to Pretoria in 1977.41 Although the situation improved to a limited extent with the opening of the Da Gama Park branch and the expansion of the shop and area depot at Wynberg, there was no military complex in the Cape comparable to Voortrekkerhoogte. Growth was, therefore, much more expensive and contained the prospect of far smaller returns. Distance complicated advertising, limited personal client contact, and delayed the delivery of goods. ${ }^{42}$ The Cape regional manager, a civilian until 1972, seemingly added to the difficulties. ${ }^{43}$ The Cape repeatedly yielded to the needs of Pretoria, the seat of Defence Headquarters since the establishment of the Union Defence Force in 1912, and the hub of all SADF activity. The Institute's growth in the Transvaal was therefore not replicated in the south.

By the end of the 1970s, business was slowing down across the country. Supermarkets, just getting off the ground when the SADFI militarised in 1968, were new competition and SADFI was not 'supermarket' orientated. The buildings were not conducive to modern trading and most of its shops were corner cafés, that traditionally only had to compete with corner cafés. The task of repositioning SADFI in terms of buildings and infrastructure and client base mostly fell to Brigadier Brian Slater, who succeeded Hopkins in August 1976. He implemented two critical measures. The first was the decision taken in 1978 to create facilities that were modern and offered an engaging shopping experience. Secondly, steps were taken to make SADFI more competitive in terms of price. ${ }^{44}$

The physical infrastructure remained a problem. The Institute had no property rights to any of their buildings, owned or hired, all of which had been erected on state property. Alterations or renovations led to growing debt to the UDFI Trust Fund, ${ }^{45}$ while the Institute remained hesitant to invest in accommodation it did not own. ${ }^{46}$ Most of the premises where SADFI conducted business were ineffective or inadequate to carry on modern business. ${ }^{47}$ Although SADFI, over the previous ten years, procured more than $50 \%$ of the buildings occupied by the Institute in 1954, these buildings were already old and, in some cases, dilapidated on the date of acquisition (Table 12.1). 
Ten of the twenty-eight buildings occupied by the Institute in that year were of wood, or wood and iron construction. ${ }^{48}$ The Wynberg shop, for example, was housed in an old timber and iron bungalow taken over from the Imperial Government in 1921 and, back in August 1930, had been condemned as rodent-infested.

Notwithstanding, converted to a general dealer's store, it was still in a fair state of repair in 1944 despite bad light, insufficient ventilation and inadequate storage. ${ }^{49}$ The position was similar elsewhere. The wood and iron building used as the Voortrekkerhoogte dairy, also gifted by the Imperial Government in 1921, had been condemned by the Surgeon General in $1957 . .^{50}$

TABLE 12.1 Classification of UDFI premises according to the year of construction and the year of occupation by the Institute

\begin{tabular}{|l|c|c|c|c|c|}
\hline Year & Pre-1925 & $1925-34$ & $1935-44$ & $1945-54$ & unknown \\
\hline Construction & 8 & 6 & 5 & 2 & 5 \\
\hline Occupation & 2 & 7 & 3 & 14 & - \\
\hline
\end{tabular}

Successive inquiries into the Institute's affairs raised the issue of the state of the buildings. In 1961, the Peat, Marwick and Mitchell team found that the "premises [were] poorly planned, dull in appearance and in a bad state of repair". ${ }^{51}$ Five years later, the Groenewald Investigation recommended that immediate steps be taken to provide suitable premises and services at state cost. ${ }^{52}$ Renovations were a matter of urgency, and there had been some positive developments. In May 1966, for example, SADFI entered an agreement with Mobil Oil Southern Africa to build a modern service centre and shopping centre at Voortrekkerhoogte. ${ }^{53}$ The first petrol was sold on 29 July $1968 .{ }^{54}$ Four new branches were added to the existing ten between 1968 and 1975 , although, in all four cases, existing buildings and temporary accommodation had to be used (Table 12.2). The recommendations made by Hopkins regarding new developments in Voortrekkerhoogte, to cater for the growing residential complexes and the first National Service intake, received a mixed reception. ${ }^{55}$ Reduced liquidity delayed renovations and new constructions. The Institute had to stabilise its finances and repay loans before they could undertake major development.

TABLE 12.2 New SADFI branches, 1968-1975

\begin{tabular}{|l|l|l|}
\hline Branch & Date opened & Form of accommodation \\
\hline Eersterivier & 20 Mar 1970 & Converted bungalow at 2 SACC Bn \\
\hline Da Gama Park & 01 Oct 1972 & Converted bungalow \\
\hline Grootfontein & 1974 (exact unknown) & Tent \\
\hline Naval Dockyard Simon's Town & 01 Aug 1975 & Old NAAFI canteen \\
\hline
\end{tabular}

A reassessment of SADFI policy came in 1974, including guidelines for expansion. SADFI may not have had the capital, but expansion could also not take place at the cost of other priority projects in the SADF. New branches had to be limited to places 
where the private sector could not provide a service. And, as far as deployability and expansibility went, the family shopping service had to be on such a scale and manner that the organisation, trade experience and contracts could be extended to ensure that SADFI was able to deliver an effective shopping service to troops in the field after mobilisation..$^{56}$ Growing insecurity on the northern borders and the impending deployment of troops proved to be a lifeline.

An expansion programme was planned to meet increasing demands. SADFI erected a new, modern supermarket in 1974 at Langebaan Road at the cost of R167000; the project had been in the pipeline for almost ten years. The new dairy and warehouse complex for Voortrekkerhoogte, requested in 1967 and delayed due to site problems, was completed in September $1975 .{ }^{57}$ The unit canteen at SAS Saldanha was taken over in 1975. They upgraded and extended other facilities and introduced a milk service from Voortrekkerhoogte to canteens and families in units deployed in the north-eastern Transvaal. SADFI opened a new café or restaurant in Voortrekkerhoogte in October 1975 and constructed similar facilities in the Naval Dockyard, Simon's Town. They modernised the family shop at Dunottar and erected a new shop and warehouse at Grootfontein. This period, on the other hand, also saw the closure, after five consecutive years of losses, of the family shop at Port Elizabeth. ${ }^{58}$ Rapid expansion marked the thirteen years after 1975. SADFI established no less than 31 branches. The number of branches doubled between 1983 and 1989. Predictably, most of the growth took place in the Transvaal and SWA (Table 12.3).

TABLE 12.3 Geographical location and date of opening of SADFI branches, 1968-1989

\begin{tabular}{|l|c|c|c|c|c|c|}
\hline Date & Transvaal & Orange Free State & Cape & South West Africa & Totals & $\%$ \\
\hline Pre-1968 & 4 & - & 6 & - & 10 & 19.6 \\
\hline $1969-1975$ & - & - & 3 & 1 & 4 & 7.8 \\
\hline $1976-1982$ & 8 & - & - & 1 & 9 & 17.7 \\
\hline $1983-1989$ & 12 & - & 3 & 7 & 22 & 43.1 \\
\hline Unknown & 2 & 2 & 2 & - & 6 & 11.8 \\
\hline Totals & 26 & 2 & 14 & 9 & 51 & 100 \\
\hline$\%$ & 51 & 3.9 & 27.5 & 17.6 & 100 & - \\
\hline
\end{tabular}

The Northern Transvaal area, particularly, experienced much growth. In 1984, a canteen in the Liberty Life Building, in Vermeulen Street, Pretoria was opened, ${ }^{59}$ and this service to the 'soldier in the office' was extended to the Hallmark Building on 5 April $1988 .{ }^{60}$ A new shop, far larger than the existing facility, was opened at Potchefstroom on 8 April 1986. ${ }^{61}$ Given this tremendous growth, the Northern Transvaal area was divided with effect from 1 July 1988 with the appointment of a Captain Jooste as area manager of the new Far Northern Transvaal Area. ${ }^{62}$ The enterprise in SWA (Namibia) commenced in 1974 with two mobile canteens and a small shop initially housed in a tent at Grootfontein. By 1989, there were no fewer than nine branches in the territory, excluding several depots and lesser facilities. 
The Windhoek operation was taken over from SWADFI (the short-lived SWA Defence Force Institute) in $1982 .{ }^{63}$ This is a clear reflection of the increased demand placed on SADFI by the military community.

Much depended as well on the image of the Institute and loyalty of its customers. Clearly, by the late 1970s, SADFI had changed from an enterprise relatively unpopular with the military community to one that had obtained their respect and confidence. Notwithstanding dramatic improvements in the benefits and facilities offered, some servicemen remained critical. ${ }^{64}$ Colonel François Dannhauser, who became assistant general manager on 1 January 1983, found that poor market orientation brought a breakdown in communication between Institute and customers. Customers, unaware of various discounts, felt prices were higher than what they were. Market research confirmed that some customers did not understand the complicated price structure, and the widespread perception remained that SADFI was still very expensive. ${ }^{65}$ A survey conducted in 1979 confirmed the notion that the military community were not giving their maximum support to SADFI. Residents of Voortrekkerhoogte spent approximately $64 \%$ of their monthly grocery budget at SADFI, while service personnel resident in neighbouring areas, such as Valhalla, where competition existed, tended to support SADFI considerably less. As a result, the discounts were done away in 1980 , and SADFI reduced all prices by an average of $10 \% .{ }^{66}$ SADFI was now becoming more competitive in terms of price.

The same survey in 1979 found that National Servicemen and junior ranks tended to support SADFI better than senior ranks. ${ }^{67}$ To a greater or lesser extent, this phenomenon can be ascribed to several factors, the first of which was the geographic problem faced by SADFI. Residential patterns reflected that senior officers, concentrated in the neighbouring suburbs, supported SADFI less than members of lower rank, who were concentrated in and around the training camps of Voortrekkerhoogte and hence had a greater opportunity to buy from the conveniently situated SADFI. ${ }^{68}$ The market SADFI catered for was a second factor. In the past, SADFI tended to concentrate on National Servicemen. This confirmed in the minds of many Permanent Force families that their needs could better be met by the supermarkets, hypermarkets, and family stores which mushroomed in South African suburbs from the end of the sixties. ${ }^{69}$ A third factor, public perception, was equally important. The junior ranks were relatively new in the SADF and were therefore only acquainted with the 'new' SADFI of the post1968 era. They were not aware of the previously poor reputation that, for years, remained implanted in the minds of many members of the Permanent Force. ${ }^{70}$

SADFI launched a massive advertising campaign in the 1980 s to reach the military community, who remained the Institute's only customer base. SADFI introduced new innovative ideas and implemented a marketing strategy and began to set competitive prices. ${ }^{71}$ 'New-look' shops gradually replaced older facilities; they extended services and the number of SADFI outlets increased (Table 12.3). The outlets granted credit 
under controlled circumstances. Considerable sums of money were diverted to provide facilities for the military community, including two kindergartens in Voortrekkerhoogte. ${ }^{72}$ SADFI had become a dynamic and profitable organisation capable of delivering real benefits to servicemen.

SADFI had a growing presence in the military towns and on military bases. Many units now had smaller SADFI outlets. These shops, cafés and canteens offered groceries, personal items, and additional rations, perhaps mostly fast foods, to resident military families and the large biannual influxes of National Servicemen. Complaints regarding official rations, perhaps mainly by National Servicemen, extended from the large training bases to deployment in the operational area. "Anthony", an 18-year-old National Service chef, relates:

They taught me to cook, but it's different when you are cooking for over 1000 guys. Everything's boil and oil. Catering in the army was about good quality food fucked up. ${ }^{73}$

The sister of two National Servicemen and girlfriend of another stated:

Really - those rat packs! For a guy who's eighteen, there was not enough food in them for one proper lunch, let alone a day or longer. They didn't even get given those often, either, when they were out in the bush - at least, not every day. ${ }^{74}$

Food and culinary experience differed vastly. ${ }^{75}$ And then there was the omnipresent SADFI seeking to fill the need. François Verster, a National Serviceman in the late 1980s, describes the general dealer role played by SADFI at the time:

Ons koop baie by die SAWI, want die armykos is maar min en nie altyd lekker nie. Die ouens sê ons sal sien as die voorrade opraak, kry ons net pap.... Ons koop ook Themde en onderbroeke by die SAWI. Jy kan omtrent enigiets daar kry, maar ons soek meestal kos. [We buy many things at the SADFI, because army rations are meagre and not always pleasant. The chaps here say that we will notice when the supplies run short. Then we get porridge. ... We also buy Tshirts and underpants at the SADFI.You can get anything there, but we mostly look for food. $]^{76}$

Besides, while SADFI met the demand for additional rations and other items, there were also notions that SADFI emptied the pockets of servicemen.Verster, who served as a National Service teacher on the Omega base, describes the SADFI there as a "... massiewe weermagswinkel wat soos 'n vliegtuigloods gelyk het". National Servicemen and the teachers with bigger salaries spent their salaries and danger pay here.

Ons danger pay is in kontant uitbetaal. Dit was altyd welkom, hoewel die meeste van ons ons geld in die SAWI gaan mors het en die geld dus net weer terug na die weermag se koffers is. Veral die Boesmans het seker omtrent elke sent van hul salarisse in die SAWI 'teruggeploeg'. Waar anders? Daar was net die een winkel. [Our danger pay is paid out 
in cash. This was always welcome, although we mostly wasted our money in the SADFI and the money in this way returned to the army coffers. The Bushmen (sic), particularly, probably 'ploughed back' every cent of their salaries in the SADFI. Where else? There was only the one shop. $]^{77}$

In 1984, South Africa entered the worst recession since 1933. Despite an increase of $15.5 \%$ in the Institute's turnover, net profit dropped by $1.7 \%$. The cost of repairs to and the maintenance of the buildings increased from R206636 to R314502. Salaries increased by $23 \%$, of which $10 \%$ was attributable to the employment of additional staff for the new outlets. ${ }^{78}$ No less than $36 \%$ of the SADFI outlets operated at a loss. Certain of the smaller outlets, often situated in isolated places, were run at a calculated loss to deliver a service to the local military communities. ${ }^{79}$ Under these circumstances, any civilian organisation would probably have closed these branches. A large amount of stock shrinkage compounded the difficult financial situation. ${ }^{80}$

The later 1980s saw something of a renaissance. The activities of SADFI had quadrupled since 1976. This was due to the growth of the trade in SWA as well as the establishment and expansion of SADFI services to isolated bases. ${ }^{81}$ SADFI opened new malls and shops at Voortrekkerhoogte (1979), Bloemfontein (1982), Bloemspruit (1983), Potchefstroom (1986), Port Elizabeth (1986) and Windhoek (1987). Prices were visibly competitive. A comparison of 400 grocery items carried out by Dannhauser in 1986, reflected a benefit for SADFI customers that varied between $5.16 \%$ and $7.14 \% .{ }^{82}$ Although SADFI was normally $4 \%$ to $5 \%$ cheaper than other supermarket chains, the Institute was as much as $8.49 \%$ cheaper than its cheapest opposition in July $1989 .{ }^{83}$

Despite calls for greater privatisation and complaints from the private sector that they could not compete with SADFI, an investigation in 1986 found compelling arguments against privatisation. There was no way to privatise SADFI if the Institute was still to offer a service. The principle of low prices with minimum profit (as a benefit to servicemen) would be lost.

Moreover, the question arose as to which large firm would be willing to operate small shops in bungalows at isolated places for small communities (in 1986, approximately $50 \%$ of SADFI branches operated with no profit). And then, profitdriven organisations would not be willing to divert funds from financially secure branches to subsidise non-profit branches as a service. Private firms could not offer a service in the operational areas. These same firms would also not be willing to pay rent for the dilapidated buildings and operate in isolated areas where it would have to increase prices drastically to cover overheads. Perhaps most of the criticism directed by the private sector was based on a poor understanding of the SADFI enterprise. Local chambers of commerce stressed the use of state accommodation, state transport in the operational area, and some state-paid Permanent Force personnel. However, as far as possible, SADFI was operated financially independent of the state. The Permanent 
Force element was kept to a minimum and concentrated on the command and control, and the operational trade. As such, SADFI did not compete with the private sector. Advertising campaigns were limited to the military community and civilians were turned away at SADFI outlets. A strict application of the regulations dissipated the tremendous amount of opposition from commercial quarters. ${ }^{84}$

In 1989, the end of the Border War, SADFI had almost 100 outlets across South Africa and SWA. The Institute offered diverse services to the military community, from convenient outlets for groceries and clothing to petrol, sports goods, furniture, household appliances, and vehicle financing. During the 1988/89 financial year, SADFI had a turnover of R145 million and engaged approximately 1200 employees. It was no small enterprise.

\section{FIELD SERVICE: OPERATIONAL ROLE, 1968-1989}

The Institute's other role, the delivery of a mobile canteen services under battle conditions, saved SADFI in 1968. Until the changes that had followed militarisation took effect, the military community had viewed SADFI with much suspicion and disregard. The Institute, which did not accompany the South African contingent to Korea, had last seen operational deployment in $1945 .{ }^{85}$ Over the following years, the Institute suffered from its poor image. Even Major General P.H. Grobbelaar, then Army Chief of Staff, had objected in 1956 to 'the presence of UDFI vehicles within the tactical area, even on exercise'. ${ }^{86}$ Grobbelaar arranged for unit canteens to supply non-ration items to his exercising troops during Operation ORANJE. As a result of this kind of opposition, the SADFI mobile field element was still non-existent by $1968 .^{87}$

The first steps taken to provide the field services followed the militarisation of the Institute in 1968. The Army Order of Battle then provided for a mobile SADFI to form on mobilisation. They ordered the first of a series of mobile canteens and a Permanent Force post for a 'Mobile Shop Manager' was created for the permanent establishment of the Institute. ${ }^{88}$ Militarisation, and then growing SADF involvement in the Border War reinstated the idea of a unified canteen system and led to the acceptance of the principle of an operationally capable and active Institute.

SADFI practised their mobile field function for the first time in May 1972 during exercise BROLLY TREE, a simulated defence of South Africa. It introduced a new primary role. Until then, the Institute had concentrated on what was its secondary role, namely the provision of static shopping facilities to the military community in South Africa. During this exercise, which lasted from 5 to 27 May 1972, SADFI proved its competence in satisfying the canteen requirements of a full brigade under 
mobile, war-simulated conditions. During the first ten days of the exercise, they sold approximately 16800 tins of cool drink, almost 88000 packets of twenty cigarettes, seven dozen (84) electric razors, twenty-three boxes of shoe polish, numerous souvenirs, and crates of sweets. ${ }^{89}$ The reaction was tremendous and in sharp contrast to the sentiments expressed after Operation ORANJE. The Commanding Officer of North-Western Command requested a SADFI presence at the next exercise. ${ }^{90}$ SADFI teams operated in the field on every major exercise between 1972 and 1990, while providing a service in one form or another to many Citizen Force units and Commandos during training camps. ${ }^{91}$

The real test came soon with operational deployment to the northern borders. From 1969, military personnel might have experienced a minimum of six months service in the operational area and, as a result, soldiers were away from home for reasonably extensive periods. Military bases in South West Africa were situated in distant, isolated areas, the climate was one of extremes, and servicemen often worked and lived under trying circumstances. There were no mobile canteens or cinemas, as the UDFI had operated during the Second World War, and opportunities for effective, quality, leisure programmes were limited, although the Director General Personnel did organise entertainment groups and provide film shows to a limited extent. Grass sports fields were practically non-existent, and it was not uncommon for a rugby match to be temporarily stopped when the ball was lost in the swirl of dust churned up by the players' bare feet. ${ }^{92}$ The need for an institute able to meet the canteen and recreational needs of the troops was evident.

The first SADFI shop opened in SWA in 1974. It first operated from a tent at Grootfontein. ${ }^{93}$ During Operation SAVANNAH, a bulk trade section was established at Grootfontein. Orders placed by bases and units in the operation area were dispatched from this depot and, from January 1976, two mobile canteens ploughed through the day to service units in transit in the Grootfontein area. ${ }^{94}$ Overnight SADFI was presented with an operational task, conducted under combat conditions.

However, several factors constrained the SADFI operational service. Misunderstanding about where SADFI fitted into the command and control structure during operations remained. SADFI also did not have the necessary personnel, vehicles and equipment to handle the mobilisation task. This led to an inefficient distribution of commodities from the base area (Grootfontein) to the front. Some units travelled from as far as Calueque and Moçâmedes, some 700 kilometres away, to collect supplies at Grootfontein. Canteen facilities were lacking at some centres, including Rundu, while SADFI retail facilities were inadequate at Grootfontein. Problems were compounded by an ineffective pay system that limited the buying power of the troops. ${ }^{95}$ All in all, in 1976, SADFI was able to deliver a praiseworthy service as far as Grootfontein and would suffer the challenges of the distances and physical geography beyond that. 
A committee, to investigate the role of SADFI in the operational areas, was appointed on 24 March 1976. ${ }^{96}$ Chaired by Major General W.A. Lombard, this committee found that a decentralised system supplying services directly to frontline troops and based on the NAAFI ideal, could not exist in the SADF. The supply of canteen facilities to small, highly mobile forces operating over a vast area in the African bush was too costly and personnel intensive. ${ }^{97}$ The same lessons had to be learnt again: the old UDFI (V) was largely unable to render a service to the frontline during the mobile periods of the North African campaign and even battled to do so during the static months of the Italian campaign in 1944. The Lombard Committee recommended that, under conventional circumstances, the final wholesale distribution point of SADFI be in the Brigade Administrative Area (BAA) and other more fixed bases. From these points, units were to undertake the distribution of commodities through the normal echelon system. The final point-of-provision would, therefore, be through the unit canteens and not the SADFI mobiles. This released the latter canteens for service in fixed bases, BAAs and on return routes where they expected amassing of troops, such as in the demobilisation areas. ${ }^{98}$

Adjusting rapidly to the circumstances, SADFI became increasingly proficient and, from 1981, participated in all SADF operations. During Operation DOLFYN, canteen supplies were transported from the SADFI depot in Oshakati to the SADFI element in the front maintenance area, from where provisions were supplied by road, air and parachute to combat groups at the front. During this operation and its successor, ASKARI (1983), SADFI suffered losses in transport. However, improved security, the presence of SADFI personnel, and the optimum use of the echelon system vastly diminished the incidence of theft. ${ }^{99}$ The SADFI bulk stores that operated during all operations since PROTEA (1981) fulfilled the dual function of wholesale provision to unit canteens and the Institute's mobiles, which as a rule did not operate in competition with unit facilities. ${ }^{100}$

This extract from a letter written by Major F. Eckhardt, the second-in-command of the Cape Town Highlanders, reflects the appreciation operational troops had for the services offered by SADFI in the operational area:

Our meeting with you on our recent tour of operational duty was truly a Godsend, and it certainly was a great boost to our sagging morale. Not only were you directly responsible for coming to our aid with SADFI necessities and allowing us the sole use of one of your trucks, but in so doing you ensured that an important aspect of life on the border was able to be carried out and made life that little bit easier. ${ }^{101}$

However, SADFI support largely took place on an ad hoc basis. ${ }^{102}$ No policy directives or procedures existed save a broad outline in the General Regulations. This had a detrimental effect on the service provided. ${ }^{103}$ SADFI only reached an agreement with the Army on its role and deployment during cross-border operations in 1987. The 
content of this agreement was included in the Army's Report on the Logistic System and provided a foundation for a number of policy documents: a policy directive or 'philosophy and doctrine of the SADFI'; a logistics pamphlet regarding SADFI activities; and a directive in respect of the tasks of the general manager, SADFI. ${ }^{104}$ They implemented these procedures during Operations MODULER (1 July to 15 December 1987), and HOOPER (15 December 1987 to March 1988) and SADFI played a key role in supplying troops when and where canteen support was needed. For the first time, they made night drops where this was the only way of getting supplies to the troops in forward positions. Great appreciation was expressed, with an emphasis on the SADFI ability to offer its services from the outset of the operation. ${ }^{105}$

Operation PACKER was launched early in 1988, with a view to a tactical disengagement of the South African forces involved in the repulsion of the Fapla offensive of 1987. ${ }^{106}$ Supplies were forwarded from the SADFI depots in South Africa by road and rail to the SADFI depot in Grootfontein. SADFI bulk trucks distributed these provisions to the various bulk stores scattered along the length of northern SWA, from Oshakati in the west to Mpacha in the east. These provisions were sold in wholesale to the local units and also provided the local SADFI shops with goods for retail trade to the local military community. Operation PACKER was executed through Rundu; and this boosted the turnover of the small shop, opened barely twenty months before, to over R1 million per month. ${ }^{107}$ Supplies were forwarded from the bulk store at Rundu by convoys of 3 Maintenance Unit to the brigade administrative and demobilisation areas. The mobile field depot deployed in the BAA consisted of two wholesale trucks (Samil 100 6x6 insulated vehicles) and two mobile canteen trucks (Samil 100 $6 \times 6$ vehicles equipped with large fridges). This mobile field depot netted an average turnover of R262800 per month. ${ }^{108}$ At the demobilisation or transit area, three SADFI canteens served approximately two thousand troops throughout Operation PACKER. These mobiles stocked all necessities from toiletries and chocolates to wines, malts and tinned mussels. However, the buying power of troops moving north was greatly restricted as they did not have their first pay. It was, however, made up by those troops moving south, who had many months' pay and several 'Victory Vouchers' (or 'Bakgat Bewyse') that they could exchange for beers or cool drinks. These three canteens produced a turnover of R90000 between 28 February and 28 March 1988. ${ }^{109}$

In May 1988, events in SWA took a new turn when negotiations between South Africa, Angola and Cuba commenced in London. This culminated in the signing of two accords on 22 December 1988, and the implementation of the negotiated peace settlement plan for SWA on 1 April 1989. The withdrawal of South African troops from Namibia and the closure of all SADFI outlets in the country ended an interesting phase in the Institute's history. The Institute managed to execute its operational task with exceptional efficiency despite the changes brought about by the recent militarisation and the fact that service often had to be provided with very little notice. ${ }^{110}$ 
Unlike the liquidation of the UDFI in 1921, the SADFI had no organisation to which it could transfer the canteen infrastructure. An SWA Defence Force Institute (SWADFI) had been established in 1978 to meet the eventuality of Namibian independence and the withdrawal of the SADF. However, because of bad management and imminent bankruptcy, SADFI took over SWADFI, accepting all the losses, and turned it into a flourishing and profitable trade. ${ }^{111}$ The final curtain dropped on the Institute's business in Namibia with the closure of most of the branches on 6 June 1989. The remaining facilities closed towards the end of 1989. While these developments left a feeling of melancholy with the people who were acquainted with SADFI facilities in Namibia, it was certainly true that there were new challenges and new horizons facing the management and staff of a much-reduced Institute.

Following the implementation of Resolution 435 and the withdrawal of South African troops from Namibia, the SADF estimated that the turnover of SADFI reduced by $30 \% .{ }^{112}$ The management made an effort to grasp the challenge of a lower turnover by promoting productivity, streamlining the management and providing a better service. ${ }^{113}$ However, as the Institute could not open branches on existing bases if this placed them in competition with the local commercial infrastructure, there was no way in which SADFI could expand its business on a large scale within South Africa. ${ }^{114}$ Two avenues remained: the extension of existing facilities and the replacement of certain old buildings; and the establishment of new branches simultaneously with the inauguration of new bases. ${ }^{115}$

In May 1988, SADFI opened a temporary shop on the new Air Force Base at Louis Trichardt. This service started in a mobile canteen but soon expanded. Shortly after, the construction of a new, modern shop. Another success story was the new store that opened in Pomfret when 32 Battalion was transferred there from Buffalo in Namibia. ${ }^{116}$ This shop had to open its doors at short notice as SADFI was called in at the last minute to provide the service. The facility was already too small, and plans were soon underway once more to double the size of the existing building. Perhaps the most significant success came with the new shopping complex, erected in 1990, which housed the SADFI head office, a furniture shop, a sports shop, a supermarket, a bakery, a café and branches of Absa and First National Bank. This complex was planned to allow for at least ten years of expansion. ${ }^{117}$ In these ways, SADFI attempted to mitigate the loss of the South West enterprise and a shrinking clientele, following the abolition of National Service, and to continue a proud tradition of service to the military community. 
"It is the dramatic and momentous events at the sharp end of the war", Keegan and Holmes remind us, "that jostle for our attention. But the inexorable advance of armoured columns ... depend upon logistics." ${ }^{118}$ Logistics, or the sinews of war, is a complex if often hidden subject. Ponderous columns of logistics vehicles have to bring ammunition and equipment and, of course, food forward. Where this fails, soldiers might live off local resources and ruin the hopes of farmers and local townspeople. Many modern armed forces now have regimented canteen systems. These may vary in nature and structure, but most are embedded within the armed forces, utilising some military personnel. These canteen systems can operate shopping malls on military bases as well as mobile canteens, and provide recreational facilities for servicemen from small permissible profits margins.

The SADFI (or SAWI) fulfilled this function in the SADF between 1957 and 1994. SADFI and its predecessors did not have an easy history. They were the subject of several inquiries and investigations. It led to the militarisation of the Institute in 1968, a time when National Service and the development of a war on the northern borders were a lifeline. However, withdrawal from SWA (soon to become Namibia) in 1989 and the concomitant rationalisation of the SADF, ushered in a new round of challenges. The extent to which the Institute accommodated these changes is perhaps an area for future research into a floundering business. The Border War brought rapid growth, not sustainable after the ending of the war followed by the abolition of National Service and the rationalisation of the armed forces. It ushered in a new era in more than one sense. The Institute had to settle down to retail and wholesale trade, within a much smaller, peacetime Defence Force. How the Institute adjusted to these changes is a story for another day. 


\section{Endnotes}

1 Ian van der Waag, A History of the South African Defence Force Institute (SADFI), 1914-1990 (MA thesis, Pretoria, 1997), Ch. 1.

2 See for example, John Fortescue, A Short Account of Canteens in the British Army (Cambridge: Cambridge University Press, 1928); NAAFI Public Relations Branch, The Story of NAAFI (1 April 1944); Harry Miller, Service to the Services: The Story of NAAFI (London: Newman Neame, 1971), and Don Bridge, ed., Naafi up! More than just char and wad: the official history of NAAFI commemorating 75 years of serving the services (Tavistock, UK: AQ and DJ publications, 1996).

3 The first histories were largely official in nature, although sometimes delivered for degree purposes through South African universities. See T.R. Ponsford, War Record of Union Defence Force Institutes (YMCA - Toc H), 1939-1946 (Cape Town: Hortors Printers, 1946); François Dannhauser, ' $n$ Ondersoek na die beeld van die Suid-Afrikaanse Weermaginstituut by sy klante, 1979 (MBA dissertation, Pretoria, 1979); Ian van der Waag, 'Traces of a military trading organization; archives appertaining to the South African Defence Force Institute', South African Archives Journal, 32, 1990; and Ian van der Waag, A History of the South African Defence Force Institute (SADFI), 1914-1990 (MA thesis, Unisa, 1997), available at: [https:// www.researchgate.net/publication/34667507_A_history_of_the_South_African_ Defence_Force_Institute_SADFI_1914_-_1990_microform].

$4 \quad$ Fransjohan Pretorius, Life on Commando during the Anglo-Boer War 1899-1902 (Cape Town: Human \& Rousseau, 1999).

5 James Bourhill, 'Red Tabs': Life and death in the 6th South African Armoured Division, 1943-1945 (PhD dissertation, Pretoria, 2016), Ch. 5 in particular.

6 Neil Roos, Ordinary Springboks; White Servicemen and Social Justice in South Africa, 1939-1961 (Aldershot, UK: Ashgate, 2005).

7 MH Swift, 'The Union Defence Force Entertainment Group in South Africa, World War II', Militaria, 4(2), 1974; MH Swift, 'The Union Defence Force Entertainment Group in the Middle East', Militaria, 4(3), 1974; and Henri Bantjes, Die Vermaaklikheidsgroep van die Unie-Verdedigingsmag gedurende die Tweede Wêreldoorlog: 'n Historiese Ontleding (MA dissertation, Pretoria, 1990). Bantjes was a National Serviceman at the SADF Archives at the time of research for his thesis.

8 Allan Millett and Williamson Murray, eds., Military Effectiveness, 1: The First World War (Boston: Unwin Hyman, 1990). Abel Esterhuyse and Lindy Heinecken, Report to the Chief of the SA Army on the Military Culture and Institutional Ethos of the South African Army (unpublished paper, Stellenbosch, January 2012).

9 Neil Orpen, The Cape Town Highlanders, 1885-1985 (Cape Town: San Printing Press, 1986). Francis Coleman, The Kaffrarian Rifles, 1876-1986 (East London:The Kaffrarian Rifles Association, 1988). Stanley Monick, A Bugle Calls; The Story of the Witwatersrand Rifles and its Predecessors, 1899-1987 (Germiston:Witwatersrand Rifles Regimental Council, 1989). Stanley Monick and Ossie Baker, Clear the Way; The Military Heritage of the South African Irish, 1880-1990, 2 (Johannesburg: SA Irish Regimental Association, 1991). James Mitchell, Tartan on the Veld; The Transvaal Scottish, 1950-1993 (Johannesburg: Transvaal Scottish Regimental Council, 1994). John Dorrington, Semper Eadem; The Cape Town Rifles (Dukes) 1855-2010 (Goodwood: DEOR Trust, 2010).

10 Ian van der Waag, A Military History of Modern South Africa (Cape Town: Jonathan Ball Publishers, 2015), 258.

11 Richard Holmes, Acts of War; The Behaviour of Men in Battle (London: Weidenfeld \& Nicholson, 2003), 128. 
These statistics were calculated for the period August 1914 to June 1917.

13 Ian van der Waag, 'War, Sex and Politics: the South African Medical Section in Korea, 1950-1953', Historia, 46(1), 1 May 2001, 101, available at: [https://www.researchgate.net/ publication/26687288_War_sex_and_politics_the_South_African_medical_section_in_ Korea_1950-1953].

14 David Williams, On the Border: The White South African Military Experience 1965-1990 (Cape Town:Tafelberg, 2008), 11-24.

15 Bertie Cloete, Pionne (Hermanus: ABC Press, 2009), 93; Cameron Blake, From Soldier to Civvie: Reflections on National Service (Cape Town: Zebra Press, 2010), 8; Cobus Bothma, Los Af! Terugblik op nasionale diensplig deur die oë van 'n dienspligtige (Hermanus: Hemel \& See Boeke, 2009), 113.

16 Bothma (2009), 124.

17 Blake (2010), 20-21, 70.

18 Kobus van Rooyen, A South African Censor's Tale (Cape Town: Zebra Press, 2010), 4.

19 Bothma (2009), 122. Barry Fowler, ed., 'Parabat' in Pro Patria: Sentinel SADF Monographs, 1 (Halifax: Sentinel Projects, 1995), 23-4 and 'Guard Commander', 74-5. François Verster, Omega, Oor en Uit: Die stories van 'n opstandige troep (Cape Town:Tafelberg, 2016), 132.

20 Anthony Feinstein, Battle Scarred; Hidden Costs of the Border War (Cape Town:Tafelberg, 2011), 48. See also Clive Wills 'Doctor' in Barry Fowler, ed., Pro Patria: Sentinel SADF Monographs, 1, 125.

21 Department of Defence Archives (hereafter DOD Archives): Quartermaster General (QMG), Group 12, box 2, file KMG/K1/2/7, vol.1 'SAWI - Beherende Gesag, Raad van Beheer', Chief of Personnel to QMG, 9 January 1969. DOD Archives: HVS, box 763, file HVS/417/2, vol.2 Inrigtings: SAWI, Enc 35B 'South African Defence Force Institute (SADFI)'.

22 DOD Archives: QMG Group 12, box 1, file KMG/K1/1/2 SAWI - Stigting, Enc. 94 'SADFI: Report to 25 November 1968'.

23 Brig B.D. Slater (personal communication, interviewed by Ian van der Waag, Pretoria, 25 July 1989).

24 DOD Archives: QMG Group 12, box 1, file KMG/K1/1/2 SAWI - Stigting, Enc. 94 'SADFI: Report to 25 November 1968'. DOD Archives: HWA DGAA (H SAW), box 81, file DGAA/42/2/1, vol.1, Instituut en Inrigtings, SAWI: Beleid 'Notes prepared for the Defence Council', SADFI, June 1973. DOD Archives: HVS, box 764, file HVS/417/2, vol.4 Inrigtings: SAWI, QMG to Chief of Defence Force Administration (CDFA), 1 July 1971.

27 DOD Archives: HWA DGAA (H SAW), box 81, file DGAA/42/2/2, vol.2 SAWI Korrespondensie, QMG to Chief of Staff Logistics, 7 May 1974. DOD Archives: QMG Group 10, box 138, file KK1/2/4 SAWI Bestuur en Kontrole - Beheerraad, document 'SADFI Linked Loan and Purchases Scheme to raise trading capital and benefit participating institutions'. DOD Archives: HVS, box 764, file HVS/417/2, vol.4, Inrigtings: SAWI, Brig L.B. Hopkins to Maj Gen H.A. Kotze, 29 January1971. DOD Archives: Surgeon General Group 8, box 129, file Q/INNS/1/0 SADF Institute Policy, Circular issued by the QMG, 10 December 1974.

31 DOD Archives: QMG Group 10, box 138, file KK1/1/1 SAWI - Stigting en Organisasie, Notule van Verdedigingstafraadvergadering gehou teVHK, 14 August 1973; 
and DOD Archives: Surgeon General Group 8, box 129, file Q/INNS/1/0 SADF Institute - Policy, Circular issued by the QMG, 10 December 1974.

Brig L.B. Hopkins (personal communication, interviewed by Ian van der Waag, East London, 13 March 1989).

DOD Archives: HWA DGAA (H SAW), box 81, file DGAA/42/2/2, vol.2 SAWI Korrespondensie, Vergadering oor SAWI Aangeleenthede, 21 May 1974.

SADFI Archives: file Board of Control SADF: Members, Circular issued by the QMG, 10 May 1974. DOD Archives: QMG Group 10, box 138, file KK1/2/4, SAWI Bestuur en Kontrole - Beheerraad, QMG to Chief of the Army, Chief of the Air Force, Chief of the Navy, and the Surgeon General, 10 May 1974; and QMG to Maj Gen I. Lemmer, 17 June 1974. DOD Archives: HWA DGAA (H SAW), box 81, file DGAA/42/2/2, vol.2 SAWI Korrespondensie), Director General of General Administration to QMG, 17 April 1974. DOD Archives: QMG Group 10, box 138, file KMG/KK1/1/1, 1, SAWI - stigting en organisasie, Chairman of the Board of Control, SADFI to CDFA, 12 July 1972. General Regulations IX and South African Defence Force Order (SADFO) 95/66. DOD Archives: Surgeon General Group 8, box 129, file Q/INNS/1/0 SADF Institute Policy, Circular issued by the QMG, 10 December 1974.

39 Brig L.B. Hopkins (personal communication, interviewed by Ian van der Waag, East London, 13 March 1989).

40 DOD Archives: QMG Group 12, box 2, file KK1/2/5 SAWI - Bestuur en Kontrole: Verslae, Balansstate en notules van vergaderings, 2 Director SADFI to QMG, 27 February 1975.

41 Brig B.D. Slater (1989); and J.D. Bredenkamp, 'Die Onstaan en Ontwikkeling van die Vloot, 1912-1982', Scientia Militaria 12(2), 1982, available at: [http://scientiamilitaria. journals.ac.za/pub/article/download/620/624], 37.

42 DOD Archives: QMG Group 12, box 2, file KK1/2/5 SAWI - Bestuur en Kontrole: Verslae, Balanstate en notules van vergaderings, vol.2, Director SADFI to QMG, 27 February 1975.

43 Major S.V.M. van Heerden (personal communication, interviewed by Ian van der Waag, Wynberg, Cape Town, 15 March 1989). In 1975, Brig Hopkins stated that the establishment of a PF post for the manager of the Da Gama Park branch was "the only solution to improve management of the SADFI as a military institution for service to military personnel". DOD Archives: QMG Group 12, box 2, file KK1/2/5 SAWI Bestuur end Kontrole:Verslae, Balansstate en notules van vergaderings, vol.2, ASP (3) INST - SSO A, n.d. [archives damaged].

44 DOD Archives: Unit History Archives: file QMG, 1 'Geskiedenis van die KMG'.

45 DOD Archives: archives of the Secretary for Defence (DC), box 208, 'Report by Hoek, Wiehahn and Cross, Enquiries into UDF Institutes'.

46 SADFI Archives: file B of C Loans from UDFI Trust Fund, Chairman, Board of Control to the Honorary Secretary, UDFI Trust Fund, 16 October 1951.

47 DOD Archives: QMG Group 8, box 102, file KK1/2/1 UVM Instituut, beleid en instruksies, Notule van Pretoria Weermaginstitute skakelkomitee vergadering, 24 August 1959.

48 Statistics worked from following: DOD Archives: DC, box 1895, file DC 247/0, Union Defence Force Institutes (Garrison Institutes) General, Appendix 'Buildings occupied by the Garrison Institutes' attached to Chief of the General Staff (CGS) to the Secretary for Defence, 26 October 1954; and SADFI Archives: file B of C Payment of Rent and 
Domestic Charges, Appendix 'Buildings occupied by Garrison Institutes' attached to QMG to General Manager, UDFI, 24 November 1956.

49 DOD Archives: CGS, 20/1 Garrison Institutes, Lt Col T.H. Rowell, Secretary, Board of Control to the CGS, 4 November 1944.

50 DOD Archives: QMG Group 12, box 1, file KMG/K1/1/2 SAW Institute - stigting, Surgeon General to QMG, 30 March 1957.

51 DOD Archives: QMG Group 12, box 1, file KMG/K1/2/2, vol.1, SAW Institute roetine, Confidential report on SADFI for period 28 February to 30 March 1961 attached to Col P.M. Retief, Chairman, Board of Control to the Commandant General (CG), SADF, 30 March 1961.

52 DOD Archives:Verslae, box 46, file K79/1 Report 'Die Groenewoudkomitee se verslag oor die SA Weermag', 31 January 1966.

53 DOD Archives: DC Group 3, box 3, file DC 11/2, Ch. 2, SADFI Trust Fund, Chairman, Board of Control to the Secretary, SADFI Trust Fund, 6 June 1967.

54 SADFI Archives: Minutes of the 78th meeting of the SADFI Board of Control, 28 June 1968.

55 Inadequate accommodation was the genesis of numerous administrative and other problems, including the loss of stock through theft and damage (SADFI Archives: file SAWI/FIN/2, Auditors Reports and Correspondence, Transvaal Area, Report By Peat, Marwick, Mitchell and Co., 8 May 1967). DOD Archives: HVS, box 763, file HVS/417/2, vol.1, Inrigtings, SAWI, Chairman, Board of Control to Chief of Defence Staff (CDS), 19 May 1967.

56 DOD Archives: HVS, box 126, file HS/42/1/1, 1, Institute en Inrigtings, SAWI - beleid, Chief of Staff Logistics to Chief of Staff, 19 September 1974.

57 DOD Archives: QMG Group 10, box 138, file KMG/KK1/1/1, vol.1, SAWI - stigting en organisasie, Director SADFI to QMG, 18 June 1974.

DOD Archives: QMG Group 12, box 2, file KK1/2/5, vol.2, SAWI, bestuur en kontrole, verslae, balansstate en notules van vergaderings, Director SADFI to QMG, 2 July 1976. DOD Archives: 'General Manager, SADFI - QMG', and 'Director SADFI to QMG, 14 October 1975. SADFI Archives: Notules-SSO Vergaderings: minutes of meeting, 26 March 1984.

60 SADFI News, August 1988, 1.

61 'New SADFI for Potchefstroom', Paratus, May 1986, 31.

62 SADFI News, August 1988, 1.

63 Col Francois Dannhauser (personal communication, interviewed by Ian van der Waag, Pretoria, 28 August 1988).

64 Dannhauser (n.d.), 53.

65 Brig B.D. Slater (personal communication, interviewed by Ian van der Waag, Pretoria, 25 July 1989) and Col Francois Dannhauser (personal communication, interviewed by Ian van der Waag, Pretoria, 25 July 1989).

66 V Adm M.A. Bekker (personal communication, interviewed by Ian van der Waag, Pretoria, 20 July 1989).

Dannhauser (n.d.), 54-55.

68 V Adm M.A. Bekker (personal communication, interviewed by Ian van der Waag, Pretoria, 20 July 1989).

69 Personal information: Lt Gen K.M. Pickersgill, Pretoria, 5 July 1989. 
70 Brig B.D. Slater (personal communication, interviewed by Ian van der Waag, Pretoria, 25 July 1989).

71 Col F. Dannhauser (personal communication, interviewed by Ian van der Waag, Pretoria, 25 July 1989).

72 Brig B.D. Slater (personal communication, interviewed by Ian van der Waag, Pretoria, 25 July 1989).

73 As quoted in JH Thompson, An Unpopular War: From afkak to bosbefok (Cape Town: Zebra Press, 2006), 26.

74 Quoted in Blake (2010), 193.

75 Cameron Blake, Troepie: From call-up to camps (Cape Town: Zebra Press, 2009), 73-75.

76 Verster (2016), 132.

77 Verster (2016), 68-70.

78 SADFI Archives: file QMG 507/4/1 Bedryf van Inrigtings - SAWI, QMG to the Chief of the South African Defence Force, 31 October 1974.

SADFI Archives: file QMG 507/4/1 Bedryf van Inrigtings - SAWI, Director SADFI to QMG, 22 October 1974.

80 SADFI News, February 1985, 1.

81 DOD Archives:Verslae, box 200, Report K86/83: KMG(1)503/1/10, 1 (D SAWI), Report 'Verslag oor ondersoek na die organisasie van SAWI', 23 December 1985.

SADFI Archives: file Notules - SSO Vergaderings, 'Minutes of SSO meeting', 5 May 1986.

83 Col F. Dannhauser (personal communication, interviewed by Ian van der Waag, Pretoria, 25 July 1989).

84 DOD Archives: QMG, Registry of the HQ Unit, file QMG 507/4/1, vol.1. Bedryf van Inrigtings - SAWI, Order (QMG Order KMG 507/4/1), 23 November 1988. Col Francois Dannhauser (personal communication, interviewed by Ian van der Waag, Pretoria, 12 January 1989); Lt Gen K.M. Pickersgill (personal communication, interviewed by Ian van der Waag, Pretoria, 5 July 1989);V Adm M.A. Bekker (personal communication, interviewed by Ian van der Waag, Pretoria, 20 July 1989); Brig B.D. Slater (personal communication, interviewed by Ian van der Waag, Pretoria, 25 July 1989).

85 The South African Korea contingent was small and largely symbolic. South African soldiers were serviced by NAAFI and the PX (Post Exchange) of the United States. DOD Archives: 2 Sqn Korea, box 47, file 2SQD/1101/MED Medical General, Policy and Instructions, BCOF Administrative Instruction 186, 30 October 1950. Carol Habgood and Marcia Skaer, One Hundred Years of Service: A History of the Army and Air Force Exchange Service, 1895-1995 (Dallas:Texas Headquarters: Army and Air Force Exchange Service, 1994 [Cynthia Reiber, ed.]), 265-280. DOD Archives: QMG Group 8, box 102, file KMG/K/1/2/4 UVM Institute - Stigting vir vredestydse veldoefeninge, Army Chief of Staff to QMG, October 1956.

87 SADFI Archives: file Policy prior to December 1968, Appendix C to Chairman of the Board of Control to the CDS, 19 May 1967. DOD Archives: HVS, box 763, file HVS/417/2, 2, Inrigtings - SAWI, CDFA to CG, c. March 1968. 
91 Brig B.D. Slater (personal communication, interviewed by Ian van der Waag, Pretoria, 25 July 1989).

92 DOD Archives: Aanvullende Dokumente-versameling, box 31, L. Jooste 'Die $S A W$ in SWA, 1969-1973', 5-10.

93 Col G. van Biljon (personal communication, interviewed by Ian van der Waag, southern Angola, 26 April 1988).

94 SADFI Archives: file QMG 507/4/1 Bedryf van Inrigtings - SAWI, Memo 'SAWI Grootfontein' attached to D SADFI to QMG, January 1977; and P. Coetzee, 'Die leuse bly diens', Paratus, June 1976, 10.

95 DOD Archives: HVS (KG DGAA), box 126, file HVS/42/1/2, 1, Institute en Inrigtings: SAWI: Roetine, Enc 32A Report 'Komitee van Ondersoek na SAWI se rol in Operasionele Gebiede', 8-9.

96 DOD Archives: QMG Group 12, box 2, file KK1/2/5, SAWI - Bestuur en Kontrole - Verslae, Balansstate en notules van vergaderings, vol.2, General Manager SADFI to QMG, 2 July 1976.

97 Lt Gen K.M. Pickersgill (personal communication, interviewed by Ian van der Waag, Pretoria, 5 July 1989).

98 DOD Archives: HVS (KG DGAA), box 126, file HVS/42/1/2, 1, Institute en Inrigtings: SAWI: Roetine, Enc. 32A Report 'Komitee van Ondersoek na SAWI se rol in Operasionele Gebiede'); and Lt Gen K.M. Pickersgill (personal communication, interviewed by Ian van der Waag, Pretoria, 5 July 1989).

99 SADFI Archives: 'Voorlegging aan die Kwartiermeester-generaal oor die rol en funksie van SAWI tydens operasies'. This document dates from somewhere between the disbandment of the Joint Monitoring Commission (16 May 1985) and the commencement of Operation MODULER (1 July 1987).

100 Col G. van Biljon (personal communication, interviewed by Ian van der Waag, southern Angola, 26 April 1988).

101 Quoted in SADFI News, October 1983, 3.

102 Lt Gen K.M. Pickersgill (personal communication, interviewed by Ian van der Waag, Pretoria, 5 July 1989).

103 SADFI Archives: file QMG/507/4/1, Bedryf van Inrigtings: SAWI, vol.1, QMG to Chief of the Army', 9 December 1982.

104 Lt Gen K.M. Pickersgill (personal communication, interviewed by Ian van der Waag, Pretoria, 5 July 1989).

105 SADFI Archives: file QMG/507/4/1, Bedryf van Inrigtings - SAWI, vol.2, QMG to Chief of the South African Defence Force, 20 January 1989.

106 Forças Populares de Libertação de Angola - the Angolan government troops.

107 Col G. van Biljon (personal communication, interviewed by Ian van der Waag, southern Angola, 26 April 1988).

108 Capt D. Pretorius (personal communication, interviewed by Ian van der Waag, southern Angola, 27 April 1988).

109 Lt David Rees (personal communication, interviewed by Ian van der Waag, southern Angola, 26 April 1988).

110 Brig B.D. Slater (personal communication, interviewed by Ian van der Waag, Pretoria, 25 July 1989).

111 V Adm M.A. Bekker (personal communication, interviewed by Ian van der Waag, Pretoria, 20 July 1989). 
112 Brig B.D. Slater (personal communication, interviewed by Ian van der Waag, Pretoria, 25 July 1989).

113 Lt Gen K.M. Pickersgill (personal communication, interviewed by Ian van der Waag, Pretoria, 5 July 1989).

114 QMG HQ Registry: file QMG 507/4/1, vol.1, Bedryf van Inrigtings - SAWI, C SADF Policy Directive 4/2/81, 21 January 1981.

115 Lt Gen K.M. Pickersgill (personal communication, interviewed by Ian van der Waag, Pretoria, 5 July 1989).

116 Lt Gen K.M. Pickersgill (personal communication, interviewed by Ian van der Waag, Pretoria, 5 July 1989); and Brig B.D. Slater (personal communication, interviewed by Ian van der Waag, Pretoria, 25 July 1989).

117 SADFI Archives: file Nuwe SAWI kompleks VTH, Director SADFI to QMG, 1 April 1983.

118 John Keegan and Richard Holmes, Soldiers: A History of Men in Battle (London: Sphere Books, 1985), 221. 



\section{Contributors}

Brig Gen McGill Alexander [SM, MMM (retired), MA (Unisa), PhD (Unisa)] served for 27 years in the South African Defence Force (SADF) and for 20 years in its successor, the South African National Defence Force (SANDF). He commanded 44 Parachute Brigade, was the Chief Instructor of the SA Army College's Command and Staff Duties Branch, and the Director of Joint Doctrine Development in the SANDF. He is also a graduate of the SA Military Academy (Stellenbosch University), the Spanish Army Staff College, and the SA National Defence College (Pretoria).

Gary BaINes [MA (Rhodes), PhD (University of Cape Town)] is Professor of History at Rhodes University. His publications include South Africa's 'Border War': Contested Narratives and Conflicting Memories (Bloomsbury, 2014), as well as the co-edited volume called Beyond the Border War: New Perspectives on Southern Africa's Late-Cold War Conflicts (Unisa Press, 2008). Recent articles include a chapter on veteran tourism in Ángel Alcalde and Xosé M. Núñez Seixas (eds.), War Veterans and the World after 1945: Cold War Politics, Decolonization, Memory (Routledge, 2018), and an entry in the Oxford Research Encyclopedia of Africa on 'Legacies of South Africa's Apartheid Wars'. [orcid: 0000-00023913-9435]

WILL Gordon [MA (Stellenbosch University)] is a doctoral candidate in the Department of History at Stellenbosch University. He has a particular interest in the Cold War in sub-Saharan Africa and the Wars for Southern Africa. He is currently a history teacher.

Albert Grundlingh [MA, D Litt et Phil (Unisa), Emeritus Professor, Stellenbosch University] has published widely on the history of war and society in South Africa, as well as on the history of sport and society. He is currently working on a biography of the South African politician, Dr Frederik van Zyl Slabbert. [orcid: 0000-0001-6606-3491]

Col James JacoBs [(retired), MA (Stellenbosch University), PhD (University of the Free State)] served for 41 years in the South African National Defence Force. He was a lecturer in Military History at the Military Academy from 1983 to 1989, and the Resident Military Historian and Head of the Research and Development Section at the South African National War College from 2005 to 2014. His publications include The First Battle of El Alamein 1-30 July 1942: A South African Perspective (iNtgrty, 2017).

Evert Kleynhans [MMil, PhD (Mil) (Stellenbosch University)] is a senior lecturer in the Department of Military History of the Faculty of Military Science at Stellenbosch University. He is also an Assistant Director of the Southern Africa Chapter of the Second World War Research Group. His primary research interests include the South African participation in both world wars. [orcid: 0000-0001-8968-5728] 
IAN Liebenberg [MA, PhD (Unisa)] is the Director of the Centre for Military Studies, Stellenbosch University. His recent publications include A Far-Away War: Angola, 1975-1989 (African Sun Media, 2015), which he co-edited with Jorge Risquet and Vladimir Shubin. [orcid: 0000-0003-0351-9476]

Chris Saunders [MA, PhD (Oxford)] taught in Historical Studies at the University of Cape Town (UCT) until his retirement. He continues to research Southern African history and politics and is now attached to the Institute for Democracy, Citizenship and Public Policy in Africa at the Centre for Social Science Research at UCT. Recent publications include Southern African Liberation Struggles: New Local, Regional and Global Perspectives (UCT Press, 2013), which he co-edited with Hilary Sapire, a chapter on Albert Luthuli in A. Adebajo (ed.), Africa's Peacemakers (Zed Press, 2014), and a chapter with Sean Morrow in Andrew Bank and Leslie Bank (eds.), Inside African Anthropology: Monica Wilson and Her Interpreters (Cambridge University Press, 2013). [orcid: 00000003-4565-4107]

Major Jean-Pierre Scherman [MA (University of the Free State)] serves at the South African School of Armour as the second-in-command of the Armour Training Wing. He has deployed on both United Nations and Southern African Development Community external military missions, as well as internal military missions. Presently, he is enrolled for doctoral studies in the Department of Military History, Stellenbosch University.

IAN VAN DeR WAag [MA (Pretoria), PhD (University of Cape Town)] is Professor of Military History and Chair of the School for Security and Africa Studies in the Faculty of Military Science, Stellenbosch University. His Military History of Modern South Africa was published by Jonathan Ball in August 2015, and a revised, northern hemisphere edition was published by Casemate in April 2018. He was rated as an internationally acclaimed researcher (B2) by the National Research Foundation in 2016. [orcid: 0000-0001-6076-2048]

AnNeke van Heerden [MA (Stellenbosch University)] completed a Postgraduate Certificate in Education and has taught at high school level since 2015. She is currently teaching at the Hoër Meisieskool Bloemhof in Stellenbosch.

Rodney Warwick [MA, PhD (University of Cape Town)] has taught History at Bishops in Cape Town since 1999. His master's and doctoral dissertations covered primarily Military History themes: the first phase of the German South West Africa Campaign (1914), and White South Africa and Defence 1960-68: Militarization, Threat Perceptions and Counter-Strategies. Warwick writes occasionally for the local press on military, historical and political topics. 
